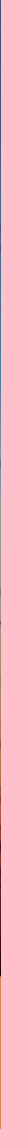



Power Market Structure 



\section{Power Market Structure}

Revisiting Policy Options

Maria Vagliasindi and John Besant-Jones

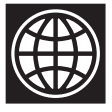

THE WORLD BANK

Washington, D.C. 
(C) 2013 International Bank for Reconstruction and Development / The World Bank

1818 H Street NW

Washington DC 20433

Telephone: 202-473-1000

Internet: www.worldbank.org

Some rights reserved

\section{3}

This work is a product of the staff of The World Bank with external contributions. Note that The World Bank does not necessarily own each component of the content included in the work. The World Bank therefore does not warrant that the use of the content contained in the work will not infringe on the rights of third parties. The risk of claims resulting from such infringement rests solely with you.

The findings, interpretations, and conclusions expressed in this work do not necessarily reflect the views of The World Bank, its Board of Executive Directors, or the governments they represent. The World Bank does not guarantee the accuracy of the data included in this work. The boundaries, colors, denominations, and other information shown on any map in this work do not imply any judgment on the part of The World Bank concerning the legal status of any territory or the endorsement or acceptance of such boundaries.

Nothing herein shall constitute or be considered to be a limitation upon or waiver of the privileges and immunities of The World Bank, all of which are specifically reserved.

\section{Rights and Permissions}

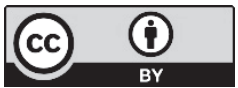

This work is available under the Creative Commons Attribution 3.0 Unported license (CC BY 3.0) http://creativecommons.org/licenses/by/3.0. Under the Creative Commons Attribution license, you are free to copy, distribute, transmit, and adapt this work, including for commercial purposes, under the following conditions:

Attribution-Please cite the work as follows: Vagliasindi, Maria, and John Besant-Jones. 2013. Power Market Structure: Revisiting Policy Options. Directions in Development. Washington, DC: World Bank. doi:10.1596/978-0-8213-9556-1. License: Creative Commons Attribution CC BY 3.0

Translations-If you create a translation of this work, please add the following disclaimer along with the attribution: This translation was not created by The World Bank and should not be considered an official World Bank translation. The World Bank shall not be liable for any content or error in this translation.

All queries on rights and licenses should be addressed to the Office of the Publisher, The World Bank, 1818 H Street NW, Washington, DC 20433, USA; fax: 202-522-2625; e-mail: pubrights@worldbank.org.

ISBN (paper): 978-0-8213-9556-1

ISBN (electronic): 978-0-8213-9557-8

DOI: 10.1596/978-0-8213-9556-1

Cover photo: iStockphoto.com/Michael Bodmann

\section{Library of Congress Cataloging-in-Publication Data}

Vagliasindi, Maria.

Power market structure : revisiting policy options/Maria Vagliasindi, John Besant-Jones. p. $\mathrm{cm}$.

Includes bibliographical references.

ISBN 978-0-8213-9556-1-ISBN 978-0-8213-9557-8 (electronic)

1. Energy policy-Developing countries. 2. Electric power systems-Developing countries. 3. Electric utilities-Developing countries. I. Besant-Jones, John, 1941- II. Title.

HD9502.D442V343 2012

333.7909172'4—dc23 


\section{Contents}

Acknowledgments xix

Abbreviations $x x i$

Executive Summary 1

Objectives and Background 1

Analytical Framework and Approach 3

$\begin{array}{ll}\text { Conclusions } & 7\end{array}$

Part 1 Power Market Structure and Performance: Evidence from a Global Database $\quad 15$

Chapter 1 Power Market Structure and Performance:

Analytical Framework $\quad 17$

Introduction 17

What Does Theory Suggest on the Costs and

Benefits of Alternative Market Structures? 19

What Does Empirical Evidence Suggest on the

Costs and Benefits of Alternative Market

Structures? 21

What Do We Know about the Taxonomy of

Market Structures? 23 
Objectives 26

Methodology 29

Analytical Approach $\quad 40$

Testing the Hypotheses 44

Evidence of Reform Outcomes from the Country Case Studies 53

Conclusions $\quad 70$

Directions for New Research $\quad 77$

Annex A $\quad 78$

Annex B 78

Notes $\quad 92$

References $\quad 92$

Part 2 Case Studies: Large System Size and High GDP per Capita Economies 95

$\begin{array}{lll}\text { Chapter } 2 & \text { Argentina } & 97\end{array}$

Reform History $\quad 97$

Impact on Sector Structure $\quad 102$

Impact on Sector Performance 103

$\begin{array}{lll}\text { Chapter } 3 \text { Brazil } & 115\end{array}$

Reform History $\quad 115$

Impact on Sector Structure $\quad 120$

Impact on Sector Performance 122

$\begin{array}{lll}\text { Chapter } 4 \text { Chile } & 133\end{array}$

Reform History 133

Impact on Sector Structure 136

Impact on Sector Performance 136

$\begin{array}{lll}\text { Chapter } 5 \text { Czech Republic } & 147\end{array}$

Reform History 147

Impact on Sector Structure 149

Impact on Sector Performance $\quad 151$

Reference 159

$\begin{array}{lll}\text { Chapter } 6 & \text { Arab Republic of Egypt } & 161\end{array}$

Reform History 161

Egypt's Private Power Generation Projects 163

The Return to Publicly Financed Power Projects 165 
Impact on Sector Structure $\quad 166$

Impact on Sector Performance $\quad 167$

Notes 174

Reference $\quad 174$

$\begin{array}{lll}\text { Chapter } 7 & \text { Indonesia } & 175\end{array}$

Reform History $\quad 176$

2005 Government Regulation on Public-Private Projects 180

Impact on Sector Structure and Performance 182

Notes 192

$\begin{array}{lll}\text { Chapter } 8 & \text { Republic of Korea } & 193\end{array}$

Reform History 193

Impact on Sector Structure 194

Impact on Sector Performance 194

$\begin{array}{lll}\text { Chapter } 9 & \text { Peru } & 205\end{array}$

Reform History 207

Impact on Sector Structure $\quad 211$

Impact on Sector Performance $\quad 212$

$\begin{array}{ll}\text { Notes } & 219\end{array}$

$\begin{array}{lll}\text { Chapter } 10 & \text { South Africa } & 221\end{array}$

Reform History 222

Impact on Sector Structure $\quad 223$

Impact on Sector Performance 224

Reference $\quad 232$

$\begin{array}{lll}\text { Chapter } 11 & \text { Turkey } & 233\end{array}$

Reform History 234

Impact on Sector Structure 238

Impact on Sector Performance 239

References $\quad 247$

Part 3 Case Studies: Intermediate Economies 249

$\begin{array}{lll}\text { Chapter } 12 & \text { Botswana } & 251\end{array}$

Reform History 251

Impact on Sector Structure $\quad 252$

Impact on Sector Performance 252 
Chapter 13 Andhra Pradesh 259

Reform History 260

Impact on Sector Structure 266

Impact on Sector Performance 266

Notes 274

References $\quad 275$

$\begin{array}{lll}\text { Chapter } 14 \text { Gujarat } & 277\end{array}$

Reform History 277

Impact on Sector Performance 278

Reference 282

Chapter 15 West Bengal 283

Reform History 284

Impact on Sector Performance 285

Reference 294

Chapter 16 Jordan 295

Reform History 295

Impact on Sector Structure 296

Impact on Sector Performance 297

Note 306

$\begin{array}{lll}\text { Chapter } 17 & \text { Vietnam } & 307\end{array}$

Reform History $\quad 307$

Impact on Sector Structure 311

Impact on Sector Performance 311

Notes $\quad 318$

$\begin{array}{lll}\text { Chapter } 18 & \text { Zambia } & 319\end{array}$

Reform History 320

Impact on Sector Structure 321

Impact on Sector Performance 321

Reference $\quad 328$

Part $4 \quad$ Case Studies: Small System Size and Low GDP per Capita Economies 329

Chapter 19 Kenya 331

Reform History 331

Impact on Sector Structure $\quad 332$

Impact on Sector Performance 332

Note $\quad 342$ 
Chapter 20 Tanzania

Reform History

Impact on Sector Structure $\quad 346$

Impact on Sector Performance $\quad 346$

Note $\quad 355$

Reference $\quad 355$

$\begin{array}{lll}\text { Chapter } 21 & \text { Uganda } & 357\end{array}$

Reform History 357

Impact on Sector Structure 358

Impact on Sector Performance $\quad 358$

\section{Box}

8.1 Challenges of Korea's Wholesale Electricity Market

\section{Figures}

ES.1 Power Sector Performance Indicators over Time

1.1 A Holistic Approach to the Governance Evaluation

Framework at the Enterprise Level

1.2 Distribution of Stages of Reforms and Market Structures in the Power Sector by Region

1.3 Stylized Framework of Market Structure in the Power Sector

1.4 System Size and Income for Unbundled and Vertically Integrated Systems

1.5 Distribution of Stages of Reforms in the Power Sector by System Size and Income

1.6 Scatter Plot of the Sample of Countries in the Initial Period, 1989

1.7 Scatter Plot of the Sample of Countries in the Intermediate Period, 1998

1.8 Scatter Plot of the Sample of Countries in the Final Period, 2008

1.9 Links between Performance and Vertical Unbundling 46

1.10 Links between Performance and Disaggregation 47

1.11 Links between Performance and Regulation 48

1.12 Links between Performance and Privatization 49

1.13 Links between Performance and Power System Size and GDP per Capita $\quad 50$

1.14 Power Sector Performance Indicators over Time 51 
1.15 Differential Impact of Performance Indicators Depending on Reforms for Group A

1.16 Differential Impact of Performance Indicators Depending on Reforms for Group D

1.17 Milestones of Power Sector Reform in Four Group A Countries

1.18 Milestones of Power Sector Reform in Four Group D Countries

1.19 Country Performance for Access to Electricity by Households in Groups A and D

1.20 Country Performance for Labor Productivity in Groups A and D

1.21 Country Performance for Tariffs in Groups A and D 68

1.22 Country Performance for $\mathrm{CO}_{2}$ Emissions in Groups A and D

1B.1 Vertical Unbundling 81

1B.2 Disaggregation in Generation 83

1B.3 Disaggregation in Distribution $\quad 85$

1B.4 Autonomous Regulator 86

1B.5 Private Ownership $\quad 88$

1B.6 Installed Capacity $\quad 89$

1B.7 GDP per Capita 91

2.1 Argentina: Taxonomy of Power Sector before

2.2 Argentina: Taxonomy of Power Sector after Reform (1998) 100

2.3 Milestones of Power Sector Reform in Argentina 106

2.4 Argentina: Access to Residential Electricity 107

2.5 Argentina: Quality of Electric Service 107

2.6 Argentina: System Energy Losses 108

2.7 Argentina: System Load Factor 108

2.8 Argentina: Electricity Generation by Source and

2.9 Argentina: Energy Security and Capital Expenditure 109

2.10 Argentina: Average Tariff and Operating Costs 110

2.11 Argentina: Labor Productivity 110

2.12 Argentina: Capacity Utilization 111

2.13 Argentina: Cost Recovery Index 111

2.14 Argentina: Market Concentration 112

2.15 Argentina: Private Ownership 112

2.16 Argentina: Private Management 113 
2.17 Argentina: Degree of Vertical Integration 113

3.1 Brazil: Taxonomy of Power Sector before Reform (1990) 116

3.2 Brazil: Taxonomy of Power Sector after First Reform (1998)

3.3 Brazil: Taxonomy of Power Sector after Second Reform (2008)

3.4 Milestones of Power Sector Reform in Brazil 125

3.5 Brazil: Access to Residential Electricity 126

3.6 Brazil: Quality of Electric Service 126

3.7 Brazil: System Losses and Operating Costs 127

3.8 Brazil: Electricity Generation by Source and Carbon Emissions 127

3.9 Brazil: Energy Security and Capital Expenditure 128

3.10 Brazil: Average Tariff and Operating Costs 128

3.11 Brazil: Labor Productivity 129

3.12 Brazil: Capacity Utilization 129

3.13 Brazil: Cost Recovery Index 130

3.14 Brazil: Market Concentration 130

3.15 Brazil: Private Ownership 131

3.16 Brazil: Private Management 131

4.1 Chile: Taxonomy of Power Sector before Reform (1990) 134

4.2 Chile: Taxonomy of Power Sector after Reform (1998) 135

4.3 Chile: Taxonomy of Power Sector after Reform (2008) 137

4.4 Milestones of Power Sector Reform in Chile 140

4.5 Chile: Access to Residential Electricity 141

4.6 Chile: Quality of Electric Service 141

4.7 Chile: System Losses and Operating Costs 141

4.8 Chile: Electricity Generation by Source and Carbon

4.9 Chile: Energy Security and Capital Expenditure $\quad 142$

4.10 Chile: Average Tariff and Operating Costs 143

4.11 Chile: Labor Productivity 143

4.12 Chile: Capacity Utilization 144

4.13 Chile: Cost Recovery Index 144

4.14 Chile: Market Concentration 145

4.15 Chile: Private Ownership 145

4.16 Chile: Private Management 146

4.17 Chile: Degree of Vertical Integration 146

5.1 Milestones in Power Sector Reform in the

5.2 Czech Republic: Access to Residential Electricity 154 
5.3 Czech Republic: Quality of Electric Service 154

5.4 Czech Republic: Quality of Electric Service (PRE) 155

5.5 Czech Republic: System Energy Losses 155

5.6 Czech Republic: Electricity Generation by Source and Carbon Emissions

5.7 Czech Republic: Energy Security and Capital Expenditure

5.8 Czech Republic: Average Tariff and Operating Costs (CEZ)

5.9 Czech Republic: Average Tariff and Operating Costs (PRE)

5.10 Czech Republic: Capacity Utilization 157

5.11 Czech Republic: Cost Recovery Index (ČEZ) 157

5.12 Czech Republic: Cost Recovery Index (PRE) 158

5.13 Czech Republic: Market Concentration 158

5.14 Czech Republic: Private Ownership 158

5.15 Czech Republic: Private Management 159

5.16 Czech Republic: Degree of Vertical Integration 159

6.1 Structure of the Egyptian Power Sector 167

6.2 Milestones of Power Sector Reform in Egypt 169

6.3 Egypt: Access to Residential Electricity 170

6.4 Egypt: Quality of Electric Service 170

6.5 Egypt: System Losses and Operating Costs 171

6.6 Egypt: Electricity Generation by Source and Carbon Emissions $\quad 171$

6.7 Egypt: Energy Security and Capital Expenditure $\quad 172$

6.8 Egypt: Average Tariff and Operating Costs 172

6.9 Egypt: Capacity Utilization 172

6.10 Egypt: Market Concentration 173

6.11 Egypt: Private Ownership 173

6.12 Egypt: Private Management 173

6.13 Egypt: Degree of Vertical Integration $\quad 174$

7.1 Milestones of Power Sector Reform in Indonesia 185

7.2 Indonesia: Access to Residential Electricity 186

7.3 Indonesia: System Energy Losses 186

7.4 Indonesia: Electricity Generation by Source and Carbon Emissions Index 187

7.5 Indonesia: Energy Security and Capital Expenditure 187

7.6 Indonesia: Average Tariff and Operating Costs 188

7.7 Indonesia: Labor Productivity 188 
7.8 Indonesia: Capacity Utilization 189

7.9 Indonesia: Cost Recovery Index 189

7.10 Indonesia: Market Concentration 190

7.11 Indonesia: Private Ownership 190

7.12 Indonesia: Private Management 191

7.13 Indonesia: Degree of Vertical Integration 191

8.1 Korea's Current Market Structure 195

8.2 Milestones of Power Sector Reform in Korea 197

8.3 Korea: Access to Residential Electricity 198

8.4 Korea: Quality of Electric Service 198

8.5 Korea: System Energy Losses 199

8.6 Korea: System Load Factor 199

8.7 Korea: Electricity Generation by Source and Carbon Emissions 200

8.8 Korea: Energy Security and Capital Expenditure 200

8.9 Korea: Average Tariff and Operating Costs 201

8.10 Korea: Labor Productivity 201

8.11 Korea: Capacity Utilization 202

8.12 Korea: Cost Recovery Index 202

8.13 Korea: Market Concentration 203

8.14 Korea: Private Ownership 203

8.15 Korea: Private Management 204

8.16 Korea: Degree of Vertical Integration 204

9.1 Peru: Taxonomy of Power Sector before Reform (1990) 206

9.2 Peru: Taxonomy of Power Sector after Reform (1998) 208

9.3 Organization of the Peruvian Electricity Market 209

9.4 Peru: Taxonomy of Power Sector after Reform (2008) 211

9.5 Milestones of Power Sector Reform in Peru 214

9.6 Peru: Access to Residential Electricity 215

9.7 Peru: Quality of Electric Service 215

9.8 Peru: System Energy Losses 216

9.9 Peru: Electricity Generation by Source and Carbon Emissions 216

9.10 Peru: Energy Security and Capital Expenditure 217

9.11 Peru: Average Tariff and Operating Costs 217

9.12 Peru: Capacity Utilization 218

9.13 Peru: Cost Recovery Index 218

9.14 Peru: System Load Factor 219

10.1 South Africa Power Market Structure 223

10.2 Milestones of Power Sector Reform in South Africa 225 
10.3 South Africa: Access to Residential Electricity 226

10.4 South Africa: Quality of Electric Service 226

10.5 South Africa: System Losses and Operating Costs 227

10.6 South Africa: Electricity Generation by Source and Carbon Emissions 227

10.7 South Africa: Energy Security and Capital Expenditure 228

10.8 South Africa: Average Tariff and Operating Costs 228

10.9 South Africa: Capacity Utilization 229

10.10 South Africa: Cost Recovery Index 229

10.11 South Africa: Labor Productivity 230

10.12 South Africa: Market Concentration 230

10.13 South Africa: Private Ownership 230

10.14 South Africa: Private Management 231

10.15 South Africa: Degree of Vertical Integration 231

10.16 South Africa: System Load Factor 231

11.1 Transitional Electricity Market Structure in Turkey 239

11.2 Milestones of Power Sector Reform in Turkey 241

11.3 Turkey: Access to Residential Electricity 242

11.4 Turkey: Quality of Electric Service 242

11.5 Turkey: System Losses and Operating Costs 243

11.6 Turkey: Electricity Generation by Source and Carbon Emissions 243

11.7 Turkey: Energy Security and Capital Expenditure 244

11.8 Turkey: System Load Factor 244

11.9 Turkey: Capacity Utilization 244

11.10 Turkey: Average Tariff and Operating Costs 245

11.11 Turkey: Labor Productivity (Distribution) 245

11.12 Turkey: Market Concentration 246

11.13 Turkey: Private Ownership 246

11.14 Turkey: Private Management 247

11.15 Turkey: Degree of Vertical Integration 247

12.1 Milestones of Power Sector Reform in Botswana 254

12.2 Botswana: Access to Residential Electricity 255

12.3 Botswana: System Losses and Operating Costs 255

12.4 Botswana: Electricity Generation by Source and Carbon Emissions 255

12.5 Botswana: Energy Security and Capital Expenditure 256

12.6 Botswana: Average Tariff and Operating Costs 256

12.7 Botswana: Capacity Utilization 256

12.8 Botswana: Cost Recovery Index 257 
12.9 Botswana: Market Concentration 257

12.10 Botswana: Private Ownership 257

12.11 Botswana: Private Management 258

12.12 Botswana: Degree of Vertical Integration 258

13.1 Milestones of Power Sector Reform in Andhra Pradesh 268

13.2 Andhra Pradesh: Access to Residential Electricity 269

13.3 Andhra Pradesh: Quality of Electric Service and Operating Costs

13.4 Andhra Pradesh: System Energy Losses and Operating Costs 270

13.5 Andhra Pradesh: Electricity Generation by Source and Carbon Emissions

13.6 Andhra Pradesh: Energy Security 271

13.7 Andhra Pradesh: System Load Factor 271

13.8 Andhra Pradesh: Capacity Utilization 271

13.9 Andhra Pradesh: Labor Productivity 272

13.10 Andhra Pradesh: Cost Recovery Index 272

13.11 Andhra Pradesh: Market Concentration 273

13.12 Andhra Pradesh: Private Ownership 273

13.13 Andhra Pradesh: Private Management 273

13.14 Andhra Pradesh: Degree of Vertical Integration 274

14.1 Gujarat: Access to Residential Electricity 279

14.2 Gujarat: Quality of Electric Service 279

14.3 Gujarat: System Energy Losses 279

14.4 Gujarat: Electricity Generation by Source and Carbon Emissions 280

14.5 Gujarat: Average Tariff and Operating Costs 280

14.6 Gujarat: Labor Productivity 280

14.7 Gujarat: Capacity Utilization 281

14.8 Gujarat: Private Ownership 281

14.9 Gujarat: Private Management 281

14.10 Gujarat: Market Concentration 282

14.11 Gujarat: Degree of Vertical Integration 282

15.1 Milestones of Power Sector Reform in West Bengal 290

15.2 West Bengal: Access to Residential Electricity 291

15.3 West Bengal: Quality of Electric Service 291

15.4 West Bengal: System Energy Losses and Operating Costs 292

15.5 West Bengal: Electricity Generation by Source and Carbon Emissions 292

15.6 West Bengal: Average Tariff and Operating Costs 293 
15.7 West Bengal: Labor Productivity 293

15.8 West Bengal: Capacity Utilization 293

15.9 West Bengal: Cost Recovery Index 294

16.1 Milestones of Power Sector Reform in Jordan 300

16.2 Jordan: Access to Residential Electricity 301

16.3 Jordan: Quality of Electric Service 301

16.4 Jordan: System Losses and Operating Costs 302

16.5 Jordan: Electricity Generation by Source and Carbon Emissions $\quad 302$

16.6 Jordan: Energy Security and Capital Expenditure 303

16.7 Jordan: System Load Factor 303

16.8 Jordan: Capacity Utilization 303

16.9 Jordan: Average Tariff and Operating Costs 304

16.10 Jordan: Labor Productivity 304

16.11 Jordan: Cost Recovery Index 305

16.12 Jordan: Market Concentration 305

16.13 Jordan: Private Ownership 305

16.14 Jordan: Private Management 306

16.15 Jordan: Degree of Vertical Integration 306

17.1 Milestones of Power Sector Reform in Vietnam 313

17.2 Vietnam: Access to Residential Electricity 314

17.3 Vietnam: Quality of Electric Service 314

17.4 Vietnam: System Energy Losses 315

17.5 Vietnam: Electricity Generation by Source and
Carbon Emissions

17.6 Vietnam: Energy Security and Capital Expenditure 315

$\begin{array}{ll}17.7 & \text { Vietnam: Labor Productivity } \\ 17.8 & 316\end{array}$

17.8 Vietnam: Capacity Utilization 316

17.9 Vietnam: Market Concentration $\quad 316$

17.10 Vietnam: Private Ownership $\quad 317$

17.11 Vietnam: Private Management 317

17.12 Vietnam: Degree of Vertical Integration 317

17.13 Vietnam: System Load Factor 318

18.1 Milestones of Power Sector Reform in Zambia 324

18.2 Zambia: Access to Residential Electricity 325

18.3 Zambia: System Losses and Operating Costs 325

18.4 Zambia: Electricity Generation by Source and Carbon Emissions $\quad 326$

18.5 Zambia: Energy Security and Capital Expenditure 326 
18.6 Zambia: Average Tariff and Operating Costs 326

18.7 Zambia: Labor Productivity 327

18.8 Zambia: Capacity Utilization 327

18.9 Zambia: Cost Recovery Index $\quad 327$

18.10 Zambia: Market Concentration 328

18.11 Zambia: Private Ownership 328

18.12 Zambia: Private Management 328

19.1 Milestones of Power Sector Reform in Kenya 335

19.2 Kenya: Access to Residential Electricity 336

19.3 Kenya: Quality of Electric Service 336

19.4 Kenya: System Losses and Operating Costs 337

19.5 Kenya: Cost Recovery Index 337

19.6 Kenya: Average Tariff and Operating Costs 338

19.7 Kenya: Energy Security and Capital Expenditure 338

19.8 Kenya: Electricity Generation by Source and Carbon Emissions 339

19.9 Kenya: Labor Productivity 339

19.10 Kenya: Capacity Utilization 340

19.11 Kenya: System Load Factor 340

19.12 Kenya: Market Concentration 341

19.13 Kenya: Private Ownership 341

19.14 Kenya: Private Management 342

19.15 Kenya: Degree of Vertical Integration 342

20.1 Milestones of Power Sector Reform in Tanzania 348

20.2 Tanzania: Access to Residential Electricity 349

20.3 Tanzania: Quality of Electric Service 349

20.4 Tanzania: System Energy Losses 350

20.5 Tanzania: System Load Factor 350

20.6 Tanzania: Electricity Generation by Source and Carbon Emissions 350

20.7 Tanzania: Energy Security and Capital Expenditure 351

20.8 Tanzania: Average Tariff and Operating Costs 351

20.9 Tanzania: Labor Productivity 352

20.10 Tanzania: Capacity Utilization 352

20.11 Tanzania: Cost Recovery Index 353

20.12 Tanzania: Market Concentration 353

20.13 Tanzania: Private Ownership 354

20.14 Tanzania: Private Management 354

20.15 Tanzania: Degree of Vertical Integration 355 
21.1 Milestones of Power Sector Reform in Uganda 361

21.2 Uganda: Access to Residential Electricity 362

21.3 Uganda: Quality of Electric Service 362

21.4 Uganda: System Energy Losses and Operating Costs 362

21.5 Uganda: System Load Factor 363

21.6 Uganda: Electricity Generation by Source and Carbon Emissions 363

21.7 Uganda: Energy Security and Capital Expenditure 363

21.8 Uganda: Average Tariff and Operating Costs 364

21.9 Uganda: Labor Productivity 364

21.10 Uganda: Capacity Utilization 364

21.11 Uganda: Cost Recovery Index 365

21.12 Uganda: Market Concentration 365

21.13 Uganda: Private Ownership 365

21.14 Uganda: Private Management 366

\section{Tables}

ES.1 Sample Selection for Econometric and Case

Studies Analysis

ES.2 Summary of Analytical Evidence Positive and Negative Results in Groups A and D

1.1 Taxonomy of Case Studies 38

1.2 Selected Power Sector Performance Indicators

1.3 Explanatory Sectoral Policy Variables Influencing Power Sector Performance (expected relationship)

1.4 Other Explanatory Variables Influencing Power Sector Performance (expected relationship)

1.5 Summary of Analytical Evidence 73

1A.1 Performance Indicators 79

3.1 Concentration Limits in the Brazilian Power Market 118

3.2 Companies' Share of Generation Capacity 122

3.3 Control of Transmission Lines 123

3.4 Distribution Companies' Market Share 123

15.1 Key Players in the Power Sector of West Bengal before Restructuring

15.2 Power Sector of West Bengal before Restructuring 


\section{Acknowledgments}

The report was developed by a team led by Maria Vagliasindi, lead economist, and John Besant-Jones, lead energy adviser, Energy Anchor, with input from Federico Goñi, Vera Kehayova, and Evgenia Shumilkina. Ashaya Basnyat and Yvonne Wang Ying provided research support. The report has been partially funded by the Energy Sector Management Assistance Program (ESMAP) and the Public-Private Infrastructure Advisory Facility (PPIAF), whose financial support and partnership are gratefully acknowledged.

We are most grateful to Aberdare Engineering Limited (Kenya, Tanzania, and Uganda), Enrique Crousillat and Enrique Tucto Lavado (Peru), Carlos Romero (Argentina), Mohamed Salah Elsobky (Arab Republic of Egypt), Tuan Anh Nguyen (Vietnam), Mercados de Energia Consultoria Ltd. (Brazil), and PA Consulting Group (Argentina, Barbados, Brazil, Chile, and Peru) for collecting data through detailed surveys and interviews with local stakeholders and for producing background reports for selected countries indicated in parentheses.

The report would not have been possible without the invaluable advice, comments, and suggestions of the Expert Advisory, including Emmanuelle Auriol, professor of economics, University of Toulouse, France; John Besant-Jones, lead energy adviser, World Bank; Pasquale 
Cirillo, lecturer and fellow in econometrics and risk analysis, Institute of Mathematical Statistics, University of Bern, Switzerland; Istvan Dobozi, lead energy economist, ESMAP; Antonio Estache; Jose Luis Guasch; Paul Grout, professor of political economy, Department of Economics and Centre for Market and Public Organisation, University of Bristol, and Ofgem adviser, United Kingdom; Clive Harris; and Jaime Millan, former principal energy economist, Infrastructure and Financial Markets, Sustainable Development Department, Inter-American Development Bank. The main results of the report and the individual case studies have been presented at a number of internal and external learning events, including Energy Week 2011, which was held March 14-16, and a halfday workshop on June 9. 


\section{Abbreviations}

$\begin{array}{ll}\text { ANEEL } & \text { Brazilian Electricity Regulatory Agency } \\ \text { APDRP } & \text { Accelerated Power Development and Reform } \\ & \text { Programme (Andhra Pradesh) } \\ \text { APERC } & \text { Andhra Pradesh Electricity Regulatory Commission } \\ \text { APGENCO } & \text { Andhra Pradesh Power Generation Corporation } \\ \text { APSEB } & \text { Andhra Pradesh State Electricity Board } \\ \text { APTRANSCO } & \text { Transmission Corporation of Andhra Pradesh } \\ \text { AT\&C } & \text { aggregate technical and commercial } \\ \text { BABBENAS } & \text { National Development Board (Indonesia) } \\ \text { BO } & \text { build-operate (Turkey) } \\ \text { BOO } & \text { build-operate-own (Turkey) } \\ \text { BOOT } & \text { build-operate-own-transfer (Peru, Turkey) } \\ \text { BOT } & \text { build-operate-transfer (Turkey) } \\ \text { BPC } & \text { Botswana Power Corporation } \\ \text { CAMMESA } & \text { Compañia Administradora del Mercado Mayorista } \\ & \text { Eléctrico S. A. (Argentina) } \\ \text { capex } & \text { capital expenditures } \\ \text { CCEE } & \text { Electric Energy Commercialization Chamber (Brazil) } \\ \text { CCGT } & \text { combined cycle gas turbine } \\ \text { CDEC } & \text { Centro de Despacho Económico de Carga del Sistema } \\ & \text { Interconectado Central (Chile) }\end{array}$


CEC

CEGCO

CESC

CHILECTRA

CNPE

COES

Copel

CTEEP

DEMR

DISCOs

DME

DPL

DPSC

DSO

DT

DVC

ECA

EDCO

EDELAP

Edelnor

EDESUR

EDENOR

EEA

EEHC

EETC

EHV

EML

EMRA

ENDESA

E.ON

ERA

ERB

ERC

Copperbelt Energy Corporation (Zambia)

Central Electric Generating Company (Jordan)

Calcutta Electric Supply Corporation (West Bengal, Gujarat)

Companhia Energética de São Paulo (Brazil)

Compañía Chilena de Electricidad (Chile)

National Energy Policy Council (Brazil)

Comité de Operación Económica del Sistema Interconectado (Peru)

Companhia Paranaense de Energia (Brazil)

Companhia de Transmissão de Energia Elétrica Paulista (Brazil)

Ministry of Energy and Mineral Resources (Indonesia) distribution companies

Department of Minerals and Energy (South Africa)

Durgapur Projects Limited (West Bengal)

Disergarh Power Supply Corporation (West Bengal)

distribution system operators (Czech Republic)

distribution transformer

Damodar Valley Corporation (West Bengal)

Europe and Central Asia

Electricity Distribution Company (Jordan)

Empresa Distribuidora La Plata (Argentina)

Empresa de Distribución Eléctrica de Lima Norte (Peru)

Empresa Distribuidora Sur (Argentina)

Empresa Distribuidora Norte (Argentina)

Egyptian Electricity Authority

Egyptian Electricity Holding Company

Egyptian Electric Transmission Company

extra-high voltage

Electricity Market Law (Turkey)

Energy Market Regulatory Authority

Empresa Nacional de Electricidad (generation, transmission, and distribution company, Chile)

Energy On (Czech Republic)

Electric Utility and Consumer Protection Regulatory Agency (Egypt)

Energy Regulation Board (Zambia)

Electricity Regulatory Commission (Jordan) 


\begin{tabular}{|c|c|}
\hline ERO & Energy Regulatory Office (Czech Republic) \\
\hline ESCELSA & Espírito Santo Centrais Elétricas (Brazil) \\
\hline ETAM & electricity tariff adjustment mechanism (Indonesia) \\
\hline EU & European Union \\
\hline EUAS & Electricity Generation Company of Turkey \\
\hline EVN & Electricity of Vietnam \\
\hline G\&T & generation and transmission \\
\hline GEB & Gujarat Electricity Board (India) \\
\hline GENCOs & generation companies \\
\hline GNI & gross national income \\
\hline GoAP & state government of Andhra Pradesh (India) \\
\hline GWh & gigawatt-hour \\
\hline HHI & Herfindahl-Hirschman Index \\
\hline IDA & $\begin{array}{l}\text { International Development Association of the World } \\
\text { Bank Group }\end{array}$ \\
\hline IDECO & Irbid District Electrical Company (Jordan) \\
\hline IMF & International Monetary Fund \\
\hline IPP & independent power producer \\
\hline JEA & Jordanian Electricity Authority \\
\hline JEPCO & Jordanian Electric Power Company \\
\hline KenGen & Kenya Electricity Generating Company \\
\hline $\mathrm{KEPCO}$ & Korean Electric Power Corporation \\
\hline $\mathrm{km}$ & kilometer \\
\hline KPLC & Kenya Power and Lighting Company \\
\hline $\mathrm{kV}$ & kilovolts \\
\hline $\mathrm{kWh}$ & kilowatt-hour \\
\hline LAC & Latin America and the Caribbean \\
\hline LEC & Electric Concessions Law (Peru) \\
\hline MAE & Wholesale Electric Energy Market (Brazil) \\
\hline MEM & $\begin{array}{l}\text { Mercado Eléctrico Mayorista (wholesale electricity } \\
\text { market, Argentina) }\end{array}$ \\
\hline MNA & Middle East and North Africa \\
\hline MOEE & Ministry of Electricity and Energy (Egypt) \\
\hline MOF & Ministry of Finance (Indonesia) \\
\hline MOIT & Ministry of Industry and Trade (Vietnam) \\
\hline MOU & memorandum of understanding \\
\hline MSOE & Ministry of State-Owned Enterprises (Indonesia) \\
\hline MVA & megavolt amperes \\
\hline MW & megawatts \\
\hline $\mathrm{MWh}$ & megawatt-hour \\
\hline
\end{tabular}




$\begin{array}{ll}\text { NEPCO } & \text { National Electric Power Company (Jordan) } \\ \text { NLDC } & \text { National Load Dispatching Center (Vietnam) } \\ \text { NPTC } & \text { National Power Transmission Corporation } \\ \text { NSE } & \text { Nairobi Stock Exchange (Kenya) } \\ \text { ONS } & \text { system operator (Brazil) } \\ \text { opex } & \text { operational expenditures/costs } \\ \text { OSINERGMIN } & \text { Organismo Supervisor de la Inversión en Energía y } \\ & \text { Mineria (Peru) } \\ \text { PA } & \text { Privatisation Administration (Turkey) } \\ \text { PLN } & \text { Perusahaan Listrik Negara (Indonesia) } \\ \text { PPA } & \text { power purchase agreement } \\ \text { PPSP } & \text { Purulia Pump Storage Project (West Bengal) } \\ \text { PRE } & \text { Pražská Energetika (Czech Republic) } \\ \text { SAIDI } & \text { System Average Interruption Duration Index } \\ \text { SAIFI } & \text { System Average Interruption Frequency Index } \\ \text { SEGBA } & \text { Servicios Eléctricos del Gran Buenos Aires (Argentina) } \\ \text { SEPGCO } & \text { Samra Electric Power Company (Jordan) } \\ \text { SLDC } & \text { State Load Dispatch Centre (West Bengal) } \\ \text { SO } & \text { system operator } \\ \text { T and D } & \text { transmission and distribution } \\ \text { TANESCO } & \text { Tanzania Electric Supply Company } \\ \text { TEAS } & \text { Turkish Electricity Generation Transmission Company } \\ \text { TEDAS } & \text { Turkish Electricity Distribution Company } \\ \text { TEIAS } & \text { Turkish Electricity Transmission Company } \\ \text { TEK } & \text { Turkish Electricity Authority } \\ \text { TETAS } & \text { Turkish Electricity Trading and Contracting Company } \\ \text { TOOR } & \text { transfer of operating rights (Turkey) } \\ \text { TSO } & \text { transmission system operator (Czech Republic) } \\ \text { TWh } & \text { terawatt-hours } \\ \text { UEB } & \text { Uganda Electricity Board } \\ \text { UEDCL } & \text { Uganda Electricity Distribution Company } \\ \text { UEGCL } & \text { Uganda Electricity Generation Company } \\ \text { UETCL } & \text { Uganda Electricity Transmission Company } \\ \text { WBPDCL } & \text { West Bengal Power Development Corporation Limited } \\ \text { WBSEB } & \text { West Bengal State Electricity Board } \\ \text { WBSEDCL } & \text { West Bengal State Electricity Distribution Company } \\ \text { WBSETCL } & \text { West Bengal State Electricity Transmission Company } \\ \text { WCM } & \text { wholesale competitive market (Vietnam) } \\ \text { ZESCO } & \text { Zambia Electripply Corporation } \\ & \end{array}$




\section{Executive Summary}

\section{Objectives and Background}

The objectives of this study are threefold:

1. To develop a taxonomy of the existing power market structures, as shown by the extent of vertical and horizontal unbundling found among restructured power systems across developing countries;

2. To design an analytical framework for assessing the desirability of unbundling under the variety of economic conditions found among developing countries; and

3. To propose insights for operational guidance on alternative market structures based on relevant criteria, in particular on the initial conditions of a country and its power sector.

Unbundling is not an end itself, but rather a means to achieve better performance. Accordingly, the key objective of the analytical framework is to explore the links between alternative market structures and performance (in terms of access, price, quality, and technical and financial performance). The results are crucial for providing policy advice by offering alternative options to policy makers based on the lessons learned 
from the taxonomy of different market structures, tailored to fit different national needs.

The study specifically examines whether power system size and country per capita income can be reliable indicators of initial conditions for guiding policy on power market structure. This guidance is needed to address issues such as whether there are solid foundations for recommending vertical unbundling for small power systems in low-income countries, particularly in the absence of short-term privatization prospects. The proposed policy recommendations therefore have to be tailored to the specific taxonomy of market structures that characterize the electricity sector in developing countries.

The existing variety of power supply structures reflects differing views and a degree of theoretical ambiguity in the economic literature on the effectiveness of unbundling and competition in network industries on issues such as gains from competition versus economies of coordination in vertically integrated systems. In practice, the benefits of each reform and restructuring must more than compensate for the increase in transaction costs of unbundling vertically integrated systems.

Reform to date, however, is unevenly spread among regions. The countries that have progressed the most are in Latin America and the Caribbean (LAC) and in Europe and Central Asia. In Africa, the Middle East, and South Asia, progress to date is generally limited to long-term contracts by independent power producers (IPPs) to supply incumbent utilities. Some countries in East Asia, for example, have made tentative steps to further their reforms.

The current distribution of power markets around intermediate structures between full integration and full unbundling suggests that there has not been a linear path to reform in practice. Instead, many developing countries may retain intermediate structures for the foreseeable future. This possibility exposes a large gap in understanding about power market structures, since most theoretical work has focused on the two extreme structures and the evidence on the impact of unbundling is limited for developing countries.

The study reports the evidence from econometric analysis and case studies on the (relative) success of achieving the objectives of unbundling. These objectives may be to enhance transparency and governance, attract private sector investment, and/or to create a competitive market and ultimately to further its impact on performance. In some cases restructuring had the purpose of creating an enabling environment to attract private sector investment, taking some level of market risks and/or commitments 
to efficiency improvements. Transferring market risks to the private investor requires greater transparency and predictability, which may be more difficult to obtain in a sector with an integrated monopoly power utility to which the private generator is obliged to sell.

\section{Analytical Framework and Approach}

The approach adopted for this study is, first, to map the existing approach to vertical and horizontal unbundling of power sectors adopted by developing countries and, second, to undertake econometric analysis and detailed case studies to better understand and assess the desirability of unbundling the sector under developing country conditions.

The study applies the "ceteris paribus" (all other things being equal) approach, while recognizing the potential influence of additional issues pertaining to the broader set of reforms in the power sector. As the form and extent of unbundling determines the market structure, particular attention is devoted to the analysis of key decisions through the lens of structure/ownership vis-à-vis contracts/market rules. In other words, the analysis separates within each market structure the key decisions that have been "internalized" within the power company through the existing structure/ownership from the decisions that have been delegated to outside contracts/market rules, depending on the transaction costs involved.

The study proposes an analytical approach to model market structure, together with ownership and regulation, controlling for several variables as determinants of performance across several indicators of performance, including access, operational and financial performance, and environmental sustainability. The study uses the following indicators of power sector performance indicators for this regression analysis:

- Access. Residential access to electricity (percentage of population)

- Operational efficiency. Energy sold per employee (megawatt-hour [MWh] per employee)

- Financial efficiency. Tariff level (\$ cent per kilowatt-hour [kWh])

- Environmental sustainability. Carbon emissions index $\left(\mathrm{CO}_{2}\right.$ ton per kilowatt-hour (kWh)

This methodology adopts a novel approach to specifying variables with respect to most empirical studies. To date, empirical work including market structure variables in the analysis has been limited, particularly in the case of developing countries. Only a selected number of variables of 
performance have been used in the literature, and there is no evidence reported on the impact of reforms in terms of environmental sustainability. The study uses the following main explanatory variables that influence power sector performance for this analysis:

- Degree of vertical unbundling. Partial vertical unbundling or full vertical unbundling: $=1$ from the year of separation of generation from transmission and distribution; $=0$ otherwise.

- Degree of disaggregation. The reverse of the Herfindahl-Hirschman Index (HHI), computed separately for the generation, transmission, and distribution segments; in the case of generation, it is expressed in installed generating capacity in megawatts (MW); in the case of transmission, expressed in terms of kilometer $(\mathrm{km})$ line length without discrimination between transmission voltage levels; and in the case of distribution, expressed in terms of total retail sales (MWh).

- Share of private sector participation. The percentage of private sector participation expressed in installed generating capacity (MW) in the generation segment; expressed in terms of $\mathrm{km}$ line length in the transmission segment; and expressed in terms of total retail sales (MWh) in the distribution segment.

- Introduction of a regulatory agency: = 1 from the year of establishment of a regulatory agency; $=0$ otherwise.

The study uses gross domestic product (GDP) per capita and installed capacity as control variables. As it is a priori difficult to make assumptions about the explanatory power of the selected independent variables, including different indicators of unbundling and other sector reforms on the dependent variables, the study runs the specifications of the model using both fixed effects and random effects regressions.

The dataset is based on a panel of 22 countries for a period beginning in 1989 and extending through 2009. The maximum total number of maximum observations is 440 . The selected countries and their power sectors are summarized in the following paragraphs.

A series of 20 country case studies is also carried out to support the analytical approach described above. The selected countries cover all six of the World Bank's regions and reflect broad regional features such as Africa's low access rates and underdeveloped transmission networks; Europe and Central Asia's (ECA) full access rates, highly developed transmission interconnections, historically surplus generating capacity, and the strong influence from the European Union (EU) and Russia; Latin America 
and the Caribbean's (LAC) leadership in market reform and large amounts of hydropower capacity; East Asia's and South Asia's high growth in power demand and therefore the need for generation capacity; and Middle East and North Africa's (MNA) emergence as a strategic crossroads in energy trade.

The case studies are predicated on the hypothesis that power system size and per capita income appear to influence the choice of power market structure in developing countries. A clear empirical threshold for unbundling power systems currently appears to separate developing countries into groups; the threshold is defined in terms of power system size of $1,000 \mathrm{MW}$ and annual per capita income of $\$ 900$. Most of the developing countries with unbundled power systems lie above both of these thresholds. On the other hand, most of the developing countries with vertically integrated power systems lie below both of these thresholds.

The performance of countries with unbundled power sectors is compared to the counterfactual of countries that have a vertically integrated structure. This comparison is undertaken within each group of countries determined by the threshold levels of system size and country annual per capita income. The four groups of countries are referred to as Groups A through D. Group A consists of countries in which both power system size and per capita income are above the threshold levels; Groups B and $\mathrm{C}$ are those for which either power system size or per capita income is below one of the threshold levels; and the countries in Group D have power system size and per capita income below the threshold levels.

The case studies proposed for each of the groups are shown in table ES.1.

Table ES.1 Sample Selection for Econometric and Case Studies Analysis

\begin{tabular}{|c|c|}
\hline Country Group & Region \\
\hline \multicolumn{2}{|c|}{ Group A (large system size and high GDP per capita) } \\
\hline $\begin{array}{l}\text { Indonesia } \\
\text { Korea, Rep. }\end{array}$ & East Asia and the Pacific \\
\hline $\begin{array}{l}\text { Czech Republic } \\
\text { Turkey }\end{array}$ & Europe and Central Asia \\
\hline $\begin{array}{l}\text { Argentina } \\
\text { Brazil } \\
\text { Chile } \\
\text { Peru }\end{array}$ & Latin America and the Caribbean \\
\hline Egypt, Arab Rep. & Middle East and North Africa \\
\hline South Africa & Sub-Saharan Africa \\
\hline
\end{tabular}


Table ES.1 (continued)

\begin{tabular}{ll}
\hline Groups B and C (intermediate cases) & \\
Vietnam ( $\uparrow$ Group A) & East Asia and the Pacific \\
Cyprus & Europe and Central Asia \\
Barbados & Latin America and the Caribbean \\
Jordan ( $\uparrow$ Group A) & Middle East and North Africa \\
Indian State of Andhra Pradesh & South Asia \\
Indian State of Gujarat ( $\uparrow$ Group A) & \\
Indian State of West Bengal ( $\uparrow$ Group A) & \\
Botswana & Sub-Saharan Africa \\
Zambia & \\
Group D (small system size and low GDP per capita) \\
Kenya ( $\uparrow$ Group B) \\
$\begin{array}{l}\text { Tanzania } \\
\text { Uganda }\end{array}$ \\
\hline
\end{tabular}

Source: An elaboration from the Power Market Structure database.

Note: The entries in italic are countries that moved from one group to another during the data period.

- Group A: The following ten countries fall into this group: Argentina, Brazil, Chile, Czech Republic, the Arab Republic of Egypt, Indonesia, the Republic of Korea, Peru, South Africa, and Turkey. The performance of Czech Republic, Egypt, Korea, Indonesia, and South Africa (all of which display either a vertically integrated structure or, in the case of Czech Republic and Egypt, simply legal unbundling, under a holding structure in the case of Egypt) are compared with Argentina, Brazil, Chile, Peru, and Turkey, which instead have moved reforms forward by introducing a competitive wholesale market.

- Groups B and C: The performance of countries that have kept a vertically integrated structure, including Barbados, Botswana, Cyprus, and Zambia, is compared with Vietnam, some of the Indian power sector regional structures (Andhra Pradesh, Gujarat, and West Bengal) that went further in the process of unbundling, and Jordan, which unbundled its power sector and privatized most of it.

- Group D: Kenya and Tanzania are compared with Uganda, the only Sub-Saharan African country where a single buyer model has been introduced. Tanzania undertook a management contract from 2002 to 2006. Overall vertical integration in the sector has not changed much in Kenya, with transmission and distribution now bundled and generation unbundled into a few suppliers. The proportion of total installed 
generating capacity under private ownership in Kenya increased from 16 percent in 2001 to 46 percent in 2007.

\section{Conclusions}

The results of the analysis carried out for this study confirm the following conclusions for policy guidance on power market restructuring for developing countries:

- Unbundling delivers results in terms of several performance indicators when used as an entry point to implement broader reforms, particularly introducing a sound regulatory framework, reducing the degree of concentration of the generation and distribution segments of the market by attracting additional public and private players and greater private sector participation.

- There seems to be a credible empirical basis for selecting a threshold power system size and per capita income level below which unbundling of the power supply chain is not expected to be worthwhile.

Partial forms of vertical unbundling do not appear to drive improvements. The most likely reason is that the owner was able to continue exercising control over the affairs of the sector and hinder the development of competitive pressure within the power market.

The analysis with the regression model used for the study produces the following main findings.

\section{Vertical Unbundling}

- The level of access is positively linked to full vertical unbundling, even if not significantly so. Partial unbundling is negatively and significantly associated with lower levels of access.

- The level of labor productivity (expressed in terms of energy sold per employee) is significantly reduced by both partial and full vertical unbundling.

- Full unbundling significantly enhances the level of tariffs, whereas partial unbundling has no significant impact on tariffs.

- Partial and vertical unbundling is associated with higher carbon emissions, but only partial unbundling is significantly so.

\section{Differential Impact of Vertical Unbundling in Groups A and D}

- Vertical unbundling (either partial or full or full only) when interacted with Group A is significantly associated with enhanced access and 
more sustainable levels of $\mathrm{CO}_{2}$ emissions generated by fossil fuels, reflecting both economic and environmental benefits to power users due to increased efficiency of use of fossil fuels. The opposite result holds for Group D.

- There is no significant link between vertical unbundling and enhanced operational or financial efficiency for Group A, whereas there is a positive and significant link for Group D. This result implies that for Group A the high prevailing level of labor productivity offers decreasing returns to scale, or that there is an increasing use of outsourcing. For Group D the benefits of unbundling may be reflected mainly through restructuring and laying off of redundant employees.

\section{Degree of Disaggregation}

- The level of access is positively and significantly linked to the increase of disaggregation in generation. This result can be interpreted as noting that developing countries have been able to scale up access after attracting more players and investment in generation.

- Labor productivity is enhanced by the increase of disaggregation in distribution. More players in distribution are expected to drive efficiency gains through means such as benchmark competition.

- More disaggregation in distribution drives electricity tariffs down, most likely as a result of benchmark competition and less collusion between players in the market.

- Higher competition in generation is significantly associated with higher sustainable environmental outcomes, reducing the carbon emissions from fossil fuels.

\section{Differential Impact of Disaggregation in Groups A and D}

- Higher disaggregation of the generation segment of the market when interacted with Group A is significantly associated with enhanced access and more sustainable levels of $\mathrm{CO}_{2}$ emissions generated by fossil fuels. This result reflects the benefits to the users as well as to the environment due to increased efficiency of use of fossil fuels when more players are introduced. For Group D a trade-off emerges between reduced access, but a more sustainable level of $\mathrm{CO}_{2}$ emissions generated by fossil fuels.

- Reduction in the concentration of the distribution segment of the market for the countries belonging to Group A is positively and significantly linked with enhanced operational efficiency, but there are no links with enhanced financial efficiency. This result implies that 
for Group A countries their level of tariff is already so high that there are decreasing returns to scale. Reduction in the concentration of the distribution segment of the market for the countries belonging to Group D is negatively linked with operational and financial efficiency, but not significantly so.

\section{Regulation}

- The introduction of an autonomous regulator is significantly and positively associated with higher access, confirming that regulators can also help ensure that contracts are effectively designed.

- The presence of an autonomous regulator has also significantly contributed to higher labor productivity, most likely by creating a more even playing field to attract private participation in distribution.

- The presence of an autonomous regulator is also significantly and positively associated with higher tariffs, reflecting the need to insulate crucial decisions related to pricing from political interferences.

- The presence of an autonomous regulator is also significantly associated with lower carbon emissions, proving that overall environmental considerations have achieved a higher priority compared to the traditional functions of energy policy and regulation, such as to protect consumers from high prices and ensure that power companies will be able to recoup their investment.

\section{Differential Impact of Regulation in Groups $A$ and $D$}

- The introduction of an autonomous regulator when interacted with Group A is significantly associated with enhanced access, higher operational efficiency, lower tariffs, and a more sustainable level of $\mathrm{CO}_{2}$ emissions generated by fossil fuels. These results reflect the benefits to the users, producers, and the environment due to increased efficiency in the use of fossil fuels. In contrast, the introduction of an autonomous regulator when interacted with Group D is significantly associated with reduced access, lower operational efficiency, and higher tariffs, all of which reflect a lack of benefits to users and producers. The introduction of an autonomous regulator is, however, associated with a more sustainable level of $\mathrm{CO}_{2}$ emissions generated from fossil fuels, as well as to the environment. This result underscores the challenges in implementing regulatory reforms in this group of countries.

\section{Private Sector Participation}

- The introduction of private sector participation in generation also is significantly linked to access expansions, proving that IPPs and divestiture 
of formerly state-owned generators can deliver positive results. The introduction of private sector participation also helps to significantly enhance operational efficiency and labor productivity in distribution.

- A higher share of private sector participation significantly raises the level of tariffs, most likely reflecting the need for higher tariffs to attract private participation in distribution.

- Private ownership in generation is also significantly and positively associated with less environmental sustainable outcomes, raising the carbon emissions from burning fossil fuels.

\section{Differential Impact of Private Sector Participation in Groups A and D}

- The introduction of private sector participation in the generation segment of the market when interacted with Group A is not significantly associated with access or carbon emissions generated from fossil fuels. This finding implies that for Group A countries the achieved level of access is already so high that privatization of generation is not sought to enhance connectivity. There is also no significant evidence of environmental unsustainability results brought by the private sector in generation. The introduction of private sector participation in the generation segment of the market in Group D countries is significantly associated with reduced level of access, but is not significantly linked to the carbon emissions generated by fossil fuels.

- The introduction of private sector participation in the distribution segment of the market for Group A countries is positively and significantly linked with enhanced operational efficiency, but not with enhanced financial efficiency. Instead, the overall link between private sector participation in distribution and tariff was positive and significant, reflecting that to attract the private sector more cost reflective tariffs were needed. This seems to imply that for Group A countries the already achieved level of tariff is enough to attract private sector participation in distribution. The introduction of private sector participation in the distribution segment of the market for Group D countries is negatively and significantly linked with operational efficiency, but not with enhanced financial efficiency.

\section{Control Variables}

- As expected, countries with higher incomes or larger system size are characterized by significantly higher levels of access, labor productivity, and tariffs. The links with environmentally sustainable outcomes are 
different. Ceteris paribus, as one would expect, higher-income countries are positively associated with higher carbon emissions, whereas countries characterized by larger system size are negatively and significantly associated with lower carbon emissions. The latter result is most likely due to the presence of economies of scale and that smaller and isolated systems are in many cases mostly dependent on oil imports and find it more difficult to diversify sources of energy.

- The interacted term between per capita GDP and power system size is negative, revealing decreasing returns to scale by the highest-income countries, such as countries belonging to the Organisation for Economic Co-operation and Development, which have already achieved close to universal access and face an exponentially increasing cost in connecting each new consumer as they approach full coverage. The explanatory power of these variables is very high, reaching 90 percent in the preferred specification of random effects.

Table ES.2 summarizes the analytical evidence for these results.

Figure ES.1 compares the average performance levels of all the selected countries as a group with the average levels for the country Groups A and D over the ten-year period 1999-2009 in terms of the four main performance indicators: access, energy sold per employee, tariff, and emissions index. Group A countries consistently outperform Group D countries on all indicators. Yet the trends for all performance indicators are rising—improving—for all country groups over this period. 
Table ES.2 Summary of Analytical Evidence Positive and Negative Results in Groups A and D

\begin{tabular}{|c|c|c|c|c|c|c|c|c|c|}
\hline \multirow[b]{2}{*}{ Group } & \multicolumn{2}{|c|}{ Access } & \multicolumn{2}{|c|}{ Labor productivity } & \multicolumn{2}{|c|}{ Tariff } & \multicolumn{3}{|c|}{ Emissions index } \\
\hline & $A$ & $D$ & $A$ & $D$ & $A$ & $D$ & $A$ & & $D$ \\
\hline \multicolumn{10}{|c|}{ Vertical unbundling (either partial or full) } \\
\hline Unbundling & \multicolumn{2}{|c|}{-} & \multicolumn{2}{|c|}{-} & \multicolumn{2}{|c|}{$+^{* *}$} & \multicolumn{3}{|c|}{$+^{*}$} \\
\hline Unbundling* group & $+^{* * *}$ & - - *** $^{* *}$ & - & $+^{*}$ & - & + & $--^{* *}$ & & $+^{* *}$ \\
\hline \multicolumn{10}{|l|}{ Full vertical unbundling } \\
\hline Full unbundling & \multicolumn{2}{|c|}{+} & \multicolumn{2}{|c|}{$-{ }^{*}$} & \multicolumn{2}{|c|}{$+* * *$} & \multicolumn{3}{|c|}{+} \\
\hline Full unbundling* group & $+^{* * *}$ & $--^{* * *}$ & - & $+^{*}$ & $--^{* * *}$ & $+^{* * *}$ & $--^{* * *}$ & & $+^{* * *}$ \\
\hline \multicolumn{10}{|l|}{ Degree of disaggregation } \\
\hline Disaggregation & \multicolumn{2}{|c|}{$+^{* * *}$} & \multicolumn{2}{|c|}{+} & \multicolumn{2}{|c|}{$-{ }^{* * *}$} & \multicolumn{3}{|c|}{$-{ }^{* * *}$} \\
\hline Disaggregation* group & $+^{* * *}$ & $-^{* * *}$ & $+^{* *}$ & - & + & - & $-{ }^{* * *}$ & & $-^{* * *}$ \\
\hline \multicolumn{10}{|l|}{ Regulation } \\
\hline Regulation & \multicolumn{2}{|c|}{$+{ }^{* * *}$} & \multicolumn{2}{|c|}{$+{ }^{* * *}$} & \multicolumn{2}{|c|}{$+^{* * *}$} & \multicolumn{3}{|c|}{$-{ }^{* * *}$} \\
\hline Regulation* group & $+^{* * *}$ & $-{ }^{* * *}$ & $++^{* * *}$ & $-{ }^{* *}$ & $-{ }^{* * *}$ & $+^{* * *}$ & $+^{* * *}$ & & $--^{* * *}$ \\
\hline \multicolumn{10}{|l|}{ Privatization } \\
\hline Privatization & \multicolumn{2}{|c|}{$+^{* * *}$} & \multicolumn{2}{|c|}{$+^{* * *}$} & \multicolumn{2}{|c|}{$+^{* *}$} & \multicolumn{3}{|c|}{$+^{* * *}$} \\
\hline Privatization* group & + & $-{ }^{*}$ & $+{ }^{* *}$ & $-{ }^{* *}$ & + & - & - & & + \\
\hline \multicolumn{10}{|l|}{ Control variables } \\
\hline GDP per capita & \multicolumn{2}{|c|}{$t^{* * *}$} & & & & & & + & \\
\hline Installed capacity & & & & & & & & $-* * *$ & \\
\hline GDP per capita* capacity & & & & & & & & $+^{* * *}$ & \\
\hline Explanatory power & & & & & & & & & \\
\hline Within R2 (fixed effect) & & & & & & & & 22 & \\
\hline Between R2 (random effect) & & & & & & & & 30 & \\
\hline
\end{tabular}

Source: An elaboration from the Power Market Structure database.

Note:****** indicate, respectively, level of significance of 10,5 , and 1 percent 


\section{Figure ES.1 Power Sector Performance Indicators over Time}
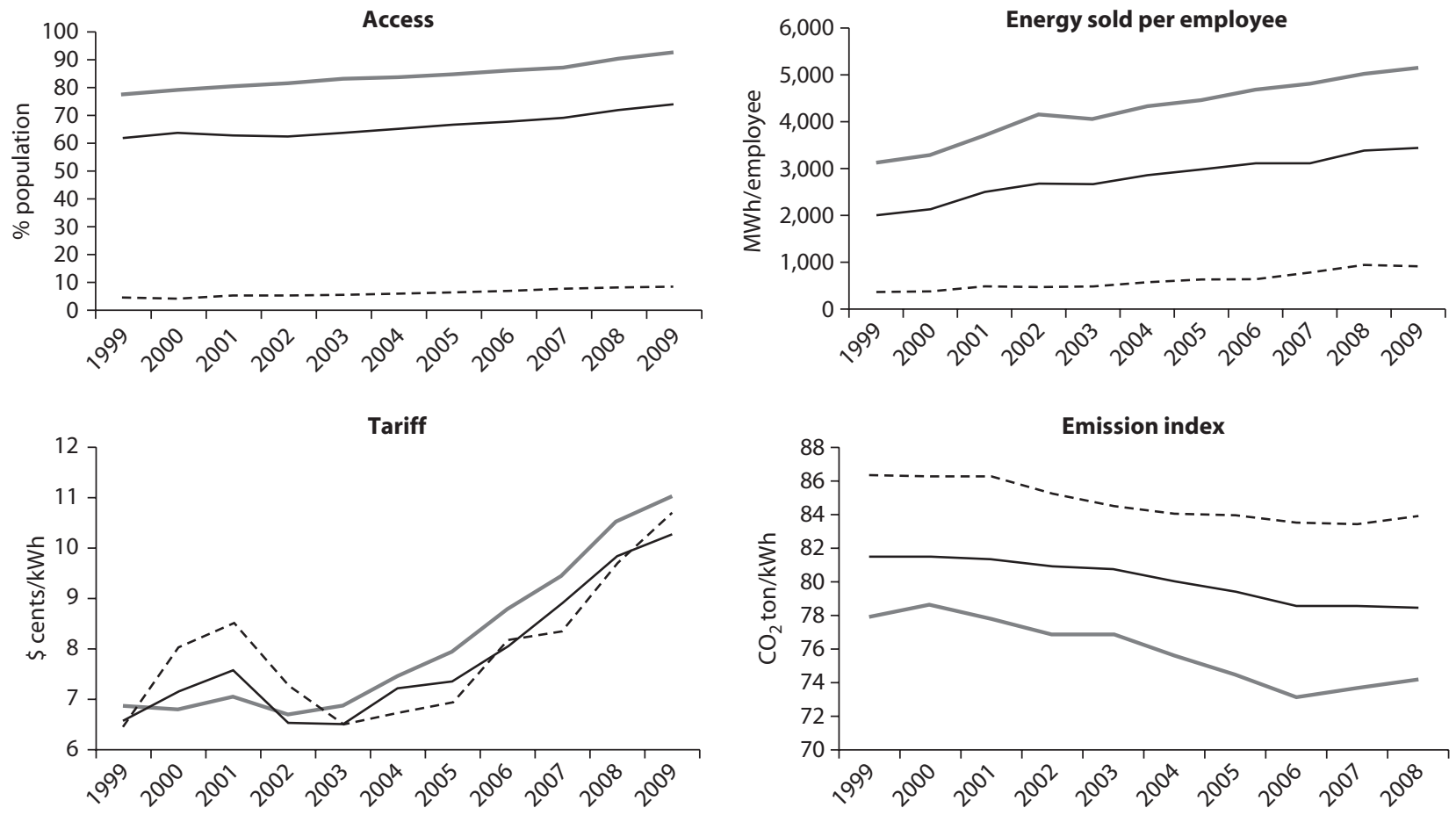

PART 1

\section{Power Market Structure and Performance: Evidence from a Global \\ Database}





\section{Power Market Structure and Performance: Analytical Framework}

\section{Introduction}

This study represents a crucial component of a work program on how to improve the performance of power sector providers. One of the key objectives of the work program is to explore the links and interaction between internal and external governance and the performance of infrastructure service providers, as illustrated in figure 1.1. Market structure is one of the key external governance mechanisms that can impose discipline on infrastructure to improve performance.

The design of market structure is often the starting point for overall reform in the power sector, having a major effect in shaping all other key decisions, including the design and structure of the contracts and decisions on prices. Accordingly, market structure has a powerful influence on whether and to what extent the electricity sector can achieve improvements in performance.

Market structure also affects performance in the power sector. If poor decisions are made on the electricity market structure-technology and the timing of investment-cost increases will be passed to consumers with negative consequences for economic performance and social welfare. This 
Figure 1.1 A Holistic Approach to the Governance Evaluation Framework at the Enterprise Level

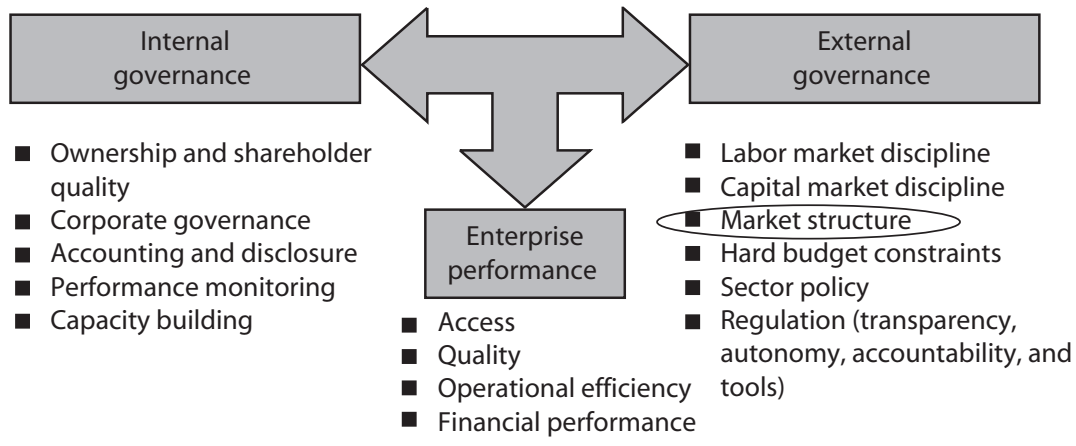

Control variables

(Legal and business environments, income and demographics, path of reform, and other idiosyncratic political economic factors)

Source: Vagliasindi 2012.

proposal looks in a systematic way at the links between alternative market structures and access, quality, and operational and financial performance in the electricity sector. The institutional model of a publicly owned monopoly industry means risks are shifted disproportionately to consumers or taxpayers. Because of information asymmetries, the regulator is unlikely to get a complete picture of costs and potential efficiency gains.

Alternative models have emerged for the electricity market. The first is competition for access to the market, including variations of the singlebuyer model. The private sector is encouraged to invest in new power generation capacity through tenders or auctions. If well managed, competition can result in improved efficiencies in technology and investment choices. When a comprehensive restructuring of power sectors is not technically feasible or politically desirable, the single-buyer model is the only remaining alternative to attract private capital. Arizu, Gencer, and Maurer (2005) provide an extensive review of how this concept was implemented and changed over time, and what arrangements have been introduced to overcome its drawbacks, while preserving its positive attributes. The second electricity market model involves competition between electricity generators and suppliers to provide power to consumers. In the latter model, competition is managed through a power exchange or bilateral markets or both, and market risks can be managed through derivative financial markets. 
Since the early 1990s about half of the 150 developing countries have embarked on reforming their power markets in response to poor technical and financial performance and the lack of public financing needed to expand the power supply (Besant-Jones 2006). Most of these countries have restructured their power supply arrangements by at least some or full vertical unbundling of generation, transmission, and distribution. The remaining countries have retained the traditional structure of a full or partial vertically integrated monopoly, in some cases because they felt it impossible or undesirable to embark on any reform strategy that entails opening electricity production or sales to private participants. A new emerging trend in a few developing countries is to revert from an unbundled structure toward a vertically integrated one (Vagliasindi and Izaguirre 2007).

To better inform the policy dialogue between donors and the World Bank's client countries, we need to see which alternative market structures performed best. The results of this work are expected to be crucial in providing policy advice by offering alternative options to policy makers based on the lessons learned from the taxonomy of different market structures. Policy makers in the client countries and the international community of experts in energy infrastructure are the primary audience of this work. The project is also intended to provide insights in order to better form policy recommendations/operational guidelines in this area that would be useful for international financial institutions in their policy dialogue with the client countries.

\section{What Does Theory Suggest on the Costs and Benefits of Alternative Market Structures?}

The existing variety of power supply structures reflects differing views and a degree of theoretical ambiguity in the economic literature on the effectiveness of unbundling and competition in network industries on issues such as gains from competition versus economies of coordination in vertically integrated systems. In practice, the benefits of each reform and restructuring must more than compensate for the increase in transaction costs of unbundling vertically integrated systems.

The traditional economic arguments against unbundling power systems were based on the following concepts: (1) electricity as a public good, as vertical integration will better ensure service reliability and uniform standards and procedure among interconnecting segments of the grid; (2) natural monopoly, as a means to avoid wasteful duplication 
of transmission and distribution ( $\mathrm{T}$ and $\mathrm{D}$ ) networks; (3) economies of scale, as horizontal integration supports the large size and capital requirement of efficient plants (hydro and coal-based load plants), although such arguments are weakened when smaller combined cycle units became more cost effective; (4) economies of scope, as tight coordination (centralized investment and operation) translates into savings in metering, billing, and so forth; (5) economies of transaction costs, due to reduced costs because of asset specificity and incompleteness of contracts; and (6) better management of investment and operational risks.

But these arguments might not hold in some country and power market conditions because they are based on specific underlying assumptions that are not valid in these conditions, including the following: (1) capital for the power utility will have a lower cost; (2) the creditworthiness of a power utility requires that it be the sole buyer of generated power; (3) third-party access should be prevented to support cross-subsidies among consumers that are mandated under government policies; and (4) savings coming from competitive pressures (to reduce costs) are minor when compared to economies of scale and scope. They ignore postrestructuring changes, including the introduction of new regulatory policies and market structures that can solve the "problem" of unbundling, but whose overall impact might go either way. For example, although integration may increase retail market power, this outcome may not be detrimental; rather, it may preserve or even enhance generation investment incentives (Dupuy 2006). In practice, there may be trade-offs between these objectives in developing countries, notably between economic efficiency and social objectives, that could be incorporated into operational guidance (World Bank 2004).

An alternative view is based on financial risk management rather than economic concepts: namely, that an optimal degree of integration can exist. Such an optimal degree of integration (Chao, Oren, and Wilson 2005, 2008) lies between total integration and total unbundling. The degree depends on the mutual interest of generators and retail services providers in mitigating "systemic" risks through the provision of (physical and financial) reserves and contracting under unbundling. This view asserts that such risks were not sufficiently taken into account when unbundling began. Retail utilities need this integration even when the cost of energy is passed through because they continue to serve a large contingent of core customers-mostly residential and small consumers-who rely on intertemporal smoothing of supply costs in their retail rates. 


\section{What Does Empirical Evidence Suggest on the Costs and Benefits of Alternative Market Structures?}

The economic literature reviewed in the previous section suggests that there were substantial vertical economies associated with networks. To date, however, there is limited evidence on the (relative) success in the implementation of vertical unbundling and its links with enhanced investment (particularly in transmission) and ultimately with the improvement of power utilities performance, particularly where shortterm privatization is out of the realm of possibilities.

The (relative) success needs to be assessed against the objectives of unbundling - which could have been to enhance transparency and governance, attract private sector investment, and/or create a competitive market and ultimately its impact on performance. In some cases restructuring aimed to create an enabling environment to attract private sector investment to take some level of market risks and/or commitments to efficiency improvements. Transferring market risks to the private investor requires greater transparency and predictability, which may be more difficult to obtain in a sector with an integrated monopoly power utility to which, for example, the private generator is obliged to sell.

Little analysis of empirical evidence about unbundling in power markets has been published, and what there is focuses on economically advanced countries. Kwoka (2002) studied the U.S. system extensively to measure economies of coordination between generation and distribution for about 150 U.S. electric utilities with a wide range of size and degree of vertical integration that operate in regional power pools. He concluded that the least integrated distributors incur on average significantly higher total costs than the most integrated $(6.27$ \$ cents/kWh [kilowatt-hour] versus $5.35 \$$ cents/kWh). But this difference increased markedly with utility size. The smallest utilities-those nearer in size to utilities in developing countries-showed small diseconomies of coordination. The largest utilities showed substantial economies of coordination (higher than 50 percent). Two studies report much lower economies of vertical integration. Nemoto and Goto (2004) estimate that the cost efficiency gain from vertical integration in 9 Japanese utilities varies from 0.2 percent to about 3 percent. Based on the sample of Spanish electricity utilities, Jara-Diaz, Ramos-Real, and Martinez-Budria (2004) conclude that about 7 percent of costs can be saved from joint generation and distribution. Despite providing useful insights, these studies are not relevant to 
developing countries, because of the large differences in economic conditions between advanced and developing countries.

Two later studies expand the available empirical analysis of vertical unbundling. Arocena, Coelli, and Saal (2009) studied the economies of integration (economies of scale and of scope) for a group of 116 investorowned power utilities in the United States based on data for 2001. The results provided a reference for the expected cost of unbundling. The researchers concluded that vertical integration provided a substantial and significant cost saving relative to vertical unbundling and that horizontal integration in the generation sector provided a further-but smallercost saving relative to horizontal unbundling. Taken together, global savings from integration amount to as much as 12.5 percent of costs for the sample average firm. Such savings indicate a level of anticipated gains needed to justify unbundling. Meyer (2010) applied a frontier benchmarking approach to measure the economies of scope between the vertical stages of electricity supply in the U.S. electric industry. Meyer's study concluded that the costs of separating the generation stage from networks and retail stages compared to integration is strongly related to the size of the utility. For the larger utilities in the sample, this type of separation lowers overall costs because the gains exceed synergy losses, whereas for the smaller utilities this type of separation increases overall costs. The threshold size that divides utilities whose costs decrease from those that increase is about 10,000 to $12,000 \mathrm{GWh}$ (gigawatt-hours) of annual generation and distribution.

There is also some published evidence about the links between integrated power systems and country-level corruption for the European Union (EU). Both for the EU-15 member states and the 10 new member states (NMS-10), the more corrupt the countries, the more likely they are to choose a weak unbundling regime, even though the results are stronger in the EU-15 member states (van Koten and Ortmann 2007).

A main unanswered question about unbundling and the establishment of liberalized wholesale markets is whether in the long run they provide adequate investments in capacity. The California electricity crisis of 2000-01 brought this issue powerfully forward. But the basic problemthat generation companies face higher capital costs now than the utilities did in the regulated era-is increasingly important in countries where some generators are in financial distress.

In developing countries there is evidence of the benefits brought by unbundling when it is associated with increased investment in generation and transmission. This result holds mainly when the institutional 
environment is sufficiently robust to attract credible independent power producers (IPPs). In this context, opening the generation segment of the market to competition may help cash-strapped governments increase investment in generation. The major problem-particularly acute in challenging institutional environments - is the high cost of procuring IPPs, resulting in charges that eat up a large portion of the revenues of the distribution companies that must purchase the electricity generated. Tanzania Electric Supply Company (TANESCO), for example, paid about 70 percent of its total average monthly revenues in 2005 to meet IPP charges; by 2006 these expenses had risen to an astonishing 95 percent (Ghanadan and Eberhard 2007). There is also anecdotal evidence that vertically integrated structures invest less in transmission, but this link needs to be tested.

\section{What Do We Know about the Taxonomy of Market Structures?}

The distinction between integration and unbundling of power supply arrangements is not clear cut in practice, as several different structures exist around the world:

- Vertical unbundling without horizontal unbundling (but not the reverse)

- Partial vertical unbundling (generation and transmission separated from distribution, generation separated from transmission and distribution, and so forth)

- Full vertical and horizontal unbundling in generation (and integration of transmission and distribution)

- Vertical unbundling in lesser forms than ownership unbundling, such as accounting, management, and legal (holding company) unbundling

- Unbundling of retail supply from distribution, and then some reintegration of generation with supply for risk management, keeping transmission and distribution unbundled

- Unbundling of generation services in wholesale power markets

In addition, unbundling can take lesser forms than full ownership unbundling. These forms include unbundling by legal/corporate means in holding companies, by internal management structure, and just by accounts. The conventional view is that the potential benefits from unbundling are greatest with full ownership unbundling, and that benefits decline with lesser forms of unbundling. Where country and market 
conditions cannot support privatization of fully unbundled power suppliers, such as in the highly suboptimal environments found in many developing countries, other forms of unbundling and associated publicprivate participation have to be adopted as the best solutions in practice, even if second-best in theory.

The objectives of unbundling and restructuring vary. In some cases restructuring had the purpose of creating an enabling environment to attract private sector investment taking some level of market risks and/or commitments to efficiency improvements. Transferring risks to the private investor market requires greater transparency and predictability, which may be more difficult to obtain in a sector with an integrated monopoly power utility to which, for example, the private generator is obliged to sell.

So far we do not have a comprehensive taxonomy of all the different forms of horizontal and vertical unbundling. We do, however, know that countries that have embarked on reform have generally progressed to different stages, which can be categorized in ascending extent of reform as follows (for more details, see Besant-Jones 2006):

- Vertical integration-a vertically integrated monopolist

- Vertical integration with IPPs-a vertically integrated monopolist with independent power producers that sell power to it

- Some extent of vertical and horizontal unbundling-a national generation, transmission, or distribution entity; a combined national generation and transmission entity; or a combined transmission and distribution entity acting as the only wholesale power trader (single buyer) with IPPs that sell power to it and regional distribution entities unbundled from the monopolist that buys power from it

- Extensive vertical and horizontal unbundling-many distribution entities and generation entities and a transmission entity formed from unbundling the monopolist, in which the transmission entity acts as a single buyer of power from the generators and IPPs and sells power to the distribution entities and large users of power

- Power market—an organized market of generation entities, distribution entities, and large users, in which power is traded competitively, supported by a transmission entity, a power system operator, and a power market administrator

Reform to date, however, is unevenly spread among regions (see figure 1.2). Countries in Latin America and the Caribbean and in 
Figure 1.2 Distribution of Stages of Reforms and Market Structures in the Power Sector by Region
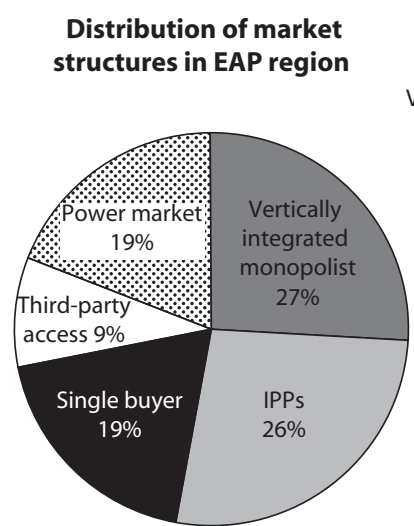

Distribution of market structures in LAC region

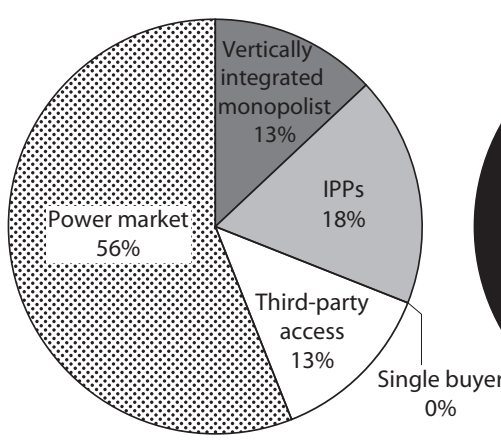

Distribution of market structures in SAR region

Power market - Third-party access

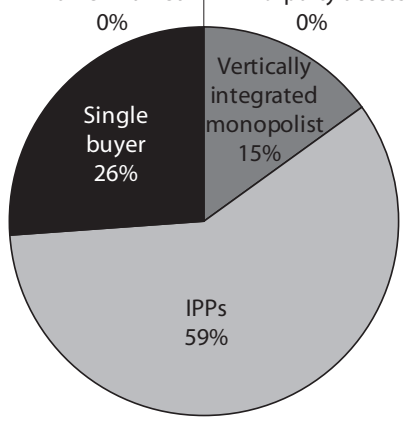

\section{Distribution of market} structures in ECA region

Vertically integrated IPPS

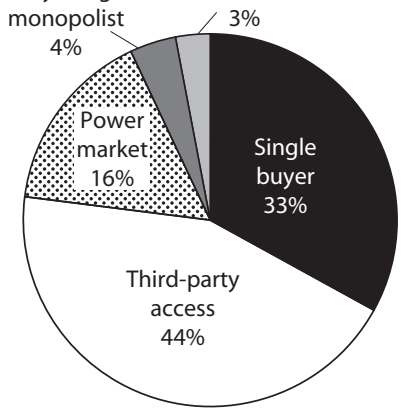

Distribution of market structures in MNA region

Power market $T$ Third-party access

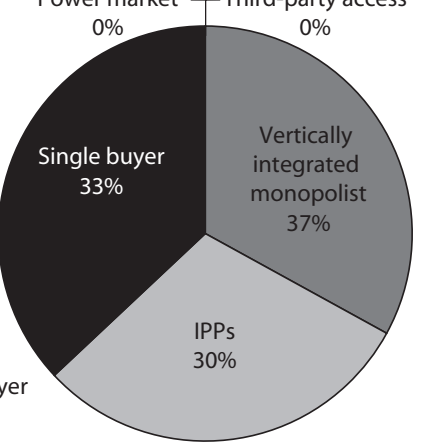

\section{Distribution of market} structures in SSA region

Power market - Third-party access

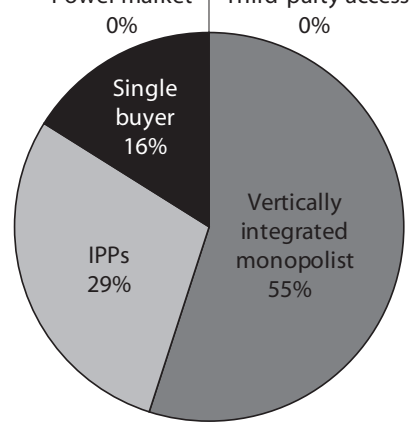

Source: An elaboration based on Besant-Jones 2006.

Note: $\mathrm{EAP}=$ East Asia and the Pacific, ECA = Eastern Europe and Central Asia, LAC = Latin America and the Caribbean, MNA = Middle East and North Africa, SAR = South Asia, SSA = Sub-Saharan Africa. 
Europe and Central Asia (ECA) account for all the countries that have progressed to the two most advanced stages. In Africa, South Asia, and the Middle East, progress to date is generally limited to the first two stages with long-term contracts by IPPs to supply incumbent utilities. Some countries in East Asia have made tentative steps to further their reforms.

The current distribution of power markets around intermediate structures between full integration and full unbundling suggests that there has not been a linear path to reform in practice. Instead, many developing countries may retain intermediate structures for the foreseeable future. This possibility exposes a large gap in understanding about power market structures, as most theoretical work has focused on the two extreme structures, and we have limited evidence on the impact of unbundling for developing countries. Nagayama (2007) finds that the introduction of IPPs contributes to lowering the industrial prices at least in some developing regions, such as ECA, whereas unbundling of generation from transmission increased industrial and residential prices in the same regions. Basically, it appears that unbundling in most developing countries is undertaken for reasons other than or in addition to the introduction of competition, which is the purpose generally advanced in the theoretical literature. One of the purposes of the proposed task is therefore to obtain a better understanding of these developments and the policy requirements for successful outcomes under the intermediate market structures in the economic, social, and political conditions of developing countries. More detailed analysis is needed to better understand the costs and benefits of unbundling and the characteristics of well-functioning unbundled power systems.

\section{Objectives}

The study has two objectives: first, to map the existing approach to vertical and horizontal unbundling adopted by developing countries and, second, to undertake an econometric analysis and detailed case studies to better understand and assess the desirability of unbundling under conditions in developing countries.

The specifics goals are

- To develop a taxonomy of the existing power market structures, as shown by the extent of vertical and horizontal unbundling found among restructured power systems, across developing countries; 
- To design an analytical framework for assessing the desirability of unbundling (or once unbundled) and reintegration under the variety of economic conditions found in developing countries by comparing economic costs and benefits and accounting for transaction costs and financial risk management considerations. The analytical framework will use inter alia specific performance indicators to guide the comparisons across different market structures;

- To propose insights to operational guidance on alternative market structures based on relevant criteria, in particular on initial conditions including but not restricted to power system size and income per capita, which can address issues such as whether there are solid foundations for recommending vertical unbundling for small power systems in low-income countries, particularly in the absence of short-term privatization prospects. The proposed policy recommendations will be tailored to the specific taxonomy of market structures that characterize the electricity sector in developing countries.

\section{Key Questions}

To achieve such objectives, we need to address the following questions:

- Is there a credible empirical basis for selecting a threshold power system size and per capita income level below which market competition is not expected to be worthwhile, and under which alternative agreements, such as participatory poverty assessments with IPPs selling to an integrated supplier, may be preferable?

- Is there a threshold power system size below which increased transaction costs begin to exceed the benefits of unbundling the power supply industry? Is power system size the primary consideration for determining whether vertical unbundling of a power supply industry is worthwhile? If not what other considerations are relevant?

- Should threshold levels for power system size and per capita national income be adopted as an operational guide to the choice of unbundling? In particular, should vertical unbundling be recommended for small power systems in low-income countries, particularly in the absence of short-term privatization prospects?

- How should the policy recommendations be adapted for a country that wants to privatize its power supply and transfer market risks to 
private generators? Alternatively, how should policy recommendations be adapted for a country where privatization of power supply is not possible?

- Which policy instruments could be used to tackle policy issues related to the taxonomy of the different market structures? In particular, what can be done to improve the key decisions on contracts and prices internalized within the power company through the existing structure/ ownership and those that have been delegated to outside contracts/ market rules, depending on the transaction costs involved?

\section{Analytical Framework}

This study examines in detail some selected issues related to market structure in the power sector. While recognizing the potential influence of additional issues pertaining to the broader set of reforms in the power sector, the study applies the ceteris paribus approach. The stylized approach to examine market structure in the power sector is illustrated in figure 1.3. As the form and extent of unbundling determines the market structure, particular attention is devoted to the analysis of key decisions through the structure/ownership lens vis-à-vis contracts/market rules.

Figure 1.3 Stylized Framework of Market Structure in the Power Sector

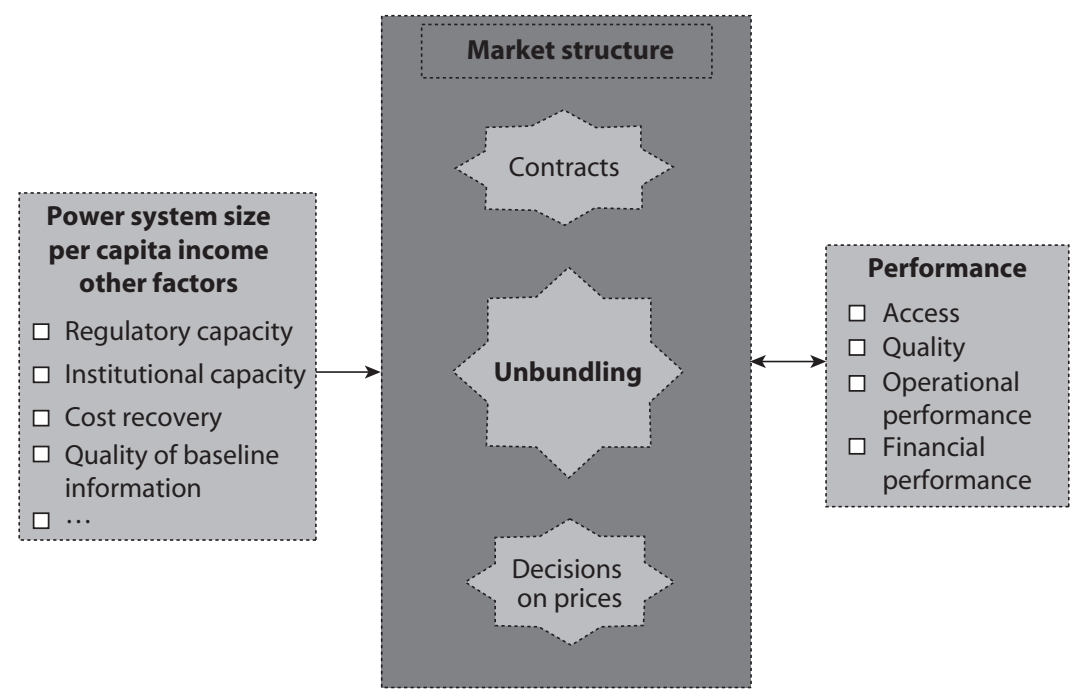

Source: An elaboration from the Power Market Structure database. 
The key decisions that are included in the analytical framework pertain to the contracts between the newly unbundled entities and decisions about prices. Unbundling decisions involve the contract provisions that are allowed-or in some cases are compulsory-among the unbundled entities in generation, transmission, and distribution. Unbundling implies a decision on prices, related to generation auctions and to the prices charged to wholesalers and whether these are passed through to end users.

Other considerations can come into play in determining the market structure. For a switch from one market structure to another, transitional costs may be also a relevant consideration in deciding the market structure. For example, in moving from a single-buyer model to a wholesale market, stranded costs must be evaluated and settled, including generation-related costs that become unrecoverable due to restructuring and retail competition. Finally, the existence of a regional power market may affect the choice of a country's market structure. Such issues will be considered on a case-by-case basis.

Unbundling is not an end itself, but rather a means to achieve better performance. Accordingly, the principal objective of the analytical framework is to explore the links between alternative market structures and performance in terms of access, price, quality, and technical and financial performance. The results are crucial for providing policy advice, by offering alternative options to policy makers based on the lessons learned from the taxonomy of different market structures, tailored to different national peculiarities.

\section{Methodology}

Jamasb et al. (2004) classified the approaches to analyzing electricity reforms into three broad categories: econometric methods, efficiency and productivity analysis methods, and comparative case studies. They argue that econometric studies are best suited to the analysis of well-defined issues and the testing of hypotheses through statistical analysis of reform determinants and performance. Efficiency and productivity analyses are suitable for measuring the effectiveness with which inputs are transformed into outputs, relative to best practice. They also maintain that single-country or multicountry case studies are suitable when in-depth investigation or qualitative analysis is needed. Within this classification, our study well suits the first and third category. Both an analytical and case study approach is used to investigate the design of market structure 
in detail. The analytical approach is used to draw robust links between the alternative market structures and performance.

The case study approach is suited to dealing with the strong influence of country-specific effects on power market performance and reform outcomes. A major disadvantage of this approach is that it will be hard to generalize results, in light of the small sample of enterprises, but we try to the extent possible to overcome some of the limitations of the case studies approach through a careful design of the sampling frame.

\section{Analytical Approach}

Our study proposes an analytical approach to model market structure $(\mathrm{M})$, together with ownership $(\mathrm{O})$, regulation $(\mathrm{R})$, controlling for several variables, as determinants of performance across several indicators of performance $(\mathrm{P})$, including access, operational and financial performance, and environmental sustainability.

$\mathrm{P}_{\mathrm{t}}=f\left(\mathrm{O}_{\mathrm{t}}, \mathrm{M}_{\mathrm{t}}, \mathrm{R}_{\mathrm{t}}, \mathrm{E}_{\mathrm{t}}\right)$

where:

$\mathrm{P}=$ performance variables (e.g., access, operational and financial efficiency, and environmental indicators)

$\mathrm{O}=$ ownership (e.g., public vs. private ownership)

$\mathrm{M}=$ market structure (e.g., degree of vertical integration, degree of concentration)

$\mathrm{R}=$ introduction of an autonomous regulator

$\mathrm{E}=$ endowment (e.g., size of the system)

$\mathrm{t}=$ time

This methodology represents a novelty with respect to most empirical studies. To date, there has been limited empirical work that includes market structure variables in the analysis, particularly for developing countries. Only a few variables of performance have been used in the literature, and no evidence has been reported on the impact of reforms in terms of environmental sustainability.

\section{Case Study Approach}

A series of country case studies was conducted to support the analytical approach. The selected countries cover all six developing country regions and reflect broad regional features such as Africa's low access rates and underdeveloped transmission networks; ECA's full access rates, highly developed transmission interconnections, historically surplus 
generating capacity, and the strong influence from the EU and Russia; Latin America and the Caribbean's (LAC) leadership in market reform and large amounts of hydropower capacity; East Asia's and South Asia's high growth in power demand and therefore need for generation capacity; and the Middle East and North Africa's (MNA) emergence as a strategic crossroads in energy trade.

The case studies are predicated on the hypothesis that power system size and per capita income appear to influence the choice of power market structure in developing countries. A clear empirical threshold for unbundling power systems currently separates developing countries into groups. That threshold is power system size of 1,000 MW (megawatts) and country annual per capita income of $\$ 900$. The majority of countries, 49 out of 70 , with unbundled power systems lies above both of these criteria (see the A quadrant as reported in figure 1.4a). From the distribution of countries for unbundled and vertically integrated power market structure, it can be surmised that power system size has a relatively stronger influence than per capita income on determining the market structures. On the other hand, country income level may have a relatively stronger influence than power system size on the roles of the public and private sectors and market regulation.

The performance of countries with unbundled power sectors is compared to the counterfactual of countries that have a vertically integrated structure. This comparison is undertaken within each of the four groups of countries determined by the threshold levels of system size and country annual per capita income (figure 1.4). We refer to the four groups of countries as Groups A, B, C, and D. Group A consists of countries in which both power system size and per capita income are above the threshold levels. Groups B and C are those countries in which either power system size or per capita income is below one of the threshold levels. In Group D countries, power system size and per capita income are both below the threshold levels. Additional control variables, including ownership structure and-more important-governance variables, will be taken into account, including those able to capture institutional and political economy dimensions.

Unbundling can also be expected to enhance governance through increased transparency and reduction of the scope for corruption, for example, by making subsidies and cross-subsidies more explicit. In this context we explore the link between unbundling and alternative 
Figure 1.4 System Size and Income for Unbundled and Vertically Integrated Systems
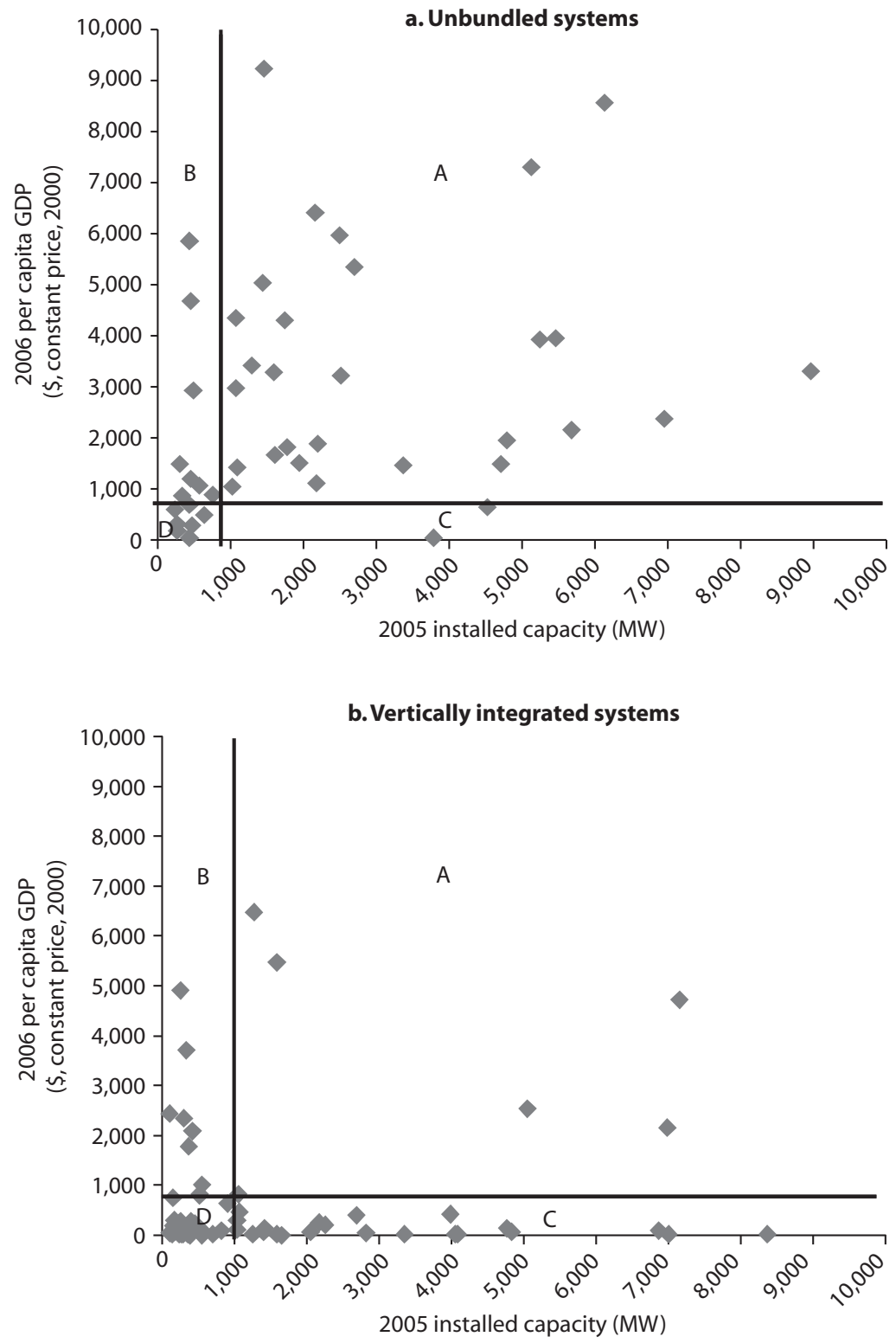

Source: Updated information based on Besant-Jones 2006.

Note: $\mathrm{GDP}=$ gross domestic product; $\mathrm{MW}=$ megawatts. 
indicators of country level governance. Significant differences emerge between country groups:

- Sixty-eight countries out of 155 lie above both threshold levels of power system size and per capita income (Group A). They are perceived to have a medium level of corruption. The Transparency International Corruption Perceptions Index average in 2006 is equal to 3.7, which indicates the presence of some degree of corruption.

- Forty-three countries lie below both threshold levels of power system size and per capita income (Group D). They are perceived to have a relatively high level of corruption. The Transparency International Corruption Perceptions Index average in 2006 is equal to 2.6, which indicates the presence of rampant corruption.

More detailed analysis is needed to better understand the costs and benefits of unbundling and the characteristics of well-functioning unbundled power systems. The analytical framework defines inter alia specific performance indicators both at the enterprise and country level that are used to compare outcomes across different market structures. The data in figure 1.5 show that all the countries that have advanced at power sector reforms lie in Group A. Of the poor countries characterized by a small system (Group D), about 80 percent are characterized by a vertically integrated structure, fewer than 20 percent have introduced IPPs, and only 2 percent have adopted a single-buyer model.

The case studies for each of the groups are as follows:

- Group A: To ensure a representative sample for this category, we selected the following ten countries: the Arab Republic of Egypt, Indonesia, the Republic of Korea, and South Africa, for vertically integrated cases; the Czech Republic for some partial form of unbundling; and Argentina, Brazil, Chile, Peru, and Turkey for the unbundled cases. The performance of the Czech Republic, Egypt, Korea, Indonesia, and South Africa (all of which display either a vertically integrated structure or simply legal unbundling, mainly under a holding structure) is compared with that of Argentina, Brazil, Chile, Peru, and Turkey, which have moved reforms forward by introducing a competitive wholesale market. Chile in 1982 unbundled the sector structure into generation and transmission companies and distribution utilities. The distribution utilities were divided according to the service areas, but they were not 
Figure 1.5 Distribution of Stages of Reforms in the Power Sector by System Size and Income
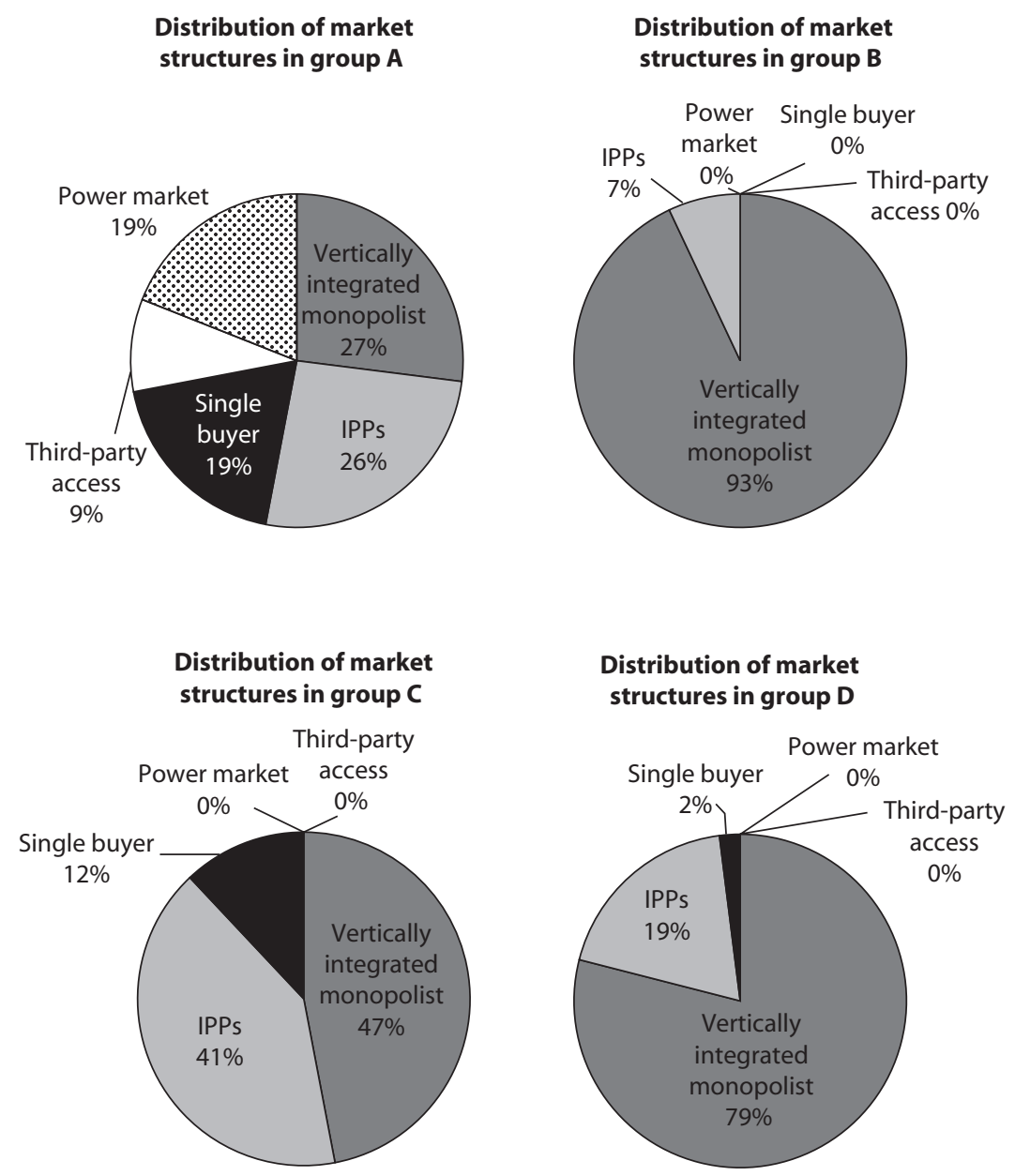

Source: An elaboration based on Besant-Jones 2006. Note: IPPs = independent power producers.

granted exclusive rights. Between 1983 and 1989 Chile's government privatized most of the generation, transmission, and distribution segments, so that all of these functions were in private sector hands through local and international investors and created a mandatory power pool administered by a system operator, Centro de Despacho Económico de Carga del Sistema Interconectado Central. Argentina implemented 
extensive reforms in the early 1990s, including vertical and horizontal unbundling of generation, transmission, and distribution and opening all segments to the private sector. In Peru the structural reform process that started in 1992 led to unbundling of the vertically integrated state monopoly into generation, transmission, and distribution and to the introduction of private operators and free entry and open access. Brazil proceeded in 2005 to the unbundling of Eletrobrás into six holding companies and 14 generation and transmission companies. Eletrobrás retained the ownership of the transmission grid, the Brazilian part of the binational Itaipu Dam and hydroelectric power station, the nuclear power plants, and Centro de Pesquisas de Energia Elétrica's research and development activities. In Turkey a competitive wholesale electricity market went into operation in 2006, after the Turkish Electricity Generating and Transmission Corporation in 2001 was unbundled into three separate state-owned entities: (1) Electricity Generation Company of Turkey for generation; (2) Turkish Electricity Transmission Company (TEIAS) for transmission and dispatch; and (3) Turkish Electricity Trading and Contracting Company, which acts as the single buyer of electricity sold under the power purchase agreements (PPAs), and then sells this electricity to the distribution companies.

- Groups B and C: The performance of countries that have kept a vertically integrated structure, including Barbados, Botswana, Cyprus, and Zambia, is compared with selected countries from East Asia, including Vietnam, some of the Indian power sector regional structures (Andhra Pradesh, Gujarat, and West Bengal) that went further in the process of unbundling, and Jordan from the MNA region, which unbundled the National Electrical Power Company (NEPCO) into three entities. These were (1) a company to own and operate the transmission network and system operation and act as a single buyer for bulk power (this company inherited NEPCO's name); (2) Central Electric Generating Company (CEGCO), which took over all the public generating capacity; and (3) Electricity Distribution Company (EDCO), which took over NEPCO's distribution activities. This move was followed by a major campaign to transfer the state's ownership to the private sector that culminated in 2007 with the sale of 51 percent of the shares in CEGCO, the state's 45 percent shareholding in Irbid District Electricity Company (IDECO), and the state's 100 percent shareholding in EDCO. The first IPP agreement was signed in 2007, and the second IPP in 2009. The case studies proposed subjects for further examination. 
Recently, Andhra Pradesh has made the best progress with improving performance under public ownership. Andhra Pradesh's government also has taken the lead in combating theft of electricity by allying with the power companies to take measures to control theft and root out corruption between utility employees and customers. In Gujarat the erstwhile Gujarat Electricity Board was unbundled and reorganized into six successor entities in 2005: Gujarat State Electricity Corporation Limited; Gujarat Energy Transmission Corporation Limited; and four distribution companies, including Dakshin Gujarat Vij Company Limited, Madhya Gujarat Vij Company Limited, Uttar Gujarat Vij Company Limited, and Paschim Gujarat Vij Company Limited (PGVCL). Since unbundling in April 2007, West Bengal State Electricity Board (WBSEB) was separated in hydro generation (along with negligible generation from diesel and gas); transmission, including State Load Dispatch Centre activities; and distribution, trading, and bulk supply activities. In Zambia, ZESCO (Zambia Electricity Supply Corporation) was originally conceived as a step toward privatization; instead, it was instrumental in driving commercialization and technical objectives, while maintaining public ownership. The comparative performance of countries with higher income but small system size, including Barbados, Botswana, and Cyprus, that adopted a vertically integrated structure will allow us to test to what extent vertical integration has been successful in integrated small supplier regions as diverse as LAC, SSA, and ECA and in terms of ownership, with Barbados being private since the outset and Botswana and Cyprus fully state-owned.

- Group D: Kenya and Tanzania are compared with Uganda, the only SSA country where a single-buyer model has been introduced. The unbundling of the Uganda Electricity Board (UEB) formally commenced in April 2001. Successor companies were created and assets and liabilities of UEB were transferred to them as follows: (1) Uganda Electricity Generation Co. Ltd (UEGCL), which owns the two major hydropower plants at Nalubaale (180 MW) and Kiira (200 MW); Uganda Electricity Transmission Co. Ltd. (UETCL), which owns and operates the transmission infrastructure above $33 \mathrm{kV}$ (kilovolts); (2) Uganda Electricity Distribution Co. Ltd. (UEDCL), which owns and operates the distribution network at $33 \mathrm{kV}$ (kilovolts) and below; and (3) UEB, a statutory corporation, which remained in place in order to wind up. Tanzania is one of the few countries that has undertaken a management contract. From 2002 to 2006 Tanzania Electric Supply 
Company (TANESCO) was placed under a management contract with the private group NETGroup Solutions. The group doubled cash flow in two years mainly due to improved collections. Its subsequent efforts to extend the gains into other operational areas were unsuccessful due to external financial constraints, among other factors. The main problems were poor hydrological conditions that reduced hydropower production and therefore increased purchases of thermal power from IPPs; the high costs of IPP power under the terms of the power purchase agreements; and tariff rates insufficient to allow TANESCO to invest in system improvements. In 2005 Tanzania's government took TANESCO off the list of utilities for privatization. The addition of two thermal power plants developed by IPPs between 2002 and 2004 changed the primary energy mix from power generation from being nearly 90 percent dependent on hydropower to 60 percent dependent on thermal power. In Kenya overall vertical integration in the sector has not changed much, with transmission and distribution now bundled and generation unbundled into a few suppliers. As a result of the public sale of shares in the Kenya Electricity Generating Company (KenGen) and the entry of IPPs to the power market, the proportion of total installed generating capacity under private ownership increased from 16 percent in 2001 to 46 percent since 2007.

The taxonomy of the twenty-two proposed case studies is summarized in table 1.1.

Figures 1.6, 1.7, and 1.8 show scatter plots of our selected sample in the four groups over time, providing a snapshot for 1989, 1998, and 2008, and distinguishing unbundled systems from vertically integrated systems.

The starting time for our samples sees only two Latin American countries (Chile and Brazil) in Group A presenting some form of unbundling. By 1998, five countries in Group A, more than 40 percent of the sample for this group implemented unbundling of the system.

\section{A Cautionary Note}

In cases where power sector restructuring was accompanied by a competitive power market, the results show the combined impact of the two policy reforms. It may not always be easy to disentangle which results were caused only by restructuring and which by competition. Similarly, in those cases where restructuring was accompanied by privatization, the 
Table 1.1 Taxonomy of Case Studies

\begin{tabular}{ll}
\hline Group/country & Type and year of unbundling \\
\hline Group A (large system size and high GDP per capita) & \\
Chile & Functional and ownership, 1982 \\
Argentina & Functional and ownership, 1992 \\
Peru & Functional and ownership, 1993 \\
Brazil & Functional and ownership, 1995 \\
Egypt & Legal, 2000 \\
Turkey & Functional and management, 2001 \\
Czech Republic & Legal, 2001 \\
Indonesia & No unbundling \\
Korea & No unbundling \\
South Africa & No unbundling \\
Group B (small system size and high GDP per capita) & \\
Jordan (from B to A) & Functional and ownership, 1999 \\
Cyprus & Legal, 2004 \\
Barbados & No unbundling \\
Botswana & No unbundling \\
Group C (large system size and low GDP per capita) & \\
Indian State of Andhra Pradesh & Organization, 2001 \\
Indian State of Gujarat (from C to A) & Organization, 2005 \\
Vietnam (from C to A) & Organization, 2005 \\
Indian State of West Bengal (from C to A) & Organization, 2007 \\
Zambia & No unbundling \\
Group D (small system size and low GDP per capita) & \\
Kenya (from D to B) & Legal, 1999 \\
Tanzania & No unbundling \\
Uganda & Functional and management, 2002 \\
\hline Soure:Ane &
\end{tabular}

Source: An elaboration from the Power Market Structure database.

Note: The entries in italic refer to countries that moved from one group to another during the data period.

impact in performance may differ from systems that adopted a comparable sector structure but did not introduce private sector participation. The assessment of the different mix of conditions for the same (or very similar) sector structure and system size may not always be possible, but the work tries to overcome such a challenge, if not through the case study approach then through the systematic analysis, subject to data availability. See Zhang, Parker, and Kirkpatrick (2008). They found the joint impact of restructuring with privatization and/or regulation stronger than the individual impact in terms of performance.

In what follows we report the evidence from (1) empirical evidence of how performance indicators evolved over time and derivation of the links between unbundling and sectoral reforms on the one hand and 
Figure 1.6 Scatter Plot of the Sample of Countries in the Initial Period, 1989

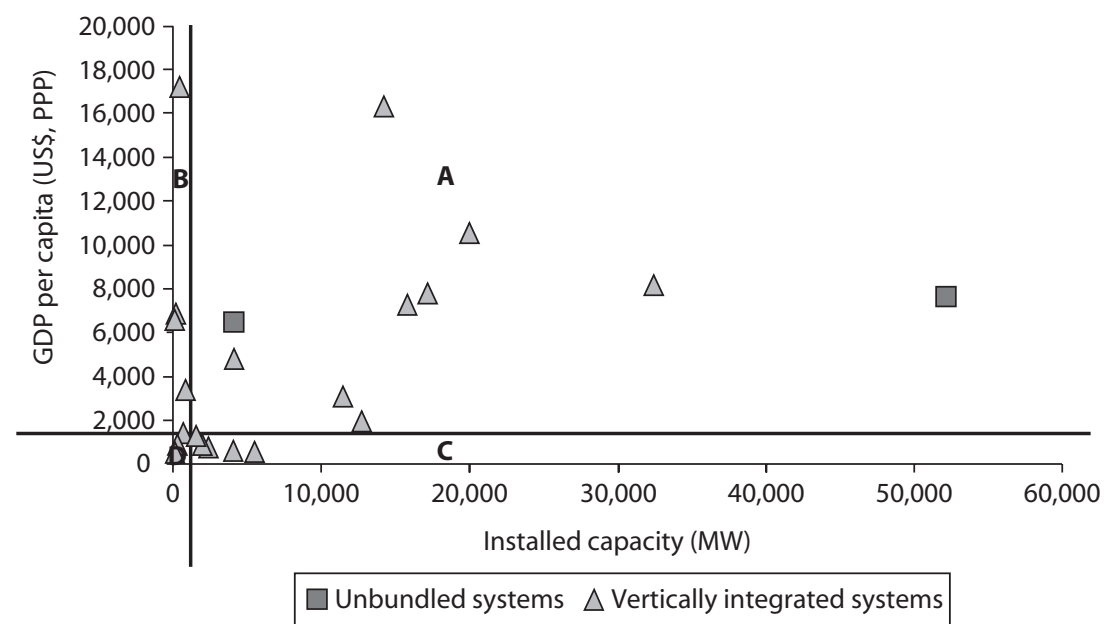

Source: An elaboration from the Power Market Structure database.

Note: To separate the countries into different groups, thresholds of 1,178.5 MW (megawatts) for installed capacity and \$1,429 for GDP (gross domestic product) per capita were applied. For Group D these thresholds represent approximately the lowest 25 percent of capacity and income of the sample.

Figure 1.7 Scatter Plot of the Sample of Countries in the Intermediate Period, 1998

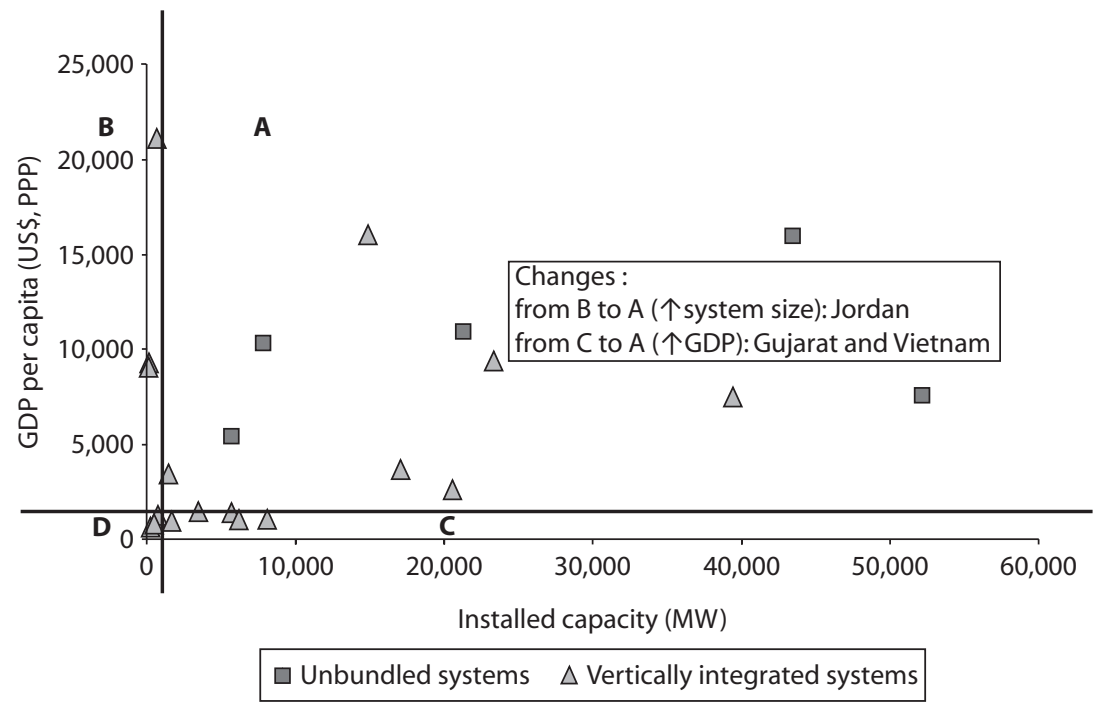

Source: An elaboration from the Power Market Structure database.

Note: To separate the countries into different groups, thresholds of 1,178.5 MW (megawatts) for installed capacity and $\$ 1,429$ for GDP (gross domestic product) per capita were applied. For Group D these thresholds represent approximately the lowest 25 percent of capacity and income of the sample. PPP = purchasing power parity. 
Figure 1.8 Scatter Plot of the Sample of Countries in the Final Period, 2008

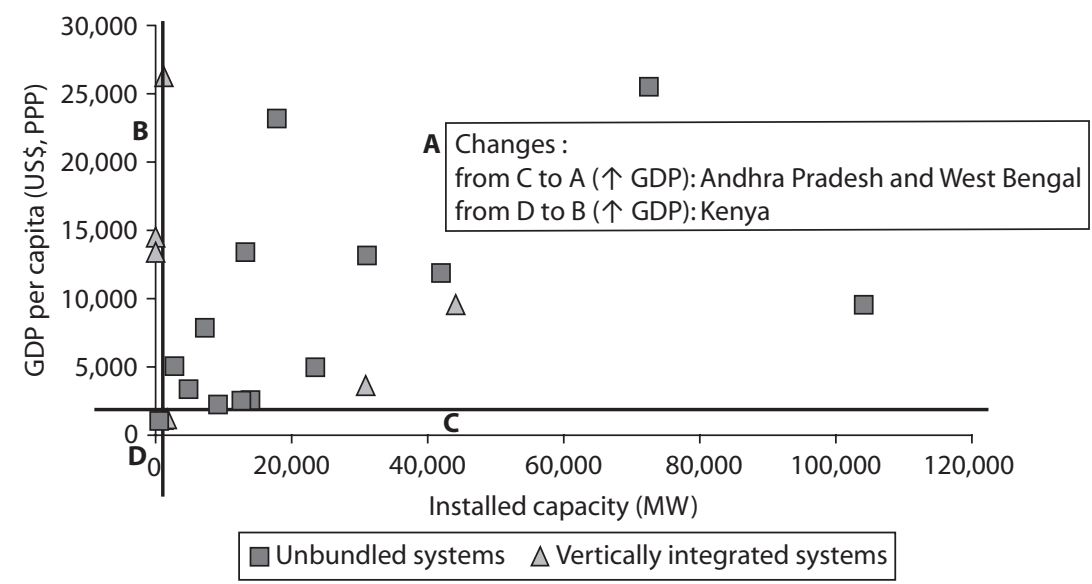

Source: An elaboration from the Power Market Structure database.

Note: To separate the countries into different groups, thresholds of 1,178.5 MW (megawatts) for installed capacity and \$1,429 for GDP (gross domestic product) per capita were applied. For Group D these thresholds represent approximately the lowest 25 percent of capacity and income of the sample.

performance indicators on the other; and (2) the case studies for the taxonomy of countries, reporting the timeline of reforms and the achieved results according to the set of chosen performance indicators.

\section{Analytical Approach}

\section{Data and Definition of Indicators}

Our dataset is based on a panel of 22 countries for a period beginning in 1989 and extending through 2009. Because the panel dataset includes data on 22 countries for 20 years, the total number of maximum observations is 440 .

The outcomes used for our econometric and case study analysis are the four indicators of power sector performance (table 1.2) that are used to measure the determinants of power sector performance: residential access to electricity, energy sold per employee of electricity suppliers as an indicator of labor productivity, average electricity tariff level as an indicator of financial efficiency, and the index of carbon dioxide emissions as an indicator of environmental sustainability.

Annex A reports the full list of variables collected in our database. Added performance indicators are the following: quality, such as the 
Table 1.2 Selected Power Sector Performance Indicators

\begin{tabular}{|c|c|}
\hline Variables & Definition \\
\hline \multicolumn{2}{|l|}{ Access } \\
\hline $\begin{array}{l}\text { Residential access } \\
\text { (\% population) }\end{array}$ & $\begin{aligned}= & \text { Number of residential connections divided by the total } \\
& \text { population }\end{aligned}$ \\
\hline \multicolumn{2}{|l|}{ Operational efficiency } \\
\hline $\begin{array}{l}\text { Energy sold per employee } \\
\text { (MWh per employee) }\end{array}$ & $\begin{array}{l}=\text { Amount of generated power consumed from the } \\
\text { interconnected system divided by the number of } \\
\text { employees of the power supply entities for the whole } \\
\text { power market (MWh per employee) }\end{array}$ \\
\hline $\begin{array}{l}\text { Financial efficiency } \\
\text { Tariff level } \\
\text { (\$cent per kWh) }\end{array}$ & $=$ Average tariff ( $\$$ cent per kWh) \\
\hline $\begin{array}{l}\text { Environmental sustainabi } \\
\text { Carbon Emissions Index } \\
\left(\mathrm{CO}_{2} \text { ton per } \mathrm{kWh}\right)\end{array}$ & $\begin{array}{l}\text { ty } \\
=\text { Energy generated from each energy source weighted with } \\
\text { the following coefficients of } \mathrm{CO}_{2} \text { emission intensity by } \\
\text { weight per unit of electricity generated divided by total } \\
\text { amount of energy generated (coal = 1.00; petroleum fuels = } \\
\begin{array}{l}0.94 ; \text { natural gas = 0.63; renewable energy and nuclear } \\
\text { power = zero) }\end{array}\end{array}$ \\
\hline
\end{tabular}

Source: An elaboration from the Power Market Structure database.

Note: $\mathrm{kWh}=$ kilowatt-hour; $\mathrm{MWh}=$ megawatt-hour.

System Average Interruption Duration Index (SAIDI) and the System Average Interruption Frequency Index (SAIFI); operational efficiency, such as capacity utilization and load factor; financial efficiency, such as the cost recovery index; long-run environmentally sustainability indicators, such as the share of renewables; and energy endowment, such as reserve capacity and self-sufficiency.

Tables 1.3 and 1.4 report the explanatory variables that our model uses to determine power sector performance. Table 1.3 includes a comprehensive list of policy variables, such as the degree of vertical unbundling and the degree of concentration and private sector participation of each segment of the market, as well as the introduction of an autonomous regulator.

Table 1.4 introduces the key control variables related to GDP per capita and power system size, with particular attention given to Group A and Group D, the interaction between the groups with the policy variables, as well as additional indicators, including the financial crisis for Latin America, capital investment, and the share of fossil fuels in generation. 
Table 1.3 Explanatory Sectoral Policy Variables Influencing Power Sector Performance (expected relationship)

\begin{tabular}{|c|c|c|c|}
\hline \multirow[b]{2}{*}{ Variables } & \multirow[b]{2}{*}{ Definition } & \multicolumn{2}{|c|}{ Expected sign } \\
\hline & & $\begin{array}{c}\text { Performance } \\
\text { indicators }\end{array}$ & $\begin{array}{c}\text { Environmental } \\
\text { indicators }\end{array}$ \\
\hline \multicolumn{4}{|c|}{ Degree of vertical unbundling } \\
\hline $\begin{array}{l}\text { Partial vertical } \\
\text { unbundling }\end{array}$ & $\begin{aligned}= & 1 \text { from the year of separation of } \\
& \text { generation from transmission and } \\
& \text { distribution } \\
= & 0 \text { otherwise }\end{aligned}$ & + & - \\
\hline \multicolumn{4}{|c|}{ Degree of disaggregation } \\
\hline $\begin{array}{l}\text { Degree of } \\
\text { disaggregation }\end{array}$ & $\begin{array}{l}\text { = the reverse of the Herfindahl- } \\
\text { Hirschman Index }(\mathrm{HHI}) \text {, computed } \\
\text { separately for the generation, } \\
\text { transmission, and distribution } \\
\text { segments; in the case of generation is } \\
\text { expressed in installed generating } \\
\text { capacity (MW); in the case of } \\
\text { transmission is expressed in terms of } \\
\text { kilometer (km) line length without } \\
\text { discrimination between transmission } \\
\text { voltage levels; in the case of } \\
\text { distribution is expressed in terms of } \\
\text { total retail sales (MWh) }\end{array}$ & + & - \\
\hline \multicolumn{4}{|c|}{ Degree of private sector participation } \\
\hline $\begin{array}{l}\text { Full vertical } \\
\text { unbundling }\end{array}$ & $\begin{array}{l}=1 \text { from the year of separation of } \\
\text { transmission from generation and } \\
\text { distribution } \\
=0 \text { otherwise }\end{array}$ & + & - \\
\hline $\begin{array}{l}\text { Share of } \\
\text { private sector } \\
\text { participation }\end{array}$ & $\begin{array}{l}=\text { the percentage of private sector } \\
\text { participation expressed in installed } \\
\text { generating capacity (MW) in the } \\
\text { generation segment; expressed in } \\
\text { terms of km line length in the } \\
\text { transmission segment; and expressed } \\
\text { in terms of total retail sales (MWh) in } \\
\text { the distribution segment }\end{array}$ & + & - \\
\hline \multicolumn{4}{|l|}{ Regulation } \\
\hline $\begin{array}{l}\text { Introduction of } \\
\text { a regulatory } \\
\text { agency }\end{array}$ & $\begin{aligned}= & 1 \text { from the year of separation of } \\
& \text { transmission from generation and } \\
& \text { distribution } \\
= & 0 \text { otherwise }\end{aligned}$ & + & + \\
\hline
\end{tabular}

Source: An elaboration from the Power Market Structure database.

Note: $\mathrm{MW}=$ megawatt; $\mathrm{MWh}=$ megawatt-hour. 
Table 1.4 Other Explanatory Variables Influencing Power Sector Performance (expected relationship)

\begin{tabular}{|c|c|c|c|}
\hline \multirow[b]{2}{*}{ Variables } & \multirow[b]{2}{*}{ Definition } & \multicolumn{2}{|c|}{ Expected sign } \\
\hline & & $\begin{array}{l}\text { Performance } \\
\text { indicators }\end{array}$ & $\begin{array}{c}\text { Environmental } \\
\text { indicators }\end{array}$ \\
\hline \multicolumn{4}{|l|}{ Basic controls } \\
\hline GDP per capita & $\begin{aligned}= & \text { GDP per capita, PPP (constant } 2005 \\
& \text { international \$) }\end{aligned}$ & + & + \\
\hline $\begin{array}{l}\text { Installed capacity } \\
(\mathrm{MW})\end{array}$ & $\begin{aligned}= & \text { Total installed capacity in the power } \\
& \text { system (MW) }\end{aligned}$ & + & - \\
\hline \multicolumn{4}{|c|}{ Power system size group controls } \\
\hline Group A & $\begin{aligned}= & 1 \text { if above the threshold GDP per } \\
& \text { capita and installed capacity } \\
& \text { (determined by the lowest } 25 \text { percent } \\
& \text { of capacity and income of the sample) } \\
= & 0 \text { otherwise }\end{aligned}$ & + & + \\
\hline Group D & $\begin{aligned}= & 1 \text { if below the threshold GDP per } \\
& \text { capita and installed capacity } \\
& \text { (determined by the lowest } 25 \text { percent } \\
& \text { of capacity and income of the sample) } \\
= & 0 \text { otherwise }\end{aligned}$ & - & - \\
\hline $\begin{array}{l}\text { Group } A^{*} \text { sectoral } \\
\text { reforms }\end{array}$ & $\begin{aligned}= & \text { Interacted variable between Group A } \\
& \text { and each of the sectoral reforms } \\
& \text { (competition, privatization, and } \\
& \text { regulation) }\end{aligned}$ & + & - \\
\hline \multicolumn{4}{|l|}{ Other controls } \\
\hline Financial crisis & $\begin{array}{l}=1 \text { for the } 5 \text { years after } 2001 \\
=0 \text { otherwise }\end{array}$ & - & \\
\hline $\begin{array}{l}\text { Share of fossil } \\
\text { fuels (\% installed } \\
\text { capacity) }\end{array}$ & $\begin{aligned}= & \text { Percentage of the total installed } \\
& \text { capacity in fossil fuels (oil, coal, and } \\
& \text { natural gas }\end{aligned}$ & $?$ & \\
\hline $\begin{array}{l}\text { Investment } \\
(\$ / \mathrm{MWh})\end{array}$ & $\begin{aligned}= & \text { Capital expenditure per unit of energy } \\
& \text { generated (MWh) }\end{aligned}$ & + & \\
\hline $\begin{array}{l}\text { Investment } \\
(\$ / M W h)\end{array}$ & $\begin{aligned}= & \text { Capital expenditure per unit of energy } \\
& \text { generated (MWh) }\end{aligned}$ & + & \\
\hline \multicolumn{4}{|l|}{ Regional control } \\
\hline $\begin{array}{l}\text { Region } \\
\text { d_region 1, 2, 3, 4, 5, } 6\end{array}$ & $\begin{array}{l}\text { Dummies }=1 \text { if region } 1=E A P, 2=E C A \text {, } \\
3=L A C, 4=M N A, 5=S A R, 6=S S A, 0 \\
\text { otherwise }\end{array}$ & & \\
\hline
\end{tabular}

Source: An elaboration from the Power Market Structure database.

Note: GDP = gross domestic product; $\mathrm{MW}=$ megawatt; $\mathrm{MWh}=$ megawatt-hour; $\mathrm{PPP}$ = purchasing power parity; * = interactions between the variables. Regions: EAP = East Asia and Pacific, ECA = Europe and Central Asia, LAC $=$ Latin America and the Caribbean, MNA = Middle East and North Africa, SAR = South Asia, SSA = SubSaharan Africa. 


\section{Theoretical Hypotheses to Be Tested}

Hypothesis 1 concerns sectoral reforms and performance and traditional and environmental power sector performance for the overall sample. The implementation of key sectoral reforms, including vertical and horizontal unbundling, privatization, and regulation, is expected to be significantly associated with higher access and better operational and financial performance of the power sector. Such reforms may, however, be associated with environmentally nonsustainable outcomes.

Some reforms, such as unbundling and wholesale competition, are expected to improve all indicators of technical and financial performance, but under some circumstances may tend to discourage low carbon options. The arguments put forward are that integrated firms can coordinate the development of the network to accommodate renewable generations and that a single-buyer model allows policy makers to choose a mix of low carbon generators in a centralized and smoother way. The great advantage of a more competitive structure (compared to a vertically integrated one) is that new entrants can spot opportunities that incumbents have not exploited. A more competitive structure is generally more conducive to better investment decisions and innovative outcomes. Ultimately, which of the two effects will prevail is an empirical question, but one would presume that overall the former effects would dominate the latter.

Hypothesis 2 addresses the differential impact of reforms depending on power system size and per capita income in Group A countries. Key sectoral reforms, particularly vertical and horizontal unbundling, are expected to produce the most significant results in the group of countries characterized by high power system size and income per capita. Such reforms are also likely to be associated with environmentally sustainable results for the same category of countries.

Hypothesis 3 looks at the same impact of reforms for the countries in Group D. Key sectoral reforms, particularly vertical and horizontal unbundling, are not expected to be effective in the group of countries characterized by low power system size and low per capita income. Such reforms are also likely to be associated with environmentally unsustainable results for the same category of countries.

\section{Testing the Hypotheses}

To gather from the data whether the hypotheses we moved forward are confirmed, we can calculate the two means between different groups (for example, the proportion of investment for the observations where vertical unbundling has been introduced) and compare them to see if one 
is greater than the other and, if so, by how much. The significance of differences between two sample means can be assessed using the t-statistic calculated as part of the t-test. The t-statistic may be thought of as a scaled difference between the two means, where the absolute difference between means is rescaled using an estimate of the variability of the means. Such tests will be performed for each of the hypotheses. The test for the complete set of variables are reported in Annex B.

\section{Testing Hypothesis 1}

Vertical unbundling is positively and significantly associated with better performance. Access and labor productivity are respectively 60 percent and 80 percent higher for systems that have introduced some form of vertical unbundling. Tariffs and $\mathrm{CO}_{2}$ emissions are lower by 10 percent and 5 percent, respectively, indicating a higher degree of competitiveness and environmental sustainability (see figure 1.9).

Disaggregation in generation is also positively and significantly associated with better performance, even if to a lower extent than vertical unbundling. Access and labor productivity are about 20 percent higher for systems that have reduced concentration in the generation segment of the market. Tariffs and $\mathrm{CO}_{2}$ emissions are lower by 5 percent and 2 percent, respectively, indicating a higher degree of competitiveness and environmental sustainability (see figure 1.10a).

In general, disaggregation in distribution is also positively and significantly associated with better performance, with the exception of labor productivity. Access is 50 percent higher for systems that have reduced concentration in the distribution segment of the market. Labor productivity is slightly lower but not significantly so. Tariffs and $\mathrm{CO}_{2}$ emissions are lower by 40 percent and 5 percent, respectively, indicating a higher degree of competitiveness and environmental sustainability (see figure $1.10 \mathrm{~b}$ ).

The introduction of an autonomous regulator is positively and significantly associated with better performance. Access and labor productivity are respectively 50 percent and higher and twice as high for systems that have introduced regulation. Tariffs are higher, indicating a stronger commitment to make tariffs more cost reflective. Finally, higher environmental sustainability is reached, with $\mathrm{CO}_{2}$ emissions lower by 3 percent (see figure 1.11).

The introduction of private sector participation shows a trend similar to that for regulation, with the exception of labor productivity. Access is about 40 percent higher for systems that have introduced private participation. Labor productivity is 30 percent lower. Tariffs are 20 percent 


\section{Figure 1.9 Links between Performance and Vertical Unbundling}

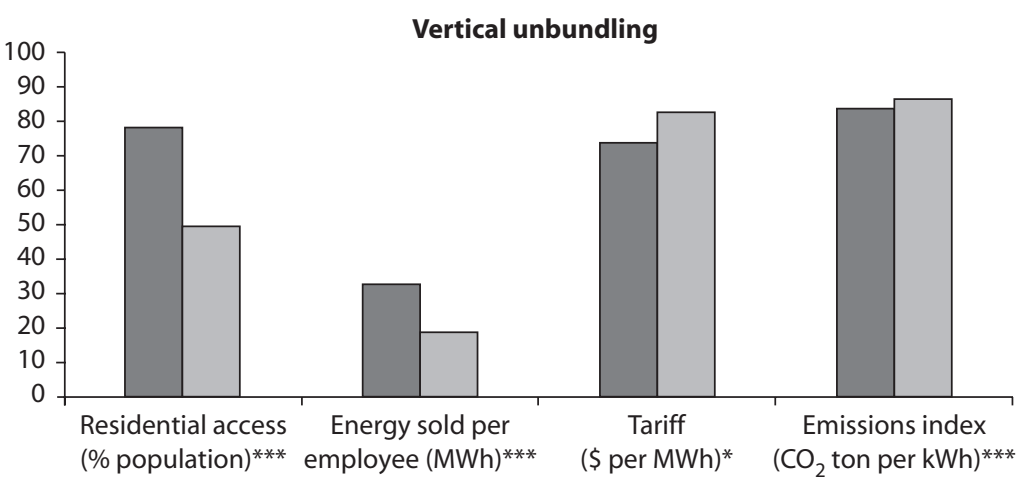

$\square$ Vertical unbundling $\square$ Vertical integration

\begin{tabular}{|l|c|c|c|}
\hline & Vertical unbundling & Vertical integration & $\mathrm{t}$ \\
\hline $\begin{array}{l}\text { Residential access } \\
\text { (\% population)*** }\end{array}$ & $\begin{array}{c}78.3 \\
(27.7)\end{array}$ & $\begin{array}{c}49.7 \\
(33.9)\end{array}$ & -8.7 \\
\hline $\begin{array}{l}\text { Energy sold per } \\
\text { employee }(\mathrm{MWh)})^{* * *}\end{array}$ & $\begin{array}{c}32.8 \\
(27.89)\end{array}$ & $\begin{array}{c}18.3 \\
(17.03)\end{array}$ & -4.9 \\
\hline Tariff (\$ per MWh)* & $\begin{array}{c}74.0 \\
(32.8)\end{array}$ & $\begin{array}{c}53.4 \\
(60.1)\end{array}$ & 1.5 \\
\hline $\begin{array}{l}\text { Emissions index } \\
\left(\mathrm{CO}_{2} \text { ton per } \mathrm{kWh)}\right)^{* * *}\end{array}$ & 83.7 & $\begin{array}{c}86.8 \\
(9.3)\end{array}$ & 3.5 \\
\hline
\end{tabular}

Source: An elaboration from the Power Market Structure database.

Note: The following adjustments were made to make the indicators fit in the same figure. Tariffs are measured as $\$$ per MWh rather than as $\$$ cent per $\mathrm{kWh}$. Emissions index is measured by an index ranging from 0 to 100 rather than 0 to 1. Energy sold per employee (measured in MWh per employee) was divided by $100 .{ }^{*}, *^{* *},{ }^{* * *}$ indicate, respectively, level of significance of 10,5, and 1 percent. $\mathrm{kWh}=$ kilowatt-hour; $\mathrm{MWh}=$ megawatt-hour.

higher, reflecting the need to make tariffs more cost reflective to attract the private sector. Finally, higher environmental sustainability is reached, with $\mathrm{CO}_{2}$ emissions lower by 5 percent (see figure 1.12).

Countries with higher power system-installed capacity are characterized by significantly better performance than countries with lower installed capacity. Access and labor productivity are respectively 70 percent and four times higher for above average power systems. Tariffs and $\mathrm{CO}_{2}$ emissions are lower by 25 percent and 3 percent, respectively, indicating a higher degree of competitiveness and environmental sustainability (see figure 1.13a). Finally, countries with higher GDP per capita are characterized by significantly better performance than countries with lower GDP per capita. Access and labor productivity are respectively 


\section{Figure 1.10 Links between Performance and Disaggregation (inverse of concentration)}

\section{a. Disaggregation in generation}

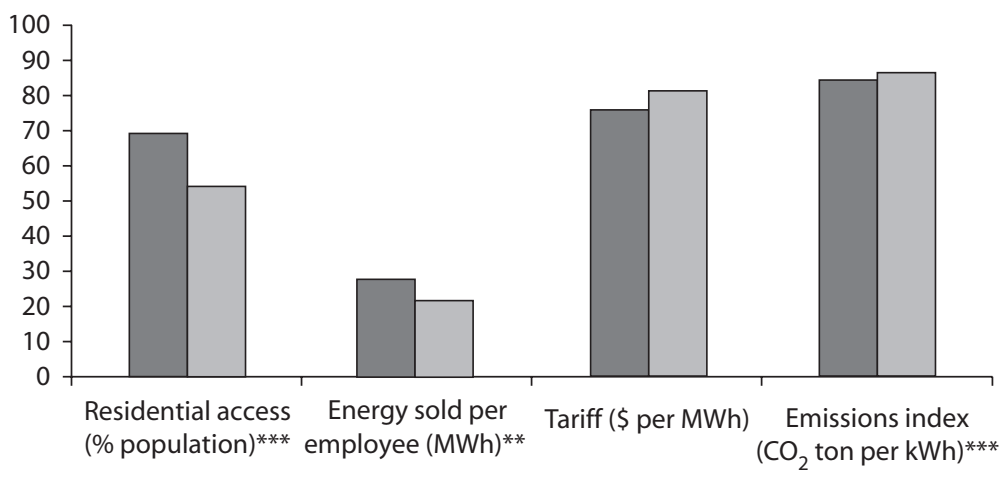

\begin{tabular}{|l|c|c|c|}
\hline & $\begin{array}{c}\text { Below average } \\
\mathrm{HH} \text { in distribution }\end{array}$ & $\begin{array}{c}\text { Above average } \\
\mathrm{HHI} \text { in distribution }\end{array}$ & $\mathrm{t}$ \\
\hline $\begin{array}{l}\text { Residential access } \\
\text { \% population) }\end{array}$ & $\begin{array}{c}71.9 \\
(28.5)\end{array}$ & $\begin{array}{c}48.3 \\
(36.3)\end{array}$ & 5.6 \\
\hline $\begin{array}{l}\text { Energy sold per } \\
\text { employee }(\mathrm{MWh}) * *\end{array}$ & $\begin{array}{c}23.4 \\
(13.5)\end{array}$ & $\begin{array}{c}25.5 \\
(28.5)\end{array}$ & -1.2 \\
\hline Tariff (\$ per $\mathrm{MWh)***}$ & $\begin{array}{c}58.2 \\
(29.3)\end{array}$ & $\begin{array}{c}94.2 \\
(49.1)\end{array}$ & -5.8 \\
\hline $\begin{array}{l}\text { Emissions index } \\
\left(\mathrm{CO}_{2} \text { ton per } \mathrm{kWh}\right)^{* * *}\end{array}$ & 84.8 & $\begin{array}{c}87.9 \\
(8.2)\end{array}$ & -3.6 \\
\hline
\end{tabular}

Source: An elaboration from the Power Market Structure database.

Note: The following adjustments were made to make the indicators fit in the same figure. Tariffs are measured as $\$$ per MWh rather than as $\$$ cent per $\mathrm{kWh}$. Emissions index is measured by an index ranging from 0 to 100 rather than 0 to 1. Energy sold per employee (measured in MWh per employee) was divided by $100 .{ }^{*}, * *$,*** indicate, respectively, level of significance of 10,5, and 1 percent. $\mathrm{HHI}=$ Herfindahl-Hirschman Index; kWh = kilowatt-hour; $\mathrm{MWh}=$ megawatt-hour.

\section{b. Disaggregation in distribution}

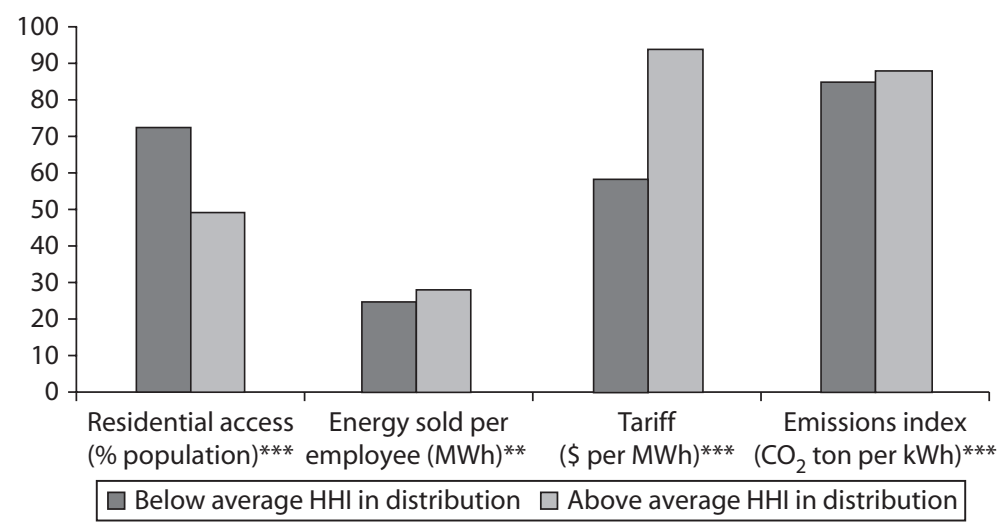


Figure 1.10 (continued)

\begin{tabular}{|l|c|c|c|}
\hline & $\begin{array}{c}\text { Below average } \\
\mathrm{HHI} \text { in generation }\end{array}$ & $\begin{array}{c}\text { Above average } \\
\mathrm{HHI} \text { in generation }\end{array}$ & $\mathrm{t}$ \\
\hline $\begin{array}{l}\text { Residential access } \\
\text { (\% population)*** }\end{array}$ & $\begin{array}{c}68.3 \\
(35.2)\end{array}$ & $\begin{array}{c}53.9 \\
(32.5)\end{array}$ & 3.6 \\
\hline $\begin{array}{l}\text { Energy sold per } \\
\text { employee }(\mathrm{MWh})^{* *}\end{array}$ & $\begin{array}{c}27.7 \\
(26.96)\end{array}$ & $\begin{array}{c}22.2 \\
(19.79)\end{array}$ & 1.7 \\
\hline Tariff $(\$ \text { per } \mathrm{MWh})^{* * *}$ & $\begin{array}{c}76.5 \\
(28.4)\end{array}$ & $\begin{array}{c}81.4 \\
(60.1)\end{array}$ & -0.8 \\
\hline $\begin{array}{l}\text { Emissions index } \\
\left(\mathrm{CO}_{2} \text { ton per } \mathrm{kWh}\right)^{* * *}\end{array}$ & $\begin{array}{c}84.1 \\
(5.9)\end{array}$ & $\begin{array}{c}86.2 \\
(10.1)\end{array}$ & -2.1 \\
\hline
\end{tabular}

Source: An elaboration from the Power Market Structure database.

Note: The following adjustments were made to make the indicators fit in the same figure. Tariffs are measured as $\$$ per MWh rather than as $\$$ cent per $\mathrm{kWh}$. Emissions index is measured by an index ranging from 0 to 100 rather than 0 to 1. Energy sold per employee (measured in MWh per employee) was divided by $100 .{ }^{*},{ }^{* *}$, ${ }^{* * *}$ indicate, respectively, level of significance of 10,5, and 1 percent. $\mathrm{HHI}=$ Herfindahl-Hirschman Index; $\mathrm{kWh}=$ kilowatt-hour; $\mathrm{MWh}=$ megawatt-hour.

\section{Figure 1.11 Links between Performance and Regulation}

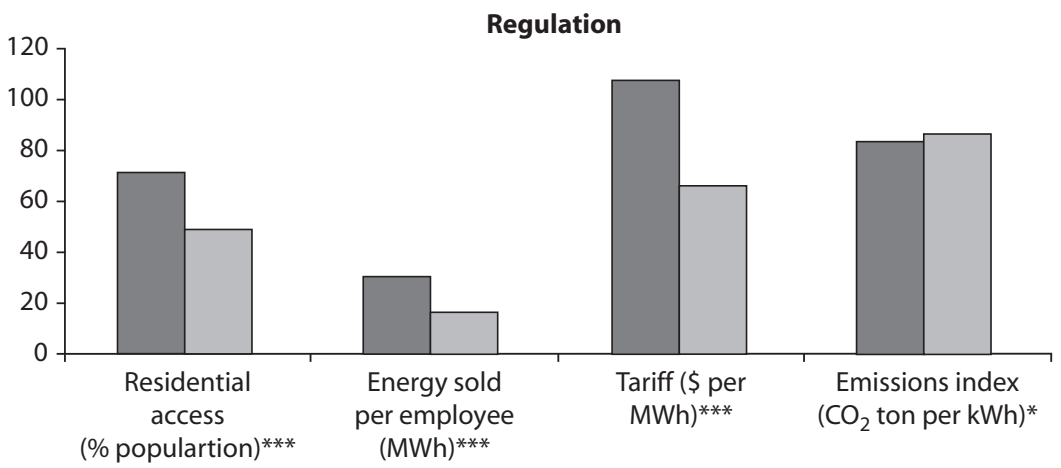

$\square$ Autonomous regulator $\square$ No autonomous regulator

\begin{tabular}{|l|c|c|c|}
\hline & $\begin{array}{c}\text { Autonomous } \\
\text { regulator }\end{array}$ & $\begin{array}{c}\text { No autonomous } \\
\text { regulator }\end{array}$ & $\mathrm{t}$ \\
\hline $\begin{array}{l}\text { Residential access } \\
\text { (\% population)*** }\end{array}$ & $\begin{array}{c}72.1 \\
(30.6)\end{array}$ & $\begin{array}{c}48.9 \\
(34.8)\end{array}$ & -6.7 \\
\hline $\begin{array}{l}\text { Energy sold per } \\
\text { employee }(\mathrm{MWh})^{* * *}\end{array}$ & $\begin{array}{c}30.9 \\
(25.1)\end{array}$ & $\begin{array}{c}15.8 \\
(17.8)\end{array}$ & -5.1 \\
\hline Tariff (\$ per MWh)*** & $\begin{array}{c}108.7 \\
(111.5)\end{array}$ & $\begin{array}{c}66.4 \\
(27.1)\end{array}$ & -3.5 \\
\hline Emissions index & 84.5 & $\begin{array}{c}86.7 \\
(8.4)\end{array}$ & 2.5 \\
\hline $\mathrm{CO}_{2}$ ton per $\left.\mathrm{kWh}\right)^{*}$ & $(8.4)$ & & \\
\hline
\end{tabular}

Source: An elaboration from the Power Market Structure database.

Note: The following adjustments were made to make the indicators fit in the same figure. Tariffs are measured as $\$$ per MWh rather than as $\$$ cent per $\mathrm{kWh}$. Emissions index is measured by an index ranging from 0 to 100 rather than 0 to 1. Energy sold per employee (measured in MWh per employee) was divided by $100 .{ }^{*},{ }^{* *}, * * *$ indicate, respectively, level of significance of 10,5, and 1 percent. $\mathrm{kWh}=$ kilowatt-hour; $\mathrm{MWh}=$ megawatt-hour. 


\section{Figure 1.12 Links between Performance and Privatization}

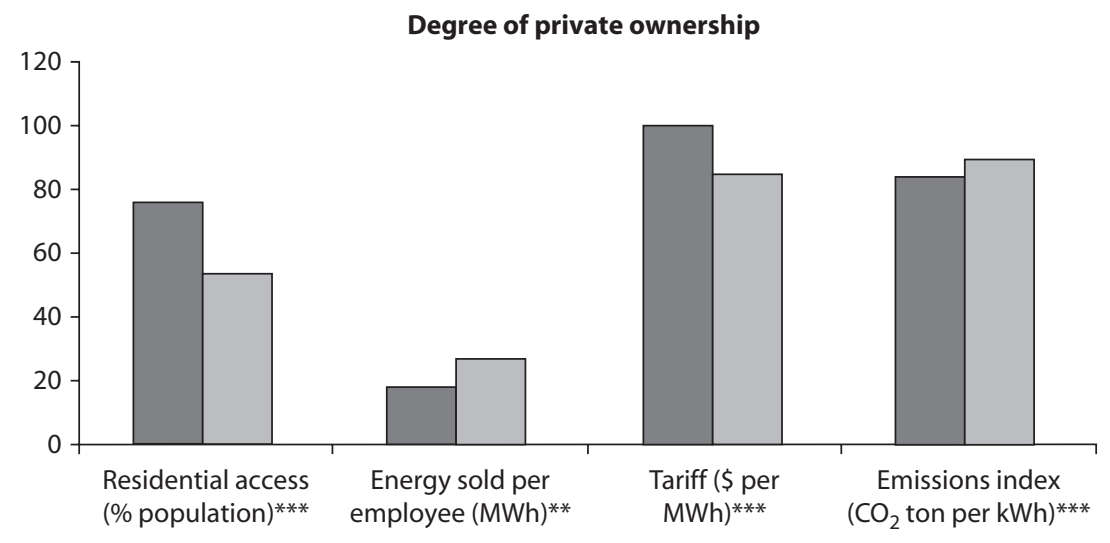

Above average private ownership $\square$ Below average private ownership

\begin{tabular}{|l|c|c|c|}
\hline & $\begin{array}{c}\text { Above average } \\
\text { private ownership }\end{array}$ & $\begin{array}{c}\text { Below average } \\
\text { private ownership }\end{array}$ & $\mathrm{t}$ \\
\hline Residential access & $\begin{array}{c}76.1 \\
(30.9)\end{array}$ & $\begin{array}{c}52.6 \\
(35.1)\end{array}$ & -4.7 \\
\hline Energy sold per & $\begin{array}{c}18.7 \\
(11.9)\end{array}$ & $\begin{array}{c}26.3 \\
(28.3)\end{array}$ & 1.8 \\
employee (MWh)** & 99.8 & 83.7 & -2.2 \\
\hline Tariff (\$ per MWh)*** & $(52.3)$ & $(40.3)$ & 5.0 \\
\hline Emissions index & 83.4 & 88.3 & $(4.9)$ \\
$\left(\mathrm{CO}_{2}\right.$ ton per kWh)*** & $(7.7)$ & & \\
\hline
\end{tabular}

Source: An elaboration from the Power Market Structure database.

Note: The following adjustments were made to make the indicators fit in the same figure. Tariffs are measured as $\$$ per MWh rather than as $\$$ cent per $\mathrm{kWh}$. Emissions index is measured by an index ranging from 0 to 100 rather than 0 to 1. Energy sold per employee (measured in MWh per employee) was divided by $100 . *^{*}, * * * * *$ indicate, respectively, level of significance of 10,5, and 1 percent. $\mathrm{kWh}=$ kilowatt-hour; $\mathrm{MWh}=$ megawatt-hour.

60 percent and three times higher for above average income. Tariffs and $\mathrm{CO}_{2}$ emissions are 30 percent and 50 percent higher, indicating that utilities are able to charge more cost-oriented tariffs, but the higher generation is reflected in higher pollution (see figure 1.13b).

\section{Testing Hypotheses 2 and 3}

Figure 1.14 compares the average performance levels of all the selected countries as a group with the average levels for the country Groups A and D from 1999 to 2009 in terms of the four main performance indicators: access, energy sold per employee, tariff, and emissions index. Group A countries consistently outperform Group D countries on all indicators. 


\section{Figure 1.13 Links between Performance and Power System Size and GDP per Capita}

a. Total installed capacity

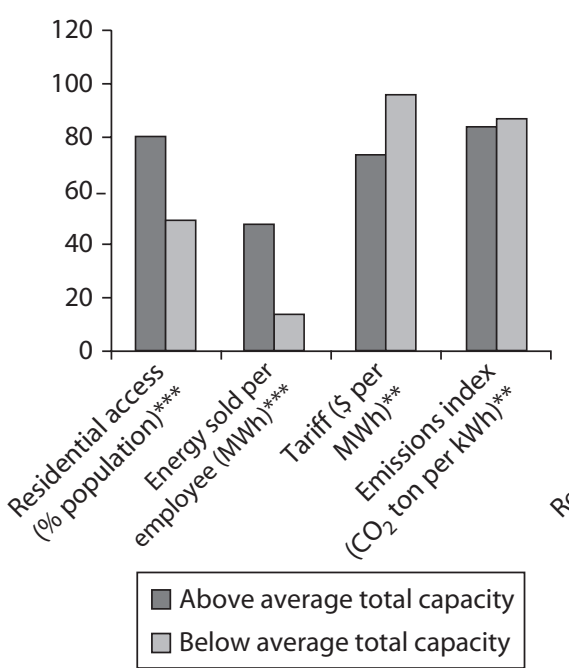

b. GDP per capita (PPP)

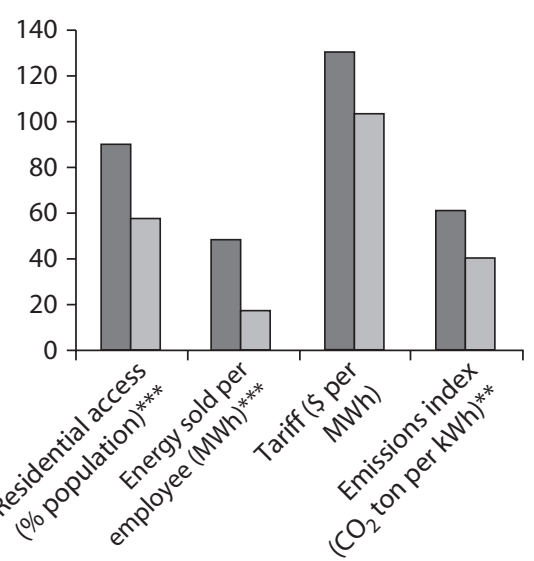

$\square$ Above average GDP per capita

$\square$ Below average GDP per capita

\begin{tabular}{|c|c|c|c|}
\hline & $\begin{array}{l}\text { Above average } \\
\text { total capacity }\end{array}$ & $\begin{array}{l}\text { Below average } \\
\text { total capacity }\end{array}$ & $\mathrm{t}$ \\
\hline $\begin{array}{l}\text { Residential access } \\
\text { (\% population)**** }\end{array}$ & $\begin{array}{c}80.7 \\
(18.8)\end{array}$ & $\begin{array}{c}48.1 \\
(36.4)\end{array}$ & -9.2 \\
\hline $\begin{array}{l}\text { Energy sold per } \\
\text { employee }(\mathrm{MWh})^{* * *}\end{array}$ & $\begin{array}{l}46.5 \\
(23.8)\end{array}$ & $\begin{array}{l}12.3 \\
(9.6)\end{array}$ & -15.3 \\
\hline Tariff $(\$ \text { per } M W h)^{* *}$ & $\begin{array}{l}73.8 \\
(42.8) \\
\end{array}$ & $\begin{array}{r}95.9 \\
(93.5) \\
\end{array}$ & 2.0 \\
\hline \multirow[t]{2}{*}{$\begin{array}{l}\text { Emissions index } \\
\left(\mathrm{CO}_{2} \text { ton per } \mathrm{kWh}\right)^{* *}\end{array}$} & $\begin{array}{l}83.9 \\
(9.8) \\
\end{array}$ & $\begin{array}{l}86.6 \\
(7.5) \\
\end{array}$ & 2.9 \\
\hline & $\begin{array}{l}\text { Above average } \\
\text { GDP per capita }\end{array}$ & $\begin{array}{l}\text { Below average } \\
\text { GDP per capita }\end{array}$ & $\mathrm{t}$ \\
\hline $\begin{array}{l}\text { Residential access } \\
\text { (\% population)*** }\end{array}$ & $\begin{array}{l}83.1 \\
(1.5) \\
\end{array}$ & $\begin{array}{l}42.1 \\
(2.5) \\
\end{array}$ & -13.9 \\
\hline $\begin{array}{l}\text { Energy sold per } \\
\text { employee }(\mathrm{MWh})^{* * *}\end{array}$ & $\begin{array}{l}40.4 \\
(25.2)\end{array}$ & $\begin{array}{l}11.5 \\
(9.1)\end{array}$ & -11.3 \\
\hline Tariff (\$ per MWh) & $\begin{array}{r}97.0 \\
(50.9) \\
\end{array}$ & $\begin{array}{c}90.7 \\
(118.2) \\
\end{array}$ & -7.4 \\
\hline $\begin{array}{l}\text { Emissions index } \\
\left(\mathrm{CO}_{2} \text { ton per } \mathrm{kWh}\right)^{* *}\end{array}$ & $\begin{array}{l}88.3 \\
(8.9)\end{array}$ & $\begin{array}{l}83.2 \\
(7.1)\end{array}$ & -6.2 \\
\hline
\end{tabular}

Source: An elaboration from the Power Market Structure database.

Note: The following adjustments were made to make the indicators fit in the same figure. Tariffs are measured as $\$$ per MWh rather than as $\$$ cent per $\mathrm{kWh}$. Emissions index is measured by an index ranging from 0 to 100 rather than 0 to 1 . Installed capacity (measured in MWh), and GDP per capita (measured in \$) were divided by $100 .{ }^{*},{ }^{* *},{ }^{* * *}$ indicate, respectively, level of significance of 10,5 , and 1 percent. GDP = gross domestic product; $\mathrm{kWh}=$ kilowatt-hour; $\mathrm{MWh}=$ megawatt-hour; PPP = purchasing power parity. 


\section{Figure 1.14 Power Sector Performance Indicators over Time}
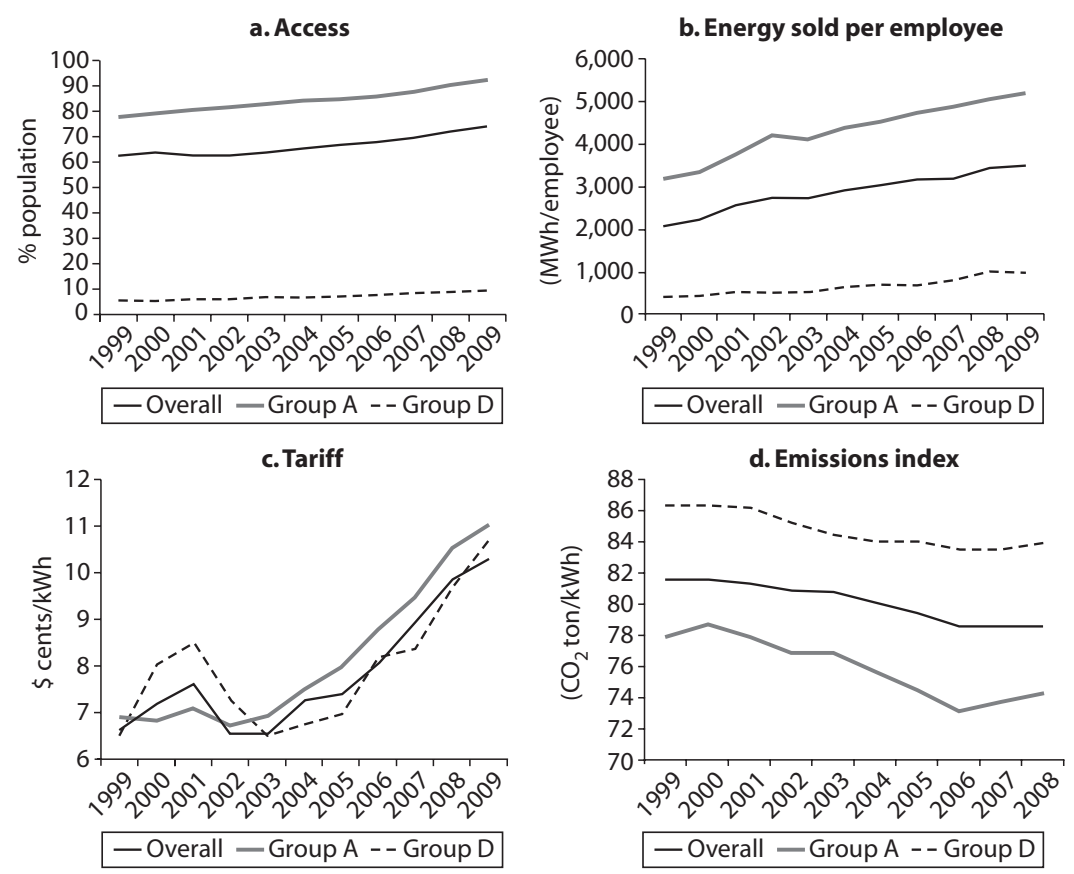

Source: An elaboration from the Power Market Structure database.

Note: kWh = kilowatt-hour; $M$ Wh = megawatt-hour.

Yet the trends for all performance indicators are rising-improving-for all country groups over this period.

To get an initial indication from the data of whether hypotheses 2 and 3 are confirmed, we can calculate the two means within Group A and Group D of countries that have implemented unbundling together with other reforms (reduction in market concentration, introduction of an autonomous regulator, and introduction of private ownership) and others that have not done so and compare them to see if the levels of access, labor productivity, tariffs, and emissions are greater in one group than in the other, and by how much. The significance of differences between two sample means can be assessed using the t-statistic calculated as part of the t-test. The t-statistic may be thought of as a scaled difference between the two means, where the absolute difference between means is rescaled using an estimate of the variability of the means. Such tests will be performed for each of the hypotheses. Annex B reports the results of the t-test for all the variables collected in the database. 
The results of t-tests for Group A are presented in figure 1.15 for the selected variables for which we ran the econometric model. The results show that high levels of reforms are associated with higher residential access and lower emissions index. Labor productivity and tariffs do not appear to vary with the level of reforms.

The same exercise was conducted for Group D. The results presented in figure 1.16 show no significant differences between the level of residential access, the level of emissions index, and tariffs between the two

\section{Figure 1.15 Differential Impact of Performance Indicators Depending on Reforms for Group A}

Aggregate level of reforms, group A

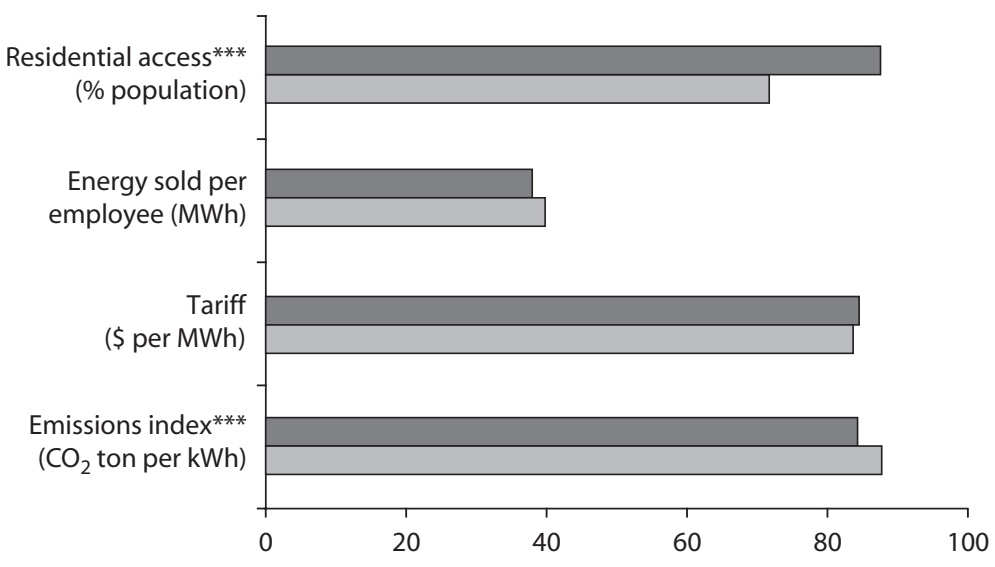

High level of reforms $\square$ Low level of reforms/no reforms

\begin{tabular}{|l|c|c|c|}
\hline & High level of reforms & $\begin{array}{c}\text { Low level of } \\
\text { reforms/no reforms }\end{array}$ & $\mathrm{t}$ \\
\hline $\begin{array}{l}\text { Residential access } \\
\text { (\% population)*** }\end{array}$ & $\begin{array}{c}87.5 \\
(10.7)\end{array}$ & $\begin{array}{c}70.9 \\
(19.6)\end{array}$ & -5.9 \\
\hline Energy sold per \\
employee (MWh) & $\begin{array}{c}37.7 \\
(32.2)\end{array}$ & $\begin{array}{c}39.2 \\
(20.9)\end{array}$ & 0.3 \\
\hline Tariff (\$ per MWh) & 84.2 & 83.0 & -0.2 \\
\hline Emissions index & $(23.3)$ & $(48.1)$ & 2.9 \\
$\left(\mathrm{CO}_{2} \text { ton per } \mathrm{kWh}\right)^{* * *}$ & 83.9 & $\begin{array}{c}87.5 \\
(8.7)\end{array}$ & 2 \\
\hline
\end{tabular}

Source: An elaboration from the Power Market Structure database.

Note: The following adjustments were made to make the indicators fit in the same figure. Tariffs are measured as $\$$ per MWh rather than as $\$$ cent per kWh. Emissions index is measured by an index ranging from 0 to 100 rather than 0 to 1. Energy sold per employee (measured in MWh per employee), installed capacity (measured in MW), and GDP per capita (measured in \$US) were divided by 100 . $^{*}, *^{*}, *^{* * *}$ indicate level of significance of 10,5 , and 1 percent, respectively. $\mathrm{kWh}=$ kilowatt-hour; $\mathrm{MWh}=$ megawatt-hour. 


\section{Figure 1.16 Differential Impact of Performance Indicators Depending on Reforms for Group D}

\section{Aggregate level of reforms, group D}

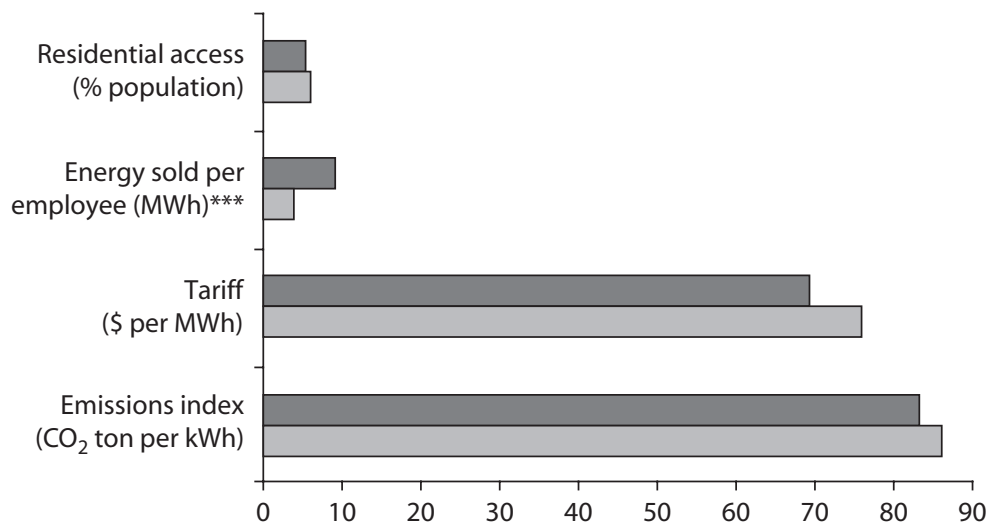

$\square$ High level of reforms $\square$ Low level of reforms/no reforms

\begin{tabular}{|c|c|c|c|}
\hline & $\begin{array}{l}\text { High level of } \\
\text { reforms }\end{array}$ & $\begin{array}{c}\text { Low level of } \\
\text { reforms/No reforms }\end{array}$ & $\mathrm{t}$ \\
\hline $\begin{array}{l}\text { Residential access } \\
\text { (\% population) }\end{array}$ & $\begin{array}{c}5.5 \\
(3.2)\end{array}$ & $\begin{array}{c}5.9 \\
(2.5)\end{array}$ & 0.4 \\
\hline $\begin{array}{l}\text { Energy sold per } \\
\text { employee }(\mathrm{MWh})^{* * *}\end{array}$ & $\begin{array}{c}9.36 \\
(2.56)\end{array}$ & $\begin{array}{c}3.94 \\
(1.47)\end{array}$ & -8.2 \\
\hline Tariff (\$ per MWh) & $\begin{array}{l}69.1 \\
(5.7) \\
\end{array}$ & $\begin{array}{l}75.6 \\
(2.2) \\
\end{array}$ & 0.5 \\
\hline $\begin{array}{l}\text { Emissions index } \\
\left(\mathrm{CO}_{2} \text { ton per } \mathrm{kWh}\right)\end{array}$ & $\begin{array}{l}83.1 \\
(0.7)\end{array}$ & $\begin{array}{l}85.7 \\
(6.8)\end{array}$ & 1.0 \\
\hline
\end{tabular}

Source: An elaboration from the Power Market Structure database.

Note: The following adjustments were made to make the indicators fit in the same figure. Tariffs are measured as \$ per MWh rather than as \$ cent per kWh. Emissions index is measured by an index ranging from 0 to 100 rather than 0 to 1. Energy sold per employee (measured in MWh per employee) was divided by $100 . *^{* * *}, * * *$ indicate level of significance of 10,5, and 1 percent, respectively. $\mathrm{kWh}=$ kilowatt-hour; $\mathrm{MWh}=$ megawatt-hour.

groups, but do show a significant difference in the levels of labor productivity. Higher levels of reforms are associated with significantly higher labor productivity.

\section{Evidence of Reform Outcomes from the Country Case Studies}

This section presents some snapshots of reform outcomes in four countries selected from Group A-Argentina, Jordan, South Africa, and Indonesia—and four countries selected from Group D-Uganda, Kenya, 
Tanzania, and Zambia. ${ }^{1}$ The countries were selected to facilitate two comparisons of outcomes: one between Group A and Group D, and the other within each group between countries that have completed most of the reform stages and countries that have completed few reform stages.

The outcomes used for this comparison are the four indicators of power sector performance (see table 1.2) that are used to measure the determinants of power sector performance analyzed earlier in the chapter: (1) residential access to electricity; (2) energy sold per employee of electricity suppliers as an indicator of labor productivity; (3) average electricity tariff level as an indicator of regulatory quality; and (4) the index of $\mathrm{CO}_{2}$ emissions as an indicator of environmental sustainability.

The milestones of power sector reform for these countries are shown in figure 1.17 for the Group A countries and figure 1.18 for the Group $\mathrm{D}$ countries. It is evident that all of these countries have tried to improve the performance of their power sectors. Argentina, Jordan, and Uganda made the most progress in the reform process. South Africa, Indonesia, Tanzania, and Zambia made the least progress. According to the hypotheses tested in this study among the Group A countries, Argentina and Jordan should have performed better than South Africa and Indonesia in terms of the four indicators. On the other hand, according to these hypotheses, among the Group D countries the performance of Uganda and Kenya is not expected to be better than for Tanzania and Zambia. In short, unbundling and subsequently implemented reform stages are expected to be linked to an improvement in performance in Group A countries but not in Group D countries, after allowing for exogenous factors that affect performance.

The trends in these countries' performance indicators are shown in figures 1.19 to 1.22. Access is shown in figure 1.19. For Argentina and Jordan the access rate increased from about 90 and 65 percent, respectively, in the mid-1990s to almost 100 percent by 2008. In South Africa and Indonesia the access rate also increased at a much higher rate to reach up to 80 percent by 2008, from much lower levels than Argentina and Jordan during the same time period. Given the difference in starting levels, all four Group A countries performed credibly on this indicator. For the Group D countries, all four countries had very low access rates, but the comparison is inconclusive because Kenya and Tanzania increased their access rates steadily, and Uganda and Zambia had setbacks in their access rates around 2005, recording little progress thereafter. 
Figure 1.17 Milestones of Power Sector Reform in Four Group A Countries

a. Milestones of power sector reform in Argentina

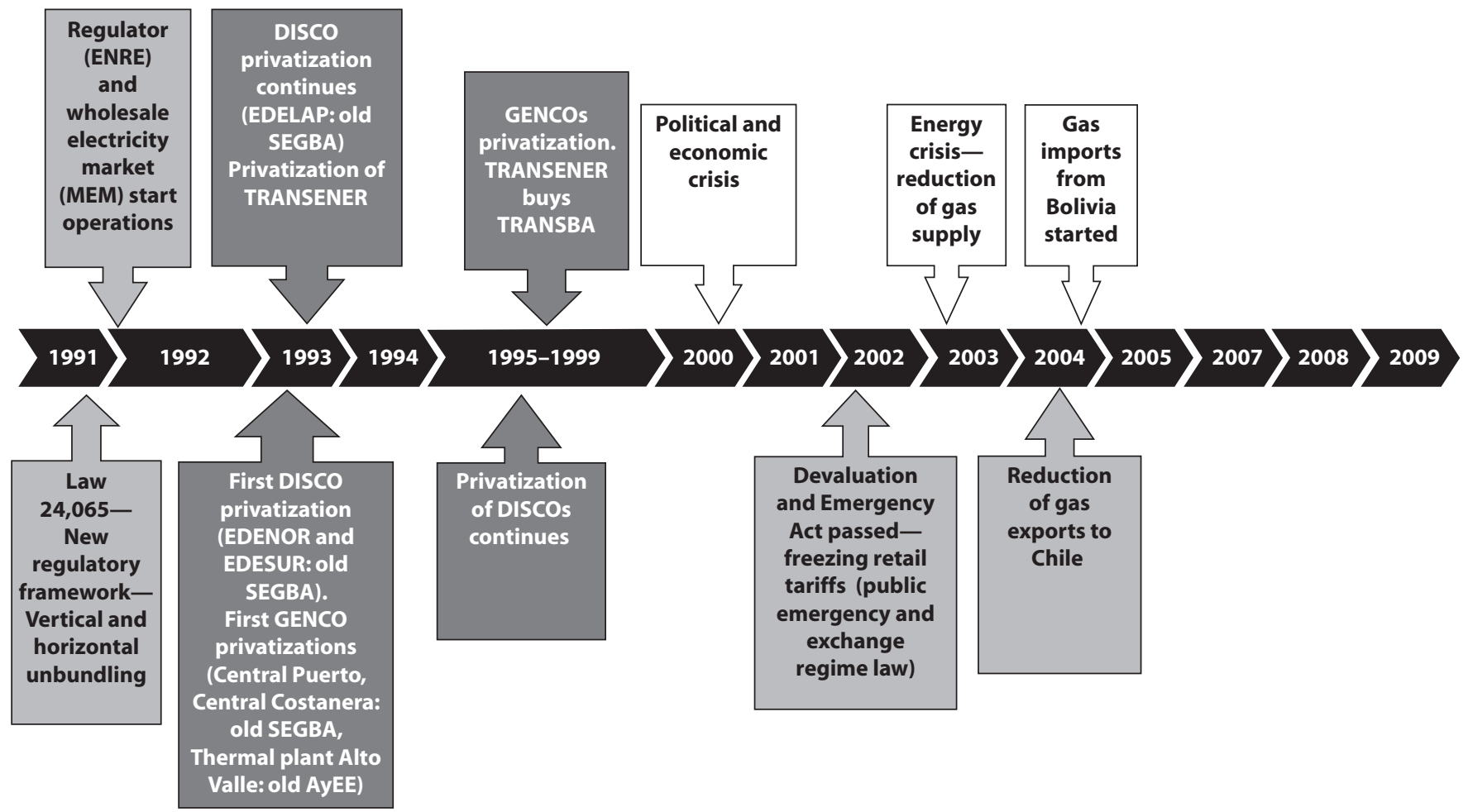

Source: An elaboration from the Power Market Structure database.

$\mathcal{G}$ Note: The milestones are reported in different shades: white = main external factors; light gray = main government interventions; dark gray = main private sector involvements. AyEE = Agua y Energía Eléctrica; DISCOs = distribution companies; EDELAP = Empresa Distribuidora La Plata; EDENOR = Empresa Distribuidora Norte; EDESUR = Empresa Distribuidora Sur; ENRE = Ente

Nacional Regulador de la Electricad; GENCOs = generation companies; MEM = Mercado Eléctrico Mayorista; SEGBA = Servicios Eléctricos del Gran Buenos Aires; TRANSBA = Empresa de Transporte de Energía Eléctrica por Distribución Troncal de la Provincia de Buenos Aires;TRANSENER = Compañia de Transporte de Energia Eléctrica en Alta Tensión. 
b. Milestones of power sector reform in Jordan

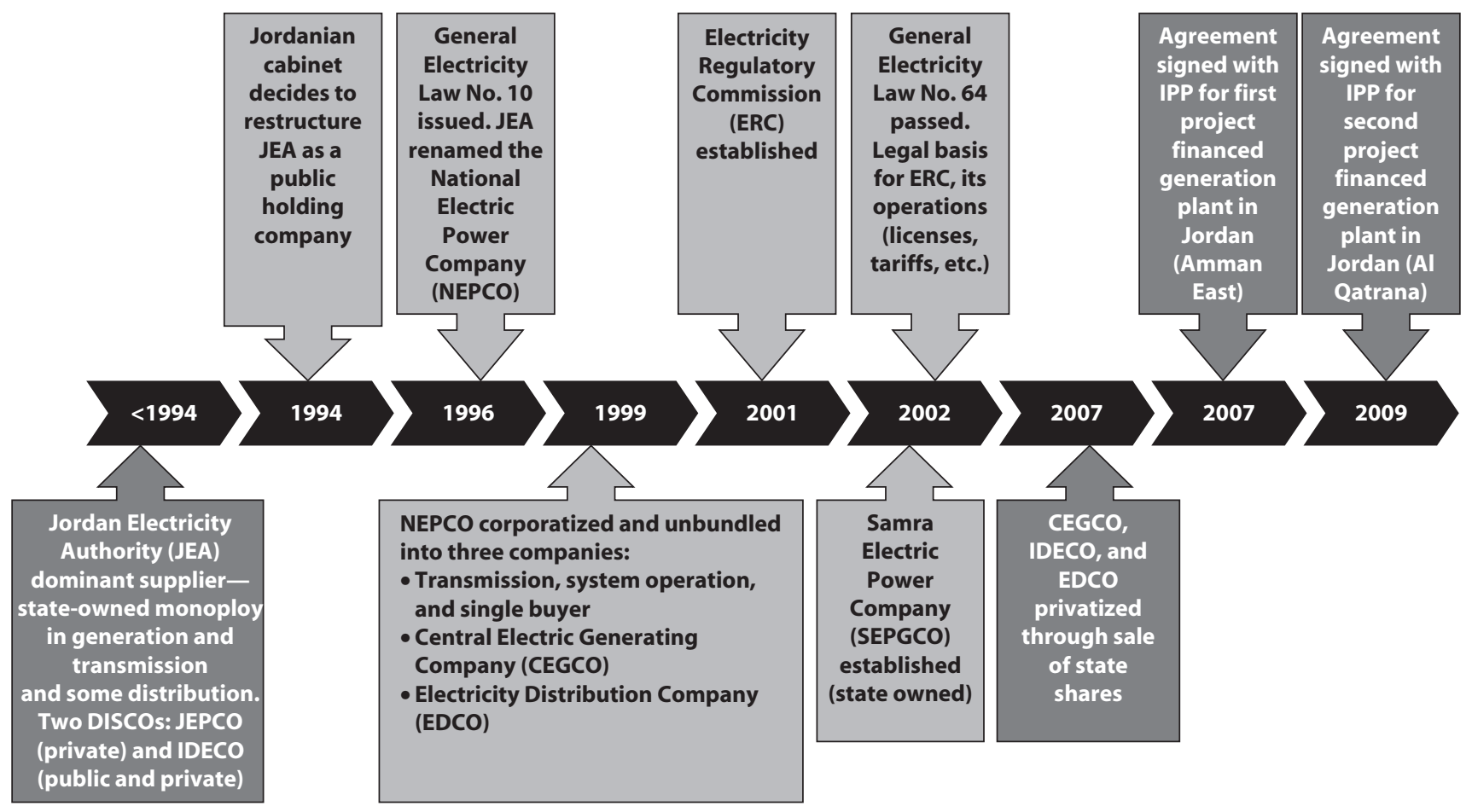

Source: An elaboration from the Power Market Structure database.

Note: The milestones are reported in different shades: light gray = main government interventions; dark gray = main private sector involvements. CEGCO = Central Electric Generating Company; EDCO = Electricity Distribution Company; IDECO = Irbid District Electricity Company; IPP = independent power producer; JEA = Jordan Electricity Authority; JEPCO = Jordanian Electric Power Company; NEPCO = National Electric Power Company. 
c. Milestones of power sector reform in South Africa

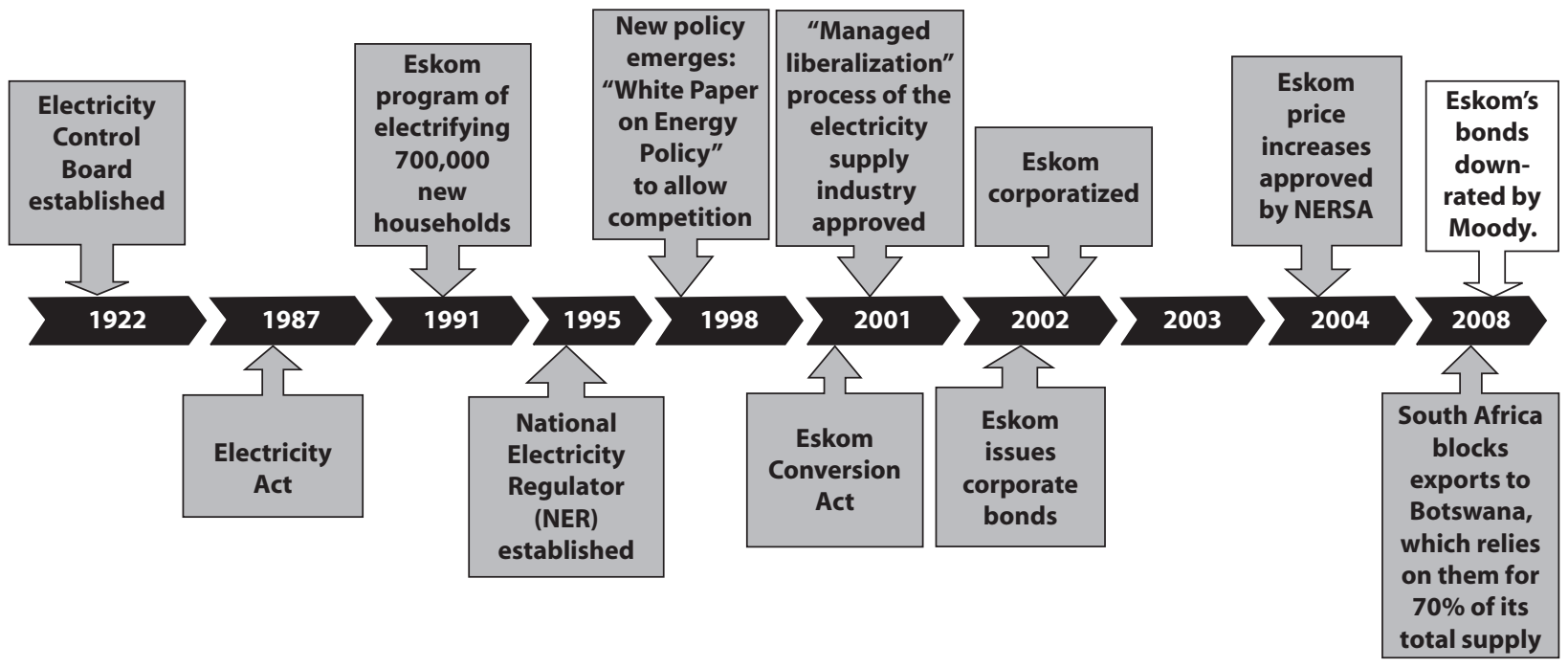

Source: An elaboration from the Power Market Structure database.

Note: The milestones are reported in different shades: white = main external factors; light gray = main government interventions. NERSA = National Electricity Regulator of South Africa (previously National Electricity Regulator [NER]) 


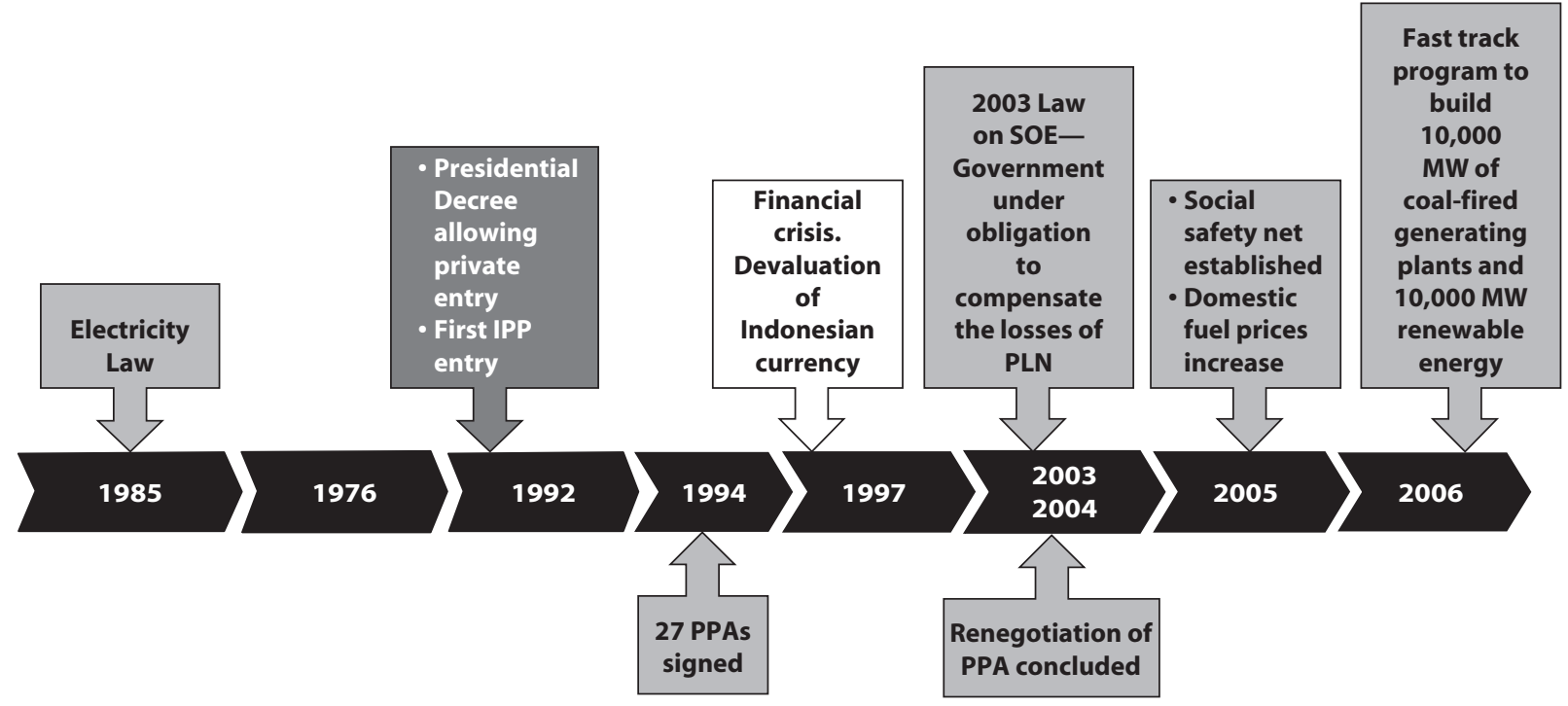

Source: An elaboration from the Power Market Structure database.

Note: The milestones are reported in different shades: white = main external factors; light gray = main government interventions; dark gray = main private sector involvements. IPP = independent power producer; MW = megawatt; PLN = Perusahaan Listrik Negara; PPA = power purchase agreement; SOE = state-owned enterprise. 
Figure 1.18 Milestones of Power Sector Reform in Four Group D Countries

a. Milestones of power sector reform in Uganda

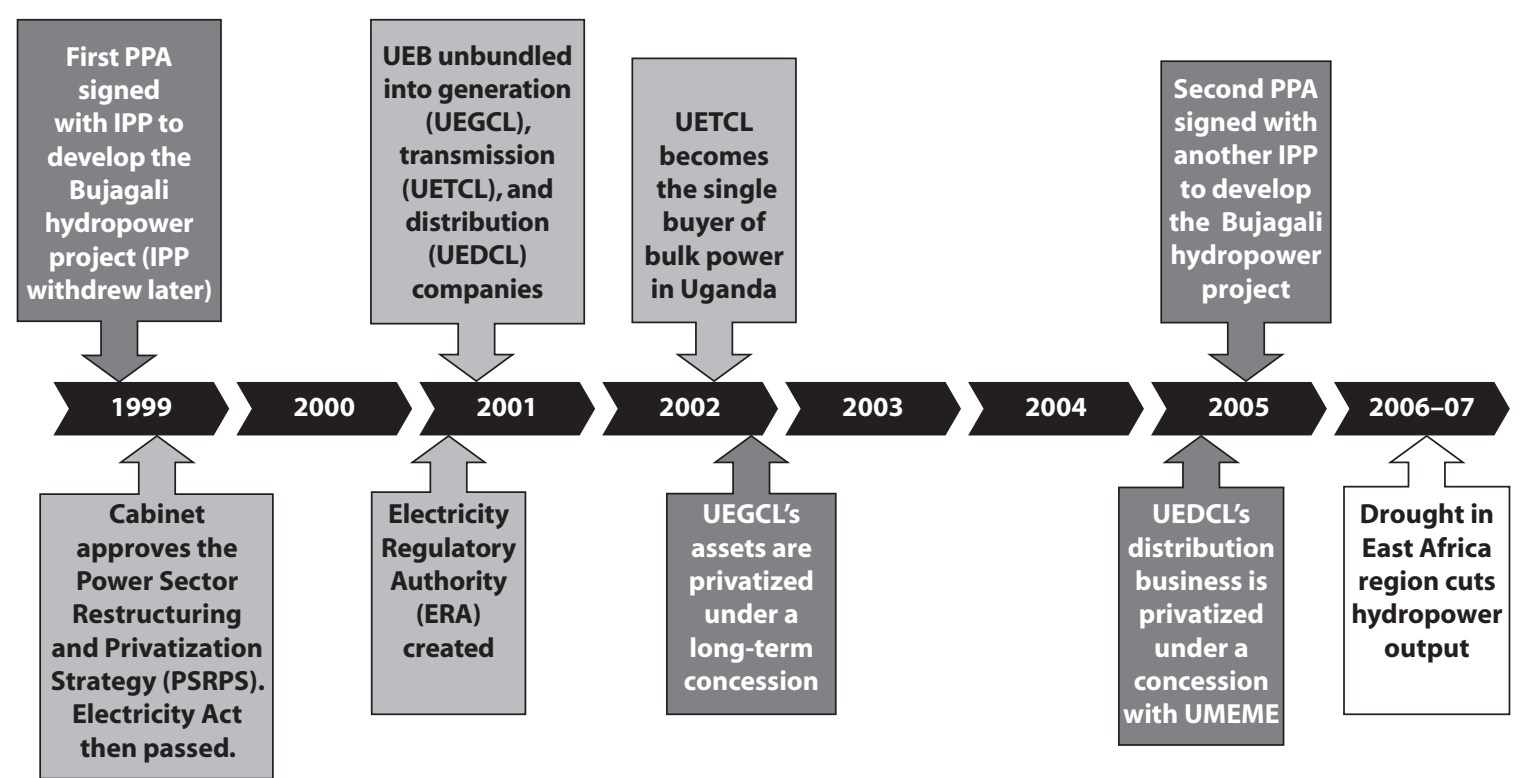

Source: An elaboration of the Power Market Structure database.

Notes: The milestones are reported in different shades: white = main external factors; light gray = main government interventions; dark gray = main private sector involvements. IPP = independent power producer; PPA = power purchase agreement; UEB = Uganda Electricity Board; UEDCL = Uganda Electricity Distribution Company Limited; UEGCL = Uganda Electricity Generation Company Ltd.; UETCL = Uganda Electricity Transmission Company. 
b. Milestones of power sector reform in Kenya

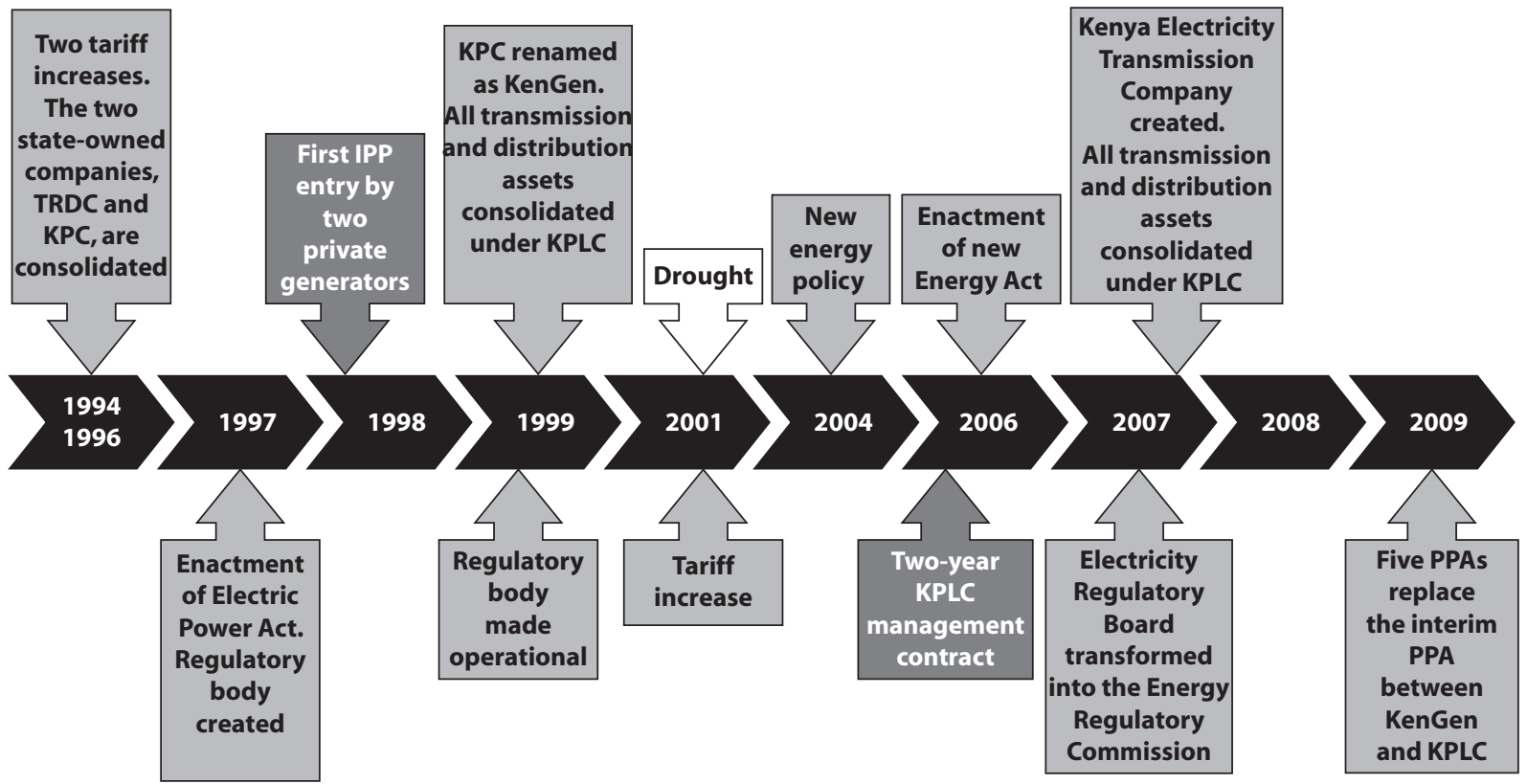

Source: An elaboration from the Power Market Structure database.

Note: The milestones are reported in different shades: white $=$ main external factors; light gray = main government interventions; dark gray = main private sector involvements.

IPP = independent power producer; KenGen = Kenya Electricity Generating Company; KPC = Kenya Pipeline Company; KPLC = Kenya Power and Lighting Company;

PPA = power purchase agreement; TRDC = Tana River Development Company. 


\section{c. Milestones of power sector reform in Tanzania}
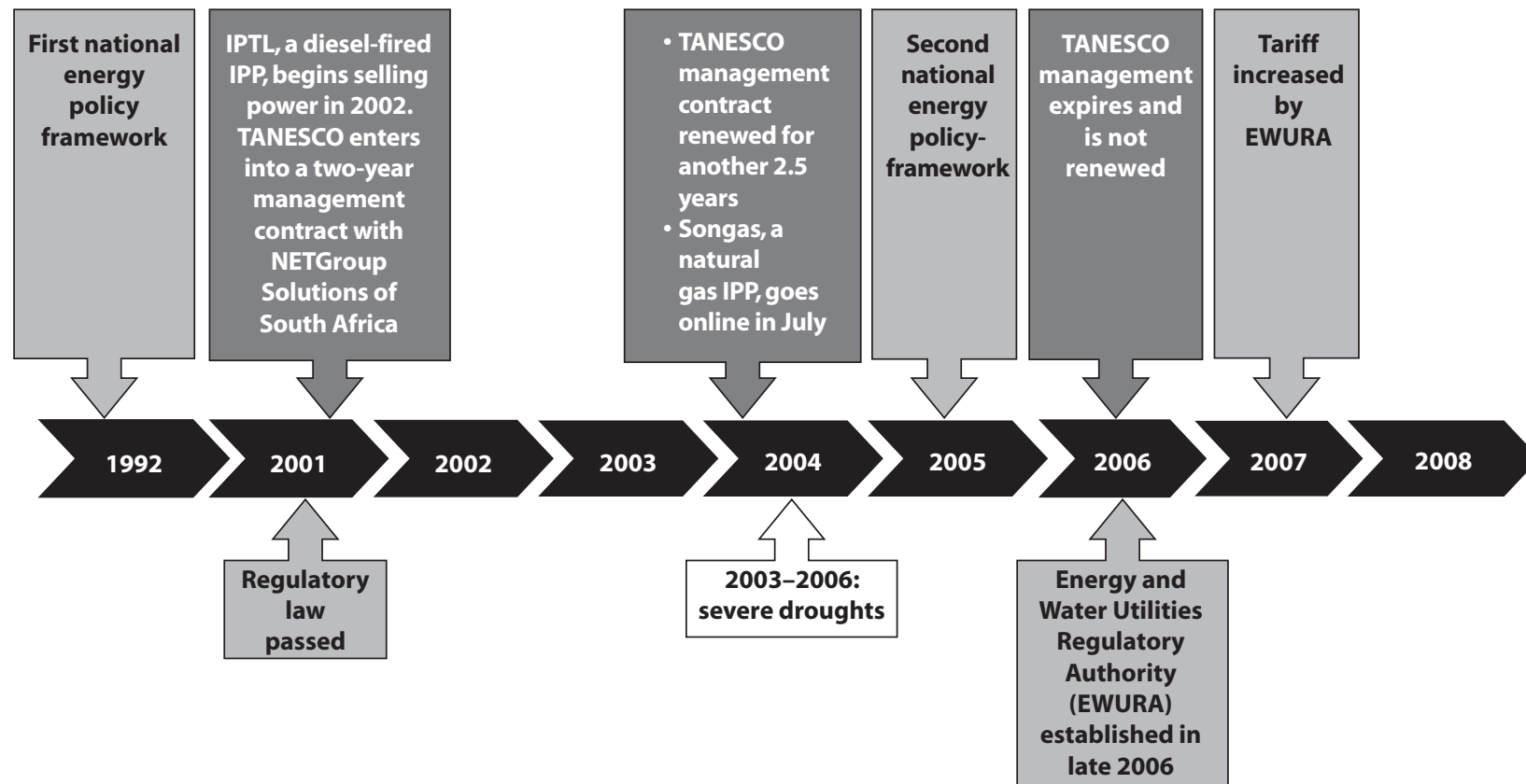

Source: An elaboration from the Power Market Structure database.

Note: The milestones are reported in different shades: white = main external factors; light gray = main government interventions; dark gray = main private sector involvements. EWURA = Energy and Water Utilities Regulatory Authority; IPP = independent power producer; IPTL = Independent Power Tanzania Limited; TANESCO = Tanzania Electric Supply Company. 


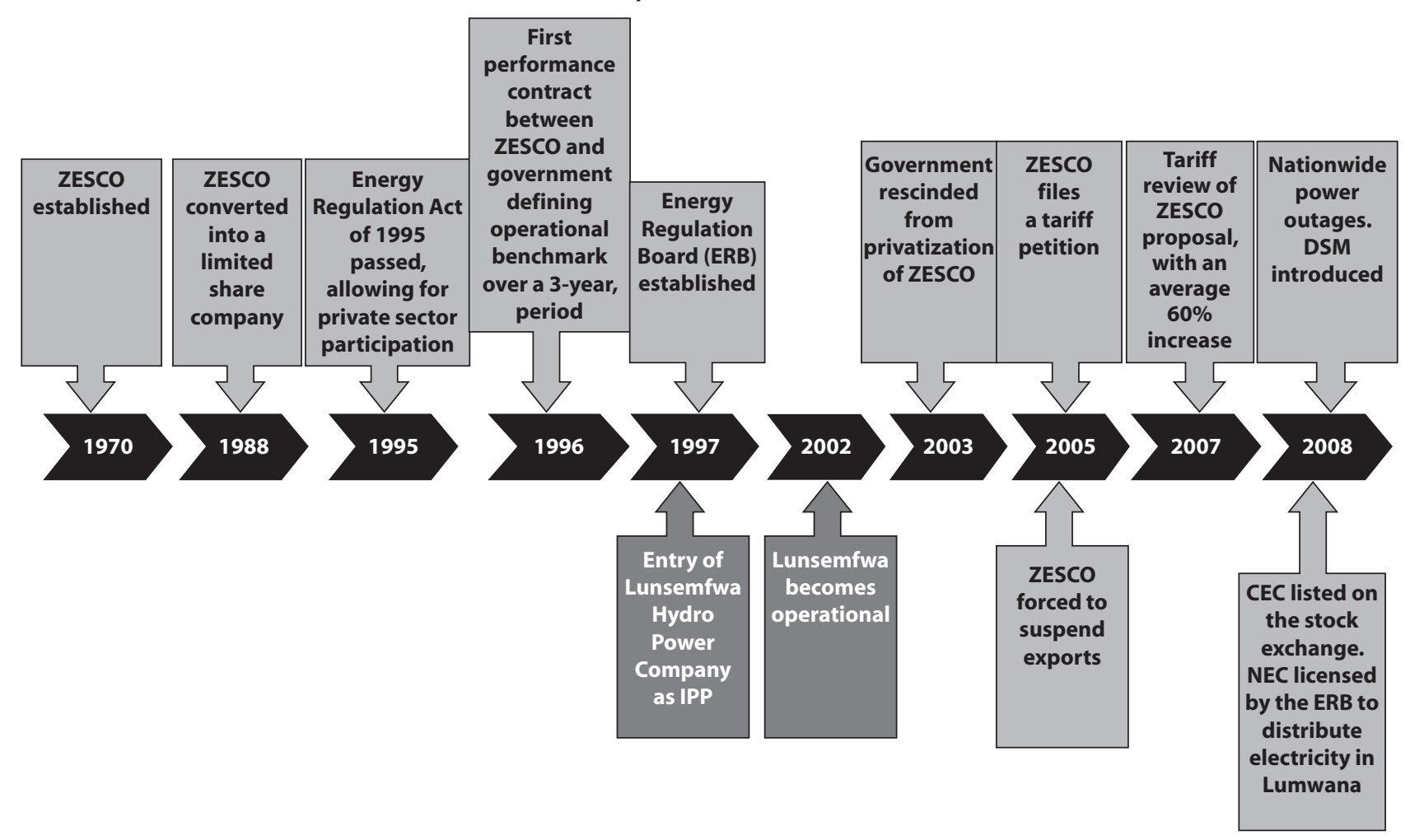


Figure 1.19 Country Performance for Access to Electricity by Households in Groups A and D
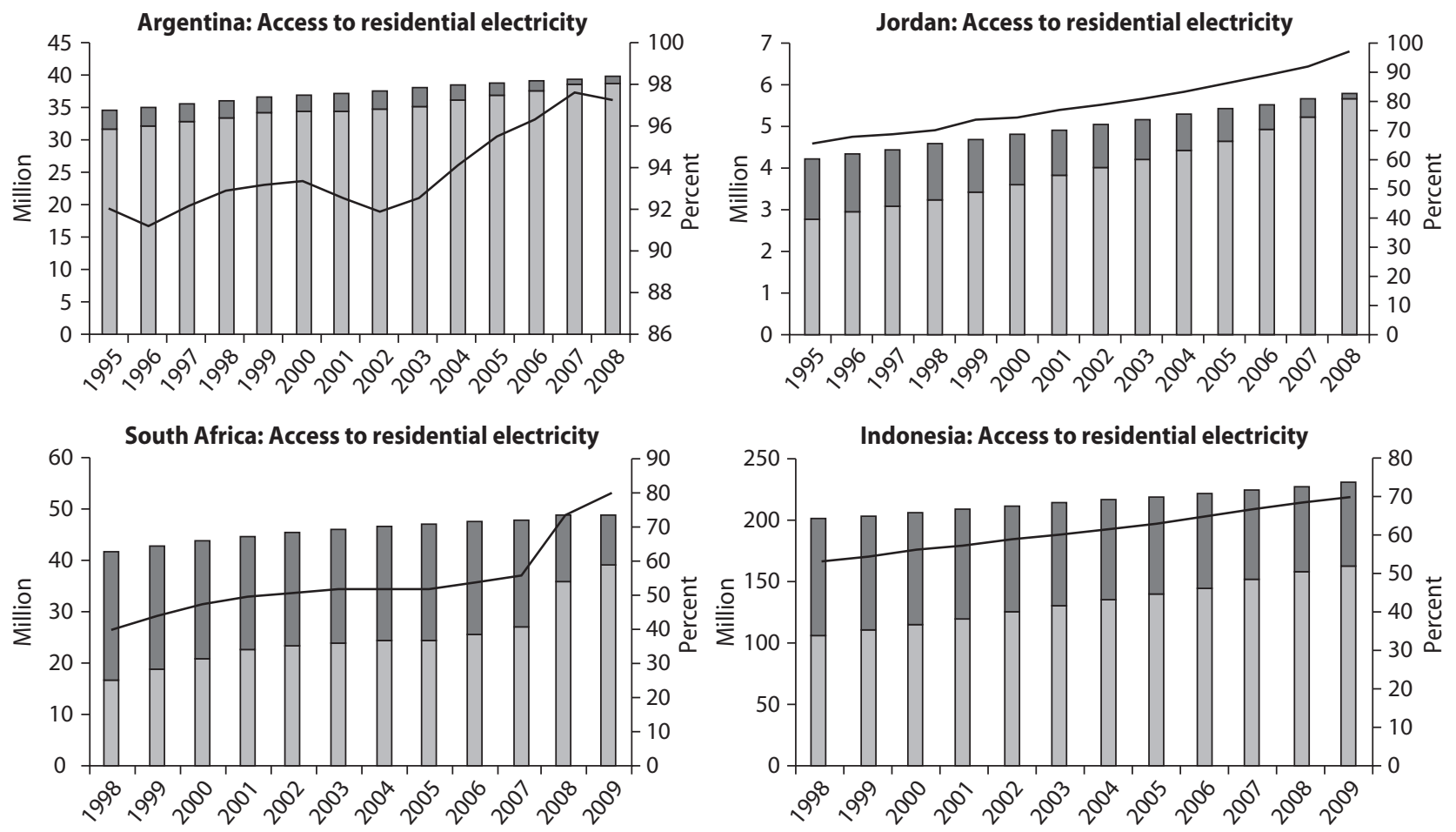

$\square$ Population without access $\square$ Residential customers with access

Access rate 

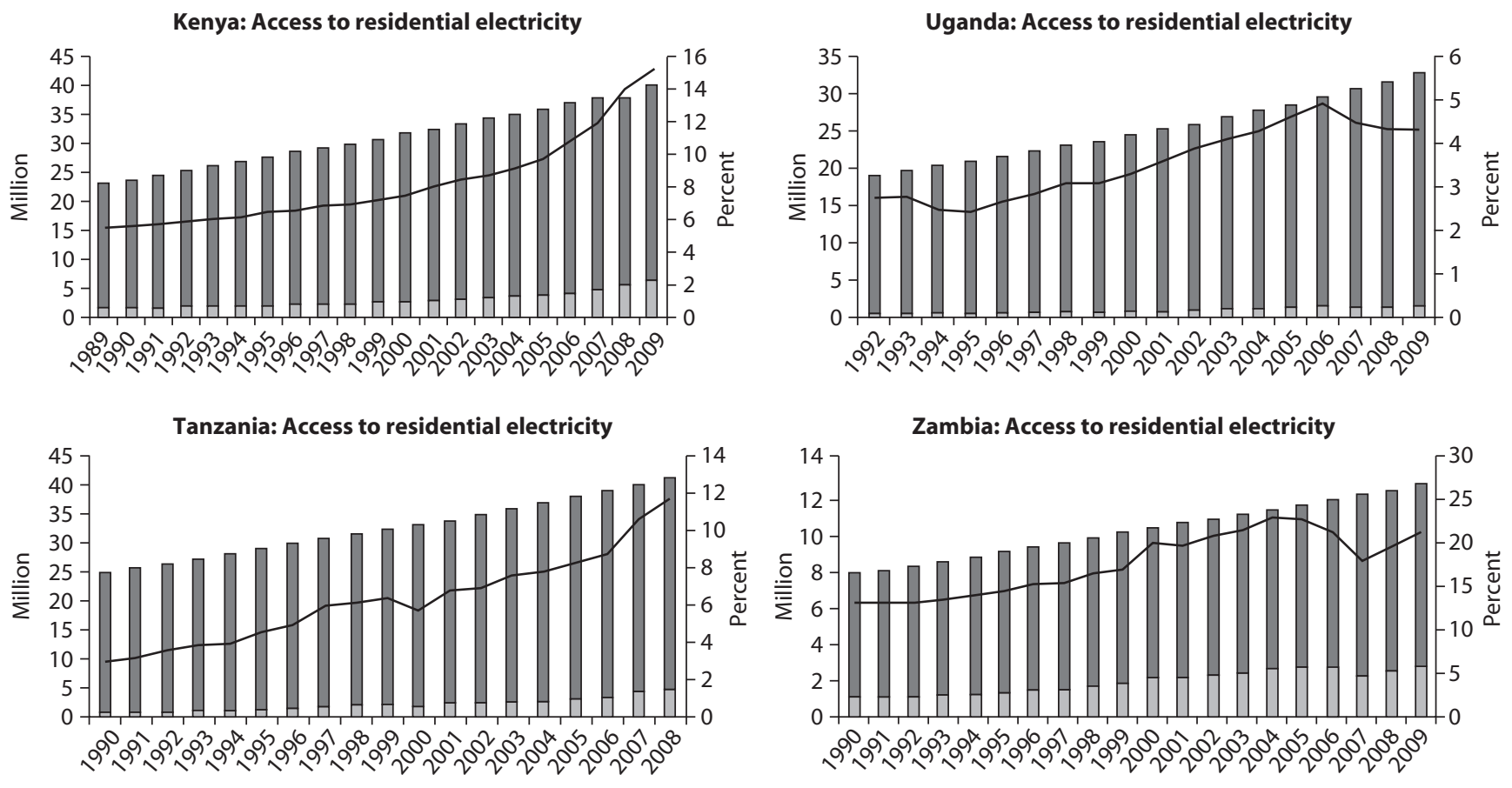

$\square$ Population without access

$\square$ Residential customers with access

Access rate 
Labor productivity improved for all the countries in both groups when measured by an increase in the amount of energy sold per employee of electricity suppliers (figure 1.20). This improvement was achieved by an increase in energy sales for all the countries and a reduction in the number of employees for some of the countries. Because employment level is one of the most contentious issues for power sector reform, it is worth noting that some of the countries that unbundled their power sectors (Argentina and Uganda, for example) reduced the number of employees, but others that unbundled (Jordan, for example) increased the number of employees. Moreover, among the countries that did not unbundle their power sectors, some-South Africa, Indonesia, Tanzania, and Zambiareduced the number of employees, and none increased the number of employees. Therefore, no clear difference between extent of power sector reform and labor productivity emerges from this snapshot, as in the case of access.

Electricity tariffs and employment levels are generally contentious issues for power sector reform. In the four Group A countries, Argentina had very low tariffs, first because of the success of the new wholesale electricity market, and then when capacity became short due to political pressures to keep tariff levels down. South Africa and Indonesia also had very low tariffs under political pressure, ${ }^{2}$ while Jordan's tariffs were sufficient to cover the cost of power supply but were not high by global standards. In the four Group D countries, Zambia had extremely low tariffs, and Uganda, Kenya, and Tanzania kept tariffs at a moderate level. No clear difference between the extent of power sector reform and electricity tariff emerges from this snapshot (figure 1.21).

Carbon dioxide emissions have not generally been one of the driving performance indicators for power sector reform in these countries. Any change to this indicator is therefore an incidental reform outcome in the sense that an increase in the index value does not necessarily indicate lack of success in achieving reform objectives, but instead shows where environmental and economic priorities can diverge. One example of this situation is a country that has relied on hydropower increases its power generation from natural gas to reduce exposure to serious droughts and to provide a more economic portfolio of generation assets for meeting the demand for power. Argentina, Kenya, Uganda, and Tanzania fall into this category, and therefore their emissions index increased in the previous decade. Jordan and Zambia reduced their emissions index by switching from oil to natural gas in Jordan's case and from coal to hydropower in 
Argentina: Labor productivity

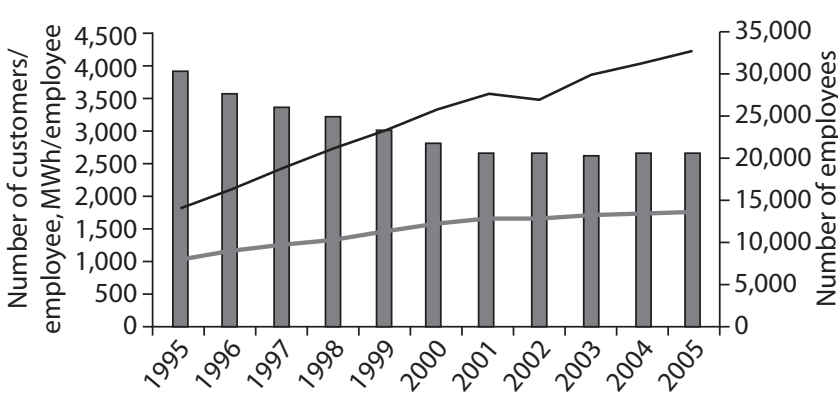

South Africa: Labor productivity

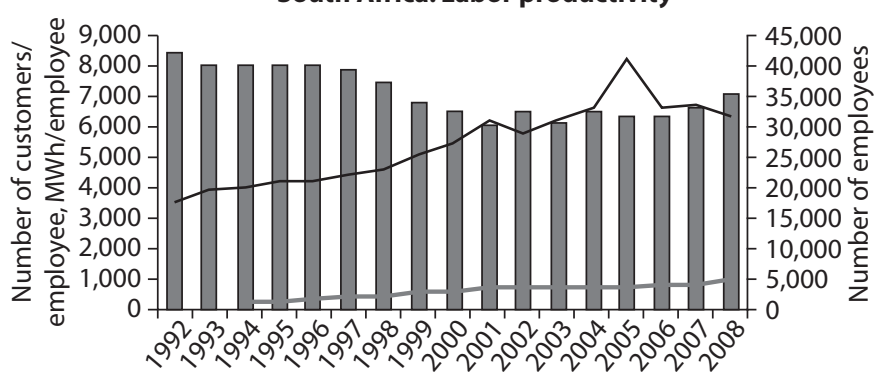

Jordan: Labor productivity

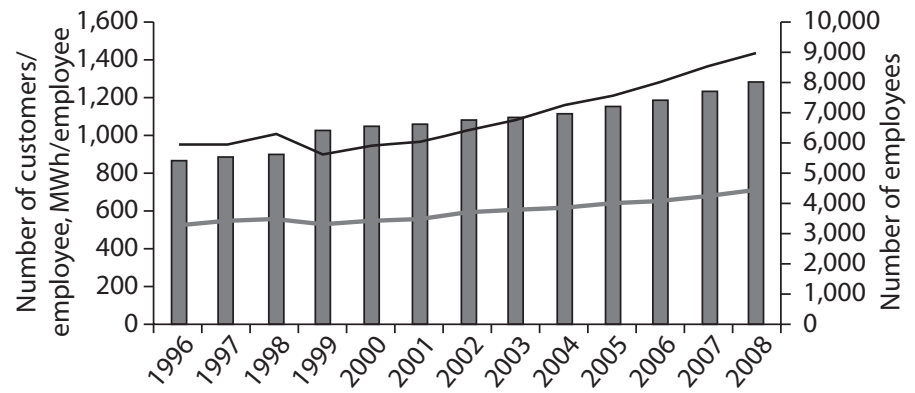

Indonesia: Labor productivity

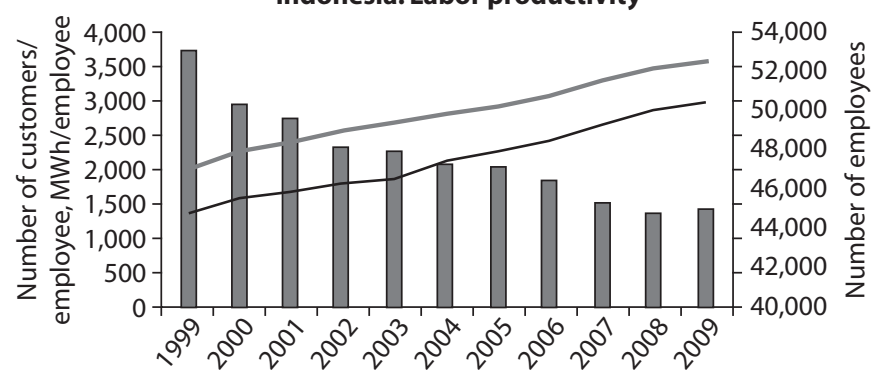

$\square \quad$ Number of employees in electricity sector

Energy consumed/employee

Number of residential customers/employee 

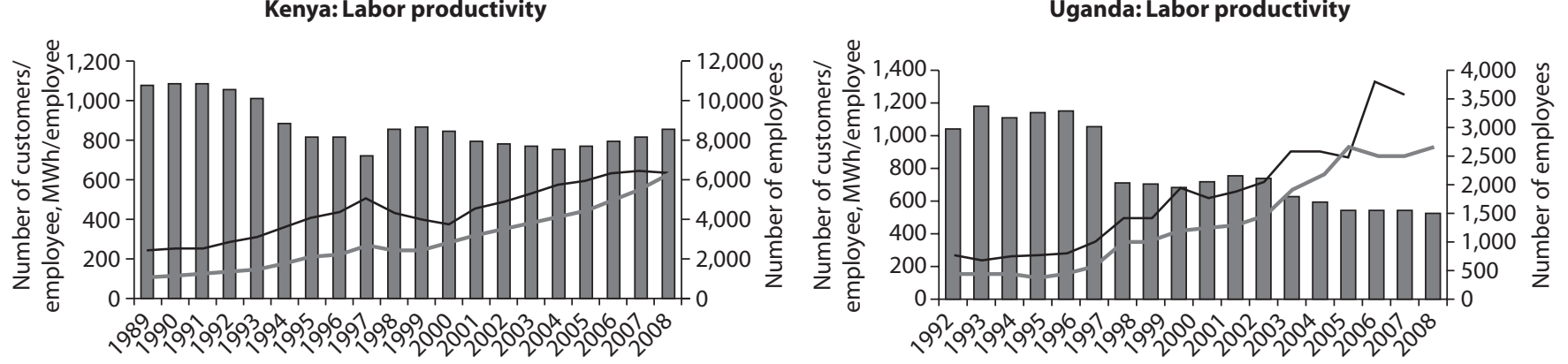

Tanzania: Labor productivity

Zambia: Labor productivity

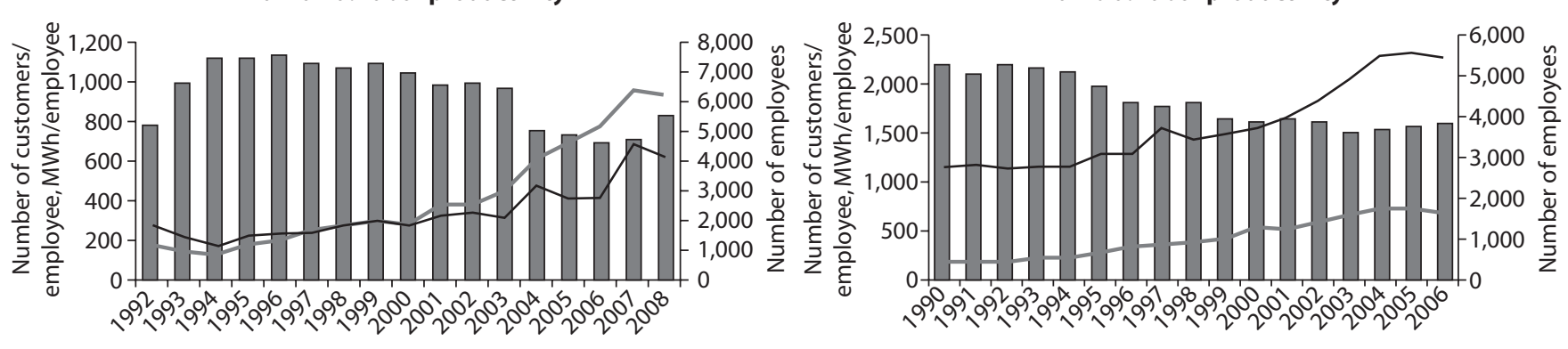

Number of employees in electricity sector Energy consumed/employee

Number of residential customers/employee 


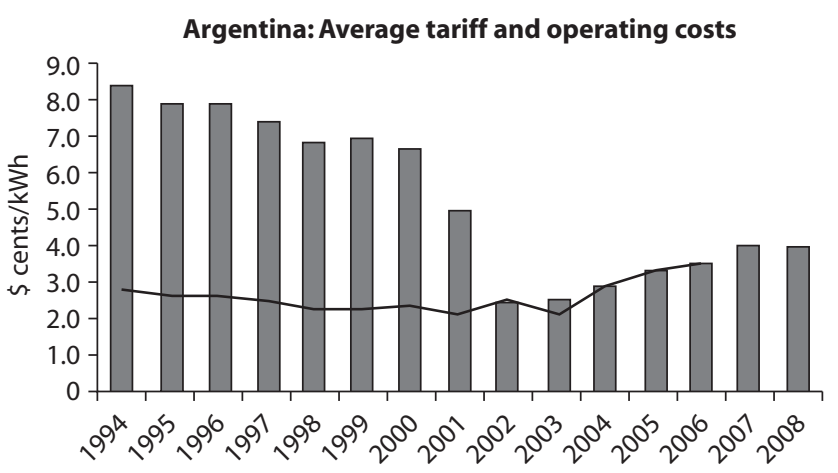

South Africa: Average tariff and operating costs

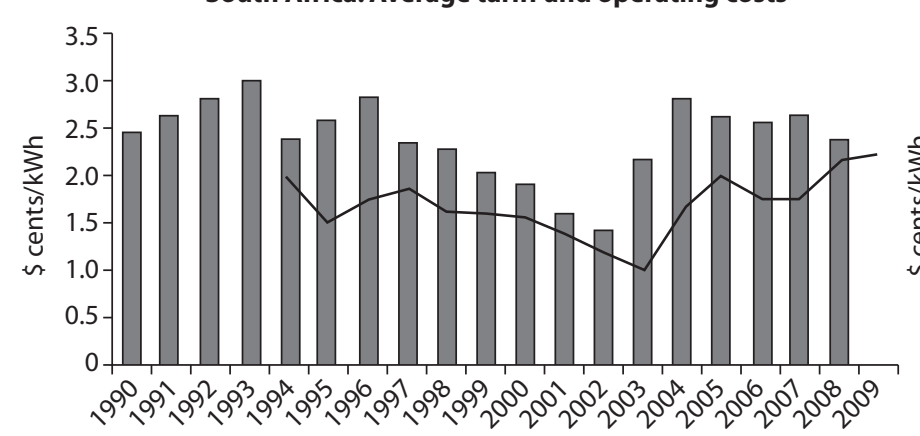

Jordan: Average tariff and operating costs

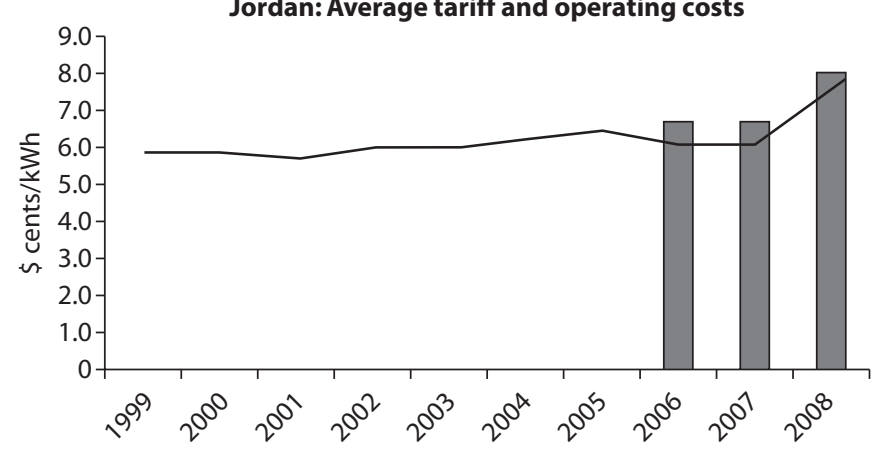

Indonesia: Average tariff and operating costs

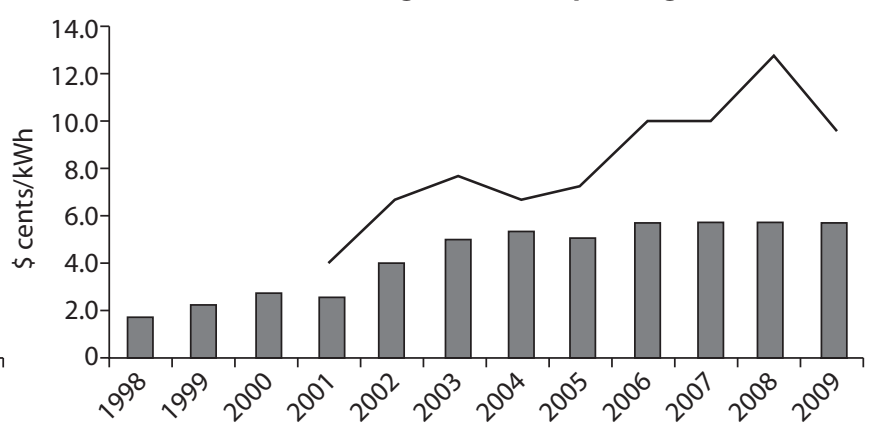

$\square$ Average tariff - Total opex per unit consumed 

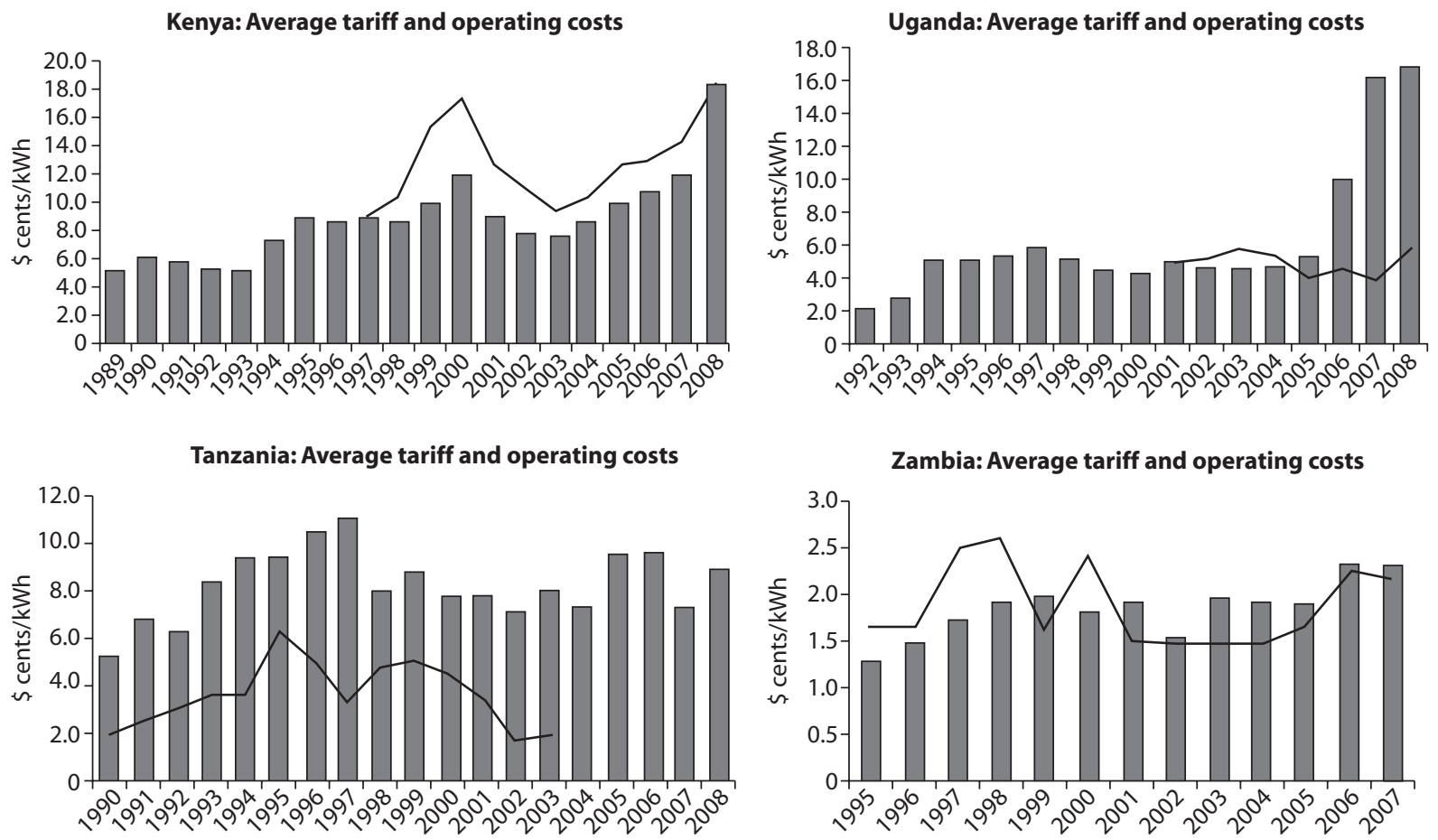

$\square$ Average tariff - Total opex per unit consumed 
Zambia's case. No clear difference between extent of power sector reform and carbon dioxide emissions emerges from this snapshot (figure 1.22).

\section{Conclusions}

Table 1.5 summarizes the analytical evidence for the results of the analysis carried out for this study. The results confirm the following conclusions for policy guidance on power market restructuring for developing countries:

- Vertical unbundling delivers results in terms of several performance indicators when used as an entry point to implement broader reforms, particularly by introducing a sound regulatory framework, attracting private sector participation, and reducing the degree of concentration of the generation and distribution segments of the market by attracting additional numbers of public and private players.

- There seems to be a credible empirical basis for selecting a threshold power system size and per capita income level below which unbundling of the power supply chain is not expected to be worthwhile.

- Partial forms of unbundling do not appear to drive improvements, probably because the owner was able to continue exercising control over the affairs of the sector and hinder the development of competitive pressure within the power market.

The analysis with the regression model used for the study produces the following main findings for each of the reform indicators (Vagliasindi 2012).

\section{Vertical Unbundling}

- The level of access is positively linked to full vertical unbundling, even if not significantly so. Partial unbundling is negatively and significantly associated with lower levels of access.

- The level of labor productivity (expressed in terms of energy sold per employee) is significantly reduced by both partial and full vertical unbundling.

- Full unbundling significantly enhances the level of tariffs, whereas partial unbundling has no significant impact on tariffs.

- Partial and vertical unbundling is associated with higher carbon emissions, but only partial unbundling significantly so. 
Figure 1.22 Country Performance for $\mathrm{CO}_{2}$ Emissions in Groups A and D

Argentina: Electricity generation by source and carbon emissions index

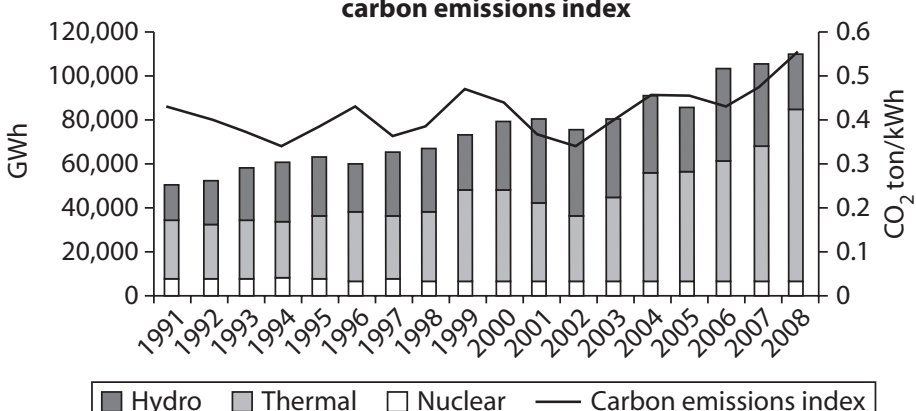

South Africa: Electricity generation by source and carbon emissions index

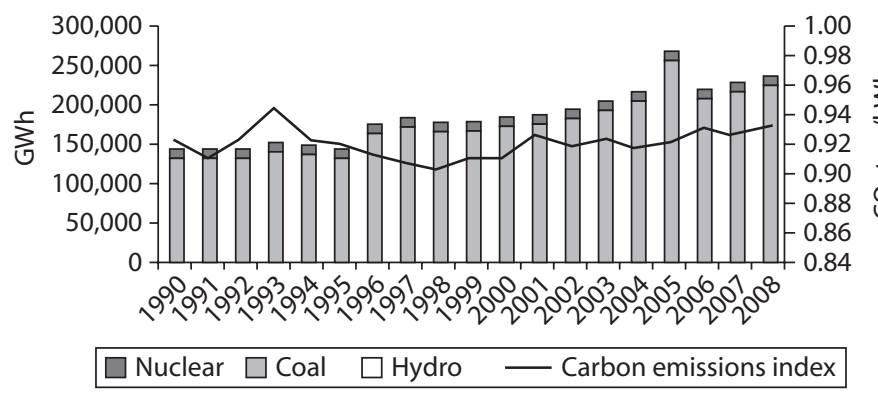

Jordan: Electricity generation by source and carbon emissions index

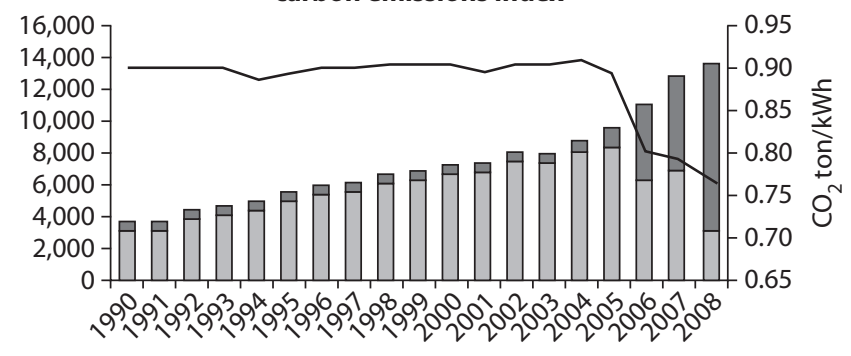

$\square$ Natural gas $\square$ Petroleum fuels $\quad$ Carbon emissions index

Indonesia: Electricity generation by source and carbon emissions index

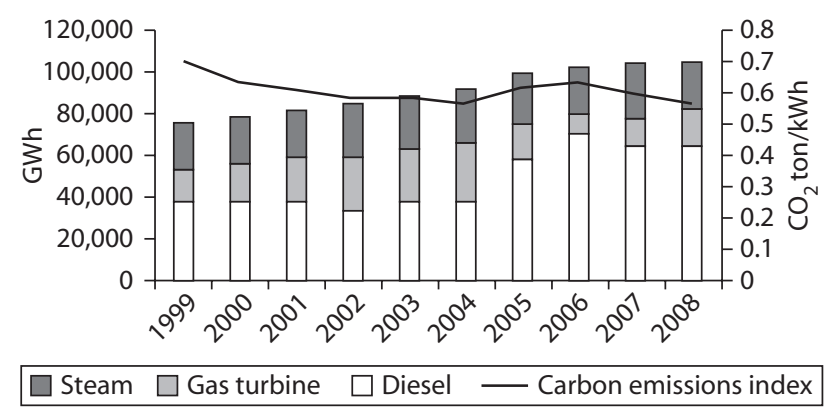



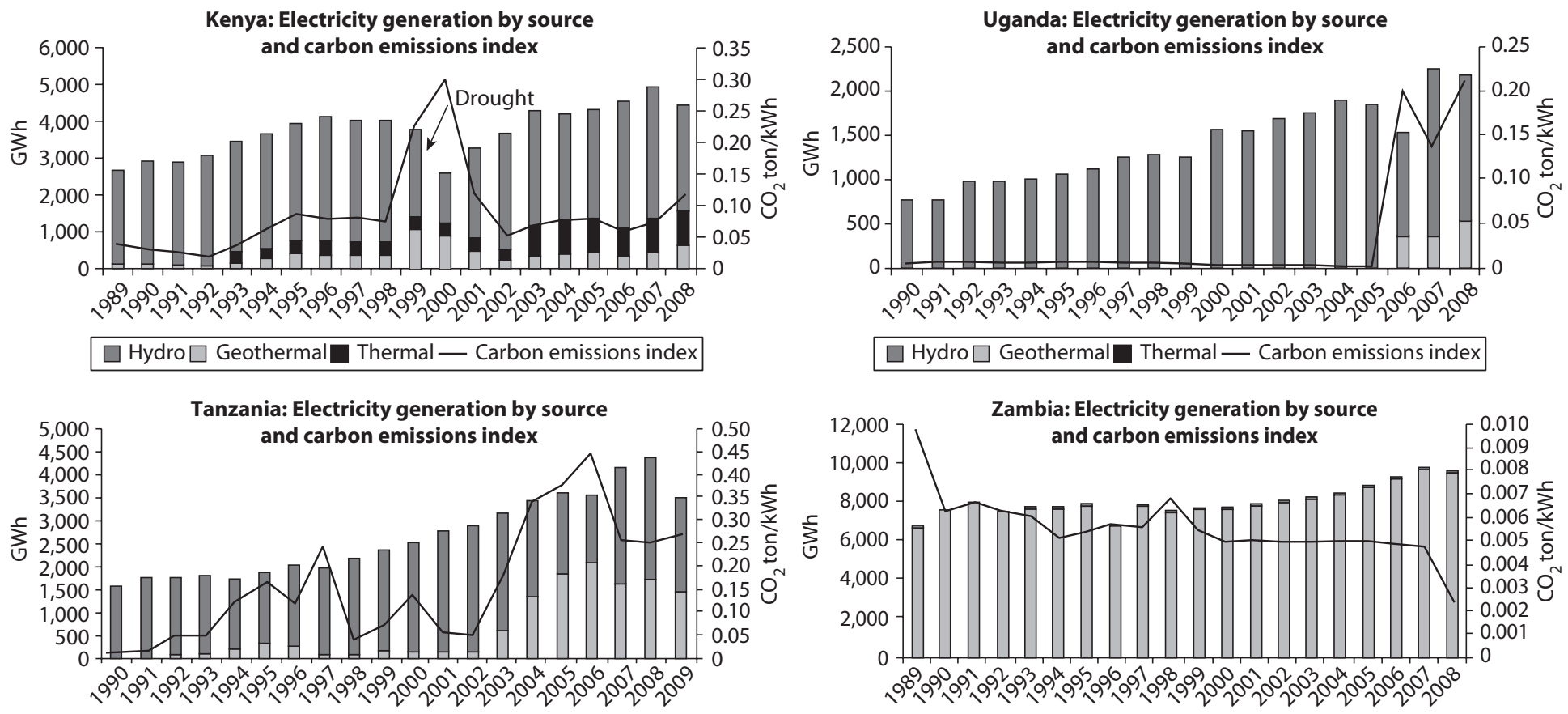

$$
\begin{aligned}
& \square \text { Renewable sources (hydro, biogas) } \\
& \square \text { Nonrenewable sources (gas, fiesel, coal, HFO) } \\
& \text { - Carbon emissions index }
\end{aligned}
$$


Table 1.5 Summary of Analytical Evidence

\begin{tabular}{|c|c|c|c|c|c|c|c|c|}
\hline \multirow[b]{2}{*}{ Group } & \multicolumn{2}{|c|}{ Access } & \multicolumn{2}{|c|}{$\begin{array}{c}\text { Labor } \\
\text { productivity }\end{array}$} & \multicolumn{2}{|c|}{ Tariff } & \multicolumn{2}{|c|}{ Emissions index } \\
\hline & $A$ & $D$ & $A$ & $D$ & $A$ & $D$ & $A$ & $D$ \\
\hline \multicolumn{9}{|c|}{ Vertical unbundling (either partial or full) } \\
\hline Unbundling & \multicolumn{2}{|c|}{-} & \multirow{2}{*}{\multicolumn{2}{|c|}{$+^{*}$}} & \multicolumn{2}{|c|}{$+^{* *}$} & \multicolumn{2}{|c|}{$+^{*}$} \\
\hline $\begin{array}{l}\text { Unbundling* } \\
\text { group }\end{array}$ & $+^{* * *}$ & $-^{* * *}$ & & & - & + & $-^{* *}$ & $+^{* *}$ \\
\hline \multicolumn{9}{|c|}{ Full vertical unbundling } \\
\hline Full unbundling & \multicolumn{2}{|c|}{+} & \multicolumn{2}{|c|}{$-^{*}$} & \multicolumn{2}{|c|}{$t^{* * *}$} & \multicolumn{2}{|c|}{+} \\
\hline $\begin{array}{l}\text { Full unbundling* } \\
\text { group }\end{array}$ & $+^{* * *}$ & $-^{* * *}$ & - & $+^{*}$ & $-^{* * *}$ & $+^{* * *}$ & $-^{* * *}$ & $+^{* * *}$ \\
\hline \multicolumn{9}{|c|}{ Degree of disaggregation } \\
\hline Disaggregation & \multicolumn{2}{|c|}{$t^{* * *}$} & \multicolumn{2}{|c|}{+} & \multicolumn{2}{|c|}{$-{ }^{* * *}$} & \multicolumn{2}{|c|}{$-* * *$} \\
\hline $\begin{array}{l}\text { Disaggregation* } \\
\text { group }\end{array}$ & $+^{* * *}$ & $-^{* * *}$ & $++^{* *}$ & - & + & - & $-^{* * *}$ & $--^{* * *}$ \\
\hline \multicolumn{9}{|l|}{ Regulation } \\
\hline Regulation & \multicolumn{2}{|c|}{$+* * *$} & \multicolumn{2}{|c|}{$+^{* * *}$} & \multicolumn{2}{|c|}{$+* * *$} & \multicolumn{2}{|c|}{$-{ }^{* * *}$} \\
\hline Regulation* Group & $t^{* * *}$ & $--^{* * *}$ & $t^{* * *}$ & $-{ }^{* *}$ & $--^{* * *}$ & $+^{* * *}$ & $t^{* * *}$ & $-{ }^{* * *}$ \\
\hline \multicolumn{9}{|l|}{ Privatization } \\
\hline Privatization & \multicolumn{2}{|c|}{$t^{* * *}$} & \multicolumn{2}{|c|}{$+^{* * *}$} & \multicolumn{2}{|c|}{$t^{* *}$} & \multicolumn{2}{|c|}{$t^{* * *}$} \\
\hline $\begin{array}{l}\text { Privatization* } \\
\text { group }\end{array}$ & + & $-^{*}$ & $+^{* *}$ & $-^{* *}$ & + & - & - & + \\
\hline \multicolumn{9}{|l|}{ Control variables } \\
\hline GDP per capita & \multicolumn{2}{|c|}{$++^{* * *}$} & \multicolumn{2}{|c|}{$++^{* * *}$} & & & & \\
\hline Installed capacity & & & & & & & & \\
\hline $\begin{array}{l}\text { GDP per capita* } \\
\text { capacity }\end{array}$ & & & & & & & & \\
\hline Explanatory powe & & & & & & & & \\
\hline $\begin{array}{l}\text { Within } R^{2} \\
\text { (fixed effect) }\end{array}$ & & & & & & & & \\
\hline $\begin{array}{l}\text { Between } R^{2} \\
\text { (random effect) }\end{array}$ & & & & & & & & \\
\hline
\end{tabular}

Source: An elaboration from the Power Market Structure database.

Note: GDP = gross domestic product. ${ }^{* * *},{ }^{* * *}$ indicate, respectively, level of significance of 10,5 , and 1 percent.

The differential impact of vertical unbundling in Groups A and D is as follows:

- Vertical unbundling (in both specifications, namely either partial or full or full only) when applied to Group A countries is significantly associated with enhanced access and more sustainable levels of $\mathrm{CO}_{2}$ emissions 
generated by fossil fuels, reflecting economic and environmental benefits to power users due to the increased efficiency of use of fossil fuels. The opposite result holds for Group D countries.

- There is no significant link between vertical unbundling and enhanced operational or financial efficiency for Group A, but the link is positive and significant for Group D. This result implies that for Group A the high prevailing level of labor productivity offers decreasing returns to scale, or there is an increasing use of outsourcing. For Group D the benefits of unbundling may be reflected mainly through restructuring and laying off of redundant employees.

\section{Degree of Disaggregation}

- The level of access is positively and significantly linked to the increase of disaggregation in generation. This result can be interpreted noting that developing countries have been able to scale up access after attracting more players and investment in generation.

- Labor productivity is enhanced by the increase of disaggregation in distribution. More players in distribution are expected to drive efficiency gains through means such as benchmark competition.

- More disaggregation in distribution drives electricity tariffs down, most likely as a result of benchmark competition and less collusion between players in the market.

- Higher competition in generation is significantly associated with higher sustainable environmental outcomes, reducing the carbon emissions from fossil fuels.

The differential impact of disaggregation in Groups A and D is as follows:

- Higher disaggregation of the generation segment of the market when interacted with Group A is significantly associated with enhanced access and more sustainable levels of $\mathrm{CO}_{2}$ emissions generated by fossil fuels, reflecting the benefits to the users as well as to the environment, due to increased efficiency of the use of fossil fuels when more players are introduced. For Group D a trade-off emerges between reduced access and a more sustainable level of $\mathrm{CO}_{2}$ emissions generated by fossil fuels. 
- Reduction in the concentration of the distribution segment of the market for the countries belonging to Group A is positively and significantly linked with enhanced operational efficiency, but there are no links with enhanced financial efficiency. This implies that for countries where the achieved level of tariff is already high there are decreasing returns to scale. Reduction in the concentration of the distribution segment of the market for the countries belonging to Group D is negatively linked with operational and financial efficiency, but not significantly so.

\section{Regulation}

- The introduction of an autonomous regulator is significantly and positively associated with higher access, confirming that regulators can also play an important role in ensuring that contracts are effectively designed.

- The presence of an autonomous regulator has significantly contributed to higher labor productivity, most likely by creating a more even playing field to attract private participation in distribution.

- The presence of an autonomous regulator is significantly and positively associated with higher tariffs, reflecting the need to insulate crucial decisions related to pricing from political interference.

- The presence of an autonomous regulator is significantly associated with lower carbon emissions, proving that environmental considerations started to be given a relatively higher priority compared to the traditional functions of energy policy and regulation, such as to protect consumers from high prices and ensure that power firms will be able to recoup their investment.

The differential impact of regulation in Groups A and D is as follows:

- The introduction of an autonomous regulator when interacted with Group A is significantly associated with enhanced access, higher operational efficiency, lower tariffs, and a more sustainable level of $\mathrm{CO}_{2}$ emissions generated by fossil fuels, reflecting the benefits to users, producers, and the environment because of increased efficiency in the use of fossil fuels.

- The introduction of an autonomous regulator in Group D is significantly associated with reduced access, lower operational efficiency, 
and higher tariffs, all of which reflect a lack of benefits to users and producers. It is, however, associated with a more sustainable level of $\mathrm{CO}_{2}$ emissions generated from fossil fuels. This result underscores the challenges in implementing regulatory reforms in this group of countries.

\section{Private Sector Participation}

- The introduction of private sector participation in generation is significantly linked to access expansions, proving that independent power producers and divestiture of formerly state-owned generators can deliver positive results. The introduction of private sector participation also helped to significantly enhance operational efficiency and labor productivity in distribution.

- A higher share of private sector participation significantly raises the level of tariffs, most likely reflecting the need to raise tariffs to attract private participation in distribution.

- Private ownership in generation is significantly and positively associated with less environmental sustainable outcomes, raising the carbon emissions from burning fossil fuels.

The differential impact of private sector participation in Groups A and $\mathrm{D}$ is as follows:

- The introduction of private sector participation in the generation segment of the market when interacted with Group A is not significantly associated with access or carbon emissions generated from fossil fuels. This implies that for countries belonging to Group A the achieved level of access is already so high that privatization of generation is not sought to enhance connectivity. There is no significant evidence of environmental unsustainability brought by the private sector in generation. The introduction of private sector participation in the generation segment of the market when interacted with Group D is significantly associated with a reduced level of access but is not significantly linked to the carbon emissions generated by fossil fuels.

- The introduction of private sector participation in the distribution segment of the market for the countries belonging to Group A is positively and significantly linked with enhanced operational efficiency, but there 
are no links with enhanced financial efficiency. Instead, the overall link between private sector participation in distribution and tariff was positive and significant, suggesting that more cost-reflective tariffs were needed to attract the private sector. This seems to imply that for Group A countries the already achieved level of tariff is enough to attract private sector participation in distribution. The introduction of private sector participation in the distribution segment of the market for the countries belonging to Group D is negatively and significantly linked with operational efficiency, but there are no links with enhanced financial efficiency.

\section{Control Variables}

- As expected, countries characterized either by higher income or larger system size are also characterized by significantly higher levels of access, labor productivity, and tariffs. The links with environmentally sustainable outcomes are different. Ceteris paribus, as one would expect, higher-income countries are positively associated to higher carbon emissions, whereas countries characterized by larger system size are negatively and significantly associated to lower carbon emissions. The latter result is most likely due to the presence of economies of scale and the fact that smaller and isolated systems are in many cases mostly dependent on oil imports and find it more difficult to diversify sources of energy.

- The interacted term between GDP per capita and power system size is negative, revealing decreasing returns to scale by the highest-income countries-such as the Organisation for Economic Co-operation and Development countries-which have already achieved close to universal access and face an exponentially increasing cost in connecting each new consumer as they approach full coverage. The explanatory power of these variables is very high, reaching 90 percent in the preferred specification of random effects.

\section{Directions for New Research}

For the purposes of this research the countries in the sample were divided into different categories based on the specific threshold levels of system size and income. The selected thresholds are in line with the previous research (Besant-Jones 2006). A different way of categorizing countries would be to apply a cluster analysis. This technique allows assigning a set 
of observations into subsets, such as GDP per capita and power system size, but the subsets differ from each other. The application of the cluster analysis allows obtaining the optimal number of subsets as well as the threshold levels based on the underlying data.

Different definitions of the aggregate index of reforms can be used to examine the robustness of the results to the different specifications. More sophisticated dynamic error correction models and the instrumental variable approach to allow for potential possible endogenous biases can be used in future research.

Finally, additional performance indicators, including indicators of quality (such as SAIDI and SAIFI), operational efficiency (such as capacity utilization and load factor), financial efficiency (such as cost recovery index), and long-run environmentally sustainability indicators (such as the share of renewables) and energy endowment (such as reserve capacity and self-sufficiency) can be studied in more detail with the help of the econometric models.

\section{Annex A}

List of Performance Indicators Included in the Database

Whereas the outcomes used for our econometric and case study analysis are selected ones, the database includes indicators of access (namely, residential access to electricity), quality (SAIDI and SAIFI), operational efficiency (such as energy sold per employee of electricity supplied, capacity utilization, load factor), financial efficiency (such as the average level of tariff and the cost recovery index), environmentally sustainability indicators (such as the carbon dioxide emissions index and the share of renewable energy in generation), and energy endowment (such as reserve capacity and self-sufficiency), as reported in table 1A.1.

\section{Annex B}

Testing Hypotheses for the Set of Indicators

To get an initial indication from the data of whether the hypotheses we moved forward are confirmed, we can calculate the two means between different groups (for example, the proportion of investment for the observations where vertical unbundling has been introduced) and compare them to see if one is greater than the other, and by how much. The significance of differences between two sample means can be 
Table 1A.1 Performance Indicators

\begin{tabular}{|c|c|}
\hline Variables & Definition \\
\hline \multicolumn{2}{|l|}{ Access } \\
\hline $\begin{array}{l}\text { Residential access } \\
\text { (\% population) }\end{array}$ & $\begin{array}{l}=\text { Number of residential connections divided by the total } \\
\text { population. }\end{array}$ \\
\hline \multicolumn{2}{|l|}{ Quality } \\
\hline $\begin{array}{l}\text { SAIDI } \\
\text { (hours per customer) }\end{array}$ & $\begin{aligned} &= \text { System Average Interruption Duration Index. Average } \\
& \text { duration of interruptions to power supply experienced } \\
& \text { by a consumer. }\end{aligned}$ \\
\hline $\begin{array}{l}\text { SAIFI } \\
\text { (number per customer) }\end{array}$ & $\begin{aligned}= & \text { System Average Interruption Frequency Index. Average } \\
& \text { number of interruptions to power supply experienced } \\
& \text { by a consumer. }\end{aligned}$ \\
\hline \multicolumn{2}{|l|}{ Operational efficiency } \\
\hline $\begin{array}{l}\text { Energy sold per employee } \\
\text { (MWh per employee) }\end{array}$ & $\begin{aligned} &= \text { Amount of the energy consumed from the } \\
& \text { interconnected system divided by the number of } \\
& \text { employees of the power supply entities for the whole } \\
& \text { power market. }\end{aligned}$ \\
\hline Capacity utilization (\%) & $\begin{array}{l}=\text { Amount of energy generated divided by the total } \\
\text { nominal generating capacity on the interconnected } \\
\text { system. }\end{array}$ \\
\hline Load factor (\%) & $\begin{array}{l}=\text { Output of a power plant divided by the maximum } \\
\text { output it can produce. }\end{array}$ \\
\hline \multicolumn{2}{|l|}{ Financial efficiency } \\
\hline Tariff level ( $\$$ cent per kWh) & $=$ Average tariff. \\
\hline Cost recovery index (\%) & $\begin{aligned}= & \text { Ratio of average revenue yield divided by average } \\
& \text { supply cost for all distributors as a group. }\end{aligned}$ \\
\hline Debt ratio (\%) & $=$ Utilities' equity divided by liability. \\
\hline \multicolumn{2}{|l|}{ Environmental sustainability } \\
\hline $\begin{array}{l}\text { Carbon Emissions Index } \\
\left(\mathrm{CO}_{2} \text { ton/kWh }\right)\end{array}$ & $\begin{array}{l}=\text { Energy generated from each fuel weighted with the } \\
\text { following coefficients of } \mathrm{CO}_{2} \text { emission intensity by } \\
\text { weight per unit of electricity generated divided by total } \\
\text { amount of energy generated (coal = } 1.00 \text {; petroleum } \\
\text { fuels }=0.94 \text {; natural gas }=0.63 \text {; renewable energy and } \\
\text { nuclear power = zero). }\end{array}$ \\
\hline Share renewable (\%) & $\begin{aligned}= & \text { Amount of energy generated from renewable sources } \\
& \text { to the total amount of energy generated. }\end{aligned}$ \\
\hline \multicolumn{2}{|l|}{ Energy endowment } \\
\hline Reserve capacity (\%) & $\begin{aligned}= & (\text { available capacity during peak demand }(\mathrm{MW}) / \text { peak } \\
& \text { demand }(\mathrm{MW}))-1\end{aligned}$ \\
\hline Self-sufficiency (\%) & $\begin{aligned}= & \text { Proportion of total bulk energy supply derived from } \\
& \text { domestic energy resources. }\end{aligned}$ \\
\hline
\end{tabular}

Source: An elaboration from the Power Market Structure database.

Note: $\mathrm{kWh}=$ kilowatt-hour; $\mathrm{MWh}=$ megawatt-hour. 
assessed using the t-statistic calculated as part of the t-test. The t-statistic may be thought of as a scaled difference between the two means, where the absolute difference between means is rescaled using an estimate of the variability of the means. The results of the t-tests reveal the following trends.

The percentage of the population with access to electric service is significantly higher in the systems characterized by the presence of an autonomous regulator, vertical unbundling, higher levels of disaggregation both in generation and in distribution sectors, and a higher share of private ownership. All results of the t-tests on access are statistically significant at the 1 percent level.

Regarding quality, the graphs indicate that levels of SAIDI (duration of outages) and SAIFI (frequency of outages) tend to be lower in more liberalized systems. Statistical significance of the results of t-tests on quality varies across market structure variables.

With respect to the relationship between market structure and operational efficiency, the results of $\mathrm{t}$-tests provide mixed evidence. Capacity utilization tends to be lower in more liberalized systems, but load factor in such systems is generally higher. The results of t-tests on labor productivity that are statistically significant vary: energy sold per employee is higher when the generation sector is less concentrated, when the system is vertically unbundled, and when an independent regulator is present; it is lower when the share of private ownership is higher.

T-tests were also applied to three indicators of financial efficiency. The tariff level is lower when the system is vertically unbundled and when more competition occurs in the distribution sector, but it is higher in the presence of an autonomous regulator and a higher share of private ownership. The cost recovery index is higher in all cases. Debt ratio appears to be affected by the market structure variables in different ways.

According to t-tests, more liberalized market conditions are beneficial to the environment. All the graphs indicate lower emissions levels and higher reliance on renewable sources (except in the case of higher private ownership, although the result is not statistically significant).

Energy security also seems to be positively affected by higher market disaggregation, presence of an autonomous regulator, and a higher degree of private ownership. Figures 1B.1 through 1B.5 depict higher levels of reserve capacity and self-sufficiency, except in the case of higher disaggregation in generation (not a statistically significant result).

Figures 1B.6 and 1B.7 illustrate relations of two key control variables, installed capacity and GDP per capita, and performance parameters. It is 


\section{Figure 1B.1 Vertical Unbundling}

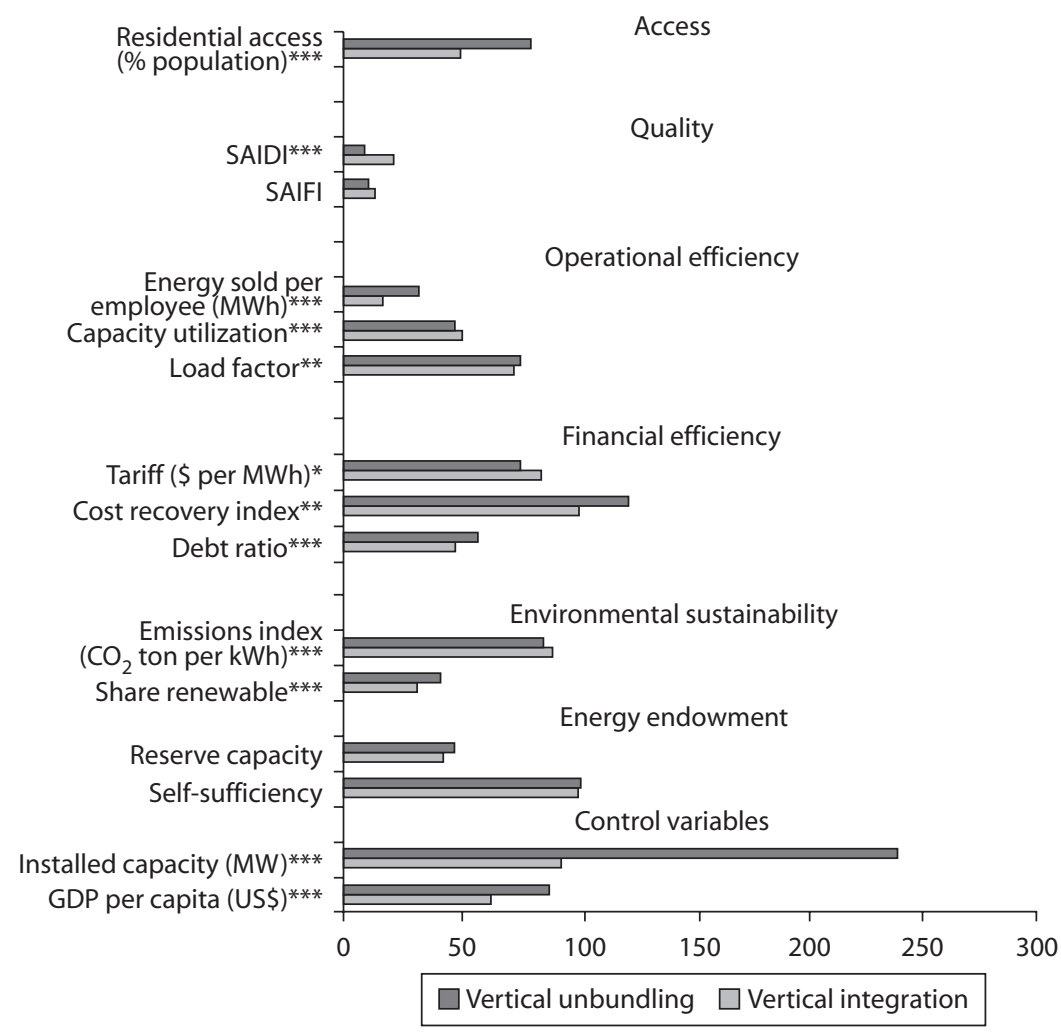

\begin{tabular}{|c|c|c|c|}
\hline & Vertical unbundling & Vertical integration & $\mathrm{t}$ \\
\hline $\begin{array}{l}\text { Residential access } \\
(\% \text { population })^{* * *}\end{array}$ & $\begin{array}{l}78.4 \\
(28.1)\end{array}$ & $\begin{array}{c}49.3 \\
(34.3)\end{array}$ & -8.7 \\
\hline SAIDI $I^{* * *}$ & $\begin{array}{c}10.4 \\
(10.9)\end{array}$ & $\begin{array}{l}22.6 \\
(22.8)\end{array}$ & 4.0 \\
\hline SAIFI & $\begin{array}{c}12.8 \\
(12.2)\end{array}$ & $\begin{array}{l}14.3 \\
(8.3)\end{array}$ & 0.8 \\
\hline $\begin{array}{l}\text { Energy sold per employee } \\
(\mathrm{MWh})^{* * *}\end{array}$ & $\begin{array}{c}33.6 \\
(28.18)\end{array}$ & $\begin{array}{c}18.7 \\
(17.17)\end{array}$ & -4.9 \\
\hline Capacity utilization*** & $\begin{array}{c}46.6 \\
(15.9)\end{array}$ & $\begin{array}{c}51.0 \\
(11.7)\end{array}$ & 2.8 \\
\hline Load factor** & $\begin{array}{l}73.5 \\
(8.3)\end{array}$ & $\begin{array}{l}71.0 \\
(9.3)\end{array}$ & -1.7 \\
\hline Tariff (\$ per MWh)* & $\begin{array}{l}75.4 \\
(3.2)\end{array}$ & $\begin{array}{l}82.6 \\
(5.3)\end{array}$ & 1.5 \\
\hline
\end{tabular}


Figure 1B.1 (continued)

\begin{tabular}{|l|c|c|c|}
\hline & Vertical unbundling & Vertical integration & $\mathrm{t}$ \\
\hline Cost recovery index** & $\begin{array}{c}110.9 \\
(64.3)\end{array}$ & $\begin{array}{c}97.5 \\
(45.9)\end{array}$ & -2.1 \\
\hline Debt ratio*** & $\begin{array}{c}57.3 \\
(23.8)\end{array}$ & $\begin{array}{c}47.1 \\
(24.5)\end{array}$ & -2.2 \\
\hline $\begin{array}{l}\text { Emissions index } \\
\left(\mathrm{CO}_{2} \text { ton per kWh)*** }\right.\end{array}$ & $\begin{array}{c}83.7 \\
(6.4)\end{array}$ & $\begin{array}{c}86.8 \\
(9.3)\end{array}$ & 3.5 \\
\hline Share renewable*** & $\begin{array}{c}41.9 \\
(28.5)\end{array}$ & $\begin{array}{c}32.1 \\
(33.8)\end{array}$ & -3.1 \\
\hline Reserve capacity & $\begin{array}{c}46.9 \\
(35.0)\end{array}$ & $\begin{array}{c}42.7 \\
(19.1)\end{array}$ & -1.2 \\
\hline Self-sufficiency & $\begin{array}{c}98.5 \\
(6.6)\end{array}$ & $\begin{array}{c}97.5 \\
(17.3)\end{array}$ & -0.7 \\
\hline Installed capacity (MW)*** & $\begin{array}{c}244.7 \\
(257.4)\end{array}$ & $\begin{array}{c}90.4 \\
(120.5)\end{array}$ & -7.9 \\
\hline GDP per capita (US\$)*** & $\begin{array}{c}85.7 \\
(60.4)\end{array}$ & $\begin{array}{c}61.7 \\
(63.3)\end{array}$ & -3.9 \\
\hline
\end{tabular}

Source: An elaboration from the Power Market Structure database.

Note: The following adjustments were made to make the indicators fit in the same figure. Tariffs are measured as $\$$ per MWh rather than as $\$$ cent per $\mathrm{kWh}$. Emissions index is measured by an index ranging from 0 to 100 rather than 0 to 1. Energy sold per employee (measured in MWh per employee), installed capacity (measured in MW), and GDP per capita (measured in US\$) were divided by $100 .{ }^{*}, * *, * * *$ indicate, respectively, level of significance of 10, 5, and 1 percent. SAIDI = System Average Interruption Duration Index; SAIFI = System Average Interruption Frequency Index.

not surprising that the populations of countries with higher income and large system sizes tend to enjoy better access to electric service and higher quality of this service. Larger system size is associated with higher labor productivity, lower capacity utilization, higher load factor, lower tariffs, lower emissions index, lower share of renewable, and higher degree of self-sufficiency. Higher income is associated with higher labor productivity, lower load factor, higher cost recovery index, lower debt ratio, higher emissions index, lower share of renewable, higher reserve capacity, and lower self-sufficiency. 


\section{Figure 1B.2 Disaggregation in Generation}

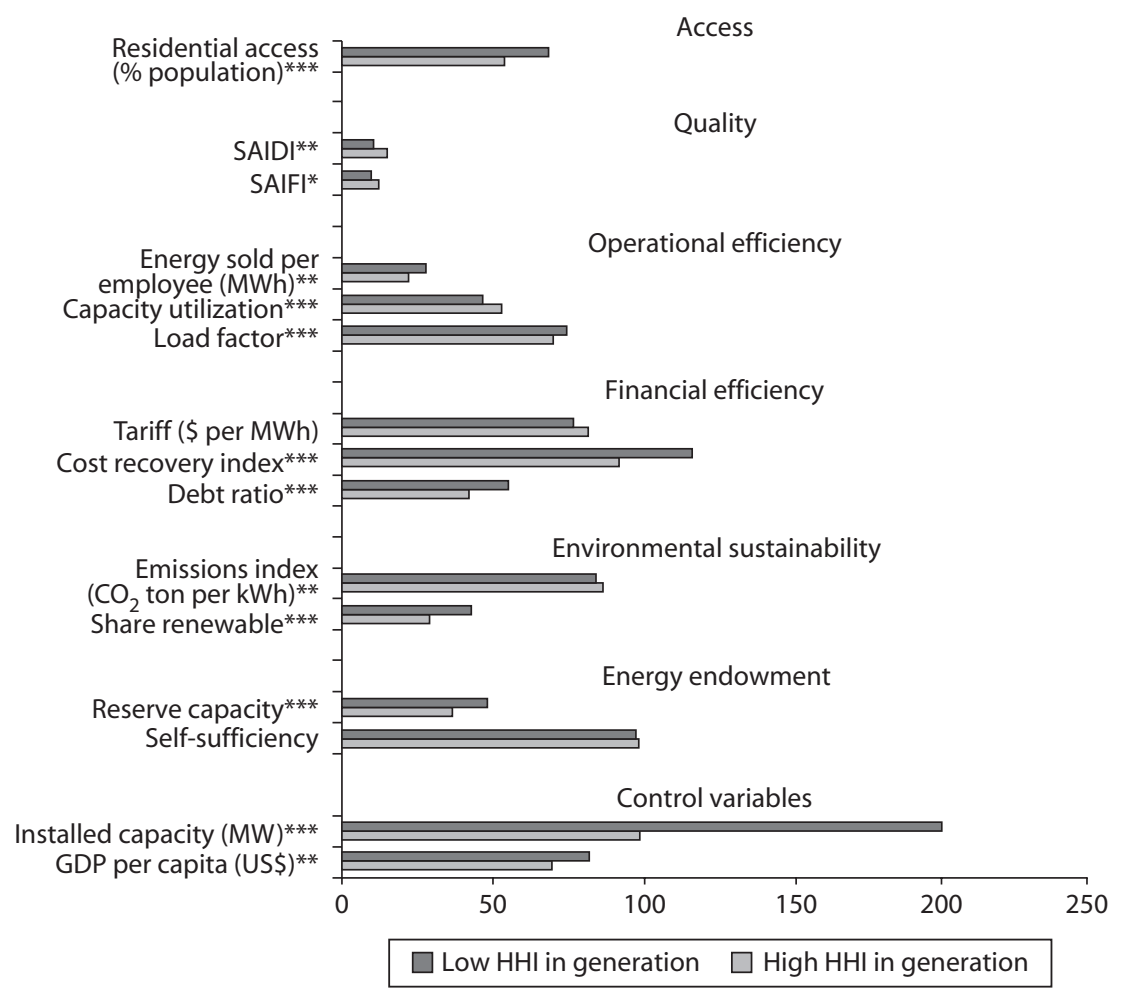

\begin{tabular}{|c|c|c|c|}
\hline & Low $\mathrm{HHI}$ in generation & High $\mathrm{HHI}$ in generation & $\mathrm{t}$ \\
\hline $\begin{array}{l}\text { Residential access } \\
\text { (\% population)**** }\end{array}$ & $\begin{array}{c}68.3 \\
(36.1)\end{array}$ & $\begin{array}{c}53.9 \\
(32.5)\end{array}$ & 3.6 \\
\hline SAIDI** & $\begin{array}{l}10.5 \\
(11.7)\end{array}$ & $\begin{array}{l}15.5 \\
(20.2)\end{array}$ & -1.6 \\
\hline SAIFI* & $\begin{array}{l}10.4 \\
(6.6)\end{array}$ & $\begin{array}{l}12.3 \\
(8.5)\end{array}$ & -1.3 \\
\hline $\begin{array}{l}\text { Energy sold per } \\
\text { employee }(\mathrm{MWh})^{* *}\end{array}$ & $\begin{array}{l}29.0 \\
(27.5)\end{array}$ & $\begin{array}{l}22.2 \\
(19.8)\end{array}$ & 1.7 \\
\hline Capacity utilization*** & $\begin{array}{c}46.1 \\
(14.8)\end{array}$ & $\begin{array}{c}52.8 \\
(10.9)\end{array}$ & -4.4 \\
\hline Load factor*** & $\begin{array}{l}74.4 \\
(9.0)\end{array}$ & $\begin{array}{l}70.1 \\
(8.5)\end{array}$ & 2.9 \\
\hline Tariff (\$ per MWh) & $\begin{array}{c}77.6 \\
(27.7)\end{array}$ & $\begin{array}{l}81.4 \\
(60.7)\end{array}$ & -0.8 \\
\hline
\end{tabular}


Figure 1B.2 (continued)

\begin{tabular}{|l|c|c|c|}
\hline & Low HHI in generation & High HHI in generation & $\mathrm{t}$ \\
\hline Cost recovery index*** & $\begin{array}{c}108.6 \\
(57.4)\end{array}$ & $\begin{array}{c}91.6 \\
(46.9)\end{array}$ & 2.4 \\
\hline Debt ratio*** & $\begin{array}{c}55.8 \\
(22.4)\end{array}$ & $\begin{array}{c}42.1 \\
(23.1)\end{array}$ & 3.1 \\
\hline Emissions index \\
$\left(\mathrm{CO}_{2}\right.$ ton per kWh)** & $\begin{array}{c}84.1 \\
(5.9)\end{array}$ & $\begin{array}{c}86.2 \\
(10.1)\end{array}$ & -2.1 \\
\hline Share renewable*** & $\begin{array}{c}43.9 \\
(23.3)\end{array}$ & $\begin{array}{c}28.6 \\
(36.9)\end{array}$ & 3.9 \\
\hline Reserve capacity*** & $\begin{array}{c}48.0 \\
29.6)\end{array}$ & $\begin{array}{c}36.4 \\
(19.2)\end{array}$ & 3.6 \\
\hline Self-sufficiency & $\begin{array}{c}97.5 \\
(12.6)\end{array}$ & $\begin{array}{c}98.2 \\
(16.2)\end{array}$ & 0.4 \\
\hline Installed capacity (MW)*** & $\begin{array}{c}206.4 \\
(250.5)\end{array}$ & $\begin{array}{c}98.5 \\
(135.2)\end{array}$ & 4.9 \\
\hline GDP per capita (US\$** & $\begin{array}{c}81.6 \\
(64.8)\end{array}$ & $\begin{array}{c}69.4 \\
(64.6)\end{array}$ & 1.7 \\
\hline
\end{tabular}

Source: An elaboration from the Power Market Structure database.

Note: The following adjustments were made to make the indicators fit in the same figure. Tariffs are measured as $\$$ per MWh rather than as $\$$ cent per $\mathrm{kWh}$. Emissions index is measured by an index ranging from 0 to 100 rather than 0 to 1. Energy sold per employee (measured in MWh per employee), installed capacity (measured in MW), and GDP per capita (measured in US\$) were divided by 100. ${ }^{*}, *^{*},{ }^{* * *}$ indicate, respectively, level of significance of 10, 5, and 1 percent. $\mathrm{HHI}=$ Herfindahl-Hirschman Index; SAIDI = System Average Interruption Duration Index; $\mathrm{SAIFI}=$ System Average Interruption Frequency Index. 


\section{Figure 1B.3 Disaggregation in Distribution}

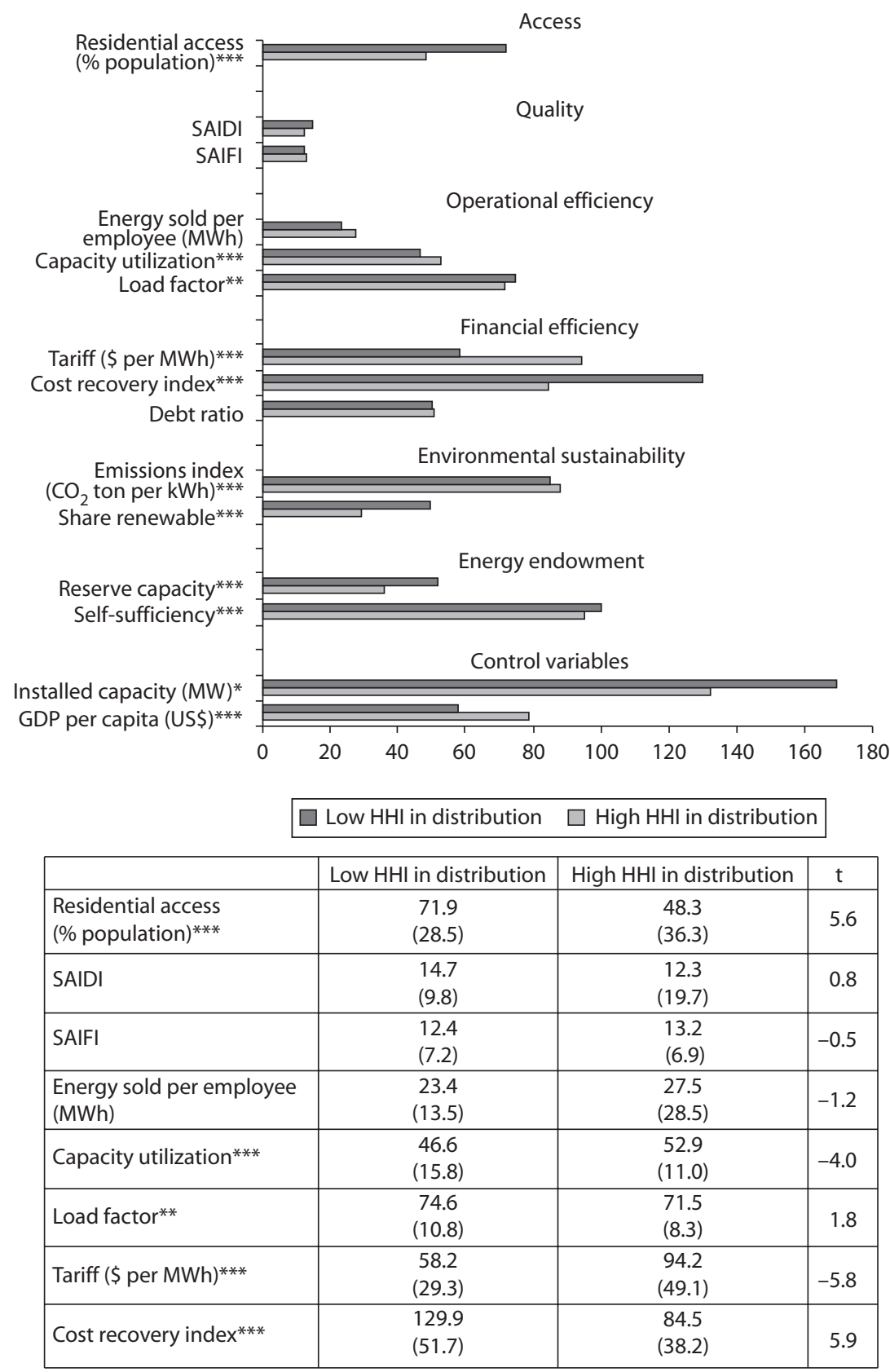


Figure 1B.3 (continued)

\begin{tabular}{|l|c|c|c|}
\hline & Low HHI in distribution & High HHI in distribution & $\mathrm{t}$ \\
\hline Debt ratio & $\begin{array}{c}50.1 \\
(24.7)\end{array}$ & $\begin{array}{c}50.4 \\
(23.9)\end{array}$ & -0.1 \\
\hline Emissions index \\
$\left(\mathrm{CO}_{2}\right.$ ton per kWh)*** & $\begin{array}{c}84.8 \\
(3.9)\end{array}$ & $\begin{array}{l}87.9 \\
(8.2)\end{array}$ & -3.6 \\
\hline Share renewable*** & $\begin{array}{c}49.7 \\
(33.8)\end{array}$ & $\begin{array}{c}29.4 \\
(32.9)\end{array}$ & 5.2 \\
\hline Reserve capacity*** & $\begin{array}{c}51.9 \\
(28.6)\end{array}$ & $\begin{array}{c}36.3 \\
(21.6)\end{array}$ & \multirow{2}{*}{4.5} \\
\hline Self-sufficiency*** & $\begin{array}{c}100.1 \\
(9.0)\end{array}$ & $\begin{array}{c}95.0 \\
(17.5)\end{array}$ & 2.7 \\
\hline Installed capacity (MW)* & $\begin{array}{c}169.4 \\
(261.2)\end{array}$ & $\begin{array}{c}132.2 \\
(179.9)\end{array}$ & 1.5 \\
\hline GDP per capita (US\$) $)^{* * *}$ & $\begin{array}{c}57.8 \\
(37.6)\end{array}$ & $\begin{array}{c}78.5 \\
(72.2)\end{array}$ & -2.8 \\
\hline
\end{tabular}

Source: An elaboration from the Power Market Structure database.

Note: The following adjustments were made to make the indicators fit in the same figure. Tariffs are measured as \$ per MWh rather than as $\$$ cent per $\mathrm{kWh}$. Emissions index is measured by an index ranging from 0 to 100 rather than 0 to 1. Energy sold per employee (measured in MWh per employee), installed capacity (measured in MW), and GDP per capita (measured in US\$) were divided by 100. ******* indicate, respectively, level of significance of 10, 5, and 1 percent. $\mathrm{HHI}=$ Herfindahl-Hirschman Index; SAIDI = System Average Interruption Duration Index; SAIFI = System Average Interruption Frequency Index.

\section{Figure 1B.4 Autonomous Regulator}

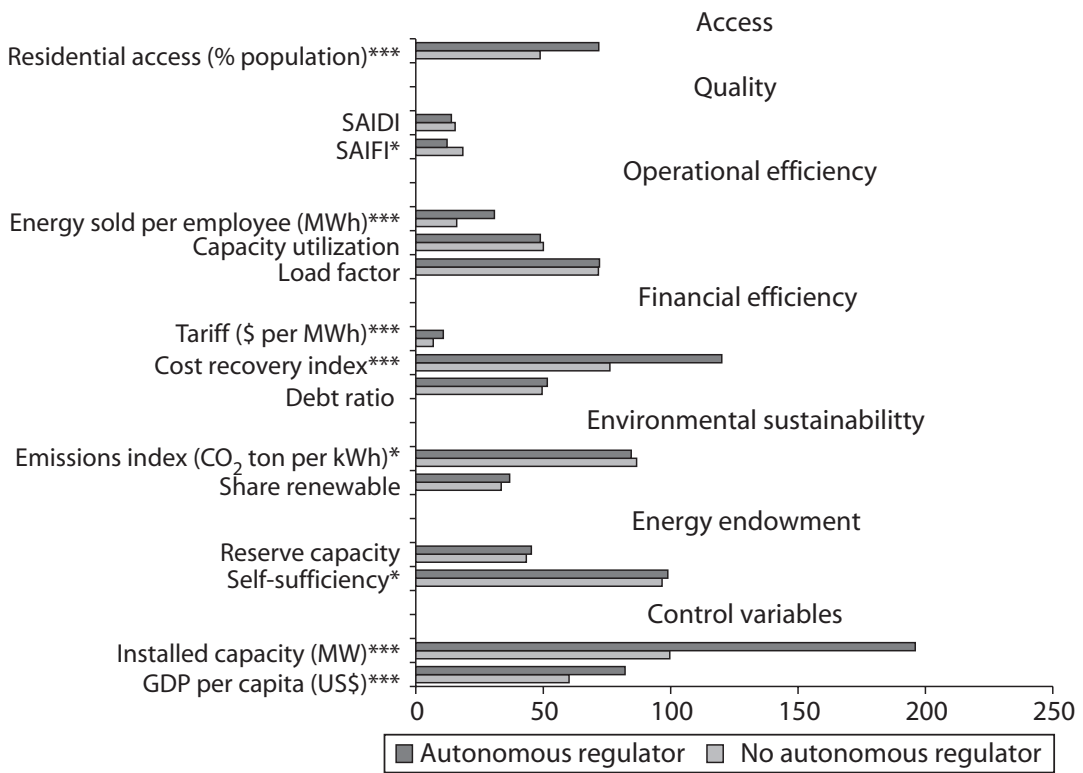


Figure 1B.4 (continued)

\begin{tabular}{|c|c|c|c|}
\hline & $\begin{array}{l}\text { Autonomous } \\
\text { regulator }\end{array}$ & $\begin{array}{c}\text { No autonomous } \\
\text { regulator }\end{array}$ & $\mathrm{t}$ \\
\hline $\begin{array}{l}\text { Residential access } \\
(\% \text { population })^{* * * *}\end{array}$ & $\begin{array}{c}72.1 \\
(31.3)\end{array}$ & $\begin{array}{c}48.9 \\
(34.8)\end{array}$ & -6.7 \\
\hline SAIDI & $\begin{array}{c}13.9 \\
(16.0)\end{array}$ & $\begin{array}{c}15.4 \\
(19.2)\end{array}$ & 0.4 \\
\hline SAIFI* & $\begin{array}{l}12.4 \\
(9.7)\end{array}$ & $\begin{array}{c}18.6 \\
(15.3)\end{array}$ & 2.2 \\
\hline $\begin{array}{l}\text { Energy sold per employee } \\
\text { (MWh)**** }\end{array}$ & $\begin{array}{c}32.1 \\
(25.3)\end{array}$ & $\begin{array}{c}15.8 \\
(17.8)\end{array}$ & -5.1 \\
\hline Capacity utilization & $\begin{array}{c}48.3 \\
(15.5)\end{array}$ & $\begin{array}{c}50.2 \\
(11.8)\end{array}$ & 1.0 \\
\hline Load factor & $\begin{array}{l}72.3 \\
(8.5)\end{array}$ & $\begin{array}{l}71.9 \\
(9.5)\end{array}$ & -0.2 \\
\hline Tariff $\left(\$\right.$ per MWh) ${ }^{* * * *}$ & $\begin{array}{l}86.1 \\
(5.1)\end{array}$ & $\begin{array}{l}66.9 \\
(2.7)\end{array}$ & -3.5 \\
\hline Cost recovery index*** & $\begin{array}{l}115.6 \\
(58.7)\end{array}$ & $\begin{array}{c}76.3 \\
(34.6)\end{array}$ & -4.4 \\
\hline Debt ratio & $\begin{array}{l}52.3 \\
(24.3)\end{array}$ & $\begin{array}{c}49.5 \\
(25.8)\end{array}$ & -0.5 \\
\hline $\begin{array}{l}\text { Emissions index } \\
\left(\mathrm{CO}_{2} \text { ton per } \mathrm{kWh}\right)^{*}\end{array}$ & $\begin{array}{l}84.5 \\
(8.4)\end{array}$ & $\begin{array}{l}86.7 \\
(8.4)\end{array}$ & 2.5 \\
\hline Share renewable & $\begin{array}{c}37.5 \\
(31.7)\end{array}$ & $\begin{array}{c}33.9 \\
(32.8)\end{array}$ & -1.1 \\
\hline Reserve capacity & $\begin{array}{c}45.5 \\
(27.9)\end{array}$ & $\begin{array}{l}43.4 \\
(27.7)\end{array}$ & -0.6 \\
\hline Self-sufficiency* & $\begin{array}{c}99.0 \\
(10.9)\end{array}$ & $\begin{array}{c}96.8 \\
(16.5)\end{array}$ & -1.5 \\
\hline Installed capacity $(\mathrm{MW})^{* * *}$ & $\begin{array}{c}200.3 \\
(237.2)\end{array}$ & $\begin{array}{c}99.8 \\
(137.7)\end{array}$ & -5.1 \\
\hline GDP per capita (US\$) & $\begin{array}{l}82.1 \\
(65.9)\end{array}$ & $\begin{array}{c}60.3 \\
(59.3)\end{array}$ & -3.6 \\
\hline
\end{tabular}

Source: An elaboration from the Power Market Structure database.

Note: The following adjustments were made to make the indicators fit in the same figure. Tariffs are measured as $\$$ per MWh rather than as $\$$ cent per $\mathrm{kWh}$. Emissions index is measured by an index ranging from 0 to 100 rather than 0 to 1. Energy sold per employee (measured in MWh per employee), installed capacity (measured in MW), and GDP per capita (measured in US\$) were divided by $100 .{ }^{*},{ }^{* *},{ }^{* * *}$ indicate, respectively, level of significance of 10, 5, and 1 percent. SAIDI = System Average Interruption Duration Index; SAIFI = System Average Interruption Frequency Index. 


\section{Figure 1B.5 Private Ownership}

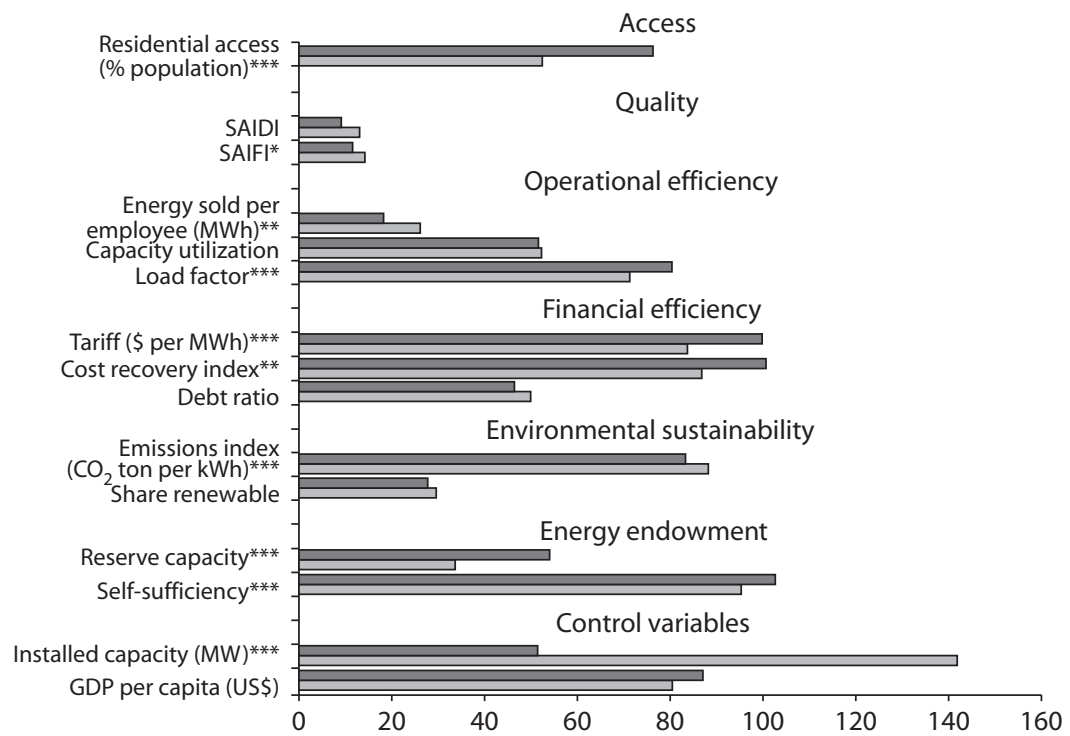

High \% of private ownership $\square$ Low $\%$ of private ownership

\begin{tabular}{|c|c|c|c|}
\hline & $\begin{array}{l}\text { High } \% \text { of private } \\
\text { ownership }\end{array}$ & $\begin{array}{l}\text { Low } \% \text { of private } \\
\text { ownership }\end{array}$ & $\mathrm{t}$ \\
\hline $\begin{array}{l}\text { Residential access } \\
(\% \text { population })^{* * * *}\end{array}$ & $\begin{array}{c}76.1 \\
(30.9)\end{array}$ & $\begin{array}{l}52.7 \\
(35.0)\end{array}$ & -4.8 \\
\hline SAIDI & $\begin{array}{c}9.7 \\
(8.2)\end{array}$ & $\begin{array}{l}13.7 \\
(20.2)\end{array}$ & 1.1 \\
\hline SAIFI* & $\begin{array}{l}11.7 \\
(7.4)\end{array}$ & $\begin{array}{l}14.1 \\
(7.6)\end{array}$ & 1.3 \\
\hline $\begin{array}{l}\text { Energy sold per employee } \\
(\mathrm{MWh})^{* *}\end{array}$ & $\begin{array}{c}18.7 \\
(11.8)\end{array}$ & $\begin{array}{l}26.3 \\
(28.3)\end{array}$ & 1.8 \\
\hline Capacity utilization & $\begin{array}{l}51.5 \\
(6.9) \\
\end{array}$ & $\begin{array}{c}52.2 \\
(11.1) \\
\end{array}$ & 0.5 \\
\hline Load factor $* * *$ & $\begin{array}{l}80.3 \\
(9.5)\end{array}$ & $\begin{array}{l}71.4 \\
(8.5)\end{array}$ & -4.5 \\
\hline Tariff $(\$$ per MWh) & $\begin{array}{c}99.8 \\
(52.3)\end{array}$ & $\begin{array}{c}83.7 \\
(40.3)\end{array}$ & -2.2 \\
\hline Cost recovery index ${ }^{* *}$ & $\begin{array}{l}100.7 \\
(22.7) \\
\end{array}$ & $\begin{array}{c}87.1 \\
(40.4) \\
\end{array}$ & -1.8 \\
\hline Debt ratio & $\begin{array}{l}47.0 \\
(23.5)\end{array}$ & $\begin{array}{l}49.9 \\
(22.9)\end{array}$ & 0.6 \\
\hline $\begin{array}{l}\text { Emissions index } \\
\left(\mathrm{CO}_{2} \text { ton per } \mathrm{kWh}\right)^{* * * *}\end{array}$ & $\begin{array}{l}83.3 \\
(4.9)\end{array}$ & $\begin{array}{l}88.3 \\
(7.7)\end{array}$ & 5.0 \\
\hline
\end{tabular}


Figure 1B.5 (continued)

\begin{tabular}{|l|c|c|c|}
\hline & $\begin{array}{c}\text { High \% of private } \\
\text { ownership }\end{array}$ & $\begin{array}{c}\text { Low \% of private } \\
\text { ownership }\end{array}$ & $\mathrm{t}$ \\
\hline Share renewable & $\begin{array}{c}28.0 \\
(29.8)\end{array}$ & $\begin{array}{c}29.8 \\
(31.4)\end{array}$ & 0.4 \\
\hline Reserve capacity*** & $\begin{array}{c}54.4 \\
(28.3)\end{array}$ & $\begin{array}{c}33.6 \\
(22.1)\end{array}$ & -5.6 \\
\hline Self-sufficiency*** & $\begin{array}{c}102.8 \\
(7.3)\end{array}$ & $\begin{array}{c}95.2 \\
(16.6)\end{array}$ & -3.7 \\
\hline Installed capacity (MW)*** & $\begin{array}{c}51.6 \\
(56.48)\end{array}$ & $\begin{array}{c}141.8 \\
(174.46)\end{array}$ & 4.5 \\
\hline GDP per capita (US\$) & $\begin{array}{c}86.9 \\
(53.1)\end{array}$ & $\begin{array}{c}80.5 \\
(74.1)\end{array}$ & -0.7 \\
\hline
\end{tabular}

Source: An elaboration from the Power Market Structure database.

Note: The following adjustments were made to make the indicators fit in the same figure. Tariffs are measured as $\$$ per MWh rather than as $\$$ cent per $\mathrm{kWh}$. Emissions index is measured by an index ranging from 0 to 100 rather than 0 to 1. Energy sold per employee (measured in MWh per employee), Installed capacity (measured in MW), and GDP per capita (measured in US\$) were divided by 100. ${ }^{*}, *^{* *},{ }^{* *}$ indicate, respectively, level of significance of 10, 5 , and 1 percent. SAIDI = System Average Interruption Duration Index; SAIFI = System Average Interruption Frequency Index.

\section{Figure 1B.6 Installed Capacity}

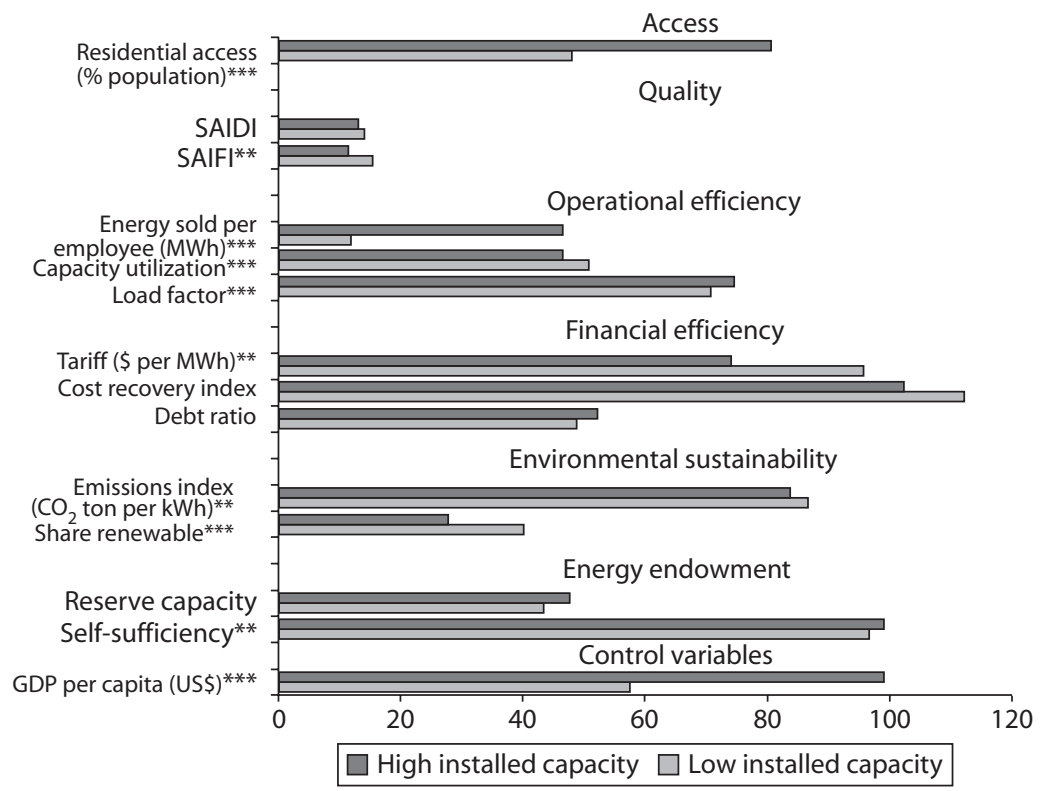


Figure 1B.6 (continued)

\begin{tabular}{|c|c|c|c|}
\hline & $\begin{array}{l}\text { High installed } \\
\text { capacity }\end{array}$ & $\begin{array}{c}\text { Low installed } \\
\text { capacity }\end{array}$ & $\mathrm{t}$ \\
\hline $\begin{array}{l}\text { Residential access } \\
(\% \text { population })^{* * * *}\end{array}$ & $\begin{array}{l}80.7 \\
(18.8)\end{array}$ & $\begin{array}{c}48.1 \\
(36.4)\end{array}$ & -9.2 \\
\hline SAIDI & $\begin{array}{l}13.6 \\
(16.2)\end{array}$ & $\begin{array}{c}14.5 \\
(16.1)\end{array}$ & 0.3 \\
\hline SAIFI** & $\begin{array}{l}11.6 \\
(7.4) \\
\end{array}$ & $\begin{array}{c}15.6 \\
(14.4) \\
\end{array}$ & 1.8 \\
\hline $\begin{array}{l}\text { Energy sold per employee } \\
\text { (MWh)*** }\end{array}$ & $\begin{array}{l}46.5 \\
(23.8) \\
\end{array}$ & $\begin{array}{l}12.3 \\
(9.6) \\
\end{array}$ & -2.7 \\
\hline Capacity utilization*** & $\begin{array}{l}46.6 \\
(16.8)\end{array}$ & $\begin{array}{l}51.1 \\
(11.4)\end{array}$ & 3.1 \\
\hline Load factor*** & $\begin{array}{l}74.6 \\
(6.8) \\
\end{array}$ & $\begin{array}{l}70.6 \\
(9.9) \\
\end{array}$ & -2.7 \\
\hline Tariff $\left(\$\right.$ per MWh) ${ }^{* *}$ & $\begin{array}{l}73.8 \\
(42.8)\end{array}$ & $\begin{array}{l}95.9 \\
(93.5)\end{array}$ & 2.0 \\
\hline Cost recovery index & $\begin{array}{l}102.4 \\
(71.4)\end{array}$ & $\begin{array}{l}112.2 \\
(53.9)\end{array}$ & 0.9 \\
\hline Debt ratio & $\begin{array}{c}52.4 \\
(15.8) \\
\end{array}$ & $\begin{array}{l}49.0 \\
(27.8)\end{array}$ & -0.8 \\
\hline $\begin{array}{l}\text { Emissions index } \\
\left(\mathrm{CO}_{2} \text { ton per } \mathrm{kWh}\right)^{* *}\end{array}$ & $\begin{array}{l}83.9 \\
(9.8) \\
\end{array}$ & $\begin{array}{l}86.6 \\
(7.5) \\
\end{array}$ & 2.9 \\
\hline Share renewable ${ }^{* * *}$ & $\begin{array}{c}28.1 \\
(27.8)\end{array}$ & $\begin{array}{c}40.5 \\
(34.8)\end{array}$ & 3.7 \\
\hline Reserve capacity & $\begin{array}{c}47.4 \\
(23.1) \\
\end{array}$ & $\begin{array}{c}43.5 \\
(30.2) \\
\end{array}$ & -1.0 \\
\hline Self-sufficiency** & $\begin{array}{l}99.4 \\
(6.8) \\
\end{array}$ & $\begin{array}{c}96.9 \\
(17.2)\end{array}$ & -1.6 \\
\hline GDP per capita (US\$)*** & $\begin{array}{l}99.0 \\
(54.6)\end{array}$ & $\begin{array}{c}57.3 \\
(61.9)\end{array}$ & -6.7 \\
\hline
\end{tabular}

Source: An elaboration from the Power Market Structure database.

Note: The following adjustments were made to make the indicators fit in the same figure. Tariffs are measured as $\$$ per MWh rather than as $\$$ cent per $\mathrm{kWh}$. Emissions index is measured by an index ranging from 0 to 100 rather than 0 to 1. Energy sold per employee (measured in MWh per employee), installed capacity (measured in MW), and GDP per capita (measured in US\$) were divided by 100. ${ }^{*},{ }^{* *},{ }^{* * *}$ indicate, respectively, level of significance of 10, 5, and 1 percent. SAIDI = System Average Interruption Duration Index; SAIFI = System Average Interruption Frequency Index. 


\section{Figure 1B.7 GDP per Capita}

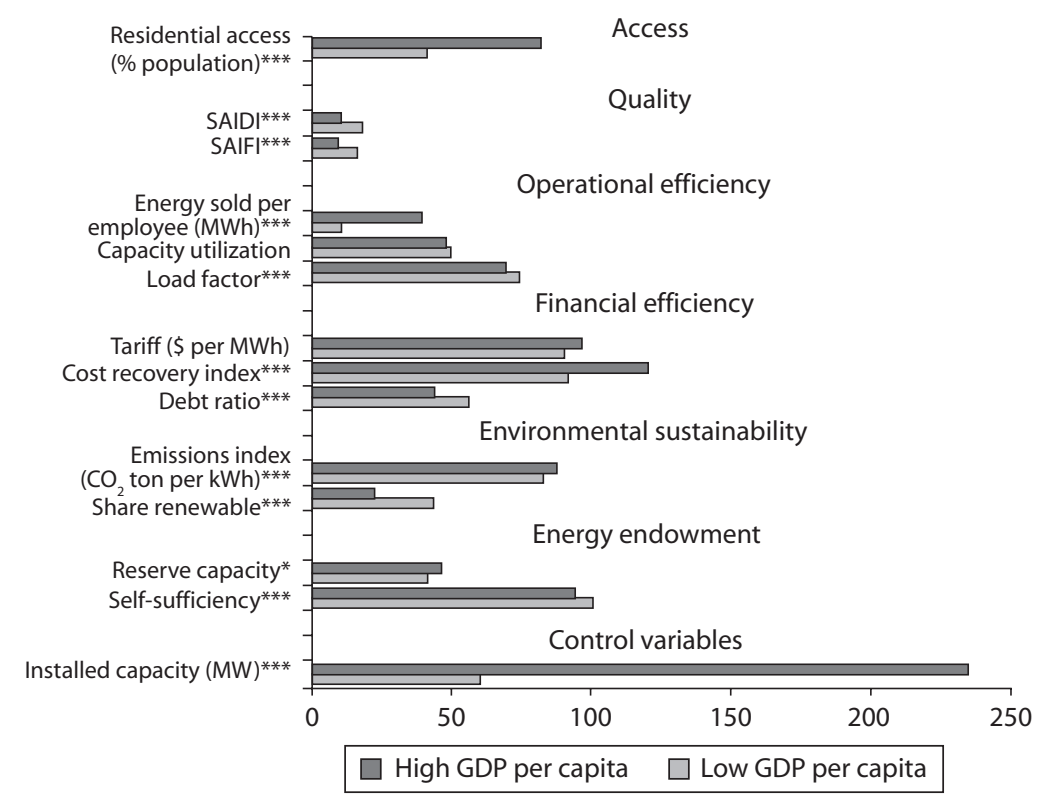

\begin{tabular}{|c|c|c|c|}
\hline & High GDP per capita & Low GDP per capita & $\mathrm{t}$ \\
\hline $\begin{array}{l}\text { Residential access } \\
(\% \text { population })^{* * *}\end{array}$ & $\begin{array}{c}83.0 \\
(19.9)\end{array}$ & $\begin{array}{c}40.8 \\
(33.5)\end{array}$ & -13.9 \\
\hline SAIDI ${ }^{* * *}$ & $\begin{array}{c}11.4 \\
(14.2)\end{array}$ & $\begin{array}{c}19.1 \\
(18.8)\end{array}$ & 2.6 \\
\hline SAIFI*** & $\begin{array}{l}10.6 \\
(7.1)\end{array}$ & $\begin{array}{c}17.7 \\
(14.2)\end{array}$ & 3.3 \\
\hline $\begin{array}{l}\text { Energy sold per employee } \\
(\mathrm{MWh})^{* * * *}\end{array}$ & $\begin{array}{l}40.4 \\
(25.9) \\
\end{array}$ & $\begin{array}{l}11.5 \\
(9.3) \\
\end{array}$ & -11.3 \\
\hline Capacity utilization & $\begin{array}{c}48.6 \\
(16.6)\end{array}$ & $\begin{array}{c}49.9 \\
(10.1)\end{array}$ & 0.9 \\
\hline Load factor*** & $\begin{array}{l}70.3 \\
(6.5) \\
\end{array}$ & $\begin{array}{c}74.9 \\
(10.9) \\
\end{array}$ & 3.3 \\
\hline Tariff (\$ per MWh) & $\begin{array}{c}98.1 \\
(49.0)\end{array}$ & $\begin{array}{c}59.7 \\
(29.5)\end{array}$ & -7.4 \\
\hline Cost recovery index*** & $\begin{array}{l}120.9 \\
(56.2)\end{array}$ & $\begin{array}{c}84.6 \\
(47.2)\end{array}$ & -4.4 \\
\hline
\end{tabular}


Figure 1B.7 (continued)

\begin{tabular}{|l|c|c|c|}
\hline & High GDP per capita & Low GDP per capita & $\mathrm{t}$ \\
\hline Debt ratio*** & $\begin{array}{c}44.6 \\
(18.5)\end{array}$ & $\begin{array}{c}56.7 \\
(27.6)\end{array}$ & 3.1 \\
\hline Emissions index \\
$\left(\mathrm{CO}_{2}\right.$ ton per kWh)*** & $\begin{array}{c}88.3 \\
(7.0)\end{array}$ & $\begin{array}{c}83.2 \\
(8.9)\end{array}$ & -6.1 \\
\hline Share renewable*** & $\begin{array}{c}23.2 \\
(28.6)\end{array}$ & $\begin{array}{c}44.1 \\
(31.8)\end{array}$ & 7.6 \\
\hline Reserve capacity* & $\begin{array}{c}47.5 \\
(47.5)\end{array}$ & $\begin{array}{c}42.0 \\
(33.5)\end{array}$ & -1.5 \\
\hline Self-sufficiency*** & $\begin{array}{c}95.1 \\
(15.8)\end{array}$ & $\begin{array}{c}100.9 \\
(11.6)\end{array}$ & 3.9 \\
\hline Installed capacity (MW) & $\begin{array}{c}60.9 \\
(235.5\end{array}$ & $(73.3)$ & -9.9 \\
\hline
\end{tabular}

Source: An elaboration from the Power Market Structure database.

Note: The following adjustments were made to make the indicators fit in the same figure. Tariffs are measured as $\$$ per MWh rather than as $\$$ cent per $\mathrm{kWh}$. Emissions index is measured by an index ranging from 0 to 100 rather than 0 to 1. Energy sold per employee (measured in MWh per employee), installed capacity (measured in MW), and GDP per capita (measured in US\$) were divided by 100. ${ }^{*},{ }^{* *},{ }^{* * *}$ indicate, respectively, level of significance of 10, 5, and 1 percent. SAIDI = System Average Interruption Duration Index; SAIFI = System Average Interruption Frequency Index.

\section{Notes}

1. Zambia strictly falls just into Group C, but it is added in Group D in this case because it shares many common features with the three countries in Group D, and its inclusion completes the desired sample for this Group.

2. South Africa substantially increased its electricity tariffs in 2010.

\section{References}

Arizu, Beatriz, Defne Gencer, and Luiz Maurer. 2005. "Centralized Purchasing Arrangements: International Practices and Lessons Learned on Variations to the Single Buyer Model." Energy and Mining Sector Board Discussion Paper Series 10, World Bank, Washington, DC.

Arocena, Pablo, Tim Coelli, and David Saal. 2009. "Measuring Economies of Integration in the US Power Industry: How Costly Is Vertical Unbundling?" Aston Business School Research Paper, Aston University, Birmingham, U.K.

Besant-Jones, John E. 2006. "Reforming Power Markets in Developing Countries: What Have We Learned?" World Bank Discussion Paper 19, World Bank, Washington, DC. 
Chao, Hung-po, Shmuel Oren, and Robert Wilson. 2005. "Restructured Electricity Markets: Reevaluation of Vertical Integration and Unbundling." New Zealand Policy Perspective Paper 06/04. Treasury, Wellington, NZ.

- 2008. "Re-evaluation of Vertical Integration and Unbundling." In Competitive Electricity Markets: Design, Implementation, Performance, ed. Fereidoon P. Sioshansi. Oxford: Elsevier.

Dupuy, M. 2006. "Electricity Generation: Competition, Market Power and Investment." Policy Perspectives Paper 06/04, New Zealand Treasury.

Ghanadan, Rebecca, and Anton Eberhard. 2007. "TANESCO Electricity Management Contract Study." March. University of Cape Town, South Africa, www.gsb.uct.ac.za/files/TanzaniaManagementContract.pdf.

Jamasb, T., R. Mota, D. Newbery, and M. Pollitt. 2004. "Electricity Sector Reform in Developing Countries: A Survey of Empirical Evidence on Determinants and Performance." CMI Working Paper 47, Cambridge, U.K.: CambridgeMIT Institute.

Jara-Diaz, Sergio, Francisco Ramos-Real, and Eduardo Martinez-Budria. 2004. "Economies of Integration in the Spanish Electricity Industry." Energy Economics 26 (6): 995-1013.

Kwoka, John E. 2002. "Vertical Economies in Electric Power: Evidence on Integration and Its Alternatives." International Journal of Industrial Organization 20: 653-71.

Meyer, Roland. 2010. "Benchmarking Economies of Vertical Integration in U.S. Electricity Supply: An Application of DEA." Jacobs University, Bremen, Germany.

Nagayama, Hiroaki. 2007. "Effects of Regulatory Reforms in the Electricity Supply Industry on Electricity Prices in Developing Countries." Energy Policy 35: 3440-62.

Nemoto, J., and M. Goto. 2004. "Technological Externalities and Economies of Vertical Integration in the Electric Utility Industry." International Journal of Industrial Organization 22 (1): 67-81.

Vagliasindi, Maria. 2012. "How to Improve the Performance of State-Owned Infrastructure Service Providers: Evidence from a Global Study." World Bank, Washington, DC.

Vagliasindi, Maria, and Ada Karina Izaguirre. 2007. "Private Participation in Infrastructure in Europe and Central Asia." Gridlines No. 26, Public-Private Infrastructure Advisory Facility (PPIAF), World Bank, Washington, DC.

van Koten, Silvester, and Andreas Ortmann. 2007. "The Unbundling Regime for Electricity Utilities in the EU: A Case of Legislative and Regulatory Capture?" CERGE-EI Working Paper 328, Center for Economic Research and Graduate Education, Charles University, Prague. 
World Bank. 2004. "Operational Guidance for World Bank Staff: Public and Private Roles in the Supply of Electricity Services." Energy and Mining Sector Board, World Bank, Washington, DC.

Zhang, Y-F., D. Parker, and C. Kirkpatrick. 2008. "Electricity Sector Reform in Developing Countries: An Econometric Assessment of the Effects of Privatization, Competition and Regulation." Journal of Regulatory Economics 33 (2): 159-78. 
PART 2

Case Studies: Large System Size and High GDP per Capita Economies 



\section{Argentina}

Argentina falls into the category of medium system size/medium per capita income. In 2008 Argentina had a total installed generating capacity of about 25,000 MW (megawatts) and a gross national income per capita of about $\$ 7,200$. The country relies mostly on hydropower and natural gas to fuel its electricity sector. Argentina provides one of the best examples of full-scale power market reform in the world to date.

\section{Reform History}

Reforms of Argentina's electricity industry began in the late 1980s and went through comprehensive changes in the 1990s that involved the unbundling and privatization of the integrated state companies and the creation of a competitive wholesale electricity market. Because Argentina is generally considered to be a leader in the global movement to reform power sectors, this review focuses at some length on the major structural and regulatory reforms during this period and the immediate aftermath until the macroeconomic crisis in the early years of the century. It tracks sector performance until 2008 to discern medium- to long-term impacts of these reforms. 
Until 1989 Argentina's electric power sector, regulated by Law 14.772 of 1958, was considered a public service provided by the state or stateowned companies. Three main state-owned utilities provided bundled generation, transmission, and distribution services. There were also nineteen provincial utilities - primarily distributors - and several electricity cooperatives. The main source of generation was hydroelectric capacity. The industry was regulated by the federal government through the secretary of energy. The pre-reform sector structure is shown in figure 2.1.

The performance electric power sector suffered from financial and operational difficulties due to poor management practices and insufficient investment, as well as from the absence of clear objectives, the political motives of the state-owned companies, and an economic environment of hyperinflation that reached 200 percent per month in 1989. Electricity theft and blackouts, which worsened during dry seasons due to the heavy reliance on hydroelectric generation, were common problems. Overall, federal utilities were losing more than 20 percent of their power to nonpaying customers.

The first piece of legislation for reforming the power sector was Law No. 23696 of 1989-the Law of State Reform-which directed the

\section{Figure 2.1 Argentina:Taxonomy of Power Sector before Reform (1990)}

\begin{tabular}{|c|c|c|c|c|}
\hline Policy & \multicolumn{4}{|c|}{$\begin{array}{l}\text { Secretariat of Energy } \\
\text { (Dependency of Ministry of Economy and Public Works and Services) }\end{array}$} \\
\hline Regulation & $\begin{array}{l}\text { Secretariat of Energy } \\
\text { regarding hydrocarbon fuel }\end{array}$ & Nat & $\begin{array}{l}\text { al and } p \\
\text { garding }\end{array}$ & $\begin{array}{l}\text { vincial governments } \\
\text { ectrical energy }\end{array}$ \\
\hline Generation & $\begin{array}{cc}\text { SEGBA } & \\
\text { capital and } & \text { HIDRONOR } \\
\text { Buenos Aires } & 26 \% \\
\text { Province 25\% } & \end{array}$ & $\begin{array}{l}\text { CONEA } \\
20 \%\end{array}$ & $\begin{array}{l}\text { AyEE } \\
19 \%\end{array}$ & $\begin{array}{c}\text { Provincial } \\
\text { companies } \\
10 \%\end{array}$ \\
\hline Transmission & $\begin{array}{l}\text { SEGBA } \\
3 \% \text { of } 500 \mathrm{kV} \text { lines }\end{array}$ & $\begin{array}{l}\text { IDRONO } \\
\text { of } 500 \mathrm{kl}\end{array}$ & & $\begin{array}{l}\text { AyEE } \\
52 \% \text { of } 500 \mathrm{kV} \text { lines }\end{array}$ \\
\hline Distribution & SEGBA 45\% & & $\begin{array}{l}\text { AyEE } \\
8 \%\end{array}$ & $\begin{array}{c}13 \text { Provincial } \\
\text { companies/co-ops } \\
47 \%\end{array}$ \\
\hline
\end{tabular}

\section{$4,000,000$ regulated customers}

Vertical integration $\square$ Privatized company

Source: An elaboration from the Power Market Structure database.

Note: $\mathrm{AyEE}=$ Agua y Energía Eléctrica; $\mathrm{CONEA}=$ Comision Nacional de Energia Atomica;

HIDRONOR = Hidroeléctrica Norpatagónica; SEGBA = Servicios Eléctricos del Gran Buenos Aires. 
executive office to reorganize and privatize public enterprises. Decree No. 634/91 of 1991 was issued by the Ministry of Economy and provided guidelines for implementing the state reform law in the electricity sector. It removed government from direct operation in the electricity industry and introduced the basic principles of competition in the power market.

Law No. 24065 (1992), the Electricity Regulation Act, was the keystone for the ambitious reform and privatization of the sector. It established the legal framework for further restructuring and privatization intended to stimulate competition and to benefit consumers both in price and quality of service. It provided for the privatization of virtually all commercial activities that had been carried out by federally owned enterprises. It established the basis for the independent sector regulator, Ente Nacional Regulador de la Electricad (ENRE), and other institutional authorities in the sector, and it created the Wholesale Electricity Market, Mercado Eléctrico Mayorista (MEM), and its independent operator, Compañía Administradora del Mercado Mayorista Eléctrico S.A. (CAMMESA). It also laid the basis for the administration of the wholesale power market, pricing in the spot market, tariff-setting in regulated areas, and the valuation of the assets to be privatized. Resolution 38/91 established rules for MEM.

The 1992 act divided the electricity industry into generation, transmission, and distribution sectors. Competition was introduced to the electricity generation sector, and regulation was applied to the electricity transmission and distribution private monopolies. Under the act, power generation companies are not allowed to own majority shares in Argentina's three transmission companies. The transmission companies have to provide open access to their systems for the power generators on a regulated basis. Transmitters are forbidden to generate or distribute power; they are permitted to charge a toll/tariff for their transmission services. Distribution companies are organized as regional monopolies and buy electricity from MEM or through contracts with power generation companies. Argentina also lowered barriers to the power market for new independent power producers and supplier groups. The energy market was initially opened to customers with demands greater than $5 \mathrm{MW}$, and this threshold has been successively reduced to $30 \mathrm{~kW}$. These customers are free to contract directly with generators and can participate directly in MEM. The post-reform sector structure is shown in figure 2.2.

Distribution and transmission networks are operated under concessions that are awarded by a process of competitive bidding. Transmission networks operate under 95-year concessions, subject to management 
Figure 2.2 Argentina:Taxonomy of Power Sector after Reform (1998)

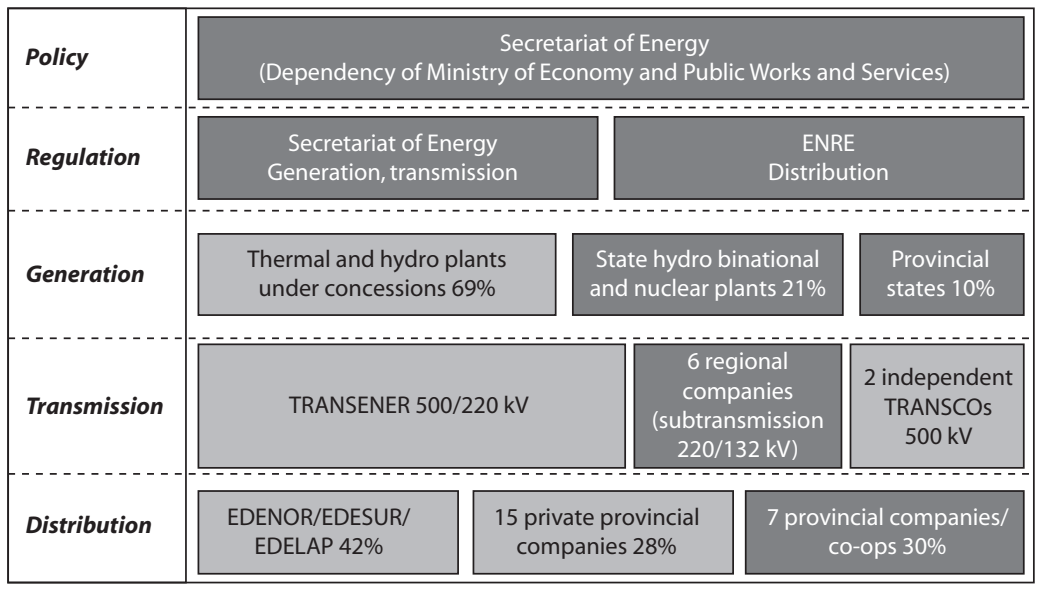

\section{$8,380,000$ regulated customers/1894 unregulated customers}

Vertical integration $\square$ Privatized company

Source: An elaboration from the Power Market Structure database.

Note: EDELAP = Empresa Distribuidora La Plata, EDENOR = Empresa Distribuidora Norte; EDESUR = Empresa Distribuidora Sur; ENRE = Ente Nacional Regulador de la Electricad; TRANSCOs = transmission companies; TRANSENER = Compañia de Transporte de Energia Eléctrica en Alta Tensión.

contracts that are renewed every 15 years. Transmission charges were to be reviewed every 5 years by ENRE. Electricity distribution in the Greater Buenos Aires area is regulated under concession contracts for 99 years, with prices originally subject to review every 5 years, at which time the distribution tariffs for regulated customers were to be reset following an assessment by ENRE under the principles of incentive regulation. Under the concession contracts, electricity distributors were given strong incentives to reduce the high energy losses caused by a combination of technical inefficiency and theft. Third-party access charges to the distribution network are negotiated, rather than regulated. For regulated customers (all residential, small commercial, and small industrial customers), the electricity tariff can be adjusted every three months on the basis of the seasonal energy price, which is set every six months. Outside Buenos Aires other provinces have their own system of regulation of distribution, but their distributors pay for energy for regulated customers using the same seasonal price formula. Most of them have based the regulation of final tariffs on the principles set out in the 1992 electricity law. By 2000 around 25 percent of provincial electricity distribution was privatized. 
MEM is a power pool that aggregates electricity supply from all generation sources, including independent power producers, federal generators, binational hydropower generators, and foreign sources of power interconnected to Argentina's grid. It comprises (1) a term market consisting of agreements for which quantities, prices, and conditions are negotiated directly between buyers and sellers; (2) a spot market with hourly prices taking into consideration economic production costs; and (3) a balancing market. All entities participating in the market, regardless of ownership, have to follow the market operating and pricing rules. Therefore, an individual power generation company is not allowed to have electricity sales that exceed 10 percent of national electricity sales.

ENRE was charged with enforcing laws, regulations, and concession terms, setting distribution service standards, resolving disputes between electricity companies, overseeing CAMMESA, and setting maximum electricity prices. CAMMESA administers the wholesale market. It is a nonprofit corporation owned equally by the federal government and four associations representing generators, transmitters, distributors, and major users. It schedules and dispatches generators in accordance with the power demand, on the basis of marginal costs and availability offered by generators, dispatching first those generators offering the lowest marginal costs.

Bilateral contracts are agreed between generators on one hand and distributors or large consumers on the other hand, at freely negotiated prices and quantities. CAMMESA uses the costs and availability declared by MEM participants to perform centralized load dispatch and to estimate hourly spot prices. The reference point for calculating the load dispatch is the Ezeiza node, in which CAMMESA calculates the system short-run marginal price, based on the variable costs of the plants and the hourly demand on the system. The spot price is complemented by a charge for available capacity in the system. Only plants dispatched under critical supply conditions receive the capacity charge. Each plant is assigned a specific node within the interconnected system, and each node has a specific factor that determines the final prices at which the plants are remunerated. The nodal factor is calculated by taking into account restrictions and technical losses in the transmission system.

Between April 1992 and June 1995, more than 25 state-operated power companies were privatized. Conventional generation (thermal and hydroelectric) facilities were sold separately, essentially making each privatized generation facility an independent power producer. The thermal generation facilities were sold outright, while concessions (averaging 
30 years) were awarded to the hydroelectric plants. By 2000 there were 43 generating companies owning 96 plants -60 thermal, 34 hydroelectric, and 2 nuclear plants. These 43 companies were owned by private enterprises and provincial and international joint ventures. Most of Argentina's privatized generation capacity was purchased by foreign companies, following a series of new laws that removed restrictions on foreign investments and allowed foreigners to acquire 100 percent of Argentine companies and to repatriate the profits and capital. Overall privatization proceeds increased significantly from \$318 million in 1994 to a peak of more than $\$ 2$ billion in 1997. Between 1994 and 2000 a total of $\$ 5.7$ billion was raised by these privatizations in the electricity sector.

With the exception of the binational projects, such as the Yacyreta hydroelectric plant and the national nuclear generation enterprises, the federal government has moved away from commercial activities in the electricity market. The government has restricted itself to policy and regulatory/oversight activities, with separate agencies in charge of these functions. Argentina has a federal system of government, and many of the provincial governments have created their own policy-making and regulatory entities and are moving away from commercial activities.

\section{Impact on Sector Structure}

Argentina's electricity market is now characterized by numerous producers in a highly competitive generation market. Many companies have more than 1,000 MW of installed capacity, and the largest one has 1,400 MW which constitutes only 6 percent of total installed capacity. The initial generation market thus has had a low concentration ratio. The market shares of the leading firms have increased since 1992, but the market remains less concentrated than most European and North American markets. The Herfindahl-Hirschman Index (HHI) of concentration was 708 in 2002 in terms of energy sold to the wholesale market by business unit (the HHI was 1,589 including cross-shareholding).

The three distribution companies divested from SEGBA (EDENOR, EDESUR, and EDELAP) represent 44 percent of the electricity market in Argentina. Including the companies divested from some regional utilities, private participation in the distribution market has increased to 60 percent. The remaining distribution companies are still in the hands of the provincial governments, but this ownership structure will change with the expansion of the new regulatory framework to the different regions of the country. 
As a result of this liberalization, the number of participants in MEM was 2,527 in December 2002, including 38 generating companies and 2,308 large energy users. The liberalized market accounted for around 50 percent of national electricity demand.

MEM wholesale prices fell significantly due to the installation of increasingly efficient capacity and the improving operating efficiencies of former state enterprises under competitive pressures. The price declined from \$45/MWh (megawatt-hour) in 1992 to about \$25/MWh in 1998. Since then the price has varied: $\$ 27 / \mathrm{MWh}$ in $2000, \$ 10 / \mathrm{MWh}$ in the depths of the economic crisis in 2002, and between \$35/MWh and \$40/ MWh in 2007. When the power system had overcapacity, the resulting low prices in the short term caused most transactions to occur in the spot market. Competition was helped by the large margins between total installed generation capacity in the market and the demand for power. Part of this margin was needed, however, to cover the drop in hydropower output during dry seasons.

\section{Impact on Sector Performance}

Evidence of the possible impacts from unbundling and the other reforms in Argentina we have described is sought from trends from the early 1990s up to 2008 in the following indicators:

- Access to electricity supply by the population in terms of new residential connections. Electricity service covers approximately 95 percent of the total population, but the level of electrification in isolated areas is only about 70 percent. The government instigated an ambitious plan to connect 650,000 households in shanty towns to the electricity network between 1994 and 1998. Many poor consumers were forced to pay for electricity that they had previously received via free (albeit illegal) connections, representing a welfare loss to this group. This result suggests that electricity reform did not lower the effective price of service for this group of the poorest households.

- Customer service quality. Quality of service improved greatly after privatization of the distributors. In 2004 the average number of outages per customer and average duration of outages per customer dropped to about 20 percent of their levels in 1993. The levels of both these indicators of service quality rose from 2005 to 2008, even though average opex (operational expenditures) per unit of electricity consumed 
increased substantially at the same time because of a shortage of natural gas for power generation during 2003-05. The improvements up to 2004 were accompanied by a steady drop in system total energy losses by the distributors following privatization from around 25 percent in 1993 to 11 percent in 1997 and thereafter (the short peak in 2000-01 was caused by the impact of the economic crisis on nonpayment of electricity bills). All these improvements can be attributed to privatization and regulation of the distribution segment.

- Supply security. In Argentina energy security is a greater concern than capacity security because the power system is highly dependent on hydropower capacity. Hydropower's energy output is subject to seasonal fluctuations with a marked drop in low-flow seasons. The system capacity reserve margins of around 70 percent that prevailed from 1992 to 2004 enabled the power system to generate sufficient energy to meet demand. But the drop in this margin to 40 percent in 2007still high by general standards-reflects the commissioning of thermal generation capacity fueled with natural gas to complement the hydropower capacity. The drop in the level of capex (capital expenditures) and the increase in the level of opex per unit of energy consumed from 2004 onward presumably also reflects the change to gas-fired plants with relatively low construction costs and higher fuel costs compared to the costs of new hydropower capacity.

- Financial sustainability. From 2000 to 2002 electricity tariffs in Argentina dropped to the lowest level in Latin America and extremely low by world standards, following the price freeze imposed by the government and the devaluation of the Argentinean currency during the economic crisis. In May 2002 tariffs were just 2.5 \$ cents per kWh (kilowatt-hour) for a residential consumer, and industrial tariffs were $1.3 \$$ cents per $\mathrm{kWh}$. Prior to the crisis the comparable prices were $8.9 \$$ cents and $4.8 \$$ cents per $\mathrm{kWh}$. These prices reflected the significant amount of hydropower in the Argentine generation mix (33 percent of total supply), low spot prices in the wholesale power market, and the efficiency improvements since 1992. The cost recovery ratio for the sector as a whole dropped from a strong 2.5 times before 2002 to about 0.9 times in 2002, and fluctuated between 1.07 and 0.89 thereafter, indicating that a significant proportion of total opex was linked to the U.S. dollar under concession agreements. Likewise, the financial performance of the privatized generators and distributors was sound on the whole 
before the crisis of 2002, suffered a severe decline in 2002-04 because of the crisis, but recovered steadily thereafter up to 2007 .

- Environmental sustainability. Carbon emissions from power generation in Argentina were relatively stable from the early 1990s up to 2006, during which emissions per unit of total energy generated averaged between 0.3 and 0.4 tons/MWh generated, which is modest by international standards. These emissions increased noticeably with the increase in gas-fired generation.

Trends in these indicators are shown in the following figures. 


\section{Figure 2.3 Milestones of Power Sector Reform in Argentina}
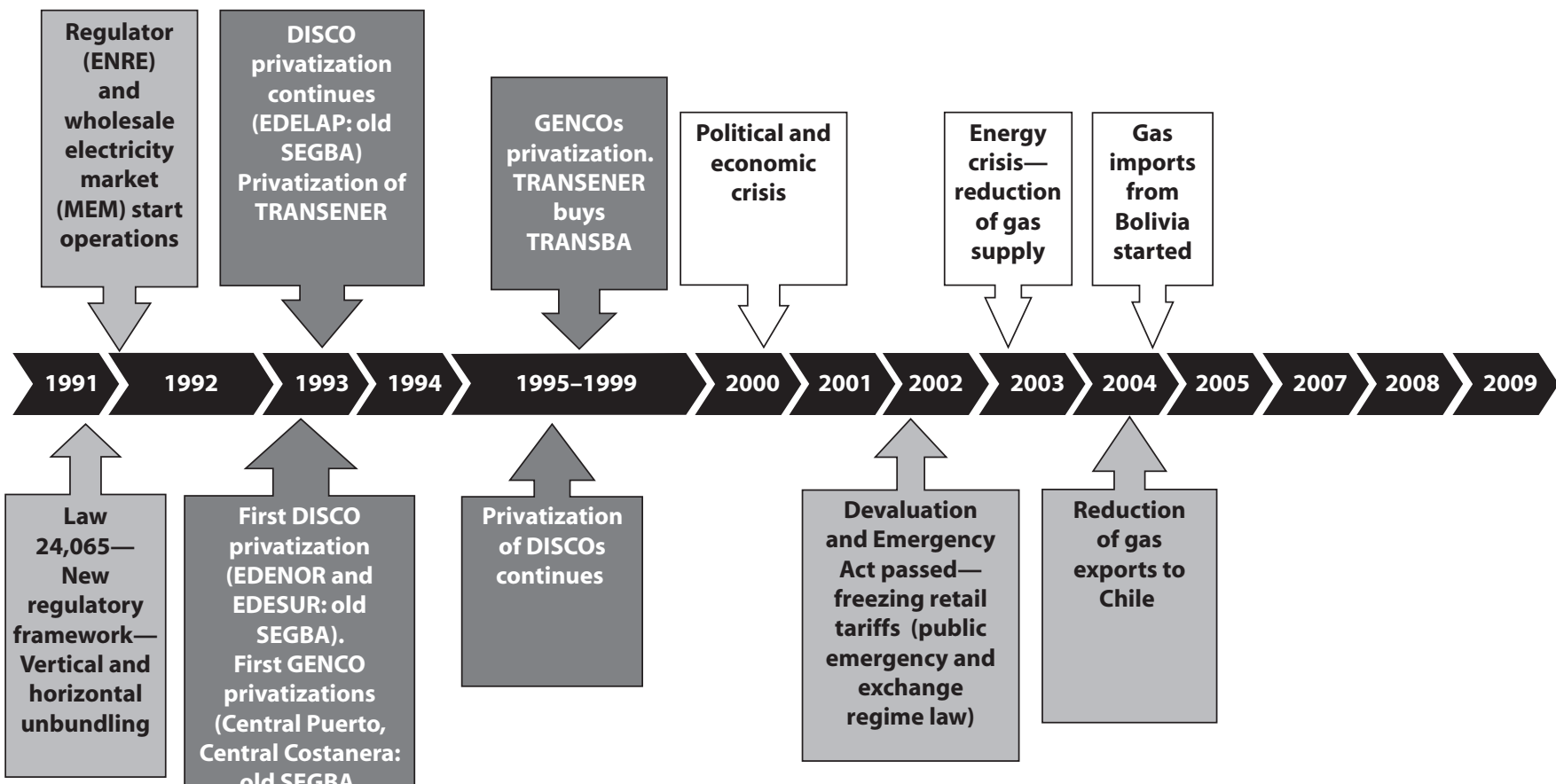

2000

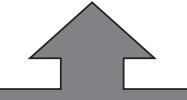

First DISCO

privatization

(EDENOR and

EDESUR: old

$$
\text { SEGBA). }
$$

First GENCO

privatizations

(Central Puerto,

Central Costanera:

old SEGBA,

Thermal plant Alto

Valle: old AyEE)

Source: An elaboration from the Power Market Structure database.

Note: The milestones are reported in different shades: white = main external factors; light gray = main government interventions; dark gray = main private sector involvements. AyEE = Agua $\mathrm{Y}$ Energía Eléctrica; DISCOs = distribution companies; EDELAP = Empresa Distribuidora La Plata; EDENOR = Empresa Distribuidora Norte; EDESUR = Empresa Distribuidora Sur; ENRE = Ente Nacional Regulador de la Electricad; GENCOs = generation companies; MEM = Mercado Eléctrico Mayorista; SEGBA = Servicios Eléctricos del Gran Buenos Aires; TRANSBA = Empresa de Transporte de Energía Eléctrica por Distribución Troncal de la Provincia de Buenos Aires; TRANSENER = Compañia de Transporte de Energia Eléctrica en Alta Tensión. 


\section{Figure 2.4 Argentina: Access to Residential Electricity}

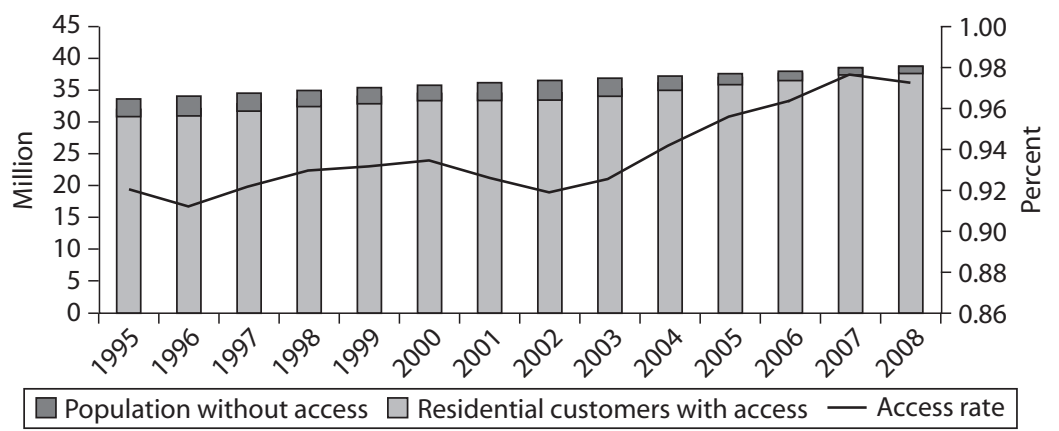

Source: An elaboration from the Power Market Structure database.

Figure 2.5 Argentina: Quality of Electric Service

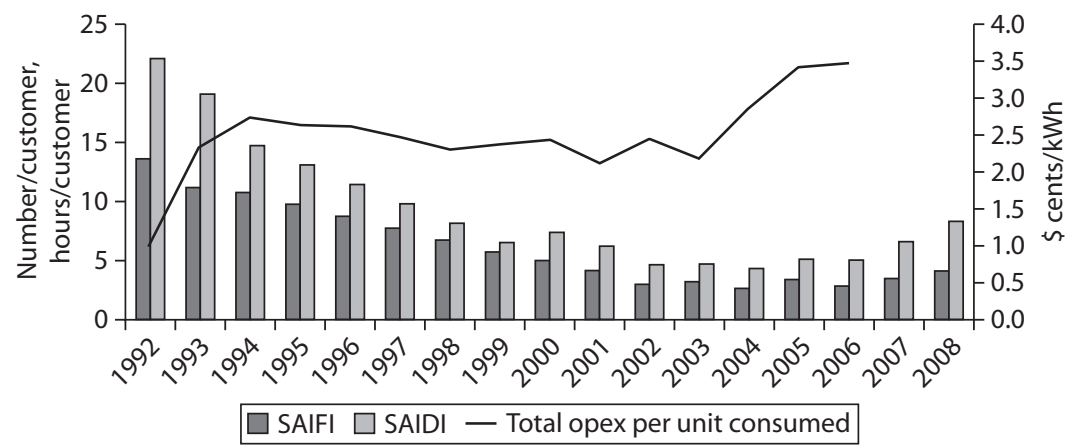

Source: An elaboration from the Power Market Structure database.

Note: Opex = operational expenditures/costs; $\mathrm{kWh}=$ kilowatt-hour; SAIDI = System Average Interruption

Duration Index; SAIFI = System Average Interruption Frequency Index. 


\section{Figure 2.6 Argentina: System Energy Losses}

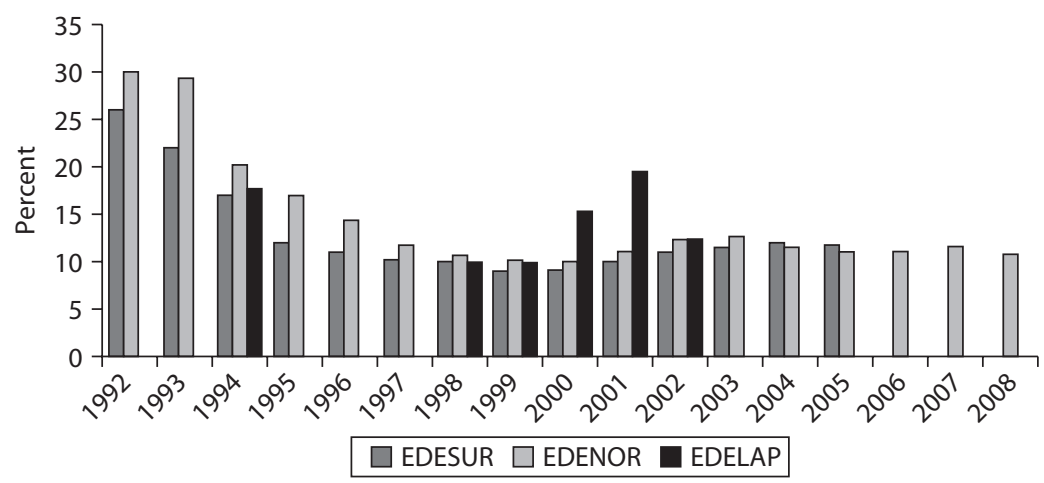

Source: An elaboration from the Power Market Structure database.

Note: $\mathrm{EDELAP}=$ Empresa Distribuidora La Plata; EDENOR = Empresa Distribuidora Norte; EDESUR = Empresa Distribuidora Sur.

Figure 2.7 Argentina: System Load Factor

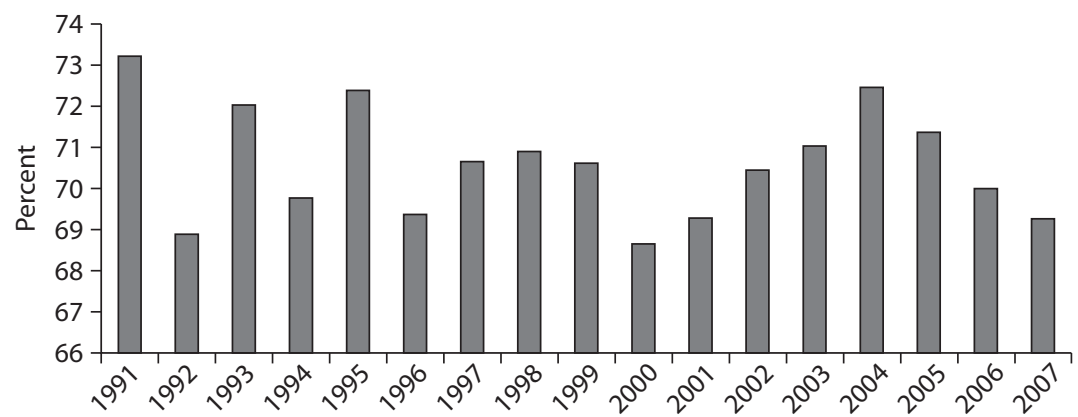

Source: An elaboration from the Power Market Structure database. 
Figure 2.8 Argentina: Electricity Generation by Source and Carbon Emissions

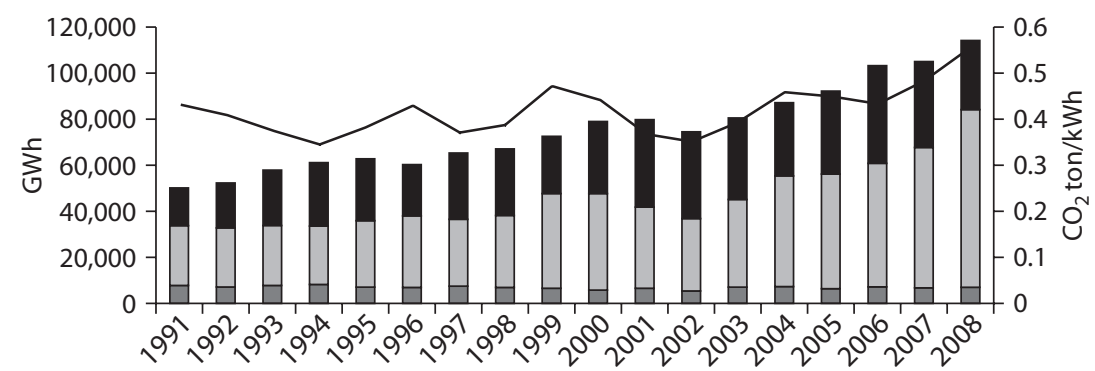

$\square$ Nuclear $\square$ Thermal $\square$ Hydro - Carbon emissions index

Source: An elaboration from the Power Market Structure database.

Note: GWh = gigawatt-hour; kWh = kilowatt-hour.

Figure 2.9 Argentina: Energy Security and Capital Expenditure

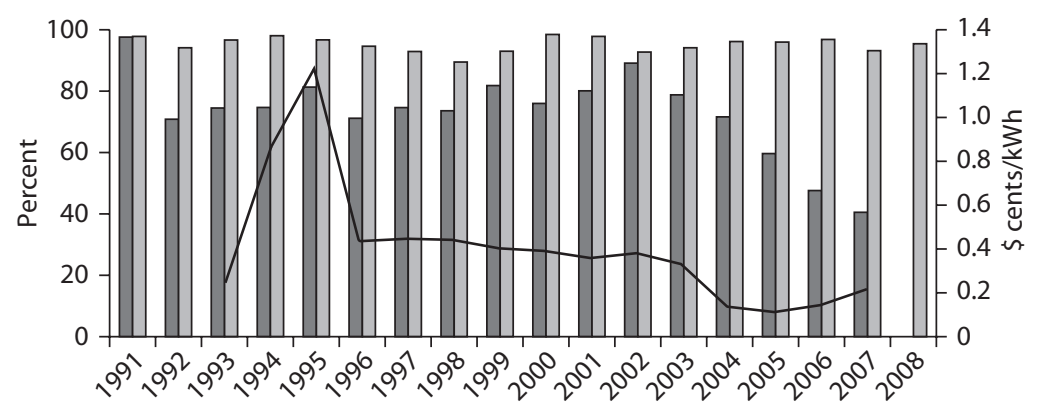

$\square$ System reserve capacity $\square$ Energy self-sufficiency

Total capex per unit consumed

Source: An elaboration from the Power Market Structure database.

Note: Capex = capital expenditures; $\mathrm{kWh}=$ kilowatt-hour. 


\section{Figure 2.10 Argentina: Average Tariff and Operating Costs}

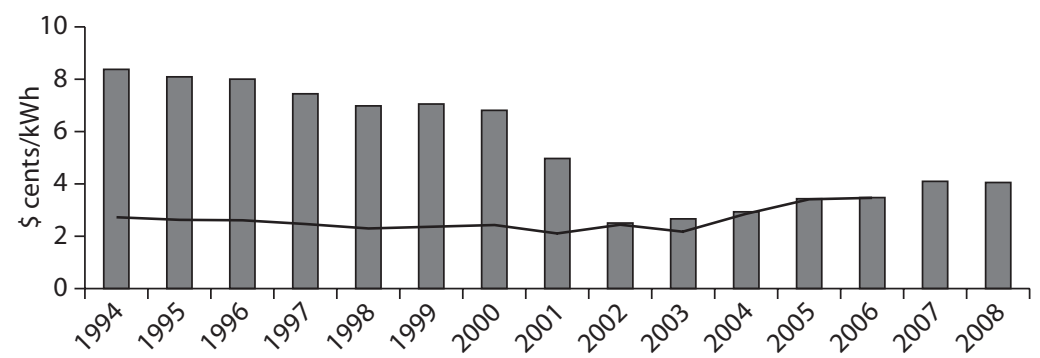

Average tariff for three utilties (EDENOR, EDESUR, EDELAP) Total opex per unit consumed

Source: An elaboration from the Power Market Structure database.

Note: $\mathrm{EDELAP}=$ Empresa Distribuidora La Plata; EDENOR = Empresa Distribuidora Norte; EDESUR = Empresa

Distribuidora Sur; kWh = kilowatt-hour; opex = operational expeditures/costs.

\section{Figure 2.11 Argentina: Labor Productivity}

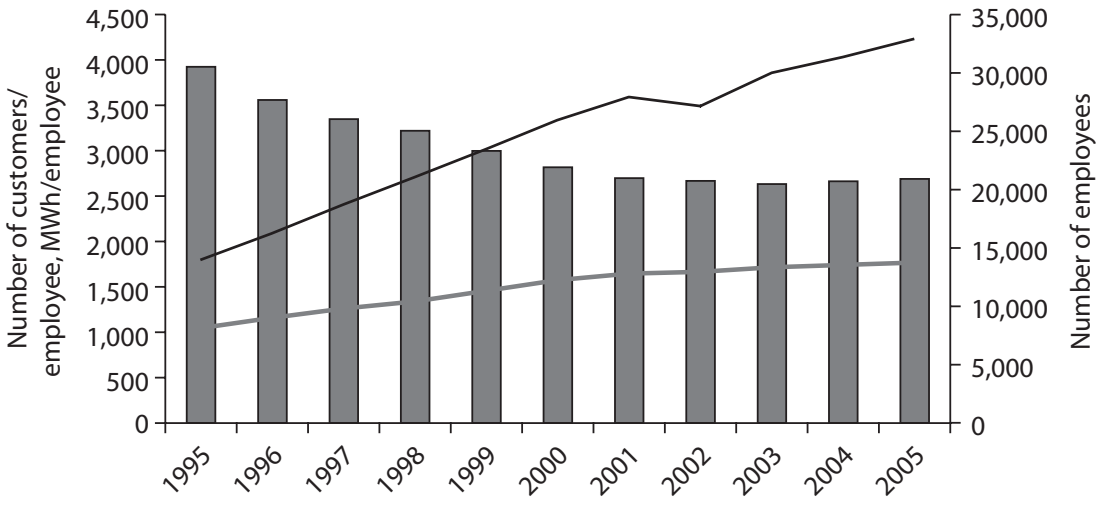

$\square$ Number of employees in electricity sector

— Energy consumed/employee

Residential customers/employee

Source: An elaboration from the Power Market Structure database. 
Figure 2.12 Argentina: Capacity Utilization

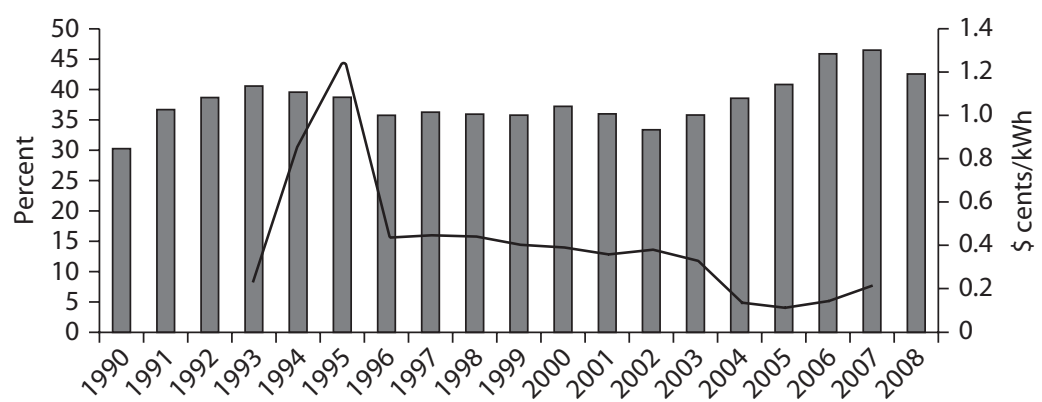

$\square$ Capacity utilization - Total capex per unit consumed

Source: An elaboration from the Power Market Structure database.

Note: Capex = capital expenditures; $\mathrm{kWh}=$ kilowatt-hour.

Figure 2.13 Argentina: Cost Recovery Index

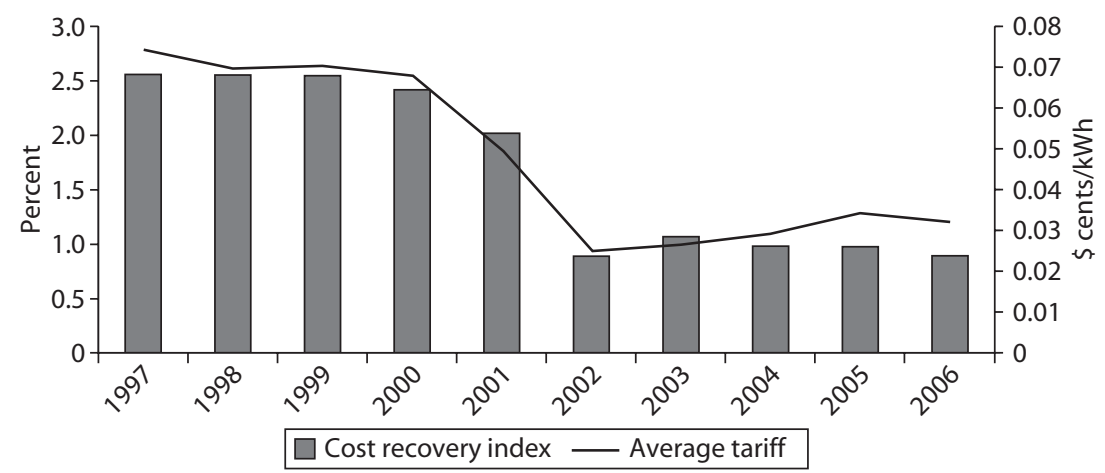

Source: An elaboration from the Power Market Structure database.

Note: $\mathrm{kWh}=$ kilowatt-hour. 


\section{Figure 2.14 Argentina: Market Concentration}

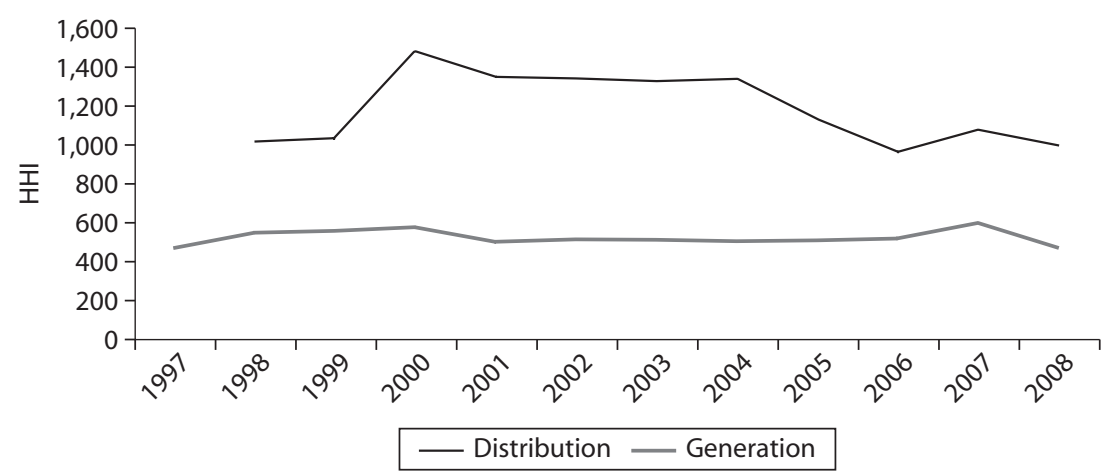

Source: An elaboration from the Power Market Structure database.

Note: $\mathrm{HHI}=$ Herfindahl-Hirschman Index.

\section{Figure 2.15 Argentina: Private Ownership}

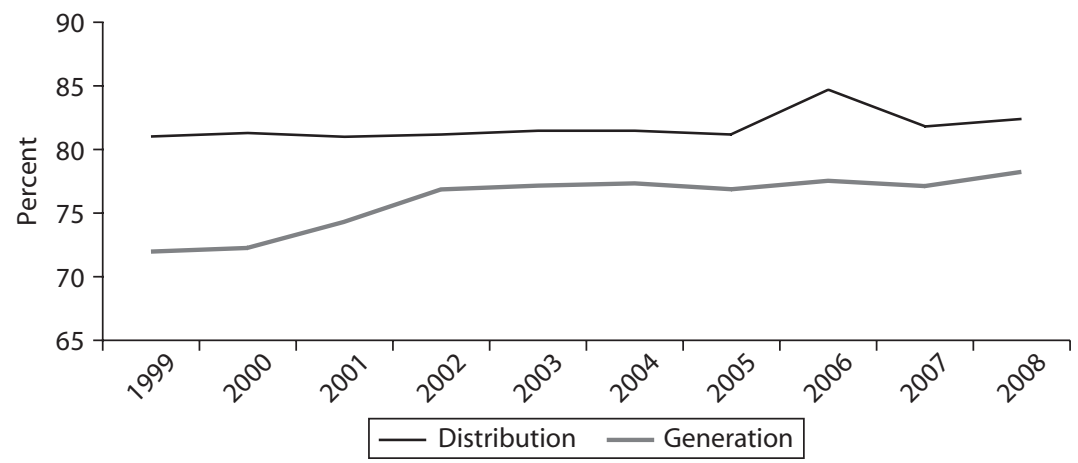

Source: An elaboration from the Power Market Structure database. 


\section{Figure 2.16 Argentina: Private Management}

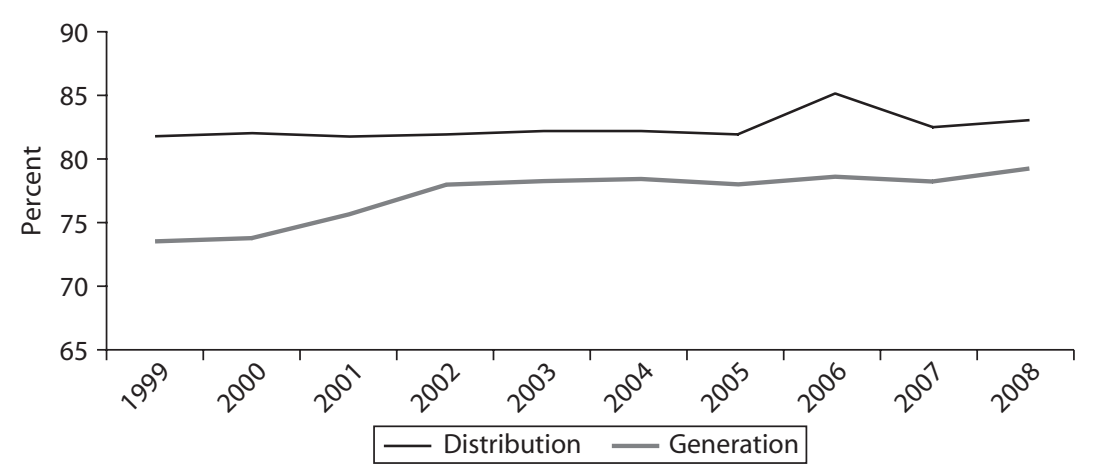

Source: An elaboration from the Power Market Structure database.

Figure 2.17 Argentina: Degree of Vertical Integration

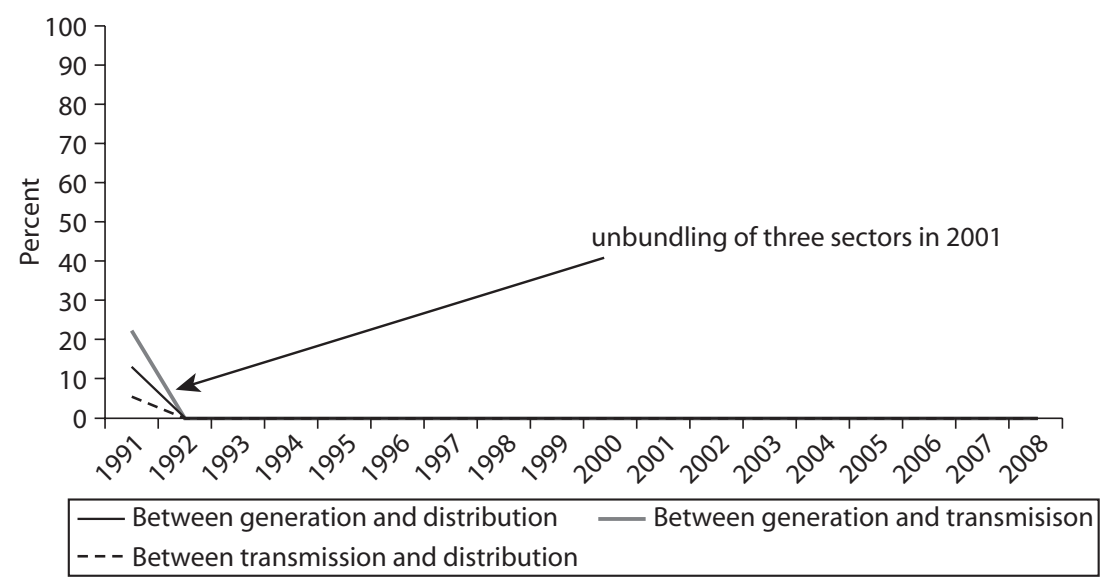

Source: An elaboration from the Power Market Structure database. 



\section{CHAPTER 3}

\section{Brazil}

Brazil offers a special case for power sector reform because of its innovations to make its power market competitive based on predominance of hydroelectricity. Brazil falls into the category of medium per capita income/large system size with a gross national income per capita of about $\$ 7,300$ and total installed generating capacity of about 100,000 MW (megawatts) in 2008. Brazil has relied on hydroelectricity for most of its power supply, but the proportion of total supply from hydropower declined steadily from over 90 percent up to 1998 to 81 percent in 2008.

\section{Reform History}

Before 1995 the power sector was predominantly government-controlled with vertically integrated companies. The federal company Eletrobrás and several state companies owned and operated most of the generation, transmission, and distribution in the country, as shown in figure 3.1.

The reform of the electric power sector in Brazil originated in the new constitution of 1988. It allowed private investment in infrastructure and provided the legal framework for regulating that investment. But the reorganization of the electricity sector in Brazil was set in motion only by the ratification of the Electricity Concession Law No. 9074 early in 1995. 
Figure 3.1 Brazil: Taxonomy of Power Sector before Reform (1990)

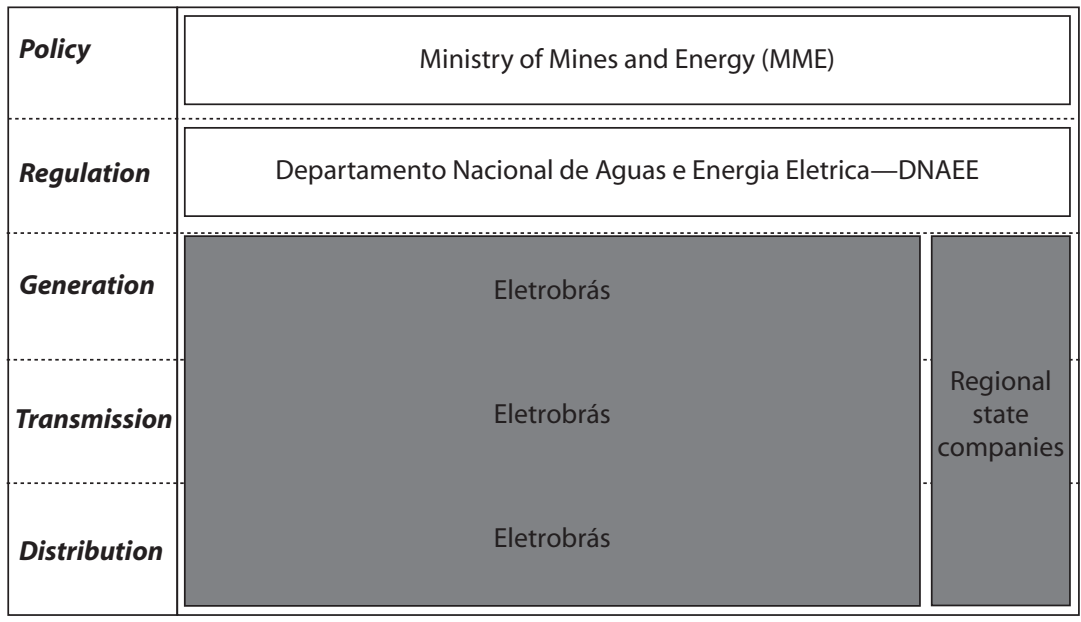

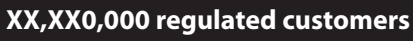

Vertical integration

Source: An elaboration from the Power Market Structure database.

Note: Number of regulated customers not available.

The law provided for the unbundling of the sector-principally the functions of the dominant power generator and transmitter Eletrobrás.

The following important institutions were created under legislation enacted between 1995 and 1998:

- Brazilian Electricity Regulatory Agency (ANEEL). Created by Law No. 9427 as an independent regulatory entity with the purpose of regulating the generation, transmission, distribution, and commercialization of electric power in the country.

- National Energy Policy Council (CNPE). Created by Law No. 9427 with responsibility for proposing national energy policies. In particular, it was charged with improving coordination between the power and oil sectors. Membership of the new institution was drawn from several ministries and representatives of the president and state governments and included a Brazilian power sector expert.

- System Operator (ONS). Created by Law No. 9648 to control power generation and transmission activities in the interconnected power system through a tight pool dispatch system. 
- Wholesale Electric Energy Market (MAE). Also created by Law No. 9648 to undertake all wholesale electricity purchase and sale transactions and to promote the accounting of the agents' transactions in the multilateral short-term market under market rules.

Law No. 9648 also provided for the unbundling of Eletrobrás into six holding companies and 14 generation and transmission companies. Eletrobrás retained the ownership of the transmission grid, the Brazilian part of the binational Itaipu Dam and hydroelectric power station, the nuclear power plants, and Centro de Pesquisas de Energia Elétrica's (CEPEL) research and development activities. The generation companies formed from Eletrobrás were put up for privatization. The first private transaction in the Brazilian power sector occurred in late 1995 when local investors acquired 100 percent of the assets of the regional utility Espírito Santo Centrais Elétricas (ESCELSA). The first privatization of federal government-owned generation companies was Gerasul at the end of 1998.

The largest privatization of distribution assets occurred between 1996 and 1999 and included Eletropaulo which was split prior to privatization into two distributors (Eletropaulo Metropolitana, a transmission company, and Empresa Bandeirante, a generation company). Another major privatization of this period was the auction of the distribution companies of Rio de Janeiro, namely Companhia de Eletricidade do Rio de Janeiro (CERJ) and Light. Other auctions included distributors in the states of Minas Gerais, Ceara, Cemig, and Bahia. These privatizations yielded the highest values per customer served by distributors among the global wave of privatizations of power distributors at that time. As a result, private sector participation in the distribution sector increased from 2.6 percent in 1994 to about 60 percent by the end of 1998 .

To promote competition, the reform model created groups of large consumers with the right to choose their suppliers and whose power purchases were not subject to price regulation, independent power producers (as an alternative to generators operating under public service concessions), and marketers/traders (private companies that operate in the electricity industry by selling energy to the unregulated consumers and to distribution companies). The model also established open access for entities in these groups to the distribution and transmission grids. Private companies were permitted to own transmission lines, which would be operated by the ONS and regulated by ANEEL. 
Competition was supported by regulations that imposed ownership limitations in each segment of the power supply chain to prevent the concentration of market power. Table 3.1 shows the ownership limitations originally established.

The taxonomy of the power sector in 1998 is illustrated in figure 3.2. It can be observed that once Eletrobrás was unbundled, the sector was less concentrated and private investment in 1998 was significant in the distribution segment.

Table 3.1 Concentration Limits in the Brazilian Power Market, in percent

\begin{tabular}{lccc}
\hline & National market & $\begin{array}{c}\text { South/Southeast/ } \\
\text { Central markets }\end{array}$ & $\begin{array}{c}\text { North/Northeast } \\
\text { markets }\end{array}$ \\
\hline Generation entities & 20 & 25 & 35 \\
$\begin{array}{l}\text { Distribution entities } \\
\text { Combined generation and }\end{array}$ & 20 & 25 & 35 \\
distribution entities & 30 & - & - \\
\hline
\end{tabular}

Source: An elaboration from the Power Market Structure database.

Note: $-=$ not available

Figure 3.2 Brazil: Taxonomy of Power Sector after First Reform (1998)

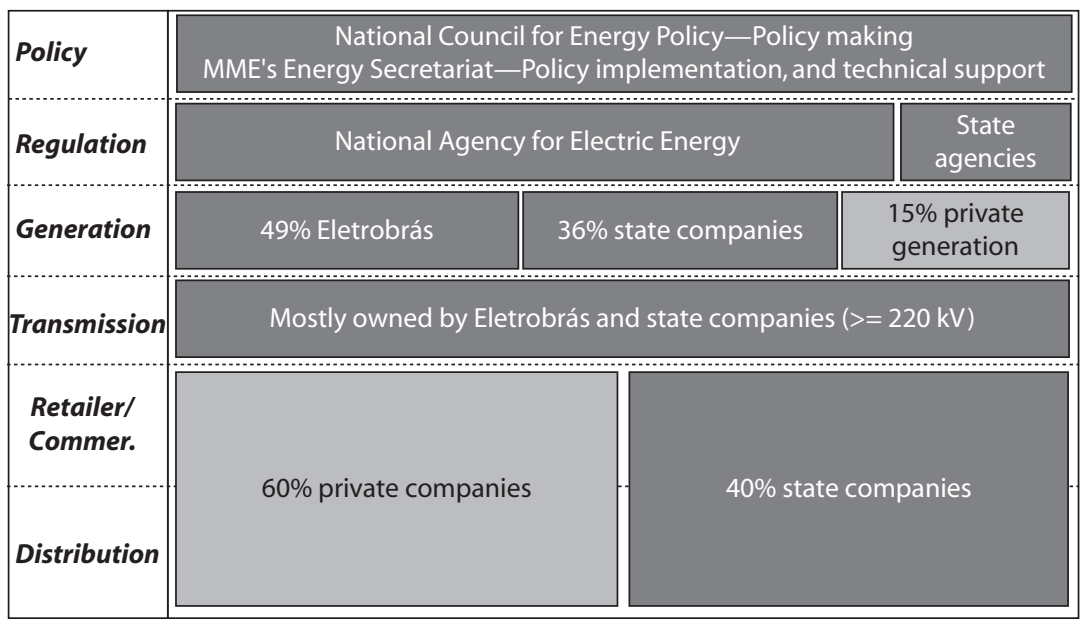

\section{$x, 000,000$ regulated customers $/ 20$ unregulated customers}

State agency $\square$ Privatized company

Source: An elaboration from the Power Market Structure database.

Note: Number of regulated customers not available; MME = Ministry of Mines and Energy. 
Even with the reforms implemented since 1996 to attract additional investment in generation, installed capacity expanded only by 28 percent from 1990 to 1999, while electricity demand grew by 45 percent. The government tried to address this supply constraint by launching in 2000 the Thermal Priority Program (PPT) to encourage private investment in gas-fired generation and to develop the market for natural gas. The plan called for the construction of 59 power plants, but only 15 power plants were built mainly due to the high cost charged by Petrobrás for gas imported from Bolivia - the only source of gas at that time-and to regulatory and political uncertainty.

During 2001-02 Brazil suffered one of the worst droughts on record. The drought, together with lower than expected generation expansion during the previous years, forced the government to take extreme measures to avoid the collapse of the power system. The government implemented a strict rationing program for nine months to reduce by 20 percent the load in 80 percent of the country. Special authority was given to an emergency committee in charge of the program. The rationing program succeeded in managing the power demand within the constrained power supply.

After the drought ended, however, power demand did not recover to the expected levels, as customers had adjusted to lower levels of electricity consumption. The country went from a situation of power supply scarcity to one of surplus, helped by some emergency generation capacity installed during the drought. This situation created other issues with distribution companies, as their sales of electricity fell along with their revenues. Distribution companies were also blamed for not purchasing capacity in the most efficient manner to minimize pass-through to final customers, reflecting the contract terms on which they had to procure emergency power supplies.

In 2004 the government implemented a second wave of power market reform, known as the new model, to address some of the problems associated with incentives for installing new generation capacity, improving competitive conditions, and strengthening the institutional framework. The main characteristics of this new model were:

- Less emphasis on the short-term "spot" market as a provider of signals for system expansion

- More emphasis on the forward contract market to induce additions of new generation capacity

- Strengthening of regulatory agencies 
- Prohibition on cross-ownership and self-dealing

- Postponement of the separation between distribution and retailing (commercialization)

- Requirement for mandatory energy auctions for distribution companies to cover 100 percent of all loads

The last requirement meant that distributors could acquire energy only through auctions for contracts of three to five years to reduce risks for generation investors and promote competition. Benchmark prices were used for pass-through of wholesale power costs to consumers procured under the new energy auctions, as supply costs reflect the average price of all contracts.

As part of the modifications introduced with the new model, the original wholesale market administrator (MAE) was absorbed by the Electric Energy Commercialization Chamber (CCEE), which was given the responsibility for coordinating energy commercialization under the new rules (Law 10,848 of March 2004). CCEE was created as a private and not-for-profit institution with responsibility for administering supply to both regulated customers and large customers. The new model also introduced the Power Sector Monitoring Committee to monitor service conditions. It is reported that the new model led to contracts for more than 16,000 MW of new generating capacity in five energy auctions with a high participation of thermal plants.

The two models differed in significant ways. The original reform model (implemented in 1995) was characterized by opening up the power market with emphasis on the privatization of all the companies; system expansion was supposed to be achieved through short-term price signals and contracting obligations. In the new model (implemented in 2004) the emphasis is on coexistence between state-controlled and private companies.

\section{Impact on Sector Structure}

The two reform waves changed the structure of the Brazilian power sector from vertical integration into substantially unbundled, both vertically and horizontally. Figure 3.3 illustrates the structure of the Brazilian power sector after these reforms in 2008.

Large government-controlled companies dominate the Brazilian electricity generation sector. Federally owned Eletrobrás holds about 40 percent of capacity (including 50 percent of the Itaipu Dam 
Figure 3.3 Brazil: Taxonomy of Power Sector after Second Reform (2008)

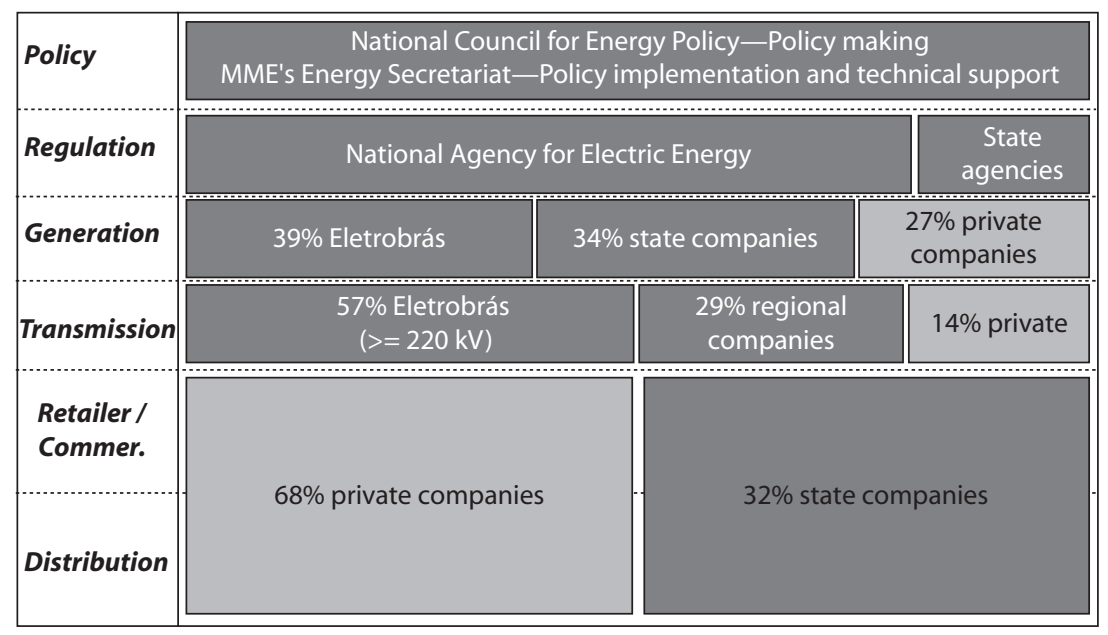

$\mathrm{X}, \mathrm{Xxx}, 000$ regulated customers $/ 651$ unregulated customers

State agency $\square$ Privatized company

Source: An elaboration from the Power Market Structure database.

Note: Number of regulated customers not available; MME = Ministry of Mines and Energy.

hydropower complex, equal to 6,300 MW to Brazil), with statecompanies CESP (Companhia Energética de São Paulo), Cemig, and Copel controlling 8 percent, 7 percent, and 5 percent of generation capacity, respectively. Generation capacity is shared among the different companies as shown in table 3.2.

Around 2007 some 27 percent of the generation assets were in the hands of private investors. Considering the plants under construction, as well as the concessions and licenses already granted by ANEEL, this proportion is expected to grow up to 31 percent in the medium term and to reach almost 44 percent over five to six years. Private capital participation in the generation business could represent 50 percent of the installed capacity in the longer term.

Until recently transmission has remained almost exclusively under government control through both federal (Eletrobrás) and state companies (mainly São-Paulo-CTEEP, Minas Gerais-Cemig, and Parana-Copel). Under the new sector regulatory model, however, there are about 80 transmission concessions in Brazil. Most of them are still controlled by the 
Table 3.2 Companies' Share of Generation Capacity

\begin{tabular}{llcc}
\hline Company & \multicolumn{1}{c}{ Controlling shareholder } & $\begin{array}{c}\text { Installed capacity } \\
\text { (MW) }\end{array}$ & Percent total \\
\hline Eletrobrás & Federal government & 38,111 & 40 \\
CESP & São Paulo state government & 7,451 & 8 \\
Cemig & Minas Gerais state government & 6,692 & 7 \\
Copel & Paraná state government & 4,550 & 5 \\
Tractebel Energia & GDF Suez & 6,870 & 7 \\
AESTiete & AES Corp. & 2,651 & 3 \\
Others & Mostly private sector & 29,969 & 31 \\
Total & & $\mathbf{9 6 , 2 9 4}$ & $\mathbf{1 0 0 \%}$ \\
\hline
\end{tabular}

Source: An elaboration from the Power Market Structure database.

government, with subsidiaries under Eletrobrás holding 69 percent of total transmission lines (table 3.3).

In Brazil 49 utilities have distribution concessions and about 68 percent of Brazilian distribution assets are controlled by private sector companies. Table 3.4 lists Brazil's most important distribution companies:

\section{Impact on Sector Performance}

Evidence of possible impacts from the reforms in Brazil that we have described is sought from trends from the early 1990s up to 2008 in the following indicators:

- Access to electricity supply by the population in terms of new residential connections. Electricity service is virtually universal in Brazil, where around 97 percent of the total population is covered. The access rate increased steadily under the privatized distribution companies.

- Customer service quality. Quality of electricity service in Brazil has generally been good by international and regional standards following reforms to the power sector. Quality of electric service in terms of SAIDI (System Average Interruption Duration Index) improved from an average of 27 hours per customer in 1997 to 17 hours per customer from 2000 onward following privatization of the distributors. Quality of electricity service in terms of SAIFI (System Average Interruption Frequency Index) also improved during this period from an average of 22 outages per customer in 1996 to around 12 outages per customer from 2004 onward. These trends continued during the major drought 
Table 3.3 Control of Transmission Lines

\begin{tabular}{|c|c|c|c|}
\hline Company & $\begin{array}{l}\text { Controlling } \\
\text { shareholder }\end{array}$ & Concession area & $\begin{array}{c}\text { Transmission } \\
\text { lines }(\mathrm{km})\end{array}$ \\
\hline \multicolumn{4}{|c|}{ Pure transmission companies } \\
\hline CTEEP & ISA (Colombia) & São Paulo State & 11,837 \\
\hline Terna Participacoes & Terna (Italy) & $\begin{array}{l}\text { Goias, Bahia, Brazilian, } \\
\text { Maranhao }\end{array}$ & 2,447 \\
\hline \multicolumn{4}{|c|}{ Companies with significant transmission operations } \\
\hline Cemig & State of Minas Gerais & Minas Gerais & 21,184 \\
\hline Copel & State of Parana & Parana & 7,045 \\
\hline $\begin{array}{l}\text { Electrosul, Furans, } \\
\text { Electronorte, Chesf }\end{array}$ & Eletrobrás & Throughout Brazil & 56,384 \\
\hline
\end{tabular}

Source: An elaboration from the Power Market Structure database

Note: $\mathrm{CTEEP}=$ Companhia de Transmissão de Energia Elétrica Paulista; Copel = Companhia Paranaense de Energia.

Table 3.4 Distribution Companies' Market Share

\begin{tabular}{|c|c|c|c|c|}
\hline Company & $\begin{array}{l}\text { Controlling } \\
\text { shareholder }\end{array}$ & Concession area & Sales (GWh) & Sales percent \\
\hline Cemig & $\begin{array}{l}\text { Minas Gerais state } \\
\text { gov't. }\end{array}$ & Minas Gerais & 20,221 & 8.0 \\
\hline Eletropaulo & AES Corp. & São Paulo city & 31,642 & 12.5 \\
\hline CPFL & VBC Energia (Brazil) & $\begin{array}{l}\text { São Paulo State } \\
\text { Outside São } \\
\text { Paulo city }\end{array}$ & 36,135 & 14.3 \\
\hline Copel & Parana state gov't. & Parana & 17,524 & 6.9 \\
\hline Energias do Brasil & EDP (Portugal) & $\begin{array}{l}\text { São Paulo, Rio } \\
\text { Grande do Sul }\end{array}$ & 15,863 & 6.3 \\
\hline Celesc & $\begin{array}{l}\text { Santa Catarina state } \\
\text { gov't. }\end{array}$ & Santa Catarina & 15,157 & 6.0 \\
\hline Light & EDF (France) & $\begin{array}{l}\text { Rio de Janeiro } \\
\text { city }\end{array}$ & 19,139 & 7.6 \\
\hline Equatorial (Cemar) & $\begin{array}{l}\text { GP Investimentos/ } \\
\text { Pactual }\end{array}$ & Maranhao & 2,793 & 1.1 \\
\hline Ampla (Cerj) & Enersis (Chile) & Rio de Janeiro & 6,832 & 2.7 \\
\hline Others & Mostly private sector & & 87,594 & 34.6 \\
\hline Total & & & 252,900 & $100.0 \%$ \\
\hline
\end{tabular}

Source: An elaboration from the Power Market Structure database.

Note: Ampla = Ampla Energia e Servicos; Celesc = Centrais Elétricas de Santa Catarina; Copel = Companhia Paranaense de Energia; CPFL = Companhia Paulista de Força e Luz; EDF = Électricité de France; EDP = Energias de Portugal; GWh = gigawatt-hour.

of 2001-02, indicating the success of the special demand management measures instituted to deal with the power shortage. After staying at around 5 \$ cents per kWh (kilowatt-hour) from 1999 to 2002, tariffs for electricity consumers increased substantially, to about $13 \$$ cents 
per kWh in 2007 under the prices in the new market needed to attract investment in new generation capacity.

- Supply security. Since 2002 the margin of installed generating capacity over annual peak demand on the national interconnected power system has been around 60 percent of the level of demand, which generally provides a generous margin. But in a hydro-dominated power system such as Brazil's, system generation energy reserve margin is more critical than capacity reserve margin. This feature was starkly shown during the drought of 2001-02, when Brazil experienced a shortage of around 20 percent in energy supply, despite a 37 percent margin of installed hydropower capacity relative to the peak demand on the power system that was about 10 percent lower than the trend value. The shortage demonstrates the vulnerability of highly regulated systems to infrequent but serious disruptions. The commendable way that the country managed the shortages during the drought may reflect responsiveness created by the reformed structure-both technical and institutional.

- Financial sustainability. The only regularly available indicator of the financial sustainability of the Brazilian power sector is the cost-recovery index for the sector as a whole. This index hovered around a value of 1.6 from 1999 to 2002, but increased to between 2.3 and 2.5 from 2003 to 2005 under that period's substantial increase in tariffs. These high levels indicate that the Brazilian power market became attractive to private investors in generation capacity, which surged in from 2002 onward compared to the much slower growth in new capacity in the previous years. Installed generation capacity increased from $61.5 \mathrm{GW}$ (gigawatts) in 1996 to $76.2 \mathrm{GW}$ in 2001, and then to $104 \mathrm{GW}$ in 2008. Total system losses-technical and nontechnicalhave remained around 17 percent from 1995 onward, not changing with the new regulatory approaches used to set allowable costs for distributors.

- Environmental sustainability. Brazil has had very low average carbon emissions per unit of energy generated for decades since power generated from fossil fuels has constituted less than 10 percent of total generated power, and natural gas has become the fossil fuel mostly used for this purpose. Nevertheless, the increase in gas-fired generation is reflected in the long-term rise in average carbon emissions since 1999.

Trends in these indicators are shown in the following figures. 


\section{Figure 3.4 Milestones of Power Sector Reform in Brazil}

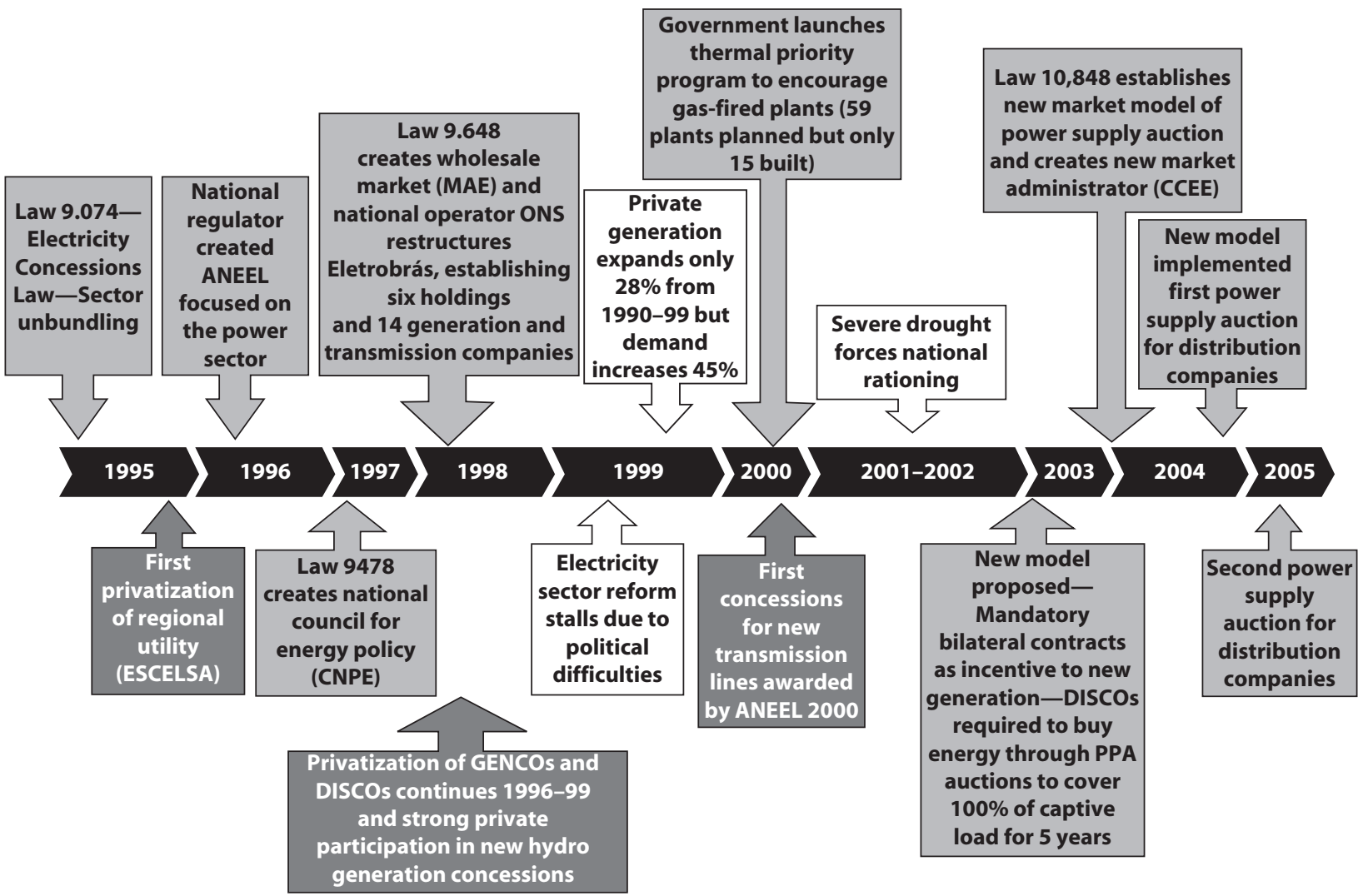




\section{Figure 3.5 Brazil: Access to Residential Electricity}

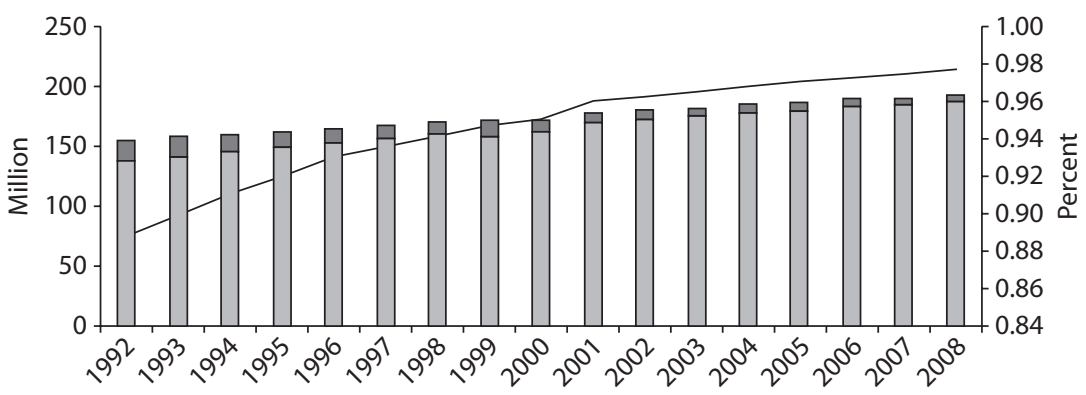

$\square$ Population without access $\square$ Residential customers with access - Access rate

Source: An elaboration from the Power Market Structure database.

\section{Figure 3.6 Brazil: Quality of Electric Service}

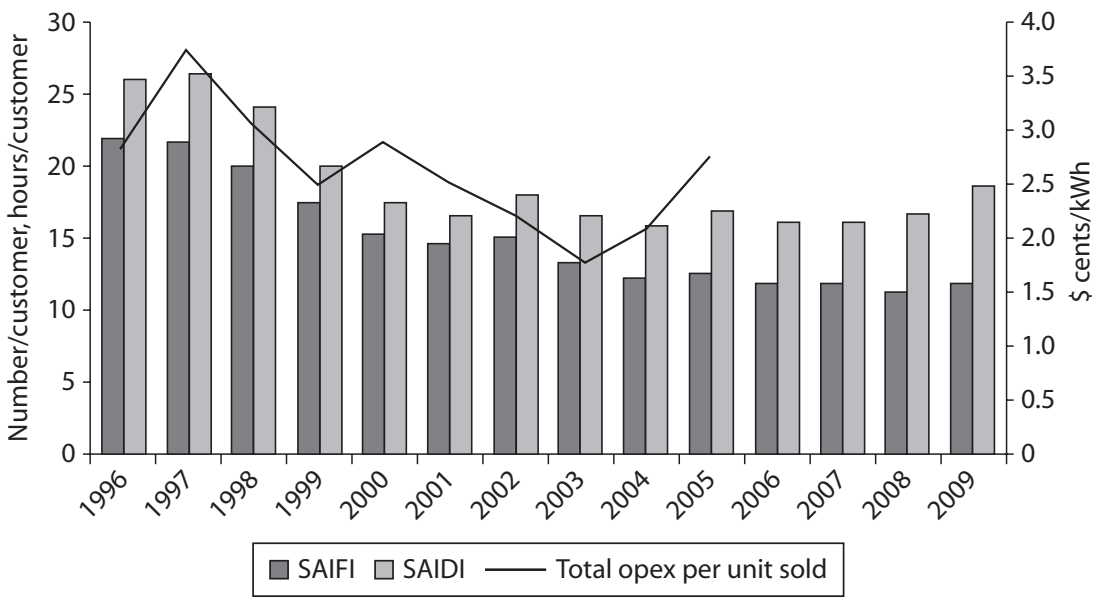

Source: An elaboration from the Power Market Structure database.

Note: opex = operational expenditures/costs; kWh = kilowatt-hour; SAIDI = System Average Interruption Duration Index; SAIFI = System Average Interruption Frequency Index. 


\section{Figure 3.7 Brazil: System Losses and Operating Costs}

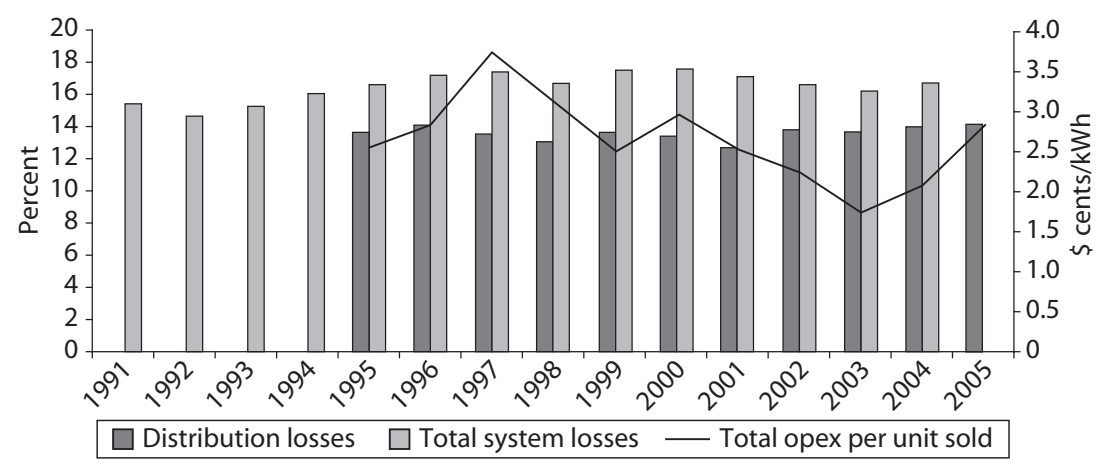

Source: An elaboration from the Power Market Structure database.

Note: kWh = kilowatt-hour; opex = operational expenditures/costs.

Figure 3.8 Brazil: Electricity Generation by Source and Carbon Emissions

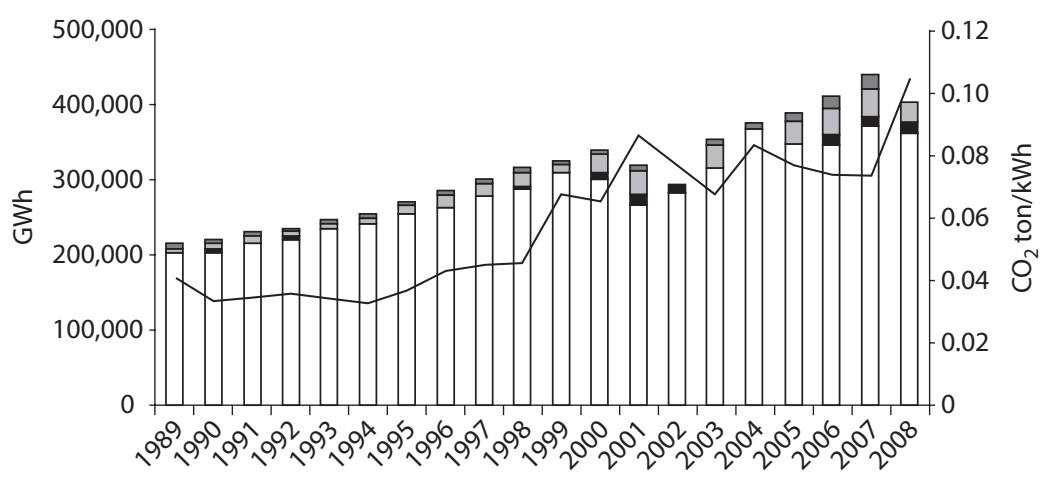

$\square$ Nonhydro renewables (mostly biomass and waste) $\quad \square$ Thermal

- Nuclear Carbon emissions index

Source: An elaboration from the Power Market Structure database.

Note: GWh = gigawatt-hour; kWh = kilowatt-hour. 
Figure 3.9 Brazil: Energy Security and Capital Expenditure

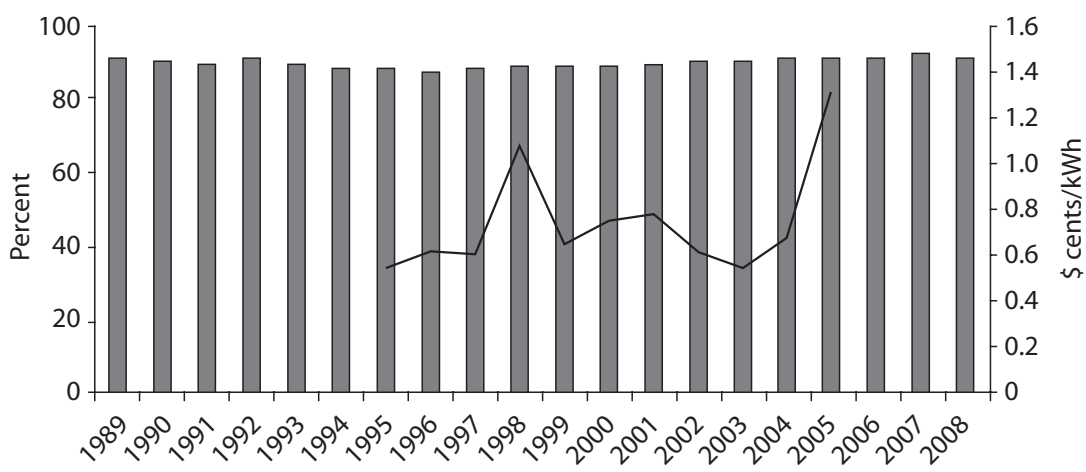

Energy self-sufficiency $\quad$ Total capex per unit sold

Source: An elaboration from the Power Market Structure database.

Note: Capex = capital expenditures; $\mathrm{kWh}=$ kilowatt-hour.

Figure 3.10 Brazil: Average Tariff and Operating Costs

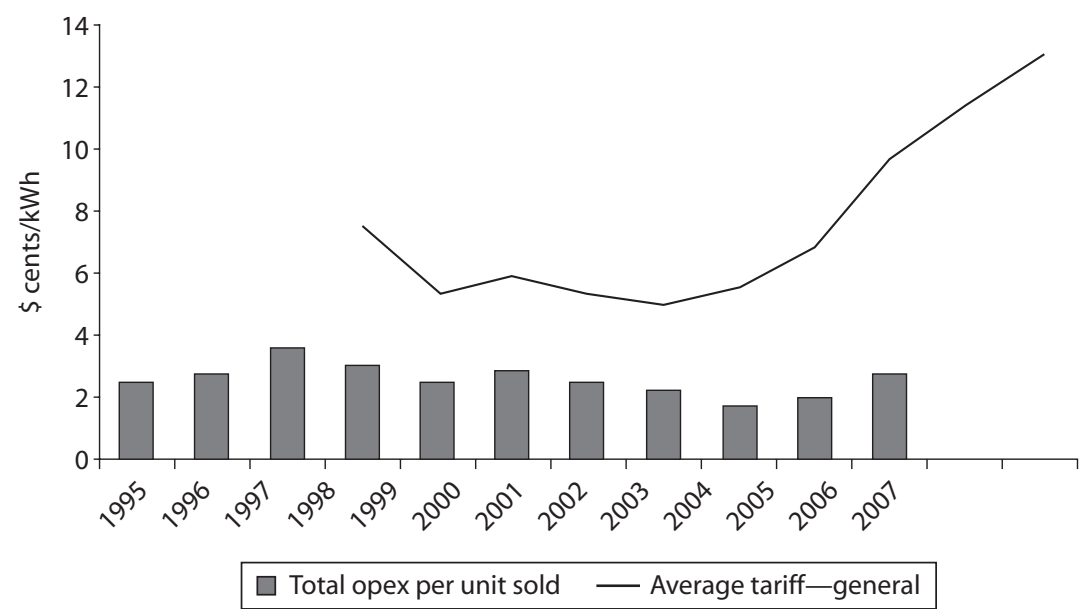

Source: An elaboration from the Power Market Structure database.

Note: kWh = kilowatt-hour; opex = operational expenditures/costs. 


\section{Figure 3.11 Brazil: Labor Productivity}

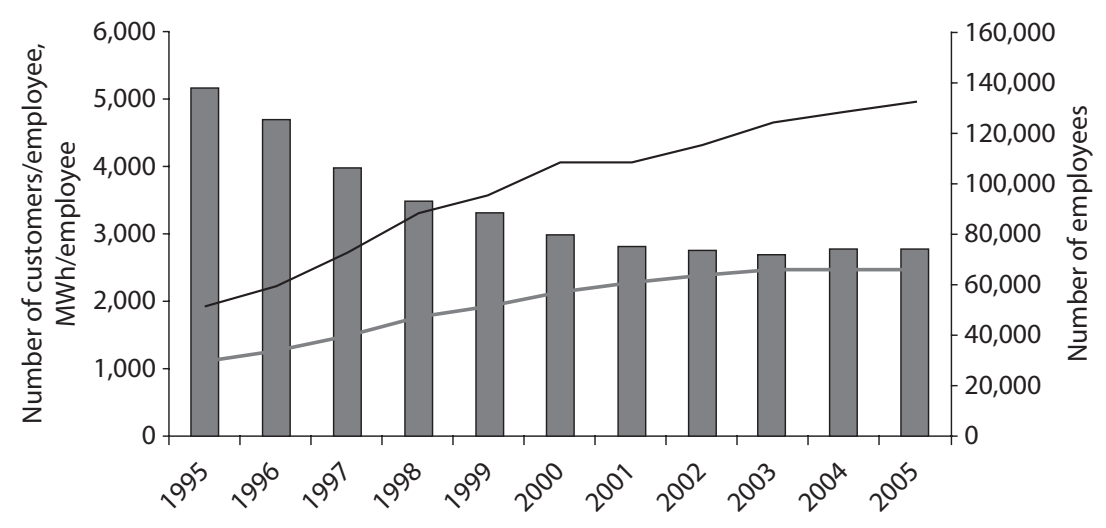

$\square$ Number of employees in electricity sector — Energy consumed/employee Number of residential customers/employee

Source: An elaboration from the Power Market Structure database.

Note: $\mathrm{MWh}=$ megawatt-hour.

\section{Figure 3.12 Brazil: Capacity Utilization}

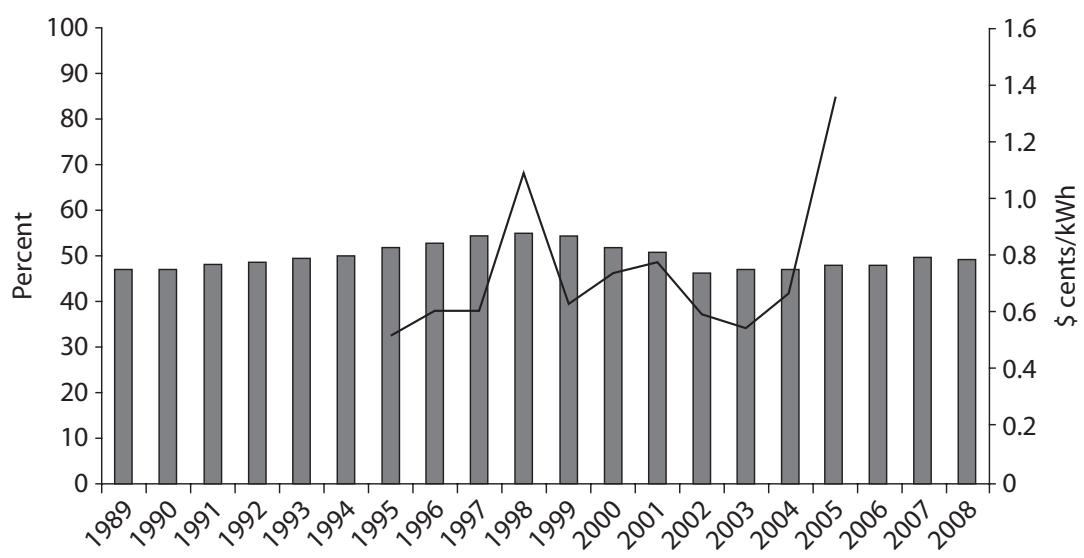

Capacity utilization - Total capex per unit sold

Source: An elaboration from the Power Market Structure database.

Note: Capex = capital expenditures; $\mathrm{kWh}=$ kilowatt-hour. 


\section{Figure 3.13 Brazil: Cost Recovery Index}

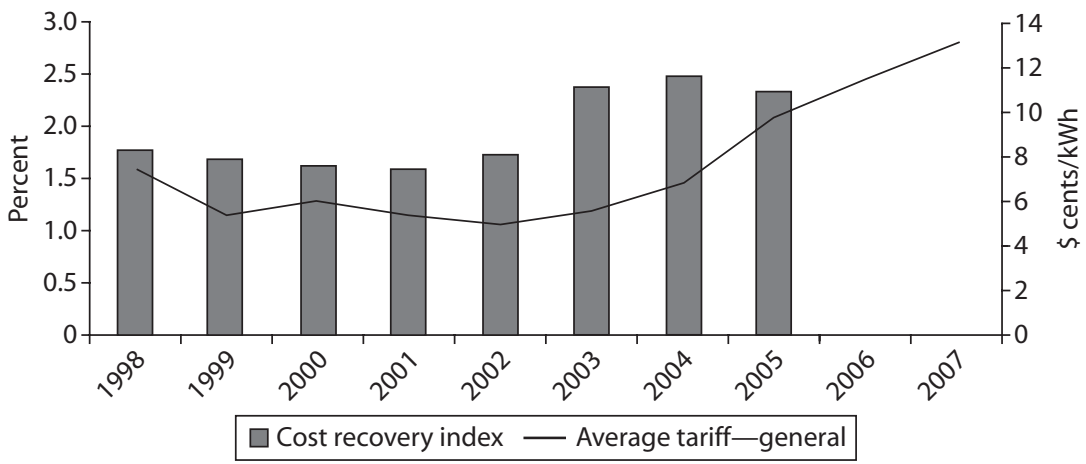

Source: An elaboration from the Power Market Structure database. Note: kWh = kilowatt-hour.

\section{Figure 3.14 Brazil: Market Concentration}

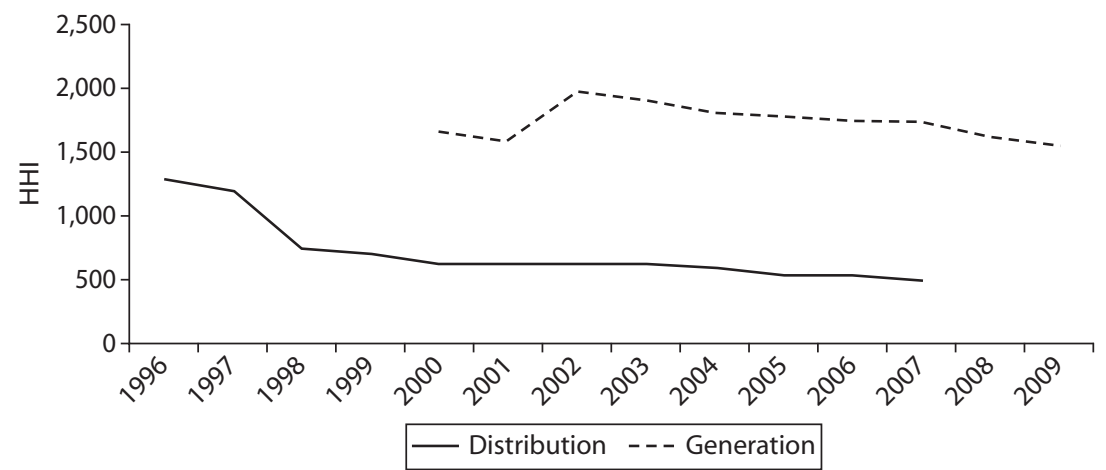

Source: An elaboration from the Power Market Structure database. Note: $\mathrm{HHI}=$ Herfindahl-Hirschman Index. 


\section{Figure 3.15 Brazil: Private Ownership}

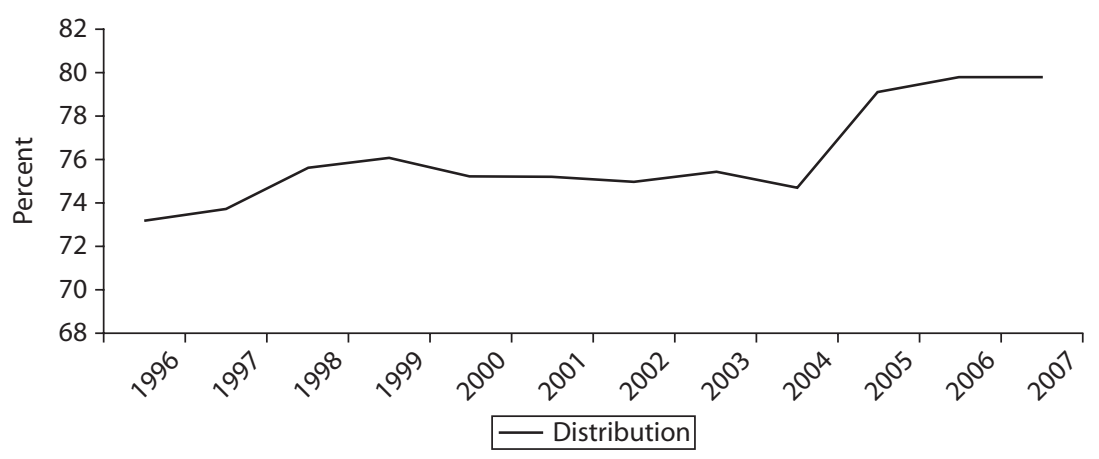

Source: An elaboration from the Power Market Structure database.

\section{Figure 3.16 Brazil: Private Management}

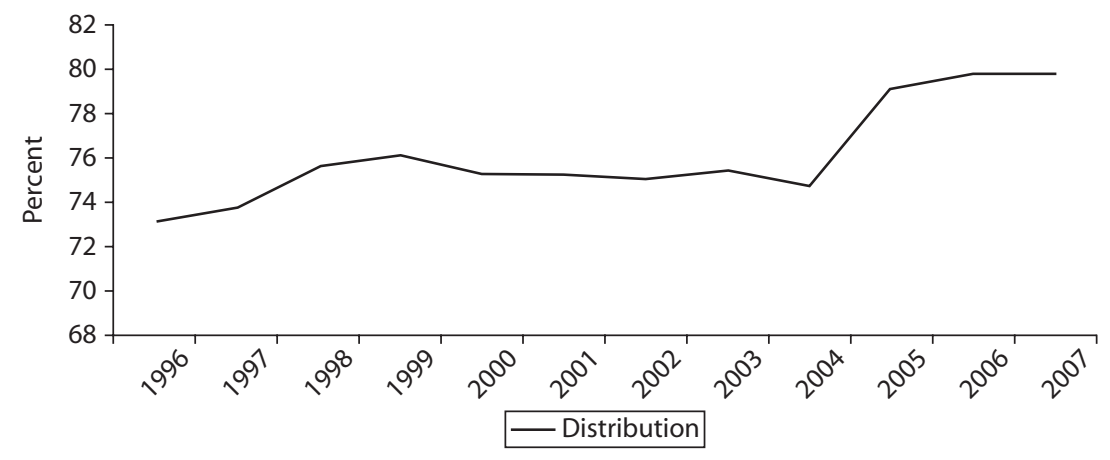

Source: An elaboration from the Power Market Structure database. 



\section{CHAPTER 4}

\section{Chile}

Chile is generally considered to be the initiator of power sector reform in modern times because it was the first country to introduce innovations for sector organization and regulation that many other countries subsequently adopted and adapted. Chile falls into the category of medium system size/medium per capita income with gross national income per capita of about $\$ 9,500$ and total installed generating capacity of about 13,000 MW (megawatts) in 2008. Chile has relied on diverse sources of primary energy for power generation, with hydropower accounting for 40 percent to 50 percent of total power generated and generation from fossil fuels for the rest. Of the fossil fuels, natural gas was the largest source from 2000 to 2006, steadily displacing coal-fired generation. With the decline in natural gas supply from Argentina, which began in May 2005 , liquid petroleum fuels and coal became the main fossil fuels for thermal power generation.

\section{Reform History}

Before the Chilean power sector was reformed, most of the electricity service was concentrated in two large state vertically integrated suppliers Empresa Nacional de Electricidad (ENDESA) and Compañía Chilena de Electricidad (CHILECTRA), as shown in figure 4.1. 
Figure 4.1 Chile: Taxonomy of Power Sector before Reform (1990)

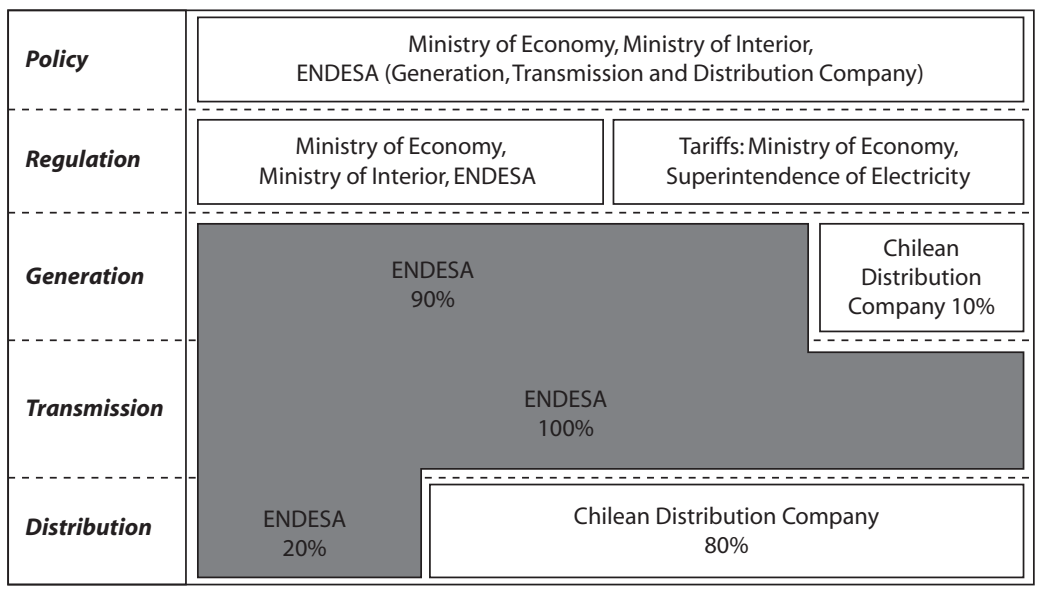

$1,750,000$ regulated customers

Vertical integration

Source: An elaboration from the Power Market Structure database. Note: ENDESA = Empresa Nacional de Electricidad.

The power sector was reformed during the 1980s as part of government's countrywide reorganization of the economy. The process of reforming the Chilean power sector was implemented through legal and institutional changes. Private participation was encouraged by establishing new investor financed enterprises to purchase existing facilities or to construct new facilities.

The reform of the electricity sector started with the formal establishment of the regulatory framework under the Electricity Law of 1981. It continued in 1983 when the government unbundled the sector structure into generation and transmission companies and distribution utilities. The distribution utilities were divided according to the service areas, but they were not granted exclusive rights. Between 1983 and 1989 the government privatized most of the generation, transmission, and distribution segments, so that all of these functions were in the hands of the private sector through local and international investors. The plan created a mandatory power pool administered by a system operator, Centro de Despacho Económico de Carga del Sistema Interconectado Central (CDEC). One of the main issues emerging with the privatization process, however, was related to the controlling interest of ENDESA Spain that 
directly or through the holding Enersis owned the majority of the generation, transmission, and distribution assets in Chile. The reformed structure is shown in figure 4.2.

After the reform of the electricity sector, the following institutions were responsible for energy policy and regulation:

- Ministry of Economy for sector policy and regulation.

- National Energy Commission (CNE) for evaluating and proposing to the Ministry of Economy laws and decrees to establish regulations and norms. Establishes wholesale pricing through a pre-established methodology and develops the system expansion plan necessary for ensuring adequate energy supply.

- Superintendence of Electricity and Fuels (SEC) for compliance, supervision, and control. This entity is a unit of the Ministry of Energy and Mines. It monitors compliance with the legal and regulatory provisions for the sector under the ministry's jurisdiction.

Generally, Chile's regulatory reform is considered quite successful in attracting private investment. The regulatory incentives became a

Figure 4.2 Chile: Taxonomy of Power Sector after Reform (1998)

\begin{tabular}{|c|c|c|c|}
\hline Policy & \multicolumn{3}{|c|}{ National Energy Commission (CNE) } \\
\hline Regulation & \multicolumn{2}{|c|}{\begin{tabular}{|c|} 
National Energy Commission (CNE) \\
Superintendence of Electricity and Fuels (SEC)
\end{tabular}} & $\begin{array}{l}\text { Tariffs: National Energy } \\
\text { Commission (CNE) }\end{array}$ \\
\hline Generation & \multirow{3}{*}{$\begin{array}{c}\text { ENDESA } \\
\text { De Enersis, holding } \\
\text { belonging to ENDESA } \\
\text { España } 60 \% \\
\text { TRANSELEC } \\
\text { (subsidiary of ENDESA) } 95 \% \\
\text { CHILECTRA De Enersis } \\
40 \%\end{array}$} & \multirow{2}{*}{\multicolumn{2}{|c|}{$\begin{array}{c}5 \text { generators with some } \\
\text { minor government ownership 40\% } \\
\begin{array}{c}\text { Other } \\
\text { private } 5 \%\end{array}\end{array}$}} \\
\hline Transmission & & & \\
\hline $\begin{array}{l}\text { Retailer/ } \\
\text { Commer. } \\
\text { Distribution }\end{array}$ & & \multicolumn{2}{|c|}{$\begin{array}{c}25 \text { private companies_but } \\
\text { concentrated in } 4 \text { companies } \\
60 \%\end{array}$} \\
\hline
\end{tabular}

$3,820,000$ regulated customers

State agency $\square$ Privatized company

Source: An elaboration from the Power Market Structure database.

Note: CHILECTRA = Compañía Chilena de Electricidad; ENDESA = Empresa Nacional de Electricidad. 
standard for reform in Peru and several countries in Central America. Substantial new investments were made and operating efficiency increased significantly following privatization. Despite this success, relations among the privatized firms, and between firms and the regulator, became contentious as inconsistencies and regulatory voids in the law began to surface. These regulatory voids did not significantly affect sector performance while the industry was state-owned, but after privatization they became a source of problems, and the regulator's decisions were frequently disputed in court.

During 1990-97 a significant issue was the lack of investment in transmission, which was caused by insufficient incentives to build new lines that resulted from the original structure of the transmission tariff. During this period some new transmission lines were built, but only through direct negotiation among interested parties. In addition, other issues surfaced associated with the need for improving CDEC's practices, as the transmission and distribution companies did not have representation in the membership of these bodies and questioned some of their decisions.

To address some of these regulatory voids, two main modifications to the original framework were introduced in 2003 and 2004 (Ley Corta I and Ley Corta II or Short Laws I and II). The 2003 Ley Corta I changed the method for calculating transmission tariffs to address transmission expansion issues and improve the incentives for constructing new lines. It also created a panel of experts to resolve disputes over technical issues. The 2004 Ley Corta II introduced changes to improve conditions for competition in generation by requiring distribution companies to purchase the electricity supplied to regulated customers through public auctions, with provisions for passing through the average price resulting from these auctions to retail tariffs.

\section{Impact on Sector Structure}

By 2008 the structure of the sector was less concentrated, particularly in the transmission segment; ownership of the assets had changed hands with more players involved, as indicated in figure 4.3.

\section{Impact on Sector Performance}

Over time ENDESA Spain's control of ownership-either directly or through Enersis, a holding company, of the majority of the generation, transmission, and distribution assets in Chile-became an issue for the regulators. They saw Spain's control as a sort of vertical integration that 
Figure 4.3 Chile: Taxonomy of Power Sector after Reform (2008)

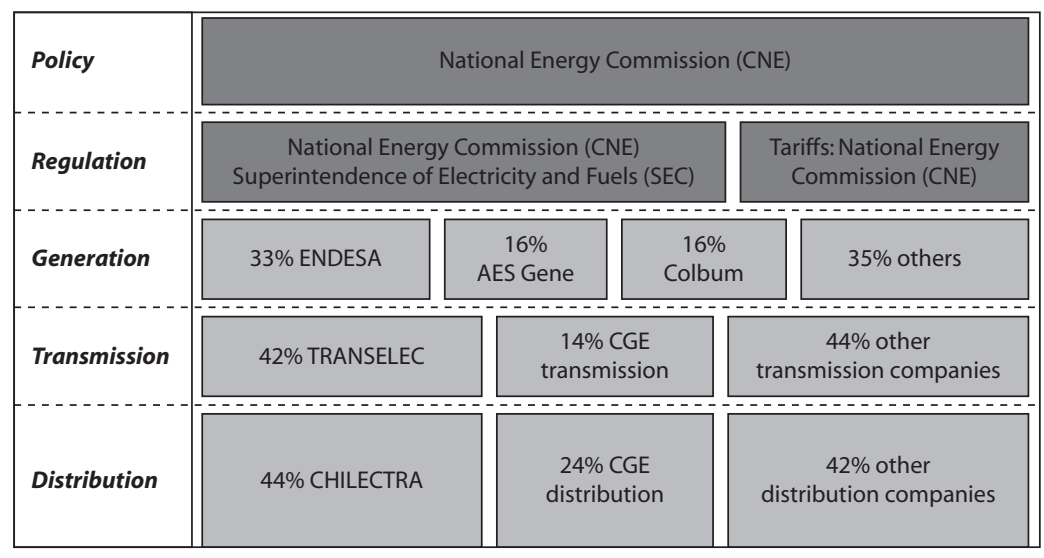

$4,700,000$ regulated customers -78 unregulated customers

State agency $\square$ Privatized company

Source: An elaboration from the Power Market Structure database.

Note: CGE = Compañía General de Electricidad; CHILECTRA = Compañía Chilena de Electricidad; ENDESA = Empresa Nacional de Electricidad.

posed a long-term threat to their attempt to develop competition in the Chilean electricity market. In 2001 Chile Enersis, the controller of ENDESA Chile, sold 100 percent of its transmission assets (Transelec) in an attempt to improve its relationship with the regulators. The sale of Transelec to Hydro-Quebec International significantly reduced Enersis's dominance of the industry.

Evidence of possible impacts from unbundling and the other reforms in Chile is sought from trends from the early 1990s up to 2008 in the following indicators:

- Access to electricity supply by the population in terms of new residential connections. Electricity service is virtually universal in Chile, where around 98.5 percent of the total population was covered by the electricity supply system in 2008. The access rate increased steadily from 80 percent in 1995 and 90 percent in 2001 to the more recent level under the privatized distribution companies.

- Customer service quality. Quality of electricity service in Chile has generally been good by international and regional standards following 
reforms to the power sector. Distribution losses declined from 8 percent in 1996 to around 6 percent from 1999 to 2008. The published data on supply interruptions is extremely limited, but showed that SAIDI (System Average Interruption Duration Index) was around 12 hours between 2000 and 2005. Tariffs for residential customers varied in the range 8 \$ cents to $10 \$$ cents per kWh (kilowatt-hour) up to 2004, which was generally affordable, but then increased quickly to $15 \$$ cents per kWh in 2007 mainly because of increased generation costs.

- Supply security. In the late 1990s and May 2005 Chile faced two crises to its energy supply for power generation to which the reformed sector responded well, partly because the system generation capacity reserve margin remained substantial at around 60 percent from 1999 onward. The first crisis was in 1998-99, soon after the reforms were implemented, when Chile suffered one of the worst droughts on record and hydropower generation dropped by about a third. Despite an increase in thermal power generation, Chile experienced some power rationing. The 2005 crisis was the reduction of gas supplies from Argentina, which Chile had relied on for about 30 percent of its total power generation. Argentina had to meet its population's rising demand for residential heating in winter and other uses. Consequently, the amount of power generated from natural gas in Chile declined sharply, and Chile had to switch gas-fired generation plants to burning liquid petroleum fuels at a substantial increase in operating costs. In response to this risk for imported gas by pipeline, in October 2009 Chile inaugurated its first natural gas re-gasification plant for the importation of liquefied natural gas as part of a strategy to diversify energy sources.

- Financial sustainability. The privatized electricity distributors maintained a healthy margin of revenues over costs that varied between 20 percent and 40 percent up to 2004 under the regulatory approach to tariff setting, but this margin declined to under 20 percent from 2005 because of the additional generation costs due to the increased use of liquid petroleum fuels for power generation.

- Environmental sustainability. Average carbon emissions per unit of energy generated rose substantially from 1993 onward with the increase in thermal power generation, peaking in 1999 due to the loss of hydropower from the drought. Average carbon emissions per unit of energy generated then declined as natural gas began to replace coal 
from thermal power generation. The carbon level peaked again in 2004 and 2007 due to changes in the fuel mix for thermal power generation.

Trends in these indicators are shown in the following figures. 
Figure 4.4 Milestones of Power Sector Reform in Chile

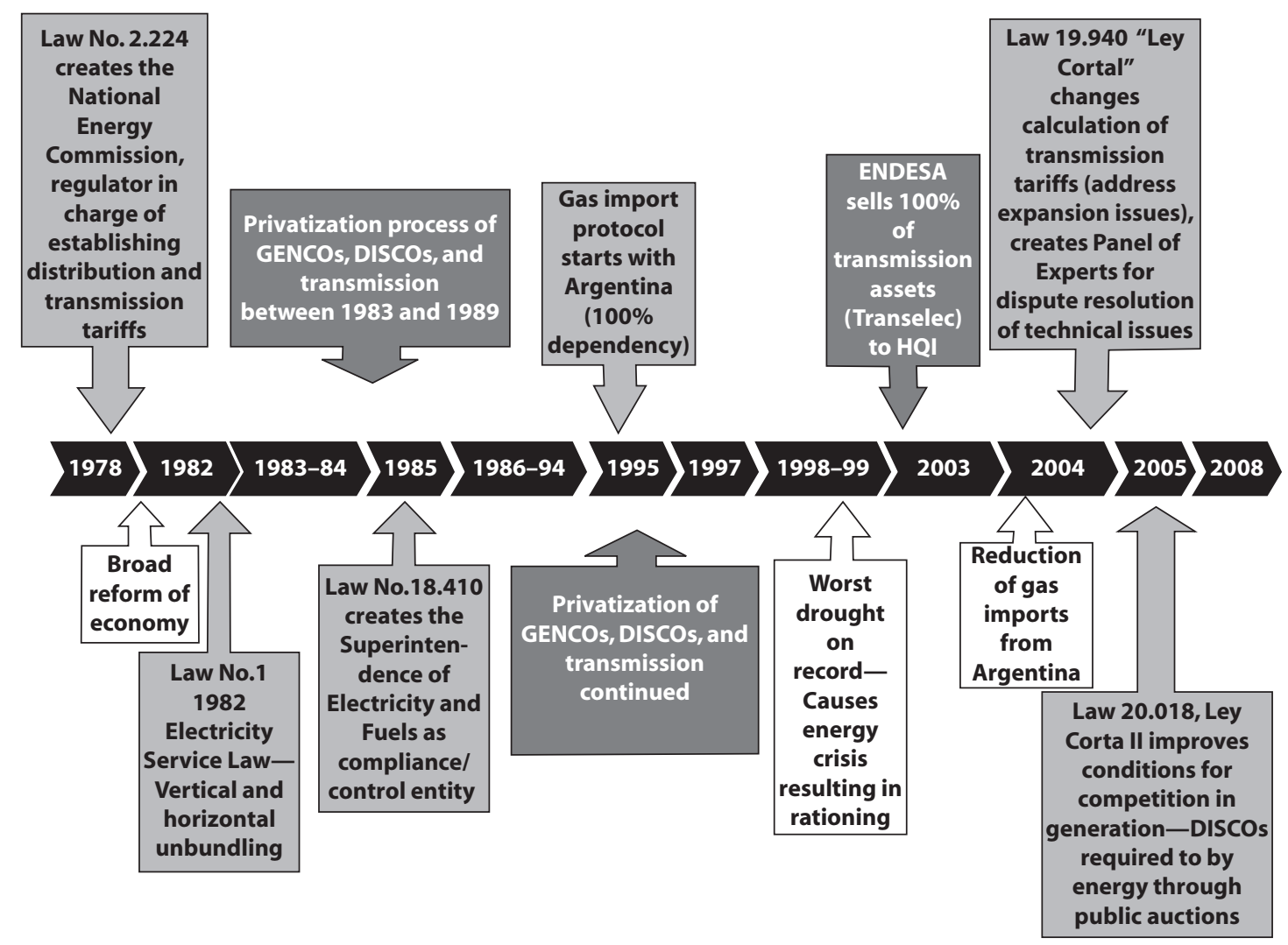

Source: An elaboration from the Power Market Structure database.

Note: The milestones are reported in different shades: white = main external factors; light gray = main government interventions; dark gray = main private sector involvements. DISCOs = distribution companies; ENDESA = Empresa Nacional de Eletricidad (generation, transmission, and distribution company); GENCOs = generation companies;

$\mathrm{HQI}=$ Hydro-Quebec International. 


\section{Figure 4.5 Chile: Access to Residential Electricity}

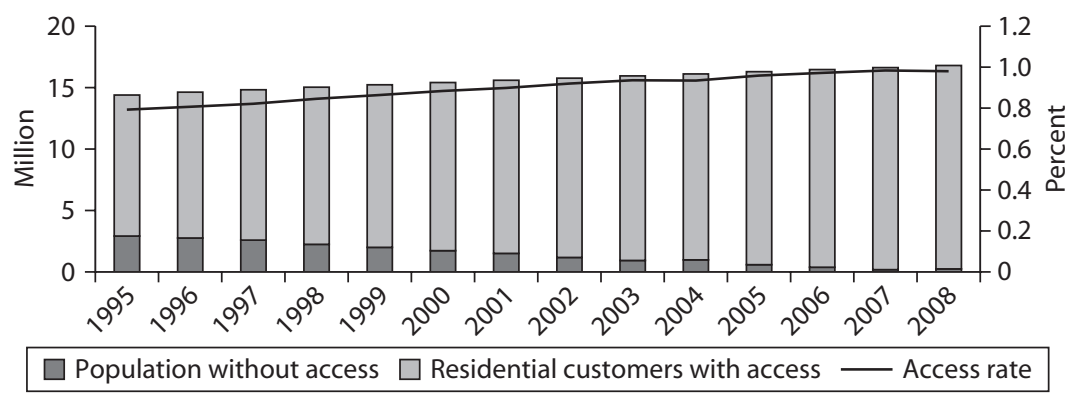

Source: An elaboration from the Power Market Structure database.

Figure 4.6 Chile: Quality of Electric Service

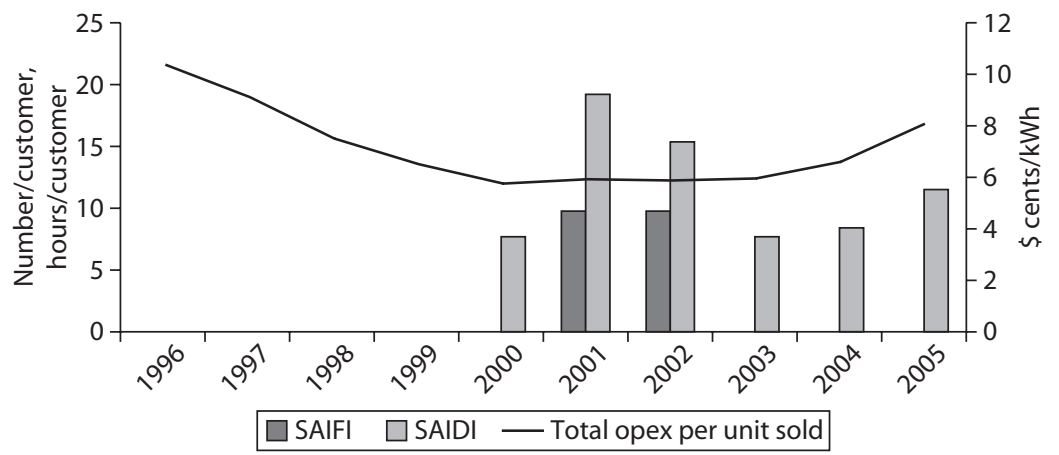

Source: An elaboration from the Power Market Structure database.

Note: opex = operational expenditures/costs; kWh = kilowatt-hour; SAIDI = System Average Interruption Duration Index; SAIFI = System Average Interruption Frequency Index.

\section{Figure 4.7 Chile: System Losses and Operating Costs}

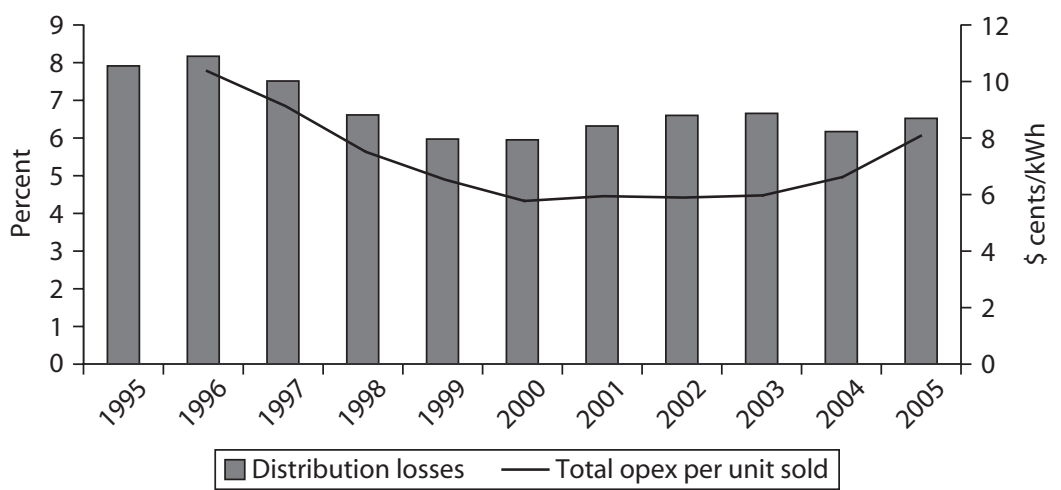




\section{Figure 4.8 Chile: Electricity Generation by Source and Carbon Emissions}

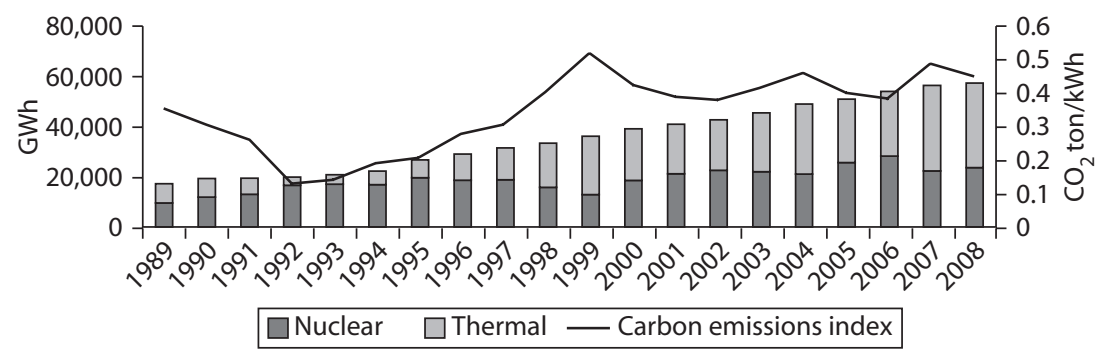

Source: An elaboration from the Power Market Structure database.

Note: $\mathrm{GWh}=$ gigawatt-hour; $\mathrm{kWh}=$ kilowatt-hour.

Figure 4.9 Chile: Energy Security and Capital Expenditure

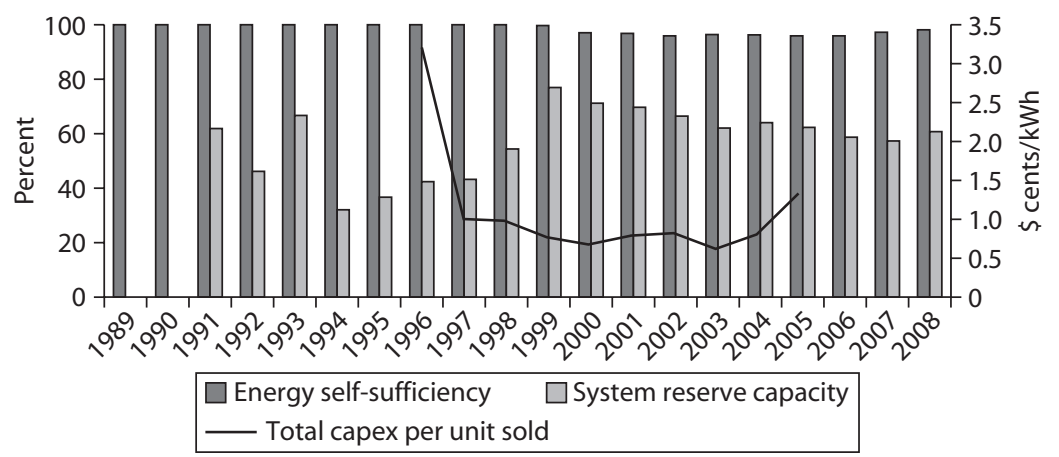

Source: An elaboration from the Power Market Structure database.

Note: Capex $=$ capital expenditures; $\mathrm{kWh}=$ kilowatt-hour. 


\section{Figure 4.10 Chile: Average Tariff and Operating Costs}

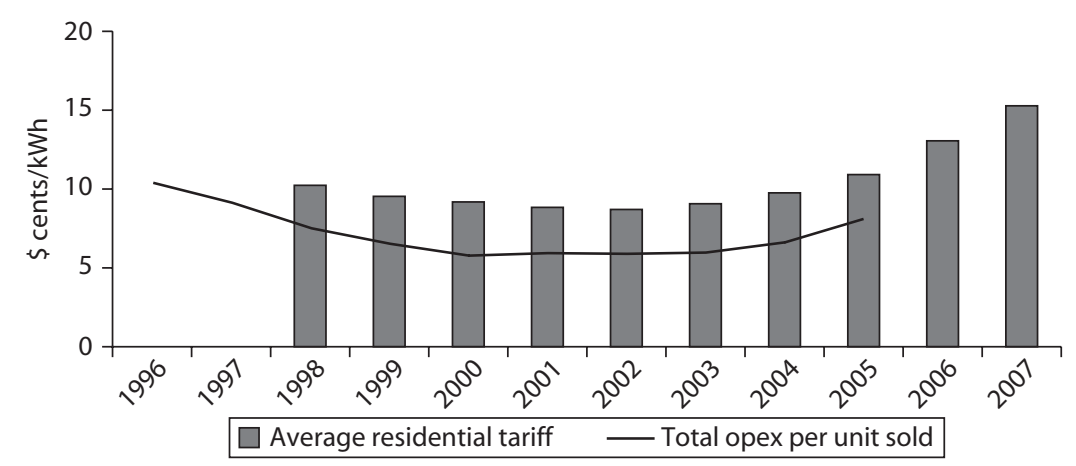

Source: An elaboration from the Power Market Structure database. Note: $\mathrm{kWh}=$ kilowatt-hour; opex = operational expenditures/costs.

Figure 4.11 Chile: Labor Productivity

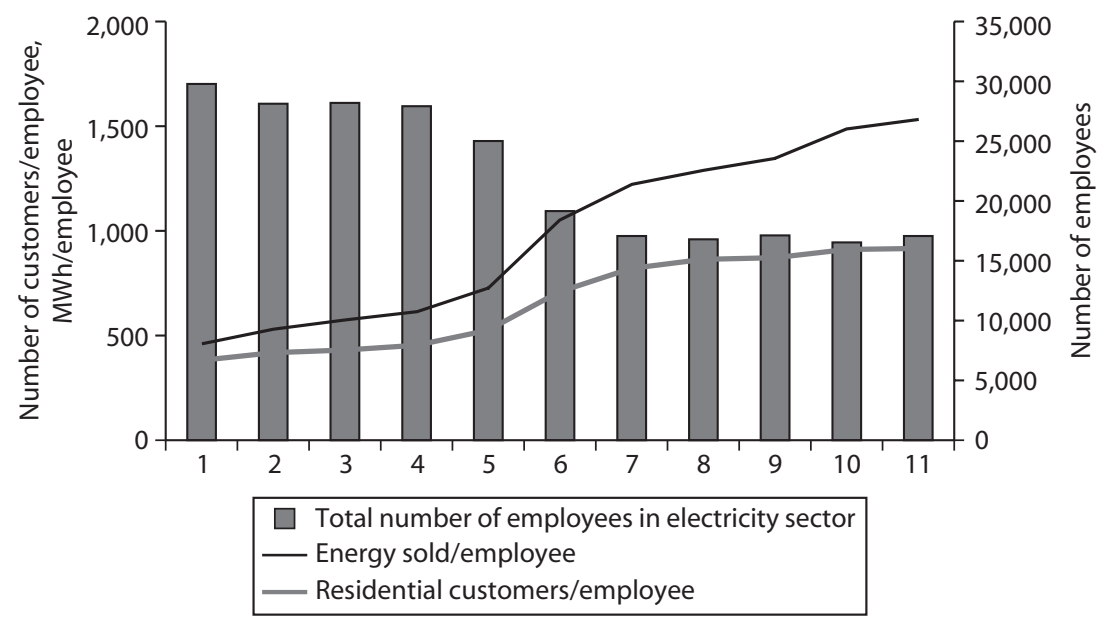

Source: An elaboration from the Power Market Structure database. Note: $\mathrm{MWh}=$ megawatt-hour. 


\section{Figure 4.12 Chile: Capacity Utilization}

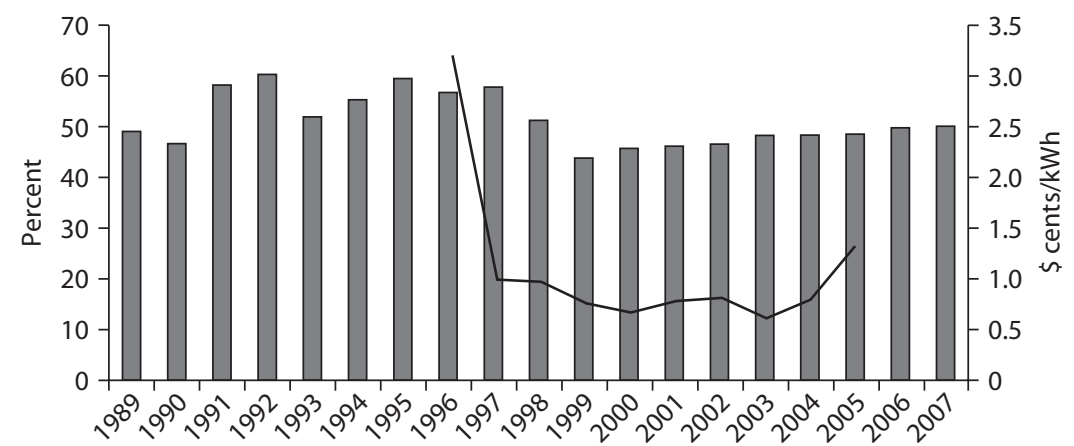

Capacity utilization - Total capex per unit sold

Source: An elaboration from the Power Market Structure database.

Note: Capex = capital expenditures; $\mathrm{kWh}=$ kilowatt-hour.

\section{Figure 4.13 Chile: Cost Recovery Index}

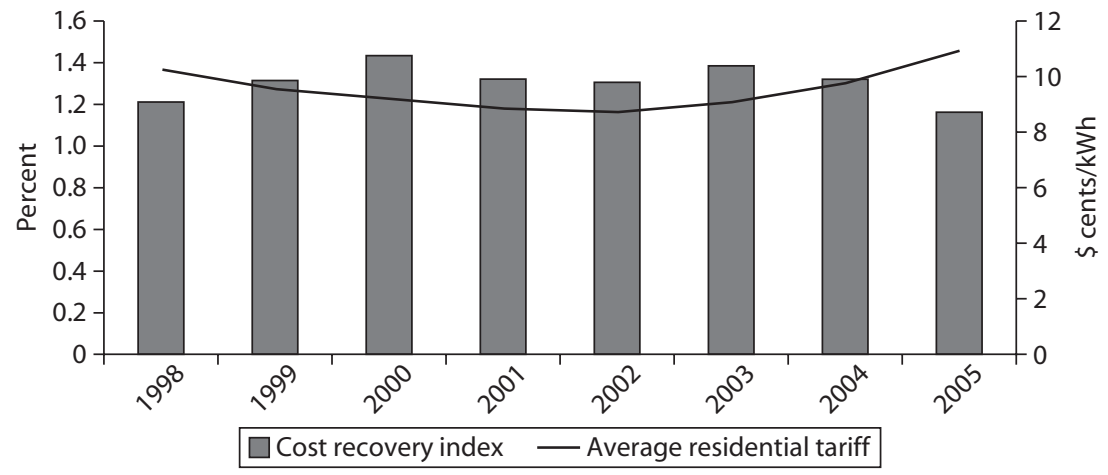

Source: An elaboration from the Power Market Structure database.

Note: kWh = kilowatt-hour. 


\section{Figure 4.14 Chile: Market Concentration}

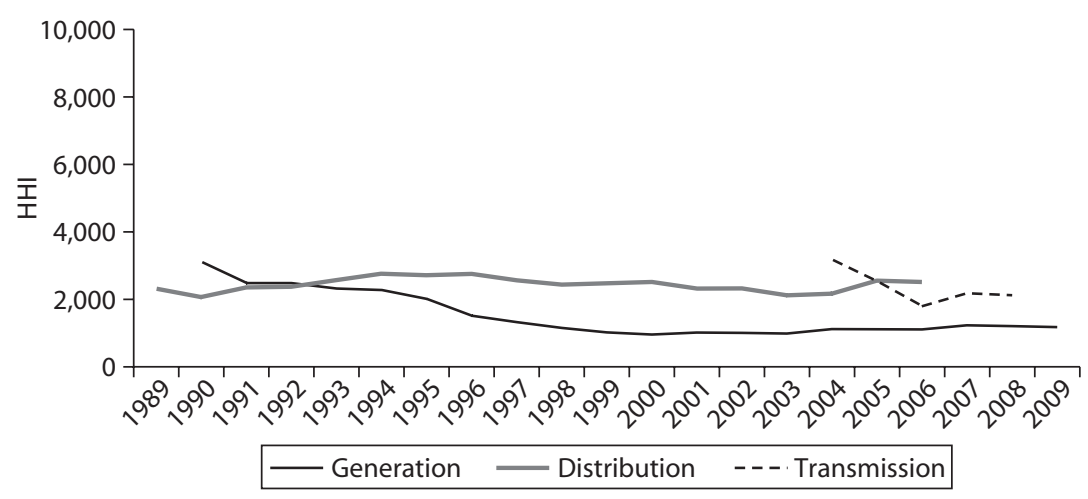

Source: An elaboration from the Power Market Structure database. Note: $\mathrm{HHI}=$ Herfindahl-Hirschman Index.

Figure 4.15 Chile: Private Ownership

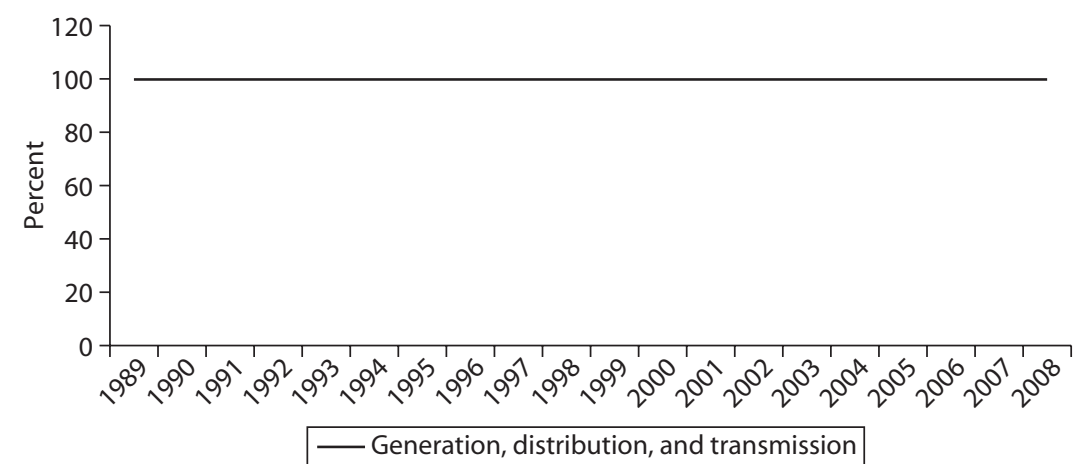

Source: An elaboration from the Power Market Structure database. 


\section{Figure 4.16 Chile: Private Management}

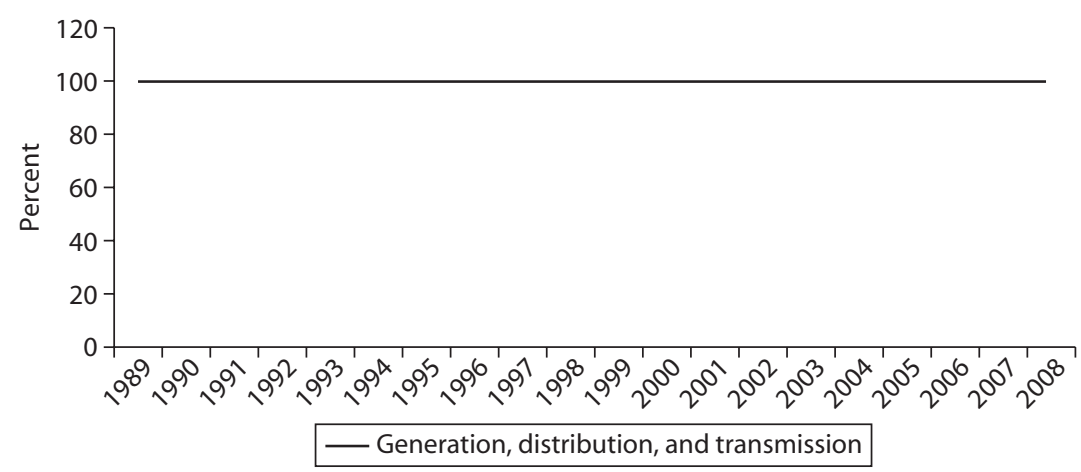

Source: An elaboration from the Power Market Structure database.

\section{Figure 4.17 Chile: Degree of Vertical Integration}

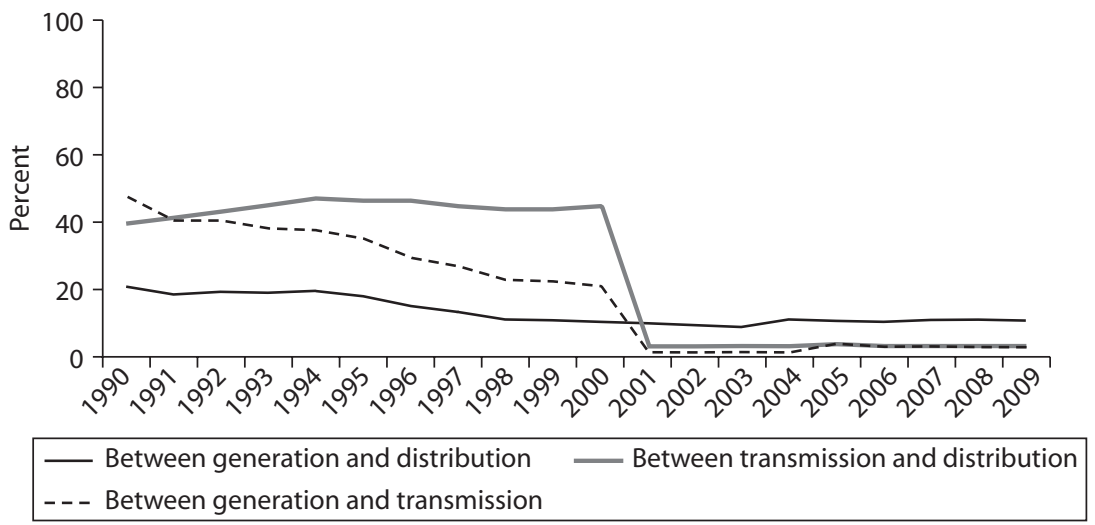

Source: An elaboration from the Power Market Structure database. 


\section{CHAPTER 5}

\section{Czech Republic}

Czech Republic falls into the category of high system size/high per capita income with a gross national income of $\$ 17,000$ per capita in 2008 (World Bank 2008) and current total installed generating capacity of just over 18,000 MW (megawatts).

The power sector is dominated by three vertically integrated companies whose subsidiaries hold a license for both electricity distribution and electricity trading. They are the Česke Energeticke Zavody (ČEZ) Group, the Energy On (E.ON) Group, and the Pražská Energetika (PRE) Group. These three suppliers' share of the electricity market accounts for more than 95 percent of final customers' total consumption in the Czech Republic; in the case of customers connected to the low voltage level their share is more than 99 percent.

\section{Reform History}

The Energy Regulatory Office (ERO) was set up in 2001 by Act No. 458/2000. Under ERO, public notice No. 540/2005 was implemented. This public notice pertained to the quality of electricity supplies and related services in the electricity industry for distribution system operators (DSOs) with more than 90,000 supply points of final customers, or, 
as applicable, electrical energy suppliers. Effective from July 1, 2007, the prices of electricity and gas supplies to final customers were deregulated, and electricity and gas supply price control for suppliers of last resort was introduced as the maximum permissible price in compliance with Article 3(3) of Directive 2003/54/EC. The ERO inspects unbundled accounts of legally unbundled companies, which are required to submit separate accounts for each of the transmission and distribution activities with a view to preventing discriminatory practices. The regulator, however, does not have any authority to impose sanctions; in Czech Republic, the ability to impose sanctions is fully within the competences of another central authority of state administration, the State Energy Inspectorate.

Czech law, acting in compliance with EU Directive 2003/54/EC, mandated that all distribution companies legally separate their competitive and noncompetitive operations by January 1, 2007. Many of these companies complied with this legal unbundling in advance of the deadline, according to the following schedule:

- Two distributors, Jihomoravska energetika (South Moravian Power Company, JME) and JihoÄŤeska energetika (South Bohemian Power Company, JCE), controlled by E.ON unbundled on January 1, 2005.

- Five distributors, West Bohemian Power Company (ZCE), North Moravian Power Company (SME), North Bohemian Power Company (SCE), East Bohemian Power Company (VCE), and Central Bohemian Power Company (STE), controlled by ČEZ unbundled in 2006.

- PRE (Prague distributor of electricity) unbundled in 2006.

- The high-voltage transmission operations already have ownership separation from any generation, supply, and lower-voltage distribution activities.

Czech Republic has made use of the opportunity to unbundle only those companies that have large numbers of customers. The Czech legislation provides for this opportunity, known as "the 90,000 customers rule," in Section 25a(9) of the Energy Act: "The separation of activities hereunder shall be effected no later than by 31 December 2006, with the exception of the vertically integrated undertakings that provide services for less than 90,000 connected final customers."

The law on support of renewable electricity is a major breakthrough in the development of electricity production from renewable sources. For investors in renewable sources, the law guarantees an up to 15-year payback period for their investment in the various categories of renewable 
sources. Since 2006 renewable electricity producers have had the opportunity under the law to choose between buyout by regional DSOs or the transmission system operator (TSO) in the system of guaranteed feed-in tariffs, and a premium on the market price of electricity (the system of green premiums, the level of which is controlled by the government). The support in the form of feed-in tariffs cannot be applied in the case of biomass and fossil fuel co-firing or parallel firing. Regional DSOs and the TSO are obliged to give priority to the connection of renewable electricity producers. The charge to meet the extra costs incurred in support for electricity from renewable sources, combined heat and power (CHP), and secondary sources has risen from CZK 40.75/MWh (megawatt-hours) for 2008 to CZK 52.18/MWh for 2009. The increase in the contribution is caused mainly by the growing quantity of electricity generated from renewable sources. The number of solar installations rose almost five times in 2008. Since the beginning of February 2009, all three Czech power distribution companies (ČEZ, E.ON, and PRE) stopped connecting new photovoltaic (PV) plants to their grids. As a result of that move, many small and medium solar installation and merchant companies have lost customers and are unable to win new orders. Many Czech solar installers have been losing business and are considerably worried about their future.

\section{Impact on Sector Structure}

The most important electricity generator on the Czech market is ČEZ, which holds a share of almost 70 percent of installed capacity and 74 percent of the electricity generated. ČEZ is also the only market participant that has a market share of more than 5 percent in relation to the installed capacity or the quantity of electricity generated. The second largest generator is Sokolovská uhelná, právní nástupce (market share of 3.5 percent), and the third is Dalkia Česká republika (market share of 3 percent). The following are the other important electricity producers with an installed capacity of more than 200 MW: International Power Opatovice (Elektrárny Opatovice until September 30, 2005), ECK Generating Energotrans, and United Energy. These companies are usually a part of larger groups, frequently multinational energy groups, that operate the whole range of business lines from generation to trade. We can track a direct connection through these ties, where the generator and trader operating in the Czech Republic are a part of a single group, such as ECK Generating (Atel Energy $\mathrm{GmbH}$ ), and others. In addition to these 
generators, who sell most of their electricity on the market, large industrial groups also have their electricity generating plants with an installed capacity of more than 200 MW, namely Unipetrol RPA, and Mittal Steel Ostrava.

One TSO is active in the Czech Republic: ČEPS, is responsible for electricity transmission at the level of the transmission system $(400 \mathrm{kV}$ [kilovolts], $220 \mathrm{kV}$, and selected $110 \mathrm{kV}$ lines), for the development of the transmission system, and for providing the system services that help to ensure safe and reliable operation of the electricity grid. At lower voltage levels ( $110 \mathrm{kV}$ and lower), electricity distribution is provided by three DSOs with more than 90,000 customers, whose installations are connected directly to the transmission system. Currently, in addition to these regional distributors, 277 operators of distribution systems connect only to these three DSOs in the Czech Republic. These local DSOs distribute electricity within areas specified in their electricity distribution licenses. The length of $110 \mathrm{kV}$ distribution lines is $15,746 \mathrm{~km}$ (kilometers); the length of all high voltage (over $1 \mathrm{kV}$ ) lines is 90,244 $\mathrm{km}$; and the length of low voltage lines is $169,787 \mathrm{~km}$. The total length of all the lines outside the transmission system is therefore more than $275,000 \mathrm{~km}$.

About 20 more important independent traders also operate on the electricity market, and their total market share is up to a few percent of customers' total consumption. So far, these suppliers have been offering electricity bought from smaller generators or imported from other countries mainly to large industrial customers; the reason has been the gradual opening of the Czech electricity market.

One feature of the Czech market that could impede the benefits of competition is the horizontal and vertical integration of ČEZ. With roughly 70 percent of generation market share and control of five out of eight local distribution companies serving 66 percent of final customers, ČEZ is in a position to influence the overall market in a noncompetitive way. On the generation side, its size could allow the company to raise the wholesale price of power to gain greater revenue or, alternatively, to lower the price to punish smaller competitors. Although the company is not so dominant that it could exercise this influence throughout the year, it is more likely able to do so on a regular basis in certain supply and demand situations. On the retail side, ČEZ's control of 62 percent of final customer delivery could pose a number of problems. First, those distribution companies could buy power from ČEZ even if more attractive prices were available on the market. (Competitive pressures would ideally 
prohibit this practice, but the price responsiveness and market sophistication of all customers has not yet been established.) Second, ČEZ could potentially deny nondiscriminatory access to the company's low-voltage networks. Even the suggestion or possibility that these distribution companies would favor ČEZ over other wholesale suppliers could be sufficient to deter new entrants.

\section{Impact on Sector Performance}

Evidence of possible impacts from unbundling and other reforms is sought from trends from the early to mid-1990s up to 2008 in the following indicators:

- Access to electricity supply by the population. In terms of new connections, the total number of connections increased at a steady annual rate of 1 percent during 2005-07.

- System reserve generation capacity. System reserve generation capacity has been kept at adequate levels. Due to the global economic recession, electricity demand in Czech Republic decreased by 6 percent from 2008 to 2009. Consequently, power generation fell by 0.5 percent. Yet, ČEZ maintained stable generation capacity of 14,395 MW during the financial crisis.

- Total system energy losses and quality. To comply with the requirement of the Energy Act the three DSOs (ČEZ, PRE, and EON) have reported SAIDI (System Average Interruption Duration Index) and SAIFI (System Average Interruption Frequency Index) since 2005. Serving the capital city, PRE Distribuce showed the best performance in terms of average number of supply interruptions and average time of supply interruptions for all three categories of low voltage-, high voltage-, and extra high voltage-level customers. With the exception of E.ON, both ČEZ and PRE quality increased over time. In addition, transmission losses fell by 12 percent from 2005 to 2008 .

- Financial performance. A significant increase in capital expenditures in all segments of the market have been recorded for ČEZ. Average revenues have been increasing substantially over the past few years. The EBITDA (earnings before interest, depreciation, and amortization) levels also register major improvements. 
- Carbon emissions. In line with the Act on Promotion of Use of Renewable Sources in 2008 the number of newly connected renewable sources of electricity increased to 909 , with aggregate installed capacity of 81.4 MW. Of these, 836 were new solar power plants with a total installed capacity of 20.2 MW. In 2007 carbon emissions grew from 527 to $558\left(\mathrm{CO}_{2}\right.$ tons/MWh $)$ from the previous year possibly due to continuation of major capital expenditure projects aimed at upgrading the Dukovany Nuclear Power Station.

Trends in these indicators are shown in the figures that follow. 
Figure 5.1 Milestones in Power Sector Reform in the Czech Republic

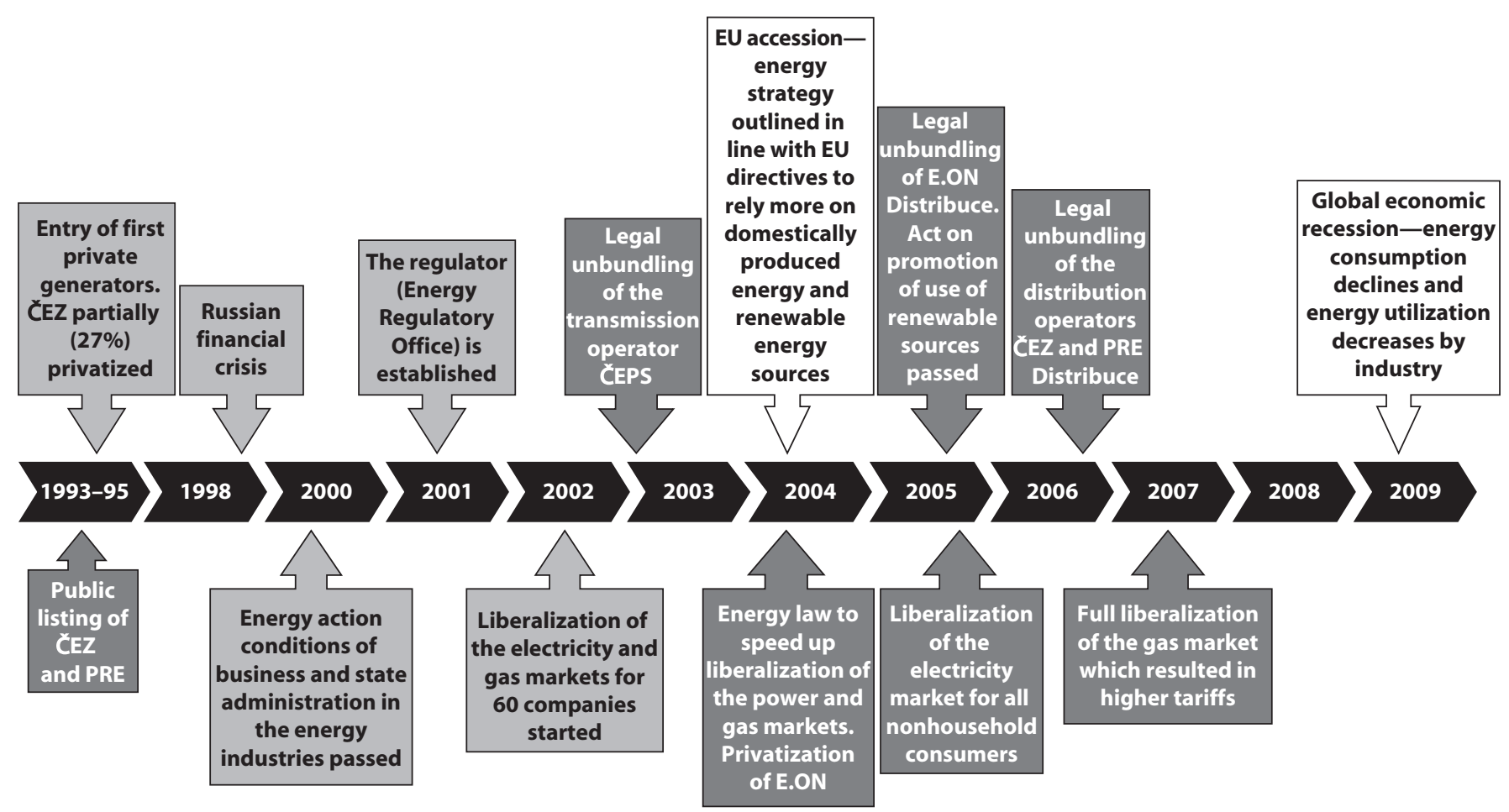

- Source: An elaboration from the Power Market Structure database

W Note: The milestones are reported in different shades: white = main external factors; light gray = main government interventions; dark gray $=$ main private sector involvements. ČEZ = Česke Energeticke Zavody; E.ON = Energy On; EU = European Union; PRE = Pražská Energetika. 


\section{Figure 5.2 Czech Republic: Access to Residential Electricity}

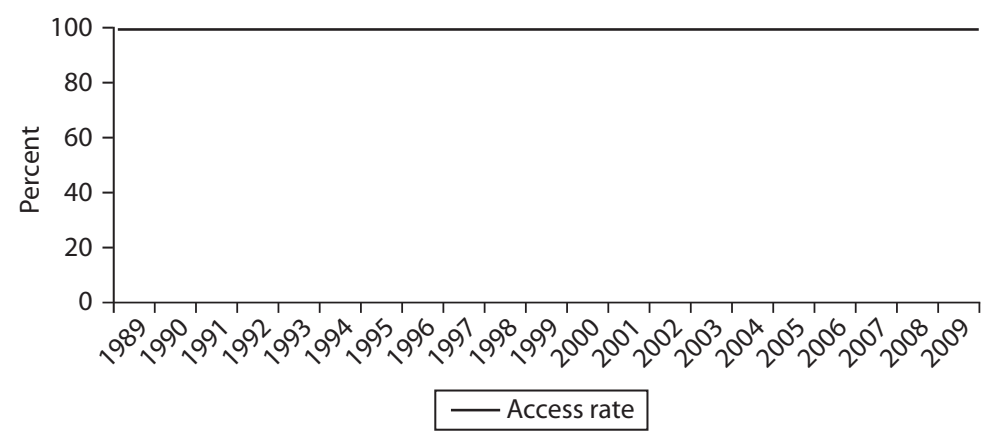

Source: An elaboration from the Power Market Structure database.

\section{Figure 5.3 Czech Republic: Quality of Electric Service}

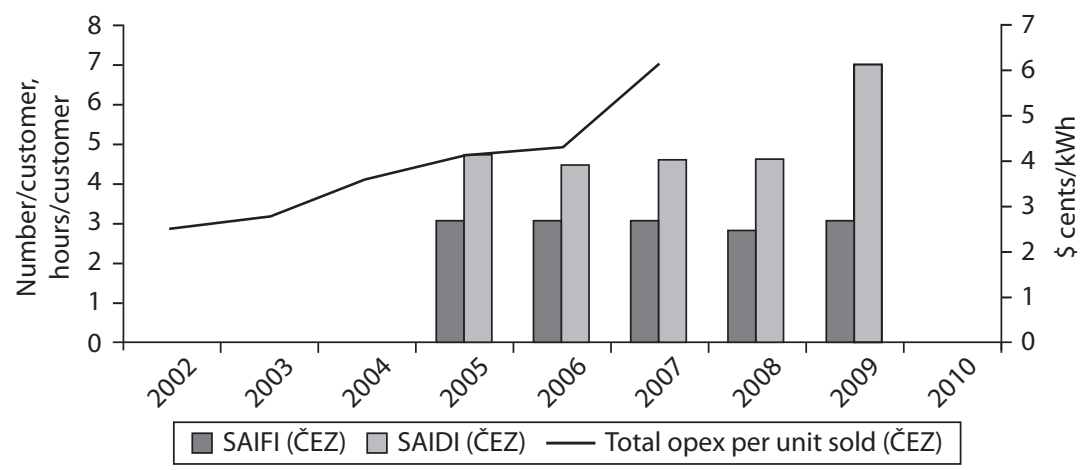

Source: An elaboration from the Power Market Structure database.

Note: ČEZ = Česke Energeticke Zavody; kWh = kilowatt-hour; opex = operational expenditures/costs;

$\mathrm{SAIDI}=$ System Average Interruption Duration Index; SAIFI = System Average Interruption Frequency Index. 
Figure 5.4 Czech Republic: Quality of Electric Service (PRE)

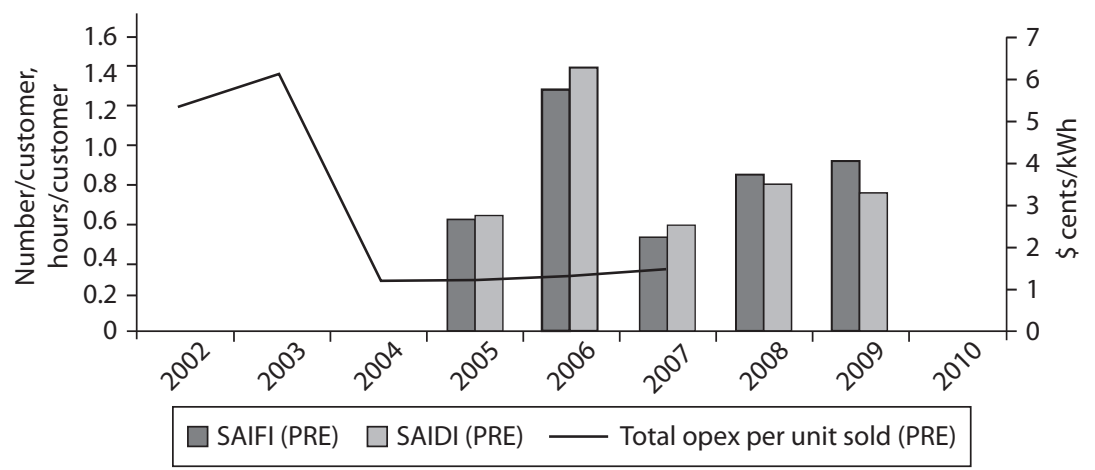

Source: An elaboration from the Power Market Structure database.

Note: kWh = kilowatt-hour; opex = operational expenditures/costs; PRE = Pražská Energetika; SAIDI = System Average Interruption Duration Index; SAIFI = System Average Interruption Frequency Index.

Figure 5.5 Czech Republic: System Energy Losses

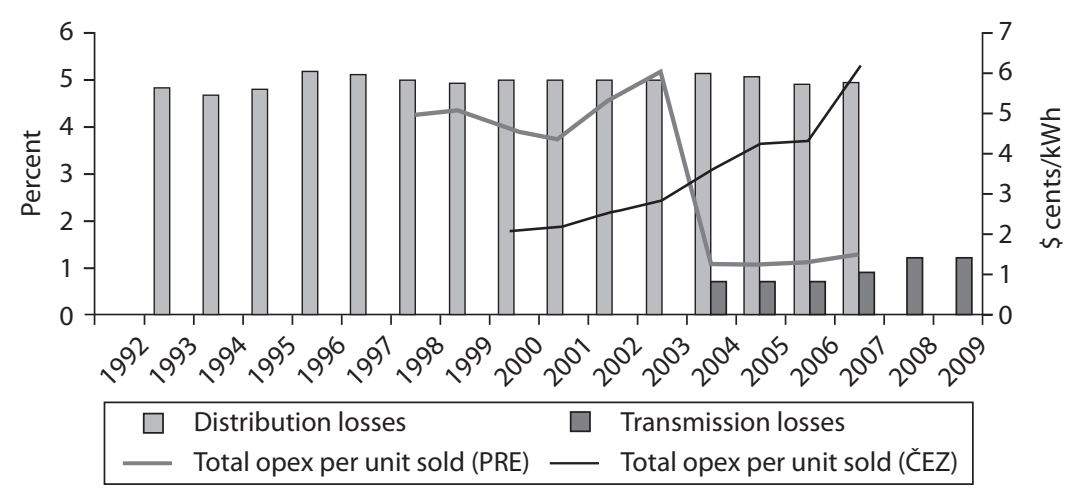

Source: An elaboration from the Power Market Structure database. Note: $\mathrm{kWh}=$ kilowatt-hour. 
Figure 5.6 Czech Republic: Electricity Generation by Source and Carbon Emissions

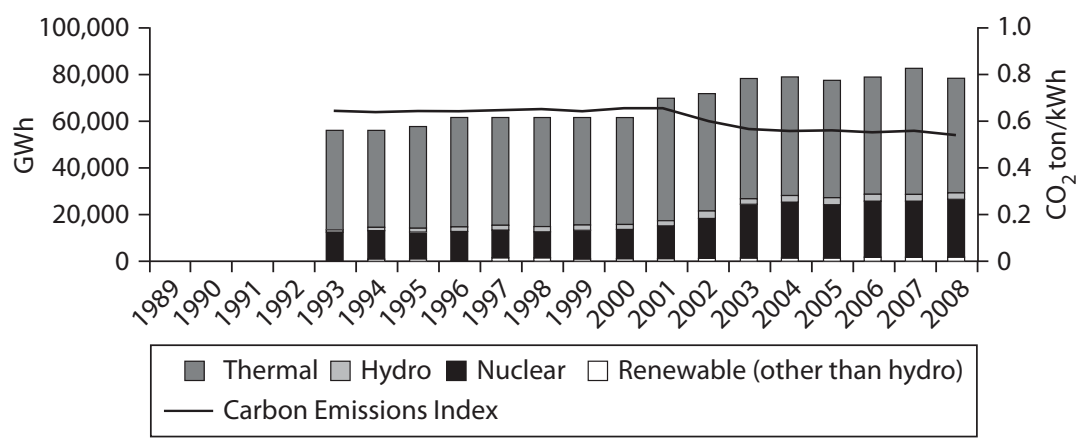

Source: An elaboration from the Power Market Structure database.

Note: GWh = gigawatt-hour; kWh = kilowatt-hour.

Figure 5.7 Czech Republic: Energy Security and Capital Expenditure

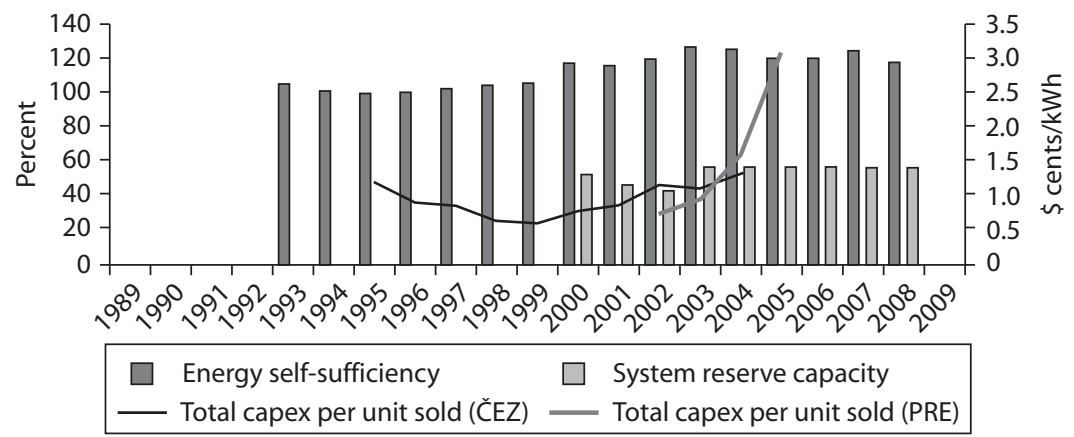

Source: An elaboration from the Power Market Structure database.

Note: Capex = capital expenditures; ČEZ = Česke Energeticke Zavody; kWh = kilowatt-hour; PRE = Pražská Energetika.

\section{Figure 5.8 Czech Republic: Average Tariff and Operating Costs (ČEZ)}

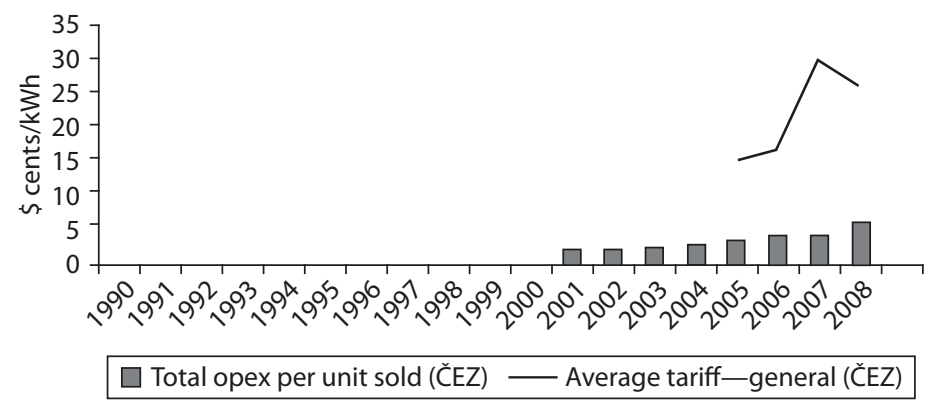


Figure 5.9 Czech Republic: Average Tariff and Operating Costs (PRE)

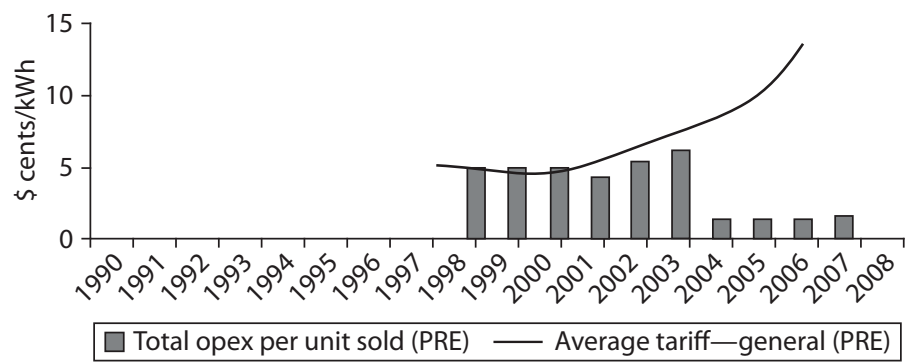

Source: An elaboration from the Power Market Structure database.

Note: $\mathrm{kWh}$ = kilowatt-hour; opex = operational expenditures/costs; PRE = Pražská Energetika.

\section{Figure 5.10 Czech Republic: Capacity Utilization}

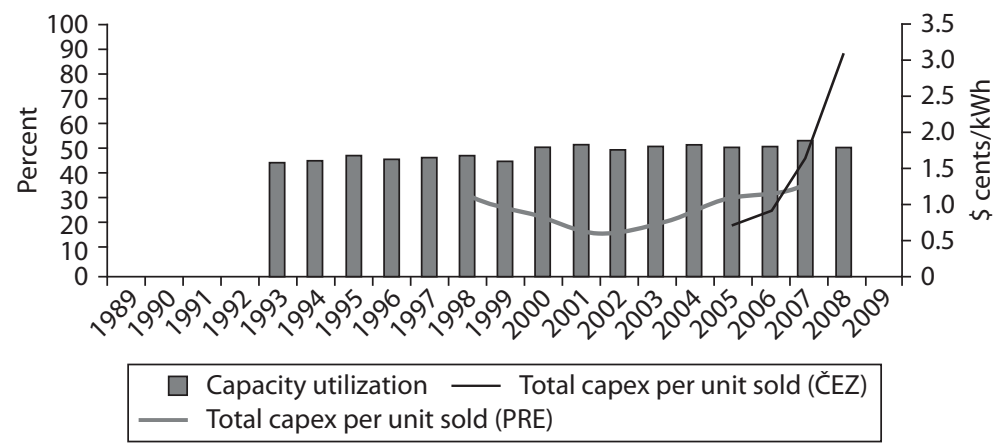

Source: An elaboration from the Power Market Structure database.

Note: Capex = capital expenditures; ČEZ = Česke Energeticke Zavody; kWh = kilowatt-hour; PRE = Pražská Energetika.

\section{Figure 5.11 Czech Republic: Cost Recovery Index (ČEZ)}

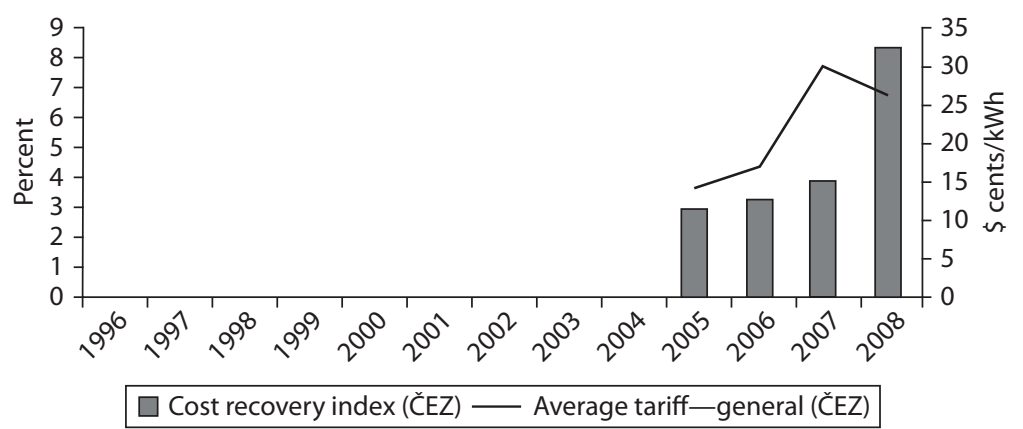


Figure 5.12 Czech Republic: Cost Recovery Index (PRE)

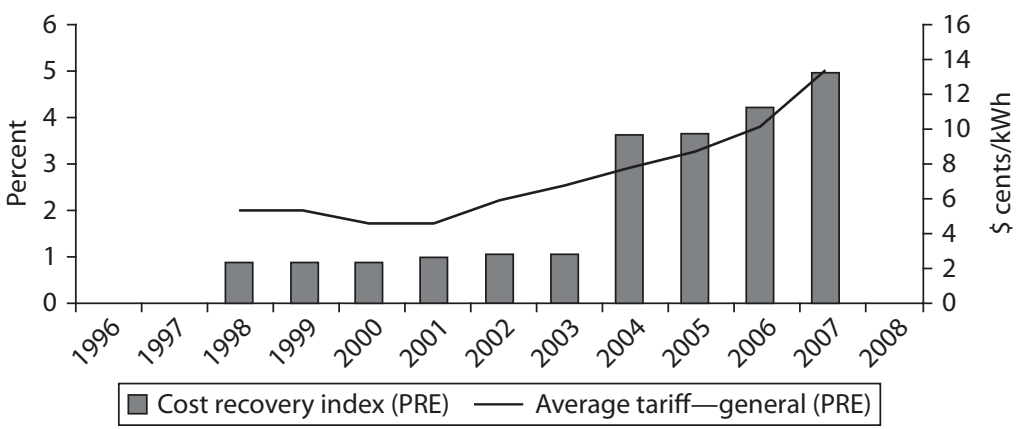

Source: An elaboration from the Power Market Structure database.

Note: kWh = kilowatt-hour; PRE = Pražská Energetika.

\section{Figure 5.13 Czech Republic: Market Concentration}

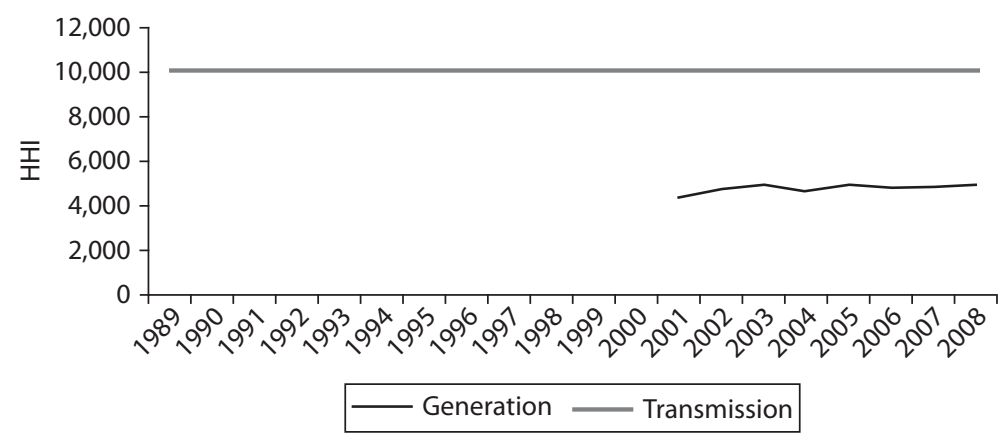

Source: An elaboration from the Power Market Structure database.

Note: $\mathrm{HHI}=$ Herfindahl-Hirschman Index.

\section{Figure 5.14 Czech Republic: Private Ownership}

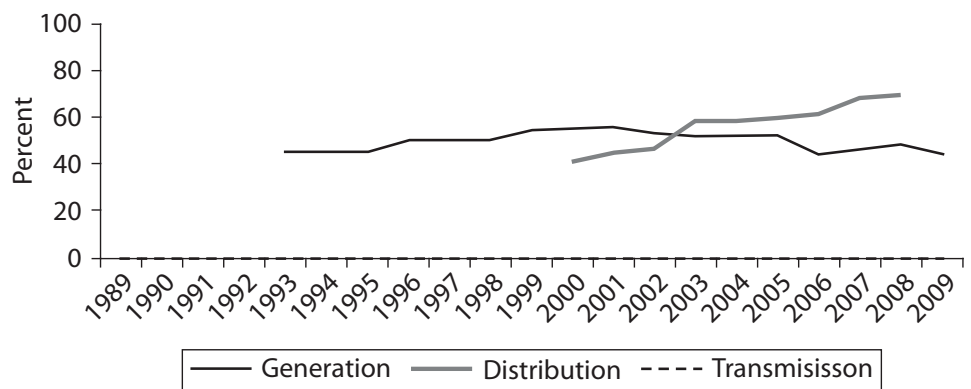

Source: An elaboration from the Power Market Structure database. 


\section{Figure 5.15 Czech Republic: Private Management}

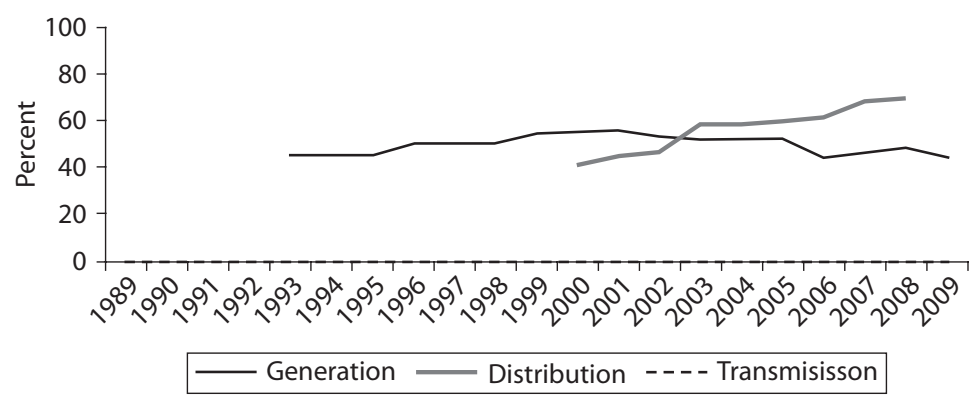

Source: An elaboration from the Power Market Structure database.

\section{Figure 5.16 Czech Republic: Degree of Vertical Integration}

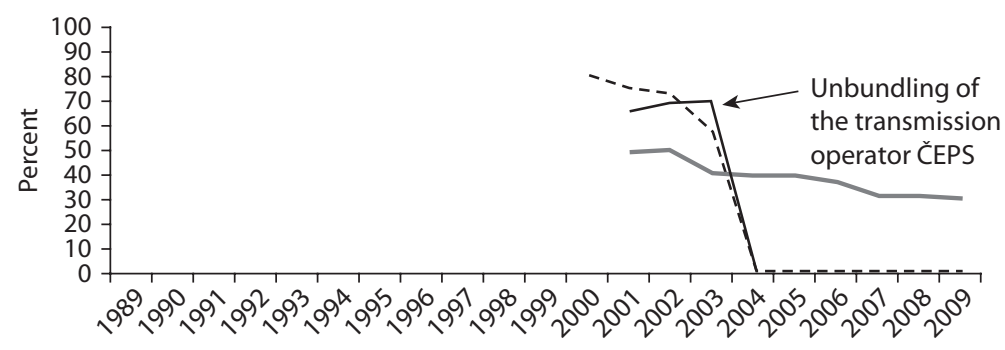

- Between generation and transmission

- Between generation and distribution

- - - - Between transmission and distribution

Source: An elaboration from the Power Market Structure database. Note: $\check{C}$ EPS $=$ Czech transmission system operator.

\section{Reference}

World Bank. 2008. World Development Indicators. World Bank, Washington, DC. 



\section{Arab Republic of Egypt}

The Arab Republic of Egypt falls into the lower-middle categories for national income $(\$ 2,000$ per capita) and high power system size $(24,700$ MW (megawatts) installed generation capacity in 2010 with more than 40 grid-connected plants). As of 2010, 99 percent of the Egyptian population had access to electricity.

\section{Reform History}

In 1962 the Egyptian government nationalized the electricity services that had been supplied by private companies since the 1890s under concessions. The government then formed three authorities-Electricity Production Authority, Electricity Distribution Authority, and Electricity Projects Implementation Authority. In 1965 a general authority of electricity was formed that took over the responsibilities of these three. Under Law No. 12, in 1976 the government established the Egyptian Electricity Authority (EEA), giving it the exclusive right to produce, transmit, and distribute electric power throughout Egypt. In 1978, seven regional companies for electricity distribution were established under EEA's supervision. 
In 1983 the distribution activities were transferred from EEA to a new authority called the Public Sector Authority for Electric Power Distribution, under the direct jurisdiction of the Ministry of Electricity and Energy (MOEE). The following year a modification of Law No. 12 of 1976 (Law No. 36) eliminated EEA's exclusive right for power generation. In 1991, under Law No. 203, the electric distribution companies were transferred from the MOEE to the Holding Company for Construction and Electric Power Distribution, under the jurisdiction of the Ministry of Public Enterprises Sector, a new ministry created for the preparation of public sector companies for privatization.

In 1998, when the prospects for privatizing the distribution entities had receded, partly because of the lack of improvement in their performance, MOEE transferred these entities back to EEA under Law No. 18 (another modification of Law No. 12 of 1976). Under Law No. 18, EEA combined these distribution entities with its generation entities into seven vertically integrated subsidiaries that served geographic zones as local monopolies. EEA continued to be responsible for transmission, dispatching, planning for new generation and transmission projects, and the purchase of the electricity produced by build, own, operate, and transfer (BOOT) projects.

Another reform was undertaken in 2000 through Law 164 (another modification of Law No. 12 of 1976) for the reorganization of EEA into an Egyptian joint stock (holding) company under the name Egyptian Electricity Holding Company (EEHC). In July 2001 more restructuring took place through the unbundling of the generation, transmission, and distribution activities into thirteen companies (five generation, one transmission, and seven distribution). Each generation and distribution subsidiary was established as a separate corporate entity with its own board. This process of corporatization apparently reflected the government's intention that EEHC should be expected to finance its own projects.

Law 164 provided for the sale of up to 49 percent of the total shareholding of these generation and distribution entities to private investors. Although shares of the seven distribution monopolies were prepared at that time for offer on the Egyptian Stock Exchange, investors' lack of interest prevented realization of this plan. Since then, the government has not shown any interest in privatizing any of these entities.

An internal wholesale power pool was also created in 2002 under Law 164 to replace the previous dispatch processes. Under the pool provisions, the generators provide bids for dispatch, and their generating units are scheduled for dispatch on the basis of these bids. The bids are based 
on costs, however, and so the pool has never operated as a genuine market-clearing exchange. Moreover, EEHC has retroactively adjusted the cost-based prices in the pool to maintain substantial cross-subsidies among the pool members, which has further blunted any competitive pressure to improve efficiency.

Due to the high growth rate of the power sector, further unbundling took place in 2002 with the division of one of the distribution companies into two companies, and again in 2004 with the division of another of the distribution companies into two companies. Egypt is now served by nine electricity distribution companies, six generation companies, and one transmission company, all of which are affiliated and controlled by EEHC, their parent company. EEHC is also responsible for the planning, development, and operation of the government-owned electric utilities.

All of these reforms took place without an independent regulator. Despite the issuance of Presidential Decree No. 326 in 1997 for the establishment of the Electric Utility and Consumer Protection Regulatory Agency (ERA), no progress was made until 2000, when Decree No. 339 was issued. The regulatory agency was established in May 2001 and started operations in early 2002. In addition to ensuring an adequate supply of electricity to meet demand at equitable prices, ERA's mandate covers preparing for competition in the power market. ERA's powers fall short of a truly independent regulatory agency, however, because it does not have tariff-setting power. Moreover, its rulings are under government influence because its board is chaired by the minister of electricity and energy.

Between 1992 and 2004 there were no changes to the tariffs in nominal terms, even though a substantial decline in real terms resulted. Then in October 2004 the cabinet of ministers approved nominal tariff increases of approximately 5 percent per annum for the next five years, with the aim of covering costs by 2009. In August 2007 the government announced a three-year plan to remove subsidies from natural gas and electricity tariffs for energy-intensive industries. In June 2008 the tariff increases under this plan were accelerated and implemented immediately.

\section{Egypt's Private Power Generation Projects}

In the early 1990s Egypt's government was advised by the main external financiers of its infrastructure projects, namely the multi- and bi-lateral agencies that provided loans on soft financing terms, to open its infrastructure markets to private sector financing and operation. The government 
was also advised to focus its limited amounts of available public sector funding on social sectors. These agencies made availability of their financing for the power sector in particular conditional on the sector reaching commercial performance standards, which required substantially higher electricity prices. Because the government considered that such price levels would be too unpopular to implement, it kept electricity prices unchanged and decided to open its power market to private participation.

In June 1996 Law No. 12 of 1976 was modified again, this time by Law No. 100 to permit the private sector to develop and operate electric power generating plants under BOOT project arrangements. ${ }^{1}$ Under such projects, a private developer has a long-term agreement to sell electricity in bulk to EEA under a long-term agreement and transfers the project assets to EEA at the end of the contract. The 1997 Investment Law provided private investors with a number of additional key features: tax exemption (for the first five years), currency conversion, full repatriation of profits, and protection against nationalization and expropriation.

EEHC organized the first tender for private power generation in 1996 and awarded a contract under a power purchase agreement (PPA) in 1998. The PPA provided for power to be supplied from a gas-fired steam generator of $682.5 \mathrm{MW}$ capacity for a period of 20 years under BOOT arrangements with project financing. Under the PPA's pricing terms, EEHC must pay for an agreed amount of power produced from the plant whether or not it takes as much as that amount. This minimum payment obligation was based on the amount of energy produced if the plant were operated at a utilization rate of between 65 percent and 70 percent of its capacity. The fuel cost was based on a formula stated in the PPA and passed through to EEHC. EEHC's payments were made in U.S. dollars and were to be backed by a guarantee from the Egyptian Central Bank.

EEHC quickly concluded two more BOOT projects for generating plants under similar contract terms and the same set of conditions extended by the government. Between 1996 and 2003 the private sector added 2 gigawatts in new power capacity in the form of three gas-fired steam generating plants of equal rated capacity of $682.5 \mathrm{MW}$, accounting at that time for about 10 percent of the country's installed capacity. Debt financing was provided by local and foreign banks as well as by institutional investors and multilateral agencies.

Egypt was able to secure power from independent power producers (IPPs) under these agreements at electricity prices that were among the lowest for such IPP projects in developing countries. Under the first PPA, power was priced at $\$ 0.0254$ per kilowatt-hour. The main factors that 
explain this low tariff are the low price for natural gas supplied to the plants, the project developers' perceptions of a favorable investment climate, the absence of currency risk for the developers, and the developers' plans at that time to expand their operations in the Egyptian market by building a portfolio of generation assets. The elements of the favorable investment climate were a clear policy framework, coherent power sector planning, international competitive bidding process, abundant low-cost fuel, the willingness of government to share risks, political stability, and a country with an investment grade rating for foreign direct investment. Retail tariff subsidies or the absence of an autonomous sector regulator were not major deterrents to foreign investors in IPPs (Eberhard and Gratwick 2007).

Despite a large devaluation of the Egyptian currency in later years and wholesale changes in ownership for all three projects, ${ }^{2}$ the original agreements have remained in force without any renegotiations of contract terms, and the three private gas-fired generating plants continue to provide reliable and affordable electricity. Power provided by the IPPs remains competitively priced by international standards (largely due to cheap state-supplied natural gas to the plants), but the major devaluation of the currency doubled the cost of power purchases in local currency terms for EEHC under the dollar-denominated contracts.

The Egyptian government, however, is apparently not keen to develop further IPPs with the same terms and conditions for sharing currency and other contractual risks. Since 2000 it has been developing a second IPP framework with new provisions for financing and off-take terms that are less attractive than those offered to the first IPPs: all foreign currency must be obtained from abroad, rather than being sourced from domestic banks; local designers, contractors, and manufacturers must contribute substantially to the execution of the projects; and local costs must be paid in local currency. In addition, the bids that have both a larger equityfinancing stake and a larger local investment component will be favored. Finally, project developers must bring their own customers with them; that is, EEHC will not be the sole buyer. ${ }^{3}$ To date, however, no new IPP projects have been undertaken within this second regime.

\section{The Return to Publicly Financed Power Projects}

With more concessionary funding becoming available, the Egyptian government has charged EEHC with procuring further generation capacity with financial support from development finance institutions. EEHC has 
continued to work on five-year development plans-particularly for generating capacity. EEHC concluded its first fast track power generation program for adding 4,500 MW of gas-fired combined cycle generating capacity during its fifth five-year plan for 2002-07. EEHC is currently implementing its second fast track power generation program during its sixth five-year plan for 2007-12, which consists of 7,240 MW of new generating capacity $(6,500 \mathrm{MW}$ gas-fired plant and $600 \mathrm{MW}$ of wind power capacity). EEHC is planning to add about 15,000 MW of new capacity during its seventh five-year plan for 2012-17. Nevertheless, EEHC's generation reserve margin is expected to remain tight for some time because of the expected growth in power demand.

In conclusion, the government's strategy for meeting Egypt's demand for electricity has managed to expand the power supply impressively, helped by the discovery of large reserves of natural gas that provide lowcost power generation while expanding access to electricity to nearly the whole population. The government has kept electricity prices down to help low-income households afford it, and energy-intensive industries remain competitive. These achievements have, however, come at a cost. The subsidies imposed substantial burdens on the government's fiscal resources and weakened the financial structure of the state-owned enterprises involved in supplying electricity and energy and in financing the energy sector. This outcome has impeded the government's intentions to privatize power supply entities and attract private investment to the sector.

\section{Impact on Sector Structure}

Egypt's reforms to its power sector have followed a sequence of unbundling and rebundling of its state-owned power entities combined with shuffling of responsibilities for policy and regulatory oversight and corporate direction. The sector's ownership and structure as state-owned monopolies remained consistent with the government's economic development strategy that gave priority to state direction of investment and pricing of public services. The entry in the late 1990s of private investors to develop three power generation plants now appears to have been a temporary diversion from this general direction.

Currently the Egyptian electricity market is composed of government-owned utilities (six generation, one transmission, and nine distribution) under the direct management of EEHC; three IPP-owned projects; one wind-generating company under the direction of the 


\section{Figure 6.1 Structure of the Egyptian Power Sector}

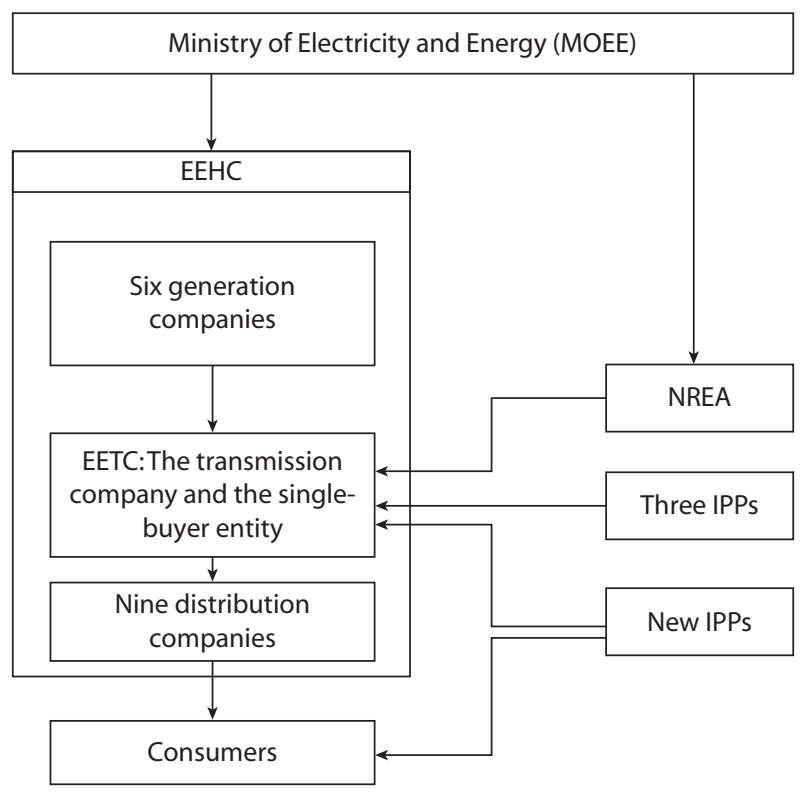

Source: An elaboration from the Power Market Structure database.

Note: $\mathrm{EEHC}=$ Egyptian Electricity Holding Company; EETC = Egyptian Electric Transmission Company; IPPS = independent power producers; NREA = New Renewal Energy Authority.

New Renewal Energy Authority within MOEE, and about 12 small isolated and/or semiconnected independent service providers in either generation or distribution. The structure of the power market is depicted in figure 6.1.

At present, the Egyptian Electric Transmission Company (EETC) operates under a single-buyer model and purchases bulk power from all generation entities. EETC in turn sells bulk power to distribution companies and to high voltage and extra-high voltage (EHV) customers. EEHC sets and controls the purchase and selling prices of electricity among the government-owned utilities. This single-buyer market does not allow free competition among incumbent generation companies. EEHC has not set up an independent transmission operator or system operator.

\section{Impact on Sector Performance}

Evidence of possible impacts from reforms is sought from trends from the early to mid-1990s up to 2008 in the following five indicators: 
- Access to electricity supply by the population in terms of new residential connections. The Egyptian distributors increased residential connections steadily at an average annual rate of 4 percent to reach 99 percent of the population.

- Customer service quality. Power outage rates and durations and distribution system losses have trended downward since the early 2000s. The total number of distribution transformer failures per year fell substantially by 48 percent from 2002 to 2008 . The total level of transmission and distribution losses as a percentage of total output dipped from approximately 13 percent in 2002 to around 11 percent in 2008. These trends indicate that the distribution entities succeeded in improving customer service quality during the previous decade.

- Supply security. The margin of the power system's generation reserve capacity declined steadily from around 20 percent in the early 2000s to less than 10 percent in more recent years, showing that the system now has little scope for avoiding power shortages during annual peak demand periods (afternoons of the hottest days). This trend underlies the need for EEHC's fast-track generation programs.

- Financial sustainability. Financial performance data for EEHC and its affiliates should be viewed cautiously because of the heavy crosssubsidies present in the Egyptian electricity and energy sectors, some of which are not fully transparent. Indicators of EEHC's financial stress are its difficulty in mobilizing sufficient funding for its investment programs and, reportedly, its difficulty in fully servicing its debts to fuel suppliers and local lenders. EEHC's debt servicing problems have had to be managed by government interventions to restructure some of the debt so as to maintain EEHC's viability with revenues based on the government-controlled electricity tariffs.

- Environmental sustainability. The carbon emissions index has been steadily increasing from 0.51 in 2002 to 0.55 in 2008, but is expected to improve due to the significant investment in renewable energies.

Trends in these indicators are shown in the following figures. 


\section{Figure 6.2 Milestones of Power Sector Reform in Egypt}

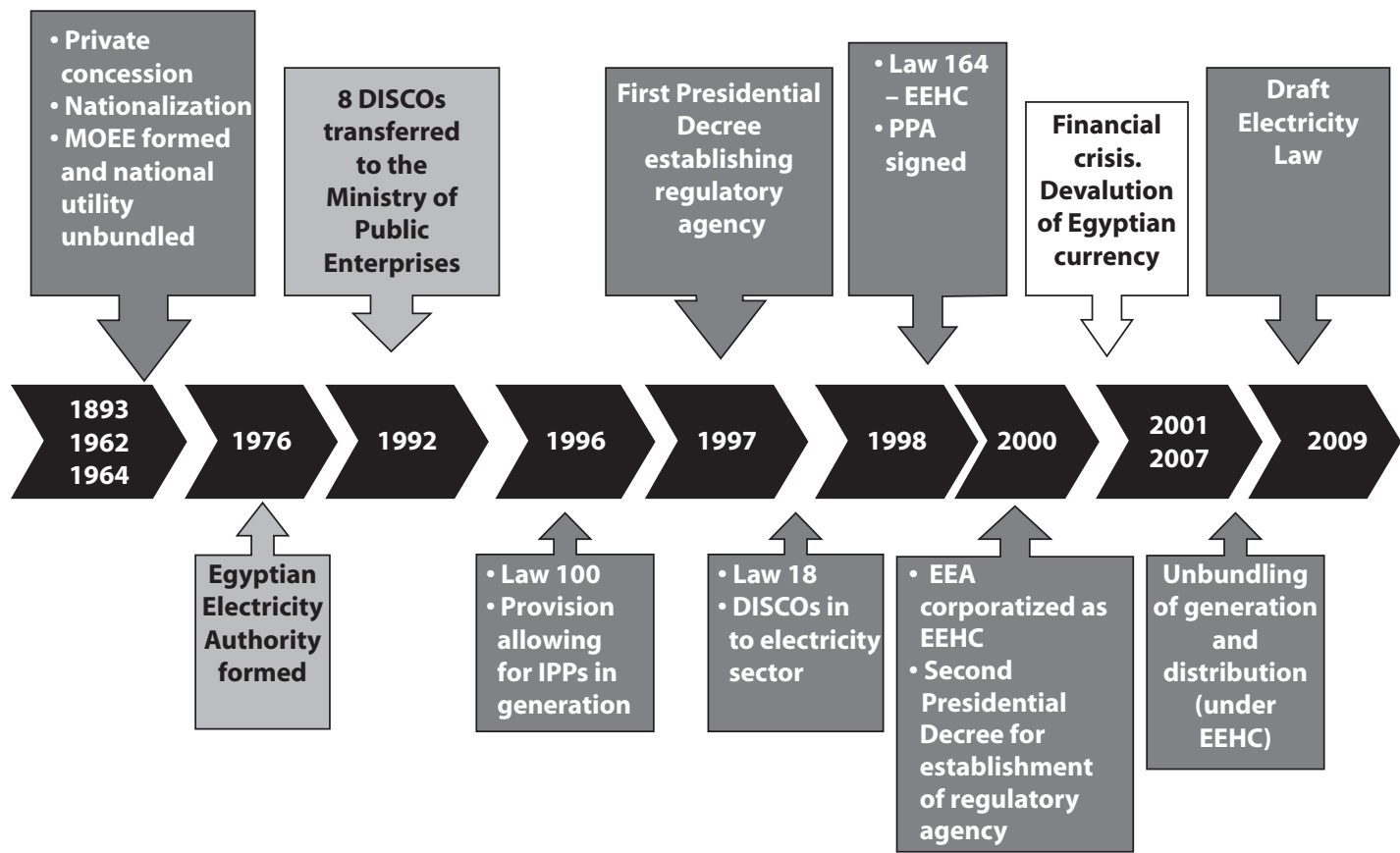

Source: An elaboration from the Power Market Structure database.

Note: The milestones are reported in different shades: white $=$ main external factors; light gray = main government interventions; dark gray = main private sector involvements. DISCOs =

distribution companies; EEA= Egyptian Electricity Authority; EEHC = Egyptian Electricity Holding Company; IPPs = independent power producers; MOEE = Ministry of Electricity and 


\section{Figure 6.3 Egypt: Access to Residential Electricity}

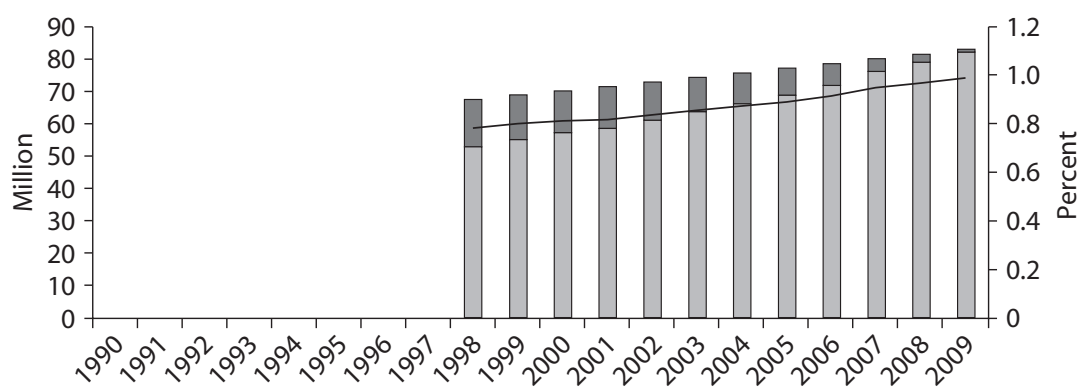

Population without access $\square$ Residential customers with access Access rate

Source: An elaboration from the Power Market Structure database.

\section{Figure 6.4 Egypt: Quality of Electric Service}

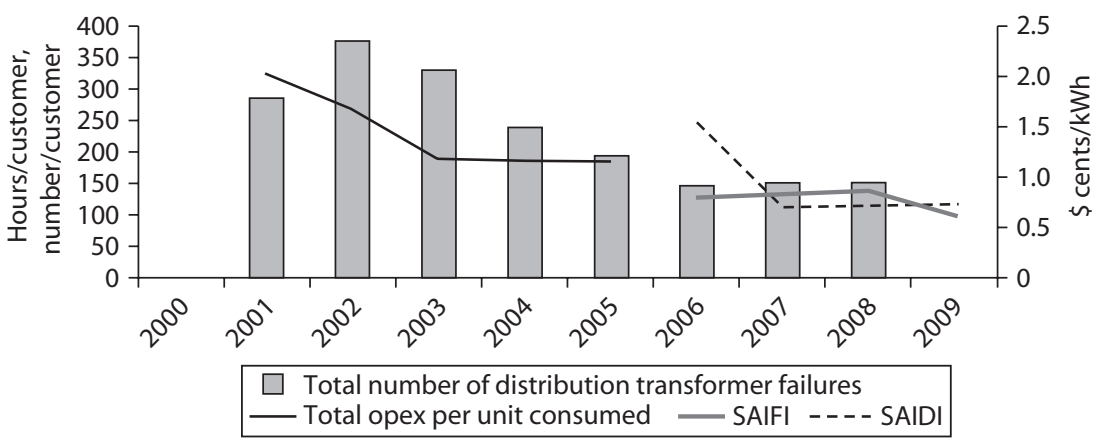

Source: An elaboration from the Power Market Structure database.

Note: kWh = kilowatt-hour; opex = operational expenditures/costs; SAIFI = System Average Interruption

Frequency Index; SAIDI = System Average Interruption Duration Index. 


\section{Figure 6.5 Egypt: System Losses and Operating Costs}

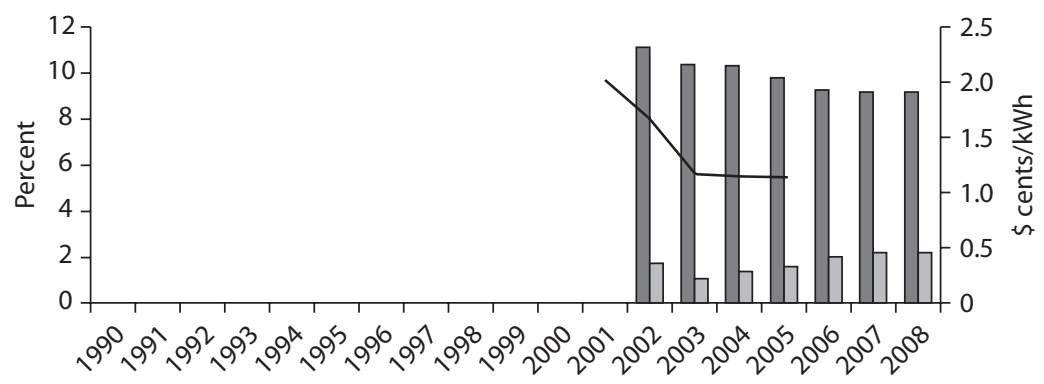

$\square$ Distribution losses $\quad \square$ Transmission losses

Total opex per unit consumed

Source: An elaboration from the Power Market Structure database.

Note: $\mathrm{kWh}=$ kilowatt-hour; opex = operational expenditures/costs.

Figure 6.6 Egypt: Electricity Generation by Source and Carbon Emissions

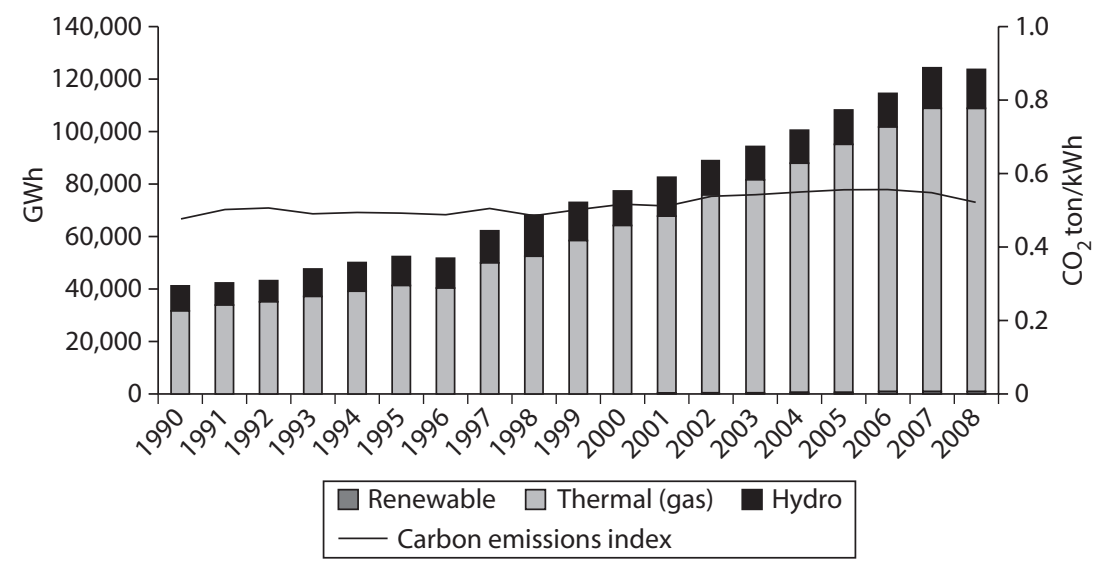

Source: An elaboration from the Power Market Structure database.

Note: GWh = gigawatt-hour. 


\section{Figure 6.7 Egypt: Energy Security and Capital Expenditure}

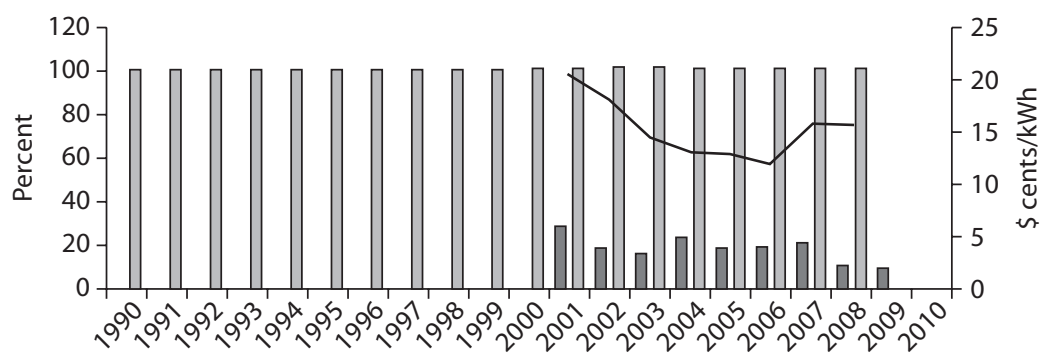

System reserve capacity $\square$ Energy self-sufficiency

Total capex per unit consumed

Source: An elaboration from the Power Market Structure database.

Note: Capex $=$ capital expenditures; $\mathrm{kWh}=$ kilowatt-hour.

\section{Figure 6.8 Egypt: Average Tariff and Operating Costs}

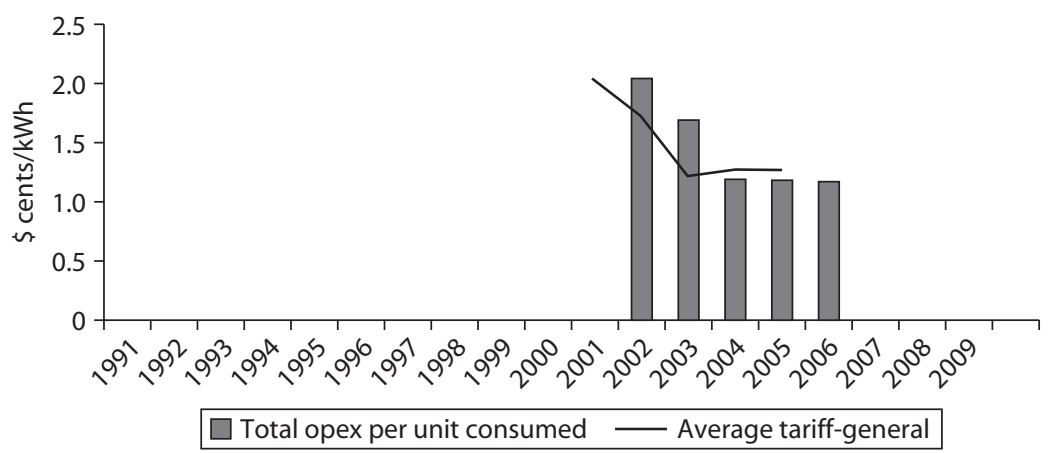

Source: An elaboration from the Power Market Structure database. Note: $\mathrm{kWh}=$ kilowatt-hour; opex = operational expenditures/costs.

\section{Figure 6.9 Egypt: Capacity Utilization}

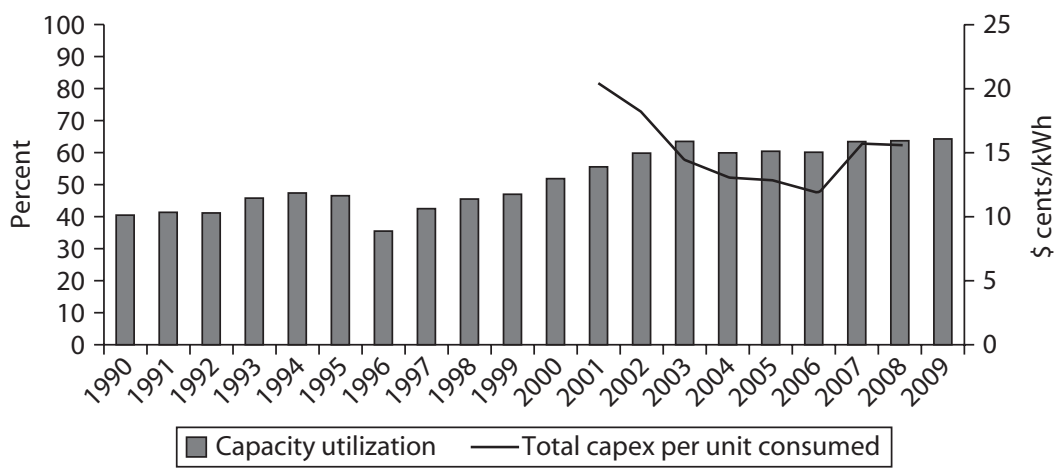

Source: An elaboration from the Power Market Structure database.

Note: Capex $=$ capital expenditures; $\mathrm{kWh}=$ kilowatt-hour. 


\section{Figure 6.10 Egypt: Market Concentration}

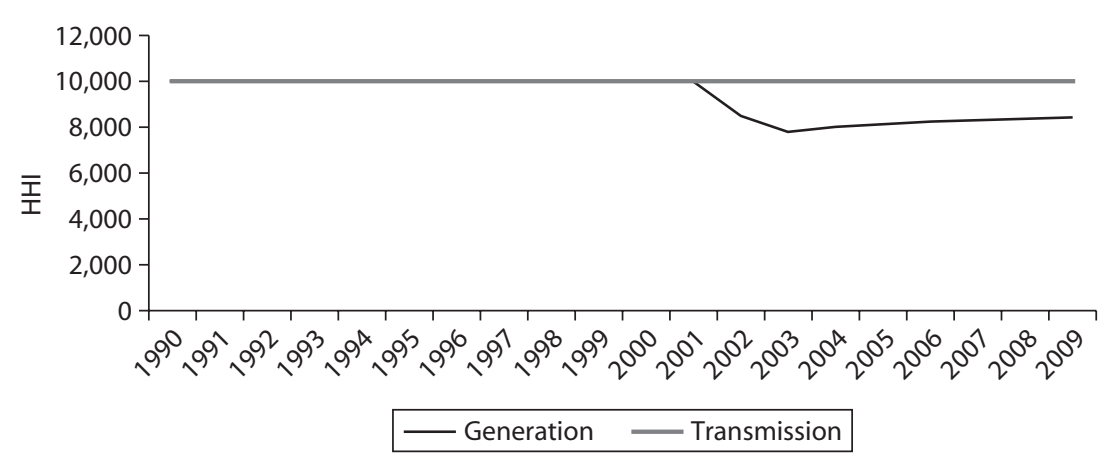

Source: An elaboration from the Power Market Structure database. Note: $\mathrm{HHI}=$ Herfindahl-Hirschman Index.

\section{Figure 6.11 Egypt: Private Ownership}

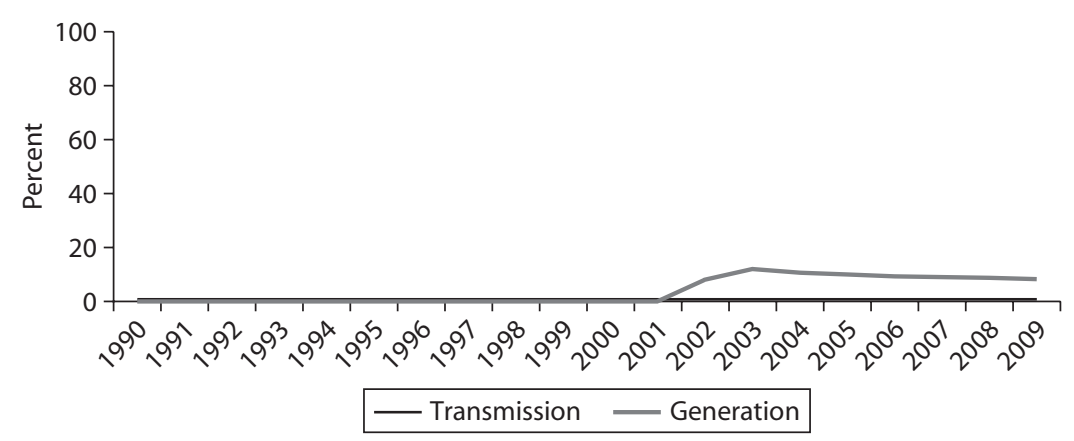

Source: An elaboration from the Power Market Structure database.

\section{Figure 6.12 Egypt: Private Management}

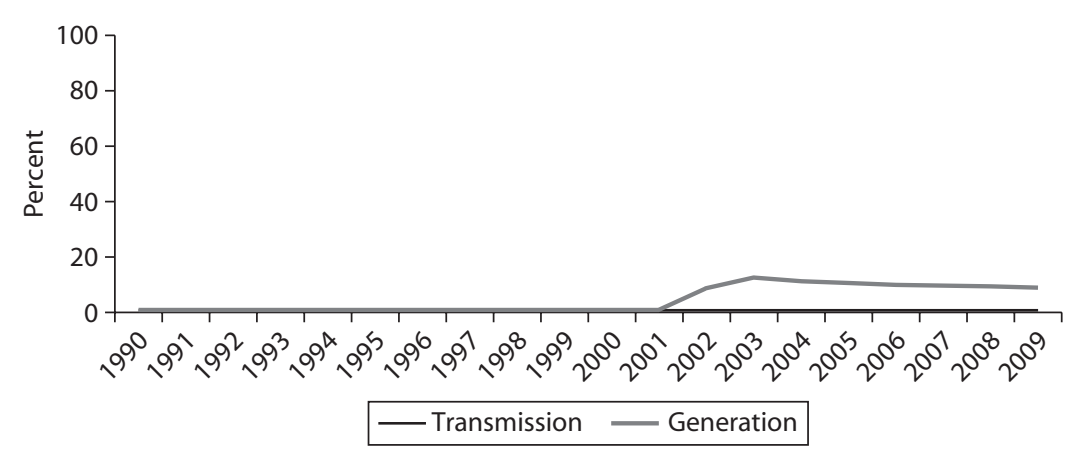




\section{Figure 6.13 Egypt: Degree of Vertical Integration}

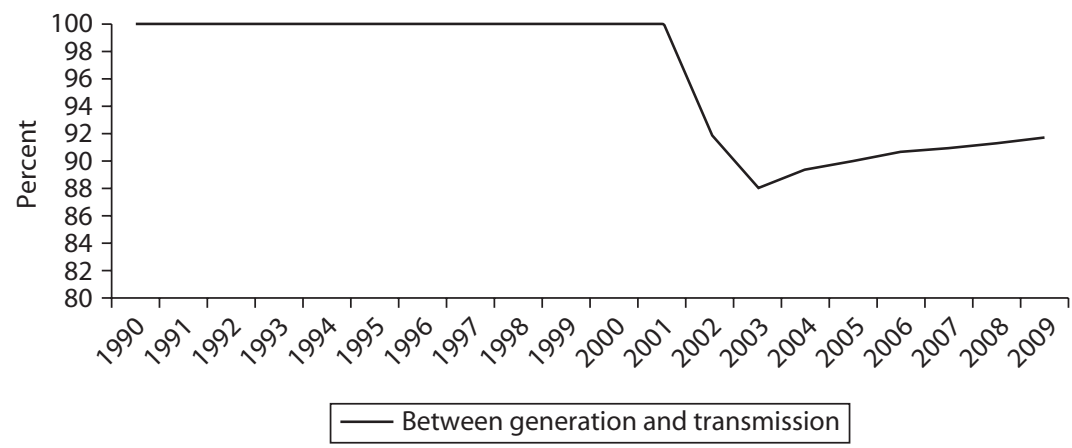

Source: An elaboration from the Power Market Structure database.

\section{Notes}

1. Law 100 specified that "local and foreign investors may be granted public utility concessions allowing them to build, operate and maintain power generation stations."

2. After two years of operation by the IPPs that developed these projects, these firms sold their interests in the projects to other IPPs.

3. ERA put out for discussion in 2010 a proposal in a white paper by which new large industrial and commercial users of electricity would have to contract bilaterally for electricity supply with other producers besides EEHC. In turn, new IPPs would have to sell a specified proportion of their output directly under bilateral contracts to large users. This proposal has not progressed.

\section{Reference}

Eberhard, Anton, and Katharine Gratwick. 2007. "From State to Market and Back Again: Egypt's Experiment with Independent Power Projects.” Energy 32: 724-38. 


\section{CHAPTER 7}

\section{Indonesia}

Indonesia falls into the lower-middle categories for national income (just above $\$ 2,000$ per capita) and high power system size (30,000 MW [megawatts] installed generation capacity). Even though the country has sizable resources of oil, gas, and coal reserves, it faces an enormous challenge in providing energy efficiently for the world's fourth largest population spread over an archipelago of more than 6,000 inhabited islands.

The electric power industry in Indonesia is managed solely by Perusahaan Listrik Negara (PLN), a state-owned monopoly. PLN has various business units that carry out functions that include generation, transmission, and distribution. About 75 percent of the power produced in Indonesia is on the main island of Java. PLN controls about 85 percent of the total generation capacity, and the remainder is owned by large industries and mines mainly for their own use and by independent power producers (IPPs) that sell their output to PLN.

In the last two decades, the power industry in Indonesia has experienced high growth in demand, averaging 8 percent per annum. In 2009 PLN served more than 40 million consumers and sold 135 TWh (terawatt-hour). The residential consumer category accounted for 41 percent of PLN's energy sales, the industrial category for 34 percent, the commercial category for 18 percent, and the public category for 7 percent. PLN 
produced 77 percent of the 157 TWh total amount of electrical energy generated, ${ }^{1}$ and IPPs produced the remaining 23 percent. PLN generated 36 percent of its output from coal-fired power plants, 29 percent from oil-fired power plants, 24 percent from gas-fired power plants, 8 percent from hydropower plants, and 3 percent from geothermal power plants.

Indonesia's power sector faces investment needs that greatly exceed the public sector's financial resources. Therefore, the government must rely heavily on the private sector to expand the country's power system. The chronology of government's attempts to reform the power sector forms the basic theme of this case study.

\section{Reform History}

Successive Indonesian governments have attempted to modernize the power sector since the mid-1980s, and in particular to create an investment climate conducive to private investment in the power sector. So far, the government's success relative to the sector's needs has been limited. The attempts to modernize have been continuously impeded by the basic institutional and legal arrangements for the sector. Institutionally, the dominant state-owned enterprise (PLN) formed strong resistance to any significant reform attempts by the government. Legally, the government's central role, particularly in the electricity sector, was stipulated by the 1945 Constitution, which provides the government with the mandate and the power as the sole provider of electricity for the nation. ${ }^{2}$ To implement this mandate, PLN has held the exclusive right and monopoly to supply and distribute electricity for public use in Indonesia.

Efforts to reform and commercialize the electricity sector started as early as the mid-1970s when multilateral agencies began to press the Indonesian government and PLN to prepare for the privatization of the electricity sector. Privatization was regarded as preferable to continued borrowing of foreign funds by PLN to fund its inefficient electricity operations. This pressure followed two decades of failed attempts by these agencies to convince the government of the need for fundamental restructuring of the electricity market. The World Bank eventually threatened the government with nonrenewal of its loan agreements unless PLN took steps to open the electricity generation market to IPPs and electric cooperatives. This pressure eventually led to passage of Law No. 15 of 1985 Concerning Electricity Business.

The law was the first serious attempt to modernize the electricity sector. It sought to improve the sector's performance by decentralizing 
control of power generation capacity and by proposing new ways of sector governance. For the first time the law allowed IPPs and electric cooperatives to supply electricity in the Indonesian electricity market, a function previously dominated by PLN. Yet the law still provided PLN with the central authority to manage essential regulatory functions by allowing it to control the issuance of electricity business permits to the IPPs and cooperatives. The law also confirmed PLN's role as the sole supplier and distributor of electricity for Indonesia.

The implementation of the 1985 electricity law was slow. The establishment of the first IPPs followed only in 1992; seven years after passage of the law. Although the law signified the start of the structural reform that contributed to the opening up of the electricity market to private investors, it had little impact on the administrative governance structures. The government lacked the means to set policy or regulate the sector itself, and PLN continued to carry out these functions.

\section{The First IPPs and the Asian Financial Crisis}

With the signing of power purchase agreements (PPAs) for 27 power plants developed and operated by IPPs dominated by large foreign enterprises and backed by foreign funds, the government was able to significantly increase the national electricity generation capacity. The amount of the IPP-generated electricity, however, remained marginal relative to the overall supply provided by PLN. In the first years of operation up to 1998, IPP-generated energy provided less than 5 percent of the total amount of energy produced and purchased by PLN.

Indonesia's electricity sector suffered greatly along with the broader economy from the Asian financial crisis in 1997-98 through severe currency depreciation and collapse of foreign investment flows. From June 1997 to July 1998 the Indonesian rupiah dropped 83 percent against the U.S. dollar. The crisis particularly affected the IPP contracts financed with dollar-denominated foreign funds. Three factors contributed to the extreme financial difficulties faced by PLN and the government. First, as the cost of power production increased, the government was unable to raise electricity tariffs due to the sensitive political situation in the country. Second, PLN had to settle its payment obligations to the IPPs in U.S. dollars from revenues earned in the rapidly depreciating local currency. Third, PLN was also forced to supply its own power plants with gas purchased in U.S. dollars from the global markets.

The bad situation was made worse by the PPA contract terms that guaranteed the IPPs a high return on their equity investment that the 
IPPs demanded in the high-risk environment posed by the Indonesian energy sector. PLN negotiators were often presented with prepared contracts for their signature with terms that President Suharto had personally agreed to with foreign statesmen. PLN negotiators lacked the experience needed to protect PLN's interests in negotiating such complex contracts with the IPPs.

When the financial burden of the IPP contracts became unsustainable for PLN, the government suspended most of the contracts. The IPPs called in guarantees as a remedy for the breach of contracts that resulted in substantial payments by the government as counterguarantor. The government honored these commitments even at substantial costs to prevent the IPPs from defaulting to their lenders and thereby managed to maintain the overall confidence of foreign investors. These actions helped the government to resume negotiations with the IPPs after the Asian financial crisis with lower target return on equity and generally more balanced contract terms for the parties to the PPAs.

By the end of 2005 PLN had renegotiated the PPAs for 26 power plant projects with IPPs. As a result, PLN's purchase price was reduced to $5 \$$ cents per $\mathrm{kWh}$, well below the level of 8.4 \$ cents set in the previous agreements. Fourteen of the IPPs agreed to continue their projects under the new pricing scheme, seven terminated their agreements, and five projects were taken over by PLN and Pertamina, the state-owned oil and natural gas corporation.

\section{Post-2000 Reforms after the Asian Financial Crisis}

The fall of Suharto's regime in May 1998 was followed by a period of political democratization and liberalization of Indonesia's economic and social environment. The institutional reforms that were implemented, including those concerning the electricity sector, were influenced by the International Monetary Fund (IMF) under its assistance to the country in the Asian financial crisis. One of these reforms is the emergence of the Ministry of Energy and Mineral Resources (DEMR) in 2000 as the formal institution for policy and regulation in these sectors and therefore for sector governance. But the electricity sector also depends on administrative decisions by the Ministry of State-Owned Enterprises (MSOE), the Ministry of Finance (MOF), and the National Development Board (BABBENAS), which exposes the administrative process for sector policy and regulation to political manipulation and interagency disputes. ${ }^{3}$

The government had attempted to depoliticize the tariff-setting process in 1994 by setting up an automatic electricity tariff adjustment mechanism 
(ETAM) that would base fees on the movements of four variables: inflation, exchange rates, fuel prices, and the level of power purchases. But electricity tariffs remained low $^{4}$ because the government and PLN could not overcome public opposition to tariff increases under the heavy politicization of the tariff-setting process. The prevailing low levels of electricity tariffs deterred most multinational power companies from developing new power projects in Indonesia in the years following the Asian financial crisis, required the government to provide large subsidies to cover PLN's production costs, and impeded any prospect of unbundling PLN into components that could operate to commercial standards in a power market.

In April 1998 PLN told the government that the company would have to multiply its tariff by 150 percent to match the prevailing market and business conditions. The government responded by first declining PLN's request and then by freezing the ETAM and proposing a lower tariff increase of 55 percent in May 1998. Its proposed increase, however, met substantial opposition in Parliament and was eventually withdrawn. ${ }^{5}$ PLN then embarked on the more politically attuned strategy of imposing tariff increases for high-income residential consumers and nonresidential consumers in 1999.

PLN's financial situation remained highly precarious throughout 2000. Its auditor issued a disclaimer to PLN's accounts, and PLN renounced its financial commitments to the government. PLN then offered a five-step proposal to solve its financial problems. The proposal included a series of tariff increases to reach the full cost-recovery level by 2005 and the restructuring of its outstanding government debts. The government accepted PLN's proposal and implemented it in 2001. PLN gradually increased tariffs up to mid-2003. ${ }^{6}$ This depoliticization of the tariff process was then stopped by the approaching presidential elections and the incoming president's support for lower electricity tariffs. PLN was still able to raise its tariffs to its business consumers during the middle years of the decade to compensate for higher oil prices.

\section{Electricity Law}

Under pressure from the IMF, in 1999 the Indonesian government started a fresh process for reforming the power sector to improve the sector's efficiency and reduce its fiscal burden. This reform included the unbundling of PLN and the establishment of a legal and regulatory framework for a competitive electricity market through new legislation. The process became protracted partly due to the opposition of PLN to competition from private suppliers and from PLN's labor unions to prospective job 
losses under privatization and competition. But the process did eventually lead to the passage of Law No. 20 of 2002 on Electricity, which aimed at a gradual liberalization of the power sector, allowing private companies to produce and sell power to customers in unregulated competition with PLN. The law replaced the Electricity Law of 1985. In late 2004, however, the Constitutional Court annulled the 2002 electricity law on the grounds that certain provisions of the law contravened Article 33 of the 1945 Constitution. According to the Constitutional Court, electricity is a vital commodity for people and should be under the control of the government. The Constitutional Court also reenacted the former 1985 electricity law; once again the government had control of electricity tariffs, and PLN operated as the single buyer and seller of all generated electricity.

\section{Government Regulation on Public-Private Projects}

During the First Indonesian Infrastructure Summit in January 2005, the government offered 91 infrastructure projects worth $\$ 22.5$ billion in five priority sectors including transportation, gas pipelines, electric power, water supply and resources, and telecommunications. The projects, which spanned the 2005-09 period, were designed to attract investment and boost annual economic growth to more than 6 percent. On February 16, 2005, the government issued Government Regulation No. 3/2005 to provide investors with legal certainty in developing power projects. According to this regulation, private investors can participate in power projects, but they must be in partnership with PLN through a tender process. ${ }^{7}$ This arrangement accorded with the Constitutional Court's position on electricity supply, namely, that it had no objection to allowing private producers to enter the power market on the condition that the state maintain ultimate authority for policy and decision making in the sector.

\section{"Crash Programs" for Power Projects}

The annulment of the 2002 electricity law-following the painful experience of renegotiation of existing PPAs as an outcome of the 1998 Asian financial crisis-effectively stalled the interest of IPPs in proceeding with more power projects in Indonesia during the early years of the century. Furthermore, PLN was unable to finance large amounts of new generation capacity from its own resources since its financial situation deteriorated from 2006 due to its dependence on oil as fuel for its power plants and the fluctuations in oil prices, which led to a sharp increase in 
its production costs and higher power subsidies. Indonesian consumers experienced serious power supply shortages as their growing demand for electricity exceeded PLN's supply capacity.

By means of Presidential Decree PR No. 71, in 2006 the government instructed PLN to carry out a "crash program" for the construction of power plants using fuels other than oil. The goal was to increase the nationwide generation capacity from 24,000 MW to 55,000 MW by 2015. In the first phase between 2006 and 2010, a PLN-run 10,000 MW accelerated plan would aim to build 35 power plants across the country, and in the second phase between 2009 and 2015, PLN would build an additional 10,000 MW. In the first phase, the increased capacity would consist predominantly of coal-fired power plants, but in the second phase, the capacity would be divided among gas, geothermal, coal, and hydro-powered plants with geothermal producing close to 50 percent of the generated capacity. Although PLN has been the main target of the government's accelerated plan, some 40 percent of the increased generation capacity in the second phase is estimated to come from IPPs.

PLN's progress has fallen short of the crash program's scheduled additions to generation capacity. By 2009 the overall national generation capacity had increased by only 6,000 MW to 30,000 MW. To meet the capacity targets set out for the accelerated power programs by 2015, PLN needs to find $\$ 17$ billion of financing for the second phase, which it is unlikely to achieve. Moreover, some of the current IPP projects are facing financing problems.

\section{Electricity Law}

Faced with the prospect of persistent power supply shortages, the Indonesian House of Representatives passed on September 8, 2009, the Electricity Law No. 30 of 2009, which ends PLN's monopoly and gives private investors an opportunity to actively participate in the electricity sector. State-owned companies, regional-owned companies, private business entities, cooperatives, and community initiatives may supply electricity for public use, but the right of first priority is still vested in PLN. The 2009 law, therefore, provides for little institutional reform or for the unbundling of PLN. Instead, it confirms the state as the controller of electricity supply and PLN's central statutory role as supplier, as stipulated in the Constitution. It appears that further sector reform requires a change to Article 33 of the Indonesian Constitution. 
In view of the need to speed up the addition of new generation capacity, in January 2010 the government passed Presidential Regulation (PR) No. 4 of 2010, which provides a mandate to PLN to expedite the construction of power projects using renewable energy, coal, and gas under Electricity Generation Program II in accordance with the Electricity Law of 2009. PR No. 4/2010 specifically invites private investors to participate in the construction of power plants, including the related transmission lines, and for PLN to purchase the electricity and therewith supply end users. It also specifically provides that PLN may cooperate with private investors under schemes whereby private investors construct the power plants and PLN purchases the power. Such an explicit provision was absent from PR No. 71 of 2006 in respect of Electricity Generation Program I. PR No. 4/2010 also introduces a government guarantee with respect to the business feasibility of PLN to be regulated by the Ministry of Finance.

\section{Impact on Sector Structure and Performance}

One effect of the introduction of IPPs is the decrease of public ownership in the generation segment from 100 percent of the total installed generation capacity to about 78 percent in 2008. The transmission and distribution sectors were not impacted because the supply of transmission services has remained an integrated monopoly.

Evidence of the possible impacts from unbundling and the other reforms in Indonesia we have described is sought from trends from the early 1990s up to 2008 in the following indicators:

- Access to electricity supply by the population in terms of new residential connections. Indonesia's per capita electricity consumption and electrification ratio are low among countries in the East Asian region. Nearly 70 percent of the total population has access to public electricity supply, but on some islands this proportion is around 40 percent. PLN increased residential connections steadily at an average annual rate of 4 percent from 1998 to 2008.

- Customer service quality. The Indonesian power system has periodically experienced major blackouts for long periods, such as in 2002 and 2005. Millions of PLN's customers have incurred substantial losses and inconvenience. Consumers and businesses have registered countless complaints of fluctuating voltage that damages electronic 
goods, localized power outages without notice, and continually increasing tariffs for this poor service. The unreliability of the power supply has imposed costs and constraints on manufacturers for meeting delivery schedules, with loss of sales and profits. The situation is barely evident from the published SAIDI (System Average Interruption Duration Index) and SAIFI (System Average Interruption Frequency Index) rates because these rates may reflect outages from transmission and distribution occurrences only and exclude shortages from inadequate generation capacity. System losses decreased steadily from 2003 onward, from rates above 16 percent to around 10 percent in 2008.

- Supply security. The margin between total available generating capacity on the interconnected system and peak demand on this system varied substantially between 2003 and 2008. It was highest in 1990 and 1998-99, and lowest in 2004 and 2005. But the occurrence of major power blackouts and routine shortages indicates that PLN has had little capacity margin to meet the rapid growth in power demand, partly because some of its generation capacity may have been unavailable for production when needed to meet demand on the power system.

- Financial sustainability. PLN's revenues from electricity sales have almost always been insufficient to cover its cost of supply, mainly because of low tariffs but also due to its operating inefficiency. Following the rapid rise of fossil fuel prices in the international market, the removal of subsidies on petroleum products by the government in 2005, and the government's suspension of electricity price increases since 2004, PLN's financial viability has deteriorated significantly. Although the prices of fossil fuel have fallen due to the current global financial crisis, PLN's tariff level is still insufficient to cover its supply cost for almost all the categories of its customers, including those who are able to pay for the electricity at cost-recovery levels. The structure of the current tariff system also needs to be rationalized to reflect the economic cost structure of supply.

- Environmental sustainability. To reduce its dependency on oil, the government of Indonesia is seeking to significantly increase the share of coal in the fuel mix of power generation. According to PLN's longterm plan, the share of coal in the generation fuel mix will increase 
from around 35 percent to around 70 percent by 2020. Consequently, Indonesia's greenhouse gas emissions from power generation will continue to grow, but the government plans to moderate this trend by raising the proportion of renewable energy in the fuel mix through expanding geothermal development.

Trends in these indicators are shown in the following figures. 
Figure 7.1 Milestones of Power Sector Reform in Indonesia

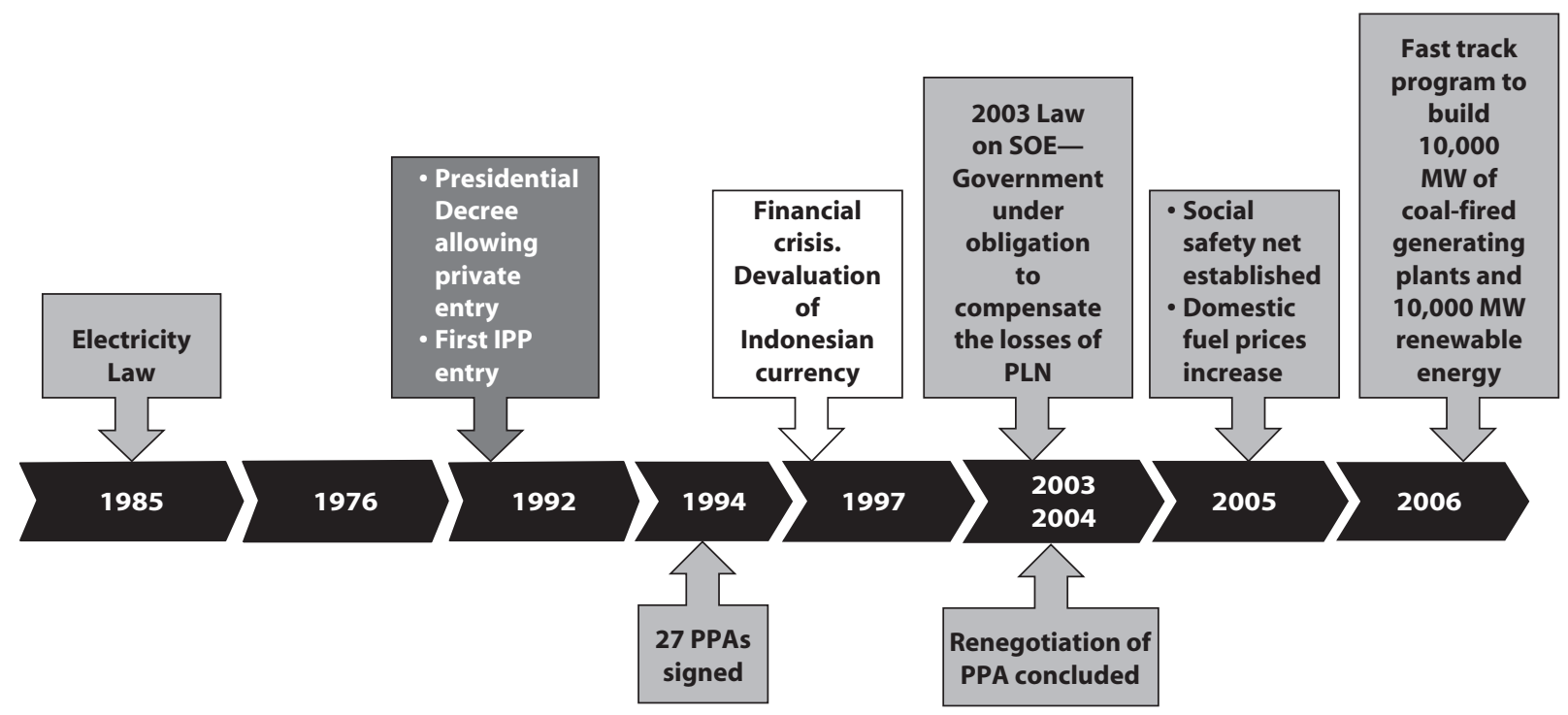

Source: An elaboration from the Power Market Structure database.

Note: The milestones are reported in different shades: white = main external factors; light gray = main government interventions; dark gray = main private sector involvements.

IPP = independent power producer; MW = megawatt; PLN = Perusahaan Listrik Negara; PPA = power purchase agreement; SOE = state-owned enterprise. 


\section{Figure 7.2 Indonesia: Access to Residential Electricity}

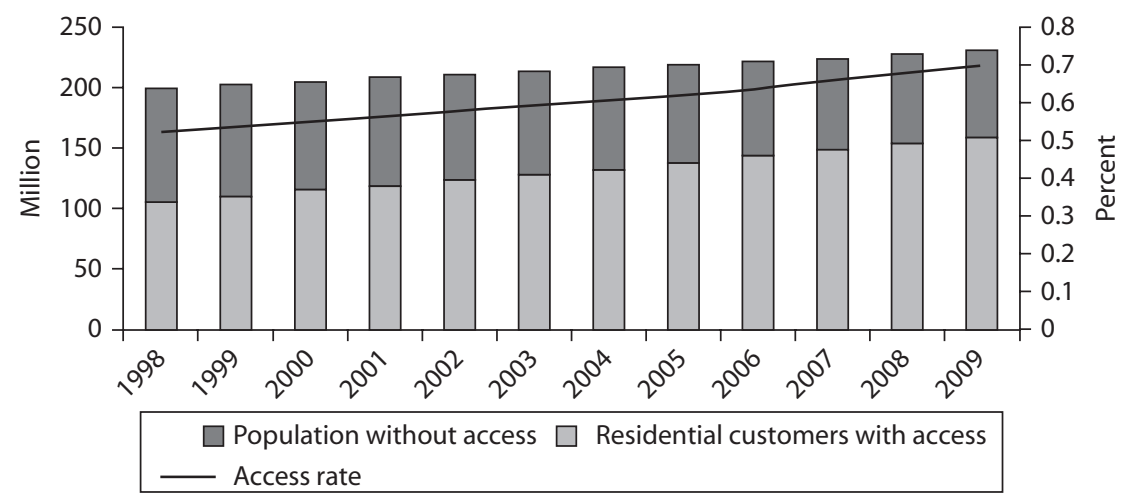

Source: An elaboration from the Power Market Structure database.

Figure 7.3 Indonesia: System Energy Losses

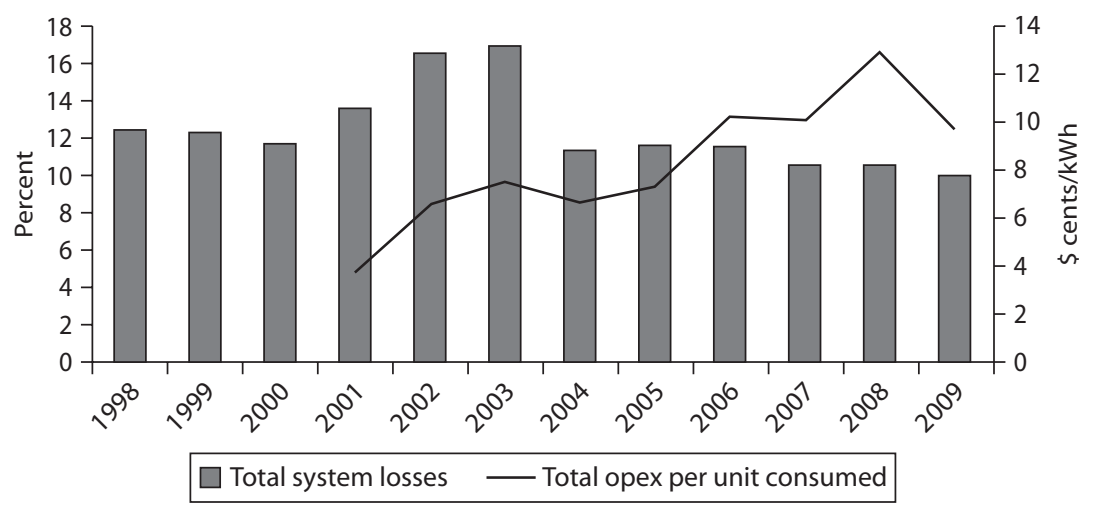

Source: An elaboration from the Power Market Structure database.

Note: kWh = kilowatt-hour; opex = operational expenditures/costs. 
Figure 7.4 Indonesia: Electricity Generation by Source and Carbon Emissions Index

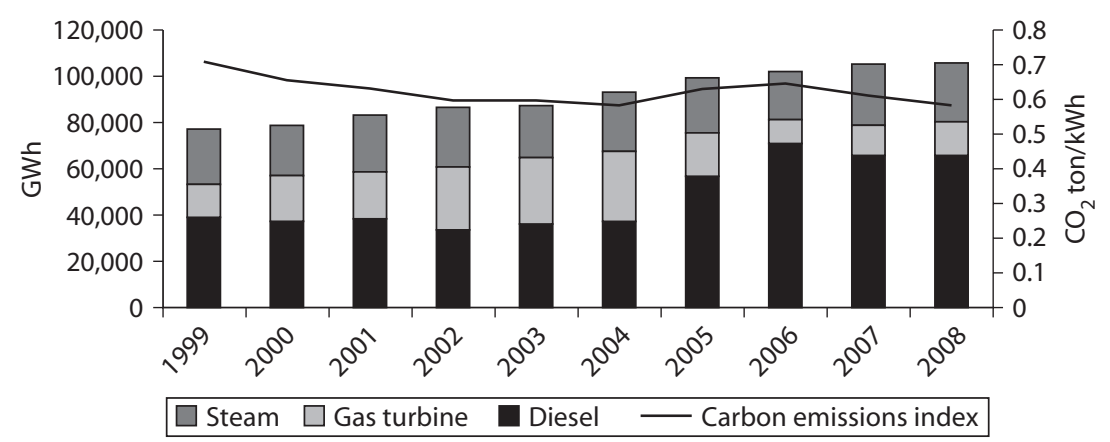

Source: An elaboration from the Power Market Structure database.

Note: GWh = gigawatt-hour; $\mathrm{kWh}=$ kilowatt-hour.

Figure 7.5 Indonesia: Energy Security and Capital Expenditure

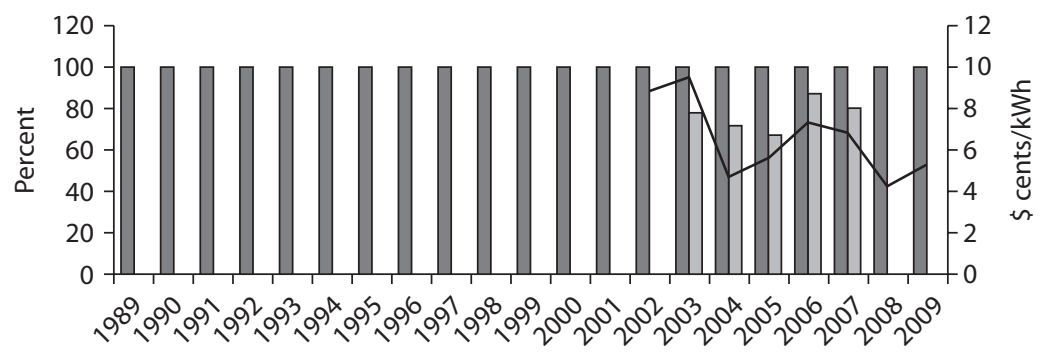

Energy self-sufficiency $\square$ System reserve capacity Total capex per unit consumed

Source: An elaboration from the Power Market Structure database.

Note: Capex $=$ capital expenditures; $\mathrm{kWh}=$ kilowatt-hour. 


\section{Figure 7.6 Indonesia: Average Tariff and Operating Costs}

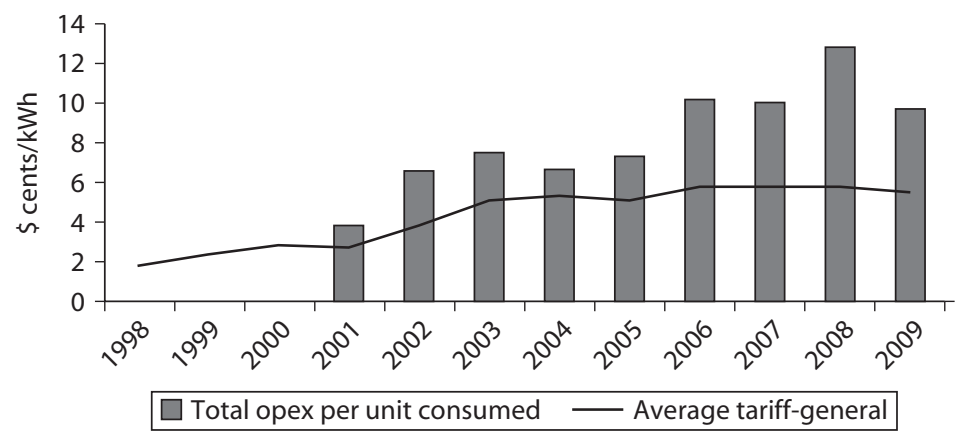

Source: An elaboration from the Power Market Structure database. Note: $\mathrm{kWh}=$ kilowatt-hour; opex = operational expenditures/costs.

Figure 7.7 Indonesia: Labor Productivity

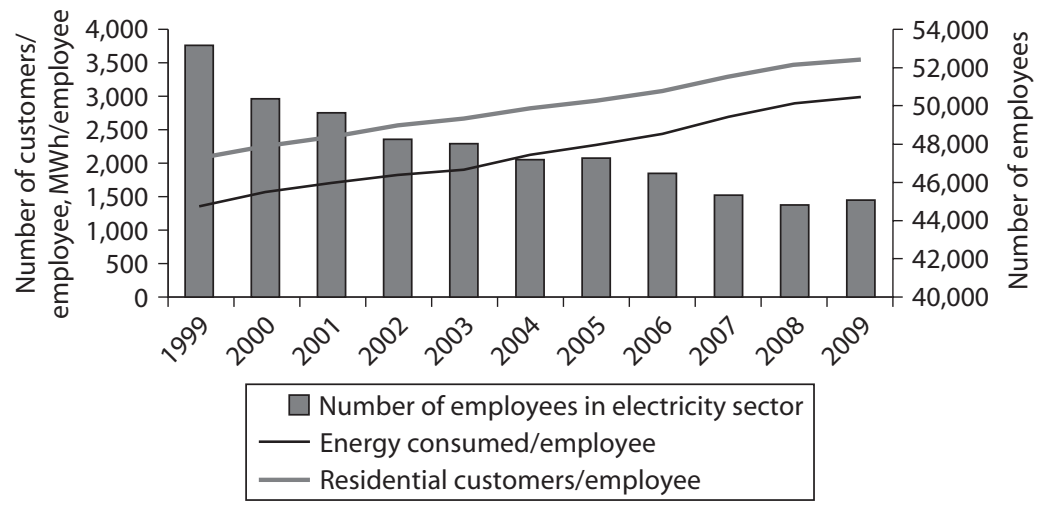

Source: An elaboration from the Power Market Structure database.

Note: $\mathrm{MWh}=$ megawatt-hour. 
Figure 7.8 Indonesia: Capacity Utilization

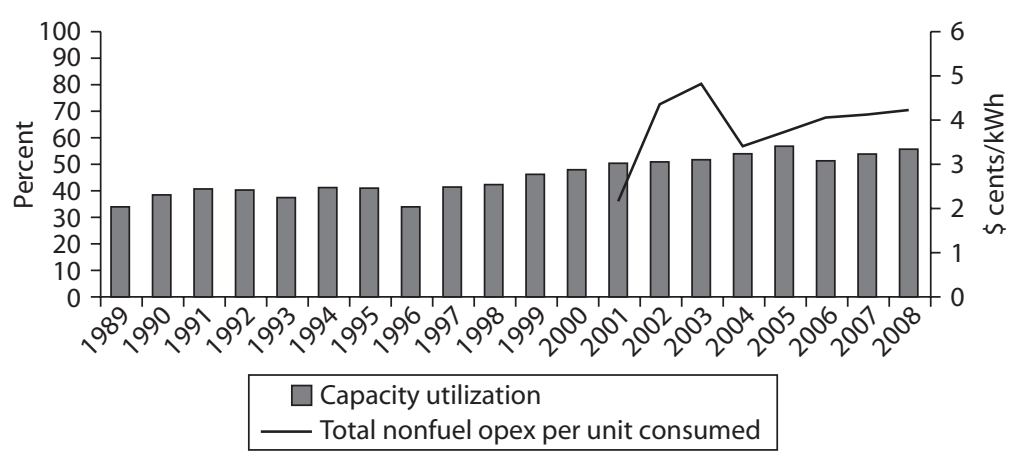

Source: An elaboration from the Power Market Structure database.

Note: $\mathrm{kWh}=$ kilowatt-hour; opex = operational expenditures/costs.

\section{Figure 7.9 Indonesia: Cost Recovery Index}

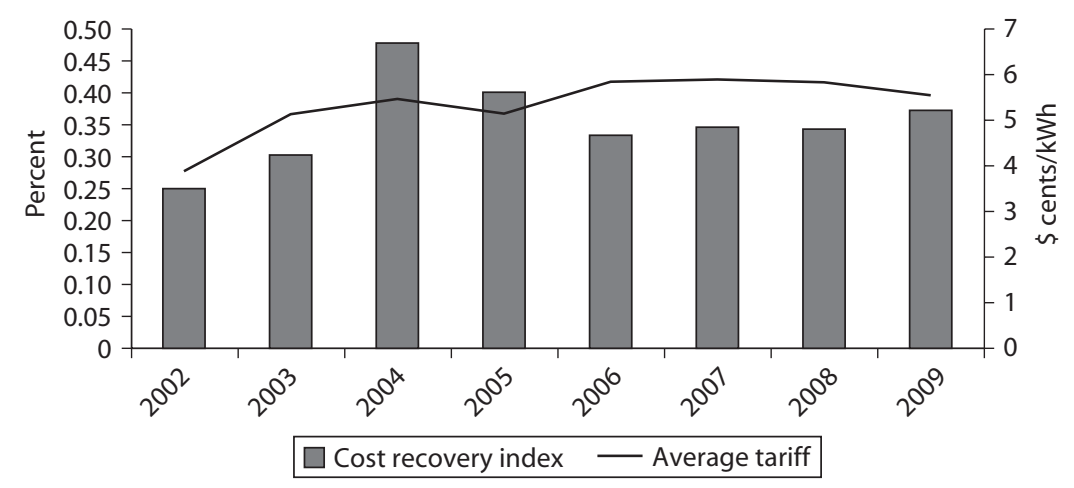

Source: An elaboration from the Power Market Structure database.

Note: $\mathrm{kWh}=$ kilowatt-hour. 


\section{Figure 7.10 Indonesia: Market Concentration}

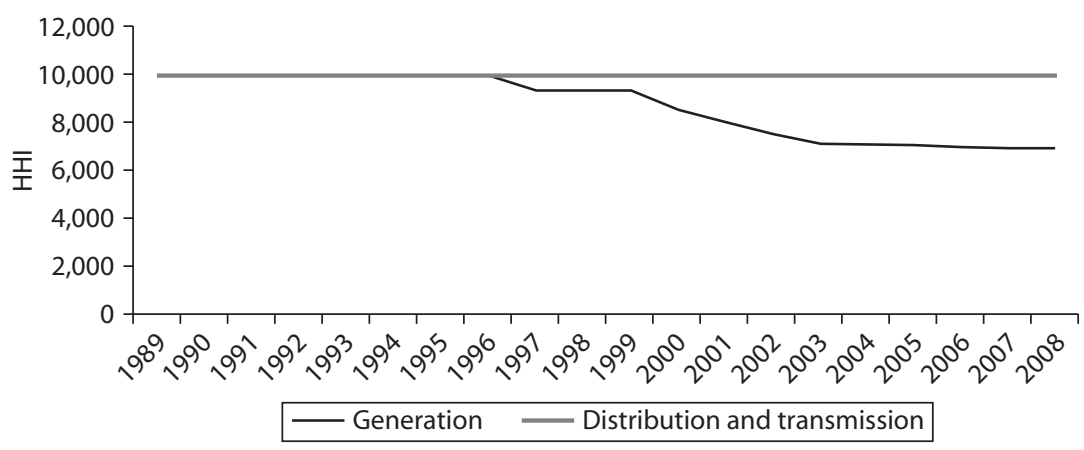

Source: An elaboration from the Power Market Structure database. Note: $\mathrm{HHI}=$ Herfindahl-Hirschman Index

\section{Figure 7.11 Indonesia: Private Ownership}

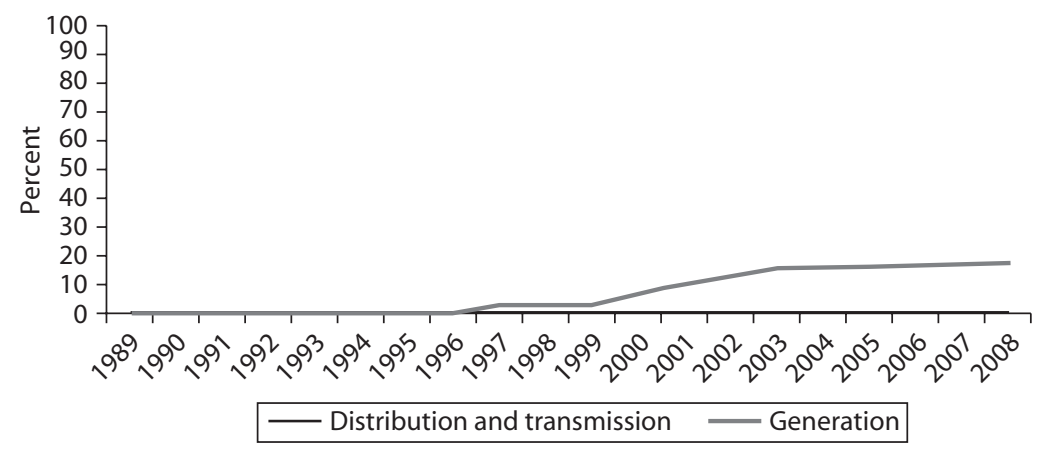

Source: An elaboration from the Power Market Structure database. 


\section{Figure 7.12 Indonesia: Private Management}

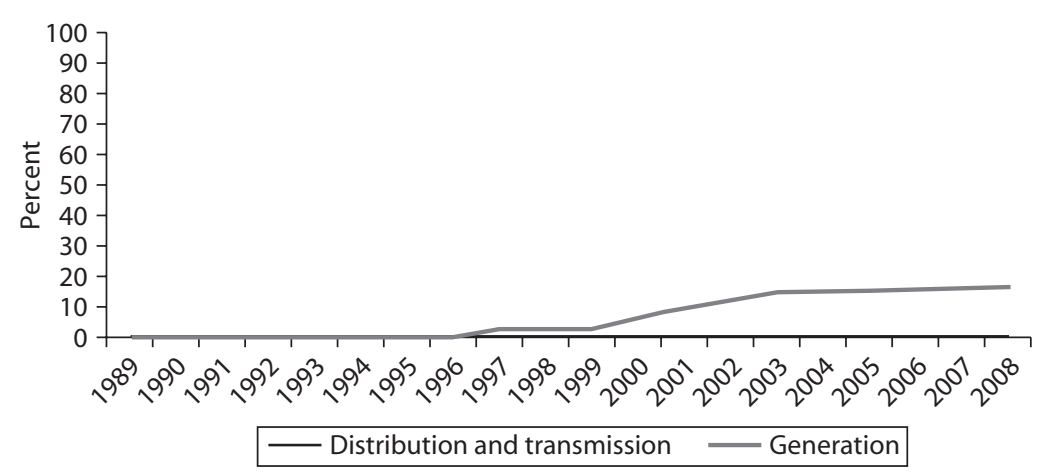

Source: An elaboration from the Power Market Structure database.

\section{Figure 7.13 Indonesia: Degree of Vertical Integration}

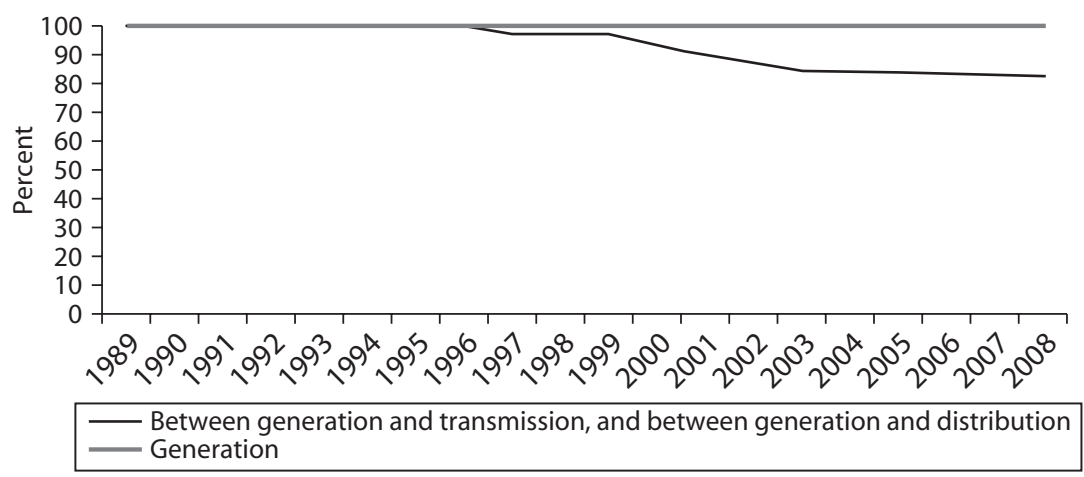

Source: An elaboration from the Power Market Structure database. 


\section{Notes}

1. PLN has additional power supply from $15,200 \mathrm{MW}$ of captive power plants that are built, operated, and used by private companies such as mining companies, oil exploration companies, pulp and paper factories, and high rise building management companies. These companies sell surplus energy from their plants to PLN. Almost 400 private companies located around Indonesia have their own power generation plants producing up to $15 \mathrm{MW}$ and mainly using diesel. They hold a special license that allows each company to generate electricity only for its own use and they may not sell it to the public.

2. "Sectors of production which are important for the country and affect the lives of the people shall be controlled by the state" (Article 33, paragraph 2, of the 1945 Constitution of the Republic of Indonesia as amended).

3. The MSOE oversees the shareholder interest of the state in PLN; the MOF is responsible for allocating government subsidies and loans to the electricity sector; and BABBENAS is responsible for planning energy sector development and has some jurisdiction over economic issues, natural resources, and regional development.

4. PLN's annual tariff yields—in \$ cents per kWh—averaged 2.1 in 1998, 2.9 in 1999, and 3.3 in 2000 and 2001.

5. This process took place at a highly sensitive time as it coincided with President Suharto's resignation. The incoming president lacked the political authority to impose the government's proposed tariff increase.

6. PLN's annual tariff yields—in \$ cents per kWh—averaged 4.8 in 2002, 6.4 in 2003, 6.5 in 2004, and 6.1 in 2005.

7. Power generated from renewable energy, marginal gas fields, and at mine mouths can be developed without a tender process. 


\section{CHAPTER 8}

\section{Republic of Korea}

The Republic of Korea falls into the upper bounds of both the system size and per capita income categories. Its power market is a medium to large size market by world standards with a total installed generating capacity of about 73,000 MW (megawatts) at the end of 2008. The Korean annual per capita income averages about $\$ 20,000$. The country relies on nuclear power and on coal and natural gas to fuel its electricity generation.

\section{Reform History}

Korea's electricity industry went through gradual changes starting in the mid-1990s. The vertically integrated state-owned company, KEPCO (Korean Electric Power Corporation) was partly unbundled and attempted privatization. When this effort failed, a competitive costbased electricity pool market was created. KEPCO has remained a vertically integrated monopoly company in generation, transmission, and distribution, including retail sales. This power industry structure has created problems for introducing market reforms, such as the one related to strong entry barriers, into all the industry sectors. To tackle those issues, in January 1999 the Korean government announced its "Basic Plan for Electricity Industry Restructuring," which set out the skeleton of the 
new electricity industry structure and the methodology for restructuring. This plan was a step-by-step action plan for transforming the Korean electricity industry from a state-owned monopoly to a privatized industry operating in a competitive power market.

In summary, the key parts of the basic plan were: (1) spin off several generation companies (GENCOs) from KEPCO's generation division to introduce competition in the supply of wholesale power; (2) gradual privatization of GENCOs to improve the efficiency of generation and thereby reduce costs; and (3) in the long run, unbundle the distribution segment from the transmission segment and introduce competition in the retail sales segment, accompanied by open access to the power system to enhance private sector participation and ensure fair competition between state-owned companies and private companies.

In April 2001 KEPCO's generation division was divided into 6 separate GENCOs, and the cost-based power pool started operation as a transitional power pool market. The electricity industry restructuring process - the privatization of GENCOs and spin-off of distribution companies-was, however, suspended in May 2004. A joint study group was established in September 2003 by a tripartite commission composed of representatives of government, the industry, and the labor unions for unbundling of KEPCO's distribution division. The group concluded that unbundling of the distribution sector could not be reasonably justified, and it recommended that this idea should be dropped, which the government quickly accepted. The Korean electricity industry restructuring plan was then suspended without any discussion about further progress.

\section{Impact on Sector Structure}

KEPCO still has more than a 95 percent market share in generation and a 100 percent market share in transmission and distribution. The current market structure is depicted in figure 8.1.

\section{Impact on Sector Performance}

- Access to electricity supply by the population. Access to electricity by household increased steadily from 85 percent in 2000 to 97 percent in 2008.

- Customer service quality. KEPCO's service quality has been good by world standards. One indicator is annual average duration of service 


\section{Figure 8.1 Korea's Current Market Structure}

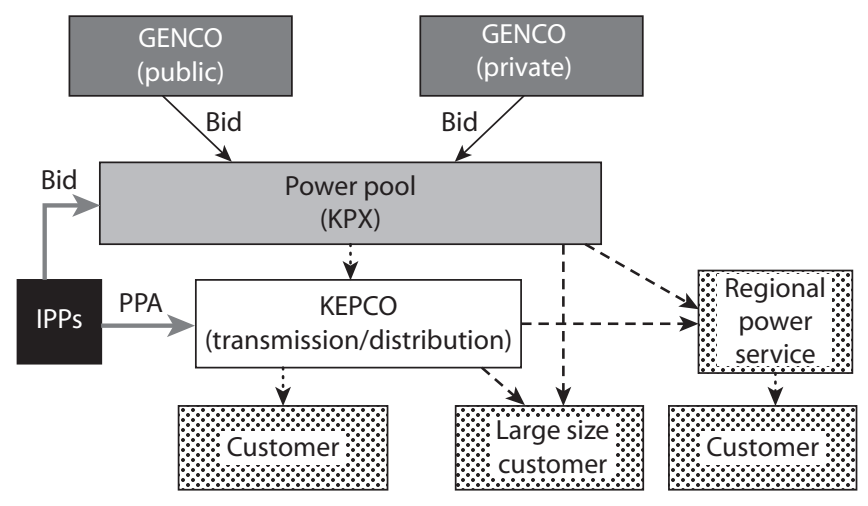

Source: An elaboration from the Power Market Structure database.

Note: GENCO = generation company; IPPs = independent power produces; $\mathrm{KEPCO}=$ Korean Electric Power Corporation; KPX = Korea Power Exchange; PPA = power purchase agreement.

interruption for KEPCO's customer, which was consistently just below 20 minutes from 2000 to 2008 . This performance coincided with a steady increase in KEPCO's nonfuel operating expenses (opex) per unit of sold energy, which indicates KEPCO's effort to maintain service quality. Another indicator of good service quality is the low level by global standards of total losses in the power system, which declined from around 5 percent in 1999 to 4 percent in 2006-08.

- Supply security. KEPCO maintained good supply security but possibly at high cost by having sufficient installed generation capacity and a diversified fuel supply. Its generating capacity utilization in the 2005-08 period was around 67 percent, which indicates the presence of substantial underutilized generating capacity. Likewise, the policy of spreading fuel supply over three imported fuels (natural gas for 18 percent of total generation, coal for 41 percent, and nuclear for 36 percent in 2008) avoided overdependence on one source, but possibly at a cost premium on generation costs. This situation is one of the main drivers for reform of the Korean power sector.

- Sustainability. The key trend since 2000 for financial sustainability is the pronounced increase in fuel costs and other opex costs that increased average opex from 3.7 \$ cents/kWh in 1998 to $13 \$$ cents $/ \mathrm{kWh}$ in 
2008. Consequently, KEPCO's cost recovery index steadily declined from 1.2 in 2000 to 0.60 in 2008, despite a steady increase in average residential tariffs from around $7 \$$ cents/kWh in 2001 to $10 \$$ cents/ $\mathrm{kWh}$ in 2007 and nearly $9 \$$ cents/kWh in 2008. These trends appeared following the unbundling of KEPCO's generation assets and the introduction of the cost-based power pool in 2001, but it is not clear whether the trends were caused by restructuring (see box 8.1). Carbon emissions have increased from 1999 onward, reflecting the increasing proportion of power generation from natural gas and coal relative to nuclear power.

Trends in these indicators are shown in charts in this section.

\section{Box 8.1}

\section{Challenges of Korea's Wholesale Electricity Market}

Many inefficiencies remain in Korea's wholesale electricity market even after the introduction of significant improvements to the payment systems for energy and capacity. The reason is that the current market is a transitional market to a twoway bidding pool with competition in the retail market. The present market structure has the following drawbacks:

- Because of the limited market share of private companies in the generation sector, with no more than 5 percent of total generation sector and no private players in transmission and distribution sectors even after restructuring, the industry is still effectively a monopoly by state-owned companies.

- The current modified cost-based pool has some problems in that end customers have to bear all inefficient overcharged generation costs. The inefficiency originated from the full production cost reimbursement guaranteed by the government to all generators.

- Distorted pricing mechanism caused by the effective state-owned monopoly results in inefficiency of resource allocation. For example, to stabilize the consumer price index for political considerations, the government prevented an increase in the electricity tariff.

- The private sector is reluctant to make firm investment commitments because of existing electricity market uncertainties. 
Figure 8.2 Milestones of Power Sector Reform in Korea

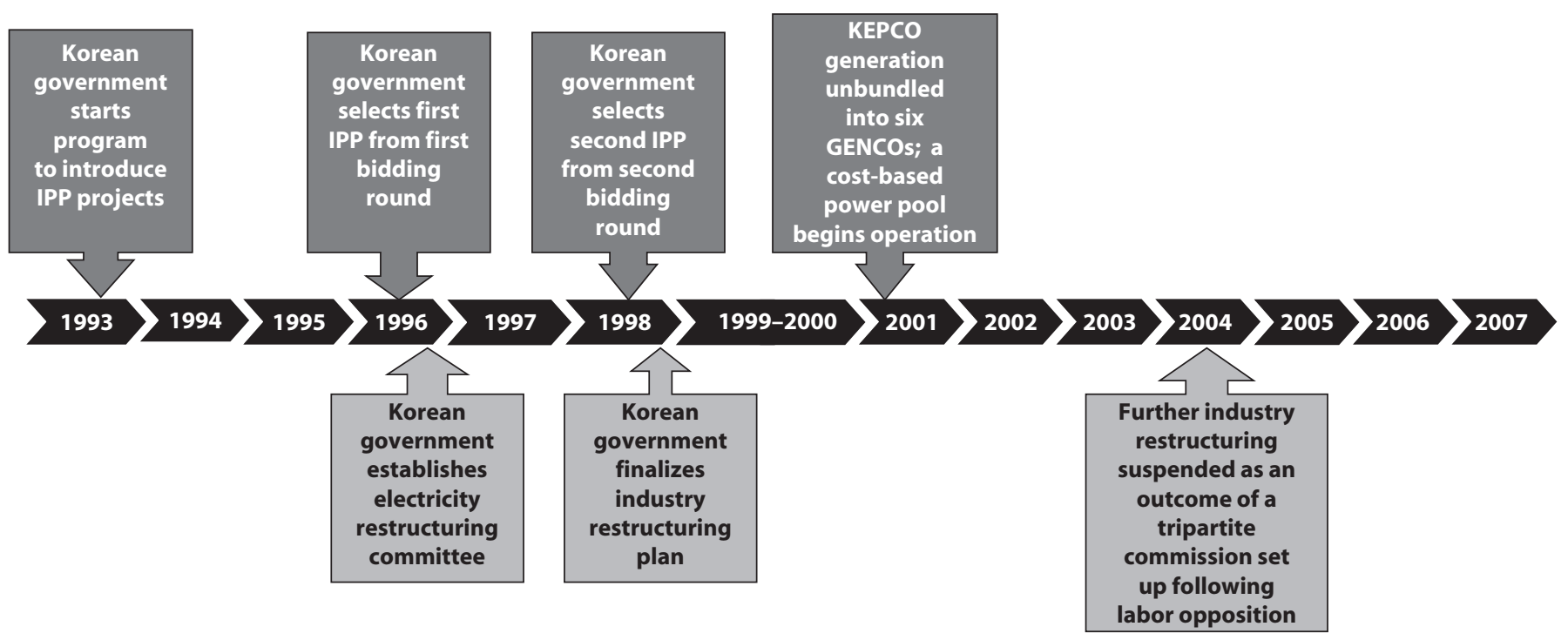

Source: An elaboration from the Power Market Structure database.

Note: The milestones are reported in different shades: white = main external factors; light gray = main government interventions; dark gray = main private sector involvements. GENCOs = generation companies; IPP = independent power producer; KEPCO = Korean Electric Power Corporation. 


\section{Figure 8.3 Korea: Access to Residential Electricity}

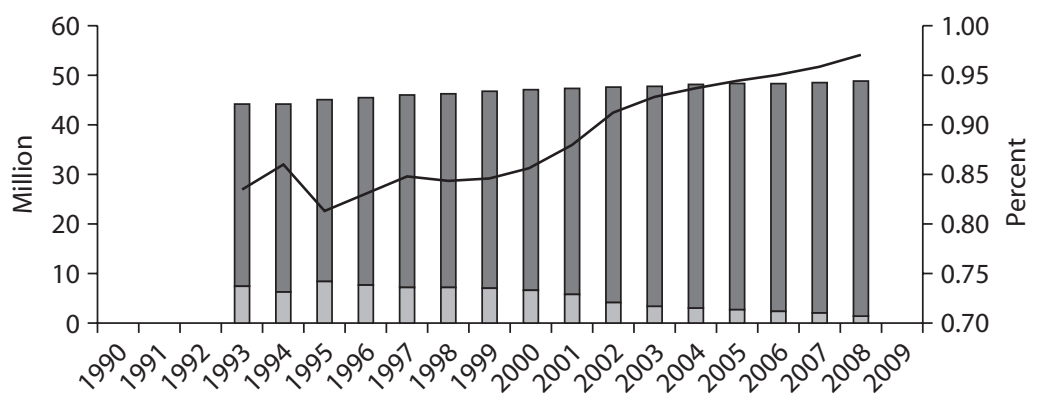

Residential customers with access $\square$ Population without access Access rate

Source: An elaboration from the Power Market Structure database.

\section{Figure 8.4 Korea: Quality of Electric Service}

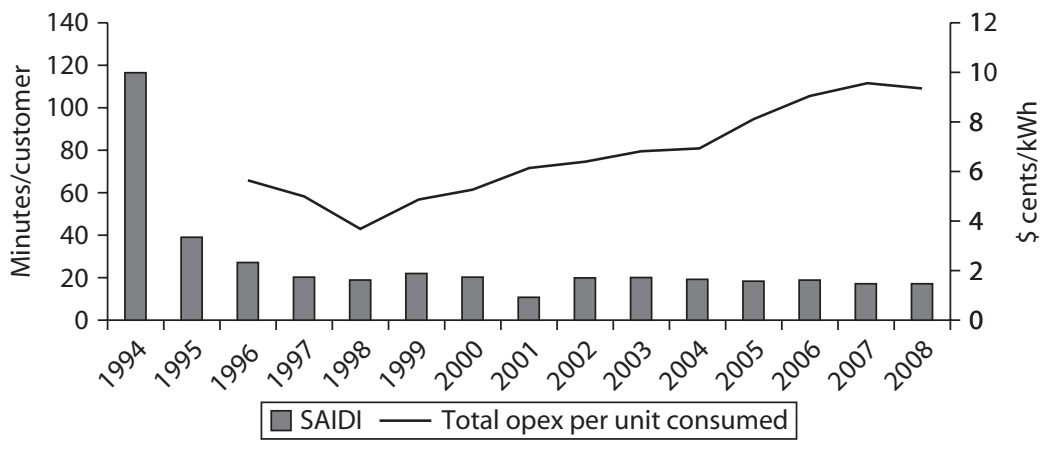

Source: An elaboration from the Power Market Structure database.

Note: $\mathrm{kWh}$ = kilowatt-hour; opex = operational expenditures/costs; SAIDI = System Average Interruption Duration Index. 


\section{Figure 8.5 Korea: System Energy Losses.}

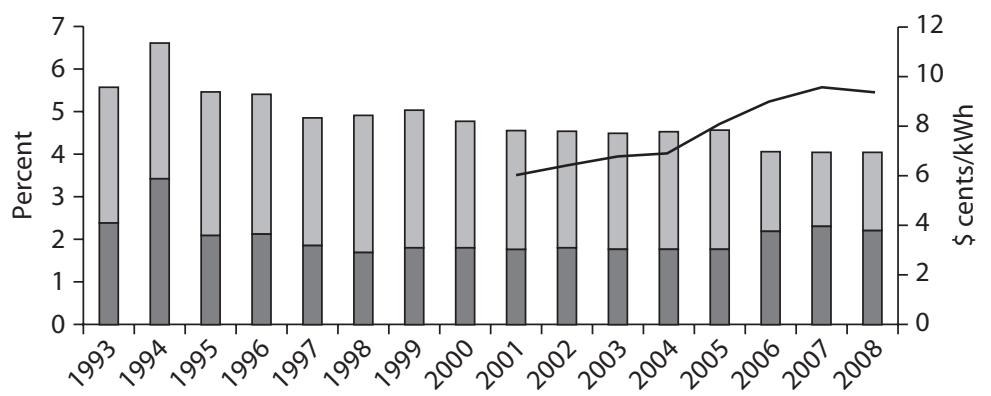

$\square$ Distribution losses $\quad \square$ Transmission losses

Total nonfuel opex per unit consumed

Source: An elaboration from the Power Market Structure database.

Note: kWh = kilowatt-hour; opex = operational expenditures/costs.

Figure 8.6 Korea: System Load Factor

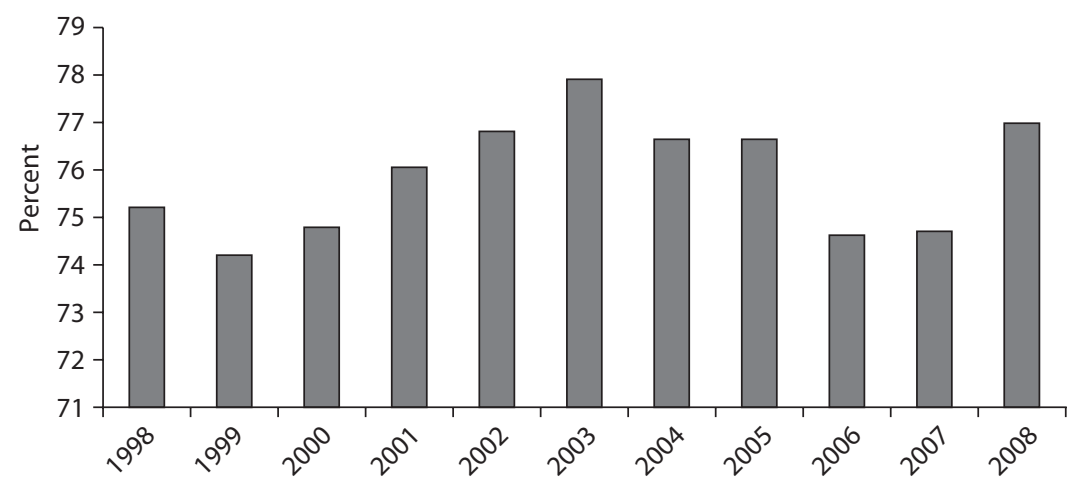

Source: An elaboration from the Power Market Structure database. 


\section{Figure 8.7 Korea: Electricity Generation by Source and Carbon Emissions}

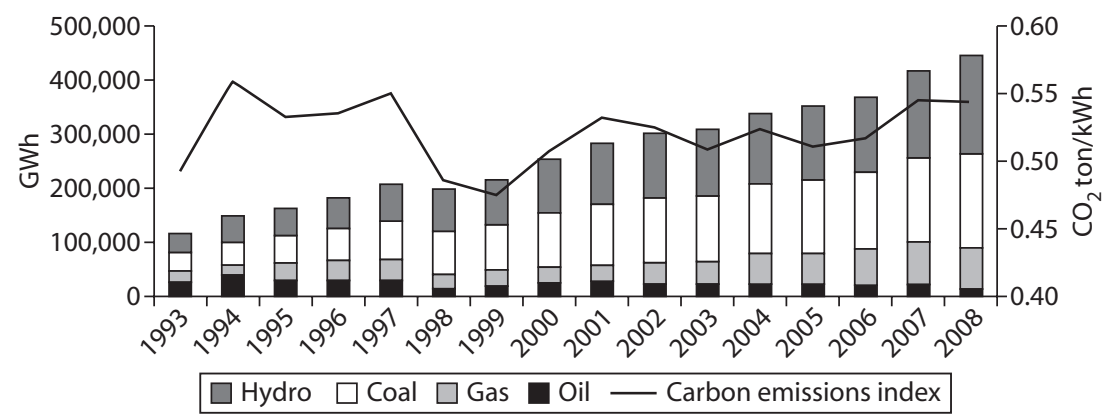

Source: An elaboration from the Power Market Structure database.

Note: GWh = gigawatt-hour; kWh = kilowatt-hour.

Figure 8.8 Korea: Energy Security and Capital Expenditure

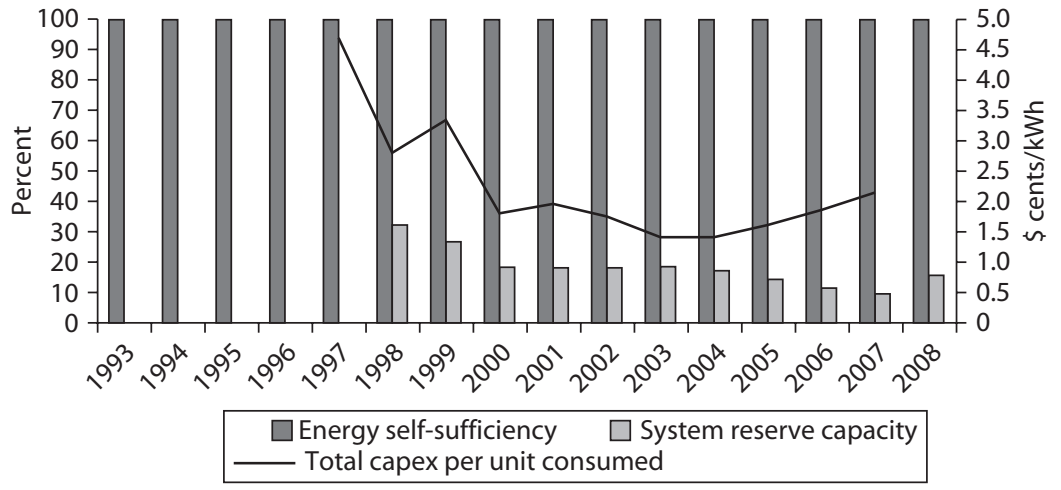

Source: An elaboration from the Power Market Structure database.

Note: Capex $=$ capital expenditures; $\mathrm{kWh}=$ kilowatt-hour. 


\section{Figure 8.9 Korea: Average Tariff and Operating Costs}

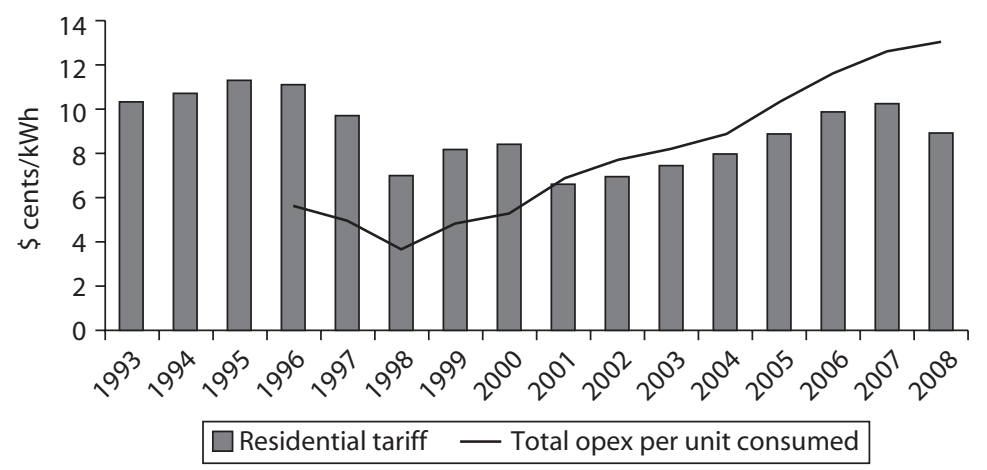

Source: An elaboration from the Power Market Structure database.

Note: $\mathrm{kWh}=$ kilowatt-hour; opex = operational expenditures/costs.

\section{Figure 8.10 Korea: Labor Productivity}

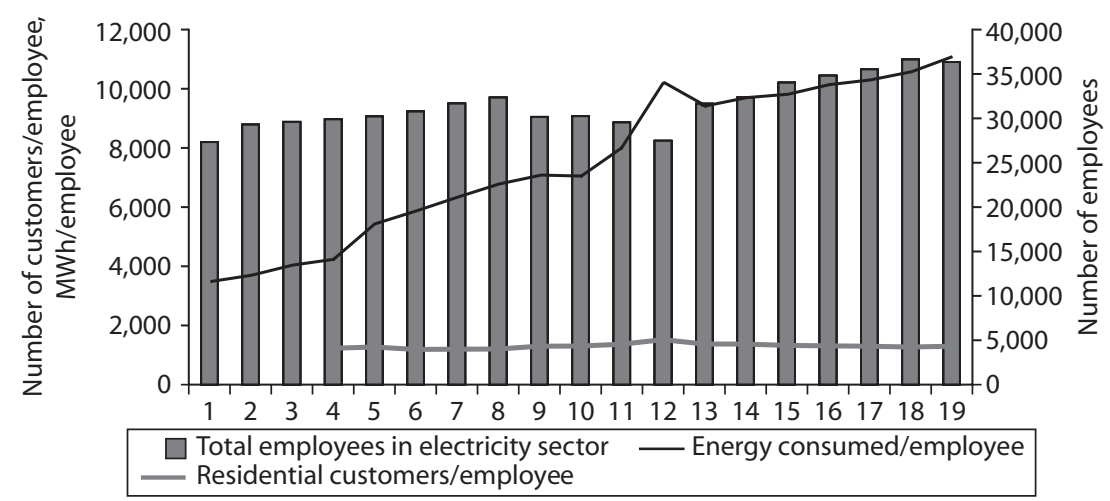

Source: An elaboration from the Power Market Structure database.

Note: $\mathrm{MWh}=$ megawatt-hour. 


\section{Figure 8.11 Korea: Capacity Utilization}

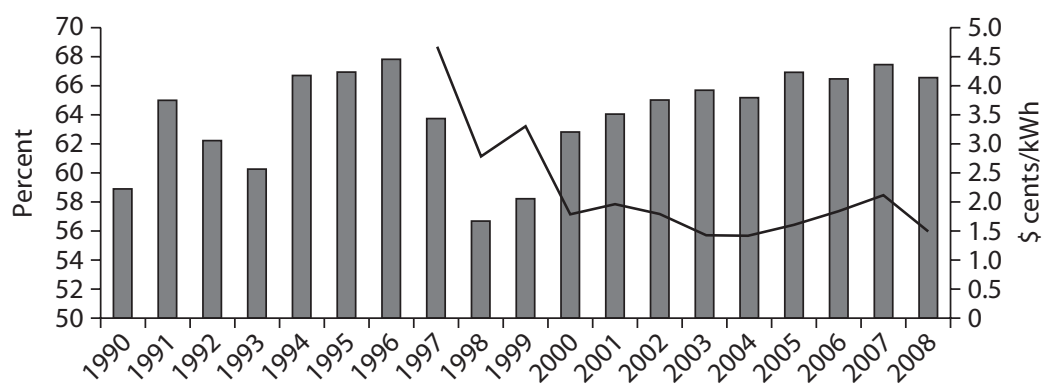

$\square$ Capacity utilization $\quad$-Total capex per unit consumed

Source: An elaboration from the Power Market Structure database.

Note: Capex $=$ capital expenditures; $\mathrm{kWh}=$ kilowatt-hour.

\section{Figure 8.12 Korea: Cost Recovery Index}

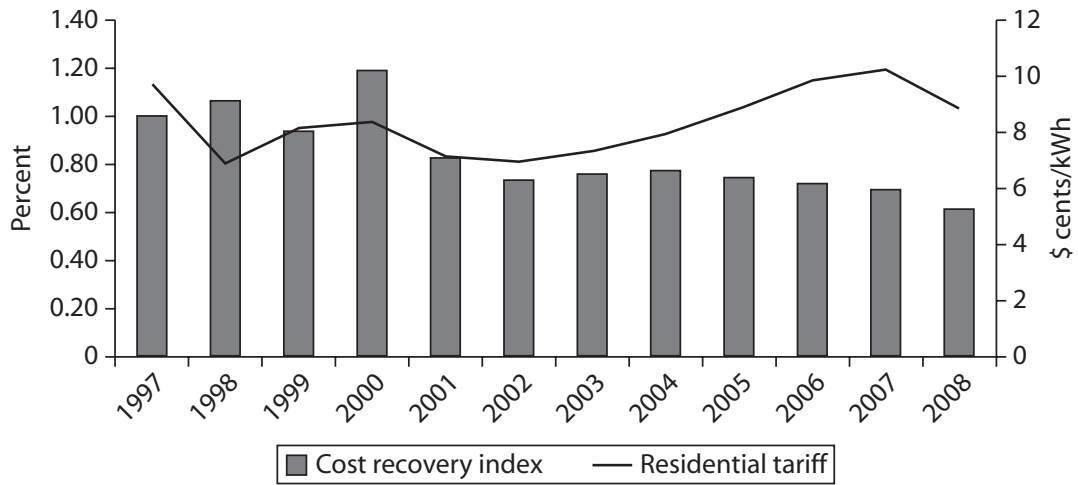

Source: An elaboration from the Power Market Structure database.

Note: $\mathrm{kWh}=$ kilowatt-hour. 


\section{Figure 8.13 Korea: Market Concentration}

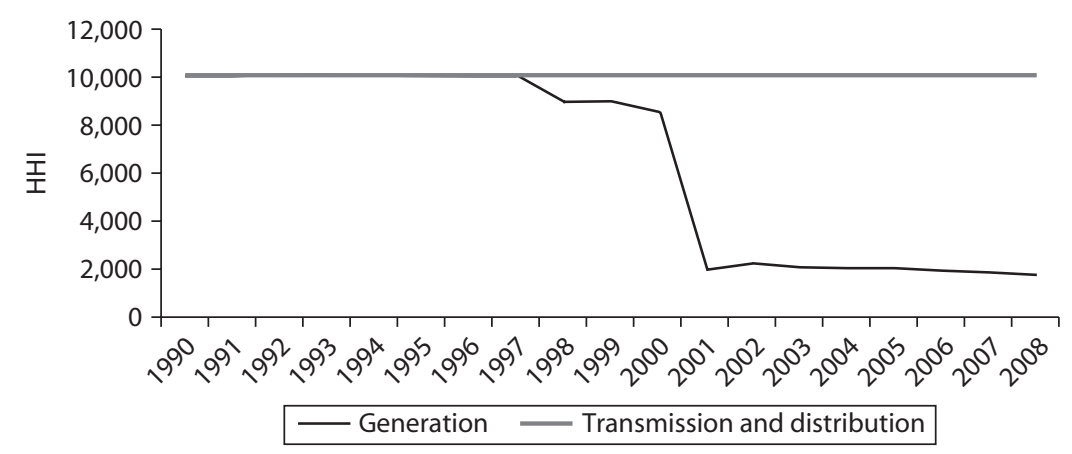

Source: An elaboration from the Power Market Structure database.

\section{Figure 8.14 Korea: Private Ownership}

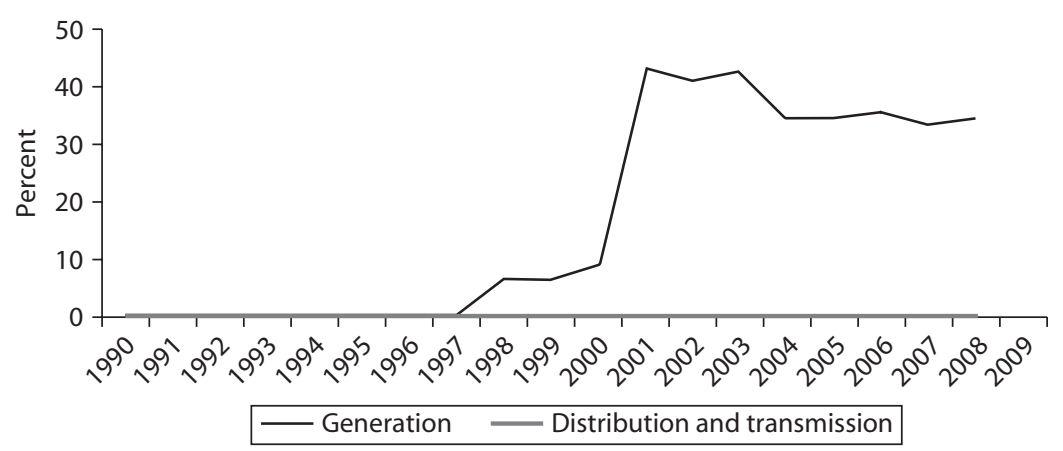

Source: An elaboration from the Power Market Structure database. 


\section{Figure 8.15 Korea: Private Management}

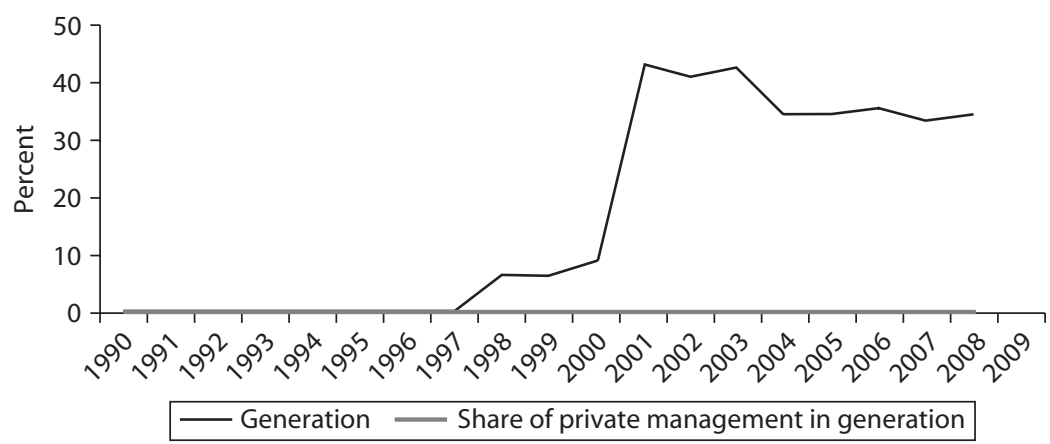

Source: An elaboration from the Power Market Structure database.

\section{Figure 8.16 Korea: Degree of Vertical Integration}

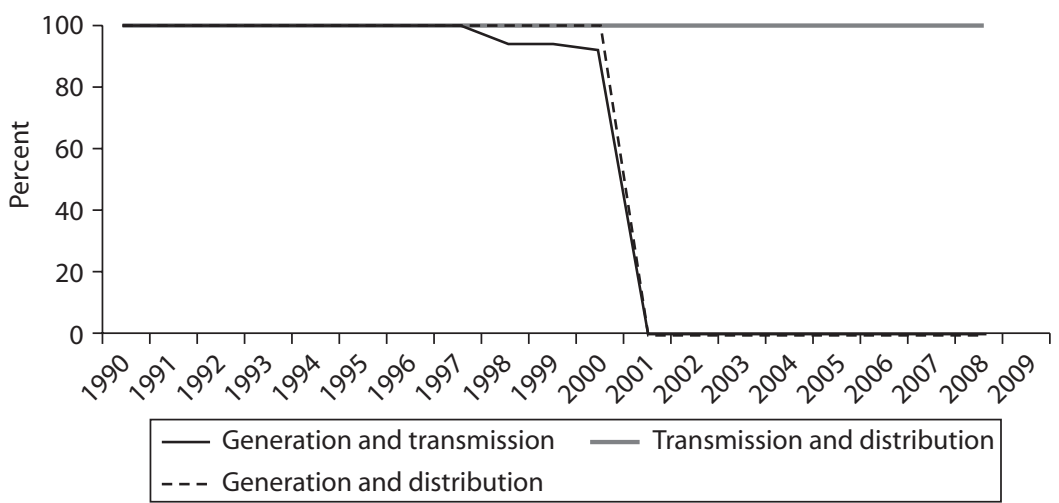

Source: An elaboration from the Power Market Structure database. 


\section{CHAPTER 9}

\section{Peru}

Peru falls into the category of medium per capita income/medium system size with a gross national income per capita of about $\$ 4,000$ and total installed generating capacity of about 7,000 MW (megawatts) in 2008. Peru is well endowed with hydroelectric and natural gas sources of energy. Its hydropower potential is considered to amount to at least 60,000 MW (producing about 400,000 GWh [gigawatt-hours] annually). Peru has about 11.8 trillion cubic feet of proven reserves of natural gas. Historically, Peru has relied mostly on hydropower, but after the entry into production in 2004 of natural gas from the huge Camisea field, current electricity generation capacity is evenly divided between thermal and hydropower. More electrical energy is still produced from hydropower, however, and thermal plants are used mainly during daily peak load periods and in seasons when hydropower output is lower than average.

The requirements of Peru's electricity users are provided by two general sources, self-generation by some users (mainly large mining and industrial consumers) ${ }^{1}$ and by regulated public service system generation, which supplies its users through the power transmission and distribution networks. Within the regulated system, power supply to the capital city, Lima, was more comprehensive and of higher quality than power supply to the rest of the country, especially to areas not connected to the main 
transmission network. Peru's pre-reform public service system was organized into vertically integrated power utilities. Two of themElectroperú and Electrolima-provided about two-thirds of Peru's electricity services through the national interconnected system Sistema Eléctrico Interconectado Nacional (SEIN). Nine regional companies provided the rest to isolated power systems (see figure 9.1).

The government's attempt to commercialize the power sector during the 1980s did not deliver significant benefits because that decade was marked by a political and economic crisis in the late 1980s and heavy political intervention in the corporate affairs of state-owned enterprises. By the early 1990s the condition of the power sector had deteriorated from lack of financing that constrained capital investment and from electricity tariffs that were below production costs. These problems led to inadequate maintenance in operating capacity and were compounded by sabotage of the power system's physical assets in the 1980s. Consequently, in 1990 only 45 percent of the population had access to electricity (a much lower proportion than in neighboring countries), the power supply was insufficient to cover demand, and power losses in the distribution segment were high-more than 20 percent.

Figure 9.1 Peru:Taxonomy of Power Sector before Reform (1990)

\begin{tabular}{|c|c|c|c|c|c|c|}
\hline Policy & \multicolumn{3}{|c|}{ Ministry of Energy and Mines } & \multicolumn{3}{|c|}{$\begin{array}{l}\text { Electroperù (Master system } \\
\text { expansion plan) }\end{array}$} \\
\hline Regulation & \multicolumn{2}{|c|}{$\begin{array}{l}\text { Ministry of Economy } \\
\text { and Finance }\end{array}$} & \multicolumn{2}{|c|}{$\begin{array}{l}\text { Electricity Tariff } \\
\text { Commission }\end{array}$} & \multicolumn{2}{|c|}{$\begin{array}{l}\text { General Electricity } \\
\text { Directorate }\end{array}$} \\
\hline Generation & \multicolumn{3}{|c|}{$\begin{array}{l}\text { Electroperú } \\
\qquad 54 \%\end{array}$} & \multicolumn{2}{|c|}{$\begin{array}{l}\text { Electrolima } \\
\qquad 24 \%\end{array}$} & $\begin{array}{c}9 \text { regional } \\
\text { companies } \\
22 \%\end{array}$ \\
\hline Transmission & \multicolumn{5}{|c|}{$\begin{array}{c}\text { Electroperú } \\
92 \% \text { of lines }>=138 \mathrm{kV}\end{array}$} & $\begin{array}{c}9 \text { regional } \\
\text { companies } \\
8 \%\end{array}$ \\
\hline Distribution & $\begin{array}{c}\text { Electroperú } \\
6 \%\end{array}$ & $\begin{array}{r}\text { Electr } \\
59\end{array}$ & & & enin & $\begin{array}{l}\text { companies } \\
\%\end{array}$ \\
\hline
\end{tabular}

$1,860,000$ regulated customers

Vertical integration $\square$ Regional company vertically integrated

Source: An elaboration from the Power Market Structure database. Note: $\mathrm{kV}=$ kilovolt. 


\section{Reform History}

Reform of the power sector started with the passage of the Electric Concessions Law (LEC) in 1992 with its regulations (Law No. 25844) and Supreme Decree (No. 009-93-EM) in 1993. These laws established a new legal framework that provided for the restructuring in 1992 and 1993 of the main vertically integrated power suppliers into separate generation, transmission, and distribution segments, and the breakup of the generation segments into various companies. They laid the basis for private operators and competition in wholesale supply and retail supply (commercialization) and for open access to the transmission and distribution networks by generators, power traders, and large power users. The new legal framework also provided for the creation of a sector regulator, OSINERGMIN (Organismo Supervisor de la Inversión en Energía y Minería), and it stipulated the methodology for rate setting, granting of concessions, customer service guidelines, and accountability of operators. The state's role was limited to sector policy and general regulations, the granting of concessions, and basic sector planning.

The generation segment was unbundled into 13 companies, of which 9 are in the private sector and account for about 70 percent of total generation capacity. The entire transmission system was transferred to 6 private companies. Restructuring of the distribution sector formed 16 companies from the distribution businesses of Electrolima and 9 regional companies. Electrolima's distribution business was split into two separate companies, Empresa de Distribución Eléctrica de Lima Norte (Edelnor) and Luz del Sur, which formed the two largest distributors in the country, to enable the regulator to apply benchmark competition in assessing the performance of these companies. The regulatory benefits from this division were deemed sufficient to outweigh any loss of economies of scale. The 1994-97 privatization in the power sector resulted in the transfer of 70 percent of generation capacity, 100 percent of transmission capacity, and 45 percent of the distribution market from public to private ownership, management, and operation.

The LEC also established the system operator COES (Comite de Operación Económica del Sistema Interconectado), which at its inception was in charge of (1) real-time dispatch of generation supply, following a merit-order procedure, independently of any bilateral contracts or the results of generation auctions; and (2) the management of the wholesale market, establishing payment obligations among generators, large users, and distribution companies. COES's membership consisted of 
20 generating companies, 5 transmission companies, and 17 distribution utilities. COES manages the dispatch of the generation capacity on the interconnected system.

The LEC recognized two categories of electricity public service users related to the size of their demand. One category consists of large userstermed free clients-with power demand greater than 1,000 kilowatts (one megawatt). Large users contract directly with generators or distribution companies through bilateral, freely negotiated contracts. They now account for about 36 percent of the total gross national consumption (including losses) of electricity. The other category consists of the small retail or regulated users who are supplied with electricity by distribution companies at regulated prices.

The power sector structure after these reforms is shown in figure 9.2.

Figure 9.3 shows the organization of the Peruvian electricity market following the reform.

The Peruvian electricity tariff scheme is designed on the basis of fullcost recovery in each of the three systems: generation, transmission, and distribution. OSINERGMIN determines the generation regulated energy

Figure 9.2 Peru:Taxonomy of Power Sector after Reform (1998)

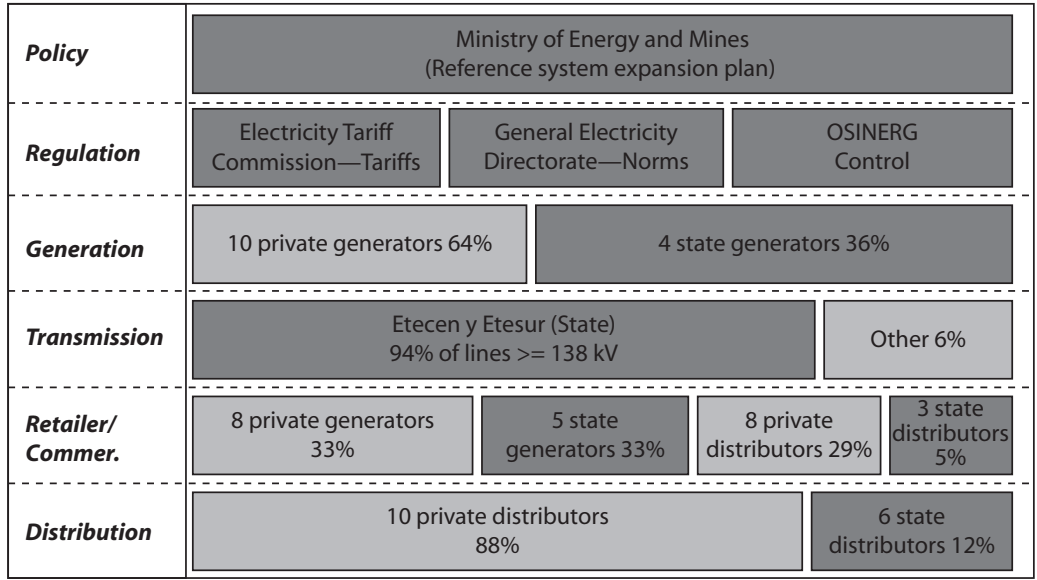

$3,052,000$ regulated customers -210 unregulated customers

State agency $\square$ Privatized company

Source: An elaboration from the Power Market Structure database.

Note: Etecen = Empresa de Transmision Electrica Centro Norte; Etesur = Empresa de Transmision Electrica Sur; kV = Kilovolt; OSINERG = Organismo Supervisor de la Inversión en Energía. 


\section{Figure 9.3 Organization of the Peruvian Electricity Market}

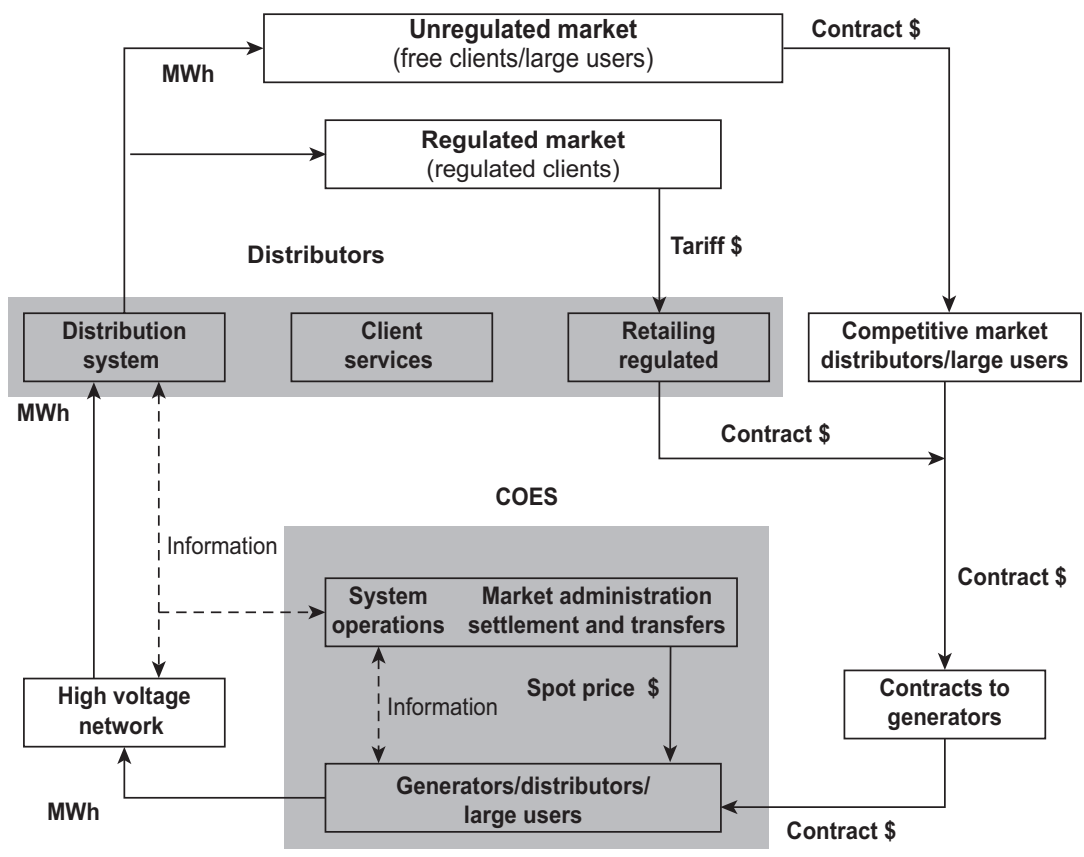

Source: An elaboration from the Power Market Structure database.

Note: $\mathrm{COES}=$ Comité de Operación Económica del Sistema Interconectado; MWh = megawatt-hour.

tariff every year, according to the expected evolution of demand and generation supply capacity, fuel prices, competitive generation auction prices, and other economic parameters, such as price indexes and inflation. COES carries out real-time dispatch of generation supply by following a cost-based, merit-order procedure independently of bilateral contracts or the results of energy auctions. Hourly transactions among generators, distribution companies, and large users in the wholesale market are done at the marginal energy price. $^{2}$

Transmission tariffs are regulated under an economic cost-based procedure and the results of competitive bidding for transmission facilities that are required according to a transmission planning exercise. They are recalculated every year. Distribution tariffs are regulated with reference to a cost-based efficient model company for each of five typical distribution sectors (urban high density, urban medium density, urban low density, urban-rural, and rural). These values are recalculated every four years. Transmission and distribution tariffs are regulated for all types of users. 
Generation, on the other hand, has different price regimes-a generation tariff for small users, established by the regulator, and two options for large users: (1) negotiate electricity quantities and prices directly with suppliers (generators or distributors) or (2) participate in the supply auctions as part of an aggregated demand with distributors.

The private companies in the Peruvian power sector that emerged from the 1992 reform made substantial investment commitments under their privatization concessions that they fulfilled in 1996-99, and their investments in generation, transmission, and distribution increased year after year, reaching a peak of about $\$ 760$ million in 1999. They reduced their levels of investments in the following years to about $\$ 230$ million in 2003. Sector authorities and the government were concerned by this reduction of investment and the resulting lower reserve margin of the system. Their concern was compounded by a drop in hydropower output caused by an extended dry period in 2003 and 2004.

Moreover, between 1997 and 2000 the privatization process slowed down considerably due to domestic and foreign factors, such as the impact of the Asian financial crisis, a brief domestic political crisis, and a steady reduction of public approval in government's privatization policy. In 2002 the government's final attempt to reengage in the privatization of power suppliers suffered an important setback when strong regional opposition and public outcry forced it to cancel the privatization of two publicly owned generating companies serving southern provinces.

To address the problems, Congress passed Law No. 28832, "To Ensure the Efficient Development of Electricity Generation," in July 2006. This law introduced important changes to the LEC, mainly regarding generation and transmission regulation, the administration and functioning of the electricity market, and the determination of electricity prices. The most important changes were (1) establishment of an obligatory competitive auction mechanism to contract the supply to distribution companies that is gradually replacing the original system of administrated tariffs in the regulated market; (2) formalization of transmission planning nationwide and a bidding process for building and operating the required system transmission expansion resulting from the planning; (3) changing the governance of COES with the introduction of more distribution companies and large users as new members to counter the perception that COES was controlled by a few large companies; (4) the pass-through of auction prices as part of the regulated generation tariff; and (5) stabilization of remuneration for the use of transmission facilities.

The power sector structure after these reforms is shown in figure 9.4. 
Figure 9.4 Peru:Taxonomy of Power Sector after Reform (2008)

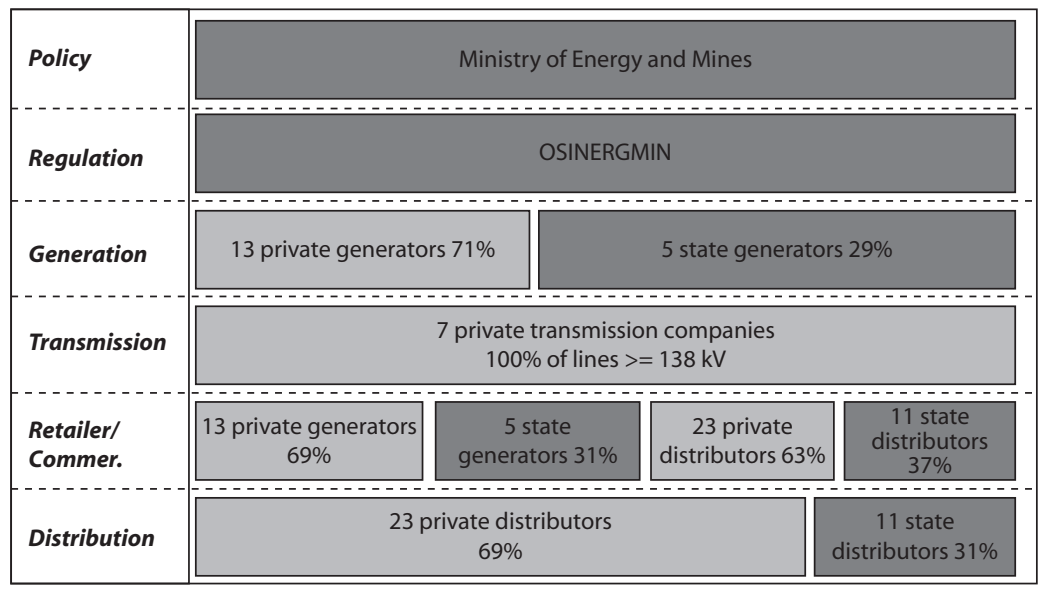

4,624,534 regulated customers -258 unregulated customers

State agency $\square$ Privatized company

Source: An elaboration from the Power Market Structure database.

Note: $\mathrm{kV}$ = kilovolt; OSINERGMIN = Organismo Supervisor de la Inversión en Energía y Minería.

\section{Impact on Sector Structure}

At present, there are about 5,590 MW of installed firm-generating capacity in the market, of which the private sector owns 70 percent (some 3,909 MW). The largest generation company, Empresa de Generación Eléctrica de Lima (Edegel) has 28 percent of the total capacity, and the largest four generators have 75 percent of the total capacity. Accordingly, Electroperú's share of the generation market declined from 72 percent in 1991 to 25 percent in 2007. The generation share of the public sector declined during the same period from 100 percent to 27 percent. As a result of the restructuring and privatization process and the subsequent expansion of privately owned generation capacity, the market concentration index (Herfindahl-Hirschman Index) dropped considerably from 5,995 in 1991 to 1,724 in 2008.

Six private companies own nearly all the high voltage transmission system (with the public sector owning only some subtransmission lines to supply remote areas). Three of these companies are subsidiaries of Interconexión Eléctrica, ISA, of Colombia, and they own about 85 percent of all the high voltage transmission assets (measured by line length). 
Privately owned companies presently own 69 percent of the distribution segment of the national power system, and various regional publicly owned distribution companies own the other 31 percent, measured by number of customers. The two largest private distribution companies serve the capital city of Lima, with 41 percent of the national market. Distriluz, ${ }^{3}$ a holding of four regional companies, is the largest of the publicly owned companies and serves a diverse market that includes several medium size cities with moderate load concentration. The remaining publicly owned distribution companies serve medium size and small towns with low load concentration and rural areas with dispersed communities and low demands.

\section{Impact on Sector Performance}

Evidence of possible impacts from unbundling and the other reforms in Peru that we have described is sought from trends from the early 1990s up to 2008 in the following indicators.

- Access to electricity supply by the population. Peru offers a successful model of electrification, increasing electrification rates from the low level of about 60 percent in 1995 to almost 80 percent in 2008. The number of connections increased exponentially from about 2 million in the early 1990s to more than 4 million in 2007. Some of this increase was achieved by electrification of rural areas under the General Directorate of Rural Electrification.

- Customer service quality. Data on service quality is available only from 2002, when the level and intensity of power cuts were already at relatively low levels compared to the levels before sector reform. Frequency and duration of power cuts have been increasing in recent years, particularly in service areas outside of metropolitan Lima where the frequency has been almost double that in Lima and their duration about three and a half times more. This difference is due partly to low levels of investment by the publicly owned distribution companies. The reformed power market has yielded remarkably stable tariffs for regulated electricity supply to consumers, even in the presence of volatile marginal energy costs in the wholesale power market. The annual average tariff declined and then increased gently from 1995 to 2007 within a narrow band of 8.3 \$ cents to 10.4 \$ cents per kWh (kilowatt-hour). Likewise, the annual average tariffs negotiated by large users were 
much lower and also varied relatively little between $4.7 \$$ cents and $5.6 \$$ cents per $\mathrm{kWh}{ }^{4}{ }^{4}$

- Supply security. In 1995 power losses in the transmission and distribution systems were close to 20 percent nationally and above 30 percent in some areas. Electricity distribution operations improved considerably following the sector reform, and these losses went down to 8.2 percent in 2007. System reserve generation capacity has been generally adequate. For the first time since the reform, the electricity system suffered power cuts of significant magnitude in 2008 due to congestion in the transmission system, a capacity limitation in the Camisea gas pipeline, and low reserve capacity during the dry season (which was as low as 5 percent in August 2008). New electricity generation was added subsequently to cover the expected demand and to increase the capacity reserve margin to more than 20 percent.

- Financial sustainability. The financial performance of the privatized generators and distributors was sound. The two private distribution companies that serve Lima have concentrated and profitable markets that support sound technical and financial performance. Distriluz's market is not highly profitable, but yields a sufficient return to sustain the business and expand the market modestly. The publicly owned distribution companies, on the other hand, have struggled to maintain their financial stability and to invest in system maintenance and expansion.

- Environmental sustainability. Peru has had low average carbon emissions per unit of energy generated for decades because power generated from fossil fuels has constituted around 20 percent or less of total generated power. The increase in carbon emissions since 1984, with the increase in thermal power generation to around 40 percent of total generation, has been mitigated by the use of natural gas from the Camisea field as the generation fuel.

Trends in these indicators are shown in the following figures. 


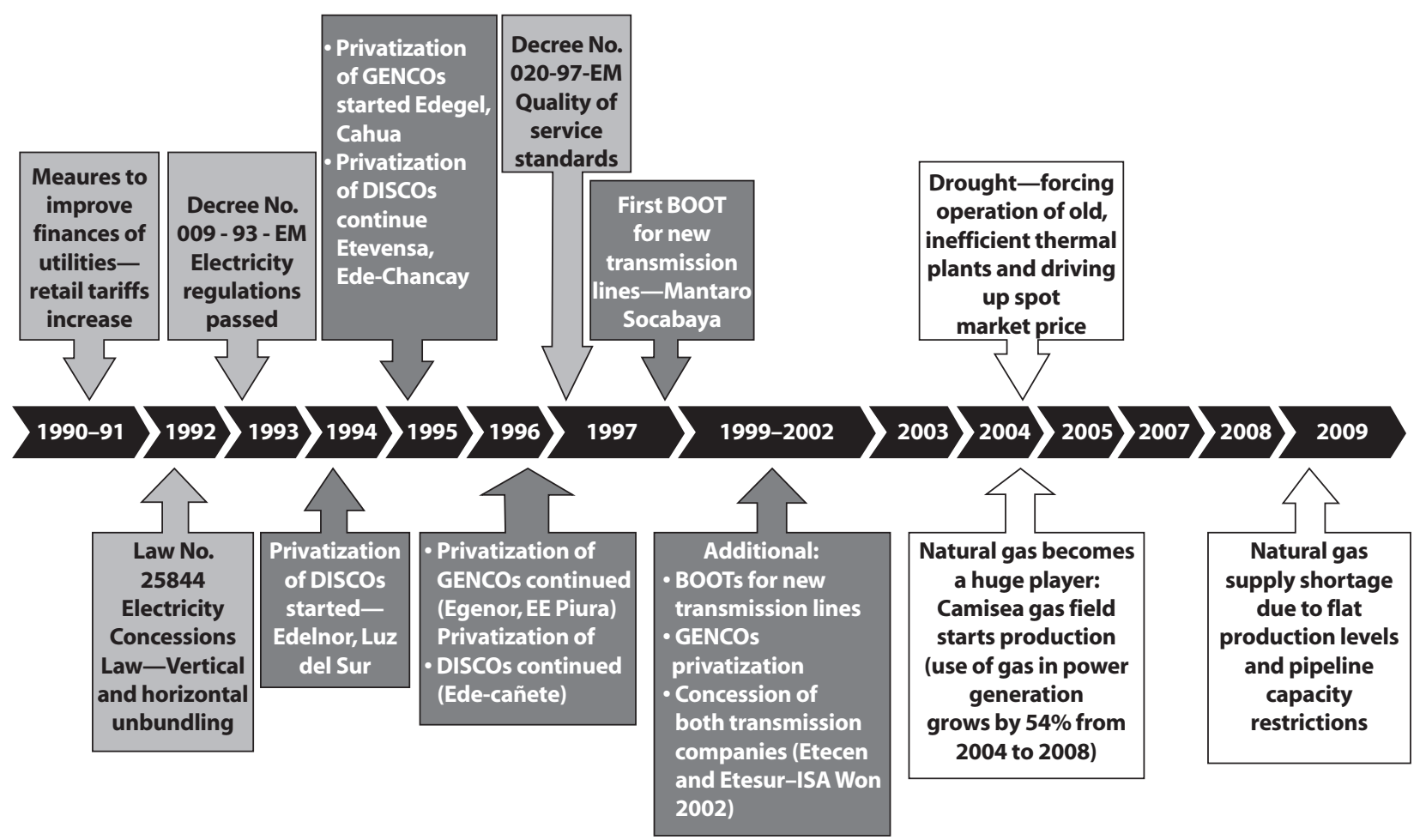

Source: An elaboration from the Power Market Structure database.

Note: The milestones are reported in different shades: white = main external factors; light gray = main government interventions; dark gray = main private sector involvements. BOOT =

build-own-operate-transfer; DISCOs = distribution companies; Edelnor = Empresa de Distribución Eléctrica de Lima Norte; Egenor = Empresa de Generación Eléctrica Nor; Etecen =

Empresa de Transmision Electrica Centro Norte; Etesur = Empresa de Transmision Electrica Sur; GENCOs = generation companies 


\section{Figure 9.6 Peru: Access to Residential Electricity}

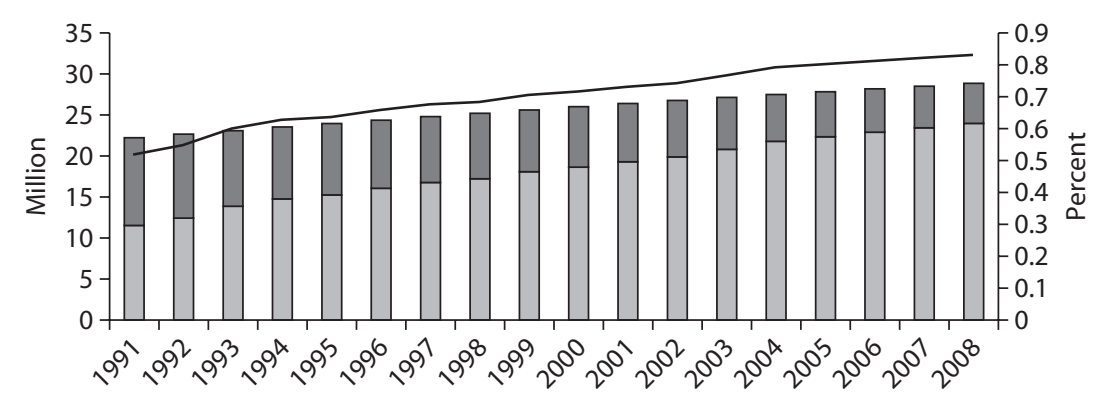

Population without access $\square$ Residential customers with access Access rate

Source: An elaboration from the Power Market Structure database.

Figure 9.7 Peru: Quality of Electric Service

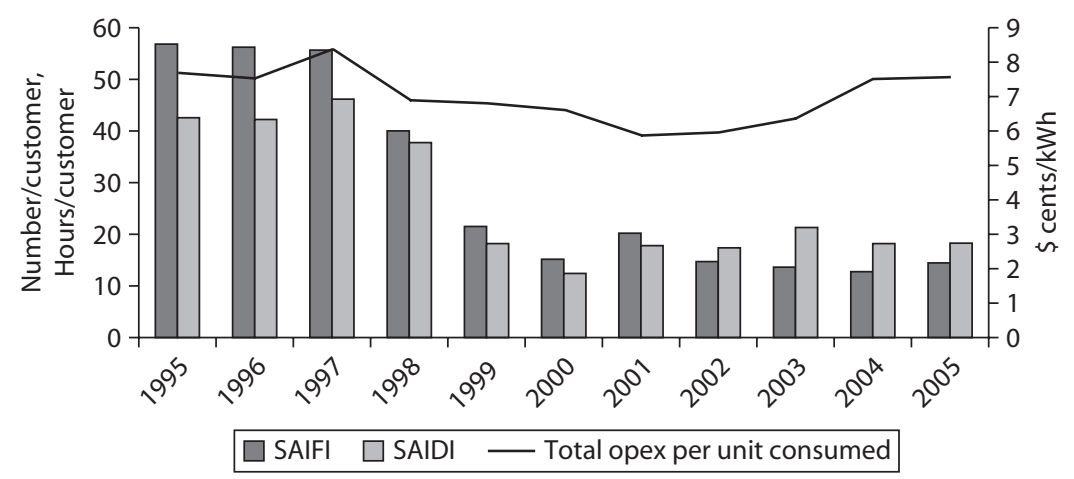

Source: An elaboration from the Power Market Structure database.

Note: kWh = kilowatt hour; opex = operational expenditures/costs; SAIDI = System Average Interruption Duration Index; SAIFI = System Average Interruption Frequency Index. 


\section{Figure 9.8 Peru: System Energy Losses}

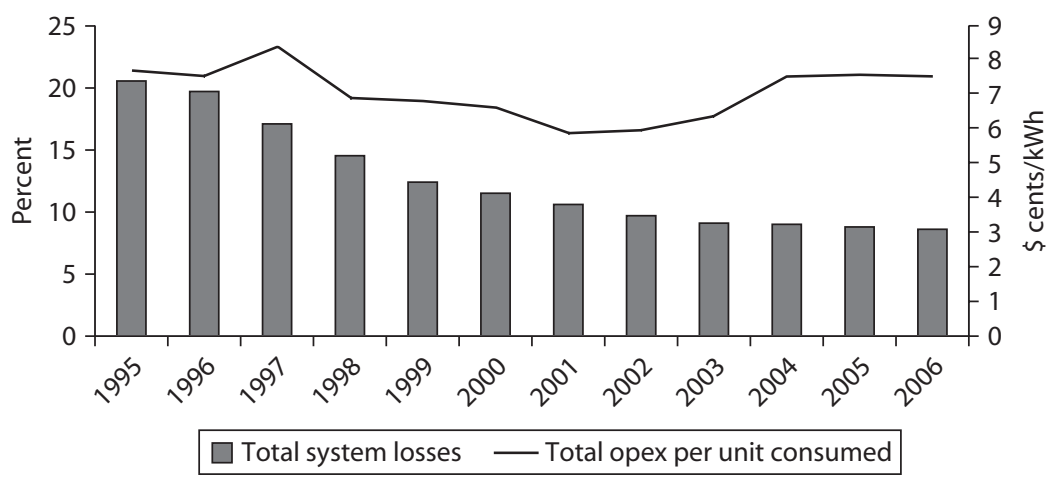

Source: An elaboration from the Power Market Structure database. Note: $\mathrm{kWh}=$ kilowatt hour; opex = operational expenditures/costs

\section{Figure 9.9 Peru: Electricity Generation by Source and Carbon Emissions}

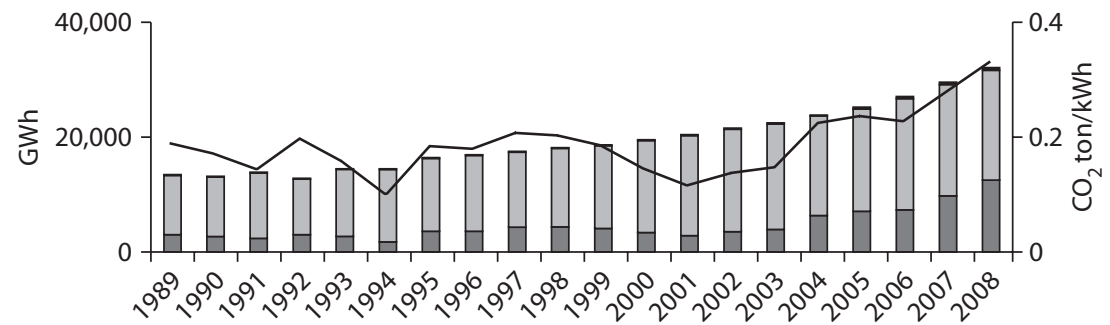

$\square$ Thermal $\square$ Hydro

- Nonhydro renewables (mostly biomass and waste) Carbon emissions index

Source: An elaboration from the Power Market Structure database. Note: GWh = gigawatt hour; kWh = kilowatt-hour. 


\section{Figure 9.10 Peru: Energy Security and Capital Expenditure}

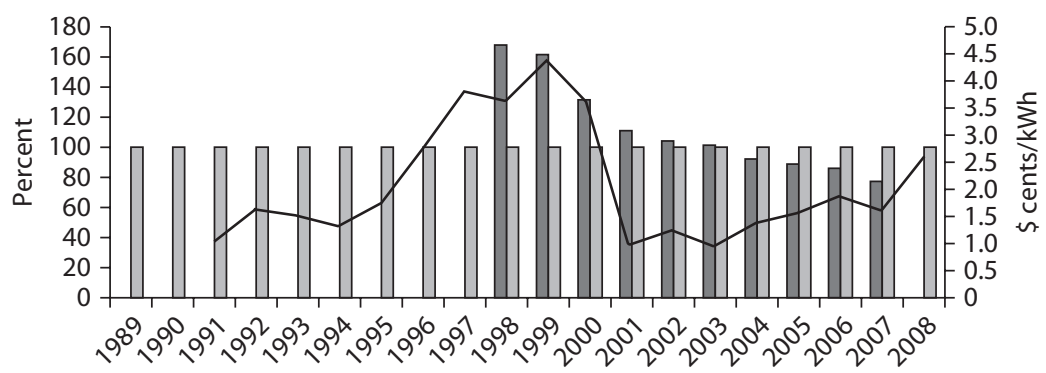

System reserve capacity $\square$ Energy self-sufficiency

Total capex per unit consumed

Source: An elaboration from the Power Market Structure database.

Note: Capex = capital expenditures; $\mathrm{kWh}=$ kilowatt hour.

Figure 9.11 Peru: Average Tariff and Operating Costs

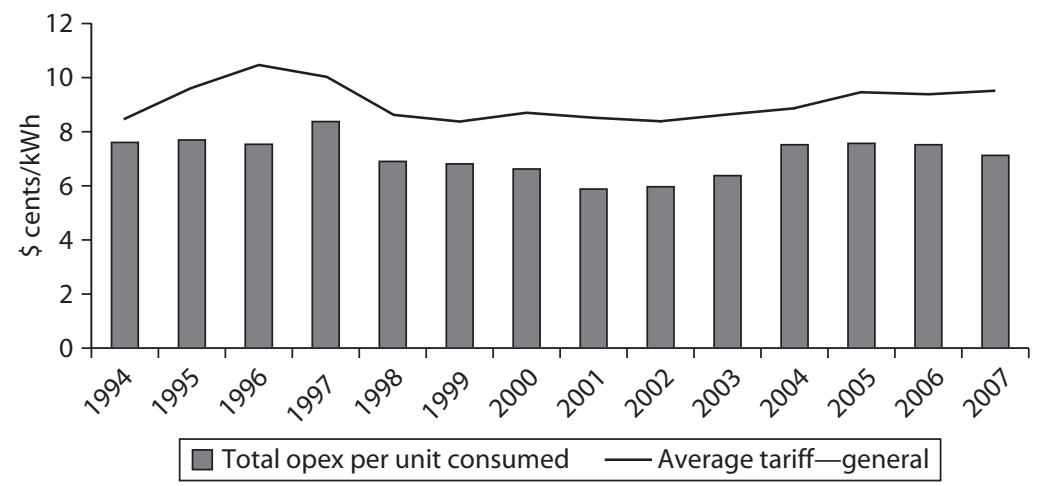

Source: An elaboration from the Power Market Structure database. Note: $\mathrm{kWh}=$ kilowatt hour; opex = operational expenditures/costs. 


\section{Figure 9.12 Peru: Capacity Utilization}

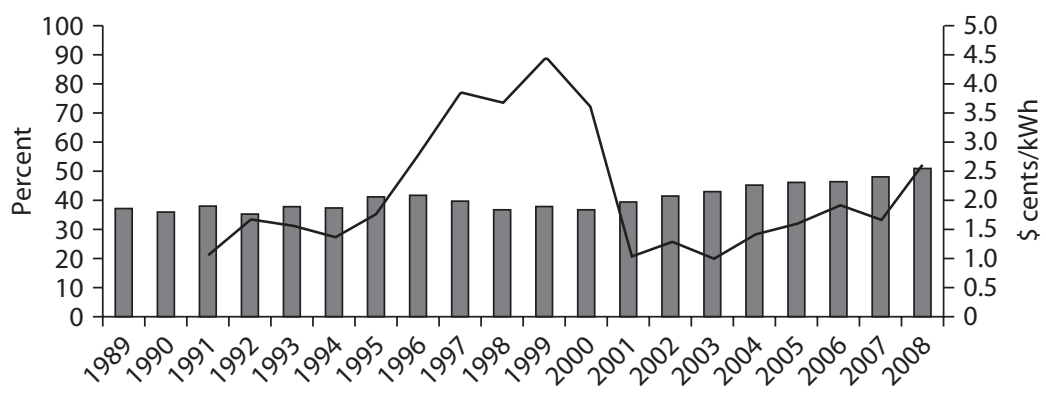

Capacity utilization —Total capex per unit consumed

Source: An elaboration from the Power Market Structure database.

Note: Capex = capital expenditures; $\mathrm{kWh}=$ kilowatt hour.

\section{Figure 9.13 Peru: Cost Recovery Index}

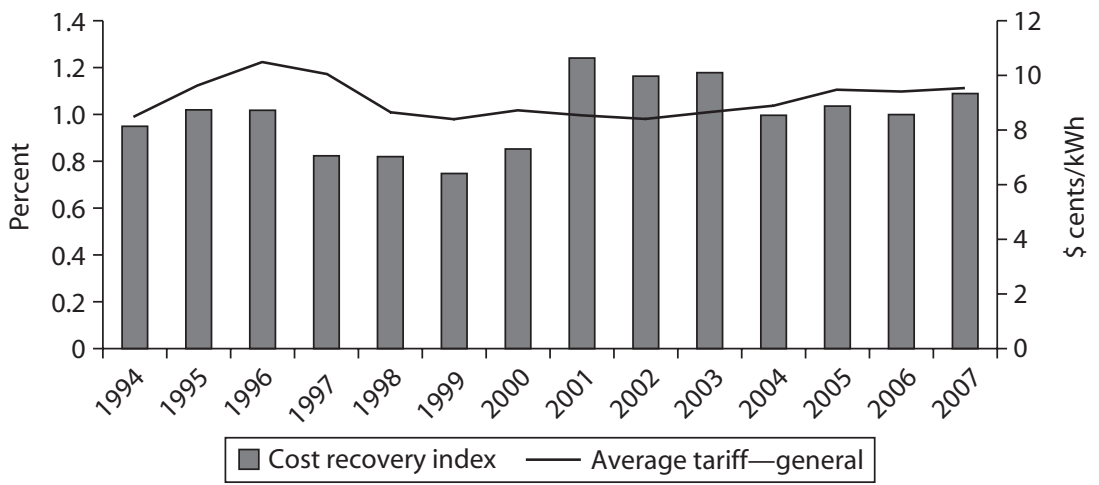

Source: An elaboration from the Power Market Structure database. Note: $\mathrm{kWh}=$ kilowatt hour. 


\section{Figure 9.14 Peru: System Load Factor}

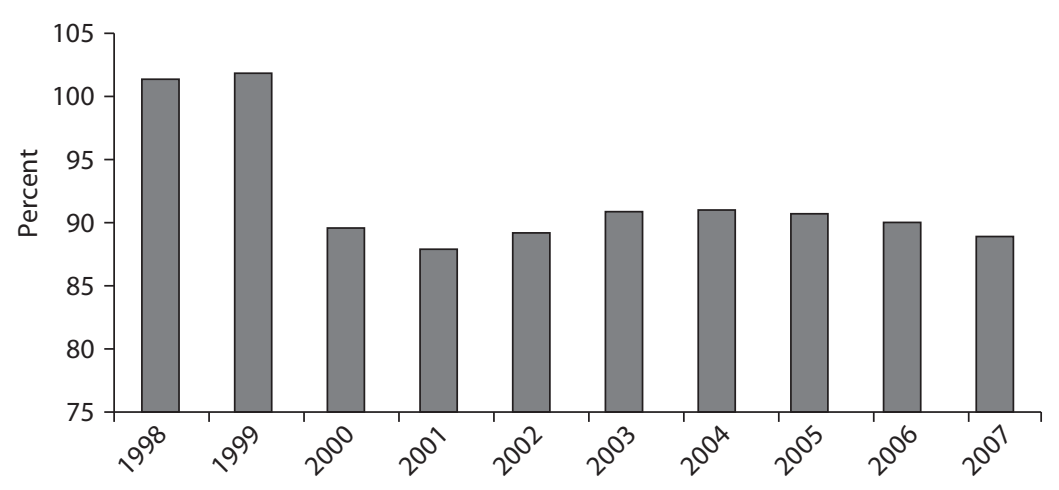

Source: An elaboration from the Power Market Structure database.

\section{Notes}

1. Mining is the major user of self-generated electricity because mines are usually located in remote locations that are difficult to reach by the electricity grid. Up to 1997 self-generation averaged about 21 percent of total electricity generation. Since 1998, with the expansion of the national interconnected system, this percentage decreased steadily, averaging about 12 percent of total generation in the period 1998-2007, and dropping to 6 percent in 2007.

2. The marginal energy price is a fluctuating value determined by the operating cost of the most expensive generating unit needed to cover the peak demand at a specific moment.

3. Distriluz was privatized in 1998, only to be returned to public hands in August 2001, after the private operator failed to comply with its contractual obligations with the state.

4. Large users benefit from lower tariffs than regulated customers partly because suppliers incur the significant costs of the distribution system and customer service only for the latter category of consumers. 



\section{South Africa}

South Africa falls well into the category of large system size/middle per capita income gross domestic product per capita of about $\$ 6,000$ ). Its total installed generating capacity reached 40,000 MW (megawatts), of which 87 percent consists of coal-fired capacity. Power supply has been in the hands of Eskom - a generation and transmission monopoly that is one of the largest power supply companies in the world. The existence of this monopoly reflects a historic national policy of concentrating supply arrangements under state ownership to obtain economies of scale and ensure the availability of the huge amounts of required financing at affordable terms, under which competition and private participation is not considered for the provision of infrastructure services. Currently, Eskom also supplies about 60 percent of total distribution, and the rest is supplied by numerous municipalities that buy most of their bulk power needs from Eskom.

By the 1980s Eskom's economic performance had deteriorated. Its management had overinvested in generating capacity, at heavy cost to the economy, without being held accountable for its decisions, yet most of the population lacked access to electricity. A large proportion of Eskom's electricity sales was-and still is- to the mining and heavy industrial sectors. This situation forced South Africa's government to consider the need 
to reform Eskom and other large state-owned enterprises that faced similar problems.

\section{Reform History}

Following the advent of democratic government in 1994, reform took the shape of corporatizing and commercializing Eskom, rather than undertaking more radical options, and creating an independent regulator in 1995. Eskom then improved its productivity.

Eskom embarked on a huge program of electrification and associated strengthening of distribution systems. It eased the financial strainbecause electricity tariffs were kept low to support economic growth and to keep electricity affordable for the population-by using its huge reserve margin of generation capacity (nearly 40 percent in the early 1990s) to defer major investment in new generating capacity. Eskom has not increased its installed generating capacity much during the past decade of high economic growth, but it has now embarked on a massive program of new capacity to avert power shortages.

The cabinet approved the "White Paper on Energy Policy" in December 1998. The white paper emphasized the need to attract private investment to the energy sector and to promote efficiency through competition. In keeping with the vision laid out in the white paper, the reform of Eskom's governance arrangements led to its reorganization into a holding company with three main subsidiaries—one each for generation, transmission, and distribution.

In May 2001 the cabinet approved proposals for the reform of the electricity supply industry through a process of "managed liberalization." The main elements are: (1) Eskom to retain no less than 70 percent of the existing electricity generation market, privatization of the remainder, and the aim of transferring 10 percent to black economic ownership no later than 2003; (2) vertical unbundling to ensure nondiscriminatory and open access to the transmission lines under a separate and independent state-owned transmission company that also carries the market operation functions (initially this transmission company would be a subsidiary of Eskom); (3) a multimarket model electricity market framework with a variety of trading platforms, including bilateral contracts, a power exchange, and a balancing mechanism; and (4) a regulatory framework that ensures the participation of independent power producers (IPPs) and the diversification of primary energy sources. 
In 2004 the government set a target of some 30 percent of the new generation capacity to come from IPPs and procured through competitive tendering processes facilitated by the Department of Minerals and Energy (DME). In 2006 the DME launched the process for procuring two new open-cycle gas turbine power plants to be run on fuel oil to help meet peak loads from IPPs, but neither process was successful in attracting private investment in such plants. The failure may have been due in part to the difficulty of developing peaking plants run on costly fuel under project financing.

\section{Impact on Sector Structure}

The current structure of power supply is shown in figure 10.1. The government has not proceeded with more substantial forms of unbundling Eskom's activities or moving into the reforms envisaged in the proposals approved in 2001, partly because of opposition by the labor unions.

Efforts to restructure the distribution sector into larger and more economically efficient units have been resisted by the municipalities concerned and their labor unions because of the economic benefits to municipal finances and employment that they derive from their electricity businesses. Little real progress in this area has been achieved to date.

Figure 10.1 South Africa Power Market Structure

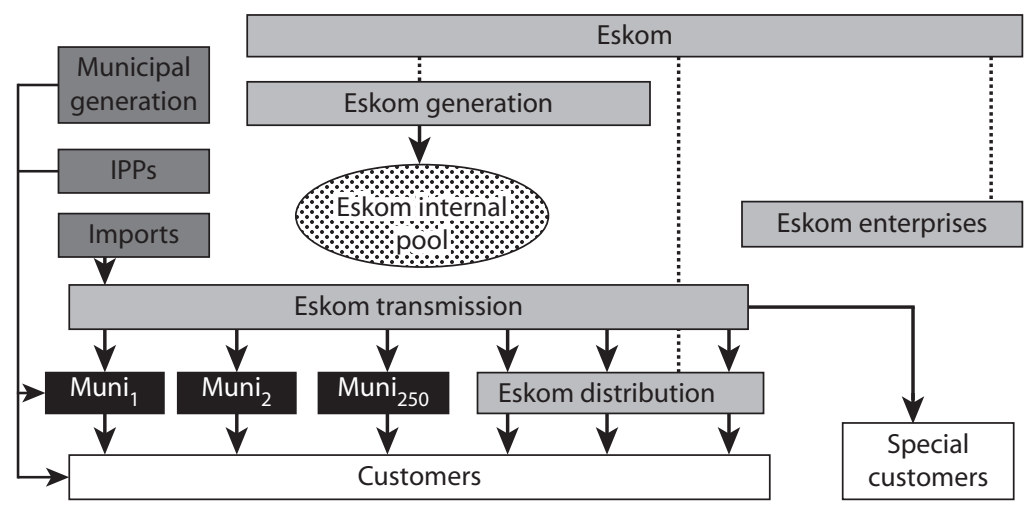

Source: Eberhard 2004.

Notes: Subscripts indicate the number of municipalities; IPPS = independent power producers. 


\section{Impact on Sector Performance}

Trends in performance indicators for Eskom under the slow and moderate reforms to date are illustrated as follows:

- Access to electricity supply by the population in terms of new residential connections. Access to electricity increased starting in the mid1990s as a result of the National Electrification Programme instituted by the new democratic government. The access rate has doubled from about one-third to about two-thirds of households, with approximately equal proportions supplied by Eskom and by municipalities.

- System reserve generation capacity. The capacity has remained adequate, albeit declining from an excessive level of 34 percent in 1994 to 15 percent in 2008, which is close to the minimum level for security of supply on a system such as Eskom's. This decline may have been a factor in Eskom's decision to suspend power exports to Botswana in 2008.

- Financial cost recovery. Eskom's operating cost recovery ratio declined steadily from 1.53 in 1998 to 1.33 in 2003, then increased to 1.53 in 2005, but has since declined to 1.09 in 2008. This long-term declinedespite a doubling in average revenue yield (in nominal price terms) over the same period — can be traced to heavy investments in extending access to power supply to customers whose business was largely unprofitable for Eskom. The current declining trend in Eskom's financial performance, coupled with uncertainty about Eskom's future under sector reorganization, led one of the rating agencies to down-rate Eskom's bonds in 2008.

- Total system energy losses. Losses in the distribution networks increased from around 6 percent in the mid-1990s to 8 percent in 2008. This trend probably reflects the drive to electrify many households in previously nonelectrified areas and Eskom's mixed experience with its huge program to install prepayment meters for low-income households, as the meters did not reduce theft of electricity as much as expected.

- Carbon emissions. Emissions of $\mathrm{CO}_{2}$ have been fairly constant from the early 1990s to the present at around 850 tons/gigawatt-hour generated, which is reasonable for the types of coal-fired plants operated by Eskom. The lack of a decline reflects little overall change in the stock of Eskom's generating plant over this period.

Trends in these indicators are shown in the following figures. 
Figure 10.2 Milestones of Power Sector Reform in South Africa

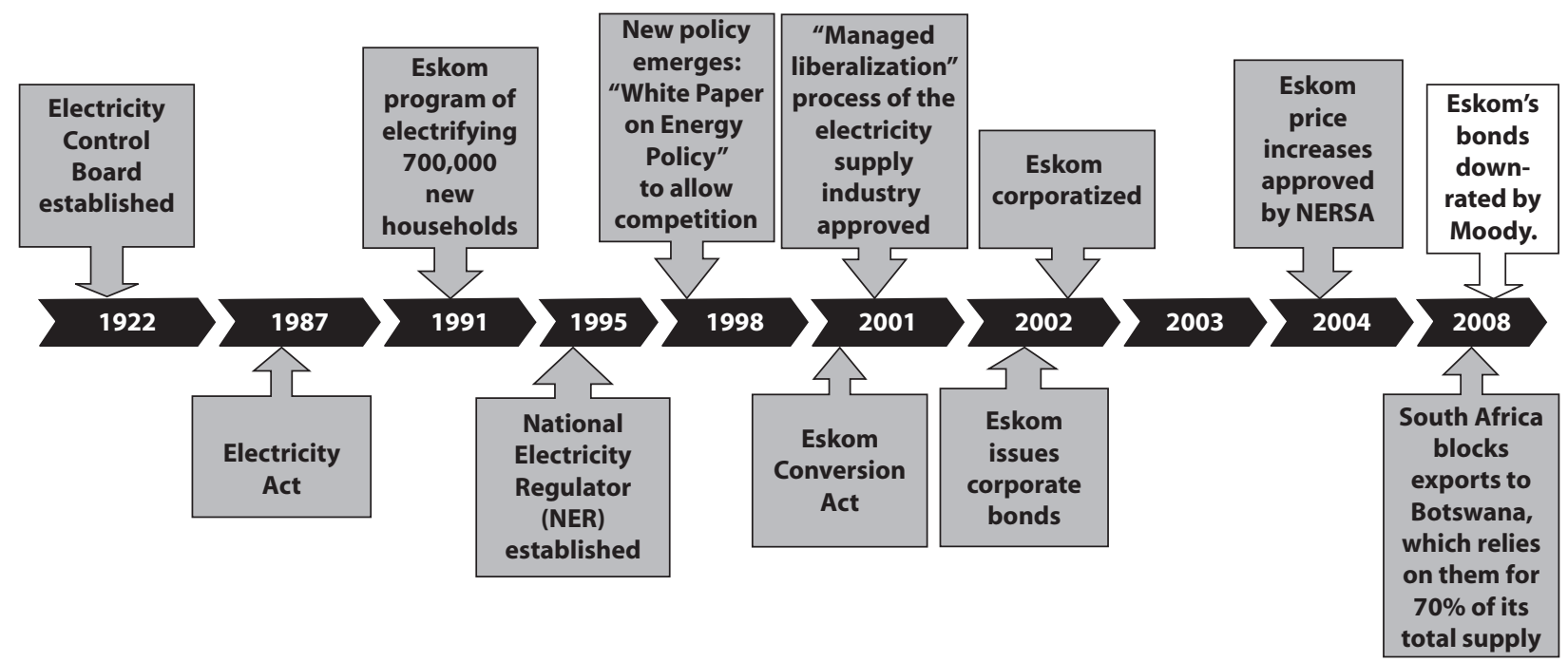

Source: An elaboration from the Power Market Structure database.

Note: The milestones are reported in different shades: white = main external factors; light gray = main government interventions. NERSA = National Electricity Regulator of South Africa (previously National Electricity Regulator [NER]). 
Figure 10.3 South Africa: Access to Residential Electricity

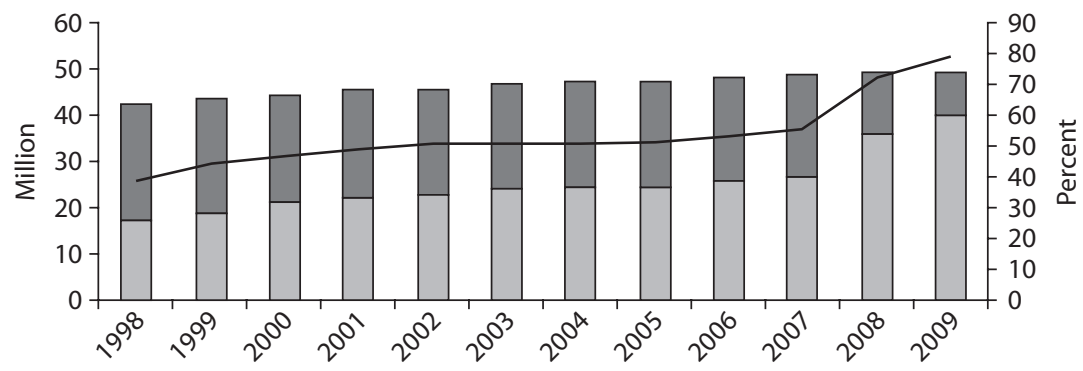

Population without access $\square$ Residential customers with access Access rate

Source: An elaboration from the Power Market Structure database.

Figure 10.4 South Africa: Quality of Electric Service

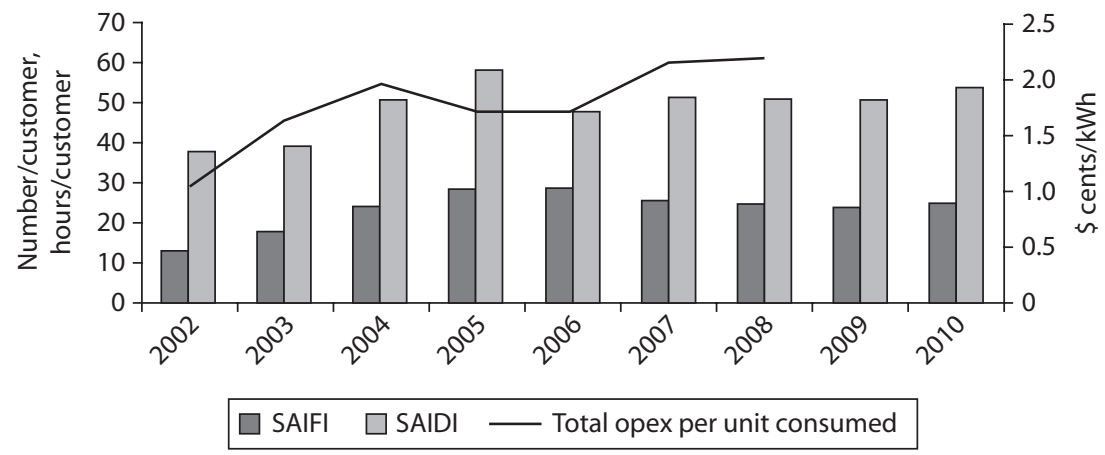

Source: An elaboration from the Power Market Structure database.

Note: kWh = kilowatt-hour; opex = operational expenditures/costs; SAIDI = System Average Interruption Duration Index; SAIFI = System Average Interruption Frequency Index. 


\section{Figure 10.5 South Africa: System Losses and Operating Costs}

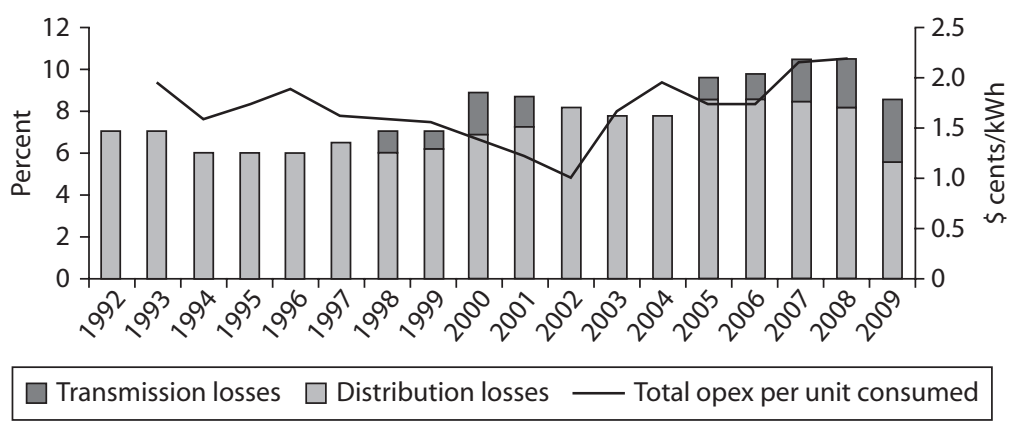

Source: An elaboration from the Power Market Structure database.

Note: kWh = kilowatt-hour; opex = operational expenditures/costs.

Figure 10.6 South Africa: Electricity Generation by Source and Carbon Emissions

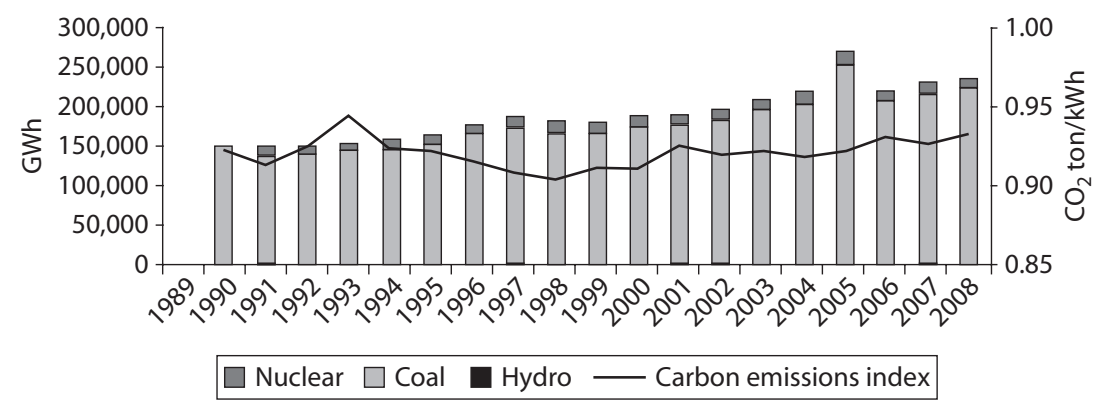

Source: An elaboration from the Power Market Structure database.

Note: $\mathrm{GWh}$ = gigawatt-hour; $\mathrm{kWh}=$ kilowatt-hour. 
Figure 10.7 South Africa: Energy Security and Capital Expenditure

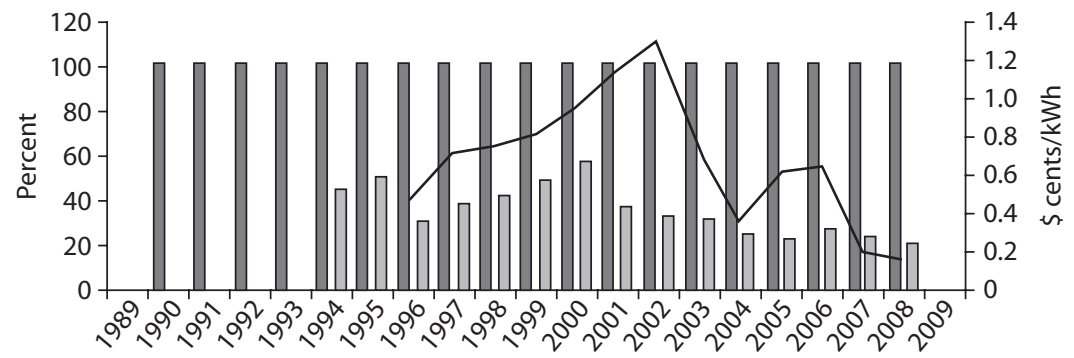

$\square$ Energy self-sufficiency $\square$ System reserve capacity Total capex per unit consumed

Source: An elaboration from the Power Market Structure database. Note: Capex $=$ capital expenditures; $\mathrm{kWh}=$ kilowatt-hour.

Figure 10.8 South Africa: Average Tariff and Operating Costs

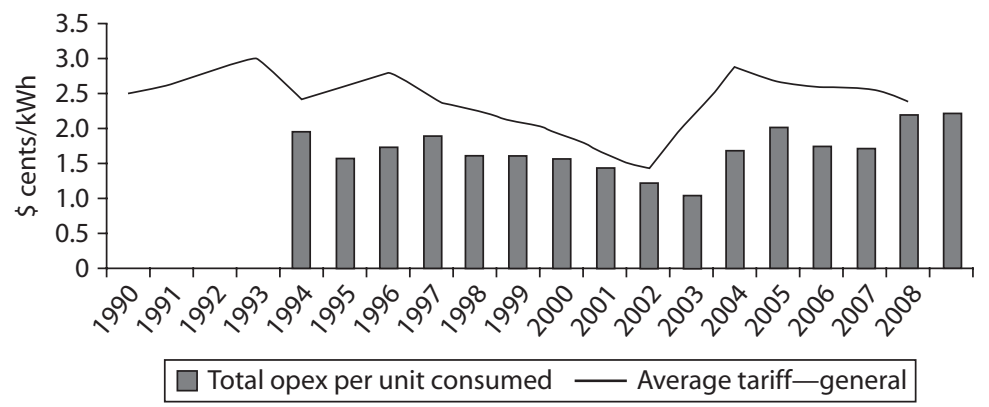

Source: An elaboration from the Power Market Structure database. Note: kWh = kilowatt-hour; opex = operational expenditures/costs. 


\section{Figure 10.9 South Africa: Capacity Utilization}

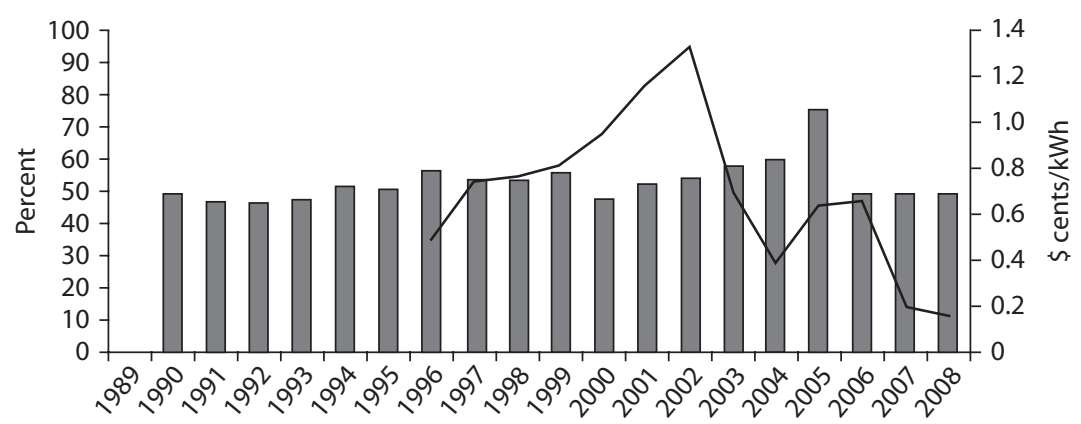

Capacity utilization - Total capex per unit consumed

Source: An elaboration from the Power Market Structure database.

Note: Capex = capital expenditures; $\mathrm{kWh}=$ kilowatt-hour.

\section{Figure 10.10 South Africa: Cost Recovery Index}

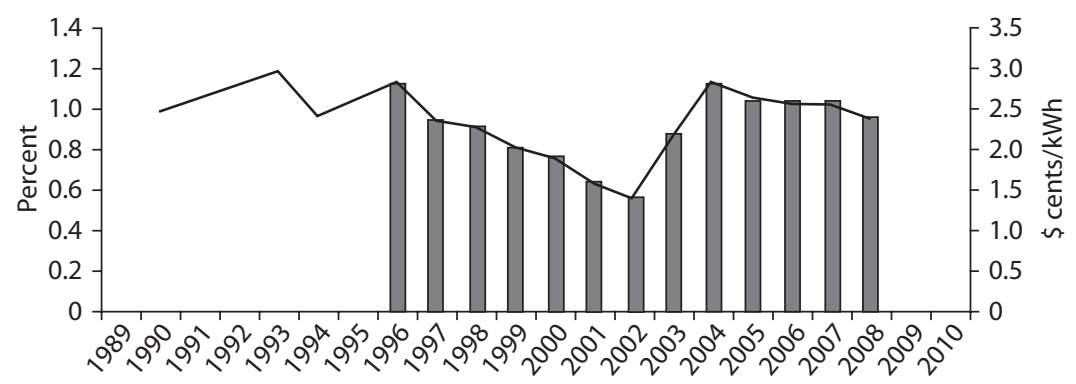

Cost recovery index Average tariff-general

Source: An elaboration from the Power Market Structure database,

Note: $\mathrm{kWh}=$ kilowatt-hour. 


\section{Figure 10.11 South Africa: Labor Productivity}

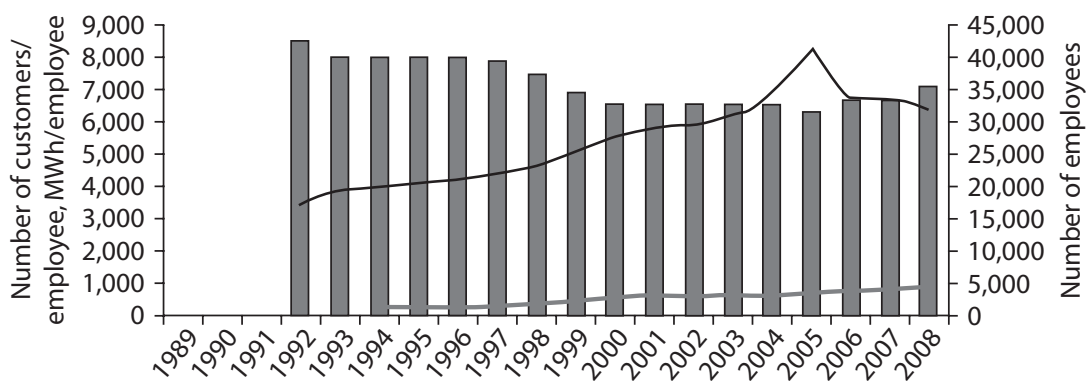

$\square \quad$ Number of employees in electricity sector

- Energy consumed/employee

Residential customers/employee

Source: An elaboration from the Power Market Structure database.

Note: $\mathrm{MWh}=$ megawatt-hour.

\section{Figure 10.12 South Africa: Market Concentration}

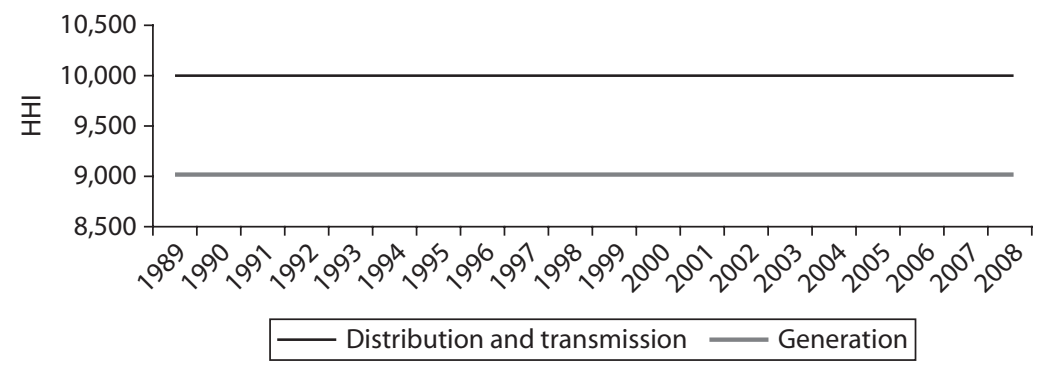

Source: An elaboration from the Power Market Structure database. Note: $\mathrm{HHI}=$ Herfindahl-Hirschman Index.

\section{Figure 10.13 South Africa: Private Ownership}

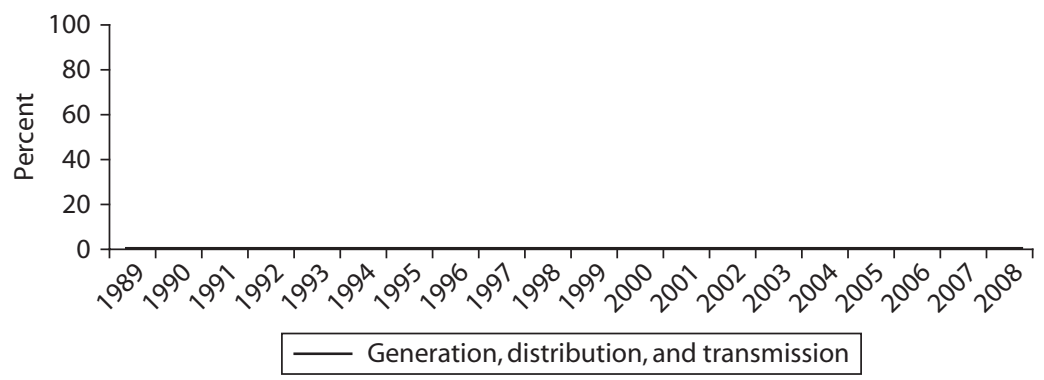




\section{Figure 10.14 South Africa: Private Management}

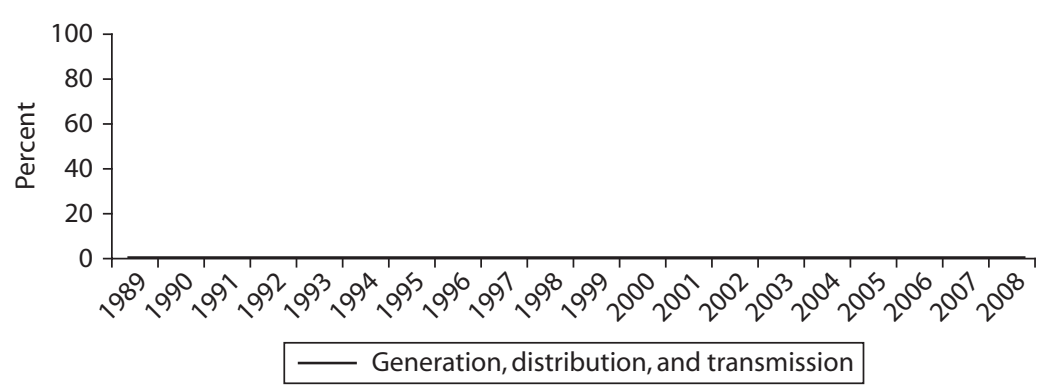

Source: An elaboration from the Power Market Structure database.

\section{Figure 10.15 South Africa: Degree of Vertical Integration}

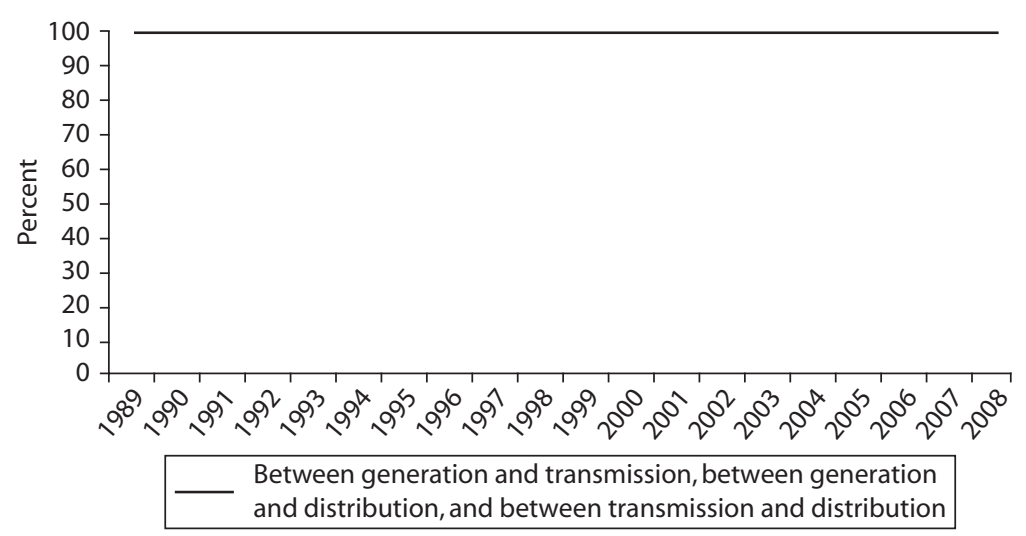

Source: An elaboration from the Power Market Structure database.

Figure 10.16 South Africa: System Load Factor

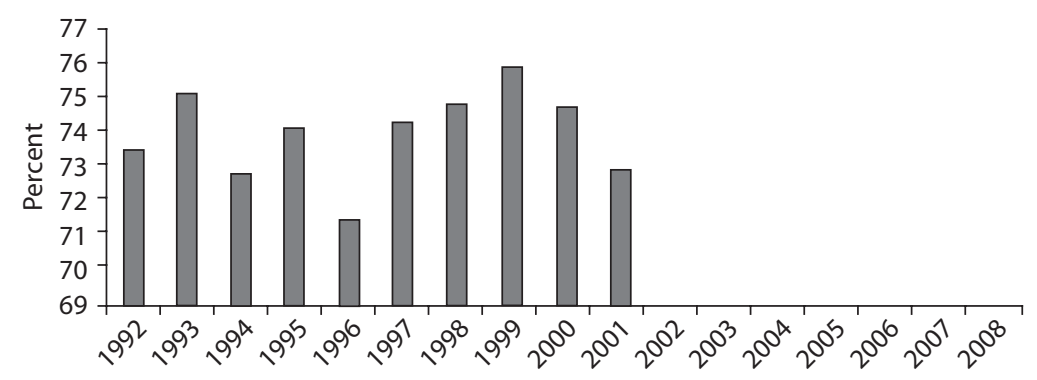




\section{Reference}

Eberhard, Anton. 2004. "The Political Economy of Power Sector Reform in South Africa." Working Paper 6 (revised). Stanford, CA: Stanford University, Program on Energy and Sustainable Development. April. 


\section{Turkey}

Turkey falls into the category of medium per capita income/large system size with a gross national income per capita of about $\$ 8,890$ (World Bank 2008) and total installed generating capacity of about 42,200 MW (megawatts) in 2008.

Turkey's installed power generation capacity in 2008 consisted of 10,100 MW of lignite- and coal-fired plant, 17,600 MW of gas- and oilfired plant, and 13,900 MW of hydroelectric plant, with $600 \mathrm{MW}$ of geothermal and other types of capacity. Annual generation of electricity was 198.6 TWh (terawatt-hours) in 2008, of which about 66 percent was from thermal power generation and 33 percent from hydroelectric generation (the remaining 1 percent was from geothermal and wind power). This amount of power was supplied to 29.52 million consumers. The country is virtually entirely electrified, mostly from the power networks.

Turkey is moderately endowed with primary energy resources, mainly hydropower and lignite with some natural gas, and therefore relies on imports for about 70 percent of its energy needs. But it lies at a major international crossroads of energy trade between the gas and oil rich regions of the Middle East and Central Asia and the major European demand centers, which enables Turkey to diversify its sources of imported energy and to profit from extensive transit trade in energy products. 


\section{Reform History}

The history of reforms to the Turkish power sector has evolved over some decades from the original state-owned and directed monopoly. The Ministry of Energy and Natural Resources was created in 1963, and the Turkish Electricity Authority (TEK) was founded in 1970 as an integrated monopoly, incorporating all electricity activities other than distribution, which was assigned to municipalities until 1982. Electrification accelerated during this period, and investment in generation capacity was given priority to meet growing demand. Due to unfavorable economic conditions of the period, however, the investment needed for renewal and maintenance, as well as for new projects, could not be provided from the central budget.

In 1984 the Turkish Parliament passed Law No. 3096 to set up a framework for private participation in the electricity sector by removing TEK's monopoly power. The goal was to attract private investment to ease strain on the government's budget. This law created three separate forms of private participation in the electricity sector. Two involved independent power producers (IPPs): the build-operate-transfer (BOT) framework for new generation ("greenfield IPPs") and the transfer of operating rights (TOOR) framework for existing generation and distribution assets ("brownfield IPPs"); the third was the autoproducer framework for companies to produce their own electricity. Under the BOT framework, private companies were allowed to build and operate power plants and sell electricity to TEK. At the end of the contract term, the assets would be transferred to the state at no cost. But all these models required the Treasury's guarantee, with contracts signed on a take-or-pay basis, and consequently they did not reduce the financial burden on the government's budget.

The BOT framework established under Law No. 3096 was unsuccessful in attracting significant private investment in the power sector due to the Constitutional Court's interpretation of the law, which held that the generation, transmission, and distribution of electricity was, according to the Turkish Constitution, a public service. Any arrangement for private electricity generation therefore must be in the form of a concession. Concessions, under the Constitution, are subject to approval by a multitude of government agencies, including the Ministry of Energy and Natural Resources, the High Planning Council, the State Planning Organization, and the Treasury. In addition, investors had limited recourse to international arbitration, and contracts had to be approved by the 
Danistay (the Supreme Administrative Court), which can be a rather lengthy process. At that time the rapid growth of 8 percent annually in electricity demand created the need for an equally rapid increase in installed generating capacity. But because of its budgetary constraints, Turkey's only option was private (in particular, foreign) investment.

In 1993 TEK was split into two separate public utilities: the Turkish Electricity Generating and Transmission Corporation (TEAS), responsible for both generation and transmission activities, and the Turkish Electricity Distribution Company (TEDAS), responsible for distribution and retail sale activities. These entities were corporatized.

In 1994 the Turkish Parliament passed Law No. 3996, which was intended to enhance the attractiveness of BOT projects to foreign investors by authorizing Treasury guarantees for the obligations of the off-taker and fuel-supplier (in the case of gas-fired IPPs), and providing tax exemptions. In an attempt to bypass the Danistay, the law contained language that laid out certain arrangements that would be nonconcessionary and therefore subject to private law, but the Constitutional Court struck down the framework as unconstitutional in March 1996.

In June the Turkish Council of Ministers issued Decree No. 96/8269 concerning a new model for private participation in the power sector. The decree created the build-operate (BO) framework, whereby private firms would retain ownership of the facility rather than transfer it to the state. After a poor response to the first government tender for power plant construction under this framework, the ministry revised the terms. One important change was that companies would be eligible for dispute resolution under the UN Commission on International Trade Laws rather than in the Turkish administrative court system. The new tender also offered the possibility of 100 percent Treasury guarantees for the obligations of TEAS for the duration of the sales contract. Before any companies had a chance to build any power plants under the new BO terms, however, the Danistay suspended the decree, claiming that the previous BOT law was applicable and that an alternative model should be passed by Parliament and not by ministerial fiat.

In July 1997 the Turkish Parliament passed the BO Law (Law No. 4283), which repeated the revised ministerial decree except that it exempted hydroelectric, nuclear, and geothermal plants from consideration. In 1999 the Turkish Parliament passed a constitutional amendment that applied private law to infrastructure investment in the electricity sector and that limited the Danistay's role in the review process. This IPP framework was successful in attracting foreign investment 
in about 6,000 MW of generating capacity, but at above market prices and take-or-pay contracts for electricity off-take backed by Treasury guarantees. These obligations put an immense financial burden on TEAS. The guarantees were necessary because of TEAS's financial weakness, which was caused by a high level of electricity losses resulting from technical factors, theft, and nonpayment. In addition, the repeated macroeconomic shocks Turkey had experienced over the previous decade had weakened the federal budget.

By the end of the 1990s, it had become clear that these types of contracts with long-term sales arrangements and predetermined fixed prices did not serve the overall objective of developing competition in the electricity market. In addition, privatization with Treasury guarantees was not going to be feasible given Turkey's rapidly deteriorating fiscal stance because a succession of economic crises had weakened the budget. As a condition attached to an International Monetary Fund loan, the Turkish government agreed to phase out these guarantees in future powerpurchase agreements. It was at about this time that the Turkish government began to recognize the need for deeper structural reforms in the electricity sector.

In 2001 the Electricity Market Law (EML) No. 4628 was passed as a fundamental approach to easing the burden of the power sector on the public budget. The provisions of the EML were designed to be in line with the European Union's Energy Acquis as part of Turkey's ambition to join the EU. The law overhauled the electricity legislation to provide the basis for a radically different framework for the design and regulation of the Turkish electricity market. The law provided for the unbundling of the state owned electricity assets, opened the market above a certain level of electricity consumption (the threshold to gradually decline), and allowed third-party access to the grid. The EML required the creation of a bilateral contracting market complemented by a residual balancing mechanism. All generation capacity is to be sold to wholesalers, retailers, and consumers either directly or via a spot market.

In response, TEAS was unbundled into three separate state-owned entities:

- The Electricity Generation Company of Turkey (EUAS) for generation. EUAS directly owns most hydropower units and acts as the holding company for six portfolio generation companies with thermal power units and some hydropower units. In addition, several private sector generating units established under $\mathrm{BOT}, \mathrm{BO}$, and TOOR supply power 
to the grid on the basis of power purchase agreements guaranteed by the government. There are also a few privately owned IPPs. Industries with captive generating units (autoproducers) and privately owned renewable energy units also supply to the grid.

- The Turkish Electricity Transmission company (TEIAS) for transmission and dispatch. It also operates the balancing market, which complements the bilateral free market, and it acts as the settlement agency.

- Turkish Electricity Trading and Contracting Company (TETAS) acts as the single buyer of electricity sold under the PPAs with BOT, BO, and TOOR units, and it on-sells this electricity to the distribution companies.

Although corporatized with separate accounts, these entities remained under government control in terms of decision making, and they had little managerial autonomy.

Distribution is handled by 21 regional distribution companies, 20 of which are the holders of operating rights for their franchise areas from TEDAS. The remaining one (Kayseri) is a privately owned distribution company.

The EML also established the Energy Market Regulatory Authority (EMRA) as an independent and financially autonomous regulator of power, gas, petroleum, and liquefied petroleum gas, supervised by the Energy Market Regulatory Board. EMRA is responsible for preparing and implementing secondary legislation; authorizing market participants; approving and publishing tariffs; monitoring and supervising market participants; conducting technical, legal, and financial audits; settling disputes; approving, amending, and enforcing performance standards; and, where necessary, applying sanctions.

In 2004 the Strategy Paper "Road Map of the Market Reform and Transition" was approved by the Higher Planning Council. It outlined the steps for further liberalization of the electricity sector. It covered procedures for privatizing distribution and generation assets with the introduction of transitory vesting contracts through which generation, either from existing contracts (via TETAS) or from public companies, will be allocated to distribution companies based on their weighted share in total demand to compensate for the demand of captive consumers. The main purpose of these contracts is to provide for a smooth transition by ensuring predictability of electricity prices and supply during the transition period and to cover stranded costs that are taken by TETAS. These contracts were designed to cover more than 85 percent of the energy demand of the captive customers in each distribution region. Publicly owned 
thermal and hydropower plants were to be allocated to a group of generating companies on a portfolio basis, and these companies were then to be privatized.

The Strategy Paper also provided the basis for determining the revenue requirements of the regional distribution companies ex ante. Any differences that may occur between the ex ante revenue requirements of the distribution companies and the real incomes collected via the tariff in force is expected to be reimbursed by means of a price equalization mechanism. The paper also envisaged the implementation of a national tariff.

As set out in the Strategy Paper, TEDAS, with its 20 regional distribution companies, was transferred to the Privatisation Administration (PA) on April 1, 2005. The PA decided to commence the privatization of the electricity distribution sector with the concurrent tender of three companies using a TOOR approach backed by a share sale model. According to this model, the investor will be the sole owner of the shares of the distribution company, which will be licensed for distribution and retail sale and to perform related activities in a designated region.

A competitive wholesale electricity market went into operation in 2006. A balancing and settlement system has been developed and is operated a branch of TEIAS. By 2010, approximately 400 private companies were trading power in this market, through which on average about 30 percent of total electricity supply is dispatched. In July 2008 the EML of 2001 was substantially amended to promote energy security (Law No. 5784). EMRA issued in April 2009 new balancing and settlement regulations to improve the functioning of the wholesale electricity market. In December 2009, the market moved from monthly settlement to hourly settlement.

\section{Impact on Sector Structure}

The present market structure is represented in Figure 11.1

Power sector ownership has shifted significantly from public to private, with an increasingly environmental friendly generation mix. The marketbased electricity reform program has helped attract private investment in the power sector, especially in renewable energy. The share of private sector generation in Turkey's electricity supply has increased steadily and reached 50 percent in 2008. It is expected to increase further.

By 2010 the privatization of five distribution companies had been completed and the tenders had been finalized for eight additional 


\section{Figure 11.1 Transitional Electricity Market Structure in Turkey}

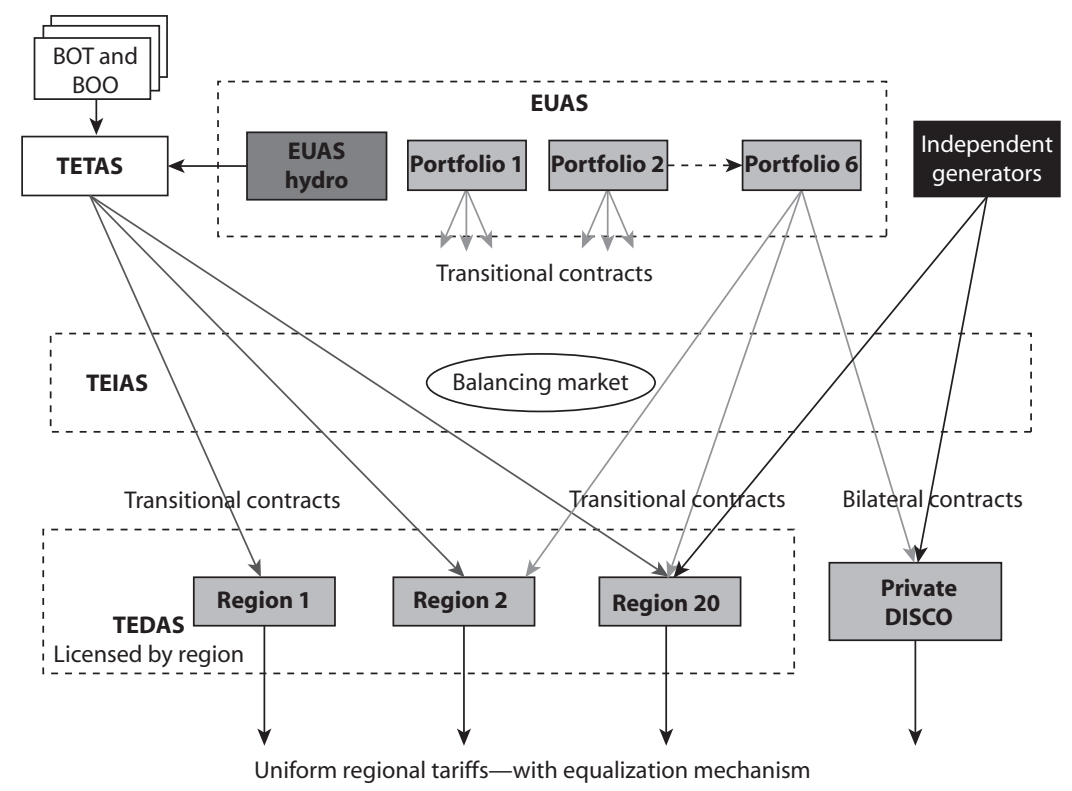

Source: Krishnaswamy 2009

Note: $\mathrm{BOO}=$ build-operate-own; $\mathrm{BOOT}=$ build-own-operate-transfer; $\mathrm{DISCO}=$ distribution company; EUAS = Electricity Generation Company of Turkey; TEDAS = Turkish Electricity Distribution Company; TEIAS = Turkish Electricity Transmission Company; TETAS = Turkish Electricity Trading and Contracting Company.

companies. All distribution companies were expected to be privatized by the end of 2010. This delay relative to the target of end 2006 set out in the 2004 Strategy Paper was due to the time taken to establish cost recovery pricing necessary for creating creditworthy distribution companies suitable for privatization and hence for attracting private investment in generation capacity.

\section{Impact on Sector Performance}

Evidence of possible impacts from reforms is sought from the following five indicators:

- Access to electricity supply by the population in terms of new residential connections. The proportion of the total population with access to electricity increased steadily from 62 percent in 1990 to 96 percent in 2009. 
The number of connections approximately doubled from 13 million to 27 million over this period. This expansion of access progressed throughout all the reform stages described herein.

- Customer service quality. Service quality by the distribution companies has improved on average since the early 2000s, as shown by data for SAIDI (System Average Interruption Duration Index) and the total volume of load shed during unplanned outages. Total network energy losses declined from around 20 percent of total energy supplied to the network around 2000 to about 15 percent at the end of the decade.

- Supply security. According to the trends in the indicators that reflect supply security—system reserve capacity, energy self-sufficiency, system load factor, and capacity utilization-it appears that Turkey has managed to cover its substantial growth in power demand reliably. System reserve capacity has steadily declined from 2003, but this may partly reflect the decline in hydropower and increase in thermal generation in the generation mix. The higher level of system load factor from 2003 onward relative to previous years could reflect a tightening on supply at periods of peak system demand, but it could also reflect more efficient use of generation capacity. Some support for the latter contention is given by the modest increase in capacity utilization from 2003 onward.

Trends in these indicators are shown in the following figures. 
Figure 11.2 Milestones of Power Sector Reform in Turkey

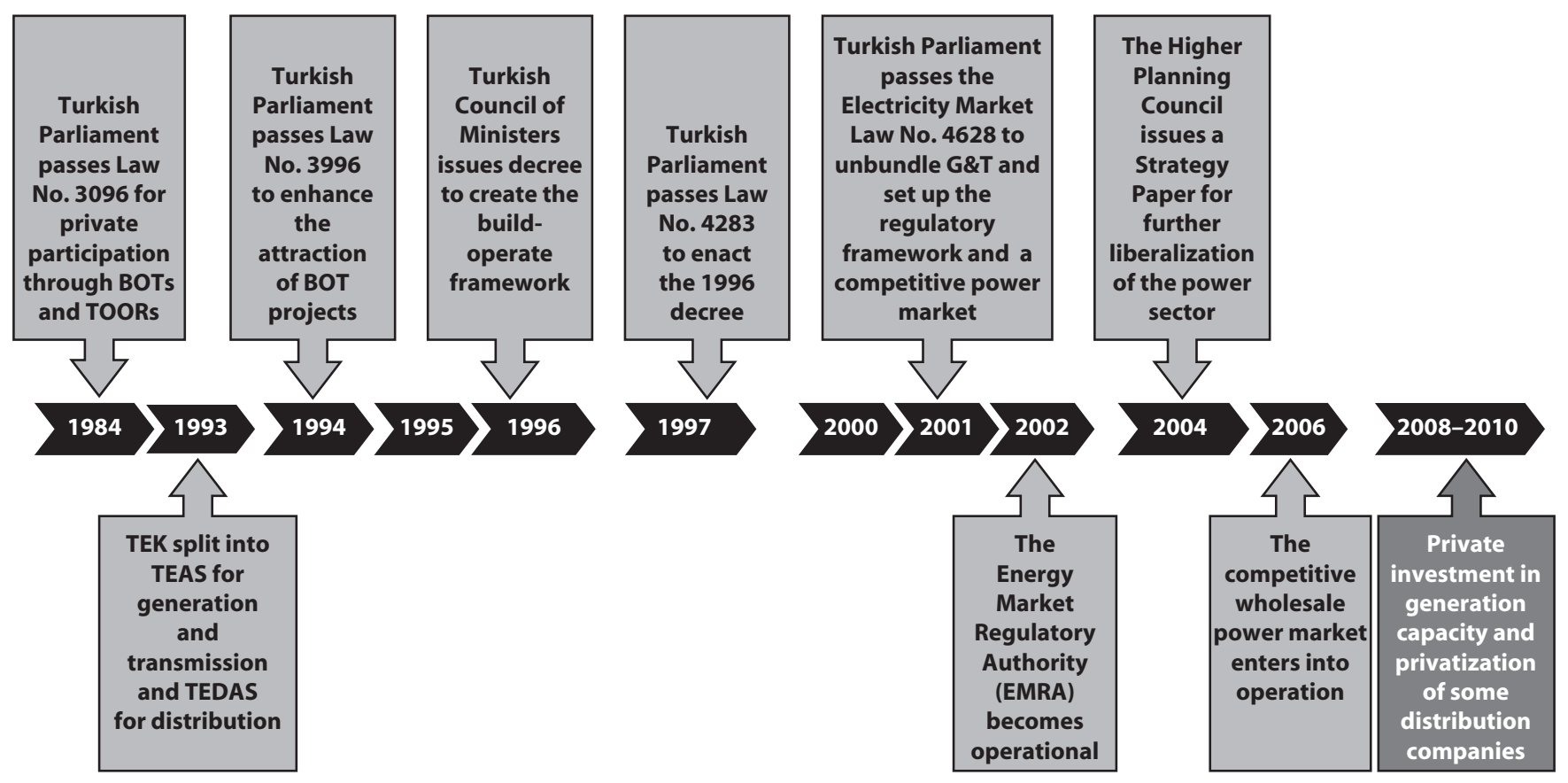

Source: An elaboration from the Power Market Structure database.

Note: The milestones are reported in different shades: light gray = main government interventions; dark gray = main private sector involvements. BOTs = build-operate-transfers; G\&T= N generation and transmission; TEAS = Turkish Electricity Generating and Transmission Corporation; TEDAS = Turkish Electricity Distribution Company; TEK = Turkish Electricity Authority;

$\pm \quad$ TOORs = transfers of operating rights. 


\section{Figure 11.3 Turkey: Access to Residential Electricity}

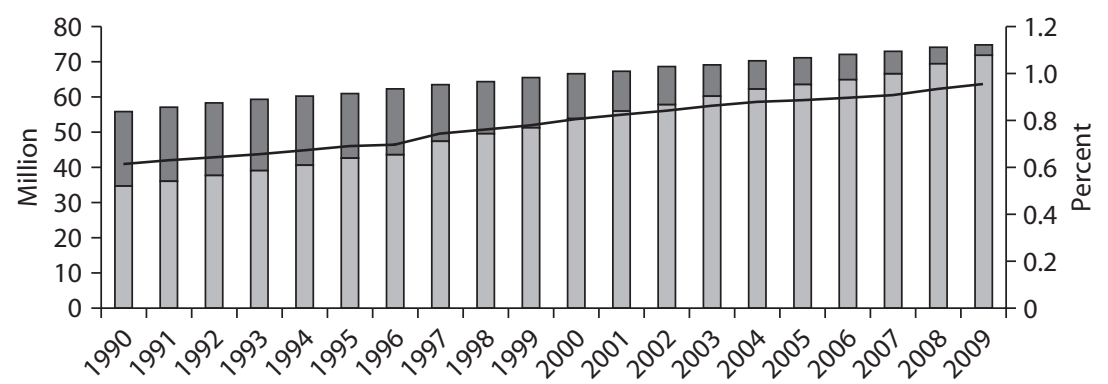

Population without access $\square$ Residential customers with access Access rate

Source: An elaboration from the Power Market Structure database.

\section{Figure 11.4 Turkey: Quality of Electric Service}

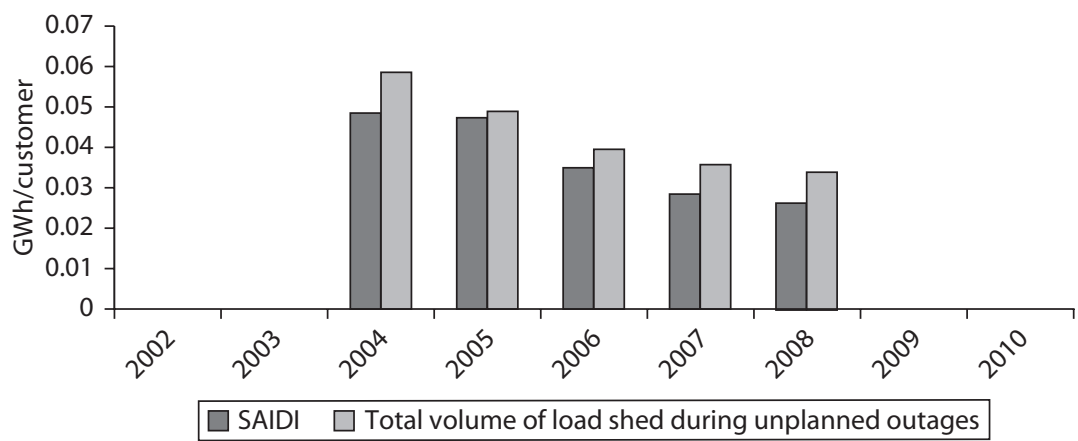

Source: An elaboration from the Power Market Structure database.

Note: $\mathrm{GWh}$ = gigawatt-hour; SAIDI = System Average Interruption Duration Index. 
Figure 11.5 Turkey: System Losses and Operating Costs

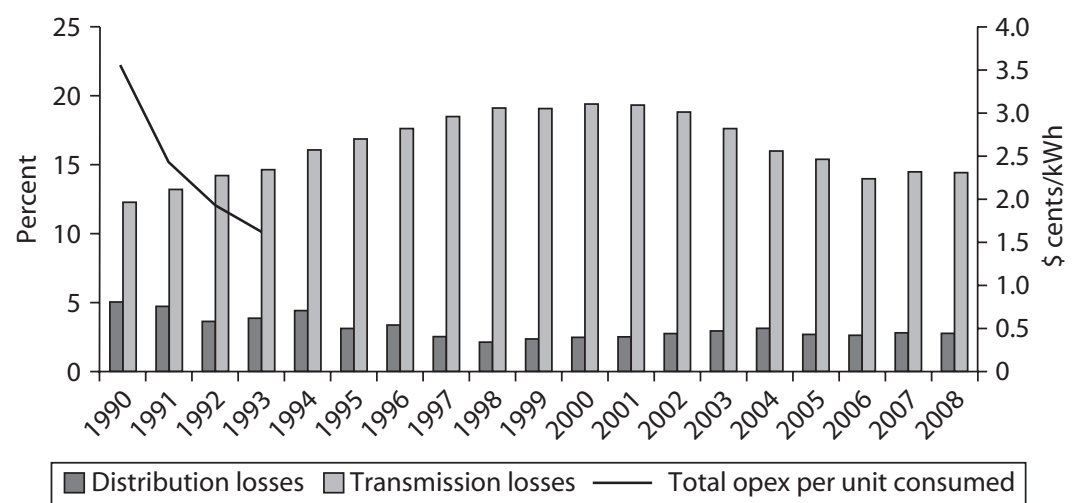

Source: An elaboration from the Power Market Structure database.

Note: kWh = kilowatt-hour; opex = operational expenditures/costs.

Figure 11.6 Turkey: Electricity Generation by Source and Carbon Emissions

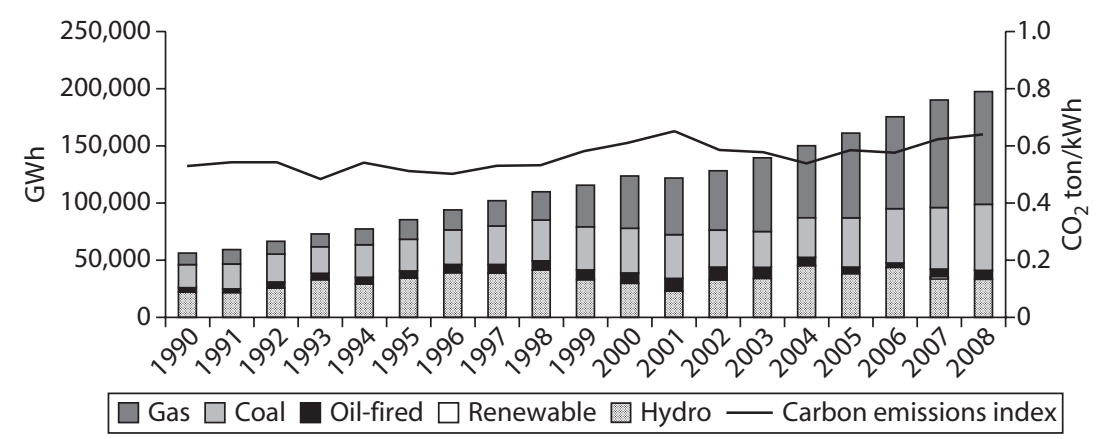

Source: An elaboration from the Power Market Structure database.

Note: GWh = gigawatt-hours. 
Figure 11.7 Turkey: Energy Security and Capital Expenditure

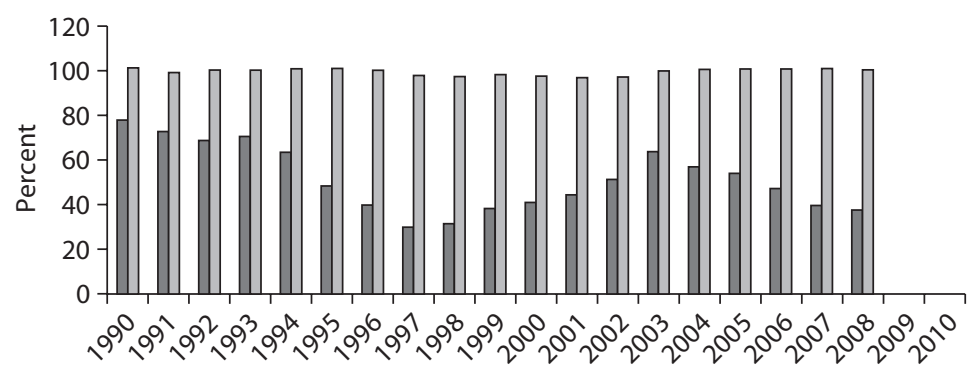

System reserve capacity $\square$ Energy self-sufficiency

Source: An elaboration from the Power Market Structure database.

Figure 11.8 Turkey: System Load Factor

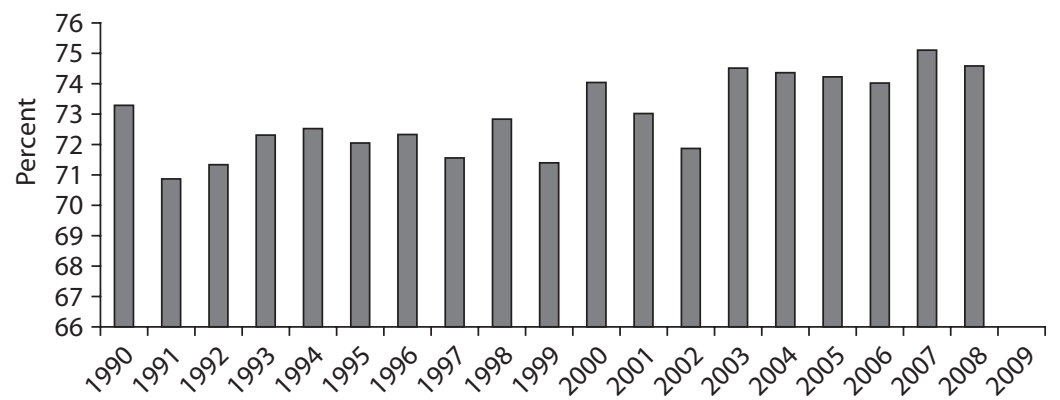

Source: An elaboration from the Power Market Structure database.

Figure 11.9 Turkey: Capacity Utilization

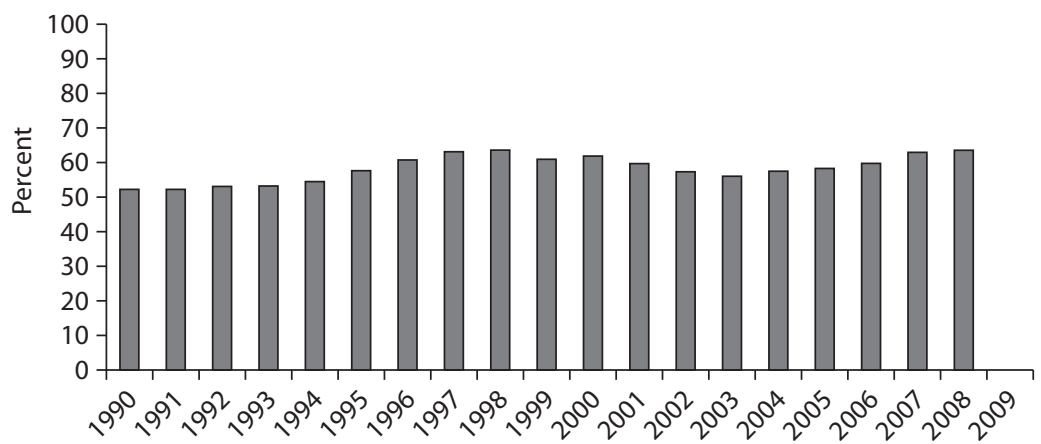

Source: An elaboration from the Power Market Structure database. 


\section{Figure 11.10 Turkey: Average Tariff and Operating Costs}

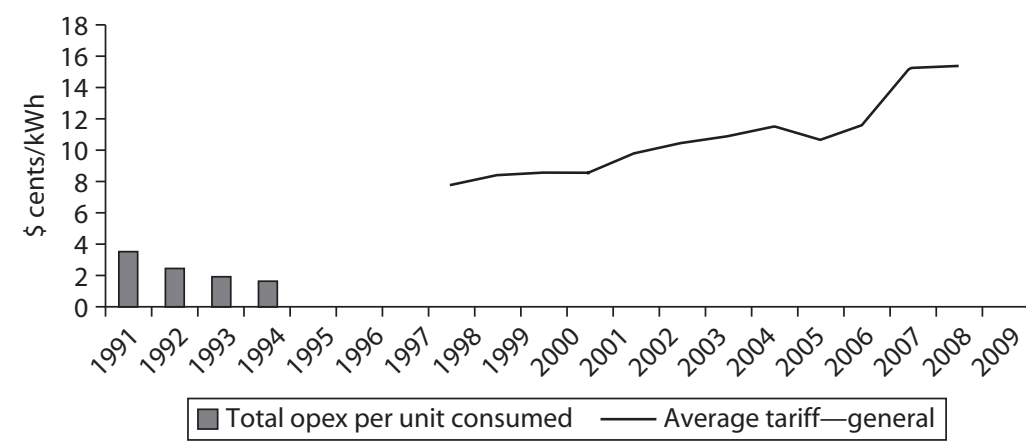

Source: An elaboration from the Power Market Structure database. Note: kWh = kilowatt-hour; opex = operational expenditures/costs.

\section{Figure 11.11 Turkey: Labor Productivity (Distribution)}

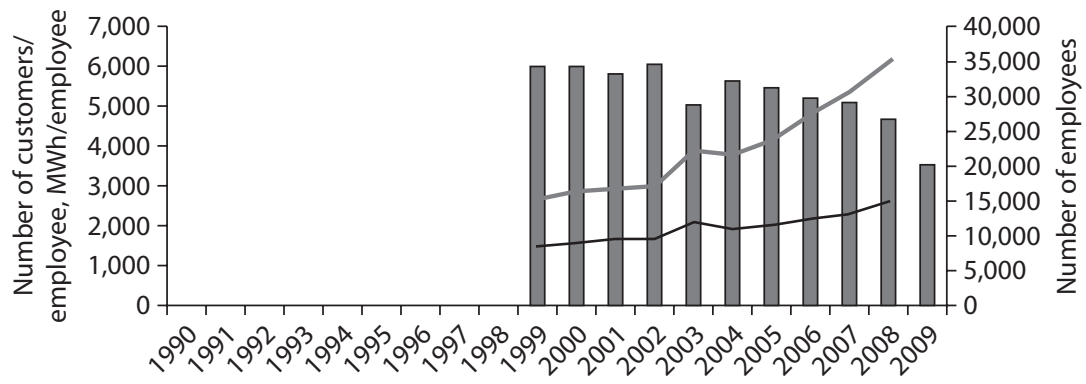

$\square \quad$ Number of employees (distribution)

Energy consumed/employee (distribution)

Number of residential customers/employee (distribution)

Source: An elaboration from the Power Market Structure database.

Note: $\mathrm{MWh}=$ megawatt-hour. 


\section{Figure 11.12 Turkey: Market Concentration}

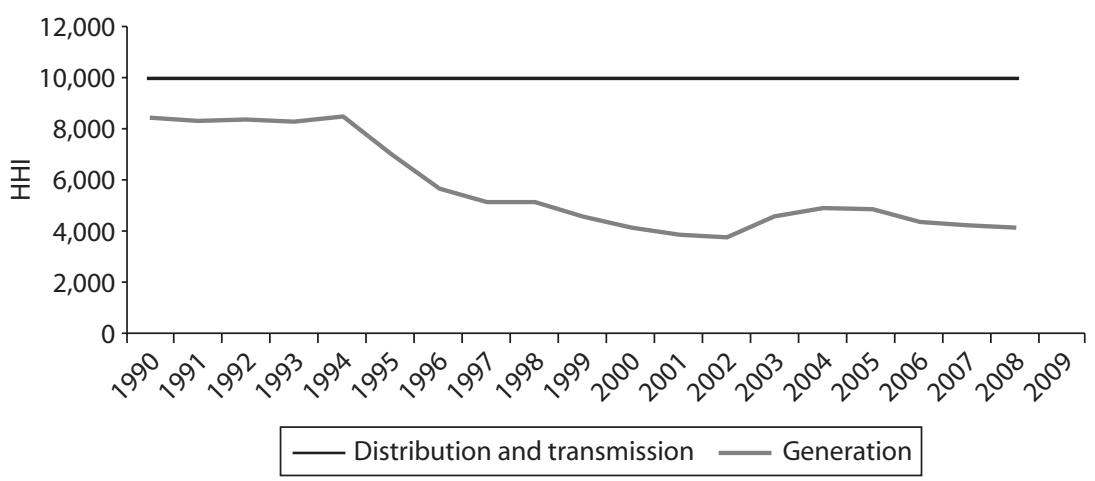

Source: An elaboration from the Power Market Structure database. Note: $\mathrm{HHI}=$ Herfindahl-Hirschman Index.

\section{Figure 11.13 Turkey: Private Ownership}

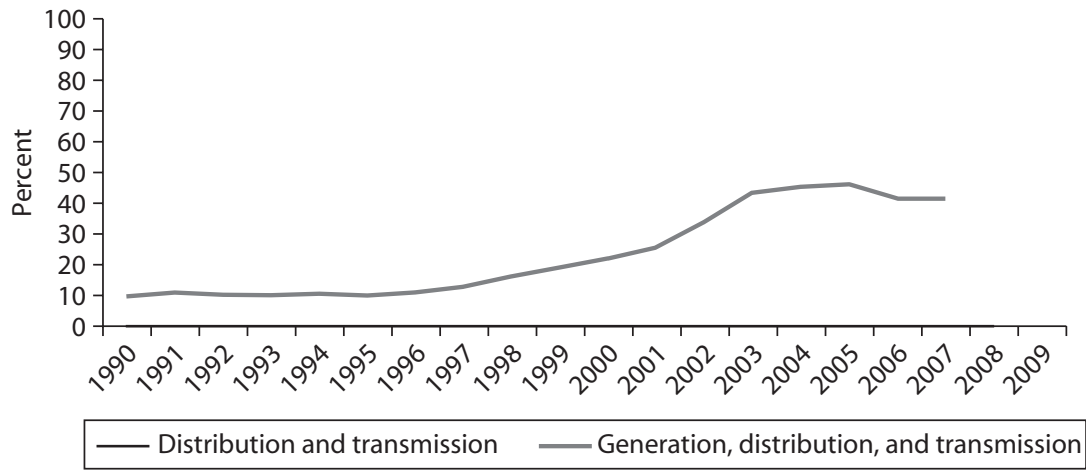

Source: An elaboration from the Power Market Structure database. 


\section{Figure 11.14 Turkey: Private Management}

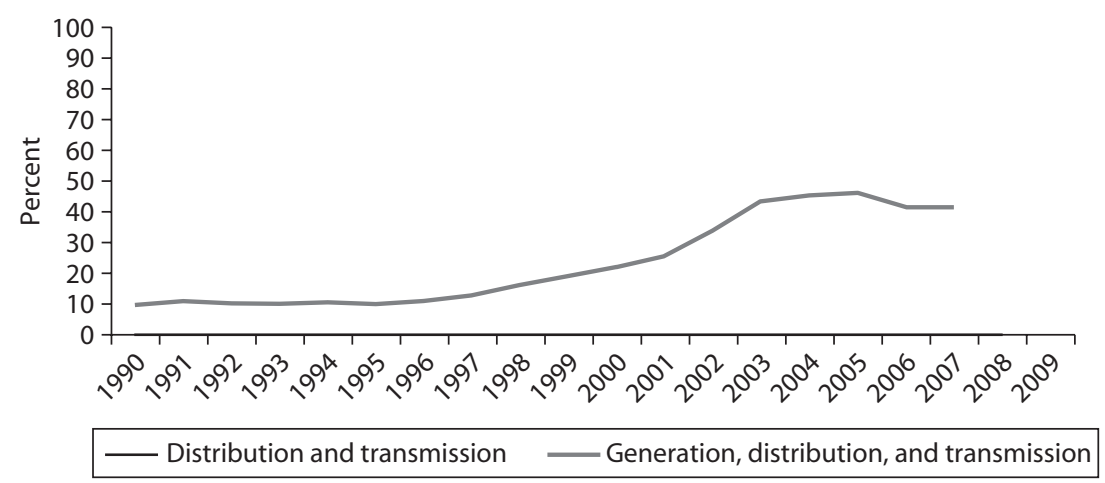

Source: An elaboration from the Power Market Structure database.

\section{Figure 11.15 Turkey: Degree of Vertical Integration}

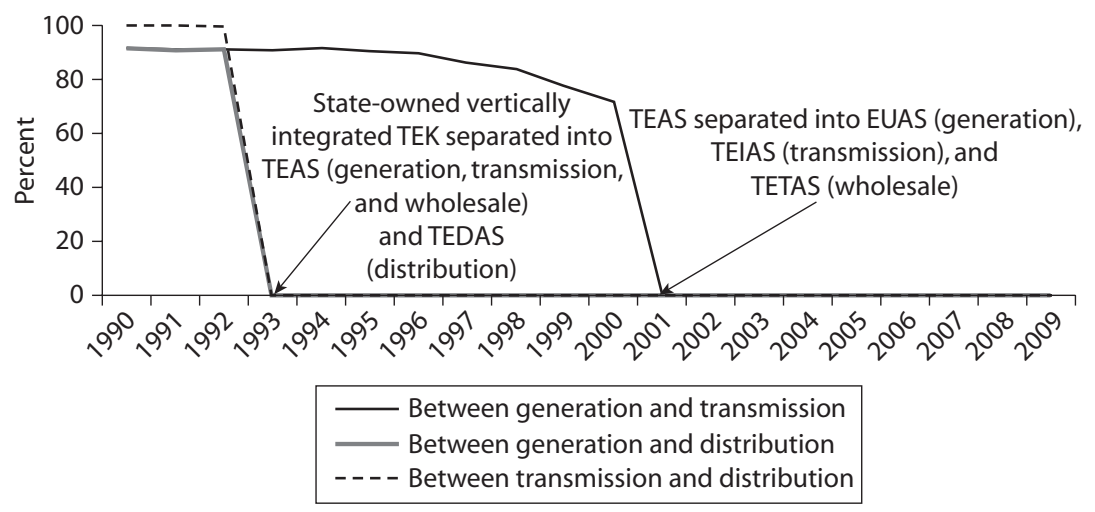

Source: An elaboration from the Power Market Structure database.

Note: EUAS = Electricity Generation Company of Turkey; TEAS = Turkish Electricity Generating and Transmission Corporation; TEDAS = Turkish Electricity Distribution Company; TEIAS = Turkish Electricity Transmission Company; TEK = Turkish Electricity Authority; TETAS = Turkish Electricity Trading and Contracting Company.

\section{References}

Krishnaswamy, Venkataraman. 2009. "Turkey—Case Study.”

World Bank. 2008. World Development Indicators. World Bank, Washington, DC. 

PART 3

Case Studies: Intermediate Economies 



\section{Botswana}

Botswana falls into the category of middle per capita income (gross domestic product of $\$ 6,200$ per capita) because of its mineral exports, but low power system size, with installed operational generating capacity of about 267 MW (megawatts) (about equal proportions of hydropower and thermal power capacity based on domestic coal reserves), relative to a system served maximum demand of about 450 MW. In 2008 this capacity supplied about one-third of domestic electricity consumption, and the rest was imported from South Africa.

\section{Reform History}

Despite its increasing dependence on power imports, Botswana has undertaken little meaningful reform of its power sector. Electricity consumption has grown at about 6 percent per year since the mid-1990s, and was satisfied by imported power. In 2007 the government amended the energy supply act to facilitate the participation of independent power producers in the electricity sector. There are plans to restructure the electricity supply industry in Botswana in accordance with the country's membership in the Southern Africa Power Pool. 
The Botswana Power Corporation (BPC) is the state-owned vertically integrated national power utility with a monopoly. The government regulates the power sector through the Energy Affairs Division of the Ministry of Minerals, Energy, and Water Resources, which monitors BPC. There are currently no specific plans to unbundle the power utility. BPC is currently expanding its coal-fired generating capacity by about 1,200 MW to compensate for the downturn in availability of power imports from South Africa. The first $600 \mathrm{MW}$ is scheduled to start coming onstream in 2012-13, according to BPC.

\section{Impact on Sector Structure}

There is no impact from reform to report as there has been no meaningful reform to the power sector in Botswana.

\section{Impact on Sector Performance}

The lack of reform has probably contributed to the following trends in performance indicators for the power sector:

- Access to electricity supply by the population in terms of new residential connections. Access is a qualified success. BPC increased its residential connections at the creditable rate of about 13 percent per year from 2002 to 2008, but still only about 40 percent of Botswanan households are connected to the public electricity supply.

- System reserve generation capacity. Botswana has not had any system reserve generating capacity since early 1992, when it imported large quantities of electricity from South Africa. By 2008 it relied on these imports to cover about two-thirds of its total electricity consumption. Its installed coal-fired generating capacity is increasingly unreliable due to its age and experiences substantial unplanned outages.

- Total system energy losses. Total system losses have been consistently around 11 percent since the 1990s. This is a reasonable level.

- Financial performance. BPC's financial situation has deteriorated since the early 2000s due to rising costs. The operating cost recovery ratio has declined steadily from 1.18 in 2003 to 0.89 in 2008, despite benefiting from low-cost power imports and reasonable power retail tariffs. BPC's 
sales revenue from electricity tariffs have averaged around $4.5 \$$ cents per kilowatt-hour since 2002.

- Carbon emissions. The unit rate of carbon emissions from an old and inefficient coal-fired plant, such as the Moropule station operated by BPC, would be expected to be high by global standards. Data from the 1990s for the operation of this plant show that $\mathrm{CO}_{2}$ emissions then were running at about 1,900 tons per gigawatt-hour generated, which is high.

Trends in these indicators are shown in the figures that follow. 


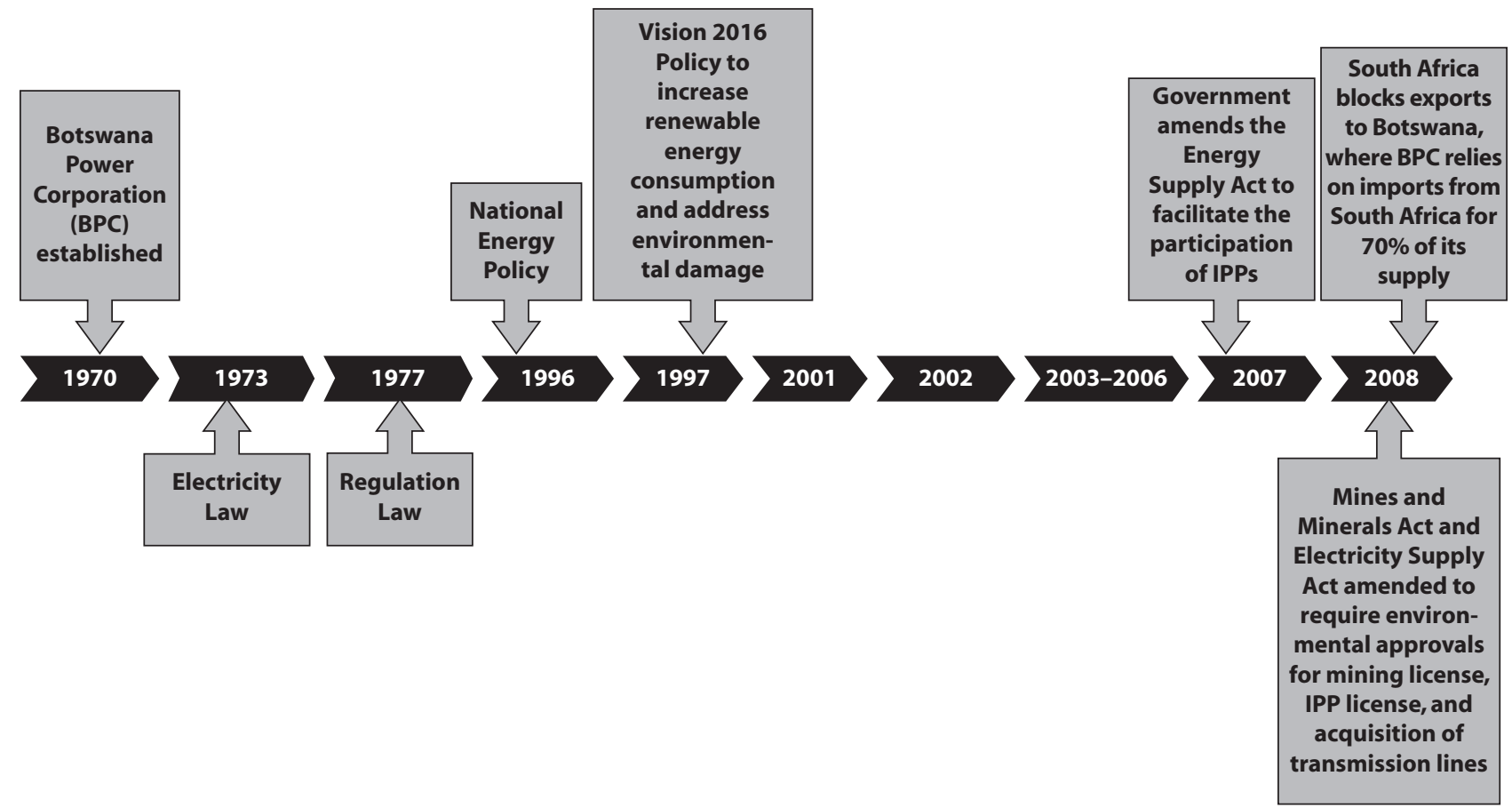

Source: An elaboration from the Power Market Structure database.

Note: The milestones in light gray refer to the main government interventions. BPC = Botswana Power Corporation; IPP = independent power producer. 
Figure 12.2 Botswana: Access to Residential Electricity

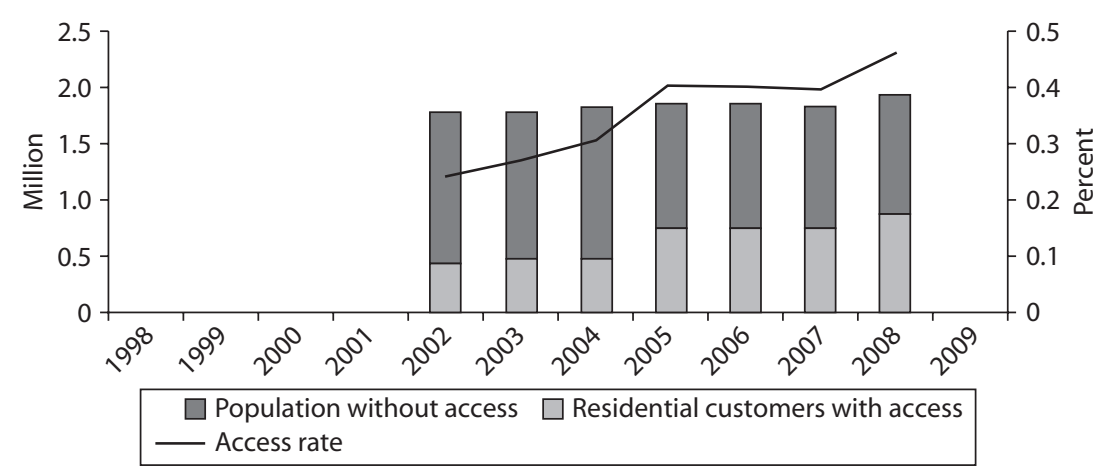

Source: An elaboration from the Power Market Structure database.

\section{Figure 12.3 Botswana: System Losses and Operating Costs}

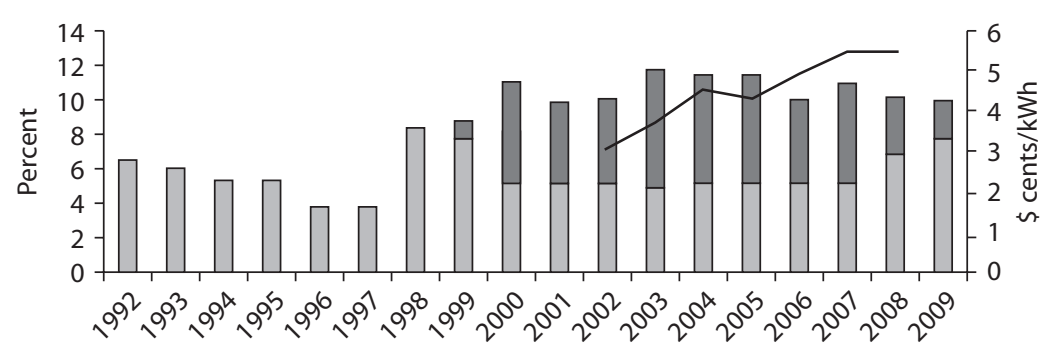

Source: An elaboration from the Power Market Structure database.

Note: $\mathrm{kWh}=$ kilowatt-hour; opex = operational expenditures/costs.

\section{Figure 12.4 Botswana: Electricity Generation by Source and Carbon Emissions}

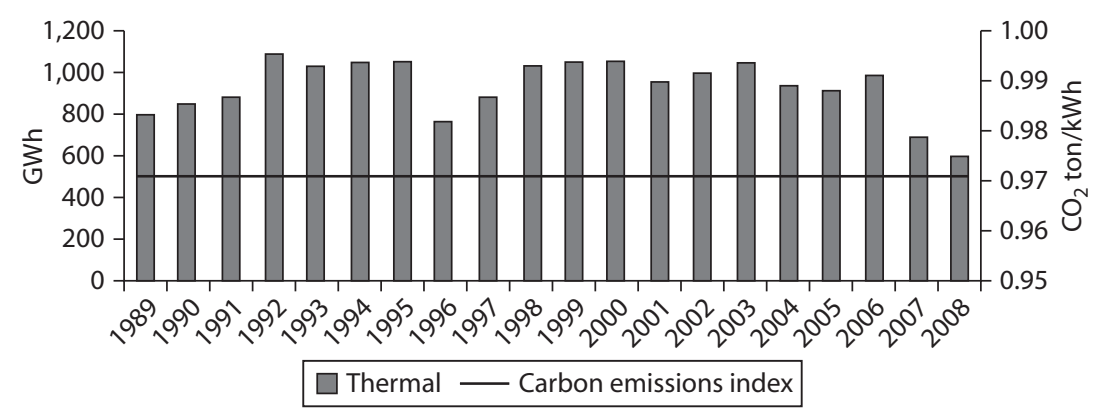

Source: An elaboration from the Power Market Structure database.

Note: GWh = gigawatt-hour; kWh = kilowatt-hour. 


\section{Figure 12.5 Botswana: Energy Security and Capital Expenditure}

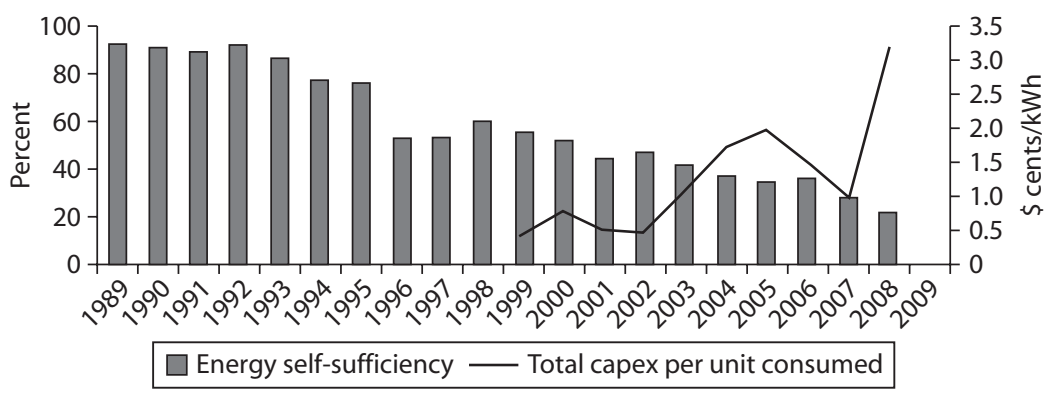

Source: An elaboration from the Power Market Structure database.

Note: Capex $=$ capital expenditures; $\mathrm{kWh}=$ kilowatt-hour.

\section{Figure 12.6 Botswana: Average Tariff and Operating Costs}

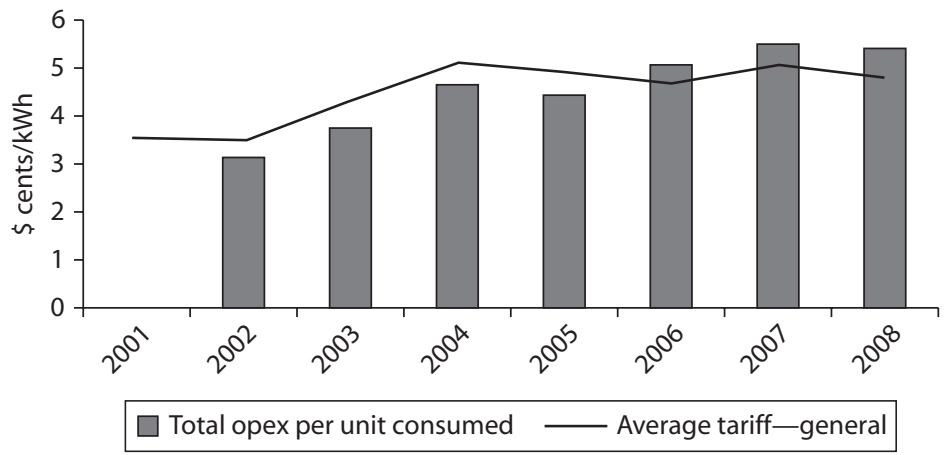

Source: An elaboration from the Power Market Structure database. Note: $\mathrm{kWh}=$ kilowatt-hour; opex = operational expenditures/costs.

\section{Figure 12.7 Botswana: Capacity Utilization}

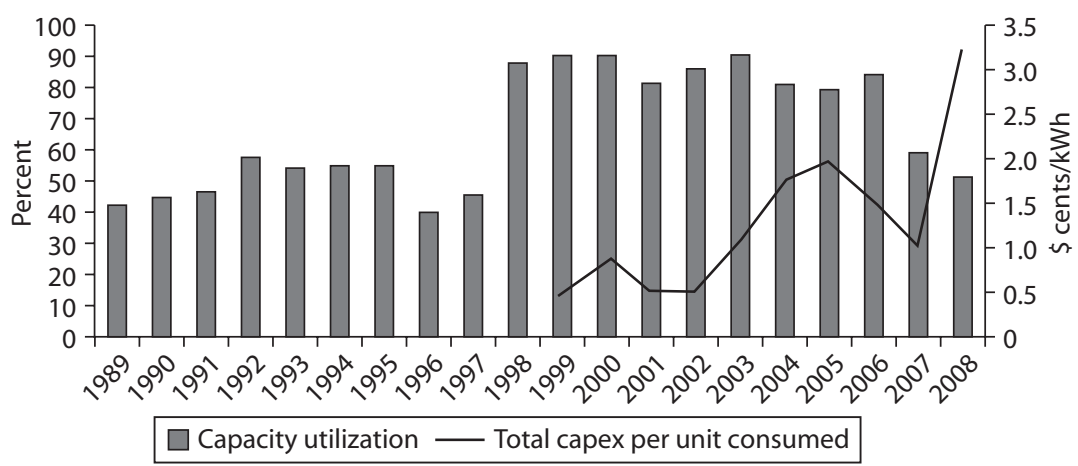

Source: An elaboration from the Power Market Structure database.

Note: Capex $=$ capital expenditures; $\mathrm{kWh}=$ kilowatt-hour. 


\section{Figure 12.8 Botswana: Cost Recovery Index}

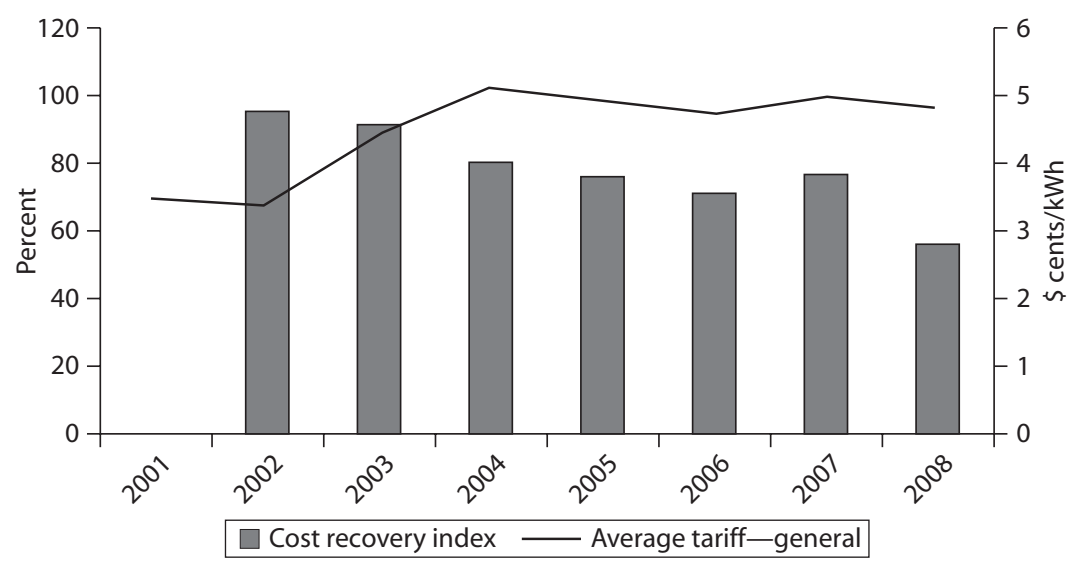

Source: An elaboration from the Power Market Structure database.

Note: $\mathrm{kWh}=$ kilowatt-hour.

\section{Figure 12.9 Botswana: Market Concentration}

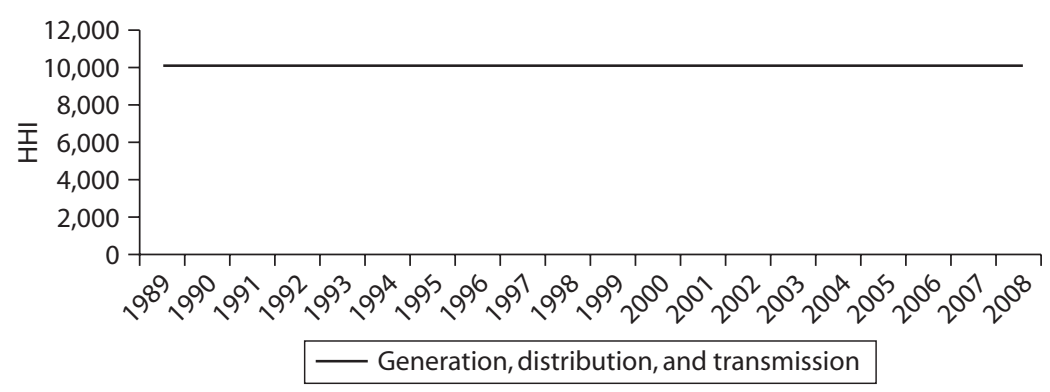

Source: An elaboration from the Power Market Structure database. Note: $\mathrm{HHI}=$ Herfindahl-Hirschman Index.

\section{Figure 12.10 Botswana: Private Ownership}

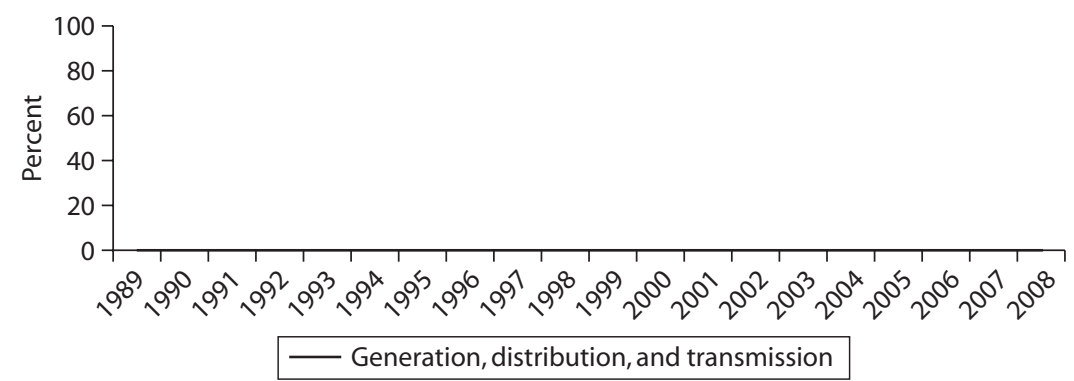




\section{Figure 12.11 Botswana: Private Management}

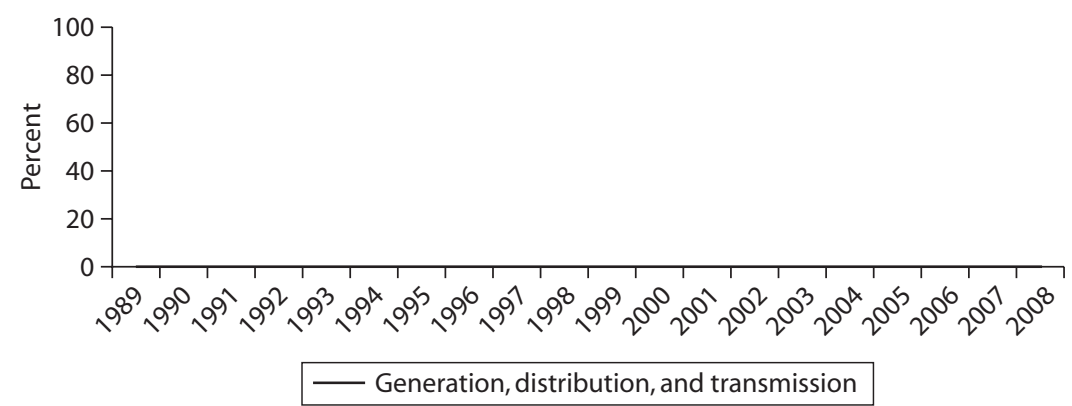

Source: An elaboration from the Power Market Structure database.

\section{Figure 12.12 Botswana: Degree of Vertical Integration}

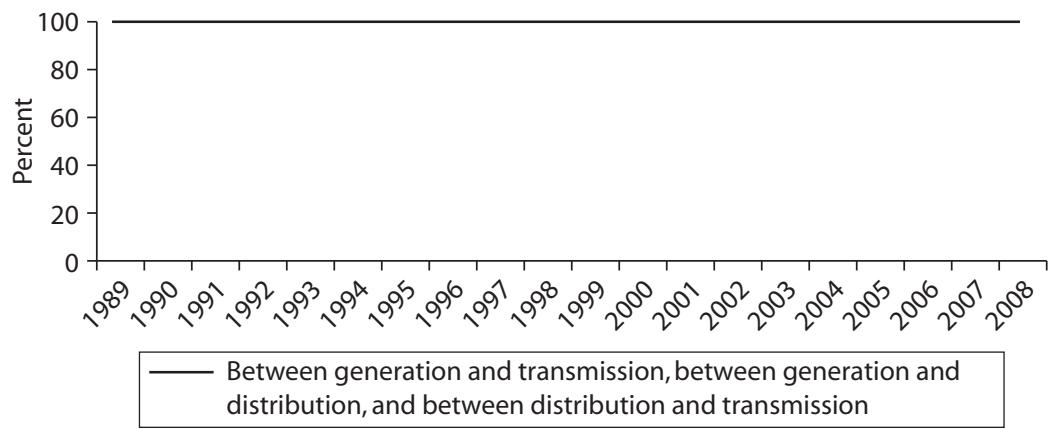

Source: An elaboration from the Power Market Structure database. 


\section{Andhra Pradesh}

If the Indian state of Andhra Pradesh (AP) were classified as a country, it would fall into the category of high system size/low per capita income (gross national income of $\$ 1,077$ per capita in 2010), which is similar to the all-India average level $)^{1}$ and current total installed generating capacity of about 15,000 megawatts (MW) (68 percent thermal, 25 percent hydro, and 7 percent renewable and nuclear). ${ }^{2}$ Access to electricity is around 90 percent of AP's urban population and 70 percent of the rural population, compared to 66 percent for all of India (International Energy Agency 2010).

AP's electricity supply is subject to both the federal government and to the state government (GoAP). The reason is that electricity was placed in the "concurrent" list in the Indian Constitution, which entered into force on January 26, 1950, meaning that electricity is assigned constitutionally to both the Indian government (GoI) and state governments. Therefore, the history of power sector reform in Andhra Pradesh draws from two interconnected strands-reforms enacted at the federal level that directly affect power markets in all or most of the states, and reforms enacted by GoAP concerning AP's power market. Reforms at the federal level form an important component of reform in AP. 


\section{Reform History}

Andhra Pradesh State Electricity Board (APSEB) was formed in 1959 under the 1948 Electricity (Supply) Act as part of Gol's policy of creating state electricity boards (SEBs) around the country. This policy reflected Gol's socialist ideology that the state should occupy the commanding heights of the economy. APSEB was incorporated as a state-owned vertically integrated utility responsible for the generation, transmission, and distribution of power. Like other SEBs, APSEB took over the existing privately owned power supply systems in its service area. Until 1982 APSEB was the sole provider of publicly supplied electricity in AP (some large users installed power generators on their premises to produce electricity for their own consumption).

Like state-owned enterprises in various Indian economic sectors, SEBs were subject to soft budgets and depended on government transfers for their capital funding and their financial survival. In turn, GoI used SEBs to advance its social policies, such as subsidized power for favored consumer groups (notably farmers and households) and employment for workers, and its economic policies, such as preference for locally manufactured electrical plant and equipment. This relationship turned SEBs into instruments of substantial political patronage for exerting influence on target groups of voters and for dealing with powerful labor unions.

Electricity tariffs were to be determined by the requirement that SEBs earn a 3 percent rate of return on their net asset value, without having specific regulatory oversight. But SEBs were not able to achieve this level of profitability because state governments held down their tariffs. Because SEBs did not generate sufficient financial resources to fund investments in new supply capacity, they turned to their state governments for financial assistance. By the late 1980s the SEBs' losses became too large to be sustained from state budgets and prevented state governments from financing important social and infrastructure services. ${ }^{3}$ The Indian government did not have a strategy for correcting the unstable financial equilibrium between SEBs and their creditors.

The government was forced to act by India's macroeconomic crisis of 1991. The crisis resulted from the huge rise in central- and state-level debt incurred during the 1980s in an effort to accelerate economic growth. The crisis ended India's socialist approach to economic management. Politicians chose instead to liberalize the economy gradually, and they adopted a policy of attracting private investment to capital-intensive infrastructure development. A new reformist central government used the crisis to implement radical currency reforms and to start improving 
the business climate for foreign investors. This policy extended to the power sector, where a new liberal approach to the power supply with private provision and investment was starting to attract attention around the world. The new government launched a "disinvestment" program (actually privatization, but more acceptable politically) to raise revenues and to meet the conditions set by the International Monetary Fund for helping India resolve its fiscal crisis.

The reforms to the power supply introduced by GoI in 1991 were designed to alleviate the shortage of generating capacity quickly by allowing private investment in this sector of the power market. The reforms did not address the SEBs' poor performance because improvements would take too long to materialize to help resolve the immediate crisis. The Electricity Laws (Amendment) Act of 1991 changed the 1948 Electricity Supply Act to allow private generators to operate on a cost-plus model with their tariffs regulated by the Central Electricity Authority. Tariff rules were set to guarantee a 16 percent return on equity (after tax) and full repatriation of profits in hard currency for the investors.

To launch this reform, GoI awarded fast-track status to eight power generation projects that included a power purchase agreement with a SEB. Only three projects actually reached the development stage, ${ }^{4}$ and only two of them, both located in AP, were actually constructed and are in operation. One of them was developed by Godavari Spectrum Power Generation Ltd. (208 MW) at Kakinada, and the other was developed by GVK Industries (216 MW) at Jegurupadu. These projects benefited from a business-friendly environment in AP and the availability of locally produced natural gas. In the late 1990s, two other independent power producers (IPPs) also developed gas/naphtha-based generating stations in AP to augment power generation in the state. ${ }^{5} \mathrm{As}$ a result, $\mathrm{AP}$ was the most successful state in attracting IPPs.

While the federal government focused on attracting IPPs to generate electricity in India, many state governments looked at the need to turn their SEBs into efficient and financially viable enterprises. In the absence of a nationwide reform strategy for SEBs from GoI, the states embarked on a variety of reform strategies that ranged from full unbundling, corporatization, regulation, and privatization (Orissa in the mid-1990s and New Delhi in the 00s) to unbundling, corporatization, and regulation without privatization (AP and others) ${ }^{6}$ to corporatization and regulation (others).

APSEB was one of few well-managed power utilities in India until the late 1980s. It had consistently earned the regulated 3 percent rate of return on net fixed assets, but its financial position started to worsen in 
1989-90 and then deteriorated further. By 1997-98 APSEB had overall outstanding debts of Rs. 26,000 million (nearly $\$ 600$ million) due to the following: (1) increased burden of debt servicing, where about one-third of APSEB's income was used to repay loans and interest in 1998; (2) increase in the operational costs due to rising costs of fuel and fuel transportation charges; (3) increase in consumption by agricultural consumers, who accounted for about 40 percent of consumption and only 4 percent to 5 percent of the revenue in $1997-98 ;^{7}$ and (4) rising transmission and distribution ( $T$ and $\mathrm{D}$ ) losses, which were about 33 percent in fiscal 1997/98, attributable to inadequate investments in the T and D network. Because of its poor financial health, APSEB was unable to raise money for its capital investments. Further, IPPs were facing difficulty in getting financial closure for their projects, as APSEB-the sole buyer of power from IPPs-was in poor financial health.

APSEB's deteriorating financial position, coupled with an increasing energy deficit in the state, led GoAP to reform APSEB. In January 1995 GoAP constituted a high-level committee (Hiten Bhaya Committee) to study and report on the issues of restructuring the power sector into separate profit centers without privatization and keeping APSEB as the holding company for the unbundled entities. In June the committee recommended the separation of generation, transmission, and distribution functions and the creation of a regulatory authority to fix tariffs and issue licenses.

GoAP issued a policy statement in 1997 that established the following reform objectives and the strategy for implementing them:

- Providing operational, managerial, and functional autonomy to successor utilities to enable them to operate on commercial lines

- Separating the policy and regulatory functions from management of the power sector

- Establishing a regulatory framework to enable rational tariff formulation to ensure cost optimization

- Limiting the role of the government to policy making and withdrawing regulatory functions from the purview of the government

- Promoting increased participation of the private sector in the power sector

- Providing good quality power to all the people of Andhra Pradesh at an affordable cost

- Achieving commercial viability in the power sector so that the sector can finance its investment needs and not be dependent on budgetary subsidies 
GoAP was one the most progressive state governments in the late 1990s. It started its reform process by passing the Andhra Pradesh Electricity Reforms Act in 1998. The act provided for the establishment of the Andhra Pradesh Electricity Regulatory Commission (APERC); restructuring the power sector; rationalizing the generation, transmission, distribution, and supply of electricity; creating avenues for private participation in the power sector; and generally for taking measures conducive to the development and management of the power sector in an efficient, economic, and competitive manner.

In accordance with the 1998 Act, APSEB was unbundled into two separate entities in February 1999 (the first transfer scheme): Andhra Pradesh Power Generation Corporation Limited (APGENCO) and Transmission Corporation of Andhra Pradesh Limited (APTRANSCO). APGENCO was mandated to acquire, establish, construct, and operate power-generating stations in the state, and APTRANSCO was made responsible for transmission and bulk supply and for distribution and retail supply. APTRANSCO was further unbundled in April 2001 (the second transfer scheme) with the separation of the transmission and distribution businesses. Four new distribution companies were created on a regional basis. APERC also awarded licenses to nine Rural Electric Cooperative Societies operating in the state.

The reform model adopted by GoAP bases the determination of tariffs and subsidies on the concept of an annual revenue requirement, which is defined as the difference between the costs of serving customers and the revenues derived from the tariffs charged. If costs exceed revenues for a class of consumers, GoAP is expected to provide a subsidy to cover this deficit, rather than resort to the previous practices of cross-subsidies and accounting tricks. This subsidy allows the distribution entities to become financially self-sufficient provided that they meet performance goals for reducing losses. Because the distributors were at different stages of transition toward commercial performance, ${ }^{8}$ APERC announced a differential bulk supply tariff among them in its tariff order for fiscal 2001/02, to allow uniform retail tariffs across the zones by customer tariff category.

Initially, the power sector reforms were met with opposition, but strong political support developed to drive the reforms ahead as the process gained momentum. The ruling party took charge of steering the reforms in the state. GoAP's strong commitment to carry out the restructuring exercise was evident in its 1997 policy statement. To clear the apprehensions of APSEB's employees, GoAP entered into a tripartite agreement with APSEB and the APSEB Engineers Association/APSEB 
Assistant Engineers Association that there would be no retrenchment of employees for any reason and their status/service would not change. ${ }^{9}$ GoAP also took other initiatives to inform the stakeholders of the urgency to usher in power reforms. It actively supported APSEB's publicity campaign to educate the public about the need for the reforms. To help the distributors reduce losses, GoAP passed strong antitheft legislation under which many consumers and APSEB employees have been convicted, fined, and even sent to prison (Bhatia and Gulati 2004).

In March 1999 GoAP established the Andhra Pradesh Electricity Regulatory Commission as a quasi-judicial body. APERC is responsible for determining electricity tariffs, issuing licenses to companies that transmit and distribute power, issuing regulations, setting performance standards, promoting competition in the power sector, and protecting the interests of consumers. The formation of APERC was in accordance with GoI's Electricity Regulatory Commissions Act of 1998, which provided a legal basis for state regulatory commissions in response to the increasing number of state electricity regulatory commissions formed during the 1990s. The act defined the rules that governed these commissions' independence, jurisdiction and powers, constitution, procedures, and qualifications of commissioners. ${ }^{10}$

Spurred by the political turmoil caused by electricity tariff adjustments in June 2000 (following APERC's first tariff order) and the strike by APSEB employees when the AP electricity reform legislation was enacted, GoAP sought quick and demonstrable gains in popular support for its power reform agenda. In parallel with an increase in tariffs, the power companies invested to improve the quality of power supply and customer service. These investments yielded the following benefits: more energy handled by the supply network, fewer interruptions and low voltage problems faced by farmers and industrial consumers, reduction in the distribution transformer failure rate, increased revenues from the installation of high-accuracy meters with tamper detection features for high-value consumers, improved supply reliability by installing dedicated feeders to large industrial users of power and separating agricultural loads from other loads on rural feeders, and reduced theft of electricity by legalizing 2 million users with unauthorized connections to the power system.

Despite these efforts, AP's power sector was still in poor condition. Tariffs remained generally low and distorted: rates to industrial and commercial consumers were much higher than costs, while rates to agricultural and household consumers were much lower than costs, which resulted in huge direct subsidies and cross-subsidies to the latter groups. 
Total losses-technical and nontechnical-remained high (around 50 percent). The sector also accumulated enormous debts to the central power supply corporations, fuel suppliers, and financiers.

Concerned about the general lack of improvement in the performance of SEBs, GoI focused its efforts on measurable performance outcomes, backed by a new funding mechanism in 2000-01, the Accelerated Power Development and Reform Programme (APDRP), which rewarded the states with the best performance. The APDRP was intended to provide funding for investments to improve the performance of state electricity distributors who could not generate sufficient funds internally or borrow funds because of their poor credit standing. Each state government signs a memorandum of understanding (MOU) with GoI about the reforms to be carried out. In return GoI increases power to the state from centrally owned power stations, upgrades interstate transmission lines, and provides other benefits and financing under the APDRP. Most state governments signed a MOU. The substantial amounts of funds under the APDRP helped states overcome local obstacles to reforming their power sectors.

A notable innovation under the APDRP was the measurement and ranking of state electricity suppliers according to a number of performance indicators that included improvements in $\mathrm{T}$ and $\mathrm{D}$, installation of meters, and institutional reform. APDRP funds were directed to the states with the best performance, thus creating competition for these funds. Two ratings firms were hired to rank the states. In the first ranking in 2003, AP was the highest, so presumably AP's power distributors were able to obtain some much-needed financing from the APDRP.

Despite the impact of the APDRP, state-level power supply remained problematical, and the federal government wanted to pass a comprehensive electricity reform act to advance the reforms and replace the variety of measures being implemented by the states. It started the process for a new act in 2001 but was unable to get Parliament to pass the law for two years (Electricity Act 2003). Under the act's framework, private investors are encouraged to participate in all stages of the power supply chain, although the act does explicitly mandate privatization of distribution. Generators can build plants without having to obtain a licence and transmission companies must provide open access to their networks, including out-of-state suppliers. The law also provides for special regulatory tribunals to streamline the judicial review of regulatory decisions.

Accordingly, in July 2005 APERC introduced open access in transmission and distribution by issuing a regulation to that effect to intrastate transmission and distribution networks. APERC determines the open 
access charges as per the 2005 regulations. No cross-subsidy surcharge is payable if the open access is provided to a person who has established a generating plant for his own use.

In June 2005 GoAP announced the third transfer scheme by virtue of which procurement and bulk supply of electricity, trading of electricity, and PPAs were transferred and allocated to the four distribution companies in specified proportions. The generation capacities of thermal and hydro energy generating stations (including those of APGENCO, which were vested with APTRANSCO under the PPAs), the IPPs, and the firm allocation of central generating stations were allocated and transferred to the distributors.

\section{Impact on Sector Structure}

Andhra Pradesh's power sector experienced major restructuring with the vertical and horizontal unbundling of APSEB and the entry of IPPs and the central thermal power generator to the sector described so far in this chapter.

\section{Impact on Sector Performance}

Evidence of possible impacts from unbundling and other reforms is sought from trends from the early to mid-1990s up to 2008 in the following indicators:

- Access to electricity supply by the population in terms of new residential connections. The total number of consumers of electricity more than doubled from 9.34 million in 1996-97 to 18.91 million in 2007-08. Before APSEB's unbundling, the growth in number of consumers was slow as compared to the period after unbundling. The access rate for both urban areas and rural areas increased steadily to around 90 percent for the former and 70 percent for the latter. This increase can be partly attributed to the improvement in the financial situation of the electricity distributors in the state, even after allowing for the impact on access ratios of converting large numbers of consumers from illegal to legal connections.

- Customer service quality. Because AP, like most Indian states, had been chronically short of power since the 1980s, a reliable indicator of customer service is the shortage of power supply relative to demand. The state had an energy deficit of 2.2 percent during 2007 and 3.9 percent in 2008 , even though demand for electricity grew rapidly 
during the decade following the reforms to AP's economy and the power sector. The total volume of power sold to various categories more than doubled from 21,607 GWh (gigawatt-hours) in 1997 to $48,013 \mathrm{GWh}$ in 2008 , indicating a strong growth in demand.

- Supply security. From the start of the reform period in 1999, T and D losses declined steadily, from 37.1 percent in fiscal 2000 to 20.2 percent in fiscal 2006. Most of this decline was in distribution losses (26.0 percent to 15.8 percent ). This decline is attributable to investments and the anti-theft campaign.

- Financial sustainability. From the start of the reform period in 1999 , the financial health of all of AP's power utilities improved and were consistently ranked number one by Credit Rating and Information Services of India. Although the utilities incurred a deficit of Rs. 17,200 million (about $\$ 380$ million) in fiscal 2000, they recorded a profit of Rs. 2,910 million (about $\$ 65$ million) in fiscal 2006. All utilities were profitable for many years. The improvement in performance of the utilities also brought down financial burden on the state government. The subsidy support provided by the state government declined from Rs. 30,644 million (about $\$ 675$ million) in fiscal 2000 to Rs. 13,510 million (about $\$ 300$ million) in fiscal 2007, but increased to Rs. 28,664 million ( $\$ 630$ million) in fiscal 2008. As a proportion of revenues of the utilities, subsidy provision declined from 49 percent in fiscal 2000 to 14 percent in fiscal 2006. This was achieved in the absence of tariff increases between 2002 and 2006 (People's Monitoring Group on Electricity Regulation 2007). Capital expenditure before unbundling showed a declining trend, indicating inadequate capital investments. It was about Rs. 6,093 million in 1997-98; after unbundling it rose to Rs. 22,730 million in 2002-03, declined again to Rs. 16,554 million, and increased to about Rs. 48,541 million in 2007-08.

- Environmental sustainability. AP's carbon emissions per unit of energy generated have experienced opposing influences, with a tendency to increase from thermal power generated by new gas-fired plants owned and operated by IPPs and more efficient newer coal-fired plants owned and operated by IPPs and by NTPC (formerly known as National Thermal Power Corporation), the large central thermal power generator.

Trends in these indicators are shown in the figures that follow. 


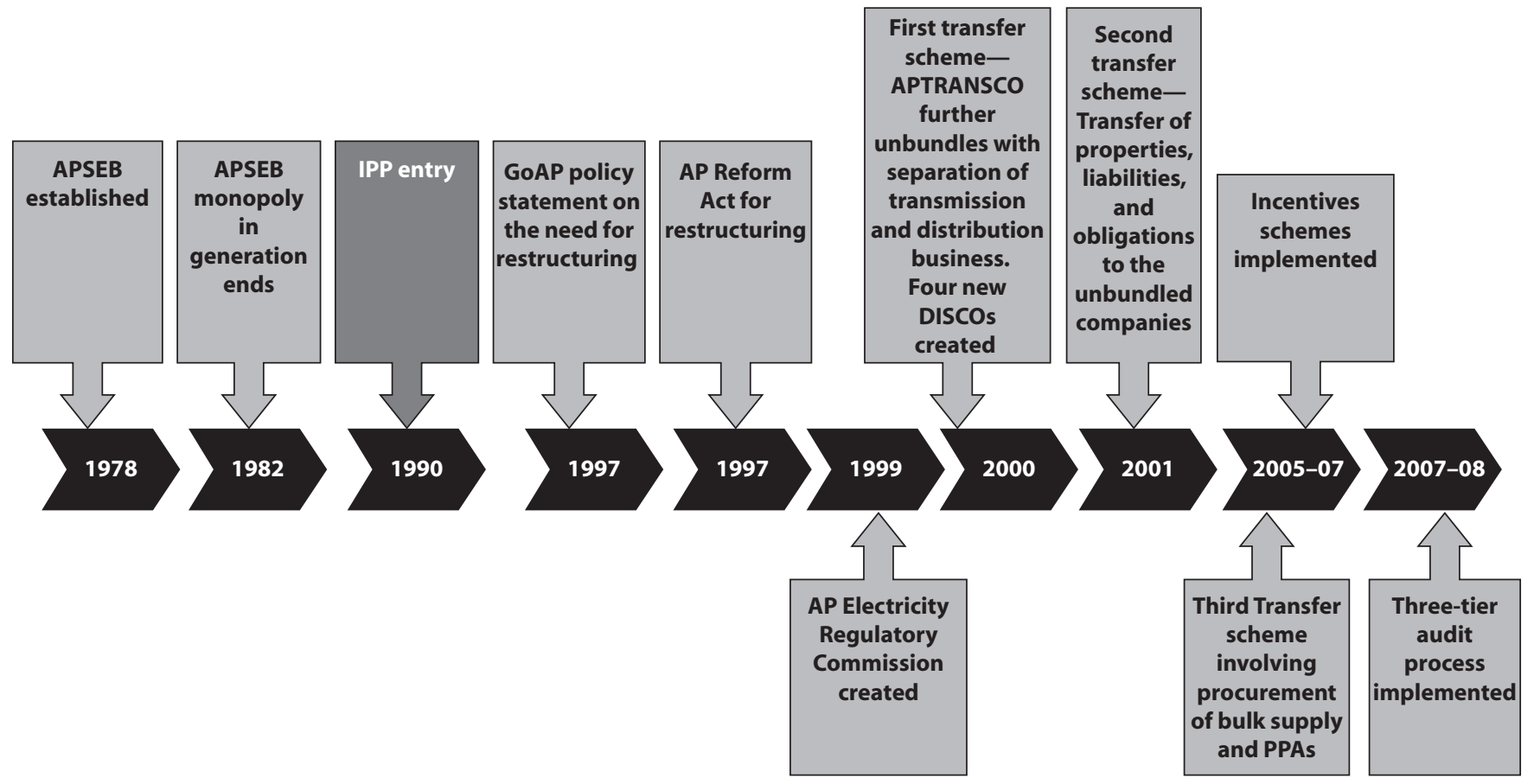

Source: An elaboration from the Power Market Structure database.

Note: The milestones are reported in different shades: light gray = main government interventions; dark gray = main private sector involvements. AP = Andhra Pradesh; APSEB = Andhra Pradesh State Electricity Board; APTRANSCO =Transmission Corporation of Andhra Pradesh; DISCOs = distribution companies; GoAP = state government of Andhra Pradesh; IPP = independent power producer; PPAs = power purchase agreements. 


\section{Figure 13.2 Andhra Pradesh: Access to Residential Electricity}

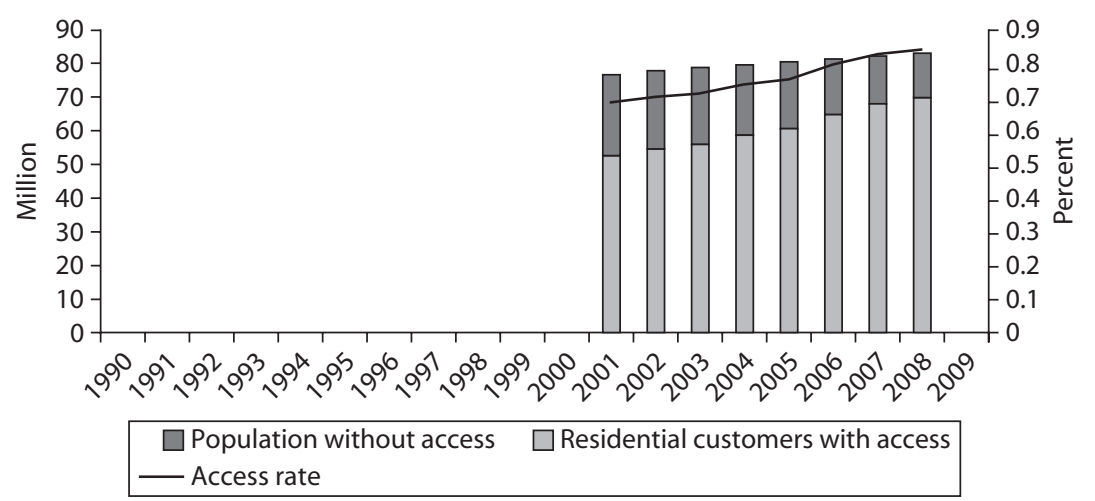

Source: An elaboration from the Power Market Structure database.

Figure 13.3 Andhra Pradesh: Quality of Electric Service and Operating Costs

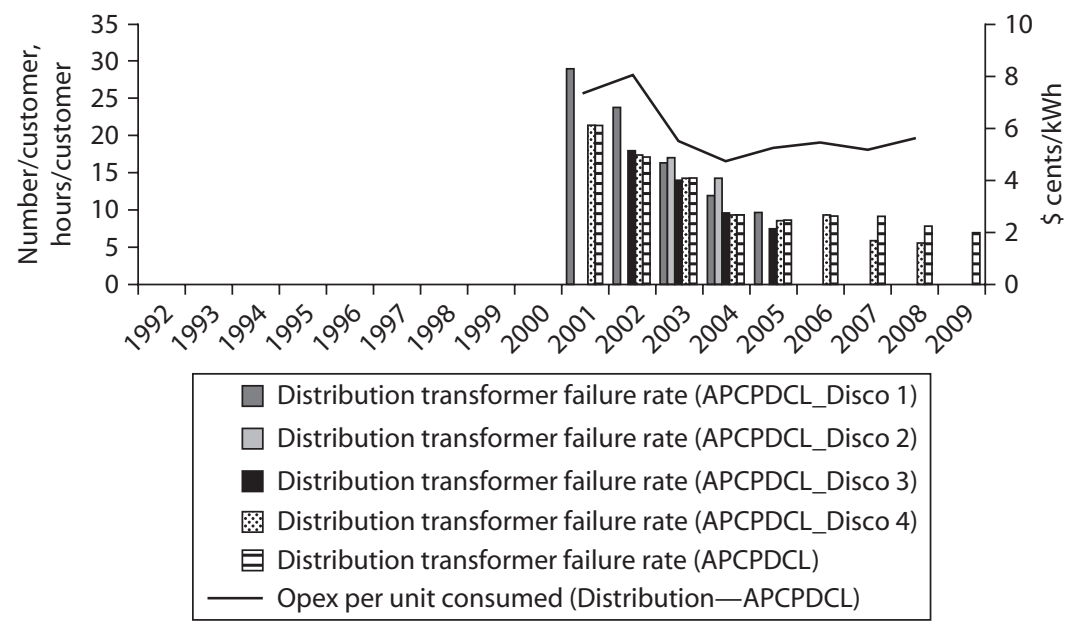

Source: An elaboration from the Power Market Structure database.

Note: APCPDCL = Central Power Distribution Company of Andhra Pradesh Ltd.; DISCO = distribution company; $\mathrm{kWh}=$ kilowatt-hour. 


\section{Figure 13.4 Andhra Pradesh: System Energy Losses and Operating Costs}

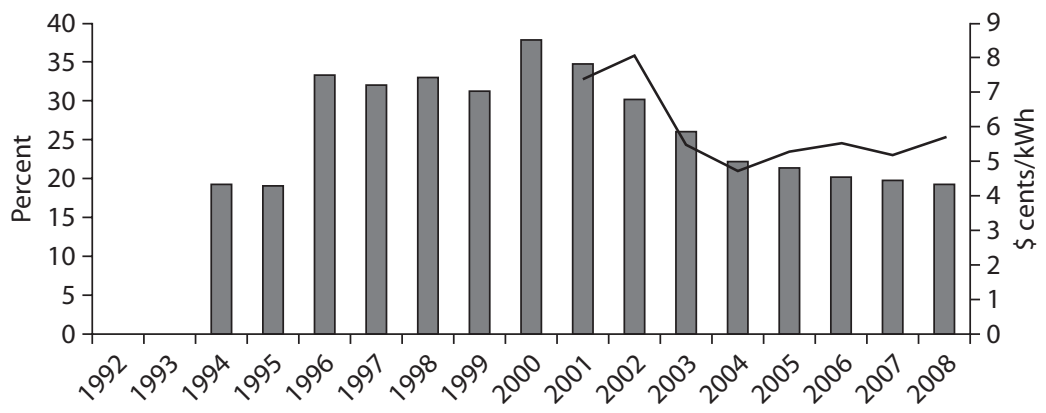

Distribution and transmission losses

Opex per unit consumed (Distribution-APCPDCL)

Source: An elaboration from the Power Market Structure database.

Note: $\mathrm{APCPDCL}=$ Central Power Distribution Company of Andhra Pradesh Ltd.; kWh = kilowatt-hour; opex = operational expenditures/costs.

Figure 13.5 Andhra Pradesh: Electricity Generation by Source and Carbon

\section{Emissions}

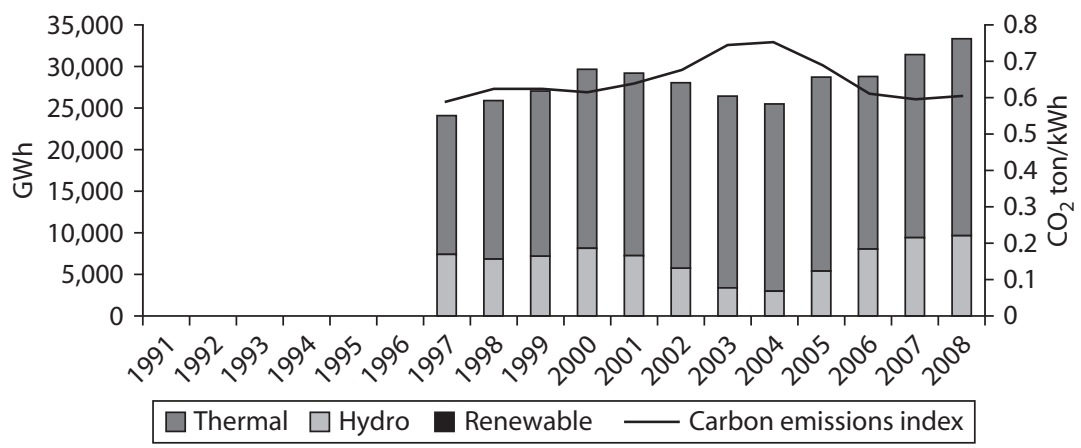

Source: An elaboration from the Power Market Structure database.

Note: GWh = gigawatt-hour; kWh = kilowatt-hour. 


\section{Figure 13.6 Andhra Pradesh: Energy Security}

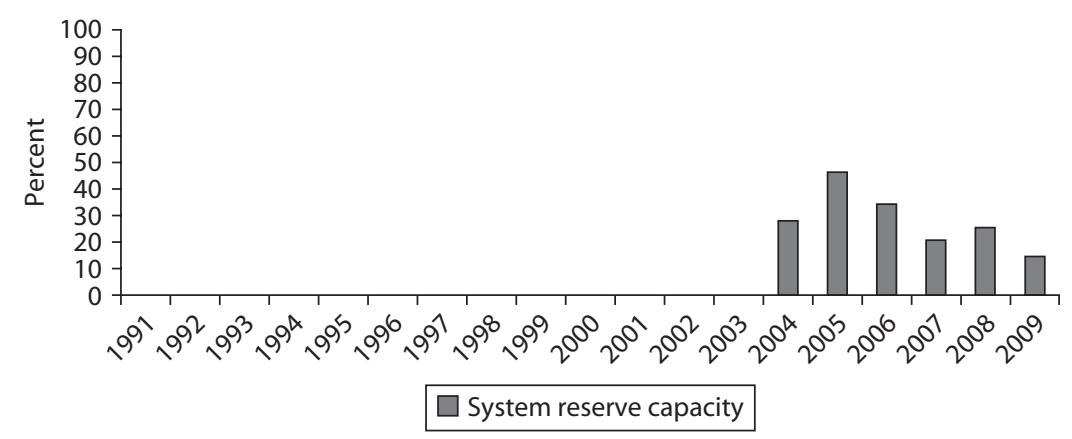

Source: An elaboration from the Power Market Structure database.

\section{Figure 13.7 Andhra Pradesh: System Load Factor}

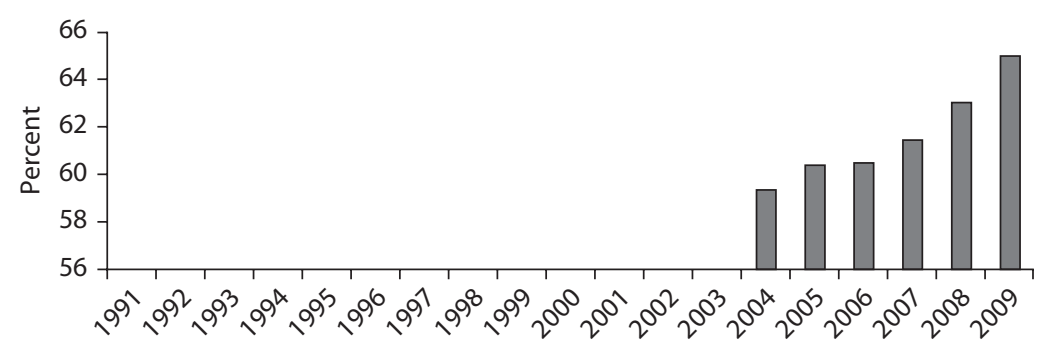

Source: An elaboration from the Power Market Structure database.

\section{Figure 13.8 Andhra Pradesh: Capacity Utilization}

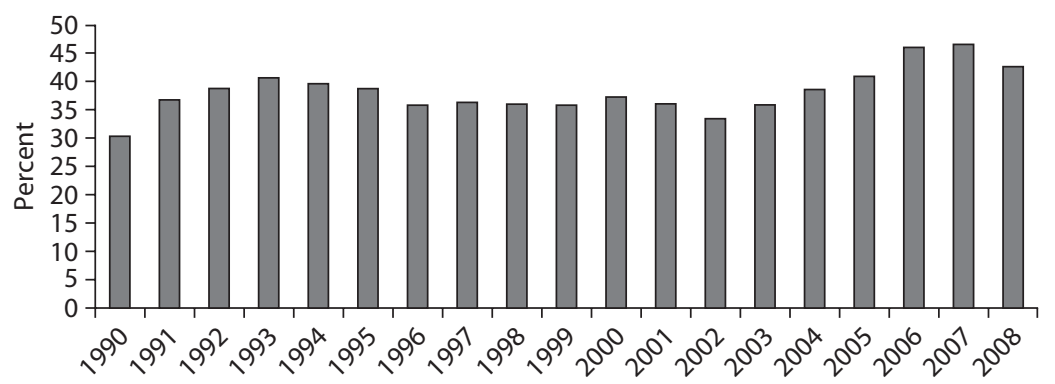

Source: An elaboration from the Power Market Structure database. 


\section{Figure 13.9 Andhra Pradesh: Labor Productivity}

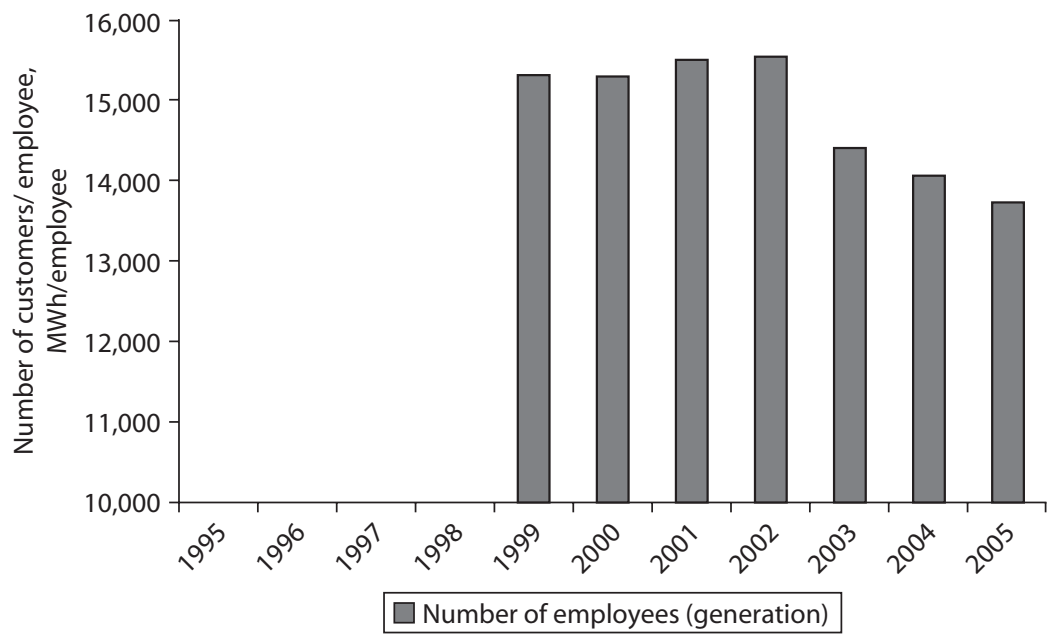

Source: An elaboration from the Power Market Structure database. Note: $\mathrm{MWh}=$ megawatt-hour.

Figure 13.10 Andhra Pradesh: Cost Recovery Index

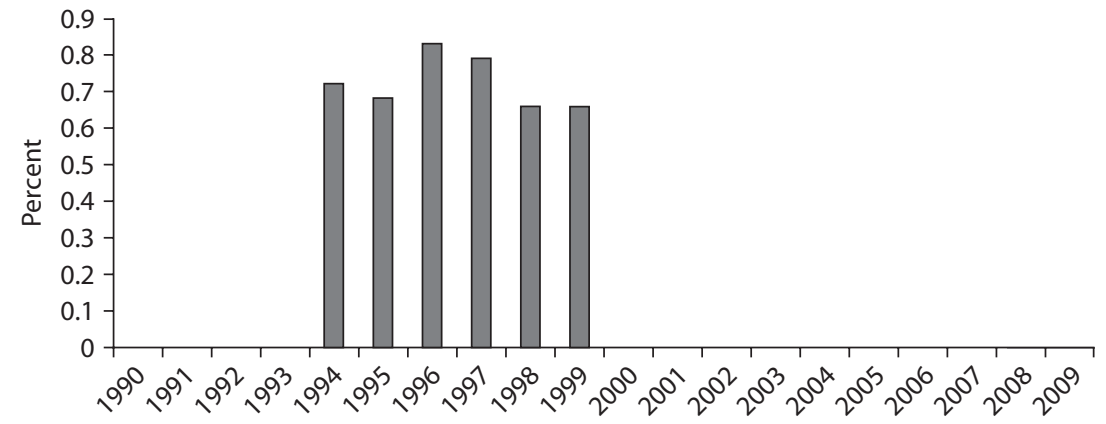

Source: An elaboration from the Power Market Structure database. 


\section{Figure 13.11 Andhra Pradesh: Market Concentration}

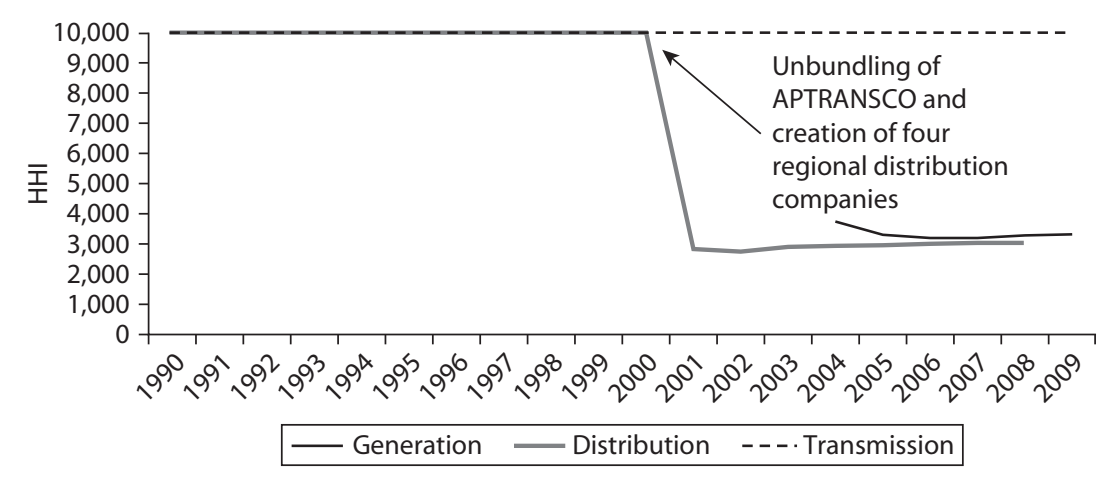

Source: An elaboration from the Power Market Structure database.

Note: APTRANSCO = Transmission Corporation of Andhra Pradesh; $\mathrm{HHI}=$ Herfindahl-Hirschman Index.

\section{Figure 13.12 Andhra Pradesh: Private Ownership}

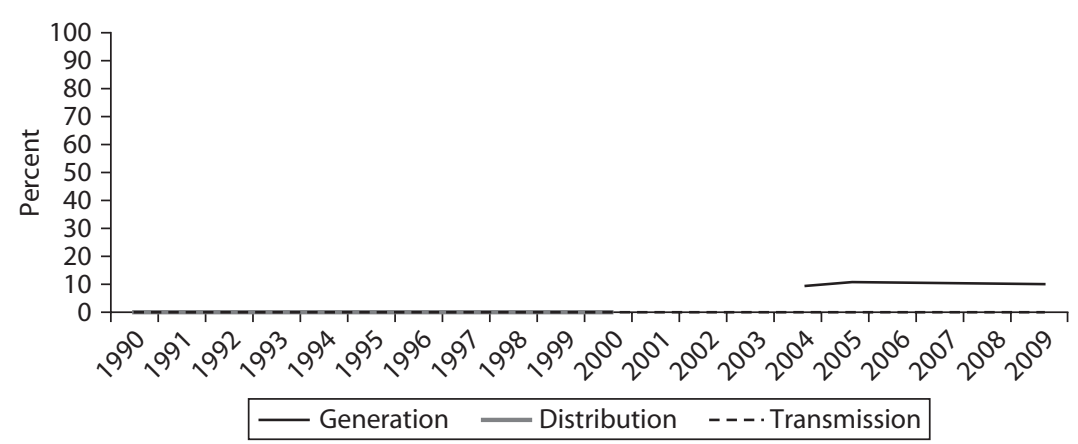

Source: An elaboration from the Power Market Structure database.

\section{Figure 13.13 Andhra Pradesh: Private Management}

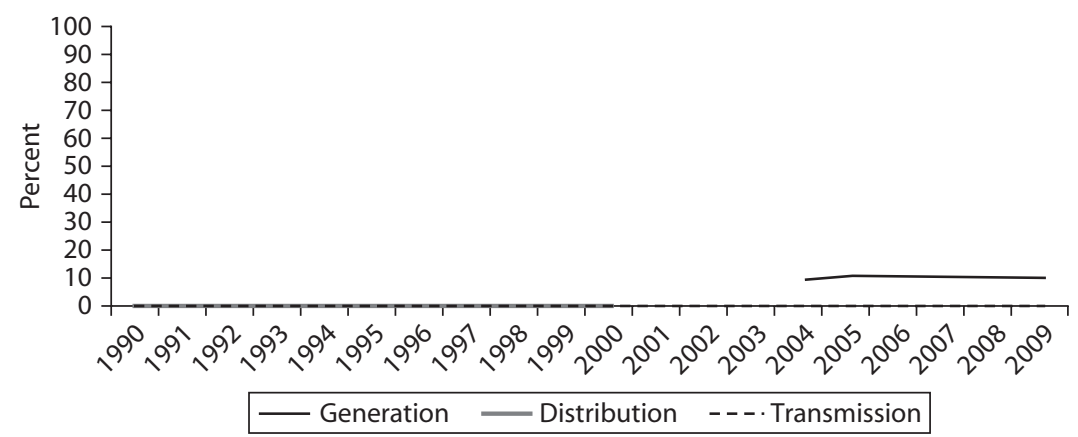




\section{Figure 13.14 Andhra Pradesh: Degree of Vertical Integration}

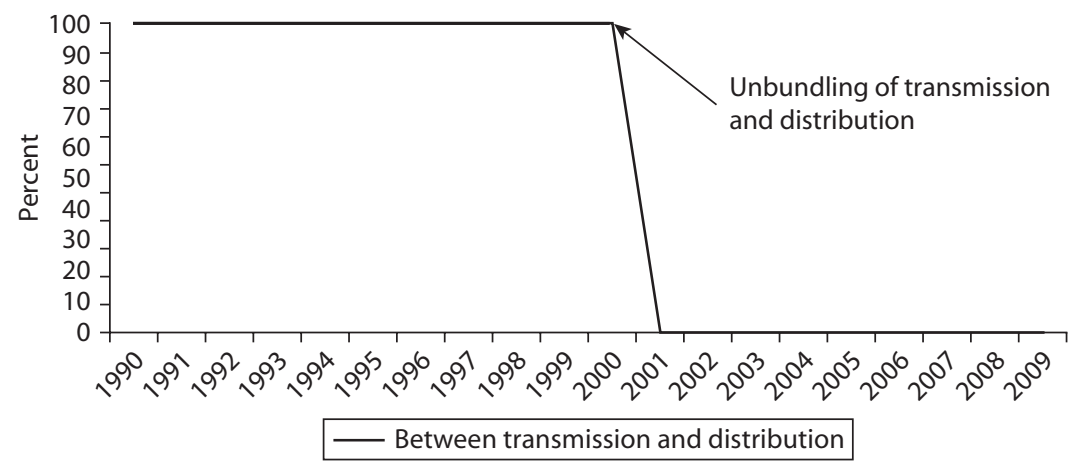

Source: An elaboration from the Power Market Structure database.

\section{Notes}

1. Wikipedia, http://en.wikipedia.org/wiki/List_of_Indian_states_by_GDP\#cite_ note-0); http://en.wikipedia.org/wiki/States_and_territories_of_India; http:// en.wikipedia.org/wiki/States_of_India_by_installed_power_capacity.

2. This capacity consists of $8,481 \mathrm{MW}$ by the state power generation company; 3,708 MW by private power generators (IPPs); and 2,845 MW by central power generators, according to the Central Electricity Authority Monthly Executive report for March 2011, http://cea.nic.in/reports/monthly/ executive_rep/mar11/28-34.pdf.

3. In practice, state governments used a range of noncash transactions to reduce or avoid cash transfers from their budgets. These transactions included foregone interest payments to the state, electricity duties, and other liabilities for SEBs. SEBs also built up huge accounts payable to GoI suppliers, particularly to National Thermal Power Corporation for bulk power supply, fuel suppliers (especially coal), Indian railways (for transporting coal) and the Power Finance Corporation (for loans). These debts effectively transferred some of SEB's financial problems to the central government.

4. One of them was the Dabhol project in Maharashtra to be developed by Enron.

5. These stations were Lanco Kondapalli (368 MW) and BSES Andhra Power Ltd. (220 MW).

6. In principle, the first two models differ in the sequencing of reform steps; in the first model, privatization of the entities in their poor condition occurs soon, whereas in the second model, considerable time and public funding is expended to improve the performance of entities in preparation for eventual privatization. 
7. This was mainly because of nonremunerative tariffs charged to agricultural consumers (charged on flat rate basis for connected load), which encouraged overuse of electric pumps.

8. This differential partly reflects differences in the mix of urban/rural service areas among the distribution companies, as serving urban areas is more profitable than serving rural areas.

9. In addition, all employment and wage benefits, welfare schemes such as compassionate appointment, medical reimbursement, and the like were to be continued without any change.

10. In $2000 \mathrm{GoI}$ set up the Central Electricity Regulatory Commission to oversee inter-state power trade and the national power suppliers such as NTPC and the national high voltage transmission company (Grid Corporation of Orissa Limited).

\section{References}

Bhatia, Bhavna, and Mohinder Gulati. 2004. "Reforming the Power Sector: Controlling Theft and Improving Revenues." Public Policy for the Private Sector. Note 272. September. World Bank, Washington, DC. http://rru.worldbank. org/Public PolicyJournal.

International Energy Agency. 2010. World Energy Outlook: The Electricity Access Database. http://www.worldenergyoutlook.org/database_electricity 10/electricity_database_web_2010.htm.

People's Monitoring Group on Electricity Regulation. 2007. "Andhra Pradesh: Power Sector Status and Issues." Note prepared by Hyderabad, Andhra Pradesh, for the workshop organized by Prayas, Pune. March 22. http://www .pmger.org/articles.asp. 



\section{CHAPTER 14}

\section{Gujarat}

Gujarat falls into the category of high system size/low per capita income with current total installed generating capacity of just below 8,000 MW (megawatts) and gross national income of $\$ 1,000$ per capita in 2008 (World Bank 2008).

\section{Reform History}

The government of Gujarat passed the Gujarat Electricity Industry (Reorganization and Regulation) Act, 2003, for the restructuring of the power sector in the state. The erstwhile Gujarat Electricity Board (GEB) was unbundled and reorganized into six successor entities in 2005, as follows:

- Generation: Gujarat State Electricity Corporation Limited

- Transmission: Gujarat Energy Transmission Corporation Limited

- Distribution: Dakshin Gujarat Vij Company Limited, Madhya Gujarat Vij Company Limited, Uttar Gujarat Vij Company Limited, and Paschim Gujarat Vij Company Limited 
A separate company, Gujarat Urja Vikas Nigam Limited, was incorporated to look after the residual functions of GEB and to undertake the purchase of electricity from various sources and in turn supply it to the distribution companies/licensees.

The most noteworthy feature of the exercise was the signing of a tripartite agreement among recognized unions and associations of GEB employees, the government of Gujarat, and GEB. This exercise was undertaken to gain the consensus of employees and allay their fears of job losses and other problems.

As part of the financial restructuring plan, a detailed road map for the successor entities was prepared. The road map included a turnaround plan for subsidy support from state government and capital infusion to improve their efficiency parameters by 2011. The assets of the erstwhile GEB were restated upward to reflect the prevailing market value.

\section{Impact on Sector Performance}

Evidence of possible impacts from unbundling and other reforms is sought from trends from the early to mid-1990s up to 2008 in the following indicators. After the power sector was restructured (unbundled) in 2005:

- Profit increased from a deficit of Rs. 969 crores in 2004-05 (GEB) to Rs. 126 crores in 2008-09 (total profit all unbundled utilities).

- Transmission and distribution losses were reduced from 33.5 percent in 2005 to 21.14 percent in 2009.

- The average cost to serve increased from Rs. 3.74 per kilowatt-hour (kWh) in 2005 to Rs. 4.64 per $\mathrm{kWh}$ in 2009, and the average realization of revenue has increased from Rs. 3.44 per kWh in 2005 to Rs. 4.68 per $\mathrm{kWh}$ in 2009, indicating a surplus.

- Electricity generation in the state increased from 23,000 MW in 2005 to above $28,000 \mathrm{MW}$ in 2009, representing an annual increase of more than 4 percent. 


\section{Figure 14.1 Gujarat: Access to Residential Electricity}

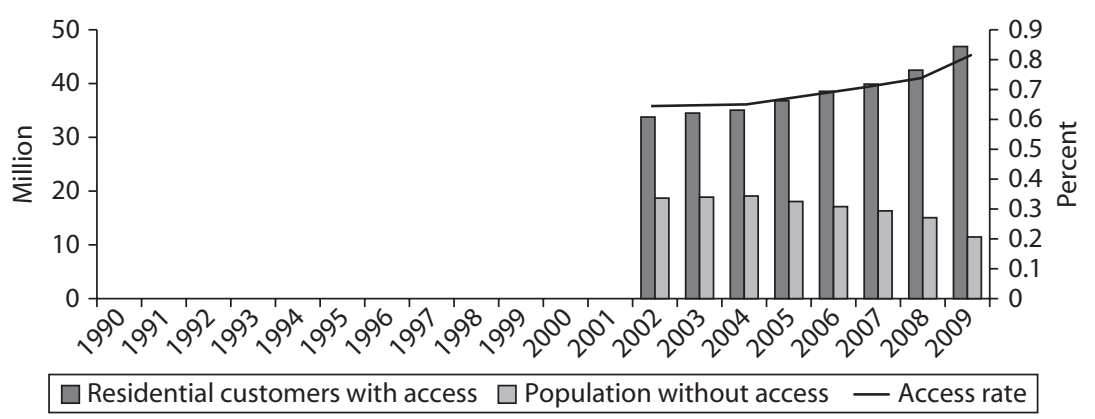

Source: An elaboration from the Power Market Structure database.

Figure 14.2 Gujarat: Quality of Electric Service

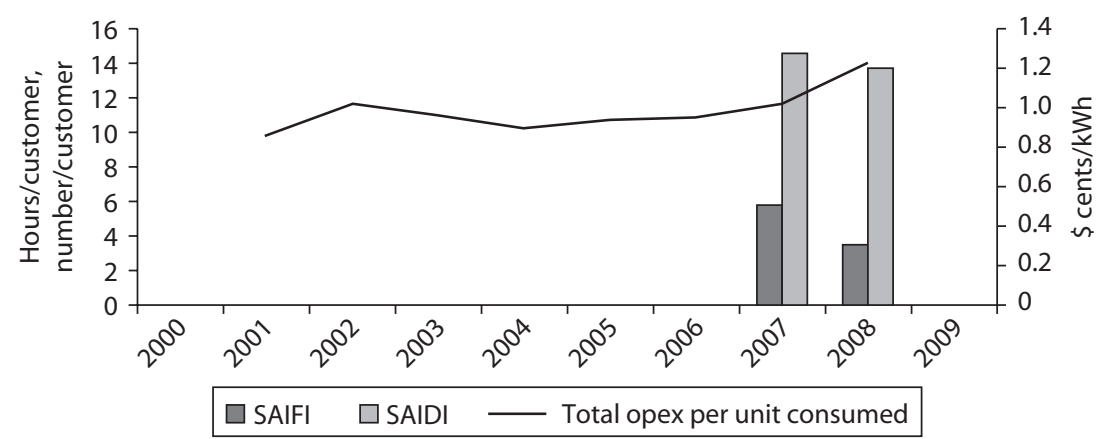

Source: An elaboration from the Power Market Structure database.

Note: $\mathrm{kWh}$ = kilowatt-hour; opex = operational expenditures/costs; SAIDI = System Average Interruption Duration Index; SAIFI = System Average Interruption Frequency Index.

\section{Figure 14.3 Gujarat: System Energy Losses}

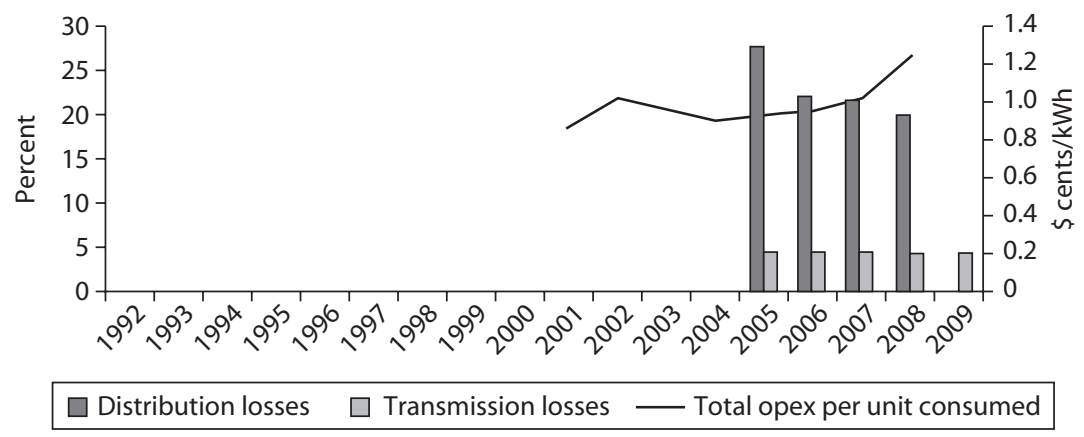

Source: An elaboration from the Power Market Structure database. Note: kWh = kilowatt-hour; opex = operational expenditures/costs. 


\section{Figure 14.4 Gujarat: Electricity Generation by Source and Carbon Emissions}

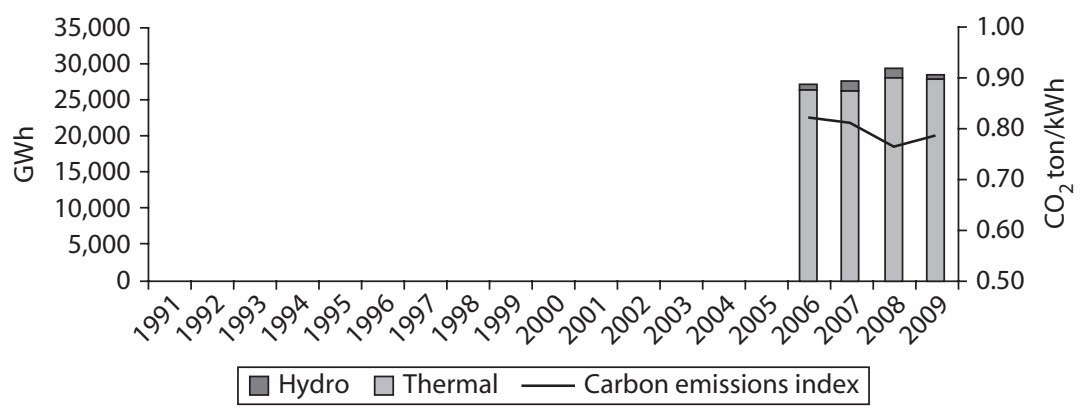

Source: An elaboration from the Power Market Structure database. Note: $\mathrm{GWh}=$ gigawatt-hour; kWh = kilowatt-hour.

\section{Figure 14.5 Gujarat: Average Tariff and Operating Costs}

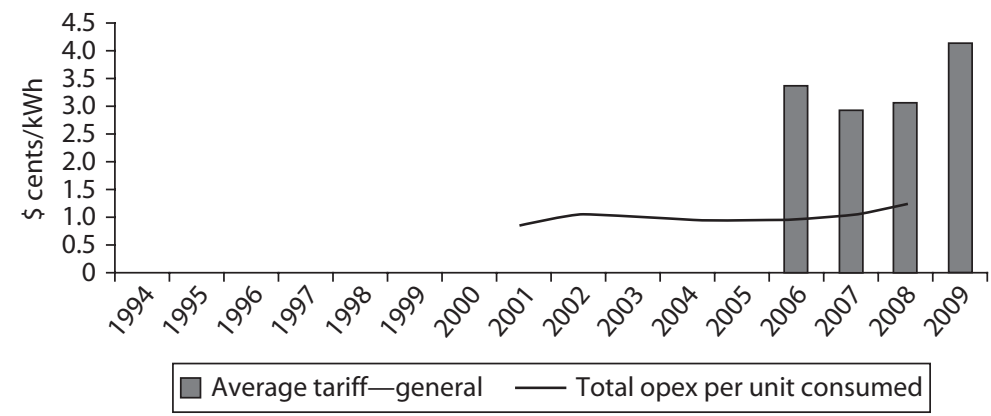

Source: An elaboration from the Power Market Structure database.

Note: $\mathrm{kWh}=$ kilowatt-hour; opex = operational expenditures/costs.

\section{Figure 14.6 Gujarat: Labor Productivity}

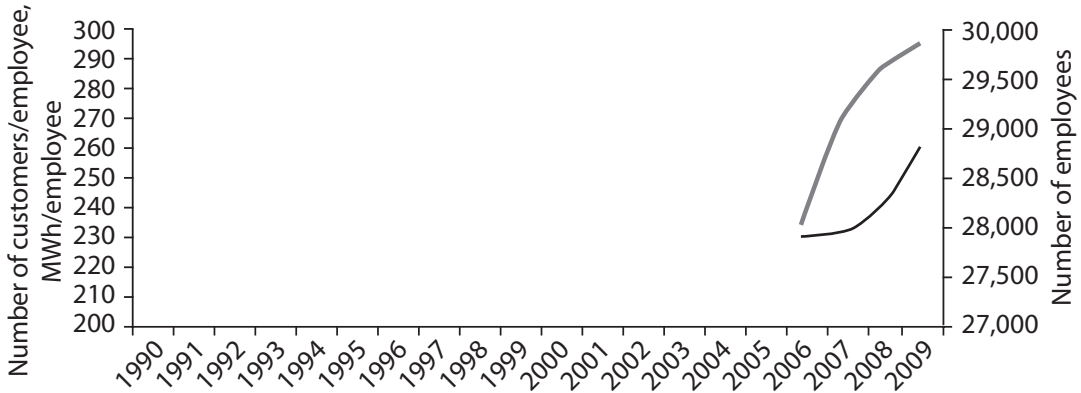

- Number of residential customers/employee Number of employees (distribution)

Source: An elaboration from the Power Market Structure database. Note: $\mathrm{MWh}=$ megawatt-hour. 


\section{Figure 14.7 Gujarat: Capacity Utilization}

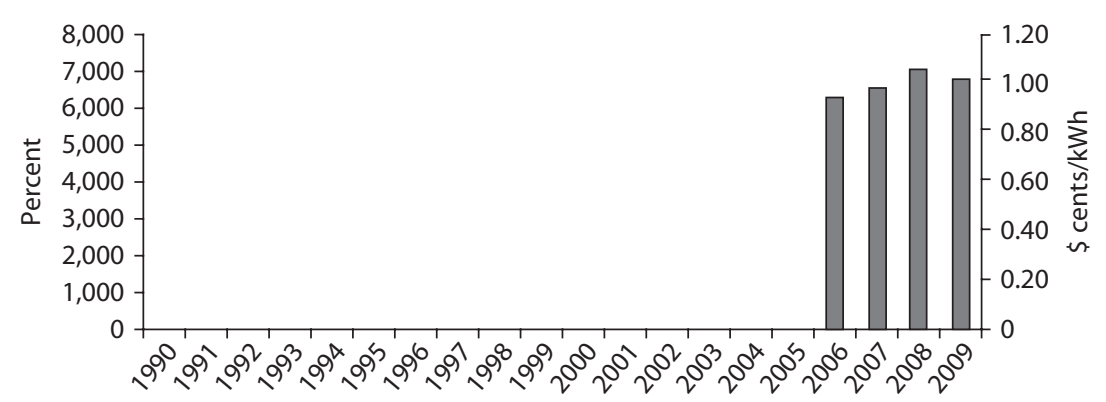

Source: An elaboration from the Power Market Structure database. Note: $\mathrm{kWh}=$ kilowatt-hour.

Figure 14.8 Gujarat: Private Ownership

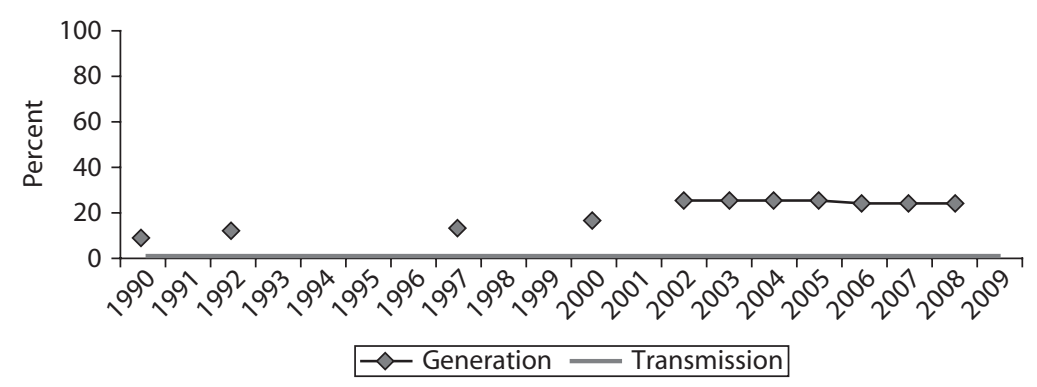

Source: An elaboration from the Power Market Structure database.

Figure 14.9 Gujarat: Private Management

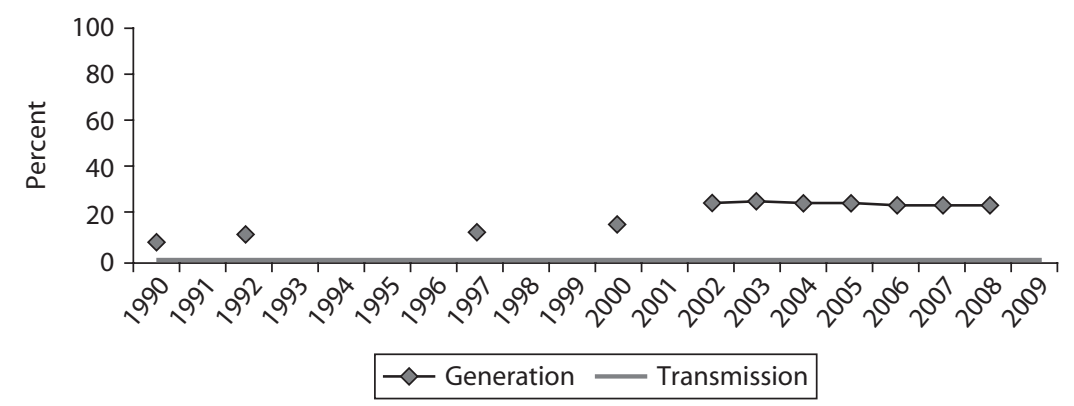

Source: An elaboration from the Power Market Structure database. 


\section{Figure 14.10 Gujarat: Market Concentration}

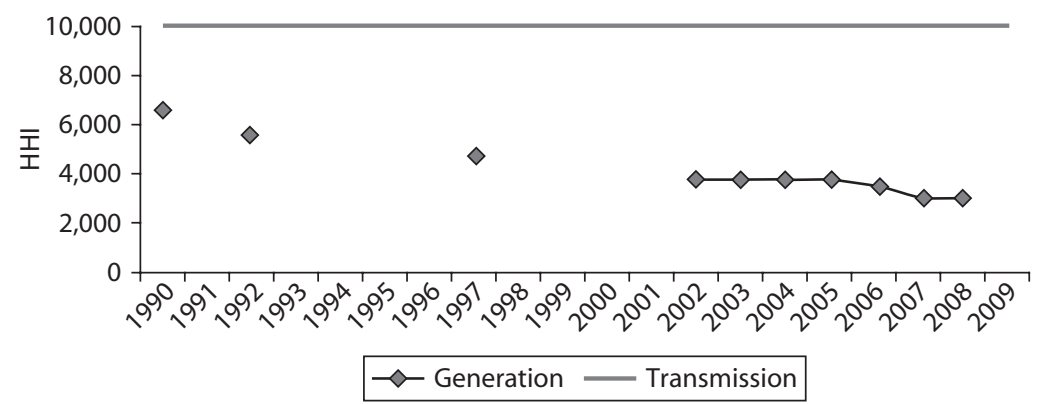

Source: An elaboration from the Power Market Structure database. Note: $\mathrm{HHI}=$ Herfindahl-Hirschman Index.

\section{Figure 14.11 Gujarat: Degree of Vertical Integration}

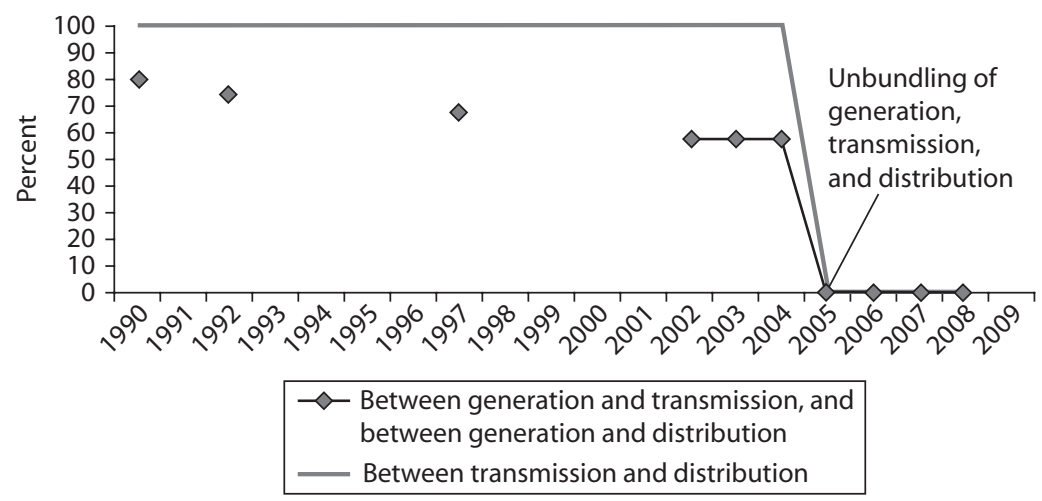

Source: An elaboration from the Power Market Structure database.

\section{Reference}

World Bank. 2008. World Development Indicators. World Bank, Washington, DC. 


\section{CHAPTER 15}

\section{West Bengal}

West Bengal falls into the category of high system size/high per capita income, with a gross national income of $\$ 1,000$ per capita in 2008 (World Bank 2008) and current total installed generating capacity of just below 8,000 MW (megawatts).

West Bengal State Electricity Board (WBSEB) was formed on May 1, 1955 , as a vertically integrated power utility covering all the spheres of the electricity business of generation, distribution, and transmission. Under the Electricity Act of 1948, WBSEB had the whole of West Bengal as its command area except the Damodar Valley Corporation (DVC) and the Disergarh Power Supply Corporation (DPSC) area. In 1985 West Bengal Power Development Corporation Limited (WBPDCL) was formed to access funds and to provide focused attention to thermal generation of the state. At first, WBPDCL operated only the Kolaghat Thermal Power Station, and subsequently the new Bakreswar Thermal Power Project. In June 2001 the process of transferring thermal generation to WBPDCL was completed when the Bandel and Santaldihi Thermal Power stations were also transferred. In 1998 the West Bengal Rural Energy Development Corporation Limited was formed to focus on rural electrification, and the following year the West Bengal Electricity Regulatory Commission was set up. 


\section{Reform History}

Before unbundling, which took place in April 2007, WBSEB was involved in hydro generation, along with negligible generation from diesel and gas; transmission, including State Load Dispatch Centre (SLDC) activities; and distribution, trading, and bulk supply activities. After the Electricity Act 2003 came into effect, the Department of Power, Government of West Bengal, in July 2003 constituted a state-level reorganization committee on restructuring the power sector's distribution system. The committee was chaired by Subimal Sen, a member of the State Planning Board.

The key objectives of the restructuring process were to improve the level of consumer service and operational efficiencies on a sustainable basis within the statutory framework, to avoid creating any tariff shocks for the consumers, and to pave the way for the government to meet its commitments on rural electrification and socioeconomic development of the state.

The Power Department also established a task force, made up of the top management of the three power utilities and officials of the Power Department, to constantly interact with consultants. The three power utilities, WBSEB, WBPDCL, and DPL (Durgapur Projects Limited), also established designated task forces at department-head level within their organizations.

The state government formulated a set of guiding principles for achieving the desired objectives in the restructuring of the power sector. These principles were:

- Ensure sustainable viability of restructured entities with minimal structural disruptions that require no recurring budgetary revenue support from government; restructure finances to clean up past debt burdens and open access to competitive funding for investments in system improvements; address transitional issues; and avoid tariff shocks for consumers

- Strengthen managerial initiatives within a government-ownership framework requiring introduction of good corporate governance practices; adopt "best-in-class" business processes and systems

- Support economic growth in the state through competitive tariffs with improved customer service, accelerated rural electrification, and generation capacity with strong transmission/distribution systems

- Safeguard the interests of the employees of the power utilities while designing the restructuring interventions 
The functions and business in transmission and load dispatch were transferred to and vested in WBSETCL (West Bengal State Electricity Transmission Company Limited); the functions and business in distribution activities and all existing hydropower stations, all gas turbine units, and diesel generation units with all associated and related equipment of WBSEB were transferred to WBSEDCL (West Bengal State Electricity Distribution Company Ltd.) from the effective date.

WBSEDCL and WBSETCL were incorporated under the provisions of the Companies Act of 1956 on February 16, 2007, and obtained a certificate of commencement of business on March 21. These companies are government entities within the meaning of Section 617 of the Companies Act, and their entire share capital is held by the government of West Bengal (GoWB), except the shares allotted to the signatories of the Memorandum of Association of the company.

\section{Impact on Sector Performance}

Evidence of possible impacts from unbundling and other reforms is sought from trends from the early to mid-1990s up to 2008 in the following indicators.

The main players in the power sector before it was restructured (pre-unbundling) in April 2007 included WBSEB, WBPDCL, West Bengal Renewable Energy Development Agency, and DPL in the state sector; Calcutta Electric Supply Corporation Ltd. (CESC) and DPSC in the private sector; and National Thermal Power Corporation (NTPC) and DVC in the central governmental sector.

Around 48 percent of the generation capacity is state-owned. WBPDCL is the mainstay of the power requirement of the state and

\section{Table 15.1 Key Players in the Power Sector of West Bengal before Restructuring}

\begin{tabular}{ll}
\hline Entity & \multicolumn{1}{c}{ Function } \\
\hline WBSEDCL & Hydro generation, distribution \\
WBSETCL & State transmission utility and SLDC \\
WBPDCL & Thermal generation \\
DPL & Thermal generation, distribution, coke oven, water supply \\
\hline
\end{tabular}

Source: An elaboration from the Power Market Structure database. Note: DPL = Durgapur Projects Limited; SLDC = State Load Dispatch Centre; WBPDCL = West Bengal Power Development Corporation Limited; WBSEDCL = West Bengal State Electricity Distribution Company Limited; WBSETCL = West Bengal State Electricity Transmission Company Limited. 
Table 15.2 Power Sector of West Bengal before Restructuring

\begin{tabular}{lll}
\hline Ownership & Entity & Function \\
\hline State sector & WBSEB & $\begin{array}{c}\text { Hydro, diesel, and gas generation; HV, MV, LV distribution, } \\
\text { transmission, load dispatch } \\
\text { Thermal generation }\end{array}$ \\
& WBPDCL & $\begin{array}{c}\text { Thermal generation, HV, MV, LV distribution, coke oven, } \\
\text { water supply }\end{array}$ \\
& WBREDA & $\begin{array}{c}\text { Nonconventional generation } \\
\text { Rural electrification }\end{array}$ \\
Central sector & WBREDC & $\begin{array}{c}\text { Thermal and hydrogeneration, transmission, HV, MV } \\
\text { distribution }\end{array}$ \\
& DVC & $\begin{array}{c}\text { Thermal generation, HV, MV distribution } \\
\text { Private sector }\end{array}$ \\
\hline
\end{tabular}

Source: An elaboration from the Power Market Structure database.

Note: HV, MV, and LV = high, medium, and low voltage, respectively. CESC = Calcutta Electric Supply Corporation Limited; DPL = Durgapur Projects Limited; DPSC = Disergarh Power Supply Corporation; DVC = Damodar Valley Corporation; WBPDCL = West Bengal Power Development Corporation Limited;WBREDA = West Bengal Renewable Energy Development Agency; WBREDC = West Bengal Rural Energy Development Corporation Limited; WBSEB $=$ West Bengal State Electricity Board.

engaged in thermal generation. It is the largest generator in the West Bengal power system followed by NTPC.

Since its establishment in 1955, WBSEB has been acting as the State Transmission Utility and SLDC, with a transmission capacity of 12,563.5 MVA (megavolt amperes). WBSEB alone handled more than half of the electricity supply in the state. Besides WBSEB, three companies, CESC, DPL, and DPSC, supply electricity in their own licensed areas.

Because not much time has passed since unbundling, its performance cannot be benchmarked clearly. But improvements can be seen as profits of unbundled utilities have increased, expenses have gone down, and cost recovery has improved. In addition, transmission and distribution losses have been reduced.

The technical and operational performance after unbundling can be summarized as the following:

- A decrease in the state's energy deficit as power procurement increased

- An increase in WBSEDCL's installed capacity of $900 \mathrm{MW}$ due to the Purulia Pump Storage Project (PPSP)

- An 80 percent increase in the total generation

- A 9 percent increase in total power purchase cost and 5 percent increase in per unit power purchase cost

- Plans for significant capacity additions in the transmission network 
- Increase in distribution network with additional 16,657 distribution transformers

- Reduction in distribution transformer (DT) failure rate

- A 6.4 percent increase in the sale of power (million unit); reduced interstate sales

- Reduction of AT\&C (aggregate technical and commercial) losses and transmission and distribution losses

- Reduction of supply outages and improvement of reliability indices

- Initiation of prepaid meter facilities

During 2007-08 West Bengal had an energy deficit of 3.9 percent as compared to 2.2 percent in 2006-07. The demand for energy has been continuously increasing over the years. Although energy availability has increased, it has not been able to keep up with the significant and continuous growth in demand, leading to a deficit situation.

- Generation. The sharp rise in installed capacity of $900 \mathrm{MW}$ is attributed to the capacity addition from the PPSP, which was commissioned in 2007-08. The mission of the 900 MW PPSP is to mitigate the peak power deficit in the state by utilizing the low-cost excess power available during periods of low demand. The Rs. 29.53 billion project of WBSEDCL, located in Ajodhya Hills in Bagmundi village of Purulia district, is being funded as loan assistance from the Japan Bank for International Cooperation. The project comprises four units, each with $225 \mathrm{MW}$, and all of them in operation. WBSEB's own generation contributes only a small proportion of the total energy available to supply power to consumers. Therefore, in addition to its own hydro generation, WBSEB purchases power from different power supply agencies. In fact, WBPDCL's entire capacity of around 15,000 MW is dedicated to WBSEB's power requirement. The plant load factor (PLF) (hydro) of WBSEB has decreased from 35.34 percent in 2002-03 to 29.48 percent in 2006-07. The PLF continued to decline after unbundling and reduced to 26.36 percent.

- Transmission. In 2008 WBSETCL registered an increase of 6.7 percent in transmission capacity as compared to that of the previous year. WBSEB increased the number of extra-high voltage (EHV) substations from 68 in 2003 to 80 in 2007. After unbundling, WBSETCL is operating through $89 \mathrm{EHV}$ substations some of which have already obtained International Organization for standardization (ISO)-9001 
certificates. During 2007-08 about 382 circuit km (kilometers) of transmission lines of capacity and 3 new substations with transformation capacity of 509 MVA were added. WBSETCL has an ambitious program of starting another 30 new EHV substations and an additional 3,000 circuit $\mathrm{km}$ of EHV transmission lines during the balance period of the eleventh five-year plan. These additions to the transmission network aim at improving the system's power supply and reliability. India's Ministry of Power, through the Central Electricity Authority gave WBSETCL the Best Transmission System Availability Award with Gold Shield for 2007-08 in appreciation that availability of the transmission system was more than 99.87 percent. The number of distribution transformers has been increasing continuously since 2003, growing from 81,072 in 2007 to 97,729 in 2008, with an average DT capacity of 0.253 kilovolt amperes, registering an increase of around 21 percent after unbundling. The DT failure rate showed an increasing trend from 2003 (10.8 percent) to 2006-07 (12.9 percent), but it reduced to 10.3 percent in 2008 .

- Distribution. The total number of consumers served by WBSEDCL was $6,954,106$ in 2008, reflecting an increase of around 10 percent over the previous year before unbundling. The consumer profile has not shown any significant change over the years. It has always been dominated by domestic consumers with a share of 85 percent followed by commercial customers (12 percent).

- Operational and technical performance. T and D losses decreased when WBSEB was in operation. Losses declined from 34 percent in 2003 to 26 percent in 2007. WBSEB's aggregate technical and commercial (AT\&C) losses were very high at 43.4 percent in 2003-04, but have decreased since then and continued to decrease after unbundling. In 2007-08 AT\&C losses of WBSEDCL stood at 25.5 percent. This can be attributed to the continuous improvement in the collection efficiency.

Total operating expenses went down by 9 percent; sale of power produced a marginal increase in revenue; the average tariff for industrial and commercial customers has increased by 19 paise/unit and 37 paise/unit, respectively. Cross-subsidies from industrial and commercial customers increased; cost recovery improved, and profits were twice than that of WBSEB during 2007; and the debt-service ratio improved. 
- Labor productivity. Since unbundling there has been a consistent percentage decrease in employees and an increase in consumers. The number of consumers rose by 10 percent, similar to that in 2006-07, and the number of employees declined by 14 percent against only a 7 percent decline in 2006-07. The result was a steep rise in the number of consumers per employee, so that productivity increased by 23 percent in 2007-08 as compared to 2006-07. 
Figure 15.1 Milestones of Power Sector Reform in West Bengal

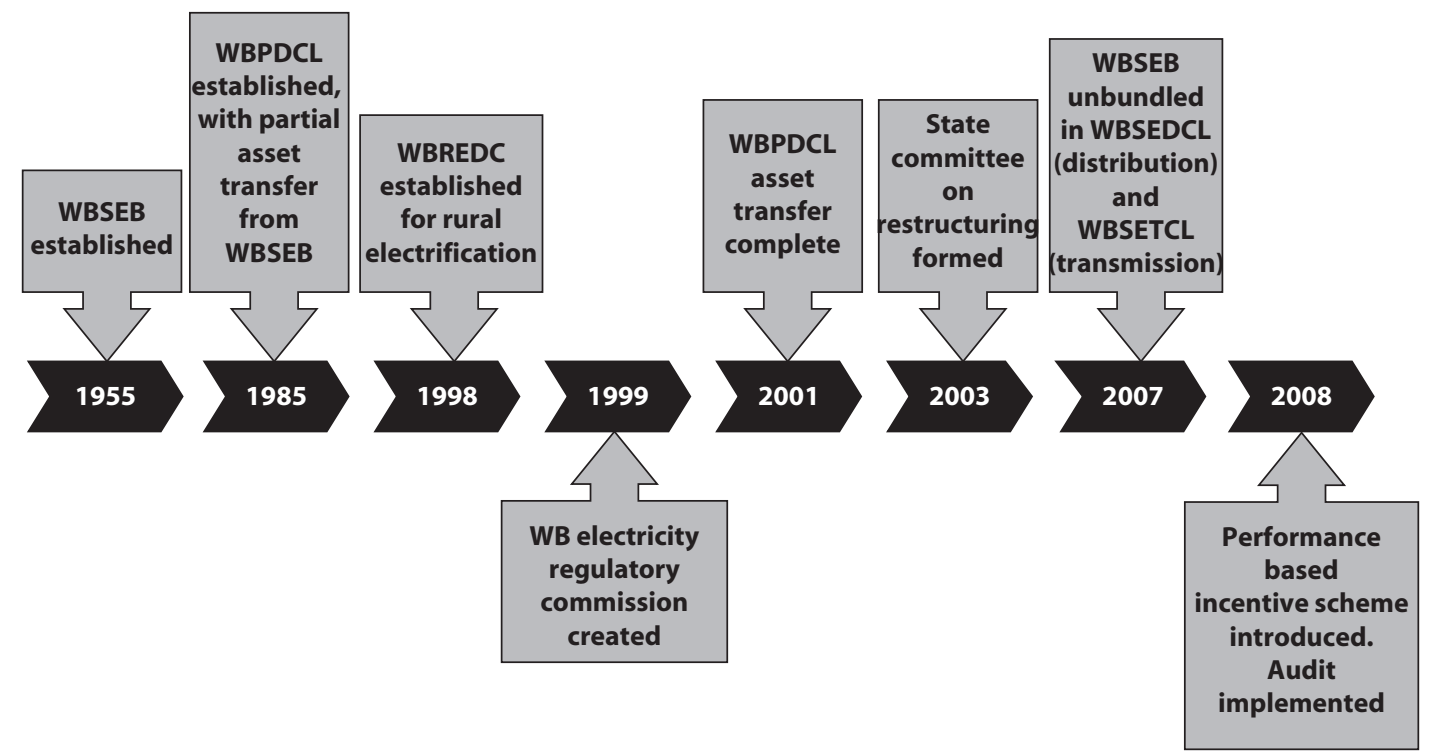

Source: An elaboration from the Power Market Structure database.

Note: The milestones in light gray refer to the main government interventions. WBPDCL $=$ West Bengal Power Development Corporation Limited; WBREDC $=$ West Bengal Rural Energy Development Corporation Limited; WBSEB = West Bengal State Electricity Board; WBSEDCL = West Bengal State Electricity Distribution Company Limited; WBSETCL = West Bengal State Electricity Transmission Company Limited. 


\section{Figure 15.2 West Bengal: Access to Residential Electricity}

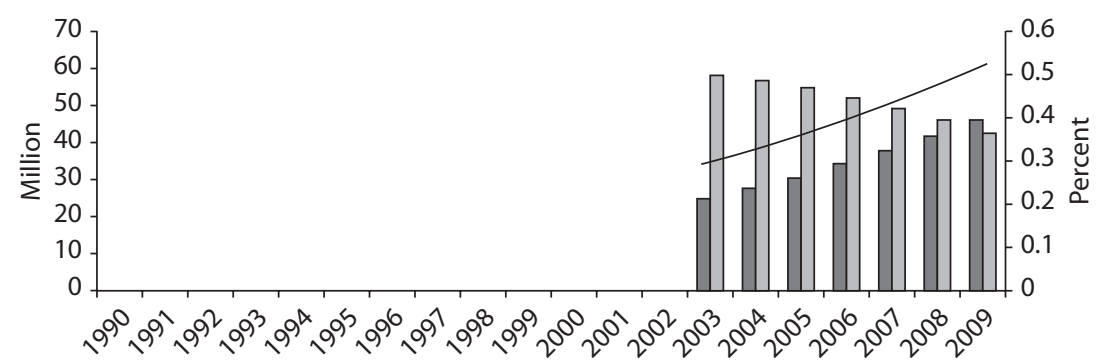

Residential customers with access $\square$ Population without access Access rate

Source: An elaboration from the Power Market Structure database.

Figure 15.3 West Bengal: Quality of Electric Service

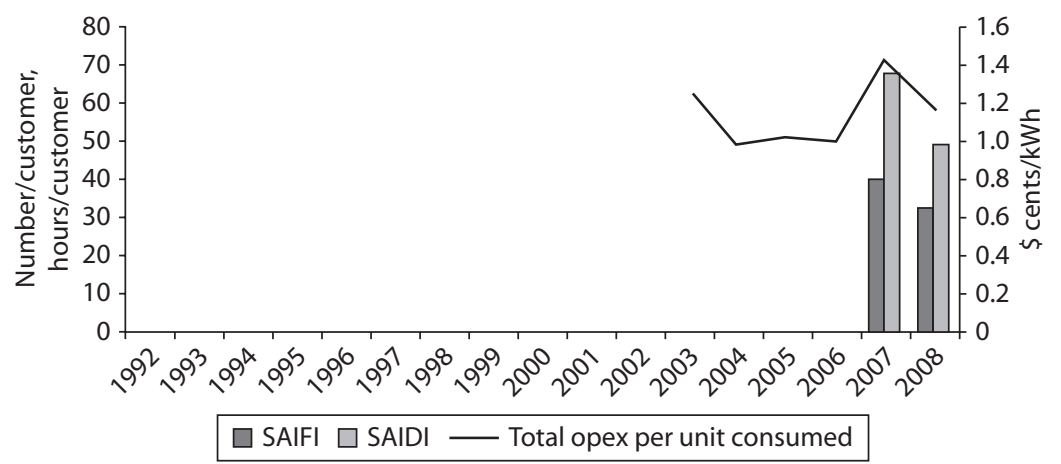

Source: An elaboration from the Power Market Structure database.

Note: $\mathrm{kWh}$ = kilowatt-hour; opex = operational expenditures/costs; SAIDI = System Average Interruption Duration Index; SAIFI = System Average Interruption Frequency Index. 


\section{Figure 15.4 West Bengal: System Energy Losses and Operating Costs}

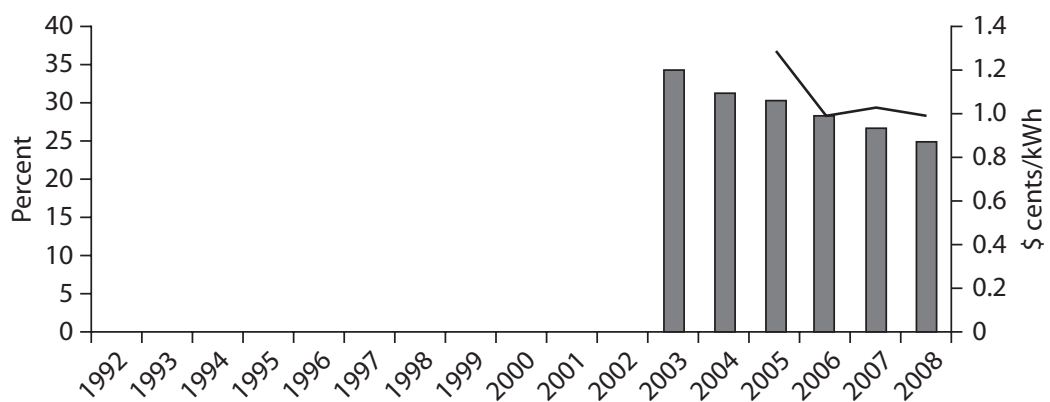

Distribution and transmission losses — Total opex per unit consumed

Source: An elaboration from the Power Market Structure database.

Note: $\mathrm{kWh}=$ kilowatt-hour; opex = operational expenditures/costs.

Figure 15.5 West Bengal: Electricity Generation by Source and Carbon Emissions

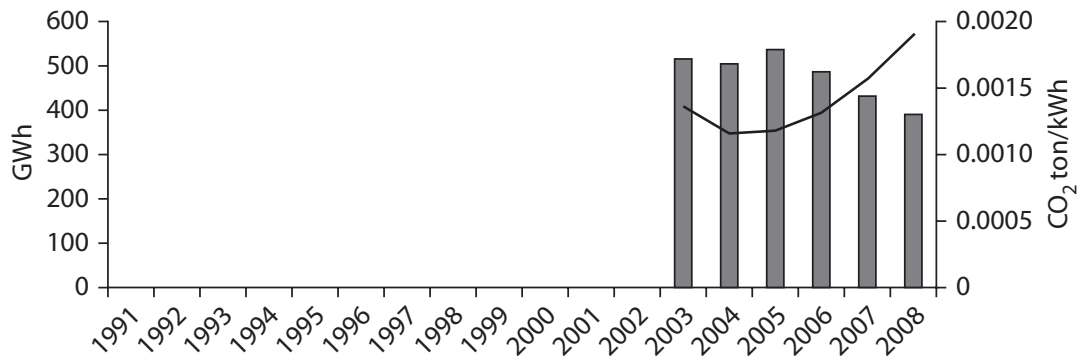

$\square$ Hydro $\square$ Diesel $\square$ Gas - Carbon emissions index

Source: An elaboration from the Power Market Structure database.

Note: GWh = gigawatt-hour; $\mathrm{kWh}=$ kilowatt-hour. 


\section{Figure 15.6 West Bengal: Average Tariff and Operating Costs}

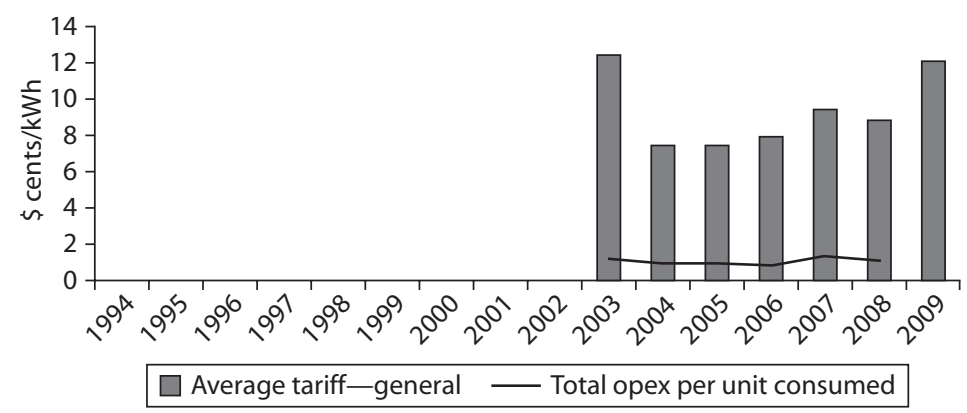

Source: An elaboration from the Power Market Structure database. Note: $\mathrm{kWh}=$ kilowatt-hour; opex = operational expenditures/costs.

\section{Figure 15.7 West Bengal: Labor Productivity}

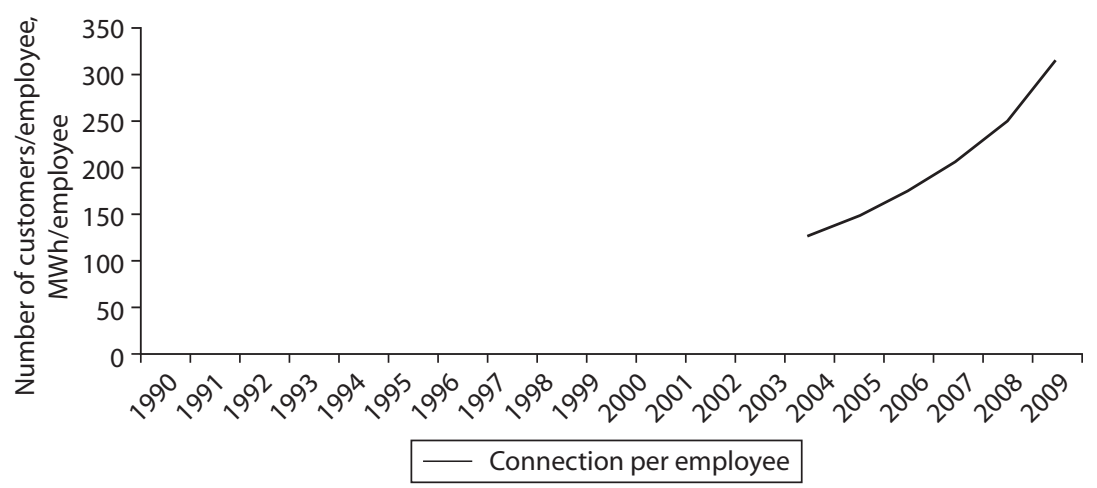

Source: An elaboration from the Power Market Structure database. Note: $\mathrm{MWh}=$ megawatt-hour.

\section{Figure 15.8 West Bengal: Capacity Utilization}

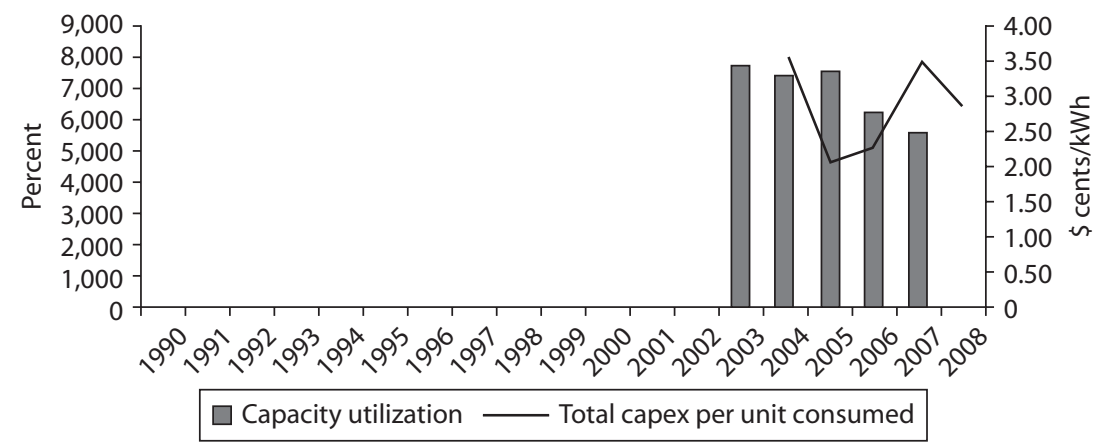




\section{Figure 15.9 West Bengal: Cost Recovery Index}

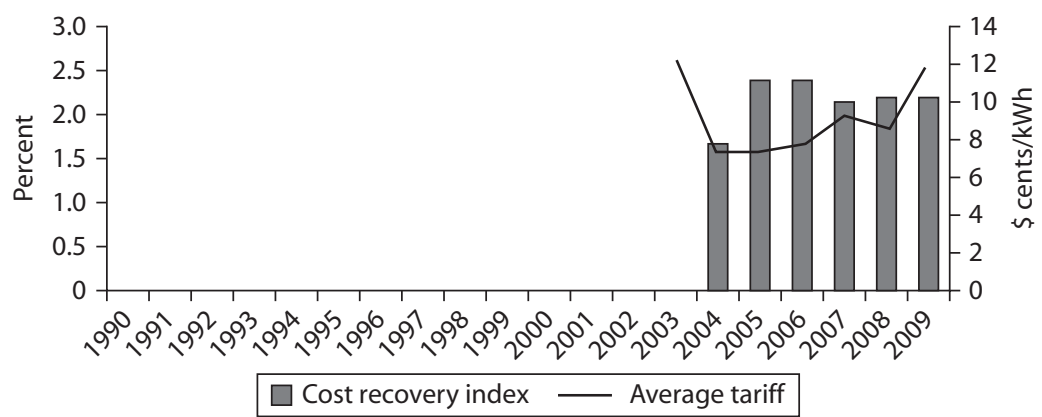

Source: An elaboration from the Power Market Structure database. Note: $\mathrm{kWh}=$ kilowatt-hour.

\section{Reference}

World Bank. 2008. World Development Indicators. World Bank, Washington, DC. 


\section{CHAPTER 16}

\section{Jordan}

Jordan in 2008 fell into the middle categories for gross national income $(\$ 3,420 /$ capita $)$ and power system size $(2,612$ megawatts [MW] installed generation capacity). At the start of the review period in the early 1990s, the structure of Jordan's power sector was a combination of a state-owned vertically integrated power utility with a monopoly in the generation and transmission segments and a minor portion of the distribution market (Jordanian Electricity Authority—JEA), a privately owned distributor with about two-thirds of the distribution market (Jordanian Electric Power Company-JEPCO), and a third distributor under almost equal state and private ownership (Irbid District Electrical Company-IDECO). This structure had been in place for nearly three decades. Stability and continuity had characterized these power market arrangements.

\section{Reform History}

This period came to an end in 1994 with the Jordanian cabinet's decision to restructure JEA as a public holding company in preparation for a longterm restructuring of the power sector with the introduction of more private sector participation. The legislative basis for the planned reform 
was laid down in the General Electricity Law No. 10 of 1996, under which JEA was renamed the National Electric Power Company (NEPCO). In 1999 NEPCO was corporatized and unbundled into three entities: (1) a company to own and operate the transmission network and system operation and to act as a single buyer for bulk power, which inherited NEPCO's name; (2) Central Electric Generating Company (CEGCO), which took over all the public generating capacity; and (3) Electricity Distribution Company (EDCO), which took over JEA/NEPCO's distribution activities.

Following this period of restructuring, the government put in place the regulatory framework for its reformed power market by establishing the Electricity Regulatory Commission (ERC) in 2001 and the following year passing General Electricity Law No. 64, the primary legislation for ERC's operations. ERC regulates the prices for transactions in the wholesale power market between NEPCO and the generators on the one hand and distributors on the other hand. In 2002 the dissolution of the monopoly in the generation segment started with the establishment of a new stateowned power company, Samra Electric Power Company (SEPGCO) to develop and operate the next addition to Jordan's generating capacity. This step was followed in 2007 by a major campaign to transfer the state's ownership to the private sector and resulted in the sale of 51 percent of the shares in CEGCO, the state's 45 percent of IDECO, and the state's 100 percent ownership of EDCO. The campaign continued with signing agreements with the first independent power producer (IPP) in 2007 and a second IPP in 2009. As a result, only the restructured NEPCO and SEPGCO remain in state ownership.

\section{Impact on Sector Structure}

The impacts of the reforms are shown in terms of the following two economic indicators in the generation and distribution segments of the power market: (1) concentration of ownership in the power market, and (2) the proportion of the power supply capacity under private ownership. The transmission sector was not impacted because the supply of transmission services remained a monopoly.

As a result of the reforms the degree of market concentration, as measured by the Herfindahl-Hirschman Index (HHI), for the generation on the interconnected system segment declined from 0.93 when CEGCO had its monopoly to 0.47 in 2008 with SEPGCO and the entry of the first IPP. This value should decline further with the entry of the second IPP by 
2012 and continue to decline if followed by more IPPs. Even a value of 0.47 indicates a highly concentrated structure when viewed from the perspective of competition in the market, which requires the value to fall well below 0.2. Nevertheless, this trend indicates that in the next 5 to 10 years, the concentration level in the generation segment is likely to decline to a level that would support a restructuring of bulk power trading from the single buyer to a bilateral trading between generators and distributors.

The degree of concentration in the distribution segment (as measured by the HHI) has not been affected by the reforms; it remained around 0.37 from 1990 to 2005, when it increased steadily to 0.40 in 2008 in line with the increase in the market share of the largest distributor, JEPCO, from 54 percent to 58 percent over the same period. This trend probably reflects the greater economic prosperity of Amman and surrounding areas that are served by JEPCO than the areas served by IDECO and EDCO.

The proportion of the total power supply capacity from generation through transmission to distribution that was under private ownership increased from the historic level up to 2006 of around 25 percent to the current level of 48 percent (according to an index in which the three stages have equal weights). Within this composite value, the proportion of the generation segment under private ownership increased from zero to 43 percent, and the proportion for distribution from 72 percent to 100 percent. Transmission and system control has remained under 100 percent state ownership.

\section{Impact on Sector Performance}

The impact of these reforms can be examined by comparing trends between the four main phases:

- pre-unbundling-before 1999

- unbundled with a single buyer of wholesale power but preautonomous regulation-2000 to 2002

- under autonomous regulation but preprivatization-2003 to 2007

- postprivatization with a single buyer from 2008 onward

The last period started too recently to allow time for any impacts on performance trends to appear.

Evidence of possible impacts from unbundling and other reforms is sought from trends from the early to mid-1990s up to 2008 in the following indicators: 
- Access to electricity supply by the population in terms of new residential connections. The Jordanian distributors increased residential connections steadily at an average annual rate of 5.7 percent from 1996 to 2008. The proportion of population served by them was almost 100 percent throughout this period, indicating that the distributors met demand for new household connections in line with new household formation. ${ }^{1}$

- System reserve generation capacity. The margin between total available generating capacity on the interconnected system and peak demand on this system varied substantially between 1990 and 2008. It was highest in 1990 and 1998-99, and lowest in 1995-97 and 2004-07. Given that investment is least predictable immediately before and after a major reform to industry structure and trading arrangements, one could observe that Jordan wisely built up a large reserve of generation capacity to carry the sector through the unbundling disruption by moving to arm's length trading through the single buyer in 1999 and introducing the new regulatory arrangements in 2002. This impact is a critical risk for these major reforms.

- Generation fuel conversion efficiency. Fuel conversion efficiency for the stock of generating capacity on the interconnected system dipped from 34 percent in 1990 to 32 percent in 1994, increased to 36 percent in 2001, declined to 34 percent in 2004, and steadily increased to above 36 percent by 2008 . The changes in the earlier years probably reflect more or less use of old inefficient generating units to meet peaks in system demand. The increase in later years reflects the introduction and expansion of gas-fired CCGTs (combined cycle gas turbines) with higher efficiencies than the existing units that run on diesel and heavy fuel oil. No impact is detectable from the sector reforms on this indicator.

- Total system energy losses. Contrary to expectations about the impact of sector reform on this key performance variable, system losses increased steadily from 1996 onward, from around 15 percent to around 18 percent for 2005-08. Most of this increase occurred in the distribution segment, an area that needs firm regulation, especially now that distribution is entirely privately owned.

- Total system nonfuel costs. The average nonfuel cost per unit of energy consumed on the interconnected system stayed fairly constant at around 23 JD/MWh in nominal price terms between 1999 and 2005, 
and subsequently declined even in nominal price terms to around $20 \mathrm{JD} / \mathrm{MWh}$ in 2006-08. This decline may reflect the improvement in labor productivity. Average fuel costs are not used because this indicator is largely out of the control of Jordanian generators from year to year. The only lever available is to change the fuel mix over time, which is happening in Jordan with the move to lower-cost, more efficient natural gas for power generation. Changes in the fuel mix will become significant only when the new CCGTs developed by SEPGCO and the IPPs come onstream.

- Labor productivity in terms of customers per employee and energy consumed per employee. Although the total number of employees in the power sector increased steadily from around 5,400 in 1996 to almost 8,000 in 2008, both indicators show a steady and marked improvement from 2000 onward, after stagnating or slightly worsening in the previous years. The decline from 1999 to 2000 may reflect the formation of new power companies from the single integrated supplier. But the improvement in these indexes thereafter is striking and shows a constant trend before and after the new regulatory framework and even the privatization in 2007. The trends suggest that the main factor in improvement was unbundling.

- Carbon emissions. This indicator is tracked to establish a basis for future performance. Past performance is a consequence of responses to economic pressures to meet growing demand and to manage fuel costs, rather than to specifically reduce carbon emissions. Jordan is expected to reduce these emissions from power generation as natural gas-fired generation increases and partly displaces generation from liquid fuels. A substantial reduction has already occurred. with the carbon emissions index dropping from 0.9 in 2005 to 0.76 in 2008, and it is expected to drop further toward 0.65 in the next five or so years. The trend beyond this period is presently unclear because of uncertainty about the new baseload generation capacity that Jordan is expected to develop. The index would drop gently if this capacity were to be based on more natural gas-fired CCGTs and drop sharply if and when Jordan's ambitions to develop nuclear power capacity is realized. Conversely, the emissions index would increase again if Jordan decides to base new capacity on burning some of its substantial reserves of oil shale.

Trends in these indicators are shown in the figures that follow. 
Figure 16.1 Milestones of Power Sector Reform in Jordan

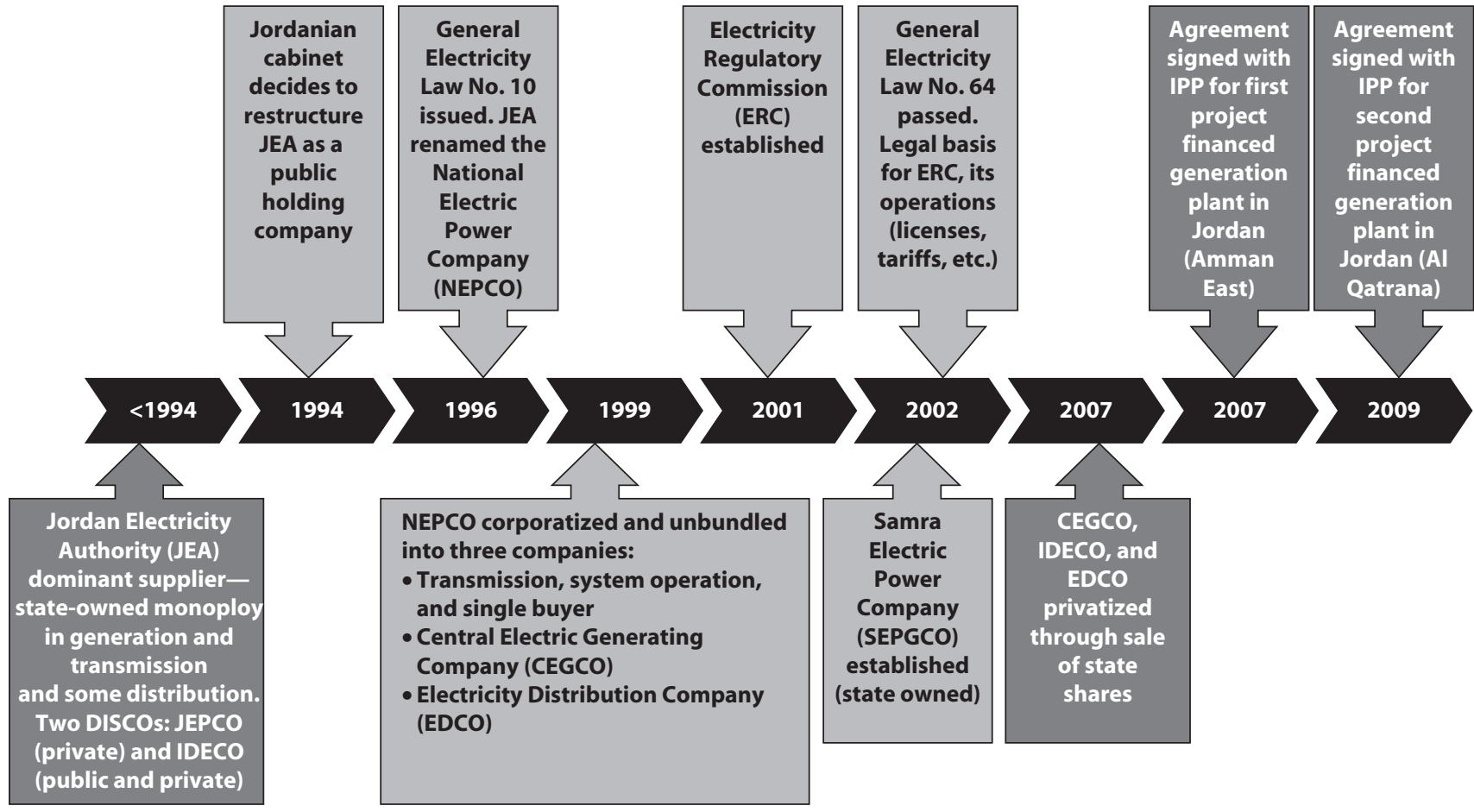

Source: An elaboration from the Power Market Structure database.

Note: The milestones are reported in different shades: light gray = main government interventions; dark gray = main private sector involvements. $\mathrm{CEGCO}=\mathrm{Central}$ Electric Generating Company; EDCO = Electricity Distribution Company; IDECO = Irbid District Electricity Company; IPP = independent power producer; JEA = Jordan Electricity Authority; JEPCO = Jordanian Electric Power Company; NEPCO = National Electric Power Company 


\section{Figure 16.2 Jordan: Access to Residential Electricity}

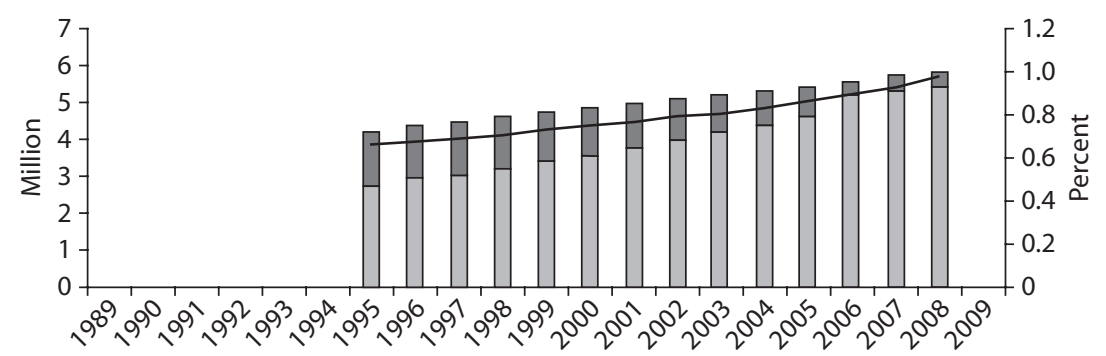

$\square$ Population without access $\square$ Residential customers with access Access rate

Source: An elaboration from the Power Market Structure database.

Figure 16.3 Jordan: Quality of Electric Service

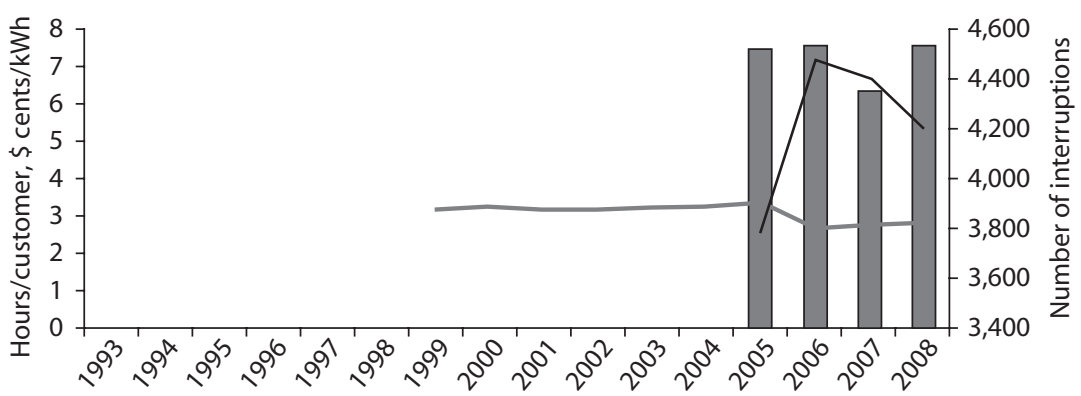

$\square$ SAIDI

Total interruption on distribution network

Total nonfuel opex per unit consumed

Source: An elaboration from the Power Market Structure database.

Note: kWh = kilowatt-hour; opex = operational expenditures/costs; SAIDI = System Average Interruption Duration Index. 
Figure 16.4 Jordan: System Losses and Operating Costs

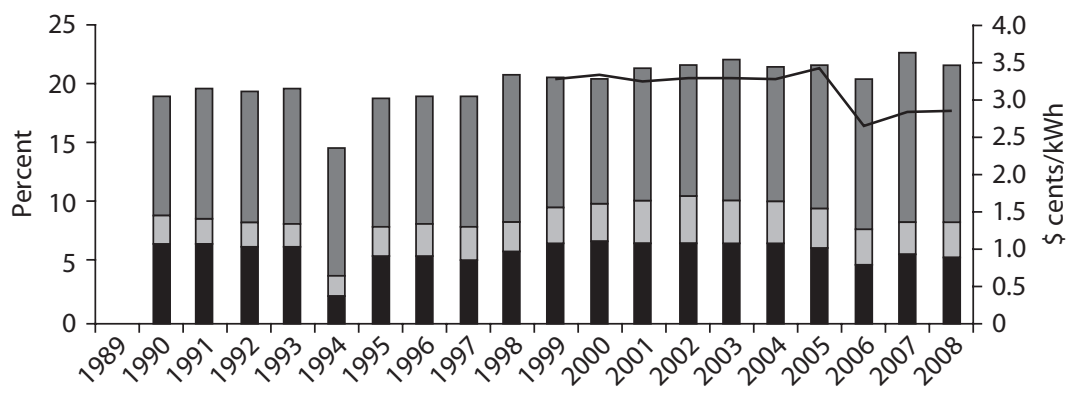

$\square$ Distribution losses $\quad \square$ Transmission losses

Generation losses __ Total nonfuel opex per unit consumed

Source: An elaboration from the Power Market Structure database. Note: $\mathrm{kWh}=$ kilowatt-hour; opex = operational expenditures/costs.

Figure 16.5 Jordan: Electricity Generation by Source and Carbon Emissions

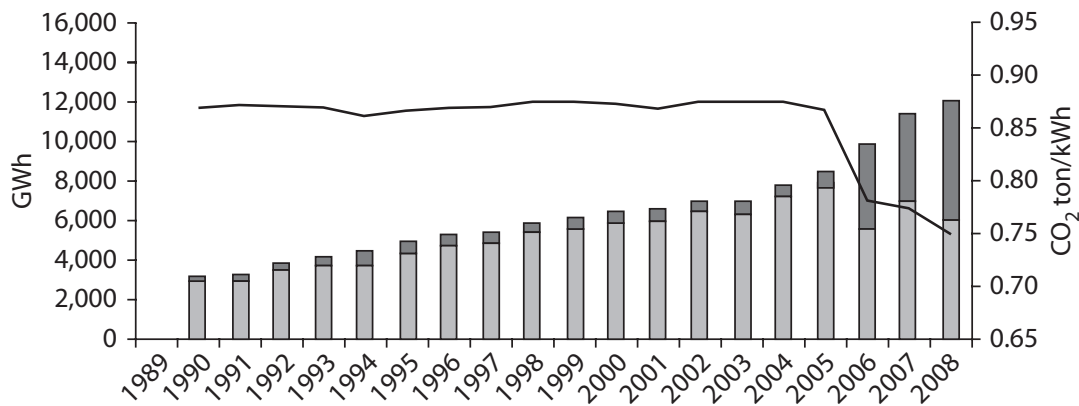

Natural gas $\square$ Petroleum fuels - Carbon emissions index

Source: An elaboration from the Power Market Structure database.

Note: GWh = gigawatt-hour; kWh = kilowatt-hour. 


\section{Figure 16.6 Jordan: Energy Security and Capital Expenditure}

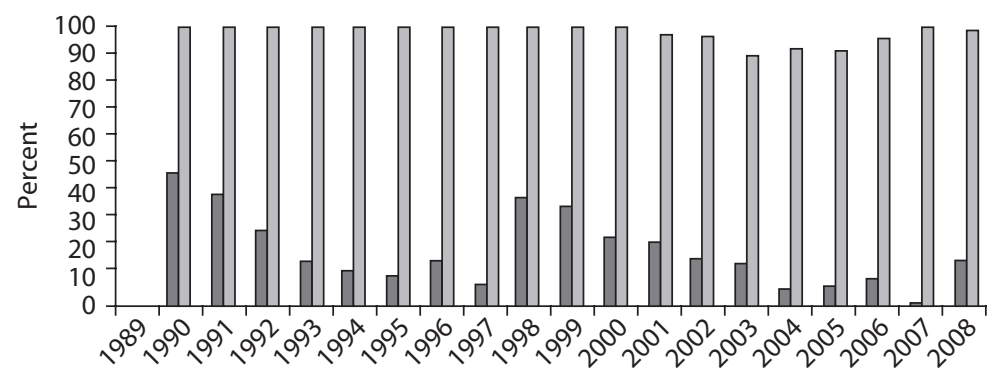

System reserve capacity $\square$ Energy self-sufficiency

Source: An elaboration from the Power Market Structure database.

Figure 16.7 Jordan: System Load Factor

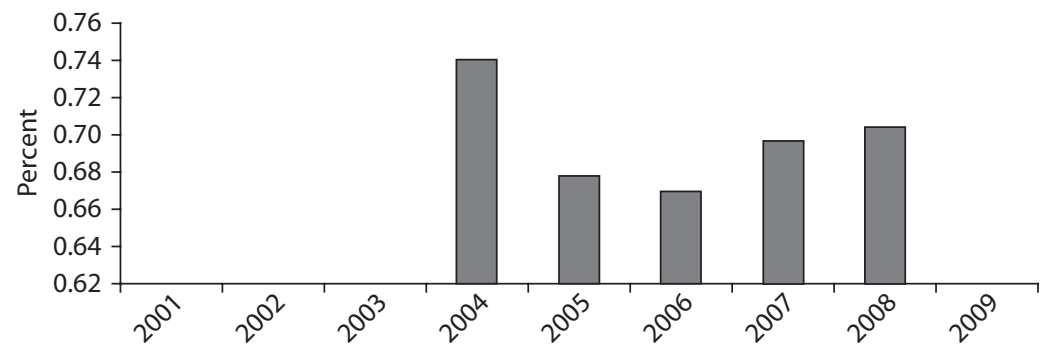

Source: An elaboration from the Power Market Structure database.

Figure 16.8 Jordan: Capacity Utilization

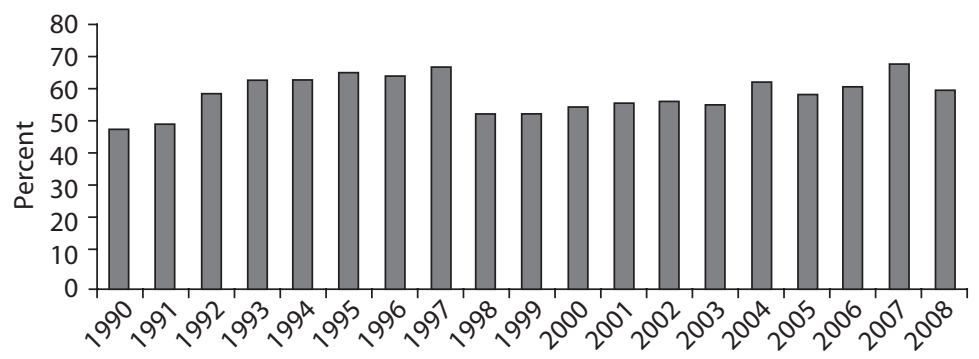

Source: An elaboration from the Power Market Structure database. 


\section{Figure 16.9 Jordan: Average Tariff and Operating Costs}

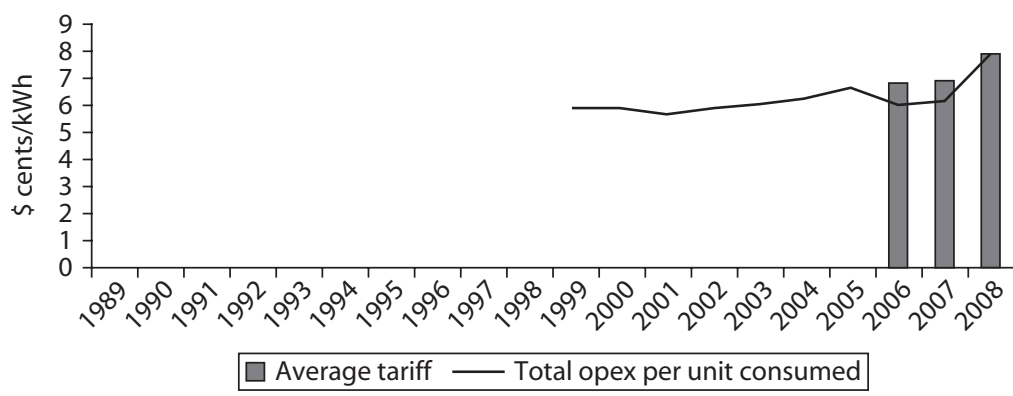

Source: An elaboration from the Power Market Structure database.

Note: $\mathrm{kWh}=$ kilowatt-hour; opex = operational expenditures/costs

\section{Figure 16.10 Jordan: Labor Productivity}

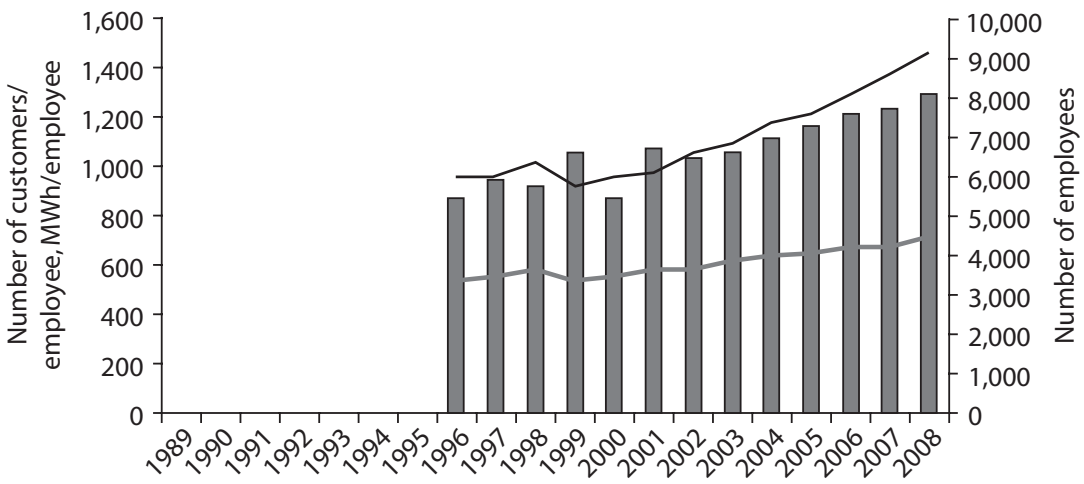

Number of employees in electricity sector

Energy consumed/employee

Number of residential customers/employee

Source: An elaboration from the Power Market Structure database.

Note: $\mathrm{MWh}=$ megawatt-hour. 


\section{Figure 16.11 Jordan: Cost Recovery Index}

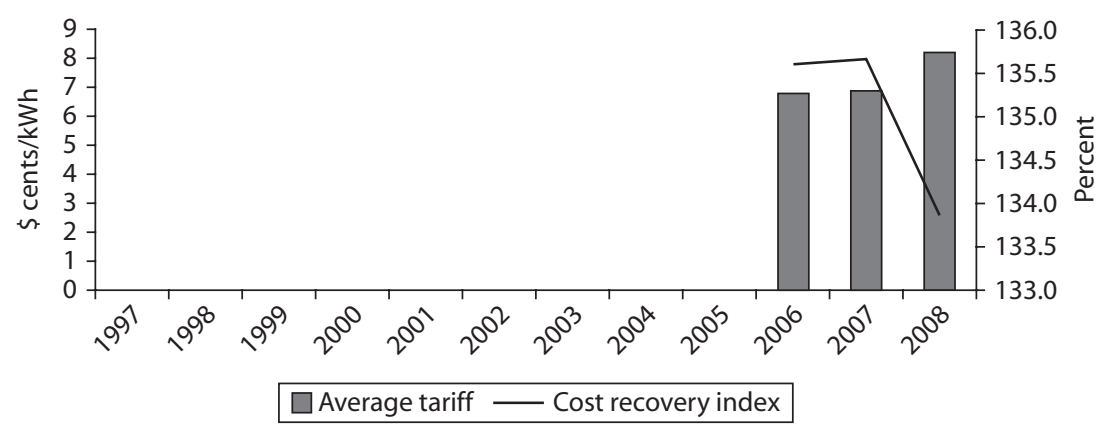

Source: An elaboration from the Power Market Structure database. Note: $\mathrm{kWh}=$ kilowatt-hour.

Figure 16.12 Jordan: Market Concentration

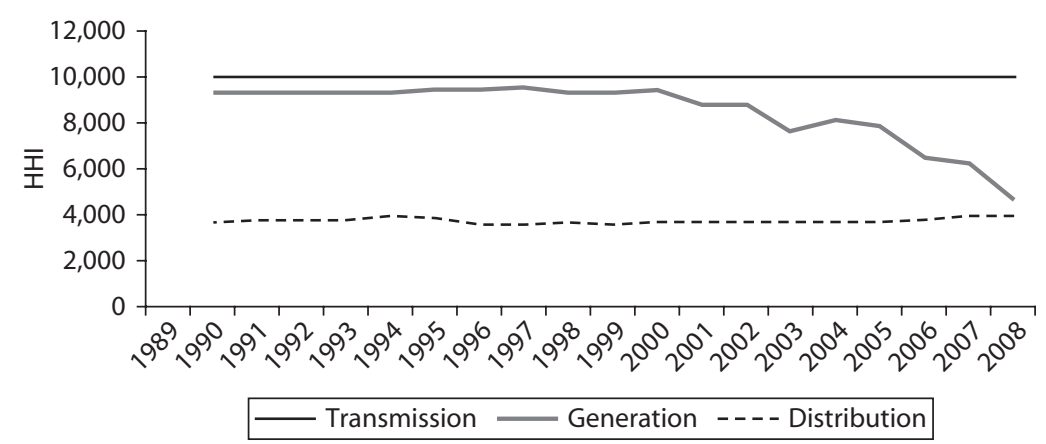

Source: An elaboration from the Power Market Structure database. Note: $\mathrm{HHI}=$ Herfindahl-Hirschman Index.

\section{Figure 16.13 Jordan: Private Ownership}

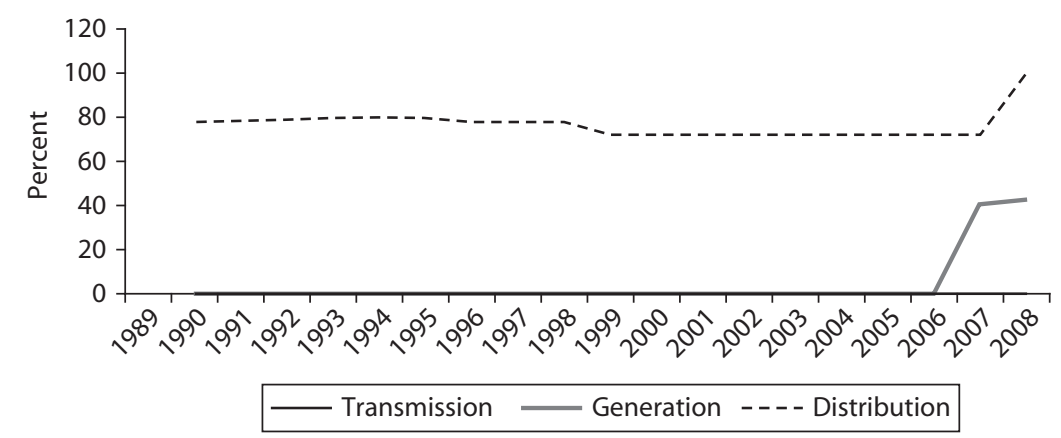

Source: An elaboration from the Power Market Structure database. 


\section{Figure 16.14 Jordan: Private Management}

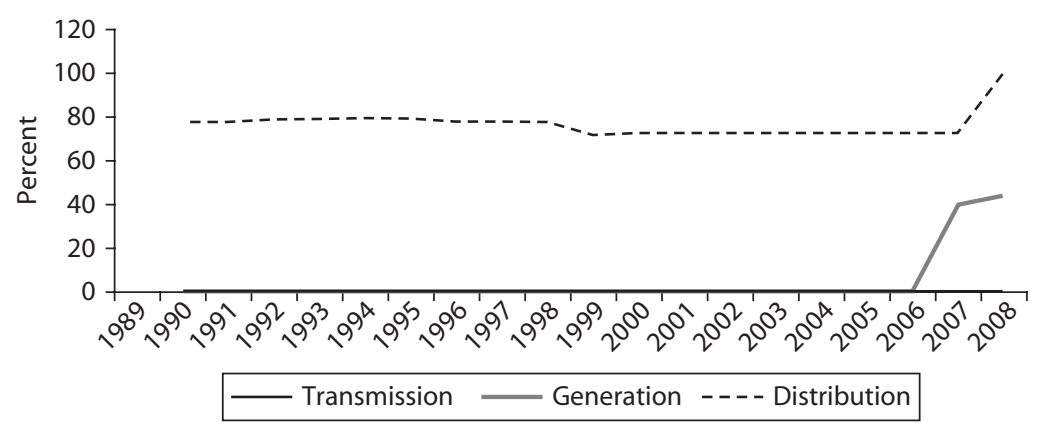

Source: An elaboration from the Power Market Structure database.

Figure 16.15 Jordan: Degree of Vertical Integration

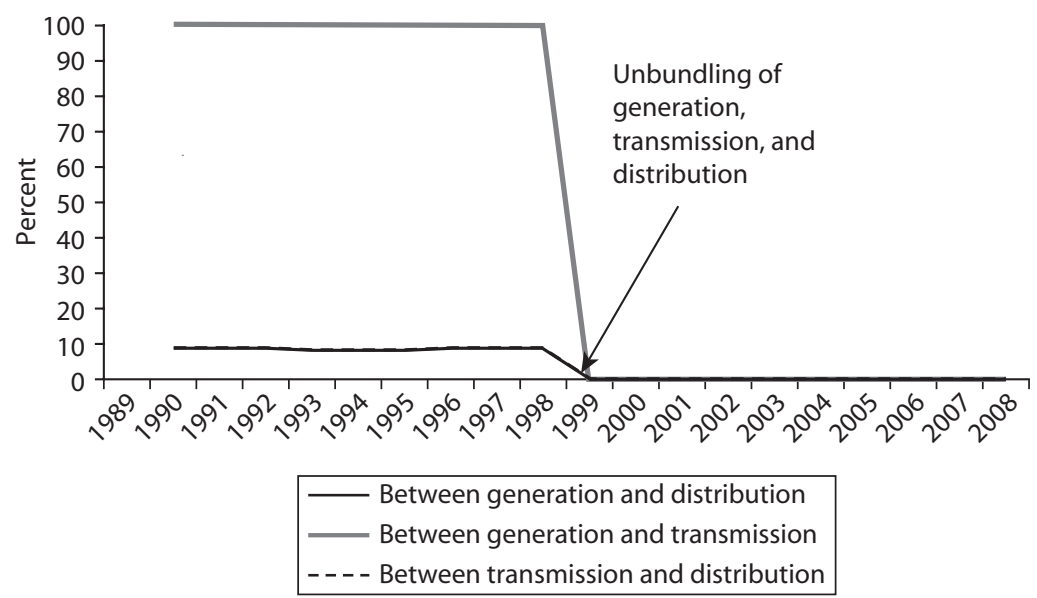

Source: An elaboration from the Power Market Structure database.

\section{Note}

1. Some larger households with higher than average electricity consumption may have acquired more than one connection in breach of their conditions of service in order to benefit from the highly progressive tariff structure for residential consumers, under which the tariffs for the lowest of the ten consumption bands are much lower than for the highest bands. 


\section{CHAPTER 17}

\section{Vietnam}

Vietnam in 2008 fell into the lower-middle category for gross national income $(\$ 1,800 /$ per capita) and in 2010 into the high power system size category (about 15,000 megawatts [MW] installed generation capacity). This chapter illustrates the pressures created by high investment needs to satisfy high growth in demand that move the power market from a stateowned monopolistic structure to a mixed public/private structure with competition in the power market where workable.

\section{Reform History}

Vietnam's power generation grew rapidly during the first decade of this century. At an average annual rate of about 13 percent. It managed to increase its installed power generating capacity at an average annual rate of about 10.5 percent, which is high by global standards, but nevertheless has not matched the growth in demand and sales, and so the generation reserve margin declined during the 00s. The country has used a combination of hydropower and thermal power to meet its needs and has domestic resources of coal and natural gas for thermal power generation. Hydropower was the larger source, supplying around 75 percent of the total generated power in the mid-1990s, but declined steadily to around 
40 percent in 2004 and 2008. The proportion supplied from thermal power increased inversely to around 60 percent.

Electricity of Vietnam (EVN) is the state-owned vertically integrated monopoly that has served most of the country's power market since it was established under Governmental Decree No 14/CP of January 27, 1995.

Private sector participation in the power sector has been limited. There are two categories of non-EVN power producers in Vietnam. In the first category are power plants developed by private investors under the provisions of the build-operate-transfer (BOT) decree. They are secured with government guarantees and long-term power purchase agreements (PPAs). Only two BOT projects are in operation, but several others are under negotiation or have recently been tendered. The other category includes power plants developed by non-EVN state-owned enterprises and domestic investors. These so-called independent power producers have medium-term PPAs that will expire at the commencement of the proposed competitive power market.

Vietnam has experienced high growth in power demand for the past decade at a trend rate of around 15 percent to support economic growth and poverty reduction. This growth has eroded power supply reserve margins to the point where power shortages leading to load shedding have been an intermittent problem since 2005, especially in dry hydrological years. To achieve an acceptable level of security for power supply, Vietnam needs to pursue a large-scale generation investment program.

To ensure that the rapidly increasing demand for power can be met efficiently, in 2005 the Vietnamese government decided to move the power sector toward competitive market-based arrangements. The government's reform program entails a major transformation of the power market, sector structure, trading and purchase agreements, generation pricing, and regulation of network services and retail tariffs. The design of the power market and the restructuring are intended to change how projects are financed, the interest and participation of the private sector (both local and foreign investors), how costs of supply are determined, and how they are reflected in tariffs. The goal is to introduce incentives and regulations to bring about improvements in the quality of service, the efficiency with which energy is used, and to enable existing and new investors to finance sufficient generation to achieve adequate levels of electricity generation capacity for supply security.

Central to the reform and restructuring is the Electricity Law that was passed by the National Assembly in November 2004 and came into effect 
on July 1, 2005. The Electricity Law establishes a new framework for the power sector that envisages a phased approach to reforms:

- The phased development of a competitive wholesale power market, starting in 2010 with a market in which multiple generators compete to generate and sell to one wholesaler (the Single Buyer), which sells wholesale power to distribution companies and large consumers at regulated prices. This market will subsequently evolve into a wholesale competitive market (WCM) with multiple wholesale buyers (power distribution companies and large consumers) and sellers (power generators) that competitively transact in a power pool. This phase is scheduled to start in 2014 with a pilot wholesale market. The final stage, scheduled for 2022, will be a retail competitive market where retail consumers will be allowed to choose their supplier.

- Limitation of the state monopoly in the sector to power transmission, national load dispatch, and strategically important large power plants, leaving power distribution and nonstrategic power generation to potential private investors.

- A planning process to select new generation investment to supply projected demand consistent with security and reliability criteria and government energy policies that will gradually evolve from the current centralized master planning process. The first step is to transfer oversight from EVN to the Ministry of Industry and Trade (MOIT). In later stages of reform, master planning is expected to give way to indicative planning, based on market information, leaving greater discretion to project proponents in choice of project location, technology, and timing.

- The establishment in October 2005 of a new economic regulator of the sector, the Electricity Regulatory Authority of Vietnam, as a separate institution within MOIT.

The restructuring of the electricity sector was initiated with the establishment of EVN as a holding company in 2006. EVN was reorganized into financially independent member units that include seven power companies and some other companies. ${ }^{1}$ EVN also included a number of financially dependent units: the National Load Dispatching Center (NLDC), four transmission/system operators, all the power generation plants, and others. ${ }^{2}$ In June 2007 EVN established the Power Purchase 
and Sale Company to buy electricity from power plants through the electricity market or through long-term PPAs and to sell electricity to the power retailing companies and big customers that are directly connected to the national power transmission system. In March 2008 EVN set up the National Power Transmission Corporation as a separate legal entity responsible for the operation of the transmission network, upon which EVN became legally unbundled.

As part of this process, the government approved in April 2007 the "equitization plan" for partial privatization of most of EVN's operating units engaged in power generation and distribution, with EVN keeping more than 50 percent of the share capital. Equitization was no longer pursued when the global financial crisis made it increasingly difficult to find investors.

The WCM will be a mandatory gross pool with cost-based bids and a spot market. Except for small generators that do not participate in the market, generation will be scheduled and dispatched using a securityconstrained least cost dispatch of generation bids. Each generator will have a contract with the Single Buyer to sell a large percentage (probably 90 percent to 95 percent) of its forecast amount of generated power. The remaining generation will be sold by generators and bought by the Single Buyer through the spot market.

Thermal bids will be subject to a cap and floor based on reference variable costs depending on technology. Thermal generation bids will include an implicit start-up cost and are required to be monotonically increasing with MW of availability offered. Marginal spot prices will be calculated with an unconstrained least cost dispatch. A capacity payment will complement the energy payments. The existing NLDC, with the regional dispatch centers, will become the system operator ( $\mathrm{SO}$ ). The $\mathrm{SO}$ is responsible for maintaining the balance and security of the system and may sign ancillary services contracts. The market operator will be responsible for settlement of spot market transactions. Contracts will be settled between the Single Buyer and generators. It is expected that the WCM will be combined into a single entity, a system and market operator.

In connection with the preparation of the competitive market, electricity tariffs were reformed. With Decision No. 21/2009/QD.TTg of February 12, 2009, effective March 1, retail electricity tariffs for gridbased energy were increased to an average D 948.5 per kilowatt-hour (kWh) (5.4 \$ cents/kWh). From January 1, 2010, generation tariffs are determined by competition. The MOIT, in coordination with the Ministry 
of Finance, decides the annual adjustments to the retail tariffs based on market-determined generation and distribution tariffs.

\section{Impact on Sector Structure}

The impacts of the reforms on sector structure have been significant in terms of institutions with the unbundling of EVN's activities under a holding company, but modest to date in terms of ownership, as little privatization of EVN's assets has occurred. The main developments are the entry of private power producers into the wholesale market and a modest amount of imported power from China. ${ }^{3}$ The entry of the two privately developed power plants under BOT arrangements placed about one-third of the total installed generating capacity in 2007 under private ownership.

\section{Impact on Sector Performance}

The impact of these reforms can be examined by comparing trends from the early to mid-1990s up to 2008 in the following indicators:

- Access to electricity supply by the population in terms of new residential connections is good. EVN increased connections steadily at an average annual rate of 12 percent from 2005 to 2007. The proportion of population with access to electricity reached almost 90 percent in 2008 , including one of the most successful rural electrification programs in the world.

- Customer service quality. Limited data about the frequency and duration of supply interruptions is publicly available to assess service quality to retail electricity consumers. Between 2005 and 2008 the System Average Interruption Frequency Index (SAIFI) averaged between 2 and 12 interruptions per customer per year among the distribution entities, and the System Average Interruption Duration Index (SAIDI) shows a marked increase in the average duration of interruption. Losses in the transmission and distribution systems are low by global standards, averaging in the 6 percent to 7 percent range of total energy supplied during recent years.

- Supply security. With the rapid growth of the power demand in Vietnam, the capacity reserve margin has not been maintained during 
critical supply/demand periods of the year. Electricity supply has been cut off by load shedding during peak hours due to power shortage, especially during summer seasons when demand peaks and hydropower output decreases due to seasonal drops in river flows.

- Financial sustainability. EVN's tariffs have generally been lower than supply costs. Tariffs fell in recent years despite increases in 2007 and 2009. The latter increase restored tariffs to the actual financial cost of power supply in 2008 (D 948/kWh, equivalent to $5.8 \$$ cents $/ \mathrm{kWh}$ ). EVN does not receive any direct subsidy support from the Vietnamese government. EVN covered its operating costs and some self-financing of capital investments in 2002-04, but its self-financing ratio declined from 2005 with increases in its costs that were not fully matched by increase in its tariffs. This decline impeded EVN's ability to invest sufficiently in its supply capacity to meet the rapid growth in demand for electricity, which has contributed to the government's decision to reform the power sector.

- Environmental sustainability. Carbon emissions from power generation in Vietnam increased steadily from the mid-1990s to 2008 as the total amount of power generated from fossil fuels increased from around 4,000 gigawatt-hours (GWh) in 1995 to $44,000 \mathrm{GWh}$ in 2008, equivalent to about 20 percent annual growth rate.

Trends in these indicators are shown in the figures that follow. 


\section{Figure 17.1 Milestones of Power Sector Reform in Vietnam}

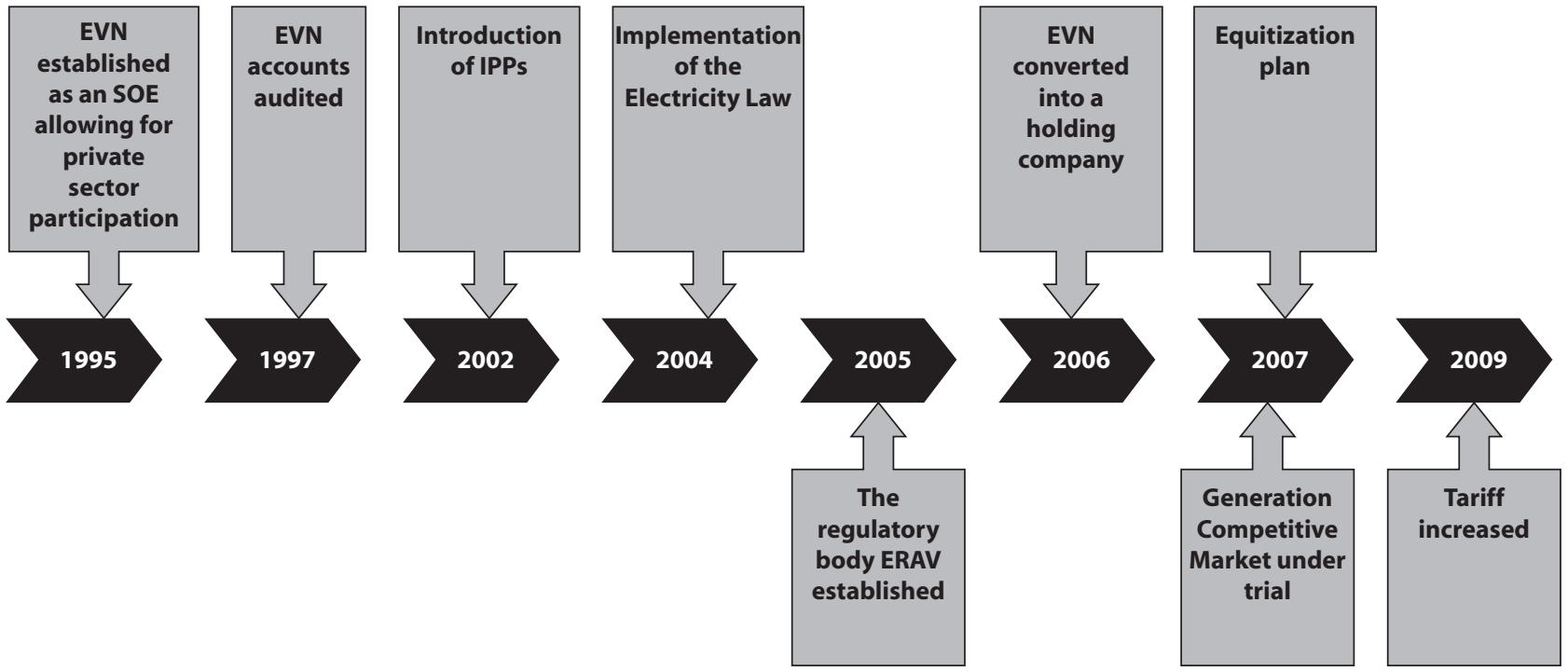

Source: An elaboration from the Power Market Structure database.

Note: The milestones in light gray refer to the main government interventions. ERAV = Electricity Regulatory Authority of Vietnam; EVN = Electricity of Vietnam; IPPS = independent power producers; $\mathrm{SOE}=$ state-owned enterprise. 


\section{Figure 17.2 Vietnam: Access to Residential Electricity}

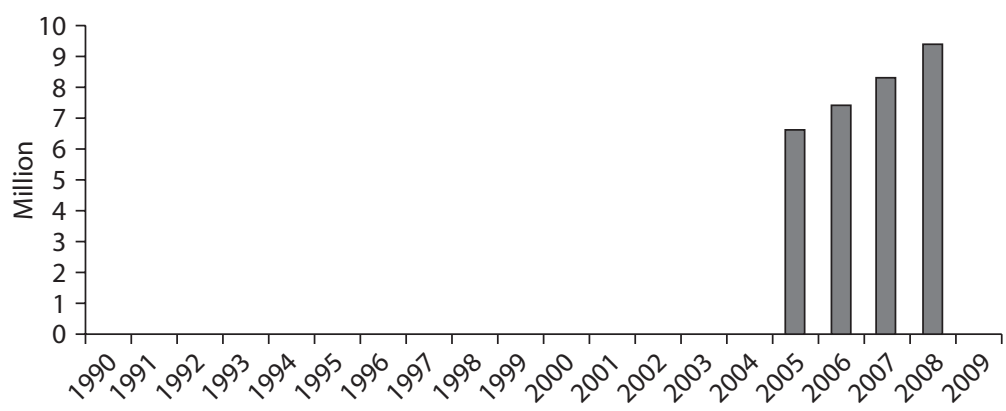

$\square$ Number of residential connections (DISCO 1, DISCO 2, DISCO 3, HCM PC, Na Noi, Hai Phong, Ninh Binh, Khanh Hoa, Hai Duong)

Source: An elaboration from the Power Market Structure database.

Note: $\mathrm{DISCO}=$ distribution company $; \mathrm{HCM} \mathrm{PC}=\mathrm{Ho}$ Chi Minh Power Corporation.

\section{Figure 17.3 Vietnam: Quality of Electric Service}

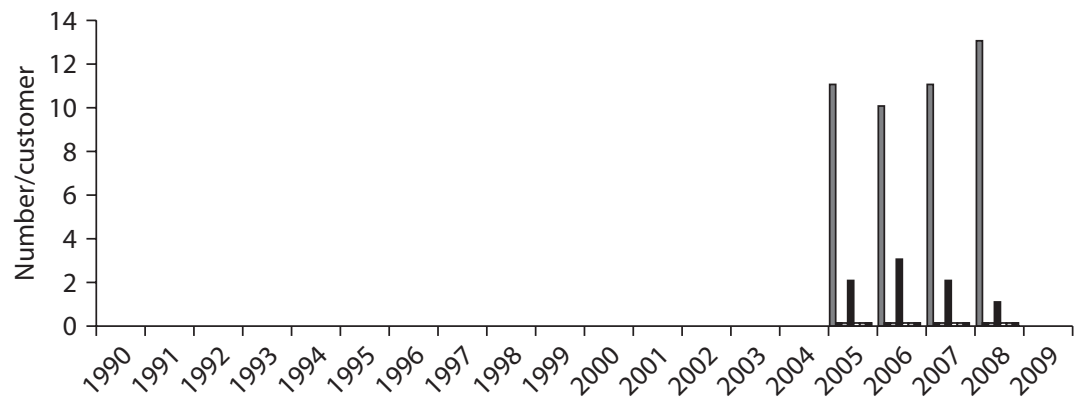

$\begin{array}{lll}\square \text { SAIFI (DISCO 1) } & \square \text { SAIFI (Hai Phong) } & \square \text { SAIFI (Ninh Binh) } \\ \square \text { SAIFI (Hai Duong) } & \text { O SAIFI (DISCO 2) } & \boxminus \text { SAIFI (DISCO 2) }\end{array}$

Source: An elaboration from the Power Market Structure database.

Note: $\mathrm{DISCO}=$ distribution company; SAIFI = System Average Interruption Frequency Index. 


\section{Figure 17.4 Vietnam: System Energy Losses}

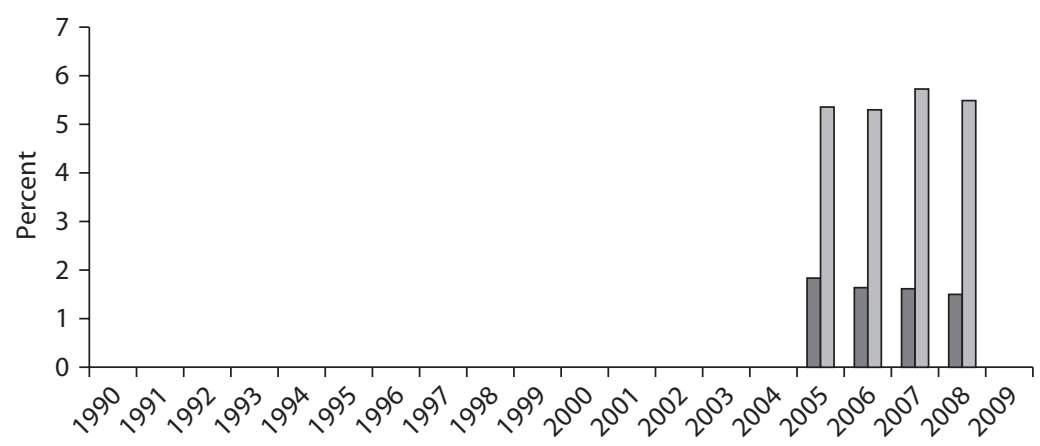

Transmission losses $\square$ Distribution losses

Source: An elaboration from the Power Market Structure database.

Figure 17.5 Vietnam: Electricity Generation by Source and Carbon Emissions

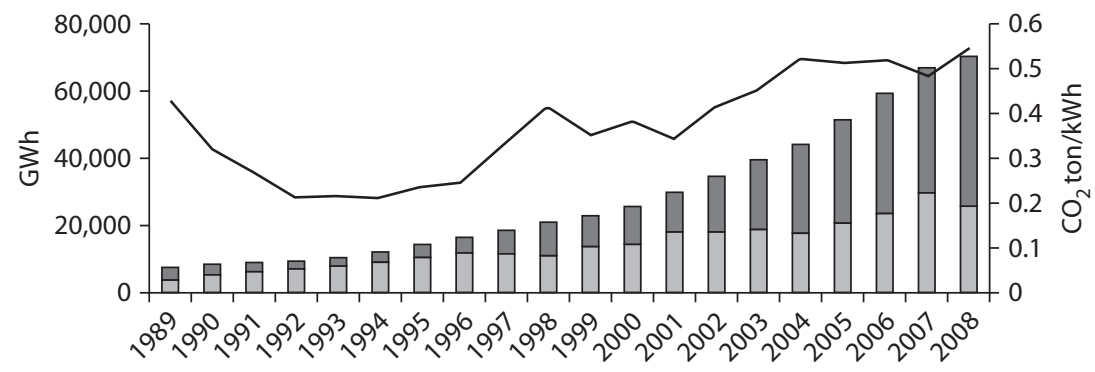

$\square$ Thermal $\square$ Hydro _ Carbon emissions index

Source: An elaboration from the Power Market Structure database. Note: GWh = gigawatt-hour; kWh = kilowatt-hour.

Figure 17.6 Vietnam: Energy Security and Capital Expenditure

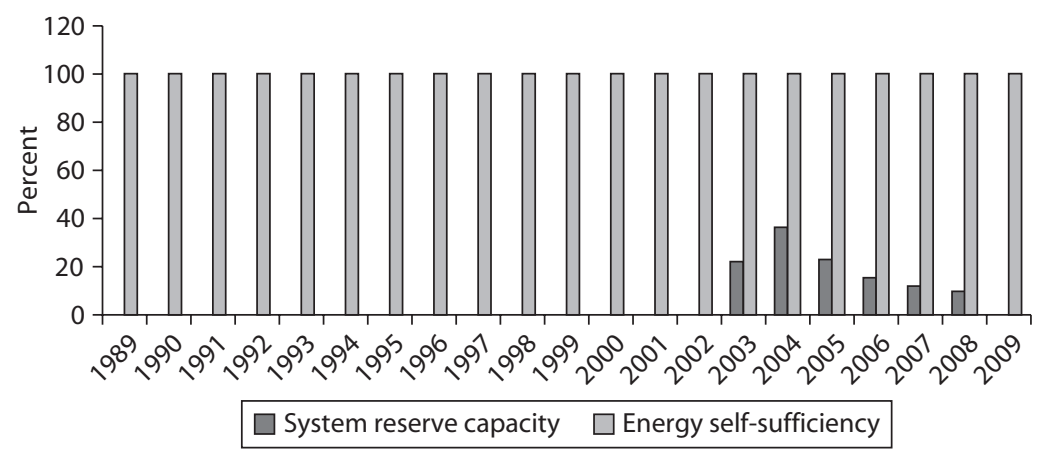

Source: An elaboration from the Power Market Structure database. 


\section{Figure 17.7 Vietnam: Labor Productivity}

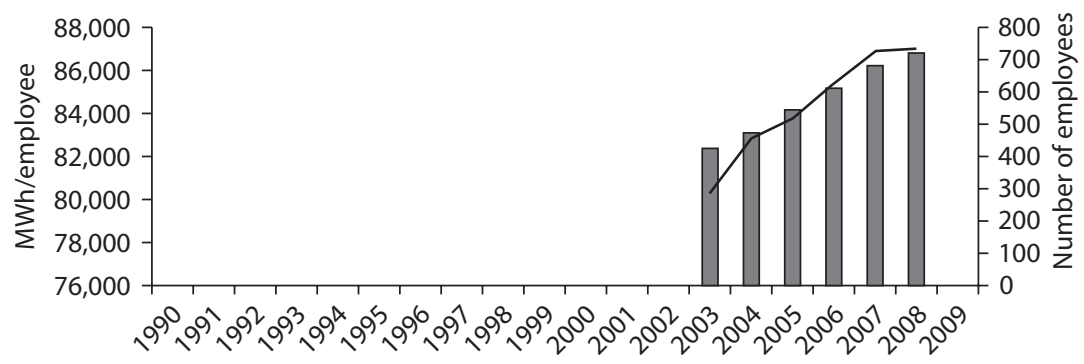

$\square$ Energy consumed/employee

Number of employees in electricity sector

Source: An elaboration from the Power Market Structure database.

Note: $\mathrm{MWh}=$ megawatt-hour.

Figure 17.8 Vietnam: Capacity Utilization

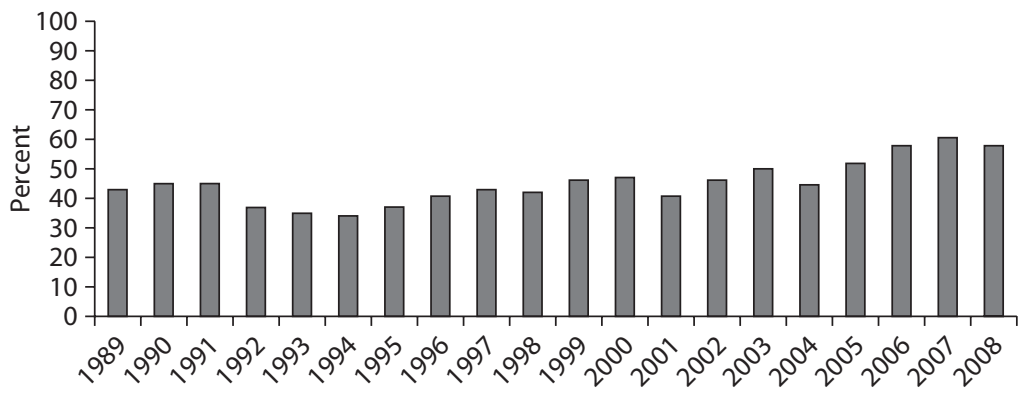

Source: An elaboration from the Power Market Structure database.

Figure 17.9 Vietnam: Market Concentration

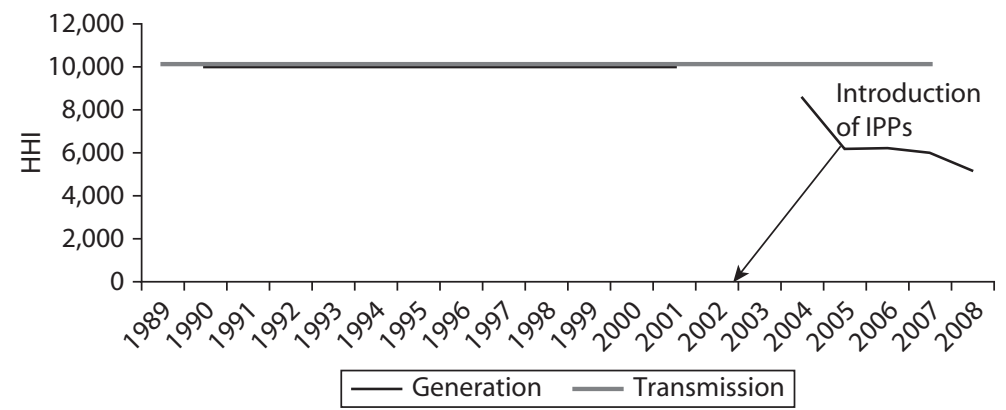

Source: An elaboration from the Power Market Structure database.

Note: $\mathrm{HHI}=$ Hirfindahl-Hirschman Index; IPPs = independent power producers. 


\section{Figure 17.10 Vietnam: Private Ownership}

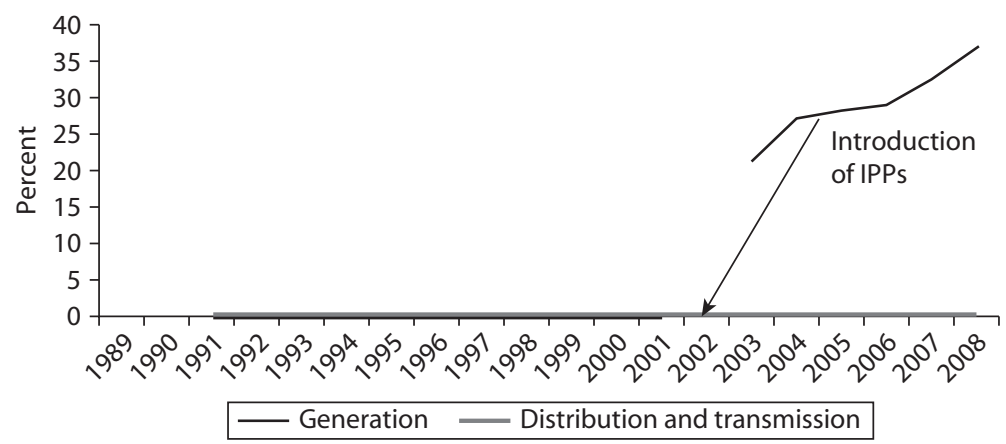

Source: An elaboration from the Power Market Structure database. Note: IPPs = independent power producers.

\section{Figure 17.11 Vietnam: Private Management}

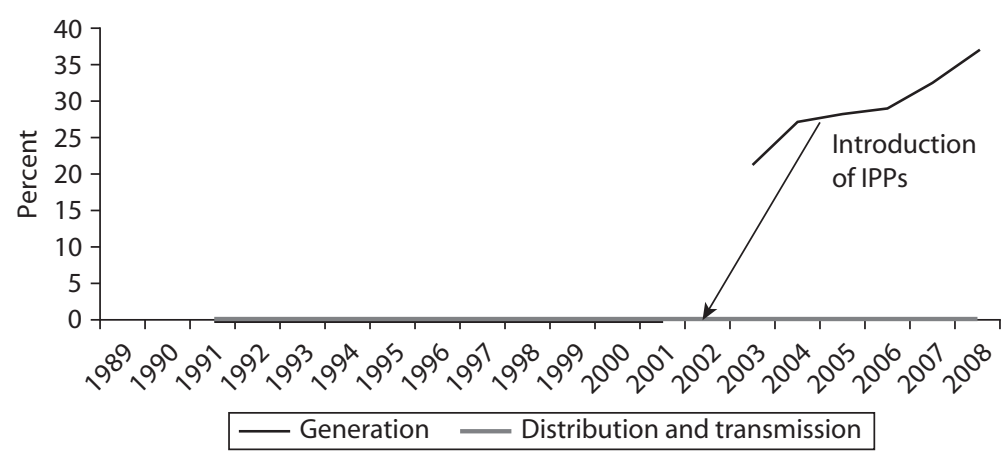

Source: An elaboration from the Power Market Structure database. Note: IPPs = independent power producers.

Figure 17.12 Vietnam: Degree of Vertical Integration

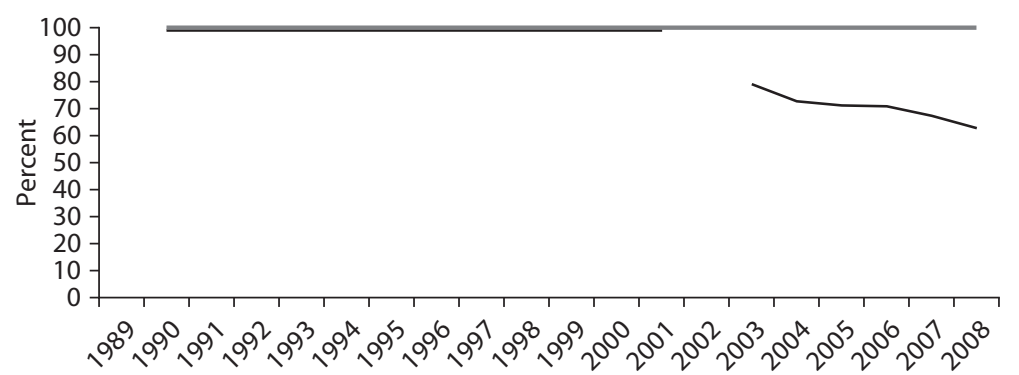

- Between generation and transmission, and between generation and distribution

Between transmission and distribution 


\section{Figure 17.13 Vietnam: System Load Factor}

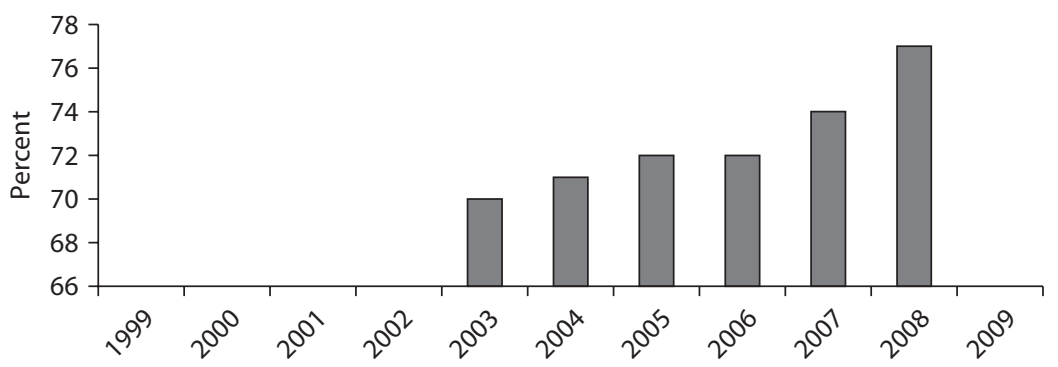

Source: An elaboration from the Power Market Structure database.

\section{Notes}

1. Information and Telecommunication Company, Electrical Manufacturing Company, and four power engineering consulting companies.

2. Institute of Energy; Center for Science, Technology, Environment, and Information; and Center for Power Engineering Information.

3. This assessment is being overtaken by events with the commencement in the near future of power imports from new hydropower capacity on the Laotian border (which may not be classified as imports if the power house is located in Vietnamese territory), as well as the possibility of more power imports from China. 


\section{CHAPTER 18}

\section{Zambia}

Zambia falls into the category of medium system size/low per capita income with total installed generating capacity of just over 1,800 megawatts (MW) and a gross national income of $\$ 950$ per capita in 2008 (World Bank 2008). Zambia provides a case study in the difficulty of reforming a power sector under difficult economic conditions and the lack of sustained political commitment.

Power supply is dominated by ZESCO (Zambia Electricity Supply Corporation), the vertically integrated state-owned utility. The other important sector participant is Copperbelt Energy Corporation (CEC), a private company that purchases bulk power from ZESCO and supplies the copper mines and neighboring population. CEC was listed on the Lusaka Stock Exchange in January 2008. CEC provides power to the mines under long-term agreements at an exceptionally favorable price. ZESCO used to sell power to CEC for $2 \$$ cents per kilowatt-hour ( $\mathrm{kWh}$ ), and CEC resold it at $3 \$$ cents per $\mathrm{kWh}$. As a consequence, demand growth has outpaced supply capacity, and the system is projected to run into a negative supplydemand balance soon. Electricity is a key input for mining-more than 50 percent of electricity generated in Zambia serves the mining sector. Lunsemfwa Hydro Power Company operates a plant of 40 MW of capacity and is the only independent power producer in the electricity industry 
connected to ZESCO's transmission system. Lunsemfwa provides electricity to a nearby manganese mine and to ZESCO.

\section{Reform History}

Zambia's government has attempted to improve ZESCO's performance, but without lasting success. The government and ZESCO signed a threeyear performance contract in late 1996 and again in 1999. ZESCO failed to meet most of the targets under the contract because neither the government nor ZESCO's management took the actions needed to reach the targets. Over the next several years there was no measurable improvement in ZESCO's financial performance.

The Energy Regulation Board (ERB) was established in 1997 after passage of a 1995 law with a mandate to oversee the entire energy sector, including electricity, petroleum, and coal. ERB reviews and approves ZESCO's tariffs. A tariff order was issued on January 1, 2008, establishing a three-year incentive-based regime and approving an increase of 27 percent on average for nonmining customers only for the first year. The tariff for the mining sector was not increased at that time.

ERB's tariff order also included a list of performance benchmarks as conditions for ZESCO to improve efficiency and quality of services, including (1) metering all new and existing consumers; (2) reducing distribution system loss; (3) reducing staff cost as proportion of operating budget and increasing staff productivity; (4) increasing the revenue collection rate; (5) reducing unplanned outages; (6) reducing waiting time for applicants to get connected; and (7) reducing the supply demand gap through demand-side management, efficiency improvement, regional energy import, and so forth.

In late 2000 the International Development Association of the World Bank Group (IDA), the International Monetary Fund (IMF), and the Zambian government agreed on a road map for the privatization of the power sector. The first stage consisted of the creation of functionally independent generation, transmission, and distribution entities within ZESCO, with commercial trading arrangements between them, as an important and critical step in the transition process toward private participation in the sector. This stage was to be followed by privatization of ZESCO through a two-step process. The first step was a concession agreement of not more than ten years, and the second was to be the sale or the concession of individual independent business units.

In January 2003 ZESCO's concession advisers published a proposal to implement the cabinet decision on the divestiture of government interest 
in ZESCO. But in April, only three months after its commitment to IDA, the government rescinded its privatization decision. IDA and the IMF agreed to the government's revised commercialization road map, which they hoped would achieve the same objective of improving ZESCO's financial performance.

To date there has been very little private investment. ZESCO's vertically integrated and monopolistic structure poses a constraint to private sector participation and competition. Future prospects of private sector involvement in the power sector lie primarily in three areas: (1) power generation - the government and ZESCO are inviting the private sector to invest jointly and develop new hydropower plants; (2) off-grid electrification-a few private developers exist for microhydro and solar photovoltaics - and the private sector is expected to be the primary service provider for off-grid electrification; and (3) grid extensionalthough it is difficult for the private sector or cooperatives to provide electricity services under the current low national uniform tariff, ZESCO will hire the private sector as supply and installation contractors for construction of grid extension projects.

The challenges faced include, inter alia, inadequate generation capacity locally and regionally to meet increasing demand, tariffs that are below cost, and the associated political economy problem of moving toward cost-reflective tariffs. These challenges have resulted in the perception of higher tariffs as the panacea to all of ZESCO's operational problems: the inability to attract new investment in the sector; low access rates due to high cost of connections and ZESCO's inability to connect customers promptly; and a poor population that limits the effective demand for electricity and exacerbates ZESCO's collection rates.

\section{Impact on Sector Structure}

The power sector is dominated by ZESCO, the vertically integrated stateowned utility.

\section{Impact on Sector Performance}

Evidence of possible impacts from unbundling and other reforms is sought from trends from the early to mid-1990s up to 2008 in the following indicators:

- Access to electricity supply by the population. Zambia has an overall national electrification rate of 20 percent with about 40 percent of the 
population in urban and surrounding urban areas and only 2 percent of the rural population having access to electricity. The proportion of the Zambian population with access to electricity hardly changed between 2000 and 2008.

- Customer service quality. ZESCO's consumers expressed concerns over the poor quality of its electricity services during ERB's public consultations for tariff adjustments. But these consumers have benefited from extremely low tariffs by international standards: below $2 \$$ cents per $\mathrm{kWh}$ up to 2005 and below 2.5 \$ cents per kWh thereafter. These low tariff levels have not allowed ZESCO to generate adequate income to invest its own resources in maintaining and replacing the distribution networks. Therefore, ZESCO's quality of service has deteriorated and its current distribution losses are about 23 percent. With the rapid development of new mines and industries and the growth of household electricity needs, the country is experiencing power shortage and load shedding. Unprecedented load shedding occurred during 2008, especially for residential consumers.

- Supply security. ZESCO's system lacks adequate reserve supply capacity, especially for the large proportion of hydropower capacity that is subject to highly variable hydrological conditions, which can cause system reserve capacity to swing between surplus and deficit almost from year to year. No new major generation capacity addition has taken place since the 1970s to match the steady increase in electricity demand.

- Financial sustainability. The historically low tariff has resulted in ZESCO's deteriorating financial performance, as shown by the sharp deterioration in profit, cost recovery, and debt equity ratios since 2003. The average tariff has oscillated around the level of the company's operating expenditures during the 00s, as shown by its cost recovery index (figure 18.9), which left it without the financial resources for major expansion in access to electricity or system supply capacity.

- Environmental sustainability. The total emissions of carbon per unit of electricity generated has oscillated between 50 and 400 tons per gigawatt-hour generated on the system, which reflects the output of hydropower. Zambia is endowed with rich renewable energy resources. To date, however, utilization of renewable energy is quite limited, except for large hydro, due to a number of barriers, including a lack of 
policy and regulatory frameworks, such as standardized power purchase agreements, technical specifications, and the like, and a limited number of project developers and renewable energy finance providers.

Trends in these indicators are shown in the figures that follow. 
Figure 18.1 Milestones of Power Sector Reform in Zambia

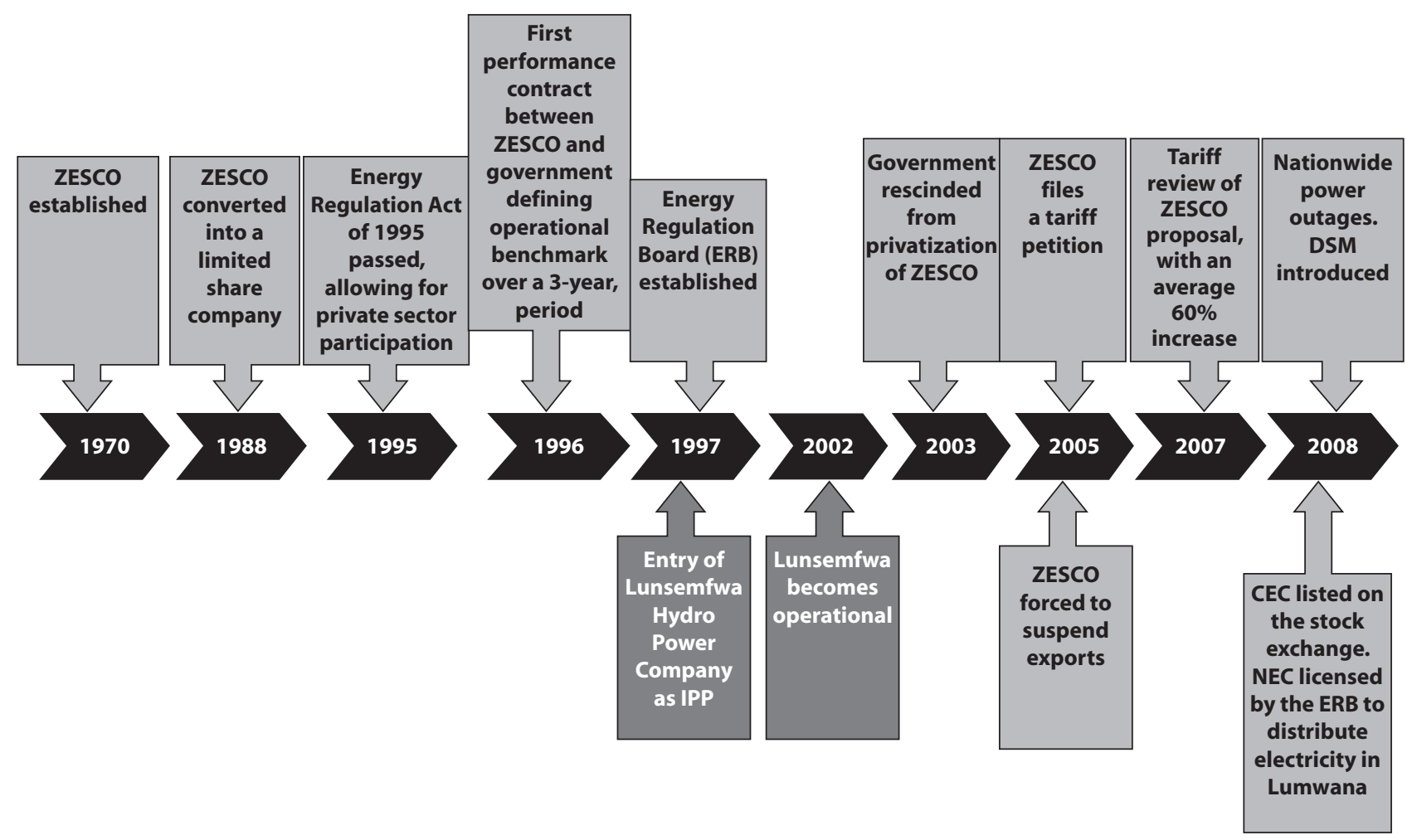

Source: An elaboration of the Power Market Structure database.

Note: The milestones are reported in different shades: light gray = main government interventions; dark gray = main private sector involvements. CEC = Copperbelt Energy Corporation; DSM = demand-side management; ERB = Energy Regulation Board; IPP = independent power producer; NEC = Ndola Energy Company; ZESCO = Zambia Electricity Supply Corporation 


\section{Figure 18.2 Zambia: Access to Residential Electricity}

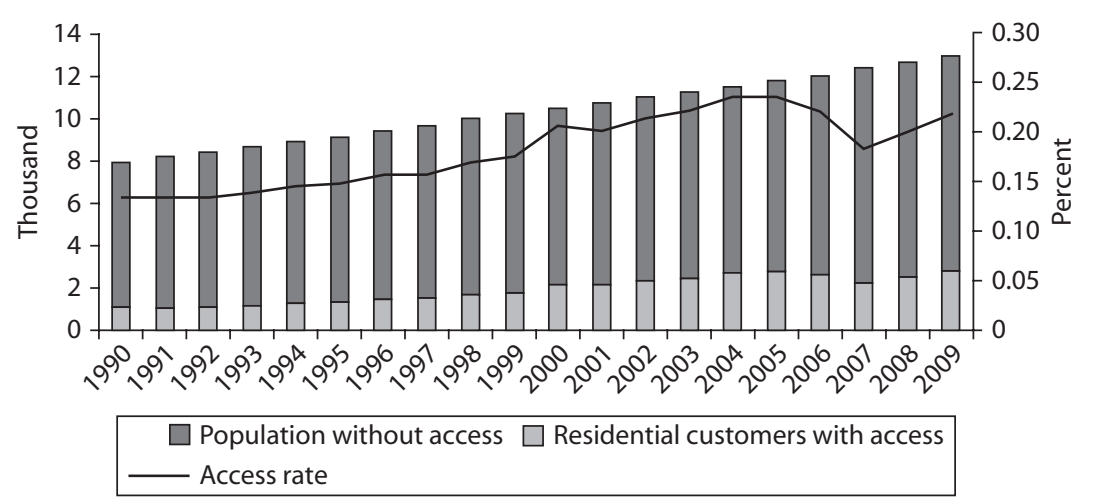

Source: An elaboration of the Power Market Structure database.

Figure 18.3 Zambia: System Losses and Operating Costs

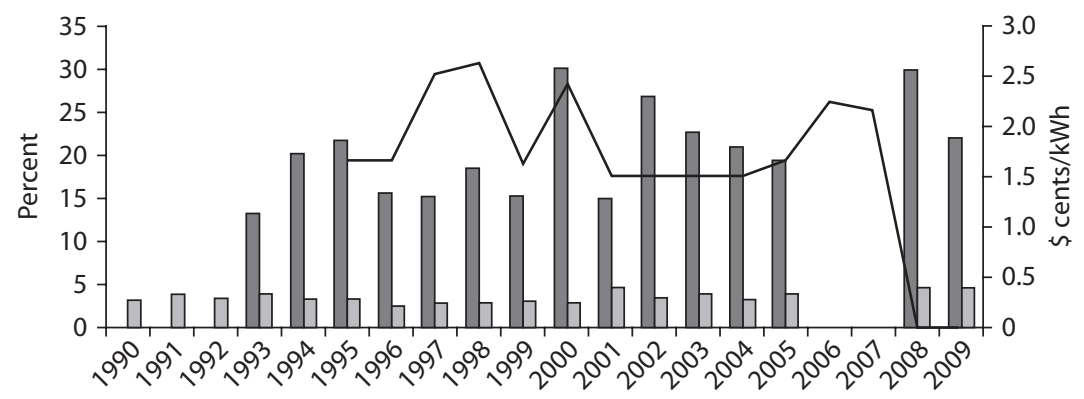

Distribution losses $\square$ Transmission losses Total opex per unit consumed

Source: An elaboration of the Power Market Structure database.

Note: $\mathrm{kWh}=$ kilowatt-hour; opex = operational expenditures/costs. 
Figure 18.4 Zambia: Electricity Generation by Source and Carbon Emissions

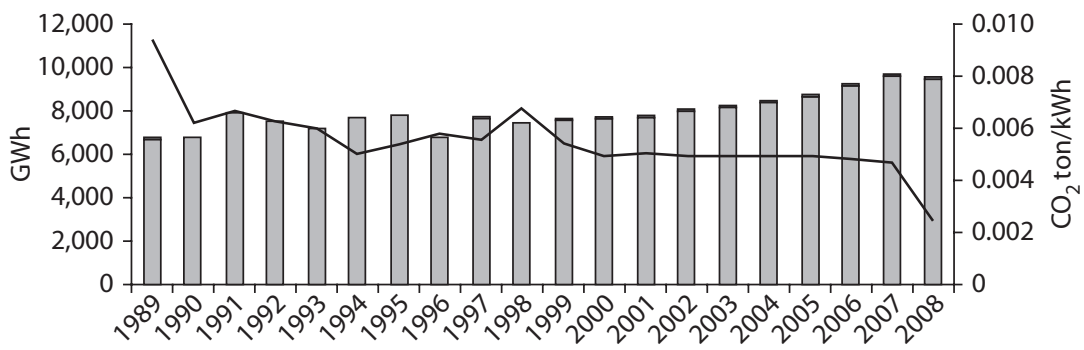

$\square$ Thermal $\square$ Hydro $—$ Carbon emissions index

Source: An elaboration of the Power Market Structure database.

Note: $\mathrm{GWh}=$ gigawatt-hour; $\mathrm{kWh}=$ kilowatt-hour.

Figure 18.5 Zambia: Energy Security and Capital Expenditure

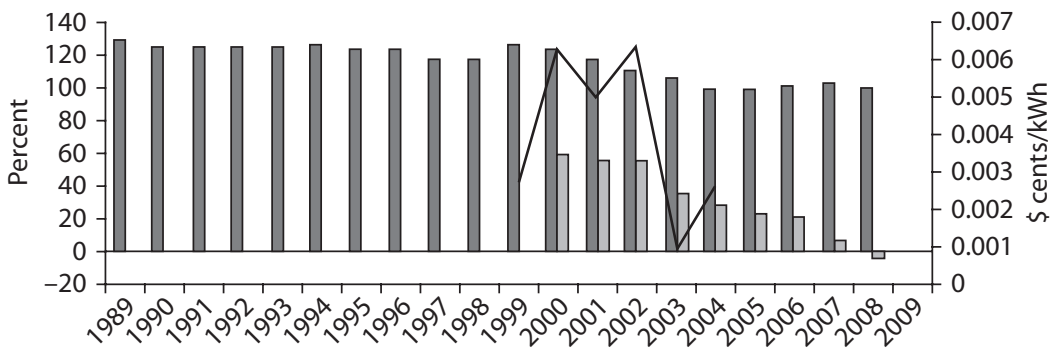

$\square$ Energy self-sufficiency $\square$ System reserve capacity
Total capex per unit consumed

Source: An elaboration of the Power Market Structure database.

Note: Capex $=$ capital expenditures; $\mathrm{kWh}=$ kilowatt-hour.

Figure 18.6 Zambia: Average Tariff and Operating Costs

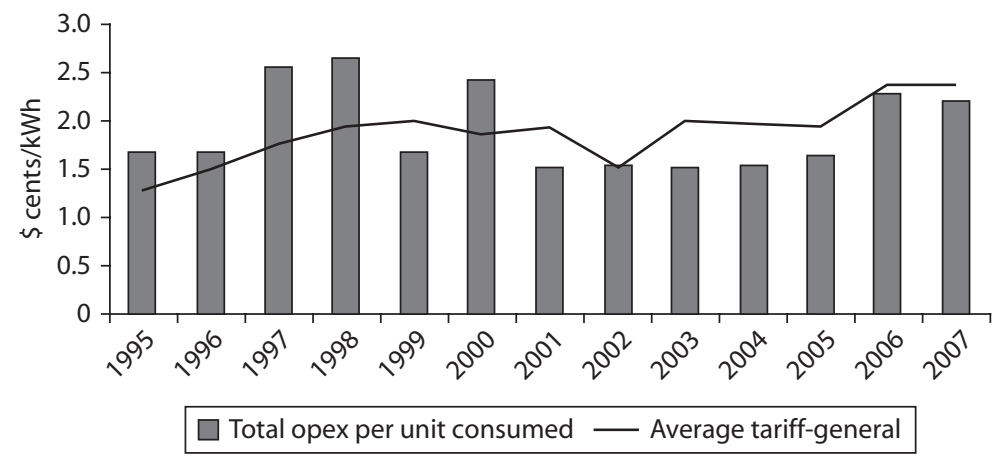

Source: An elaboration of the Power Market Structure database.

Note: $\mathrm{kWh}=$ kilowatt-hour; opex $=$ operational expenditures/costs. 


\section{Figure 18.7 Zambia: Labor Productivity}

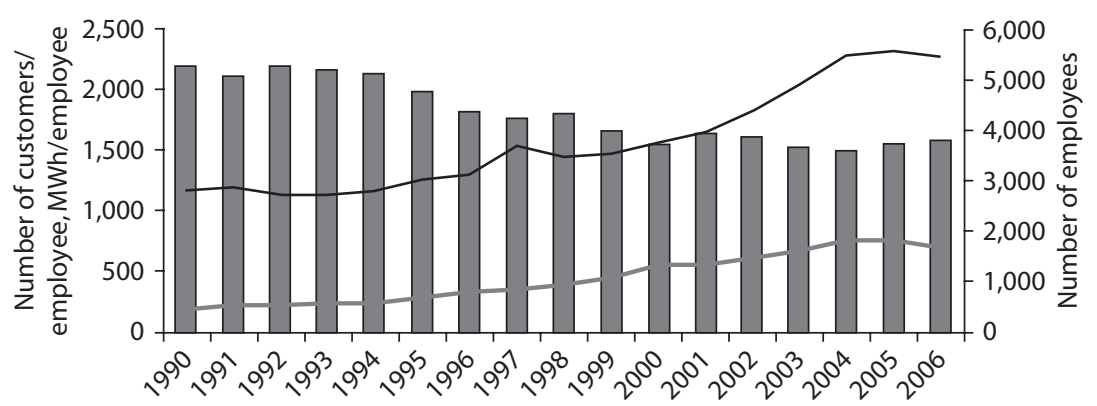

$\square$ Number of employees in electricity sector
$\square$ Energy consumed/employee
$\square$ Residential customers/employee

Source: An elaboration of the Power Market Structure database.

Figure 18.8 Zambia: Capacity Utilization

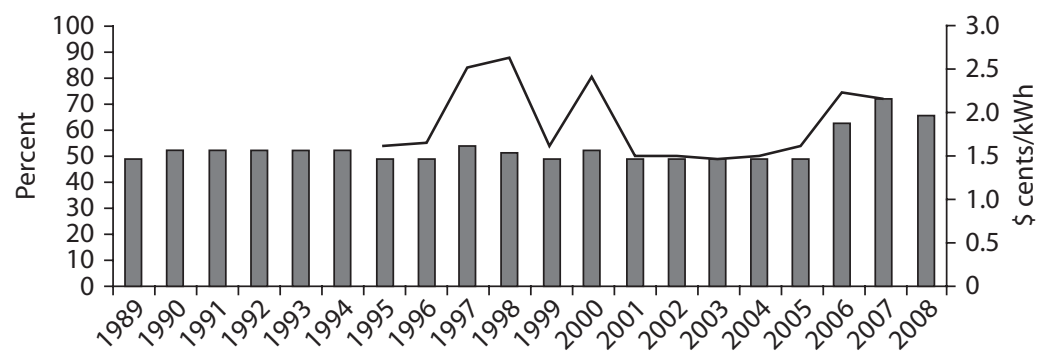

\section{Capacity utilization - Total opex per unit consumed}

Source: An elaboration of the Power Market Structure database.

Note: kWh = kilowatt-hour; opex = operational expenditures/costs.

\section{Figure 18.9 Zambia: Cost Recovery Index}

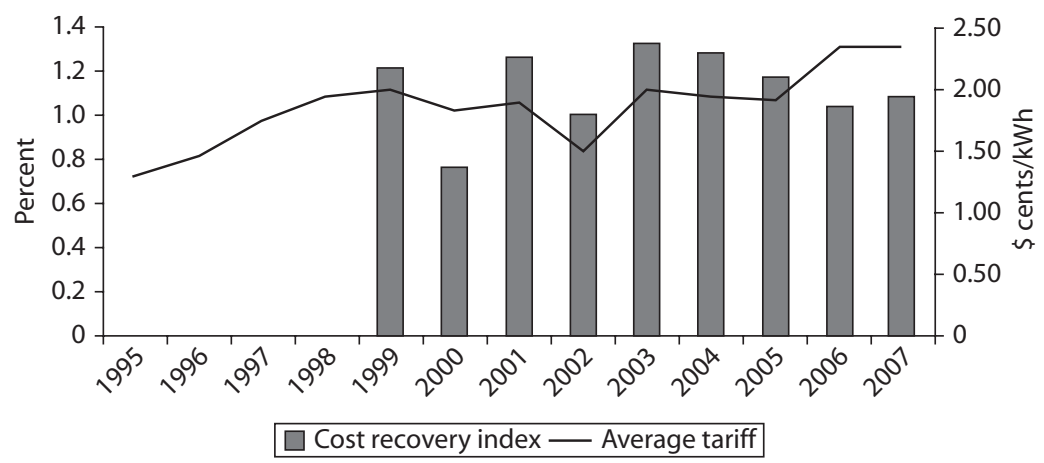

Source: An elaboration of the Power Market Structure database. 


\section{Figure 18.10 Zambia: Market Concentration}

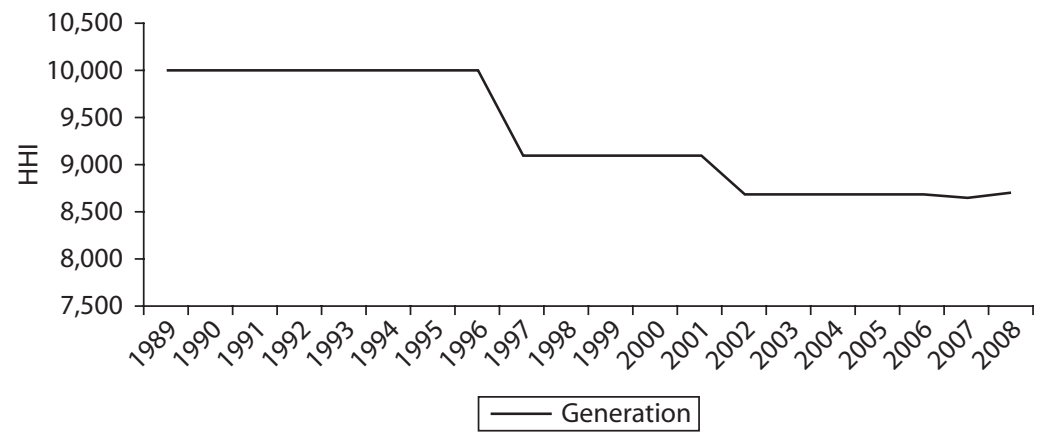

Source: An elaboration of the Power Market Structure database. Note: $\mathrm{HHI}=$ Herfindahl-Hirschman Index.

\section{Figure 18.11 Zambia: Private Ownership}

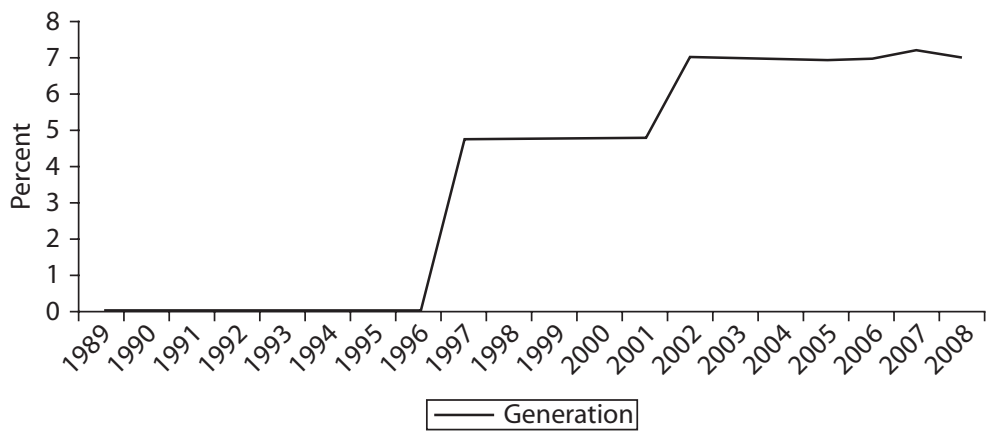

Source: An elaboration of the Power Market Structure database.

\section{Figure 18.12 Zambia: Private Management}

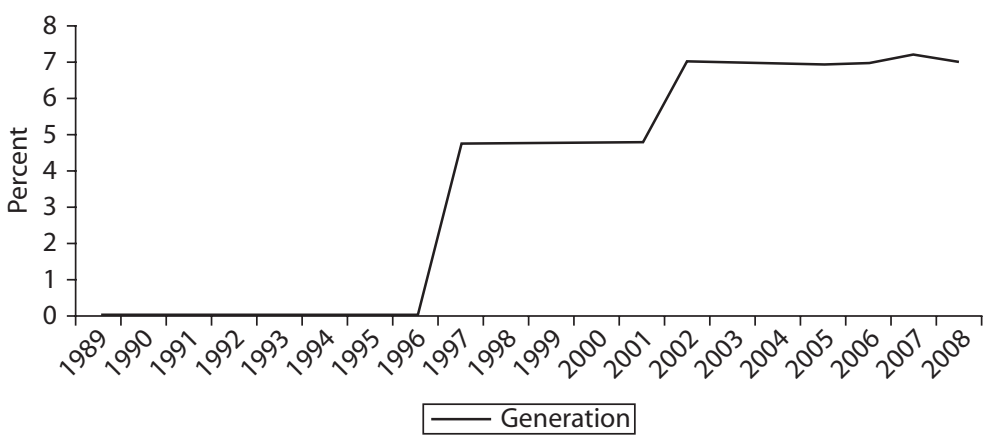

Source: An elaboration of the Power Market Structure database.

\section{Reference}

World Bank. 2008. World Development Indicators. World Bank, Washington, DC. 
PART 4

Case Studies: Small System Size and Low GDP per Capita Economies 



\section{CHAPTER 19}

\section{Kenya}

Kenya falls near the upper limit of the category of low system size/low per capita income, with current total installed generating capacity of just over 1,200 MW (megawatts) and per capita gross domestic product of about $\$ 800$. These parameters are too low to categorize Kenya in the large system size/medium per capita income group of countries.

\section{Reform History}

Since the early 1990s Kenya has periodically carried out some restructuring to its power suppliers, without substantially changing the underlying economic structure. It consolidated two distribution companies in the mid-1990s, then consolidated this successor company with the transmission company in 1999. Currently, Kenya Power and Lighting Company (KPLC) is responsible for the transmission, distribution, and sale of electricity throughout the country. In 1998 the first private generators started to supply the Kenyan power market.

In 2006 the government sold 30 percent of its stake in KenGen (Kenya Electricity Generating Company) to the public in what was hailed as the best initial public offering ever at the Nairobi Stock Exchange. The government had sold part of KPLC to the public in 1972, and over time the 
government's stake has shrunk to 40 percent. Because the poor financial condition of these companies prevented them from raising the large amounts of capital needed to fund the required sector expansion, in 2007 the government formed two new companies: Kenya Electricity Transmission Company Ltd. to operate parallel to the Kenya Power and Lighting Company, and the Geothermal Development Corporation to work alongside KenGen. This move was to allow the state to inject funds into the sector. ${ }^{1}$

On the policy and regulatory front, the enactment of the Electric Power Act in 1996 led to the creation of the Electricity Regulatory Board. This entity was transformed into the Energy Regulatory Commission in 2007 following the announcement of a new energy policy in 2002 and the passage of the 2006 law. The arrangements for trading bulk power were converted in 2009 to bilateral contracting between the generators and KPLC through power purchase agreements.

\section{Impact on Sector Structure}

Overall vertical integration in the sector has not changed much, with transmission and distribution now bundled and generation unbundled into a few suppliers. As a result of the public sale of shares in KenGen and the entry of independent power producers to the power market, the proportion of total installed generating capacity under private ownership increased from 16 percent in 2001 to 46 percent in 2007. Despite the creation of a formal regulatory framework in the early and mid-00s, the sector experienced severe financial problems in that period, with average tariffs below operating costs and the sector unable to finance sufficient investments in generation, transmission, and distribution, despite an impressive expansion of medium and low voltage networks between 2002 and 2008.

\section{Impact on Sector Performance}

Evidence of possible impacts from unbundling and other reforms is sought from trends from the early to mid-1990s up to 2008 in the following indicators:

- Access to electricity supply by the population in terms of new residential connections. Access is a qualified success, as KPLC and its predecessor increased its residential connections at a creditably steady rate of 
about 8.5 percent per year from 1989 to 2009 while the changes to sector structure and ownership were taking place. Nevertheless, only 16 percent of Kenyan households are connected to the public electricity supply. The expansion took place predominantly in urban areas, so that nearly 50 percent of the urban households are connected, compared to less than 5 percent of rural households.

- Customer service quality. Consumers' perception of service qualityrepresented by the number of complaints about supply-improved markedly from about seven complaints per customer in 2002 to about three complaints per customer in 2008. System losses declined substantially from 20 percent to 12 percent of energy supplied to the system over the same period. These trends coincided with a substantial steady increase in nonfuel operational expenditures/costs per unit consumed from 9 \$ cents to 16 \$ cents per kWh (kilowatt-hour), which was facilitated by a steady increase in tariffs from an average level of about 8 \$ cents per kWh in 2002 to 18 \$ cents per kWh in 2008. Structural or regulatory reforms do not appear to be the underlying factors, as few-if any—of these reforms occurred during this period.

- Supply security. Kenya has relied on hydropower for most of its power generation, which sheltered the country from volatility in international fossil fuel prices, but exposed it to shortages caused by serious droughts, as occurred around 2000 when hydropower output dropped by around half the normal level. Diversification into more thermal and geothermal power coincided with the policy to attract private investment in this area. Although not successful from initiation in 1998 until 2004, during which capex (capital expenditures) per kWh consumed declined markedly, the situation was reversed subsequently with a substantial increase in capex and growth in privately financed thermal power generation. New capacity has not, however, kept pace with the growth in demand on the power system, as shown by the decline of system reserve capacity to effectively zero by 2007 and the substantial increase in the utilization of total generation capacity from around 40 percent in the early 00s to nearly 60 percent in 2007. The latest reform in 2009 to convert power sales from private thermal generators from a central buyer arrangement with the single transmission and distribution company (KPLC) to bilateral contracts between these generators and KPLC appears to be designed to attract more private investment in power generation. 
- Sustainability. This factor has two main aspects-financial and environmental. The sector's financial sustainability has been precarious, with increases in average tariffs lagging increases in operating costs from 1997 until 2007. The cost recovery index has been displaying substantial nonpayment problems, but has risen from a seriously low level of about 40 percent in 2002 up to 80 percent in 2008. This situation occurred despite the steady improvements in labor productivity and utilization of generation capacity and decline in system energy losses. It hindered the mobilization of the investment funding needed to increase power supply in line with the increase in demand. Environmental sustainability in terms of carbon emissions has declined recently after remaining steady from the mid-1990s (apart from a spike during the drought around 2000). The decline reflects the trend to more thermal power generation in the country.

Trends in these indicators are shown in the figures that follow. 
Figure 19.1 Milestones of Power Sector Reform in Kenya

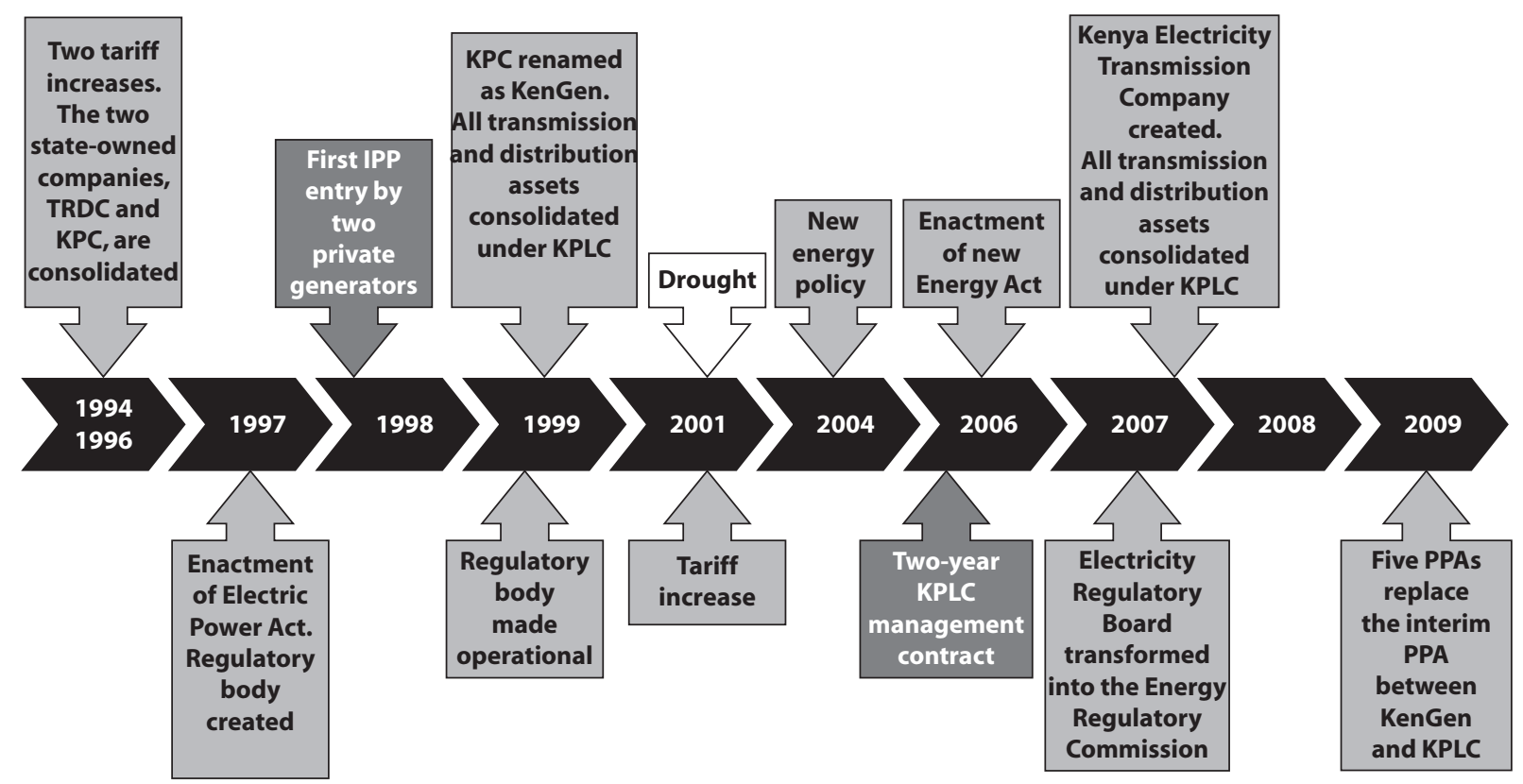

Source: An elaboration from the Power Market Structure database.

Note: The milestones are reported in different shades: white = main external factors; light gray = main government interventions; dark gray = main private sector involvements.

IPP = independent power producer; KenGen = Kenya Electricity Generating Company; KPC = Kenya Pipeline Company; KPLC = Kenya Power and Lighting Company: 


\section{Figure 19.2 Kenya: Access to Residential Electricity}

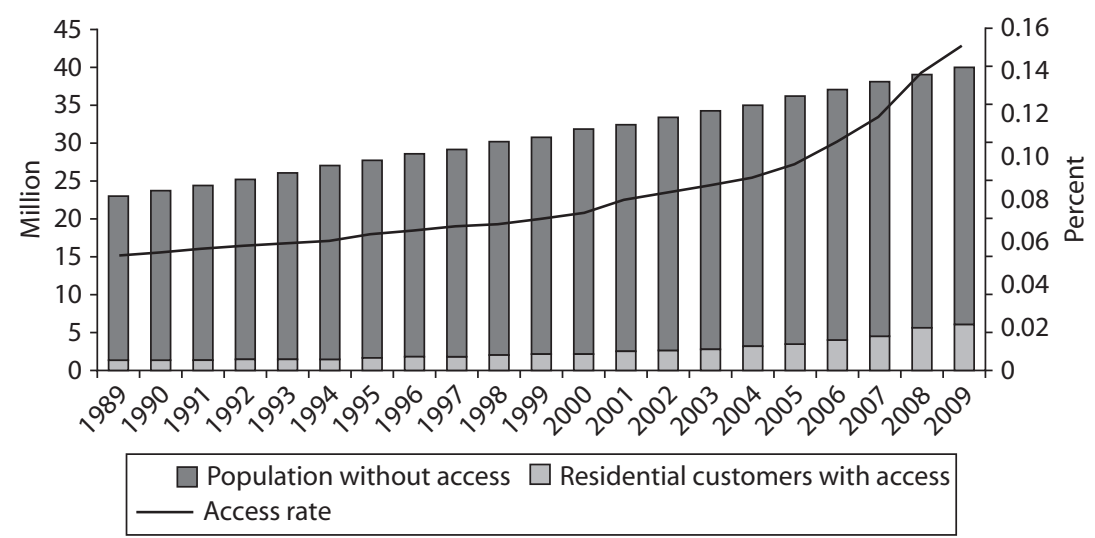

Source: An elaboration from the Power Market Structure database.

Figure 19.3 Kenya: Quality of Electric Service

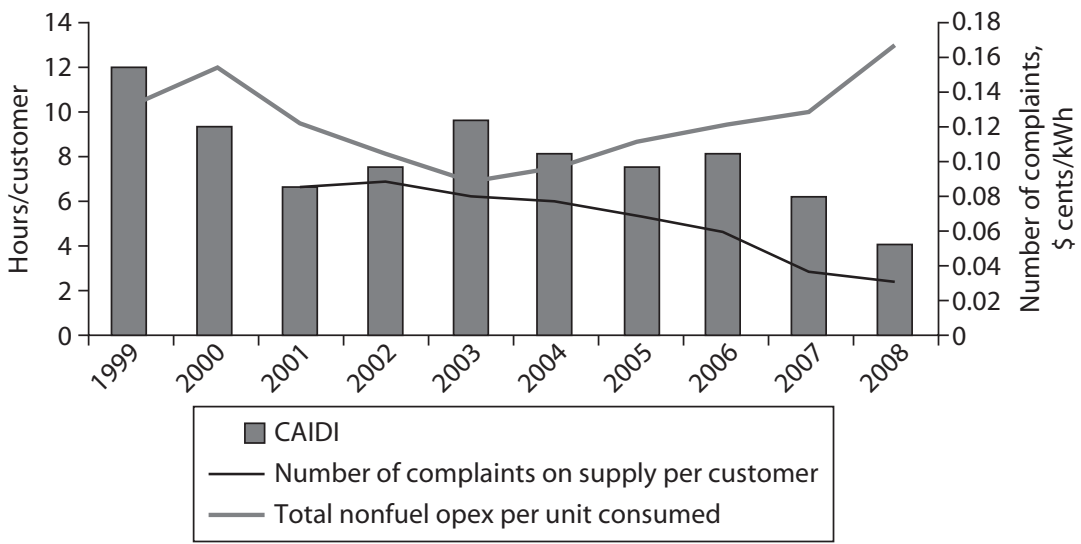

Source: An elaboration from the Power Market Structure database.

Note: $\mathrm{CAIDI}=$ Customer Average Interruption Duration Index; kWh = kilowatt-hour; opex = operational expenditures/costs. 
Figure 19.4 Kenya: System Losses and Operating Costs

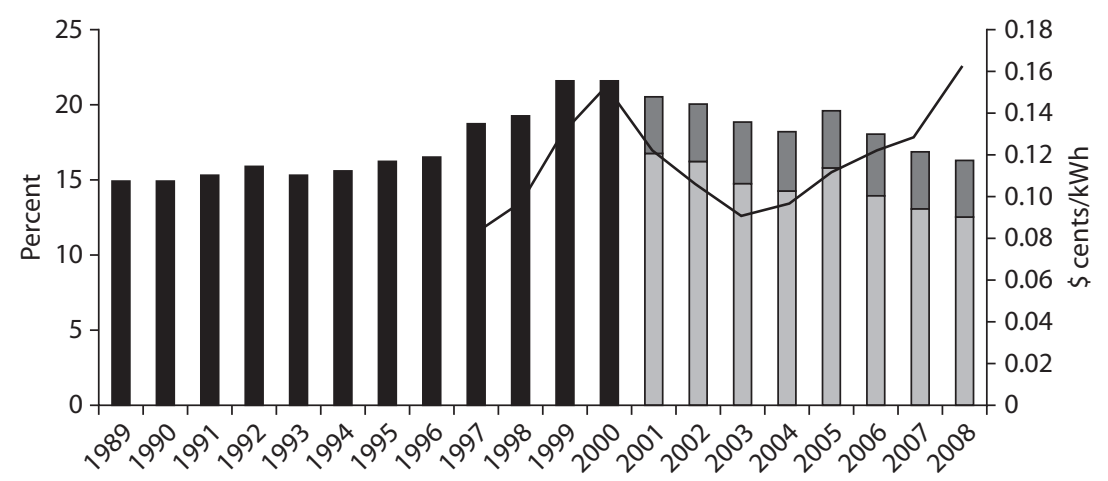

$\square$ Transmission losses $\quad \square$ Distribution losses

- Total system losses _ Total nonfuel opex per unit consumed

Source: An elaboration from the Power Market Structure database.

Note: $\mathrm{kWh}=$ kilowatt-hour; opex = operational expenditures/costs.

Figure 19.5 Kenya: Cost Recovery Index

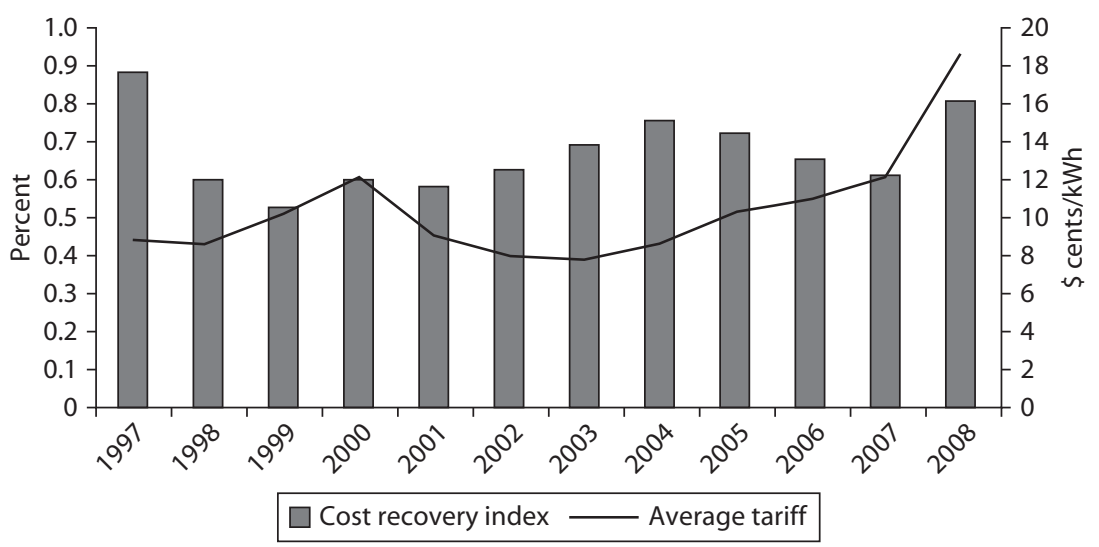

Source: An elaboration from the Power Market Structure database. 


\section{Figure 19.6 Kenya: Average Tariff and Operating Costs}

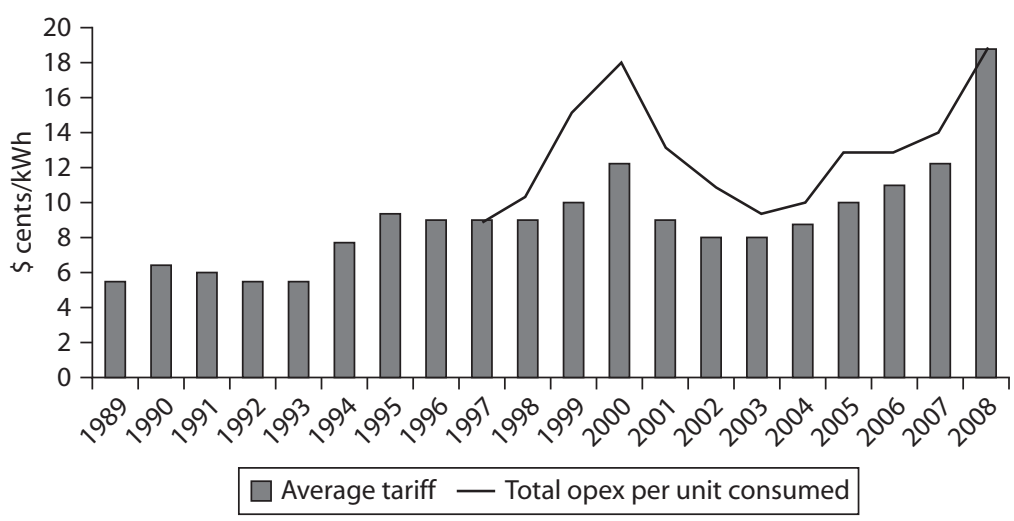

Source: An elaboration from the Power Market Structure database.

Note: $\mathrm{kWh}=$ kilowatt-hour; opex = operational expenditures/costs.

Figure 19.7 Kenya: Energy Security and Capital Expenditure

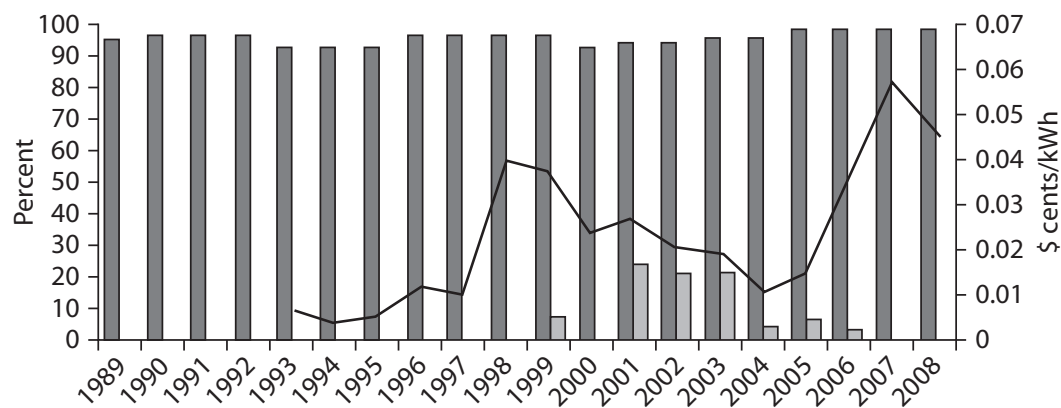

$\square$ Energy self-sufficiency $\square$ System reserve capacity Total capex per unit consumed

Source: An elaboration from the Power Market Structure database.

Note: Capex $=$ capital expenditures; $\mathrm{kWh}=$ kilowatt-hour. 


\section{Figure 19.8 Kenya: Electricity Generation by Source and Carbon Emissions}

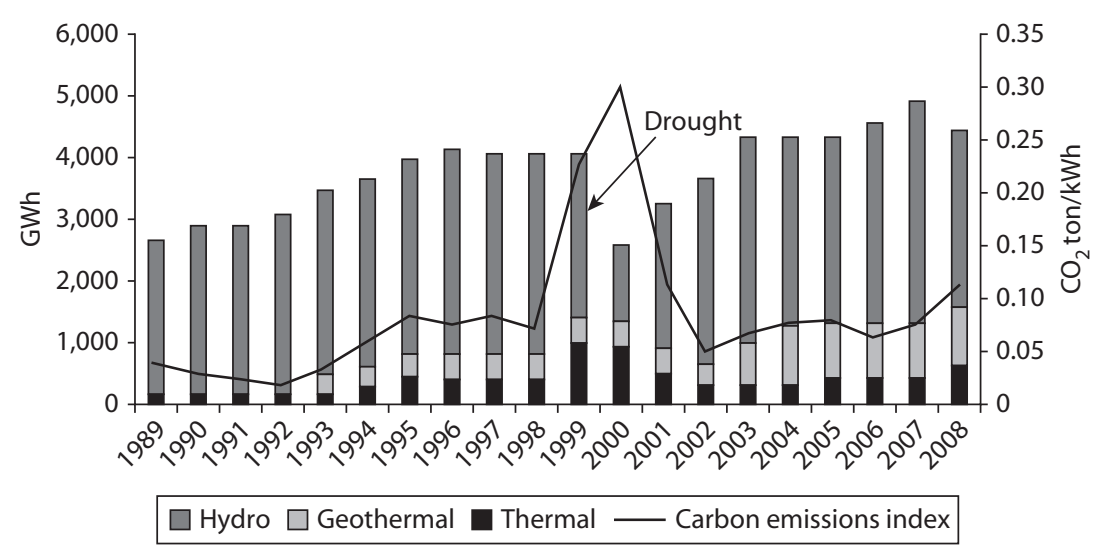

Source: An elaboration from the Power Market Structure database.

Note: $\mathrm{GWh}=$ gigawatt-hour; $\mathrm{kWh}=$ kilowatt-hour.

Figure 19.9 Kenya: Labor Productivity

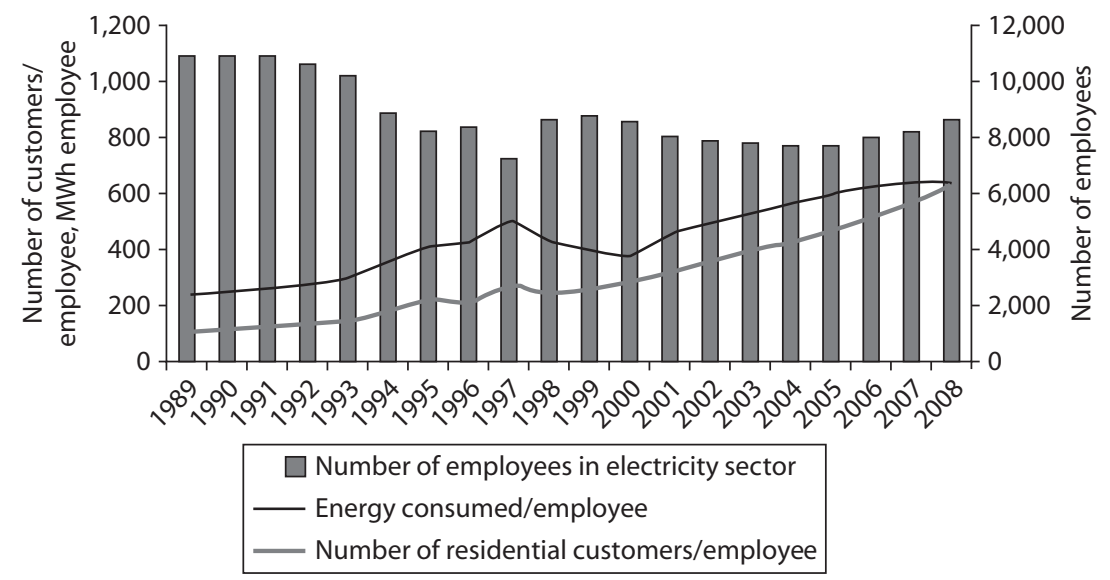

Source: An elaboration from the Power Market Structure database.

Note: $\mathrm{MWh}=$ megawatt-hour. 
Figure 19.10 Kenya: Capacity Utilization

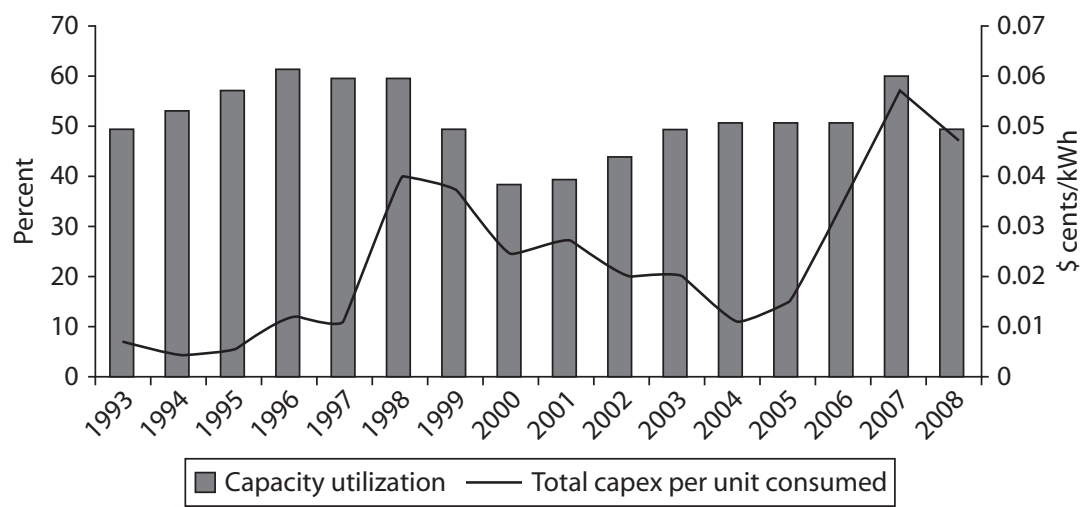

Source: An elaboration from the Power Market Structure database. Note: Capex = capital expenditures; $\mathrm{kWh}=$ kilowatt-hour.

Figure 19.11 Kenya: System Load Factor

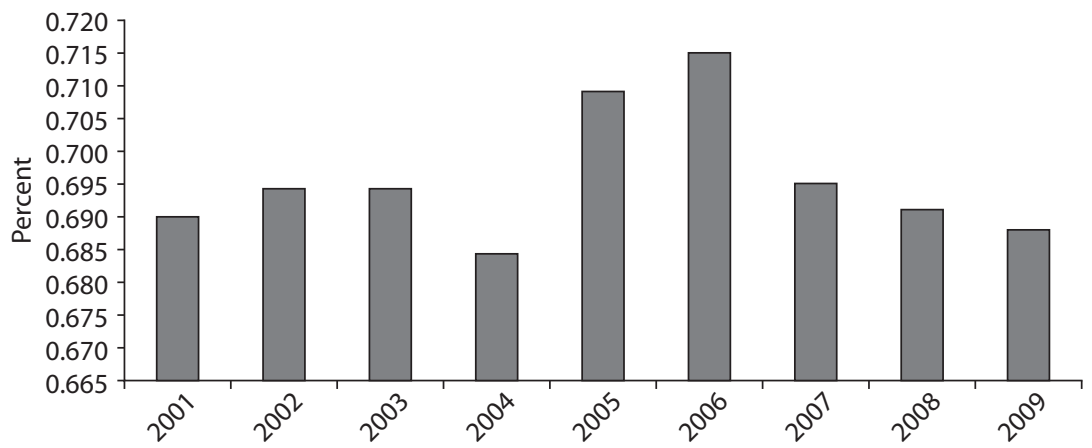

Source: An elaboration from the Power Market Structure database. 


\section{Figure 19.12 Kenya: Market Concentration}

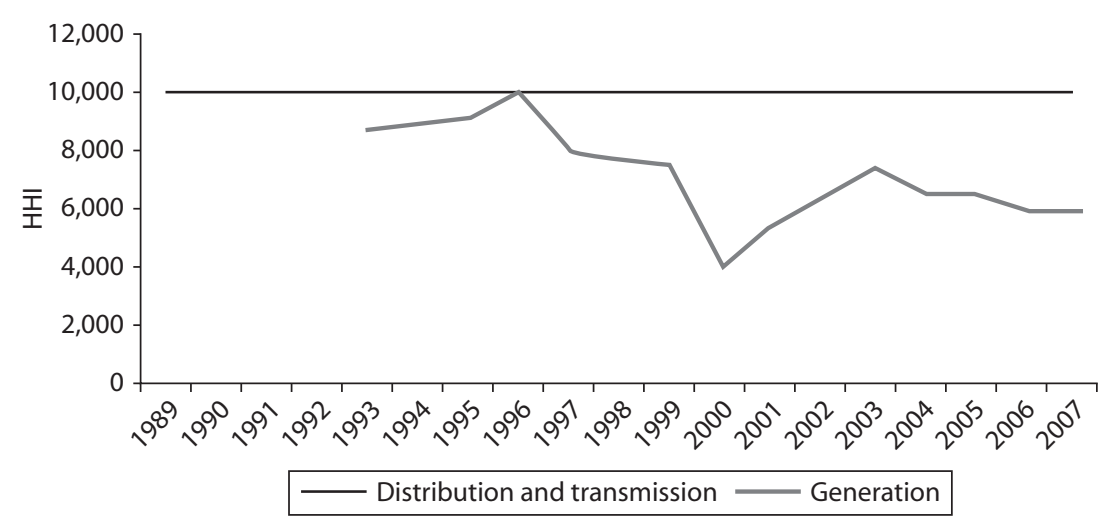

Source: An elaboration from the Power Market Structure database. Note: $\mathrm{HHI}=$ Herfindahl-Hirschman Index.

\section{Figure 19.13 Kenya: Private Ownership}

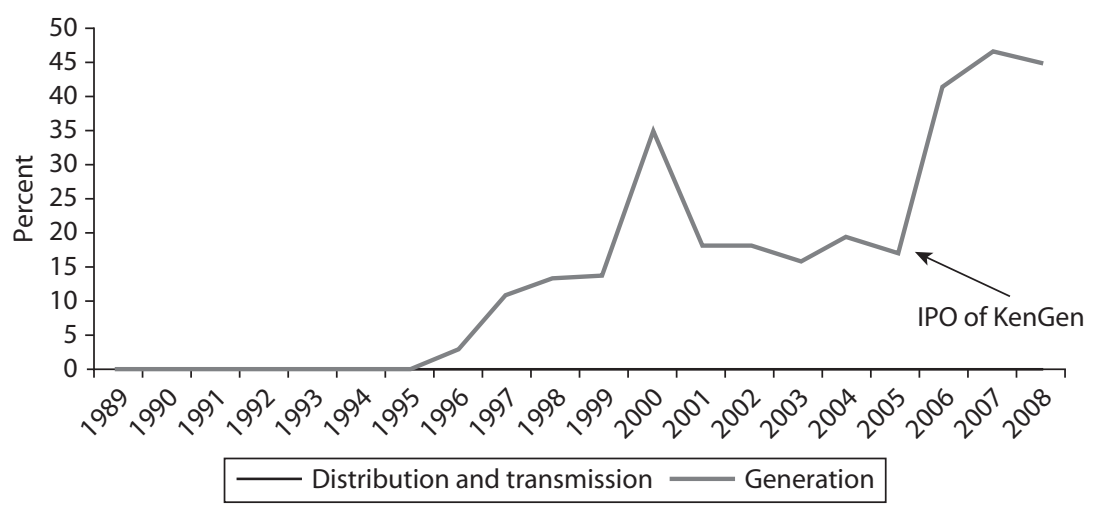

Source: An elaboration from the Power Market Structure database.

Note: $\mathrm{IPO}=$ initial public offering; KenGen = Kenya Electricity Generating Company. 


\section{Figure 19.14 Kenya: Private Management}

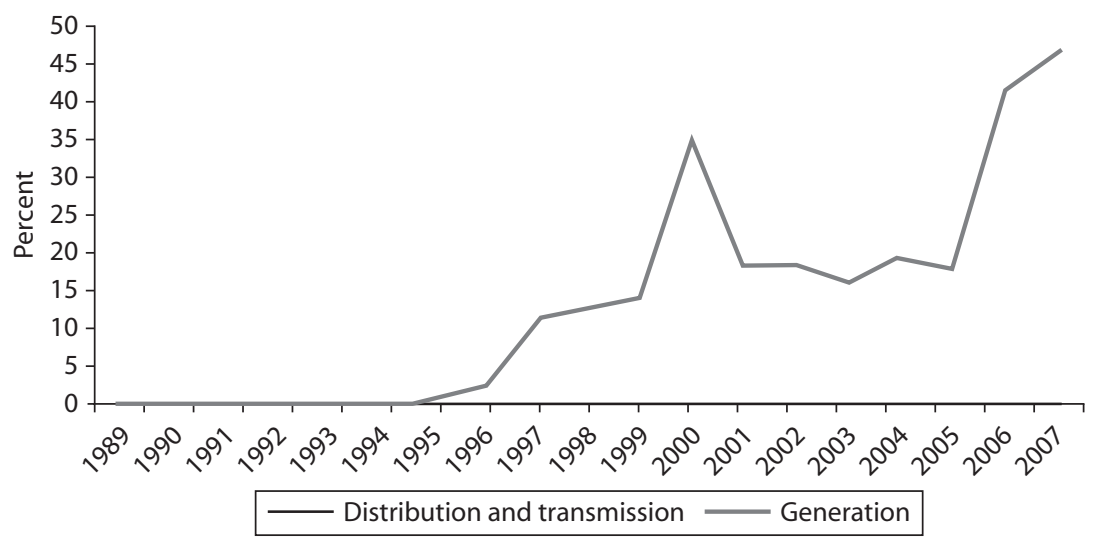

Source: An elaboration from the Power Market Structure database.

\section{Figure 19.15 Kenya: Degree of Vertical Integration}

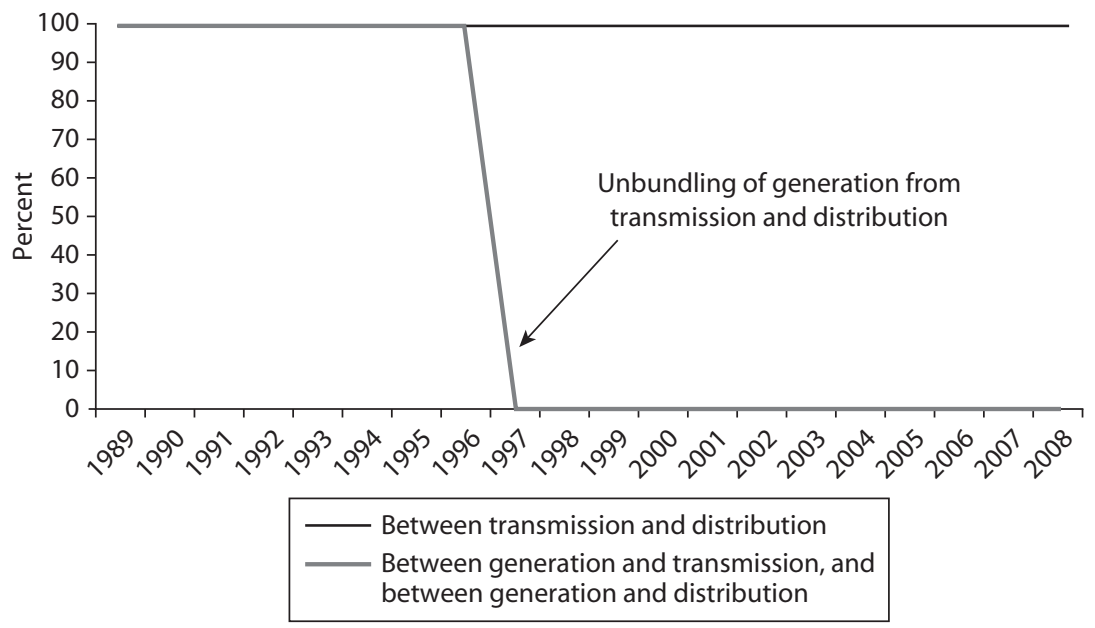

Source: An elaboration from the Power Market Structure database.

\section{Note}

1. This move took into account the restrictions placed by the Nairobi Stock Exchange listing and trading rules on the existing publicly listed power companies KPLC and KenGen. According to the laws regulating the stock market, if the government is to inject new capital into any listed company, it can do so only by buying additional shares, either in a rights issue or increased issued 
shares. The most direct effect of such a move would be to alter the shareholding structure and, in the case of KenGen, from the current 70:30 percent share structure. Any such changes would most likely see KenGen run afoul of the Capital Markets Authority rules on continuous listing obligations, which require any listed company to have at least 25 percent of its issued shares held by the public. "State's Big Return in Power Business," Daily Nation, July 27, 2009. 



\section{CHAPTER 20}

\section{Tanzania}

Tanzania falls into the category of low system size/low per capita income (gross national income of $\$ 440$ per capita in 2008 [World Bank 2008]). Its total installed generating capacity reached just over 1,100 MW (megawatts) in 2008-09, but the capacity of a company to produce energy was lower because output from its substantial proportion of hydropower capacity (amounting to about half of the total capacity ${ }^{1}$ ) is highly uncertain under the region's variable hydrology.

\section{Reform History}

In 1992 Tanzania's first National Energy Policy included plans to involve the private sector in energy sector development-both electricity and natural gas. In the same year, facing a drought-induced electricity crisis and extensive load shedding, the government lifted the monopoly on generation held by the state-owned vertically integrated power corporationTanzania Electric Supply Company (TANESCO)—-to attract private generation and alleviate power shortages. This policy laid the basis for the introduction of the first power plant developed by an independent power producer (IPP) under project financing arrangements in 2002, and a second one based on off-shore natural gas resources in 2004. 
From the early 1990s onward, the government and donors financed considerable efforts to improve TANESCO's operating and financial performance from a generally poor level, but without much success. In 1997 TANESCO was put under the president's Parastatal Sector Reform Commission, created in 1992 to oversee the privatization of state-owned enterprises in industry and manufacturing. A 1999 cabinet decision outlined an electric industry policy and restructuring framework to unbundle and restructure for privatization, but no progress was made.

Instead, from 2002 to 2006 TANESCO was placed under a management contract with NETGroup Solutions, a private consulting firm. NETGroup doubled TANESCO's cash flow in two years mainly by improved collections. Its subsequent efforts to extend the gains into other operational areas were unsuccessful partly because of external financial constraints to the contract. The main external constraints were poor hydrological conditions that reduced hydropower production and necessitated purchases of thermal power from the IPPs, the high costs of IPP power under the terms of the power purchase agreements, and tariff rates insufficient to allow TANESCO to invest in system improvements. In 2005 the government took TANESCO off the list of utilities for privatization.

\section{Impact on Sector Structure}

The addition of two thermal power plants developed by IPPs between 2002 and 2004 changed the primary energy mix for power generation from nearly 90 percent dependence on hydropower to 60 percent dependence on thermal power. One reason for the relative decline in dependence on hydropower was a prolonged drought throughout East Africa in the mid-1980s. These plants contribute approximately $300 \mathrm{MW}$ or about one-third of the country's present generation capacity of $900 \mathrm{MW}$. As a result, the market concentration index as measured by installed capacity has fallen from 1.00 before 2002 to just below 0.40 .

The transmission and distribution segments remain monopolies.

\section{Impact on Sector Performance}

Evidence of possible impacts from unbundling and other reforms is sought from trends from the early to mid-1990s up to 2008 in the following indicators:

- Access to electricity supply by the population in terms of new residential connections. Access is a qualified success. TANESCO increased its residential connections at the creditable rate of about 11 percent per 
year from 1990 to 2008, but only 11 percent of Tanzanian households are connected to the public electricity supply. The expansion took place predominantly in urban areas, so that nearly 40 percent of the urban households are connected, compared to less than 2 percent of rural households.

- Customer service quality. The available data are not adequate to detect quantifiable trends in service quality. But TANESCO's generally poor performance indicates that service quality to its customers also was poor.

- Supply security. In a power supply system that has such a large proportion of hydropower capacity subject to highly variable hydrological conditions, security of power supply is subject to the deterioration experienced during the extended East African drought of the early 00s. Tanzania's system reserve capacity has swung between surplus and deficit almost from year to year. The advent of the two thermal plants under private development and ownership has partly stabilized this situation, but the country still faces a shortage of stable power capacity with the definition of firm hydropower capacity based on long-run hydrological records.

- Sustainability. TANESCO's financial situation has been consistently precarious. Its operational expenditures/costs and capital expenditures have been low, and its tariffs appear to have consistently lagged costs, especially once it started to incur payments under the first private power sales agreement. Total system energy losses increased steadily from 10 percent in 1996 to around 25 percent in 2008. The only positive trends occurred during 2002-06 when TANESCO was under a management contract. Tariffs grew, labor costs went down, and unserved peak load fell. The latter promptly declined after the management contract ended. Tanzania increased its carbon emissions with the advent of the privately owned thermal plants, but these emissions are moderate relative to the energy produced because the main private plant uses natural gas, rather than liquid fuel. The total emissions per unit of electricity generated has oscillated between 50 and 400 tons per gigawatthour generated on the system, which reflects the variable output of thermal power to complement changes in output of hydropower.

Clearly, the reforms undertaken to date have not been effective in resolving the basic problem facing TANESCO's performance.

Trends in these indicators are shown in the figures that follow. 


\section{Figure 20.1 Milestones of Power Sector Reform in Tanzania}

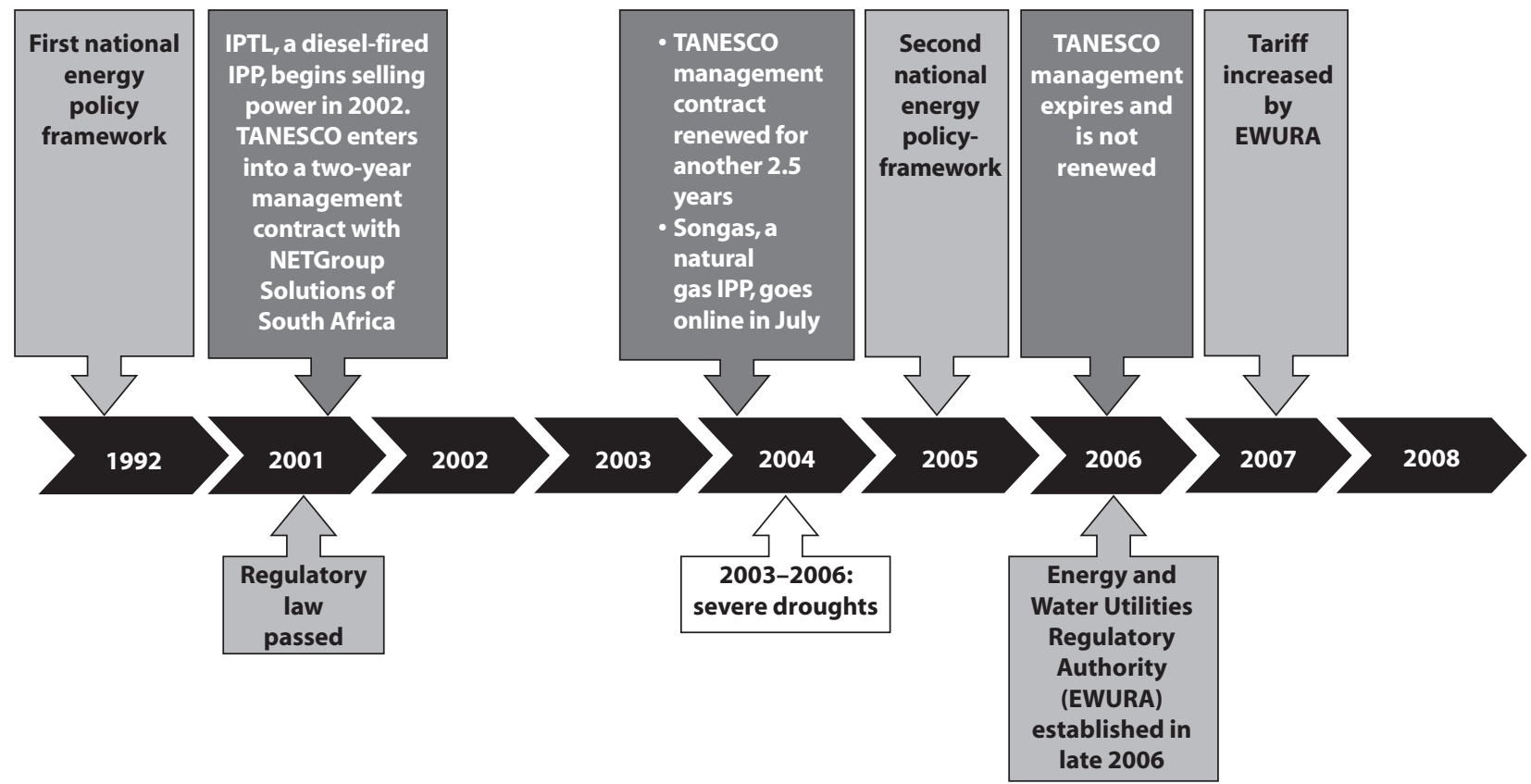

Source: An elaboration from the Power Market Structure database.

Note: The milestones are reported in different shades: white = main external factors; light gray = main government interventions; dark gray = main private sector involvements. EWURA = Energy and Water Utilities Regulatory Authority; IPP = independent power producer; IPTL = Independent Power Tanzania Limited; TANESCO = Tanzania Electric Supply Company. 


\section{Figure 20.2 Tanzania: Access to Residential Electricity}

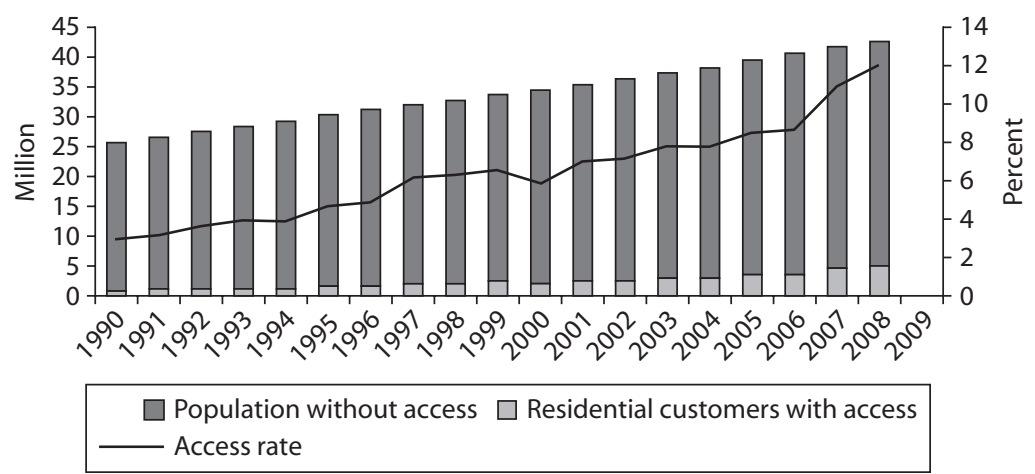

Source: An elaboration from the Power Market Structure database.

\section{Figure 20.3 Tanzania: Quality of Electric Service}

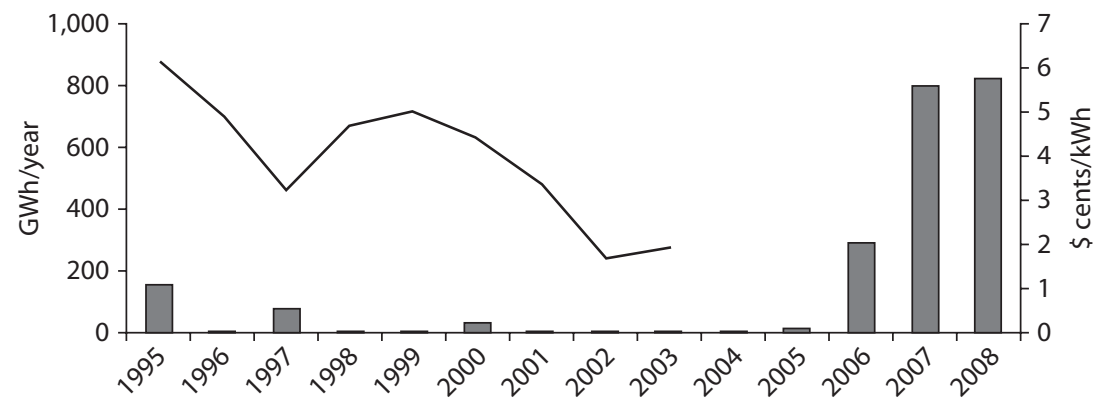

$\square$ Total volume of load during unplanned outages Total nonfuel opex per unit consumed

Source: An elaboration from the Power Market Structure database.

Note: $\mathrm{GWh}=$ gigawatt-hour; $\mathrm{kWh}=$ kilowatt-hour; opex = operational expenditures/costs. 


\section{Figure 20.4 Tanzania: System Energy Losses}

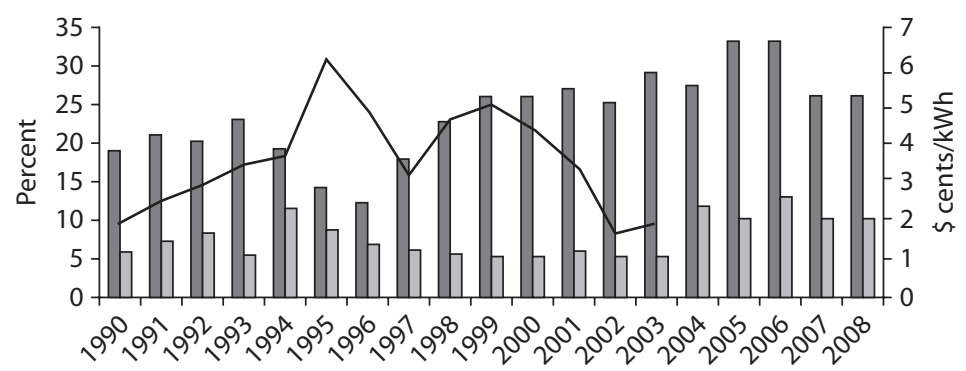

$\square$ Total system losses $\quad \square$ Nontechnical losses

Total nonfuel opex per unit consumed

Source: An elaboration from the Power Market Structure database.

Note: $\mathrm{kWh}=$ kilowatt-hour; opex = operational expenditures/costs.

Figure 20.5 Tanzania: System Load Factor

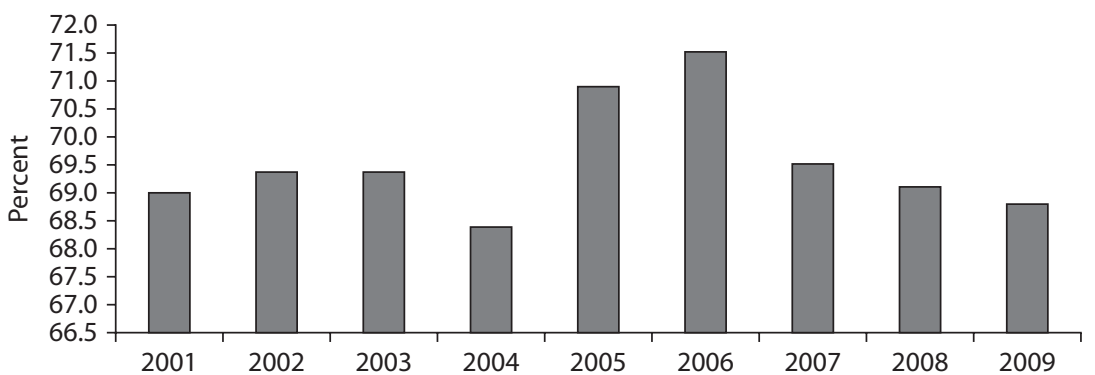

Source: An elaboration from the Power Market Structure database.

Figure 20.6 Tanzania: Electricity Generation by Source and Carbon Emissions

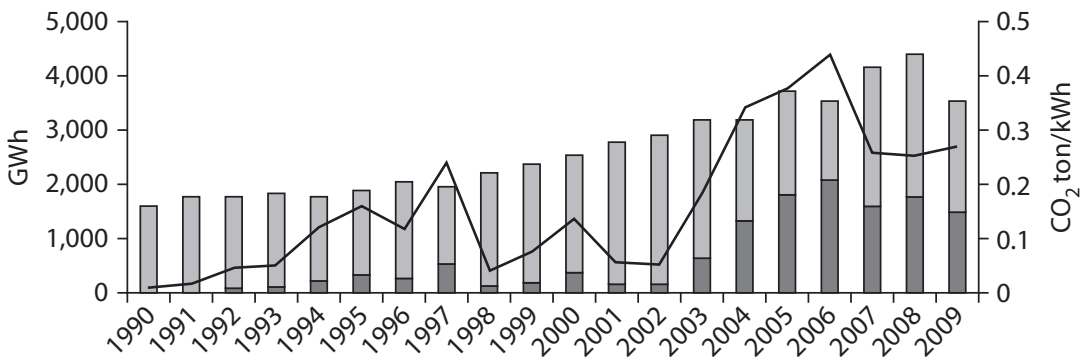

$\square$ Nonrenewable sources $\square$ Renewable sources

- Carbon emissions index

Source: An elaboration from the Power Market Structure database.

Note: GWh = gigawatt-hour; kWh = kilowatt-hour. 
Figure 20.7 Tanzania: Energy Security and Capital Expenditure

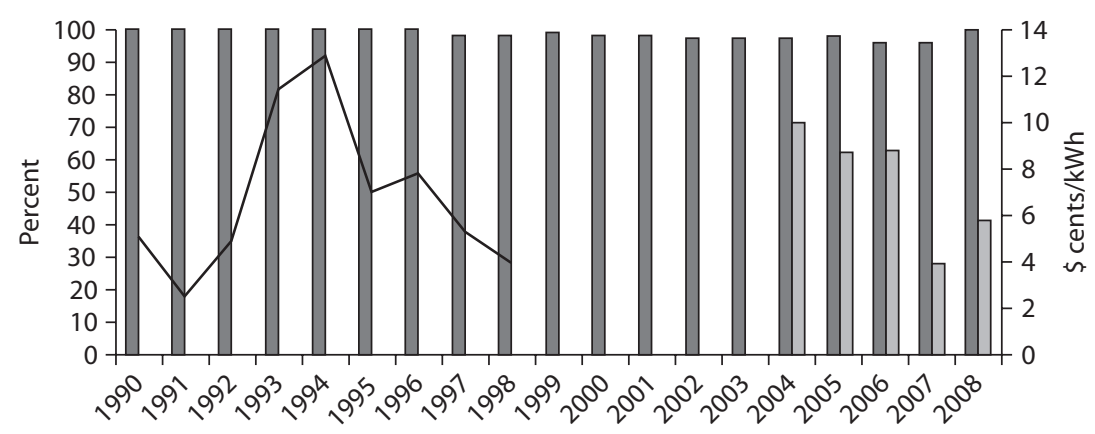

$\square$ Energy self-sufficiency $\square$ System reserve capacity Total capex per unit consumed

Source: An elaboration from the Power Market Structure database.

Note: Capex = capital expenditures; $\mathrm{kWh}=$ kilowatt-hour.

Figure 20.8 Tanzania: Average Tariff and Operating Costs

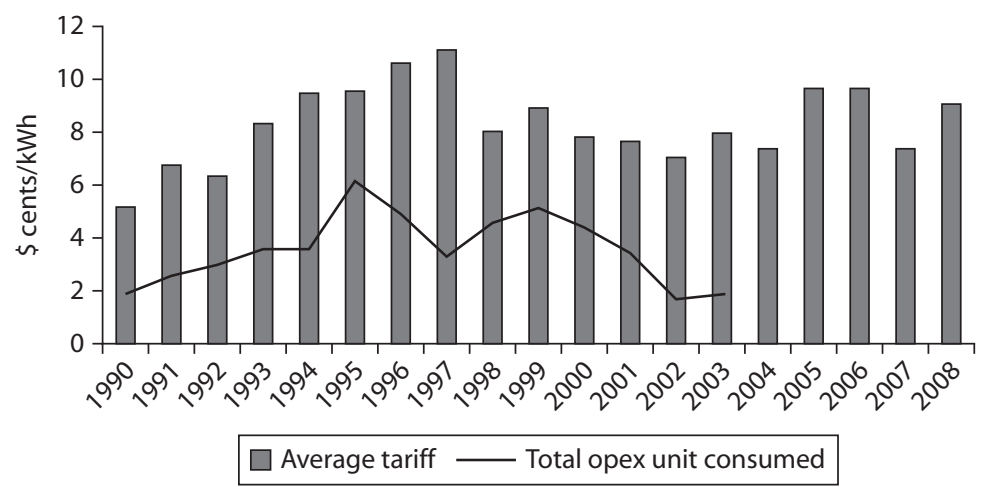

Source: An elaboration from the Power Market Structure database.

Note: $\mathrm{kWh}=$ kilowatt-hour; opex = operational expenditures/costs. 
Figure 20.9 Tanzania: Labor Productivity

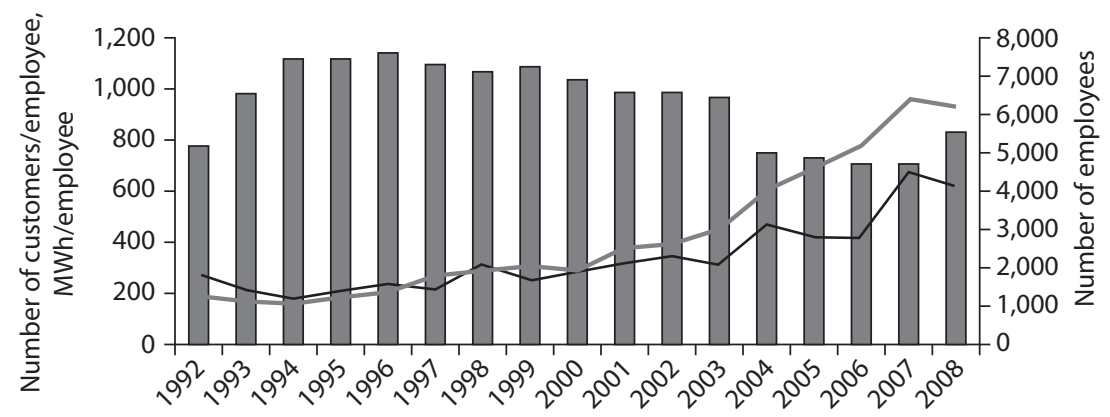

$\square$ Total employees in electricity sector

_ Energy consumed/employee

Residential customers/employee

Source: An elaboration from the Power Market Structure database.

Note: $\mathrm{MWh}=$ megawatt-hour.

Figure 20.10 Tanzania: Capacity Utilization

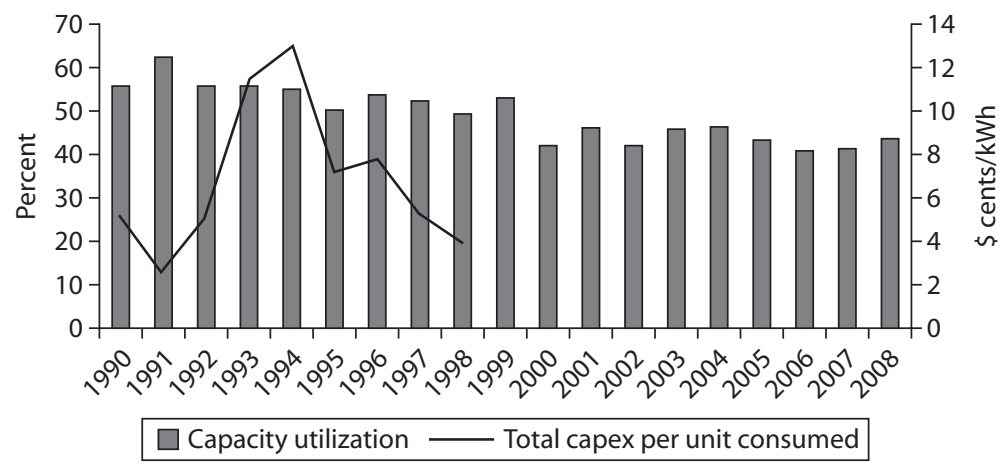

Source: An elaboration from the Power Market Structure database.

Note: Capex = capital expenditures; $\mathrm{kWh}=$ kilowatt-hour. 
Figure 20.11 Tanzania: Cost Recovery Index

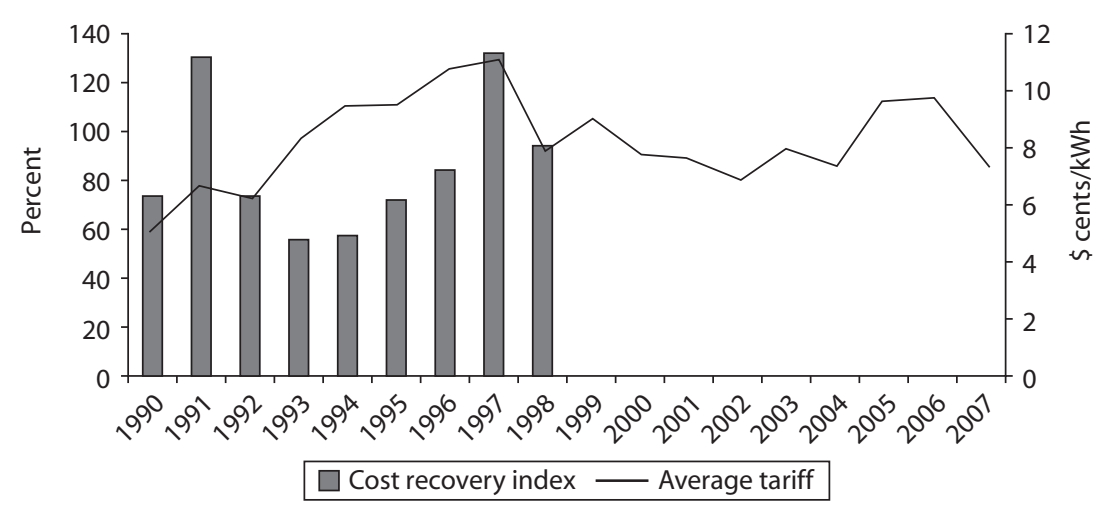

Source: An elaboration from the Power Market Structure database. Note: $\mathrm{kWh}=$ kilowatt-hour.

Figure 20.12 Tanzania: Market Concentration

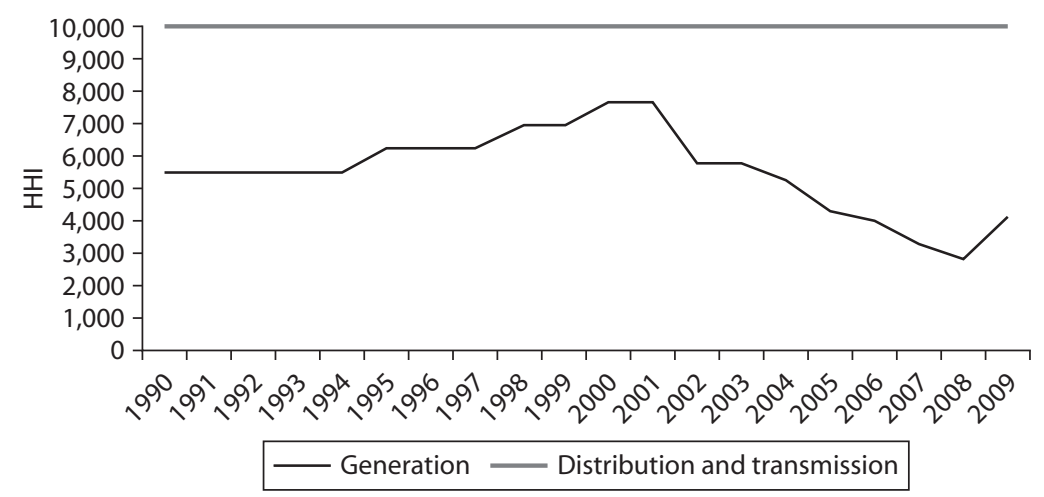

Source: An elaboration from the Power Market Structure database. Note: $\mathrm{HHI}=$ Herfindahl-Hirschman Index. 


\section{Figure 20.13 Tanzania: Private Ownership}

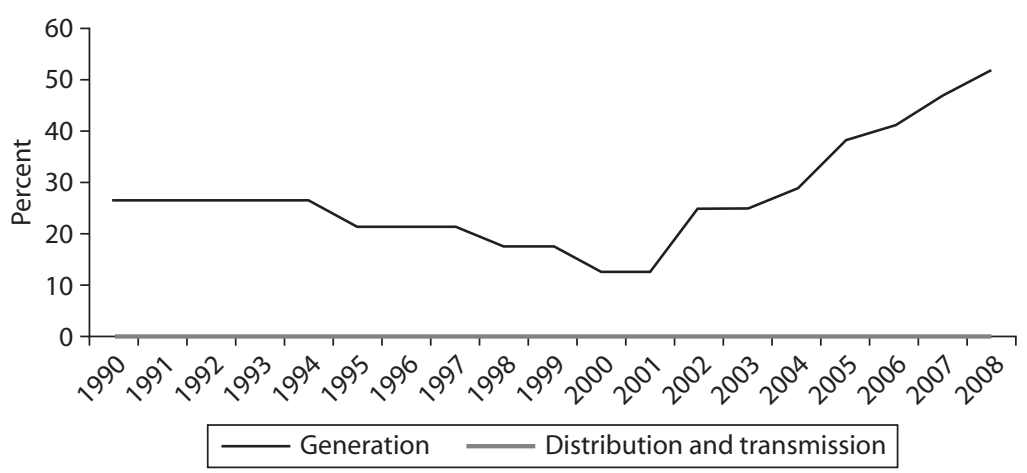

Source: An elaboration from the Power Market Structure database.

\section{Figure 20.14 Tanzania: Private Management}

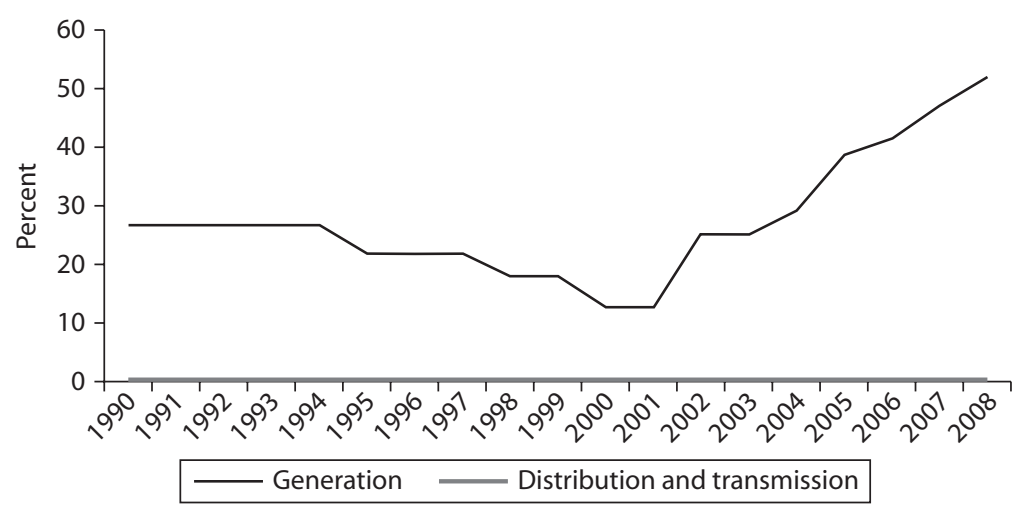

Source: An elaboration from the Power Market Structure database. 


\section{Figure 20.15 Tanzania: Degree of Vertical Integration}

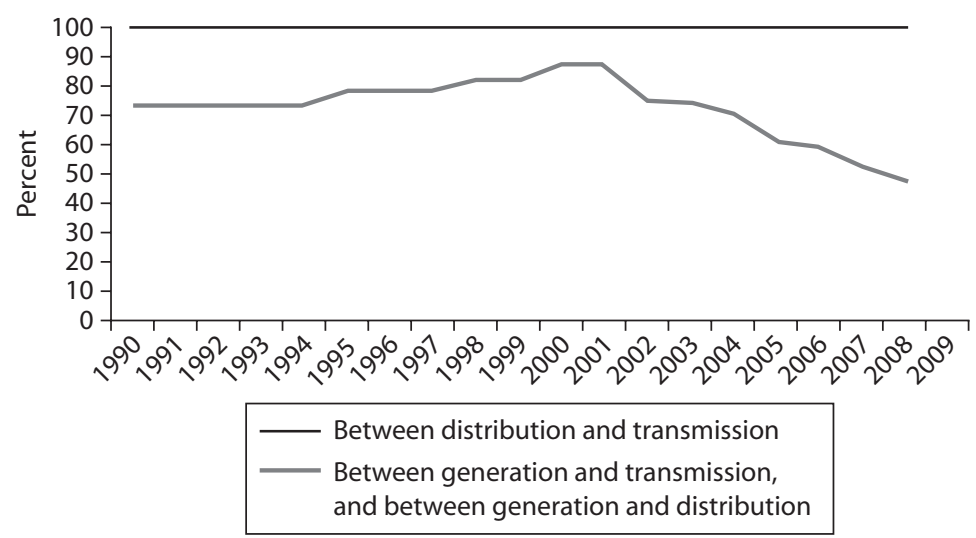

Source: An elaboration from the Power Market Structure database.

\section{Note}

1. Installed hydropower capacity in 2007 was 557 MW, according to Monitoring Performance of Electric Utilities: Indicators and Benchmarking in Sub-Saharan Africa. Washington, DC: World Bank, 2009.

\section{Reference}

World Bank. 2008. World Development Indicators. World Bank, Washington, DC. 



\section{Uganda}

Uganda falls in the category of low system size/low per capita income, with a current total installed generating capacity, largely hydropower, of about $400 \mathrm{MW}$ (megawatts) and per capita gross domestic product of about $\$ 400$.

\section{Reform History}

In 1999 Uganda's government decided to reform the power sector by dissolving the monopoly of the Uganda Electricity Board (UEB), attracting private investment and management to the sector, and setting up a regulatory framework for this purpose. It passed the Electricity Act later that year to implement the policy. At about the same time, the first power purchase agreement (PPA) for a major private investment was signed to develop the $200 \mathrm{MW}$ Bujagali hydropower project. The Electric Regulatory Authority was created in 2001. This step was followed by the unbundling of UEB's business into three separate companies to handle generation, transmission, and distribution. The transmission company became the single buyer of bulk power in Uganda. The assets of the generation company were privatized under a long-term concession in 2002, and the business of the distribution company was privatized 
under a concession in 2005. Also in 2005 a new PPA was signed with a different developer, the first developer having withdrawn from its agreement much earlier.

\section{Impact on Sector Structure}

From the late 1940s until 2005 Uganda obtained its electricity from one hydropower plant. Emergency thermal generation capacity was brought onstream in 2005 to fill the widening supply deficit, which started the diversification of bulk power supply. This diversification will increase as new hydropower and thermal power capacity are commissioned in the next few years. The impact of the reforms on the trend is that generation will no longer be a monopoly; rather, this new capacity will be developed by various private investors. Trading in the wholesale power market is likely to remain under bilateral contracts, with the transmission company acting as a single buyer for the foreseeable future. The prospects for a more competitive arrangement would become serious were Uganda to join the putative Eastern Africa Power Pool.

\section{Impact on Sector Performance}

Uganda's substantial reforms have had modest success to date relative to the potential substantial gains for the sector and its customers. Three factors have impeded progress toward sector unbundling and regulatory reforms. Arguably, these factors are largely out of the control of government and the sector management. One is the severe decline in hydropower output from the existing capacity due to the drought in East Africa, which undermined the financial position of the distribution company. The second is the financial crisis for international investors in 2001-02, which contributed to the withdrawal of the first independent power producer for the Bujagali hydropower project. Had that developer gone ahead as scheduled, the output from this project would have come onstream around 2005-06 and prevented the energy shortage that took place. The third factor is the huge increase in operating costs because of the increase in thermal generation based on costly fuel. The fuel cost imposed a major stress on sector finances and resulted in steep tariff increases that not only hit efforts to reduce theft but also put electricity beyond the affordability of many households, both the relatively few that were already connected and the many that aspired to be connected. 
The distribution and retail supply parts of the power system remain the most problematical and where the reforms to date-a concessionhave yet to show real progress. The potential gains from the concession arrangement may appear once bulk power supply increases sufficiently to meet demand at an affordable cost, because the main issue for distribution and retail supply has been the lack of financial sustainability.

Evidence of possible impacts from unbundling and other reforms is sought from trends from the early to mid-1990s up to 2008 in the following indicators:

- Access to electricity supply by the population in terms of new residential connections. Uganda has not matched Kenya or Tanzania in the rate of increase of residential connections, mainly because of a falloff since 2007. From 1996 to 2007 Uganda increased residential connections at an average of nearly 9 percent per year, but then the rate of new connections declined sharply, partly because of lack of energy to supply them. Only 9 percent of Ugandan households are connected to the public electricity supply. This expansion took place predominantly in urban areas, so that nearly 5 percent of the urban households are connected, compared to less than 3 percent of rural households.

- Supply security. Uganda has lacked any real system reserve generating capacity for some years due to drought in East Africa and the lack of investment in new capacity. To overcome the acute shortage of energy supply relative to demand, Uganda took short-term leases on $100 \mathrm{MW}$ of thermal plant capacity in 2005 and 2006 and is leasing another $50 \mathrm{MW}$ and developing $50 \mathrm{MW}$ of its own thermal capacity. A new 200 MW hydropower station will be commissioned soon.

- Sustainability. The financial sustainability of the power sector has been undermined by the persistently high total system energy losses in the distribution networks-varying between 30 percent and 40 percent-of which nonpayment and theft are reportedly major components. These losses were reduced from the higher bounds of this range to the lower when the distribution concession to private operators came into force. Further reductions have been impeded by the lack of financial resources for the necessary investments and by the rise of electricity theft after tariffs were increased substantially. The environmental sustainability of the power sector has been good, as Uganda historically has emitted little carbon from power generation. With the 
use of thermal power generation, however, the sector has begun to emit more carbon. The commissioning of major new hydropower capacity in the near future will displace production from thermal generators on short-term leases, and so return carbon emissions to low levels.

Trends in these indicators are shown in the figures that follow. 


\section{Figure 21.1 Milestones of Power Sector Reform in Uganda}

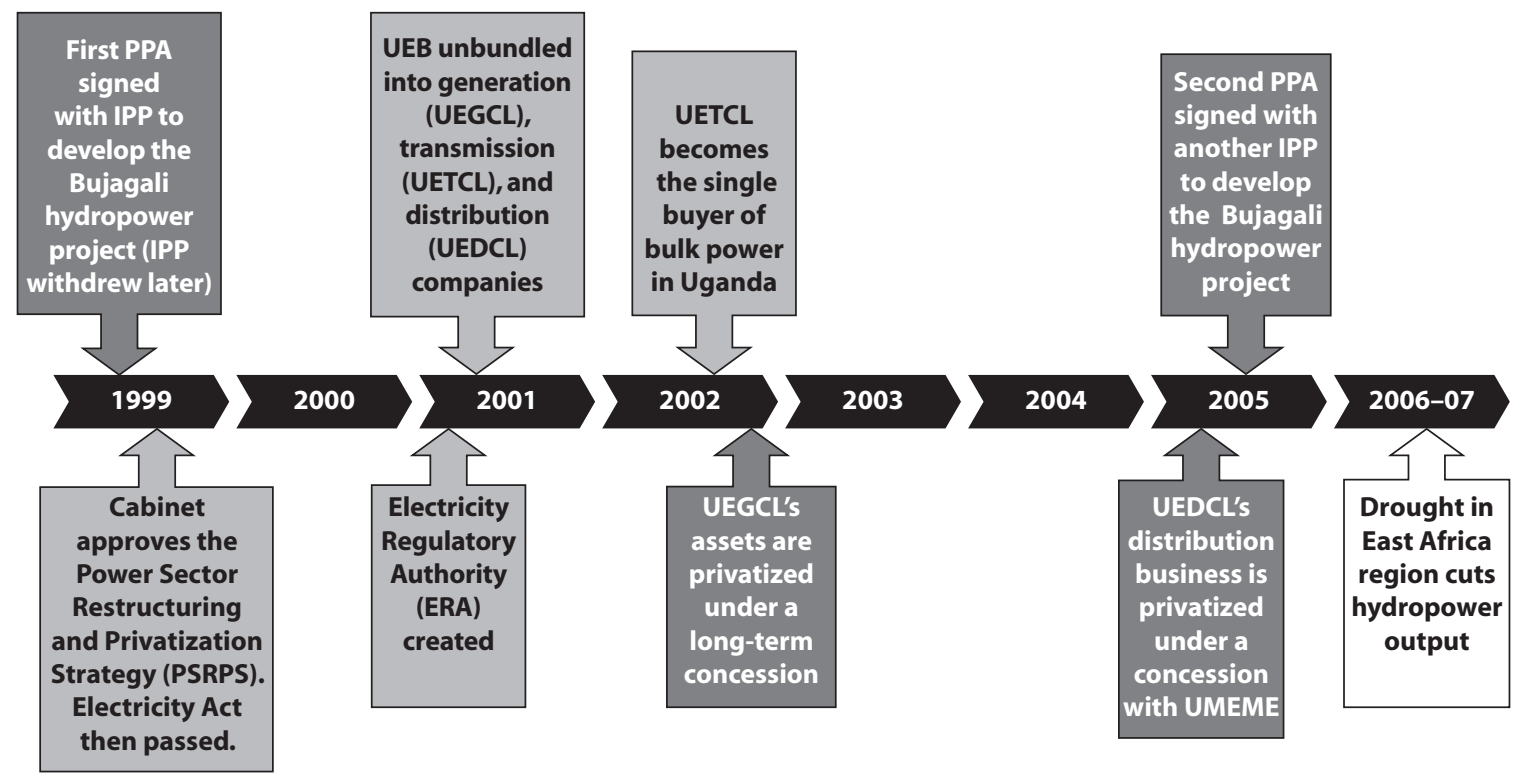

Source: An elaboration of the Power Market Structure database.

Notes: The milestones are reported in different shades: white = main external factors; light gray = main government interventions; dark gray = main private sector involvements. IPP =

independent power producer; PPA = power purchase agreement; UEB = Uganda Electricity Board; UEDCL = Uganda Electricity Distribution Company Limited; UEGCL = Uganda Electricity 


\section{Figure 21.2 Uganda: Access to Residential Electricity}

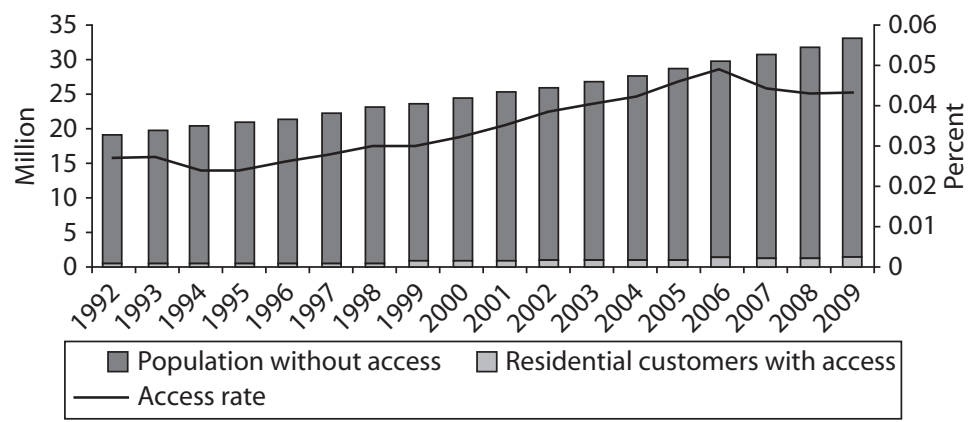

Source: An elaboration of the Power Market Structure database.

Figure 21.3 Uganda: Quality of Electric Service

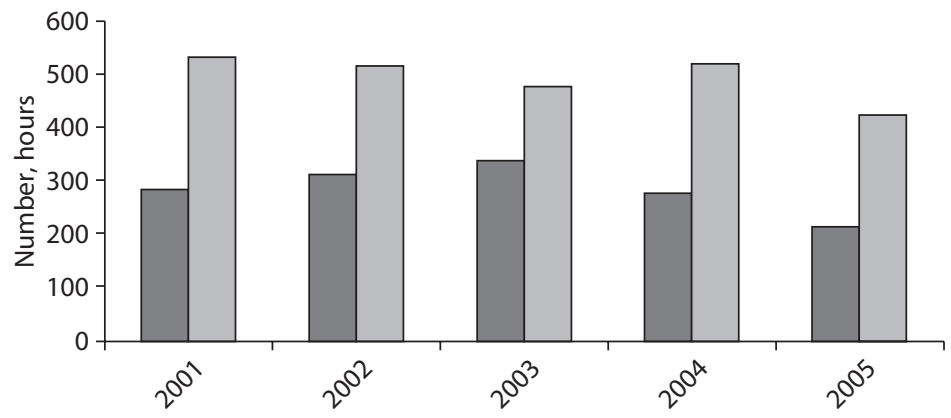

Number of unplanned outages per year $\square$ Total duration of unplanned outages

Source: An elaboration of the Power Market Structure database.

Figure 21.4 Uganda: System Energy Losses and Operating Costs

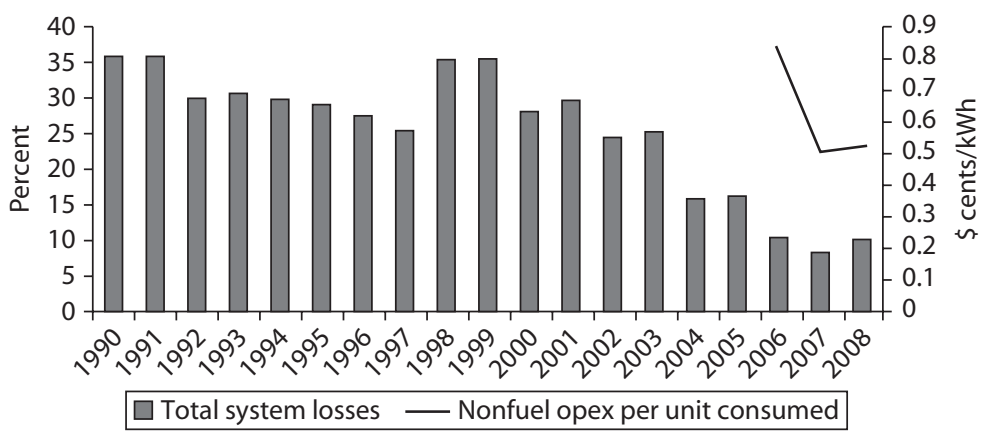

Source: An elaboration of the Power Market Structure database.

Note: $\mathrm{kWh}=$ kilowatt-hour; opex = operational expenditures/costs. 
Figure 21.5 Uganda: System Load Factor

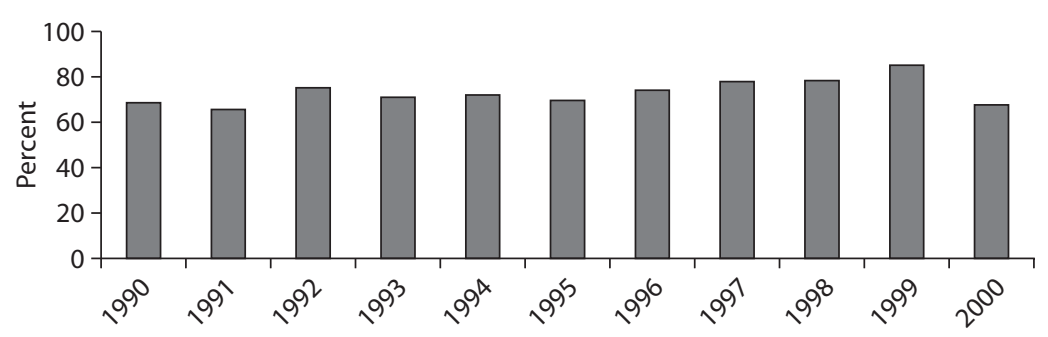

Source: An elaboration of the Power Market Structure database.

Figure 21.6 Uganda: Electricity Generation by Source and Carbon Emissions

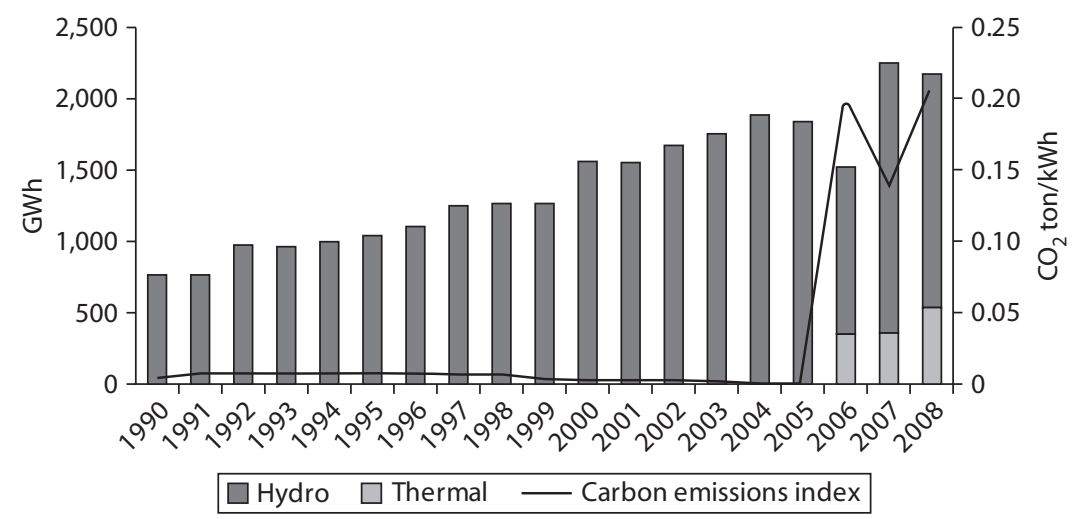

Source: An elaboration of the Power Market Structure database.

Note: $\mathrm{GWh}=$ gigawatt-hour; $\mathrm{kWh}=$ kilowatt-hour.

Figure 21.7 Uganda: Energy Security and Capital Expenditure

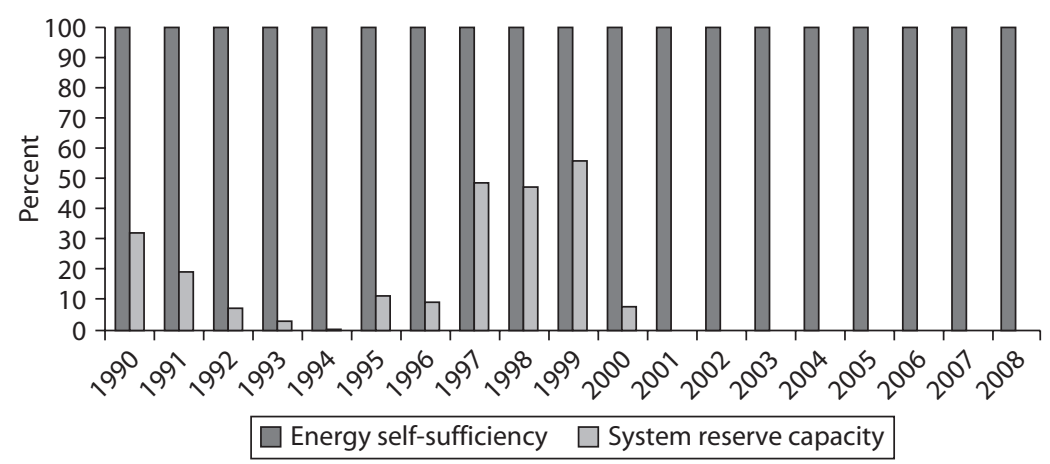

Source: An elaboration of the Power Market Structure database. 


\section{Figure 21.8 Uganda: Average Tariff and Operating Costs}

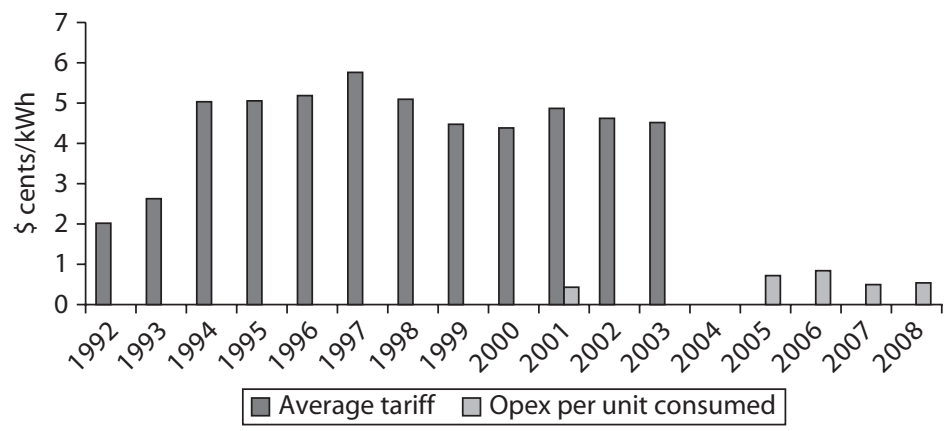

Source: An elaboration of the Power Market Structure database.

Note: $\mathrm{kWh}=$ kilowatt-hour; opex = operational expenditures/costs.

\section{Figure 21.9 Uganda: Labor Productivity}

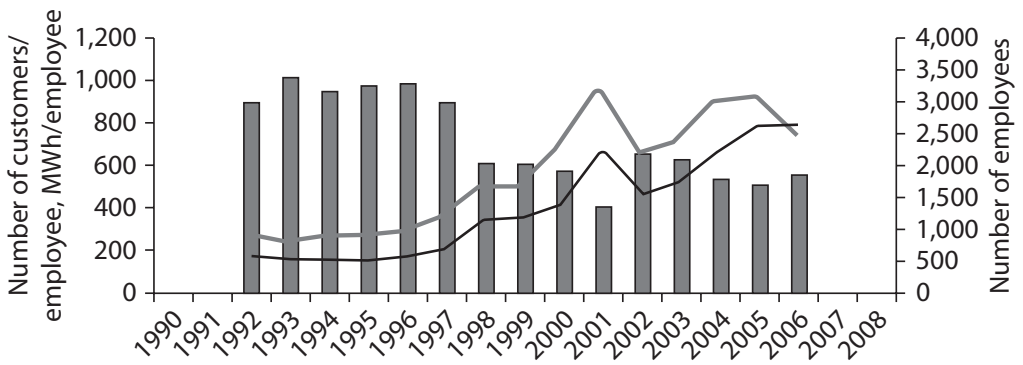

$\square$ Number of employees in electricity sector

— Residential customers/employee

Energy consumed/employee

Source: An elaboration of the Power Market Structure database.

Note: $\mathrm{MWh}=$ megawatt-hour.

\section{Figure 21.10 Uganda: Capacity Utilization}

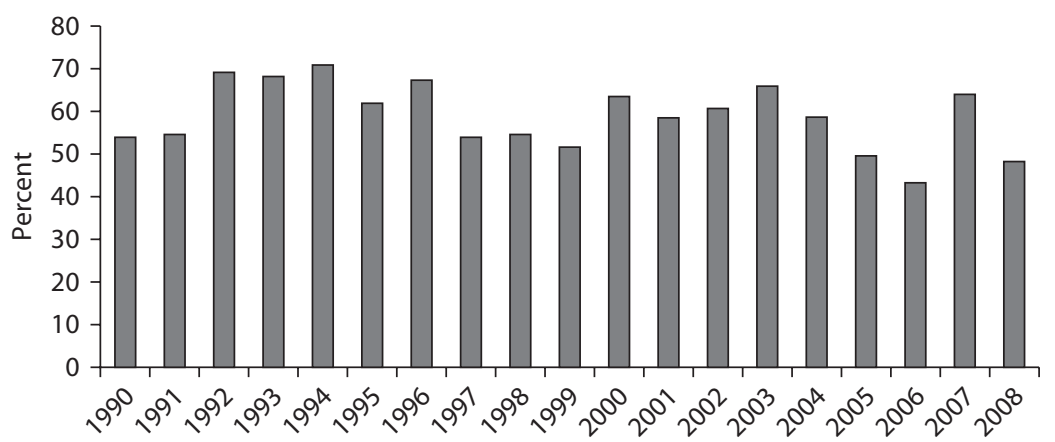

Source: An elaboration of the Power Market Structure database. 


\section{Figure 21.11 Uganda: Cost Recovery Index}

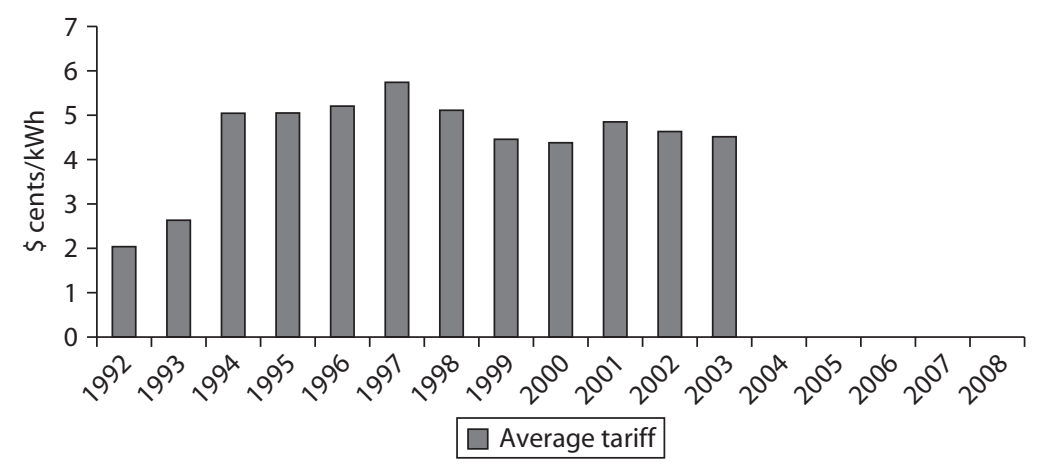

Source: An elaboration of the Power Market Structure database. Note: $\mathrm{kWh}=$ kilowatt-hour.

\section{Figure 21.12 Uganda: Market Concentration}

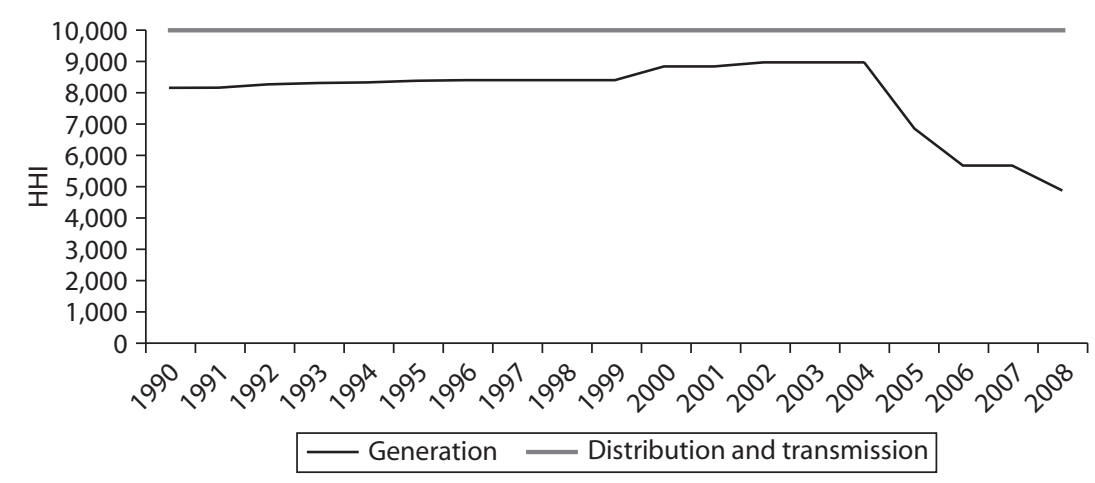

Source: An elaboration of the Power Market Structure database. Note: $\mathrm{HHI}=$ Herfindahl-Hirschman Index.

\section{Figure 21.13 Uganda: Private Ownership}

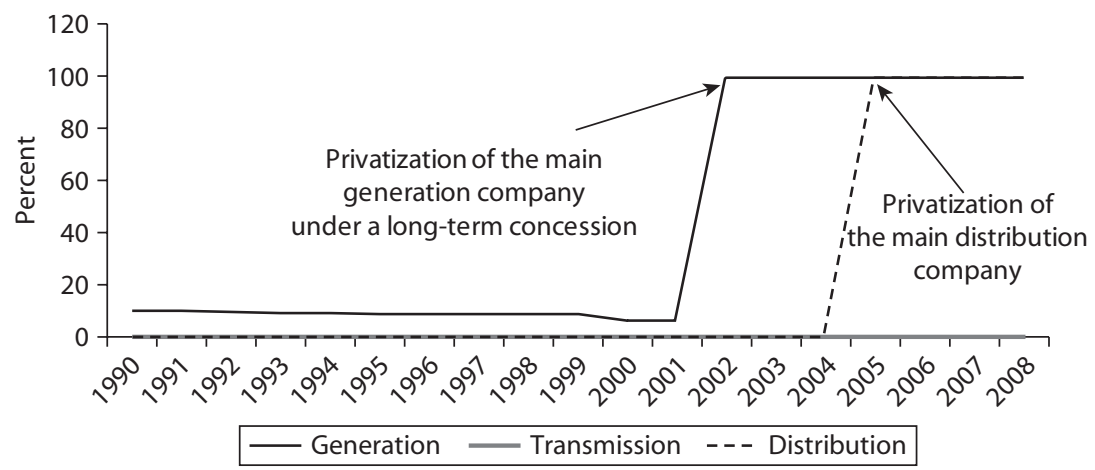


Figure 21.14 Uganda: Private Management

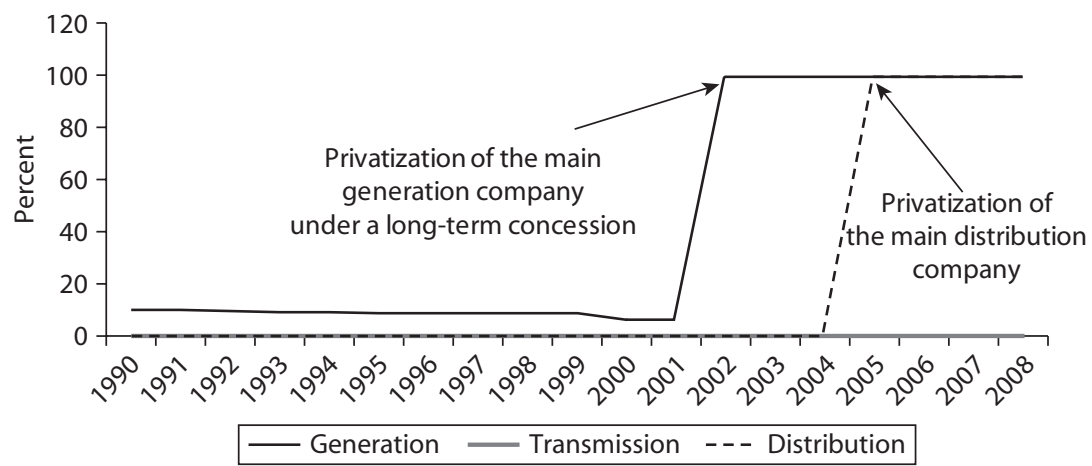

Source: An elaboration of the Power Market Structure database. 
The current distribution of power markets around intermediate structures that fall between the two extremes of full integration and unbundling suggests that there has not been a linear path to power market structure reform. Rather, many developing countries may retain intermediate structures into the foreseeable future. This possibility exposes a gap in the understanding of power market structures, since most theoretical work has focused on the two extreme possibilities and there is limited evidence of the impact of unbundling for developing countries.

Power Market Structure takes a novel analytical approach to modeling market structure, together with ownership and regulation, in determining performance across several indicators, including access, operational and financial performance, and environmental sustainability. Its conclusions-which will be of particular interest to policy makers, academics, and development practitioners-reflect evidence drawn from statistical analysis and a representative sample of 20 case studies, selected based on initial conditions such as income and power system size. The key result of the analysis is that unbundling delivers results when used as an entry point to implementing broader reforms, particularly introducing a sound regulatory framework, and reducing the degree of concentration of the generation and distribution segments of the market by attracting additional public and private players and greater private sector participation. In addition, there seems to be a credible empirical basis for selecting a threshold power system size and per capita income level below which unbundling of the power supply chain is not expected to be worthwhile. Partial forms of vertical unbundling do not appear to drive improvements. The most likely reason is that the owner was able to continue exercising control over the affairs of the sector and hinder the development of competitive pressure within the power market. 